ИНСТИТУТ ВСЕОБЩЕЙ ИСТОРИИ РАН

ЦЕНТР ИНТЕЛЛЕКТУАЛЬНОЙ ИСТОРИИ

РОССИЙСКОЕ ОБЩЕСТВО

ИНТЕЛЛЕКТУАЛЬНОЙ ИСТОРИИ

\title{
*
}

INSTITUTE OF WORLD HISTORY

CENTRE FOR INTELLECTUAL HISTORY

RUSSIAN SOCIETY OF INTELLECTUAL HISTORY

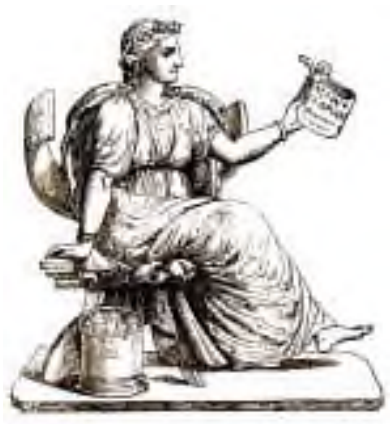

ДИАЛОГ СО ВРЕМЕНЕМ

76

\section{DIALOGUE WITH TIME}




\section{DIALOGUE WITH TIME \\ INTELLECTUAL HISTORY REVIEW \\ 2021 Issue 76}

\section{EDITORIAL COUNCIL}

Carlos Antonio AGUIRRE ROJAS

La Universidad Nacional

Autónoma de Mexíco

Mikhail V. BIBIKOV

Institute of World History RAS

Vera P. BUDANOVA

Institute of World History RAS

Tamara A. BULYGINA

North-Caucasus Federal University

Wojciech WRZOSEK

Uniwersytet im. Adama Mickiewica w Poznaniu

Piama P. GAIDENKO

Institute of Philosophy RAS

Stefano GARZONIO

Università di Pisa, Italia

Galina I. ZVEREVA

Russian State University for the Humanities

Valentina P. KORZUN

Omsk State University

German P. MYAGKOV

Kazan Federal University

Igor V. NARSKIJ

National Research

South Ural State University,

Cheljabinsk
Valery V. PETROFF

Institute of Philosophy RAS

Jefim I. PIVOVAR

Russian State University

for the Humanities

Jörn RÜSEN

Kulturwissenschaftliche Institut, Essen

Irina M. SAVELIEVA

Higher School of Economics

National Research University

Gyula SZVÁK

Eötvös Loránd University,

Budapest, Hungary

Natalia B. SELUNSKAYA

Lomonosov Moscow State University

Andrej B. SOKOLOV

Yaroslavl State Pedagogical University named after K. D. Ushinsky

Rolf TORSTENDAHL Uppsala Universitet, Sweden

Victoria I. UKOLOVA

Moscow State Institute of International Relations (University) MFA of Russia

Chen QINENG

The Institute of World History, Chinese Academy of Social Sciences

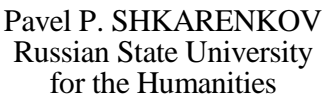




\section{ДИАЛОГ СО ВРЕМЕНЕМ \\ АЛЬМАНАХ ИНТЕЛЛЕКТУАЛЬНОЙ ИСТОРИИ \\ 2021 Выпуск 76}

\section{РЕДАКЦИОННЫЙ СОВЕТ}

Карлос Антонио АГИРРЕ РОХАС

Национальный автономный

университет Мехико

М. В. БИБИКОВ

Институт всеобщей истории

Российской академии наук

В. П. БУДАНОВА

Институт всеобщей истории РАН

Т. А. БУЛЬГИНА

Северо-Кавказский

федеральный университет

Войцех ВЖОСЕК

Университет им. Адама Мицкевича,

Познань, Польша

П. П. ГАЙДЕНКО

Институт философии

Российской академии наук

Стефано ГАРДЗОНИО

Пизанский университет, Италия

Г. И. ЗВЕРЕВА

Российский государственный гуманитарный университет

В. П. КОРЗУН

Омский государственный университет им. Ф. М. Достоевского

\section{Г. П. МЯГКОВ}

Казанский

федеральный университет

И. В. НАРСКИЙ

Национальный исследовательский

Южно-Уральский государственный университет, Челябинск

\author{
В. В. ПЕТРОВ \\ Институт философии \\ Российской академии наук \\ Е. И. ПИВОВАР \\ Российский государственный \\ гуманитарный университет
}

Йорн РЮЗЕН

Институт наук о культуре, Эссен, ФРГ

И. М. САВЕЛЬЕВА

НИУ «Высшая школа экономики»

\section{Дюла СВАК}

Будапештский университет им. Лоранда Этвеша, Венгрия

Н. Б. СЕЛУНСКАЯ

Московский государственный университет им. М. В. Ломоносова

А. Б. СОКОЛОВ

Ярославский государственный

педагогический университет

им. К. Д. Ушинского

Рольф ТОШТЕНДАЛЬ

Уппсальский Университет, Швеция

В. И. УКОЛОВА

МГИМО (Университет) МИД России

Чен ЧИНУН

Институт мировой истории

Академии социальных наук, КНР

П. П. ШКАРЕНКОВ

Российский государственный гуманитарный университет 


\section{ББК 63.3}

\section{ГЛАВНЫЙ РЕДАКТОР}

доктор исторических наук, профессор, член-корреспондент РАН

Лорина Петровна РЕПИНА

\section{РЕДАКЦИОННАЯ КОЛЛЕГИЯ}

АФАНАСЬЕВА А. Э., кандидат исторических наук, доцент ВЕДЕШКИН М. А., кандидат исторических наук (отв. секретарь)

ВИШЛЕНКОВА Е. А., доктор исторических наук, профессор

ВОРОБЬЕВА О. В., кандидат исторических наук, доцент

ГОРЕЛОВ М. М., кандидат исторических наук

ИОНОВ И. Н., кандидат исторических наук

КИСЕЛЕВА М. С., доктор философских наук, профессор

КОРЧИНСКИЙ А. В., кандидат филологических наук, доцент

МАЛОВИЧКО С. И., доктор исторических наук, профессор

НЕДАШКОВСКАЯ Н. И., кандидат филологических наук, доцент

ПЕТРОВА М. С., доктор исторических наук, доцент (зам. гл. редактора)

РУМЯНЦЕВА М. Ф., кандидат исторических наук, доцент

СЕЛУНСКАЯ Н. А., кандидат исторических наук

СЕРЕГИНА А. Ю., доктор исторических наук

СТОГОВА А. В., кандидат исторических наук, доцент

ЭКШТУТ С. А., доктор философских наук

\section{ДИАЛОГ СО ВРЕМЕНЕМ 76}

$$
\text { М.: Аквилон, 2021. - } 464 \text { с. }
$$

Журнал «Диалог со временем» посвящен проблемам интеллектуальной истории, которая изучает исторические аспекты всех видов творческой деятельности человека, включая ее условия, формы и результаты.

\section{ISSN 2073-7564}

\section{Эл. № ФС 77-53624}

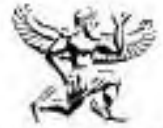

$$
\text { A KB } \triangle \triangle O H
$$

\section{DIALOGUE WITH TIME 76}

Moscow: Aquilo-Press, 2021. - 464 p.

Journal "Dialogue with Time" is specially intended for consideration of the problems of intellectual history understood as a study of historical aspects of all kinds of human creative activity, including its conditions, forms and products.

Подписной индекс в общероссийском каталоге «Роспечать» - $\mathbf{3 6 0 3 0}$

\footnotetext{
(C) Общество интеллектуальной истории, 2021

(C) Институт всеобщей истории, 2021

(C) Издательство «Аквилон», 2021

(C) Журнал «Диалог со временем», 2021

Репродуцирование (воспроизведение) данного издания или его части любым способом без письменного соглашения с издателем запрещяется
} 


\section{Н.Н. ГУБАНОВ, Н.И. ГУБАНОВ \\ ИСТОРИЯ НАУЧНЫХ ИДЕЙ СКВОЗЬ ПРИЗМУ ИСТОРИИ ИДЕЙ ФИЛОСОФСКИХ}

В статье предлагается метод, который наводит мост между историей науки и историей философии - метод параллельной реконструкции истории становления научной теории и её философского прообраза, под которым понимается совокупность философских предпосылок и оснований этой теории. Метод основан на концепции, согласно которой актуальное бытие философских идей представляет собой, помимо возможностей собственного развития, потенциальное бытие научных идей. Из обширного и многомерного резервуара философских идей развитие науки актуализирует лишь некоторые смыслы и только в исторически специфической конкретно-научной интерпретации. Мы не знаем заведомо, какие новые преломления в научном сознании может получить та или иная старая философская идея: теоретически количество таких интерпретаций бесконечно. Но в имеющейся научной теории мы в состоянии проследить её философскую подоплёку до самых базовых её предпосылок. По мнению авторов, рассмотрение истории науки в таком ключе способствует видению интеллектуальной истории как единого процесса, в котором постоянно перекликаются история философских идей и история научных идей, взаимно стимулируя друг друга и сливаясь в процессе интеллектуального прогресса. Нахождение философских оснований какой-либо современной научной теории позволяет провести её определённое философское обоснование, что в ситуации конкуренции с другой научной теорией, при прочих равных условиях, может служить дополнительным аргументом в пользу данной теории.

Ключевые слова: интеллектуальная история, история идей, философия, наука, история науки, история философии

Что делает идеи значимыми в историческом масштабе? Представим мнение одного из наиболее авторитетных современных исследователей интеллектуальной истории Рэндалла Коллинза: «Великой интеллектуальной работой является та, что создает большее пространство, в котором могут работать последователи. Это означает, что именно несовершенства важных доктрин являются источником их привлекательности. Но величие должно быть на обеих сторонах: великие доктрины и великие несовершенства» ${ }^{1}$. Несовершенство философских идей, их многозначность, даже противоречивость могут быть источником различных направлений интеллектуального поиска не только в самой философии, но и в науке. Поскольку мы заговорили об идеях, то сознанию невольно навязывается имя Платона. Читаем далее Коллинза: «Одна из причин возведения Платона в ранг доминирующей фигуры в поздней античности состоит в том, что неясные моменты в его теории идей вели к дальнейшим разработкам и даже формированию весьма различных школ. Платоновские неясные теории души, бессмертия и реинкарнации были одним из источников популярности Платона и продуктивности его последователей» ${ }^{2}$. И это распространялось не только на философские школы, но и направления в дру-

\footnotetext{
${ }^{1}$ Коллинз 2002: 81.

2 Там же: $81-82$.
} 
гих областях знания. Обратим внимание на такой неоднозначный компонент философии Платона как учение об «анамнесисе» - припоминании душою тех идей, которые в ней уже содержатся и которые она созерцала в мире идей до вселения в человеческое тело. Часто это воззрение полагают самым уязвимым местом платоновской философии. Вот что по этому поводу утверждал В.Ф. Асмус: «...заговорив о “припоминании”, Платон как будто покидает почву трезвого философского исследования, как будто отдаётся во власть своей мифотворческой фантазии. Учение теории познания оборачивается мифом, в философе возвышает голос поэт» ${ }^{3}$.

Возражение против такой оценки выдвигает С.А. Лебедев: «Платон был абсолютно прав, когда подчёркивал ту по своей сути аналитическую истину, что любая идея может быть взята сознанием только из сознания же (из “души”). А это означает, что она там должна находиться, по крайней мере, потенциально, в виде возможности... Если перевести эту мысль Платона на объективистский язык, то она будет состоять в утверждении, что мир идей существует, при этом вполне объективно, но лишь как мир потенций, мир возможностей. Такую трактовку платоновского мира идей как мира объективных возможностей предложил в XX в. один из создателей квантовой механики В. Гейзенберг» ${ }^{4}$. В.В.Казютинский пишет: «Платон открыл существование идей как идеальных, но объективных схем реальности и ее понимания. Проблема отношения этого мира к другим мирам, в том числе физическому и психическому, в истории философии возникала в разных мировоззренческих контекстах, включая отличные от платоновского. Например, в варианте, предложенном К. Поппером, три мира образуют мир физический - первый мир, мир психический - второй мир, мир объективного знания - третий мир (я не согласен с Поппером, что существование третьего мира возможно вне мира культуры)» 5 .

Выскажем своё скромное мнение, навеянное этой дискуссией, и попытаемся объяснить, как осуществляется преемственность в истории интеллектуального развития общества, т.е. смены и воспроизводства идей. Идея в том виде, в каком она существует в голове человека, актуально является лишь этой идеей и ничем больше. Она может в чём-то соответствовать реальности, а в чём-то не соответствовать. Если она соответствует сущностным чертам реальности, то её можно назвать истинной ${ }^{6}$. Каждая актуально существующая мысль в то же самое время содержит в себе веер потенциальных возможностей стать другой мыслью, генетически связанной и произошедшей из данной. Какая из возможностей будет реализована, зависит от последующего опыта взаимодействия человека с окружающим миром и от когнитивной деятельности его психики, включающей дискурсивную, интуитивную и т.д. деятельности. Появившись, уточнившись и закрепившись во внутренней речи человека, новая

\footnotetext{
${ }^{3}$ Цит. по Лебедев 2018: 18.

${ }^{4}$ Там же: $18-19$.

${ }^{5}$ Казютинский 2010: 176.

${ }^{6}$ Губанов Н.И., Губанов Н.Н. 2016.
} 
идея может быть зафиксирована с помощью знаковых средств. Будучи обозначенным и включенным в поток культурной трансляции, смысл этой идеи начинает своё независимое от породившего его человека существование. Теперь спектр возможностей этого смысла стать другим смыслом значительно расширяется, потому что он становится доступен для обработки множеству других мыслящих субъектов.

Отметим, что в строгом смысле слова сами по себе идеи не передаются, будучи неотделимыми от породившего их сознания и его носителя - головного мозга, а вызываются у другого субъекта посредством знаков, при условии, что этот субъект обладает значениями этих знаков. При восприятии знака у субъекта актуализируется только то значение, которое он знает, а при восприятии кода как системы знаков (напр., текста), возникают новые связи между значениями, соответствующие отношениям между знаками в коде. В результате этого субъект приобретает новые знания и усваивает новые значения ${ }^{7}$. Содержание сознания субъекта, передающего информацию, представлено во внешних кодах. Однако это не даёт оснований считать, что общественное сознание существует в некой сугубо внеличностной и надличностной форме. «Сознание есть единство относительно объективного содержания и субъективной формы. Содержание сознания может отделяться от субъекта и опредмечиваться. Субъективная форма сознания от личности неотделима. Поэтому трансляционные коды - это не само общественное сознание, а его опредмеченное содержание, не имеющее во внешних кодах субъективного, т.е. идеального, проявления. Эти коды могут быть охарактеризованы лишь как возможность возникновения при условии их взаимодействия с субъектом соответствующих актов сознания, но не как само общественное сознание» ${ }^{8}$. Итак, на наш взгляд, мир платоновских идей существует в индивидуальном и общественном сознании людей, но не где-то на небесах; форма его, сознания, бытия - идеальная, т.е. субъективная реальность. По содержанию же идеи могут более или менее соответствовать объективной реальности, которую они отражают. Общественное сознание в онтологическом аспекте можно определить как совокупность идей, представлений, чувств, обладающих социальной значимостью, включенных в сеть коммуникации и выполняющих регулятивную функцию в отношении поведения социальных групп. Таким образом, общественное сознание существует лишь посредством множества индивидуальных сознаний. Фактором, интегрирующим социально значимые элементы индивидуальных сознаний в сознание общественное, является система общественной коммуникации. Идеальность общественного сознания заключается в том, что оно есть субъективная реальность ${ }^{9}$. Коды как совокупности материальных знаков в системе коммуникации сами по себе качеством идеального не обладают. Идеальными являются лишь психические образы, значения

\footnotetext{
${ }^{7}$ Губанов Н.И., Губанов Н.Н. 2017.

${ }^{8}$ Альжанов Губанов 1983.

9 Дубровский 2018.
} 
знаков, т.е. информация, воплощенная в определенных нейродинамических кодах, способная актуализироваться указанными знаками.

Итак, преемственность в истории интеллектуального развития общества обусловлена наличием двух условий: 1) существования отделенных от людей кодов информации и системы коммуникации; 2) сохранения у субъектов в процессе смены поколений значений знаков, идеальных по своей природе. Эти значения и актуализируются каждый раз знаками, которые созданы в предшествующие эпохи и постоянно создаются в процессе общественной жизни.

В дальнейшем мы опираемся на концепцию, согласно которой множество наличных философских идей представляет собой, в том числе, потенциальное бытие научных идей. Историческое развитие науки актуализирует из этого виртуального континуума лишь те смыслы, которые наилучшим образом коррелируют с текущими запросами науки и уровнем её развития. Наука весьма избирательна: она никогда не заимствует целиком философские концепции, а тщательно отбирает те их фрагменты, которые могут помочь ей в решении вполне конкретных проблем. Как отмечали В.С. Степин и А.Н. Елсуков: «...естествознание ориентировалось не столько на целиком взятые философские системы, сколько на их отдельные принципы и идеи, в которых раскрывались некоторые наиболее общие особенности структуры мира и человеческого мышления» ${ }^{10}$. Актуализируемая философская идея преломляется сквозь призму наличных когнитивных средств науки и её концептуальный аппарат, получает специфическую конкретно-научную интерпретацию и начинает своё новое независимое от философского родительского лона научное бытие. Далее происходит уже её чисто научная жизнь. Будучи включена в качестве компонента в структуру научного знания, она может значительно изменяться в процессе развития науки. Если в науке окончательно утверждается новая теория, в составе которой развивалась данная идея, то посредством этой теории наука оказывает обратное воздействие на философию, предоставляя ей новый материал для обобщения и осмысления, а сама идея в преобразованном виде может вернуться в философию при условии, что философы ею заинтересуются. Так и происходит постоянная перекличка между историей научных идей и историей идей философских.

Попробуем разобраться в том, что делает возможной эту перекличку. «Сегодня уже не нужно доказывать, что наука в своем познавательном движении постоянно резонирует с развитием других областей культуры (искусства, философии, религии, обыденного сознания и др.). Ближе всего к ней всегда была философия» ${ }^{11}$. Возможно, причина близости коренится в некоей глубинной родственной черте этих двух форм духовного производства. «Строго говоря, понятие теоретическое, которое ассоциируется с наукой в собственном смысле слова, во многом принадлежит и философии. Между этими двумя различными типами теоретического

\footnotetext{
${ }^{10}$ Степин Елсуков 1974: 37-38.

${ }^{11}$ Степин 2003: 15.
} 
существует не только генетическая связь. Философское знание и в развитой науке активно участвует в становлении новых научных теорий и научных картин мира, опосредуя их включение в поток культурной трансляции. В свою очередь, после конституирования науки как автономной формы познания философия испытала на себе ее огромное влияние. Образцы научного рассуждения в новоевропейской традиции длительное время служили идеалом для многих философских школ» ${ }^{12}$. Чтобы лучше понять родство философии и науки, постараемся установить главные особенности научного познания и выяснить, есть ли у него некий фундаментальный общий признак с философским познанием.

Существует ряд признаков, по которым различают обыденную, стихийно-эмпирическую познавательную деятельность и научное исследование. Например, науке требуются специально подготовленные люди, прошедшие длительное предварительное обучение, особые средства познания (приборы, экспериментальные установки, математические методы и т.д.), особый язык. Но все эти признаки являются вторичными, которые вытекают из главной особенности научного познания. А главная же особенность заключается в том, что «в отличие от обыденного познания, которое изучает предметы, только непосредственно вплетенные в практику человека и преобразуемые в сегодняшних видах практического действия, наука ориентирована на изучение таких фрагментов реальности, которые могут встретиться и в практике далекого будущего. Изучение указанных объектов в науке происходит задолго до их массового практического освоения» ${ }^{13}$. Так, наука сначала ввела представление об электромагнитных волнах, предвосхитила способность атома расщепляться, выделяя огромную энергию, описала возможность перехода электронов с более высокого энергетического уровня на низкий, и только через несколько десятилетий, появилась радиоаппаратура, телевизоры, атомные электростанции и ускорители элементарных частиц, лазерные установки. Но философия представляет собой ещё более удаленный горизонт прогнозирования. Здесь счёт может идти на тысячелетия опережения, как в примере с атомами. Главное родовое сходство философии и науки - в том, что они пытаются прорваться за рамки наличного опыта к возможным мирам, но делают это разным способом. В случае науки - это строгая экстраполяция имеющегося знания, а в случае философии - ничем не ограниченное концептуальное моделирование, свободное творчество по созиданию всевозможных смыслов. Именно поэтому множество философских идей представляет собой потенциальное бытие научных идей.

Как известно, успешность любой деятельности, в т.ч. научной, зависит от используемых в ней методов. Для получения надёжного метода мы должны получить истинную картину объекта, зафиксированную в теории, раскрывающей объективные законы его функционирования и развития, но это возможно лишь при условии, когда выработаны правильные

\footnotetext{
12 Там же.

${ }^{13}$ Степин Елсуков 1974: 7.
} 
методы познания. Итак, для построения теории нужен метод, а он в свою очередь возникает как результат теории. Как разрывается этот порочный круг? Создание метода всегда целенаправляется предварительными представлениями об изучаемом объекте. Знания, содержащиеся в более общих научных теориях, служат основанием для разработки методов конкретных научных дисциплин. Фундаментальные науки регулируют исследования в прикладных дисциплинах. Например, теоретическое естествознание целенаправляет научное познание в таких прикладных инженернотехнических дисциплинах, как детали машин, сопротивление материалов, теплоэнергетика, электротехника... А как обстоит дело с самими фундаментальными науками? Учёный, разрабатывая методы своей науки, обязан опять-таки иметь в своем распоряжении предварительные знания об изучаемой действительности. Откуда же он получает необходимую информацию? «Как показывает опыт развития науки, в периоды перестройки принципов фундаментальных научных теорий знания такого рода черпаются в сфере философии. Они представляют собой научные обобщения философского характера и используются в качестве методологических рекомендаций, целенаправляющих процесс научного поиска» ${ }^{14}$.

Сама философия способна вырабатывать новые категориальные структуры и методологические принципы благодаря тому, что в ней постоянно происходит развитие философских понятий. Существует два способа такого развития: а) экспликация (выявление глубинного смысла) универсалий культуры; б) применение аппарата логического оперирования с философскими категориями как с идеальными объектами, в ходе которого вырабатывается их новое определение и содержание, в результате чего в философии появляются нестандартные категориальные модели мира, выходящие за пределы старой культуры.

Предлагаемый нами метод параллельной реконструкции истории становления научной теории и её философского прообраза допускает как движение «сверху вниз» - от научной теории к её философскому основанию, так и движение «снизу вверх» - от философских идей к тем научным теориям, на которые они оказали влияние. Для удобства изложения мы воспользуемся движением «снизу вверх». Ввиду ограниченного объёма данной работы мы остановимся только на философских идеях Античности и только на самых ярких, на наш взгляд, примерах. Основным фактором становления науки в собственном смысле слова явились образцы теоретического рассуждения, впервые данные античной философией, способные отражать свойства, связи и отношения объектов, выходящие за рамки повседневного опыта и связанного с ним обыденного сознания.

Элеаты (VI-V вв. до н. э.). Парменид и Зенон, размышляя над проблемой изменения, части и целого, пришли к невероятному с точки зрения здравого смысла решению - мир един, неделим, неподвижен. Зенон сформулировал ряд знаменитых апорий - «Стрела», «Ахиллес», «Дихотомия» и т.д., показывающих, что представление о движении тел приво-

${ }^{14}$ Там же: 18-19. 
дит к парадоксам. В этих экзотических рассуждениях были поставлены проблемы пространства, времени и движения, к которым наука неоднократно возвращается на протяжении всей истории.

Мыслители позднего Средневековья под влиянием «Стрелы» обсуждали вопрос: можно ли говорить о движении в точке? Движение характеризуется скоростью, а это - путь, деленный на время. Точка - это нулевое расстояние, а ноль, деленный на $t$, даёт ноль. Значит движущееся тело в точке покоится... После появления механики Галилея эта проблема вновь всплыла и стала связываться с понятием мгновенной скорости. Сформулированная философами проблема превратилась в конкретнонаучную. Математически решить её получилось благодаря теории пределов и дифференциальному и интегральному исчислению, примененным в физике. Апория «Дихотомия» показывала, что любой отрезок предстаёт как бесконечное множество точек, но тогда любая часть этого отрезка тоже бесконечное множество и на этом основании может быть приравнена к целому. Историк науки А. Койре отмечал, что эта проблема через два с половиной тысячелетия стала фундаментальной для математики. Она немало озадачила великих математиков Б. Больцано и Г. Кантора, стимулировав разработку современной теории множеств и, в частности, такого её понятия как «мощность множества» ${ }^{15}$.

Интересное преломление в современной науке имеет также обсуждение вопроса о непрерывности и дискретности пространства-времени. Зенон строит свою «Дихотомию» на предположении, что пространство непрерывно и бесконечно делимо. С этой точки зрения между двумя любыми точками лежит бесконечное число отрезков пространства и, соответственно, на их преодоление должно уйти бесконечное время. Но если предположить, что нельзя до бесконечности делить отрезок пути, а рано или поздно мы дойдём до «минимальной длины» $1_{0}$, которая далее не делится, то апория теряет смысл. Тогда между двумя точками лежит не бесконечное множество отрезков пути, а число их хоть и большое, но конечное. Согласно этому, реализуются не любые длины, а только кратные элементарной длине $\mathrm{l}_{0}: \mathrm{l}_{0}, 2 \mathrm{l}_{0}, 3 \mathrm{l}_{0}, \ldots \mathrm{nl}_{0}$.

Естествознание долгое время не давало никаких подтверждений гипотезе дискретного пространства, но она разрабатывалась в философии. Ещё Демокрит пытался разрешить обсуждаемые апории Зенона с помощью идеи об атомистической структуре пространства. Также средневековые арабские философы мутакаллимы полагали, что не только материя, но и пространство дискретно. Движение атомов есть скачкообразный процесс исчезновения атома в одной ячейке пространства и его возникновение в другой. Похожие взгляды высказывали Николай из Отрекура, Лейбниц и Гассенди. Только естествознание XX в. дало некоторое подкрепление гипотезе дискретного пространства и времени благодаря появлению квантовой физики. Сама квантованность физических величин и наличие квантовых скачков заставляет по-новому посмотреть на эту ги-

${ }^{15}$ Степин 2003. 
потезу. В квантовых теориях появляются величины размерности длины, составленных из фундаментальных мировых констант. Какое-то время в физике даже выдвигался «претендент» на роль элементарной длины $\mathrm{l}_{0}=\mathrm{h} / \mathrm{m}_{\mathrm{p}} \mathrm{c}-$ комптоновская длина волны протона, где $\mathrm{h}-$ постоянная Планка, $\mathrm{m}_{\mathrm{p}}-$ масса протона, с - скорость света в вакууме ${ }^{16}$.

Перечислим некоторые физические концепции дискретных пространства и времени. В 1930 г. В.А. Амбарцумян и Д.Д. Иваненко предложили модель, в которой пространственные и временные координаты принимают лишь целочисленные значения. Канадский физик Снайдер предложил трактовку квантования пространства, использовав аналогию с принципом неопределенности. Интересна идея дискретного пространства-времени на световом конусе, высказанная Я.И. Френелем. Немецкий физик Б. Абраменко предположил, что дискретность структуры мира вытекает из открытой Планком элементарности кванта действия $h$. Однако эти и другие гипотезы сталкиваются с серьезными трудностями. «По словам Германа Вейля, идея дискретного пространства потому не вступает в достаточный контакт с реальностью, что остается неясным, как на её основе ввести метрические отношения, понятия длины и расстояния» ${ }^{17}$. Итак, вопрос во многом остаётся открытым... Конечно, сами элеаты даже не догадывались об этих эвристических возможностях философского познания, открывающего проблемы науки будущего.

Пифагорейцы (VI-IV вв. до н.э.) выдвинули принцип: началом всего является число. Считали числовые отношения ключом к пониманию мира, чем создали предпосылки для возникновения теоретического уровня математики. Поставили задачу изучения чисел и их отношений не просто как моделей практических ситуаций, а самих по себе - как идеальных объектов. Путём мысленного оперирования с ними добывалось новое знание, осуществлялся прорыв к неизвестным ранее свойствам и отношениям, не привязанным к наличному опыту. Осуществили важные шаги к соединению теоретического исследования свойств геометрических фигур со свойствами чисел. «Нужно сказать, что связь геометрии и теории чисел обусловила постановку перспективных проблем, которые стимулировали развитие математики и привели к ряду важных открытий. Так, уже в античной математике при решении задачи числового выражения отношения гипотенузы к катетам были открыты иррациональные числа. Исследование «фигурных чисел», продолжающее пифагорейскую традицию, также получило развитие в последующей истории математики» ${ }^{18}$.

Эмпедокл (ок. 490 - ок. 430 г2. до н. э.). Согласно его учению, основу мира составляют четыре неизменные и вечные стихии («корни вещей») - огонь, воздух, вода, земля, которые перемещаются, смешиваются, разъединяются под действием двух противоположных сил - Любви и Вражды. В природе происходит циклический процесс, в котором сначала

\footnotetext{
${ }^{16}$ Мостепаненко 1974.

${ }^{17}$ Цит. по там же: 228.

${ }^{18}$ Степин 2003: 68.
} 
господствует Любовь, соединяющая все элементы - «корни всех вещей», а затем господствует Вражда, разъединяющая эти элементы. Когда господствует Любовь, тогда в мире воцаряется единство, качественное своеобразие отдельных элементов пропадает, образуется Сфайрос - однородная неподвижная масса, имеющая шаровидную форму.

Известны ли современной науке процессы и объекты, обладающие подобными характеристиками? Мы предлагаем следующую естественнонаучную интерпретацию этих любопытных философских идей. Господство Любви, стягивающее материю в единый центр - это процесс, известный науке под термином «гравитационный коллапс». Сфайрос объект, в котором в результате гравитационного сжатия материя стянута в однородную массу, без явного качественного своеобразия отдельных частей, можно, например, проинтерпретировать с помощью такого объекта астрофизики как нейтронная звезда. Нейтронная звезда - очень плотное космическое тело, являющееся одним из возможных результатов эволюции звёзд, в котором гравитационное сжатие привело к тому, что из атомов «выдавлено» пространство между электронами и ядрами, в результате чего всё оно состоит в основном из одних нейтронов. Возможна физическая интерпретация Сфайроса Эмпедокла при помощи ещё более экзотического объекта Вселенной - черной дыры, в котором гравитационный коллапс приводит к ещё более интересным свойствам.

Эмпедокл высказал много других гениальных идей, которые в его время не могли быть проверены эмпирически. Он утверждал, что свету требуется какое-то время для своего распространения, т.е. скорость света является очень большой, но все же конечной величиной. Даже Аристотель в IV в. до н. э. считал это мнение неверным. Эмпедокл, подобно элеатам, признавал закон сохранения - из ничего не происходит ничего. Замечательной была идея Эмпедокла о выживаемости биологических видов, которые отличались целесообразностью. Подобно Анаксимандру он считал, что живое произошло от неживого. Из разных комбинаций организмов, случайно возникающих по мере усиления Любви в мире, выживали наиболее приспособленные. В этом можно заметить зачатки теории эволюции в результате естественного отбора ${ }^{19}$.

Анаксагор (ок. 500 - ок. 428 г2. до н. э.). Утверждал, что в основе мира лежат бесконечно делимые частицы - гомеомерии (греч. «то, что имеет подобные части»). Весь мир состоит из бесконечного количества гомеомерий, каждая из которых содержит в себе гомеомерии вообще всех существующих в мире вещей. Окружающие вещи отличаются друг от друга тем, что в каждой всё же преобладают гомеомерии именно этой вещи. Обычно концепцию Анаксагора характеризуют фразой «всё во всём». Согласно его взглядам, мы не можем представить себе самую маленькую частицу, которая бы не делилась дальше, ибо, увеличив масштаб её рассмотрения, мы обнаружим в ней более мелкие самоподобные части. Можно ли найти в современной науке какой-либо объект с подобными ${ }^{19}$ Семушкин 1985. 
характеристиками и приложимы ли подобные свойства к каким-либо реальным явлениям природы? Математик Бенуа Мандельброт (1924-2010) в 1970-е гг. ввел понятие фрактала: «Фракталом называется структура, состоящая из частей, которые в каком-то смысле подобны целому» ${ }^{20}$. Главное свойство фрактала - это одинаковая (похожая) структура при рассмотрении в разных масштабах. Известно множество примеров объектов окружающего мира, обладающих фрактальной природой. Растения, береговая линия, снежинка, узор на окне, облако, нервная система человека и др. Примеры повторения структуры даёт физика элементарных частиц и астрономия (явление кластеризации галактик). Фракталы широко используются в технике. В радиотехнике конструируют фрактальные антенны (например, антенна на основе кривой Коха), обладающие лучшими эксплуатационными характеристиками по сравнению с обычными антеннами тех же размеров. Фрактальные алгоритмы используют: в компьютерной графике; для сжатия изображений и видеозаписей; в криминалистике для экспертизы звуковых фонограмм; в медицине для моделирования системы кровеносных сосудов, нейронных сетей; для моделирования экономических процессов. Лингвисты рассматривают язык как фрактальную структуру, на основе чего производят более глубокий анализ текста. На наличие повторения структур на разных уровнях науки указывали некоторые ученые, например, Ли Сегель, Людвиг фон Берталанфи. «Фракталы предлагают новый взгляд на мир, благодаря которому он представляется не скоплением простейших элементарных составляющих, а сложной системой, тем не менее обладающей сходством на разных уровнях и масштабах. Такой подход на данный момент начинает развиваться в науке, следовательно, можно сделать вывод, что позиция Анаксагора “всё во всем", если и не является единственно верной, то все же незаслуженно забыта и более справедлива, чем может показаться» ${ }^{21}$.

Демокрит (ок. 460 - ок. 370 z2. до н. э.). Описывал мир как систему неделимых вечных атомов, движущихся в Великой Пустоте согласно механическим причинам. Поскольку атомы различаются по форме и размерам, то некоторые из них подходят друг другу по конфигурациям и могут соединяться вместе в тела, тогда как другие - нет. В этом Демокрит отчасти предвосхитил проблематику валентности в химии. Атомы не могут соприкасаться, поскольку все, что не имеет внутри себя пустоты, является неделимым, т.е. единым атомом. Между двумя атомами всегда есть хотя бы маленькие промежутки пустоты, так что даже в обычных телах есть пустота. Отсюда следует, что при сближении атомов на очень маленькие расстояния между ними начинают действовать силы отталкивания. Это также подтверждается современной наукой, так как при сближении атомов их положительно заряженные ядра начинают отталкиваться. Великий американский физик Ричард Фейнман в своих лекциях писал, что если бы в результате мировой катастрофы научные знания оказались бы уничто-

${ }^{20}$ Цит. по Коломийцев 2016: 37.

21 Там же: 40. 
женными и к грядущим поколениям перешла бы только одна фраза, несущая наибольшую информацию об исчезнувшей науке, то это была бы фраза - все тела состоят из атомов» ${ }^{22}$. Атомы двигаются в Пустоте в любых направлениях с разными скоростями. Если на их пути не встречаются другие атомы, то они продолжают движение, которое само по себе не нуждается в объяснении, причину нужно искать только для изменения движения. По сути, это чёткая формулировка принципа инерции - основы всей классической физики. Галилей, которому обычно приписывают открытие инерции, признавал, что корни этого принципа уходят в античный атомизм. Великая Пустота пространственно бесконечна. В первоначальном хаосе движущихся атомов спонтанно образуется вихрь. Тяжелые тела, образующиеся в вихре, имеют тенденцию скапливаться вблизи центра, а более легкие вытесняются ближе к периферии вихря. Опять-таки, эти представления в первом приближении воспроизводят то, как, согласно современной науке, возникают протозвёзды и протогалактики.

Демокрит - сторонник концепции множественности миров. Если в данном месте пространства возникло вихреобразное движение атомов, приведшее к формированию нашего мира, то схожий процесс должен происходить и в других местах, приведя к формированию других миров. Получающиеся миры не обязательно одинаковы. Все миры движутся в разных направлениях, поскольку равноправны все направления и все состояния движения. При этом миры могут сталкиваться, разрушаясь. Последнее представление тоже подтверждается современной астрономией, фиксирующей столкновение галактик во Вселенной с освобождением колоссальной энергии. Астрономы предполагают, что наша галактика, Млечный Путь, может столкнуться с галактикой Андромеды через пять миллиардов лет. Предполагается, что в этом случае две спиральные галактики сольются в одну эллиптическую галактику. Демокриту принадлежит гениальная догадка, что Млечный Путь является множеством звезд, расположенных на таком маленьком расстоянии друг от друга, что их изображения сливаются в единое слабое свечение.

В Новое время интерес к атомистической концепции возрос благодаря трудам французского математика и философа Пьера Гассенди (1592-1655). Он полагал, что атомов существует не бесконечное число, однако всё окружающее многообразие происходит оттого, что они могут соединяться по-разному, и ввел понятие «молекула» (лат. - уменьшительное от слова «масса»), обозначающее небольшую группу атомов. Но самую большую популярность атомизму принёс английский учёный Джон Дальтон (1766-1844). «Введя понятие “атомный вес”, Дальтон стал первым ученым, составившим таблицу атомных весов некоторых известных на тот момент времени химических элементов. Благодаря принятию атомистического учения Дальтону удалось открыть и объяснить закон кратных отношений. Так, гипотетическая концепция Демокрита стала

${ }^{22}$ Цит. по Степин 2003: 609. 
научной теорией, а несмотря на то, что атом еще оставался для человека невидимым, понятие атома приобрело вполне конкретный смысл» ${ }^{23}$.

Платон (ок. 429-347 г2. до н. э.). Синтезировал представления об элементах и атомистическую теорию строения вещества. В «Тимее» пишет, что элементы - огонь, воздух, вода и земля - не являются простейшими составными частями предметов, а сами состоят из мельчайших частиц, которые обладают сложной внутренней структурой, могут разрушаться, переходить друг в друга, имеют разные формы и величины. Платон приписывает им формы четырех правильных многогранников - куба, тетраэдра, октаэдра, икосаэдра, соответствующих земле, огню, воздуху и воде. Частицы могут переходить друг в друга благодаря преобразованию одних многогранников в другие за счёт перестройки их внутренних структур. Для этого в их фигурах должно быть нечто общее. Таким общим является грань этих фигур, представляющая собой правильный треугольник.

Предложенные американским физиком М. Гелл-Манном и независимо от него Дж. Цвейгом фундаментальные частицы материи - кварки обладают некоторыми характеристиками, подобными платоновским элементарным треугольникам. И те, и другие не существуют по отдельности, в свободном состоянии; их свойства определяются числом 3. Существует три поколения кварков, три цвета кварков, электрический заряд кварка равен одной трети или двум третям заряда электрона и т.д. Как заключает И.Д. Рожанский, изложенная в «Тимее» атомистическая концепция Платона «представляет собой поразительное, уникальное и в каких-то отношениях провидческое явление в истории европейского естествознания» 24 . В теории кварков пока остаются открытыми следующие вопросы: почему ровно три цвета и три поколения кварков? Случайно ли совпадение числа цветов и поколений? Случайно ли совпадение этого числа с размерностью пространства в нашем мире? Из чего состоят кварки? Как кварки складываются в адроны? Откуда берется такой разброс в массах кварков?

В своей статье большое влияние некоторых идей Платона на современную космологию отмечает В.В. Казютинский, ссылаясь на мнения многих физиков, космологов, философов, среди которых В. Гейзенберг, Дж. Джинс, Р. Пенроуз, А. Уайтхед ${ }^{25}$. Показательно высказывание английского физика и математика Пенроуза: «Но можно ли сказать, что платоновский математический мир действительно существует (в каком бы то ни было постижимом смысле этого слова)?.. Точка зрения Платона обладает огромной научной ценностью, прежде всего потому, что проводит четкое разделение между точными математическими объектами и теми приближениями, что мы наблюдаем в физическом мире вокруг нас» ${ }^{26}$. Это общее для многих учёных мнение санкционирует широкое использование метода математической гипотезы в космологии.

\footnotetext{
${ }^{23}$ Коломийцев 2016: 35-36.

${ }^{24}$ Цит. по Кохановский, Зототухина, Лешкевич, Фатхи 2003: 106.

${ }^{25}$ Казютинский 2010.

${ }^{26}$ Цит. по там же: 170.
} 
Велико оказалось влияние идей Платона на британского физикатеоретика, астронома и математика Джеймса Джинса. «Стены пещеры, в которой мы заключены, есть пространство и время, тени реальности, которые мы видим спроектированными солнечным светом извне, есть элементарные частицы, которые мы видим движущимися на фоне пространства и времени, тогда как реальность вне пещеры, порождающая эти тени, находится вне пространства и времени» ${ }^{27}$. Получается, как и у Платона, подлинная реальность, порождающая физические явления, имеет трансцендентную природу, а физическая реальность (мир явлений) образует лишь «сечение мира реальности». В другом месте Джинс проводит такую аналогию, что тени на стенах пещеры - не что иное, как двумерные проекции трехмерной реальности, космологические же феномены, по его мнению, представляют собой четырехмерные проекции многомерной «последней реальности» ${ }^{28}$. Тем самым Джинс как бы предвосхитил современные представления о пространствах многих измерений. Казютинский отмечает: «В самом деле, мы, обитатели Метагалактики, все же чем-то похожи на узников пещеры Платона, которые не могут выглянуть за горизонты событий. Мы судим о реальности по проникающим в пещеру теням, проектирующимся на ее стены. Это - смутные тени идей, создаваемых современной теоретической физикой. Они могут помочь нам в познании реальности за пределами Метагалактики, но могут и направить по ложному пути. Мы довольно плохо знаем даже то, как устроена наша «пещера», т.е. Метагалактика, не говоря уже о внеметагалактических реальностях; не знаем даже, существуют ли другие вселенные с их необычными свойствами, и т.д. Так что образ платоновской пещеры, на мой взгляд, очень хорошо коррелирует с миром современной космологии» ${ }^{29}$. В статье В.В. Казютинского рассматривается и космологическая концепция Дж. Мантзоса. «Начальным состоянием, из которого все возникло, является для него, как и для большинства современных космологов, первичный вакуум, флуктуации которого и породили нашу Вселенную. Относительно оригинальный момент его концепции, вытекающий из платонистской философской позиции автора, состоит в том, что законы квантовой механики или, точнее, математика квантовой механики существовала всегда (“нерожденная математика")»). Важный вывод в этой обстоятельной статье состоит в том, что «...попытки нового осмысления платоновского “Тимея” стимулируются исследовательской спецификой современной космологии. Эта физическая наука применяет метод, при котором сначала создается математический "скелет" космологической теории, а уже потом он сопоставляется с наблюдениями... Ум теоретика как бы “творит” математические формы и структуры, из которых потом с помощью эмпирических и внеэмпирических критериев когерентности

\footnotetext{
27 Jeans 2008: 131-132.

28 Jeans 2009.

${ }^{29}$ Казютинский 2010: 169.

30 Там же: 174.
} 
знания, простоты, красоты и т.п. отбираются наиболее перспективные. Но выступает ли этот познавательный механизм «творением» самого мира? Вовсе не обязательно. “Демиурги” - космологи творят лишь возможные образы мира или космоса, но не самого мира вне нас» ${ }^{31}$.

Итак, как мы видим, некоторые идеи Платона продолжают вдохновлять учёных на новые подходы к объяснению реальности. И вопрос даже не в том, какие из этих концепций будут в дальнейшем признаны истинными, а в том, что учёный, испытывая трудности при дефиците информации, исчерпав ресурсы своей области знания, всегда может обратиться к философии как хранилищу лучших бессмертных идей человечества, всегда открытых к новым интерпретациям. Как справедливо констатирует С.А. Лебедев: «В принципе никто не отрицает влияние философских представлений на развитие и особенно оценку научных достижений. История науки и, в частности, высказывания на этот счёт её великих творцов, не оставляют в этом никаких сомнений» ${ }^{32}$. Отец медицины Гиппократ когда-то произнёс: «Врач-философ подобен Богу». Мы можем перефразировать Гиппократа: «Учёный-философ подобен Богу!».

\section{БИБЛИОГРАФИЯ/REFERENCES}

Альжанов Р.Г., Губанов Н.И. К проблеме идеальности общественного сознания (о возможности кодово-семиотического подхода) // Философские науки. 1983. № 3. С. 52-58 [Al'zhanov R.G., Gubanov N.I. K probleme ideal'nosti obshchestvennogo soznaniya (o vozmozhnosti kodovo-semioticheskogo podhoda) // Filosofskie nauki. 1983. № 3. S. 52-58].

Губанов Н.И., Губанов Н.Н. Об универсальной концепции истины // Вестник Воронежского государственного университета. Серия: Философия. 2016. № 3 (21). C. 21-32. [Gubanov N.I., Gubanov N.N. Ob universal'noj koncepcii istiny // Vestnik Voronezhskogo gosudarstvennogo universiteta. Seriya: Filosofiya. 2016. № 3 (21). S. 21-32].

Губанов Н.И., Губанов Н.Н. Критический анализ концепций персонализма и расширенной психики // Философские науки. 2017. № 12. C. 88-106. [Gubanov N.I., Gubanov N.N. Kriticheskij analiz koncepcij personalizma i rasshirennoj psihiki // Filosofskie nauki. 2017. № 12. S. 88-106].

Дубровский Д.И. Субъективная реальность // Философская антропология. 2018. № 2. C. 186-217. [Dubrovskij D.I. Sub"ektivnaya real'nost' // Filosofskaya antropologiya. 2018. № 2. S. 186-217].

Казютинский В.В. Платон и современная космология // Эпистемология \& философия науки. 2010. T. XXVI. № 4. C. 167-176. [Kazyutinskij V.V. Platon i sovremennaya kosmologiya // Epistemologiya \& filosofiya nauki. 2010. T. XXVI. № 4. S. 167-176].

Коллинз Р. Социология философий: глобальная теория интеллектуального изменения. Новосибирск: Сибирский хронограф, 2002. 1280 с. [Kollinz R. Sociologiya filosofij: global'naya teoriya intellektual'nogo izmeneniya. Novosibirsk: Sibirskij hronograf, 2002. 1280 s.].

Коломийцев С.Ю. Демокрит и Анаксагор: сравнение концепций применительно к современной науке // Вестник ВГУ. Серия: Философия. 2016. №. 4. С. 33-41. [Kolomijcev S.Yu. Demokrit i Anaksagor: sravnenie koncepcij primenitel'no k sovremennoj nauke // Vestnik VGU. Seriya: Filosofiya. 2016. №. 4. S. 33-41.].

Кохановский В.П., Зототухина Е.В., Лешкевич Т.Г., Фатхи Т.Б. Философия для аспирантов. Ростов н/Д: Феникс, 2003. 448 с. [Kohanovskij V.P., Zototuhina E.V., Leshkevich T.G., Fathi T.B. Filosofiya dlya aspirantov. Rostov n/D: Feniks, 2003. 448 s.].

Лебедев С.А. Курс лекций по методологии научного познания. М.: Изд-во МГТУ им. Н.Э. Баумана, 2016. 293 c. [Lebedev S.A. Kurs lekcij po metodologii nauchnogo poznaniya. M.: Izd-vo MGTU im. N.E. Baumana, 2016. 293 s.].

\footnotetext{
31 Там же: $175-176$.

32 Лебедев 2016: 56.
} 
Лебедев С.А. Научный метод: история и теория. М.: Проспект, 2018. 448 с. [Lebedev S.A. Nauchnyj metod: istoriya i teoriya. M.: Prospekt, 2018. 448 s.].

Мостепаненко А.М. Пространство и время в макро-, мега- и микромире. М.: Политиздат, 1974. 240 c. [Mostepanenko A.M. Prostranstvo i vremya v makro-, mega- i mikromire. M.: Politizdat, 1974. 240 s.].

Семушкин А.В. Эмпедокл. М.: Мысль, 1985. 191 с. [Semushkin A.V. Empedokl. M.: Mysl'. 1985. $191 \mathrm{~s}$.$] .$

Степин В.С., Елсуков А.Н. Методы научного познания. Минск: Вышэйшая школа, 1974. 152 c. [Stepin V.S., Elsukov A.N. Metody nauchnogo poznaniya. Minsk: Vyshejshaya shkola, 1974. 152 s.].

Степин В.C. Теоретическое знание. М.: Прогресс-Традиция, 2003. 744 с. [Stepin V.S. Teoreticheskoe znanie. M.: Progress-Tradiciya, 2003. 744 s.].

Jeans J. The Mysterious Universe. Cambridge: Cambridge University Press, 2008. 142 p.

Jeans J. Physics and Philosophy. Cambridge: Cambridge University Press, 2009. 236 p.

Губанов Николай Николаевич, доктор философских наук, профессор, кафедра философии, МГТУ имени Н.Э. Баумана: gubапоvпп@таil.ru

Губанов Николай Иванович, доктор философских наук, профессор, заведующий, кафедра философии и истории, Тюменский государственный медицинский универсиmem: gubanov48@mail.ru

\section{The history of scientific ideas through the prism of the history of philosophical ideas}

The article proposes a method that builds a bridge between the history of science and the history of philosophy - a method of parallel reconstruction of the history of the formation of a scientific theory and its philosophical prototype, which is understood as a combination of philosophical premises and foundations of this theory. The method is based on a concept, according to which the actual being of philosophical ideas is, besides the possibilities of their own development, the potential being of scientific ideas. From the vast and multidimensional reservoir of philosophical ideas, the subsequent development of science actualizes and develops only some meanings and only in a historically specific concrete scientific interpretation. We certainly do not know what new reflections in the scientific consciousness one or another old philosophical idea can receive: theoretically, the number of such interpretations is infinite. But in the existing scientific theory, we are able to trace its philosophical background to its most basic premises. According to the authors, the consideration of the history of science in this vein contributes to the vision of intellectual history as a single process in which the history of philosophical ideas and the history of scientific ideas constantly resonate, mutually stimulating each other and merging in the process of intellectual progress. Finding the philosophical foundations of any modern scientific theory allows us to carry out its certain philosophical justification, which in a situation of competition with another scientific theory, ceteris paribus, can serve as an additional argument in favor of this theory.

Keywords: intellectual history, history of ideas, philosophy, science, history of science, history of philosophy.

Nikolay Nikolaevich Gubanov, PhD, Professor; Department of Philosophy, Bauman Moscow State Technical University, gubanovnn@mail.ru

Nikolay Ivanovich Gubanov, Ph.D., Professor, Head of Department of Philosophy and History, Tyumen State Medical University, gubanov48@mail.ru 


\title{
СОЦИАЛЬНЫЕ РАМКИ ИСТОРИЧЕСКОЙ ОТВЕТСТВЕННОСТИ В ПОИСКАХ РАЦИОНАЛЬНЫХ ОСНОВАНИЙ ИСТОРИЧЕСКИХ ОЦЕНОК ${ }^{1}$
}

\begin{abstract}
Автор статьи настаивает на необходимости определения оснований социальной ответственности, чтобы избежать апелляции к эмоциям и моральному дискурсу при оценке исторических событий. Показано, что идеи И. Канта не дают возможности разрешить проблему ответственности вне свободы и концептуализировать коллективную ответственность. Некоторые решения предложены Х. Арендт, осмысляющей политическую ответственность как коллективную. Структурный подход А.М. Янг позволяет перенести акцент на деперсонализацию в условиях большого числа посредников, последствия действий которых невозможно просчитать, и оценивать ответственность в категориях каузальности. Говоря о присвоении коллективной ответственности личностью и оценивая степень ответственности, необходимо учитывать уровень вовлеченности в структуру и качество выполняемых задач.
\end{abstract}

Ключевые слова: историческая ответственность, коллективная ответственность, политическая ответственность, структурный подход, Х. Арендт, А.М. Янг

Дискуссии об исторической ответственности в публицистическом, политическом, историческом дискурсах приводят к размыванию этой категории. Интуитивно понятно, про что идет речь, однако этим словосочетанием называется этическая (или «морально-политическая») оценка событий прошлого ${ }^{2}$, «готовность признать, что те обстоятельства, в которых ты действуешь, твои мысли и потребности в значительной мере есть результат исторического процесса и действий предыдущих поколений» ${ }^{3}$; ответственность может относиться к прошлому или будущему ${ }^{4}$, быть ставкой в спорах политических лидеров и дискуссиях историков. Сам исторический нарратив, который не может быть сведен к совокупности фактов и/или событий, оказывается носителем этического измерения.

Вслед за О.М. Зиновьевой, мы будем трактовать поле исторической ответственности как необходимость извлекать уроки из истории, соглашаясь с тем, что это предполагает «сознательный анализ, выводы и заключения, исключающие саму возможность их двусмысленности, ревизии» ${ }^{5}$. Историческая ответственность может выступать в качестве критерия оценки исторических ситуаций. Этот оценочный фактор не содержится прямо в данном социальном конструкте, но позволяет практически использовать его как основание суждений в отношении различных исторических практик и исторического опыта прошлого. Он же позволяет выстраивать парадигмы исторического будущего ${ }^{6}$ В этой ситуации важным

\footnotetext{
${ }^{1}$ Работа выполнена по результатам исследований, поддержанных грантом Российского научного фонда № 19-18-00421.

2 Томильцева 2016: 8; Лаврухина, Тимошенко 2014.

${ }^{3}$ Переходько 2019.

${ }^{4}$ Smith 2019.

5 Зиновьева 2015.

${ }^{6}$ Авдеева 2019.
} 
представляется различение морального и содержательного аспекта исторического события. Иными словами, эмоциональные факторы, которые зачастую бывают определяющими ка при моральной оценке события прошлого, так и при осмыслении его содержательной части, задают риски искажения исторических событий и избирательности исторического сознания. Причина может быть не только в большой символической нагруженности этой категории, но прежде всего в отсутствии четких рациональных (а не эмоциональных) оснований исторической ответственности.

Такие рациональные основания мы будем искать в философии и социальной теории. Представляется, что это позволит избежать смешения этических и политических порядков при обсуждении исторической ответственности и, избегая морализаторства, крайностей юридического и этического подходов, создать концепцию исторической ответственности, применение которой в исторических исследованиях будет способствовать рациональному переосмыслению и исследованию событий прошлого. Для решения этой задачи подходят некоторые идеи исследователей корпораций и трудовой ответственности, которые, используя выводы теоретиков политической ответственности, ищут для них другие основания или, анализируя одинаковые кейсы, приходят к иным результатам. Мы не предполагаем обращения к истории понятий, хотя, некоторые замечания (так, П. Рикер отметил, что термин «ответственность» был изначально связан с политической теорией), могут представлять интерес; мы также не обращаемся к хорошо представленной в литературе проблеме соотношения юридического и этического дискурса об ответственности.

На первом этапе исследования обратимся к ресурсам этических идей И. Канта, с концептуальным аппаратом которого связаны истоки осмысления исторической ответственности. Рассматривая возможные основания для ответственности, Кант сделал акцент на свободе выбора, присущей только человеку. В соответствии с постулируемым Кантом нравственным императивом, главное проявление свободы заключается в том, что человек может следовать нравственному закону или не следовать ему, но, принимая решение, свободный человек затем несет ответственность за последствия этого решения. Такая линейная каузальность основана на идее вменения ответственности, выступающей таким образом, как прямое следствие предыдущих действий/решений. Поэтому так важно разбираться в себе «по моральному совершенству в отношении твоего долга - познай своё сердце» ${ }^{7}$.

В основе тезиса лежит убеждение в существовании четких критериев, позволяющих отличить добро от зла, т.е. человек способен сознательно сделать рациональный выбор в пользу правильного решения. Несмотря на акцент на этические аспекты ответственности, Кант описывает моральное вменение как аналогичное юридическому, отличающееся только апелляцией к нравственному закону, что затрудняет осмысление корреляции между чувственными и моральными аспектами принятия

\footnotetext{
${ }^{7}$ Кант 1999: 835.
} 
решений. Поступок, совершенный в соответствии с велением долга, скорее будет поставлен в заслугу, чем решение, принятое с опорой на чувственные основания, но с другой стороны, использование модели юридического вменения не позволяет различать эти порядки на операциональном уровне. Если, вслед за Кантом, принять, что человек - главный субъект в нравственном мире ${ }^{8}$, то определяющим оказывается не вменение (юридическое, моральное), а априорные основания поступков, выявление которых не имеет эвристической ценности при анализе исторических событий и формировании исторического сознания.

Таким образом, существуют определенные трудности с применением решения Канта для анализа социальных оснований исторической ответственности. Во-первых, довольно сложная категория ответственности связывается им с еще более сложной категорией свободы, т.е., чтобы понять, что такое ответственность, мы сначала должны осмыслить свободу, что требует привлечения дополнительной аргументации и ресурсов (поэтому посткантовская линия исследования исторической ответственности связана с попытками концептуализировать ответственность вне свободы). Во-вторых, можно принять определение свободы, предлагаемое Кантом, но в этом случае нужно согласиться с тем, что за любое решение, принятое в условиях «несвободы», можно не нести ответственность. С учетом того, что влияние различных обстоятельств в той или иной степени имеет место при принятии решений, идеи Канта оказываются плохо применимы для анализа конкретных действий и исторических событий. Например, аргументация многих обвиняемых на нацистском трибунале («Мы исполняли приказ») в логике аргументации Канта должна привести к снятию обвинения. В-третьих, интуиции Канта не применимы в случае коллективной ответственности, однако именно о таком типе мы говорим, рассуждая об исторической ответственности.

Решение некоторых проблем предлагает Ханна Арендт. Немецкие интеллектуалы не могли пройти мимо вопросов вины и ответственности за нацистские преступления. Вместо личной ответственности, концептуализируемой Кантом, Арендт предлагает говорить о политической ответственности как той форме ответственности, «которую каждое правительство несёт за все решения своих предшественников, а каждый народ - за свершения и прегрешения прошлого». Это позволяет говорить о событиях прошлого, избегая ссылок на социальный порядок, не оставляющий выбора, однако при такой форме ответственности вина как бы растворяется, соответственно, «виноватого» нет. Поэтому Арендт настаивает на том, что коллективной вины быть не может, «вина и невиновность имеют смысл только в отношении отдельной личности» 9 .

Но ведь речь идет о признании вины не отдельными людьми, как в случае юридического вменения, а целым сообществом, что важно при осмыслении исторических событий. Поэтому можно говорить о присвое-

\footnotetext{
${ }^{8}$ Кант 1999: 240.

${ }^{9}$ Арендт 2013б: 58-60.
} 
нии коллективной ответственности: отдельный представитель коллектива чувствует свою личную ответственность за то, что делает он как представитель коллектива; коллективная ответственность в таком случае ощущается как личная, т.е. современный немец, невиновный в совершении нацистских преступлений, готов отвечать за их последствия, потому что он немец. Однако этот тезис, на признании которого строятся практики немецкого покаяния, при детальном рассмотрении, может трактоваться как не менее нацистский, чем те, которые вызывали Холокост или преследования цыган. Если человек должен отвечать только по причине своей национальной принадлежности, то в чем принципиальная разница между убеждениями, например, в вине евреев? Мы в данном случае не претендуем на пересмотр существующих практик покаяния, но подчеркиваем, что вменение вины только по факту принадлежности к сообществу, которая не является фактом выбора, не соответствует нашим критериям осмысления исторической ответственности.

Как и Кант, Арендт подчеркивает необходимость сознательной оценки ситуации и рационального выбора при принятии решений, но она описывает ситуацию, в которой разделение на добро и зло затрудне-но, скорее, приходится отдавать предпочтение (если выбор вообще возможен) в пользу меньшего из зол. Поэтому ее концептуализация политической ответственности оставляет мораль только в сфере отношений индивидов. Если мораль, продолжим мысль Арендт, касается только личных отношений, то какие основания лежат в основе практик покаяния немцев тех поколений, которые не участвовали в Холокосте? (даже немцевсовременников Холокоста). Предвосхищая возражения, Арендт говорит о солидарности, связи ответственности и коллективной идентичности, в основе которой лежит понимание индивидом того обстоятельства, что принадлежность к сообществу накладывает на него необходимость быть ответственным за деяния этого сообщества, даже в том случае, если он лично имеет к ним опосредованное отношение ${ }^{10}$, но если формы коллективной ответственности можно объяснить, исходя из каких-либо уже существующих теорий солидарности, то понятие ответственности оказывается эвристически бессмысленным следствием солидарности, а говорить о согласии в условиях диктатуры невозможно.

Решение Арендт не устраивает нас по нескольким основаниям. Вопервых, проблемным остается соотношение личной и коллективной ответственности, что особенно важно при осмыслении исторических событий. Сведение коллективной ответственности к личной может нивелировать дискурс исторической ответственности к юридическому, так как вина, ответственность индивидов являются, в основном, предметом исследования юристов, к тому же, историческая ответственность предполагает осмысление причинно-следственных связей в рамках масштабных событий и, признавая ответственность личности за ход исторических процессов, мы перечеркиваем многочисленные дискуссии о роли лично-

${ }^{10}$ Арендт 2013a: 207. 
сти в истории; опять же, при разговоре об исторических событиях невозможно говорить только об одном виновном. Во-вторых, убеждение в необходимости рационального осмысления и сознательного выбора противоречит тезису о том, что в условиях диктатуры субъектом является только сам диктатор. Поэтому, с одной стороны, нужно учитывать, что ситуация ответственности может быть только для потомков, которые уже в условиях относительно свободного государства отвечают за совершивших действия, или обратить внимание на необходимость разделения исторической ответственности и вины, с другой - рассмотреть сложности соотношения осмысления своих решений и солидарности с сообществом. Таким образом, некоторые интуиции Арендт позволили говорить о политической ответственности как коллективной в противовес акценту на личной ответственности, постулируемой Кантом. Мы также соглашаемся с необходимостью рационального осмысления поступков как критерия ответственности. Однако проблемным остается противоречие между солидарностью с сообществом и личным решением, ответственность за которое несет человек и сообщество.

Если Кант концептуализировал личную ответственность как следствие свободного выбора, то Арендт, сохраняя кантовскую интуицию о необходимости рационального осмысления поступков, разрабатывает теорию политической (полисной) ответственности. Однако есть определенная сложность как с акцентом на рациональном осмыслении и принятии ответственности, так и с солидарностью с сообществом. Попробуем разрешить эти сложности с опорой на идеи А.М. Янг. В своей работе «Ответственность и глобальная трудовая справедливость» она анализирует ответственность агентов в связи со структурной несправедливостью, которую рассматривает на примере кейса с транснациональными корпорациями и общественным движением, выступающим против плохих условий труда работников на предприятиях швейной промышленности. Мы считаем, что ее идеи насчет ответственности в рамках транснациональных корпораций, высказанные в этой статье, и обоснование структурных аспектов ответственности в других ее работах ${ }^{11}$, можно применить для разрешения указанных выше противоречий.

В больших корпорациях отдельный работник испытывает трудности с тем, чтобы определить реальные последствия своих действий, так как они растворяются в последствиях действий других людей. Но ответственность - не вопрос оценки последствий: Янг обращает внимание на соучастие в причинах действий, а не анализе последствий. Это перекликается с идеями о необходимости осмысления своих действий, но Янг переставляет акценты с описываемого Арендт отсутствия свободного выбора как самооправдания на деперсонализацию в условиях большого числа посредников, влияния конкретных людей/сообществ на какую-либо ситуацию, просчитать последствия которой почти невозможно. Это и дает право Янг, в отличие от Арендт говорить о структурном подходе,

${ }^{11}$ Young 2003; Young 2005. 
опираясь на который можно рассуждать о коллективной ответственности. Янг тоже использует концепцию политической ответственности, но вместо модели полиса говорит о структурных процессах ${ }^{12}$. Этот ход позволяет избежать противоречия между личным рациональным решением и принадлежностью к сообществу, на которое мы обратили внимание в позиции Арендт. В своей терминологии Янг говорит не о солидарности, а о распределенной ответственности в рамках одной структуры (ниже мы вернемся к этому основанию), но эта распределенность впервые после Канта позволяет говорить об ответственности вне рационального индивидуального субъекта. Это не значит, что конкретный индивид не имеет никакого влияния. У Янг ответственность из явления (состояния) становится отношением. Если ответственность оказывается отношением, то человек (отвечающий) выступает, пусть и одним из, но все-таки актором, т.е., от его действий, наряду с другими акторами, также зависит результат. Поэтому он не может снимать с себя ответственность, хотя и не является единственным отвечающим. Янг опирается на идеи Оноры О'Нил утверждающей, что сфера моральных обязательств агента (актора) распространяется на тех, кого агент включает в свою деятельность. Причем О'Нил подчеркивает асимметричность этих обязательств, что, на наш взгляд, свидетельствует о неравнозначности ответственности участников процесса. Работники менее ответственны, чем топ-менеджеры, но это не означает, что в рамках одной структуры ответственность работников совсем отсутствует. Согласно Янг, жертвы системы несут ответственность и обязаны добиваться перемен. Не имеет значения личная мотивация соучастников, мы обращаем внимание только на их место и роль в структуpe, однако фактор осознания своей возможной роли и места также важен. «Я не могу избежать этих обязательств, заявляя, что я не участвовал в проектировании производственных отношений, или говоря, что я не знаю, кем все эти люди являются и где они находятся. Я знаю, что связан с ними одними институтами и процессами. Моя первая ответственность состоит в том, чтобы получить более конкретные знания» ${ }^{13}$. Частью структуры, о которой говорит Янг, являются потребители, которые, ориентируясь на более дешевый продукт, оказываются ответственны за плохие условия труда работников и влияют своей потребительской активностью на действия топ-менеджеров и владельцев предприятий.

Структурный подход к коллективной ответственности противостоит рассмотренным кейсам, где может идти речь об ответственности целого сообщества, выбор которого конкретные индивиды не осуществляли. Янг подчеркивает, что «основания ответственности лежат не в политических структурах нация-государство и не в самосознании людей и их связях с другими людьми, а в объективных системных институциональных отношениях». Так понятая ответственность оказывается следствием идентификации с сообществом и возникает в момент этой идентификации. При-

12 Young 2004: 368.

13 Young 2004: 372. 
чем, как видно из этой цитаты, Янг отдает приоритет институциональной идентичности над национальной, государственной, семейной. Выше мы рассматривали проблему солидарности с сообществом с опорой на взгляды Арендт, но структурный подход заставляет вернуться к ней на другом уровне. «Политическая ответственность вытекает из социальных и экономических структур, которые действуют и взаимно влияют друг на друга, а политические институты являются важным средством выполнения ими этих обязанностей» ${ }^{14}$. Поэтому человек не может за что-то отвечать только по факту своего рождения, но если выбирает какое-либо сообщество (например, корпорацию), то в дальнейшем ответственен не только за свои действия в рамках этого сообщества, но и за действия сообщества вообще. Данная точка зрения сохраняет кантовскую интуицию свободного выбора, но это выбор не конкретного действия/решения, а выбор работы, деятельности, сообщества, определяющий дальнейшие действия / peшения и, соответственно, ответственность за них. Находясь в выбранном сообществе, субъект теряет часть своей свободы (и предлагаемая Кантом модель уже неприменима), так как подчиняется требованиям и нормам сообщества, но может влиять на эти требования и нормы в зависимости от позиции, которую занимает в этом сообществе.

При этом, так как ответственность у Янг является распределенной (о чем мы писали выше), отдельный индивид, какие бы решения он ни принимал, не может прямо переопределить ситуацию. В примерах, описываемых Янг, если один покупатель отказывается приобретать продукцию, производитель которой замечен в несоблюдении условий труда работников для минимизации издержек, это не сможет трансформировать текущее положение дел, но, наверное, если бы этот индивид инициировал кампанию в социальных сетях, которая получила бы популярность или обратил внимание крупных корпораций (если бы имел такую возможность) на эту ситуацию, то это могло иметь результат. Но в этом случае действующим выступал бы уже не отдельный индивид, а сообщество. К тому же защита прав работников может привести, например, к повышению цен на продукцию, что вызовет ее недоступность для некоторых категорий покупателей или к закрытию этого сегмента продукции предприятием, что приведет к безработице. В конце концов, в современном мире человеку практически невозможно не быть связанными со структурами, которые производят несправедливость ${ }^{15}$, но - хотя Янг об этом не пишет - это не избавляет нас от ответственности.

Проблемой в предлагаемой трактовке является то, что субъект ответственности признается тождественным сообществу, совершающему определенные действия, хотя этот тезис не очевиден, если мы обратимся к конкретным историческим примерам. Делает ли человека ответственным факт службы в НКВД или только его подпись на «расстрельных» документах? Янг подчеркивает, что признание лица или группы лиц ви-

\footnotetext{
14 Young 2004: 371-372.
}

15 Young 2004: 386. 
новными в совершении преступления означает, что другие оказываются невиновными, но как отделить одних от других и тождественна ли в таком случае вина ответственности? Жертвы, виновные, наблюдатели части одного сообщества, но определение степени их ответственности должно осуществляться не через самоидентификацию или следствия принимаемого решения, а путем анализа степени включенности в сообщество. Разрешить это противоречие Янг помогает обращение к работам Роберта Гудина. В отличие от концепций политической ответственности, Гудин предлагает ответственность за исполнение задач, т.е. дело не столько в принадлежности к сообществу, сколько в том, какие задачи в рамках этого сообщества решает индивид. Это решение позволяет избежать крайностей теории политической ответственности (все отвечают за все), но оно не позволяет нам дальше продвинуться в исследовании исторической ответственности как коллективной. Опираясь на идеи Гудина, Янг отмечает важность вовлеченности в дела сообщества, через которую она описывает полномочия и способность влиять на структурные процессы: принимающие решения о депортации более ответственны, чем непосредственные исполнители, однако последние ответственны уже тем, что связали свою жизнь (или определенный ее период) со структурой, в рамках которой они обязаны совершать такие действия.

Такой подход требует определения границ сообщества. Производители и покупатели (подписывающие приказ и репрессированные) - это разные сообщества или они являются представителями одной структуры? Если мы признаем их разными сообществами, то столкнемся с другими противоречиями, в частности, с необходимостью поиска (или конструирования) теоретической рамки, которая позволит анализировать кейсы, связанные с тем, что индивид или группа могут переходить из одного сообщества в другое (подписывающий приказ оказывается репрессированным), а потомок, принимающий на себя ответственность, может иметь родителей, относящихся к разным сообществам. Жертва не перестает быть ответственной за последствия тех преступлений, которые она совершила, когда была палачом. Если мы говорим о признании ответственности всем сообществом, включающим в себя условных «палачей» и «жертв», то следует обратиться к самому понятию «признание ответственности». Существует хрестоматийный для всех исследователей этой тематики кейс о немецком покаянии, т.е. немцы признали свою ответственность за преступления нацистского режима и сделали это добровольно - без вменения. Однако значит ли это, что каждый современный житель Германии (даже если мы будем говорить только об этнических немцах, что тоже не совсем корректно) сознательно в какой-то момент взял на себя эту ответственность? При этом, говорить о «непризнании» ответственности также невозможно, во-первых, потому что это поставит под сомнение весь кейс, во-вторых, немцы платят налоги, часть средств из которых идет на выплаты «жертвам», в-третьих, и это представляется основным, другие сообщества оценивают немцев в соответствии с обра- 
зом. Мы не знаем, что думает и чувствует каждый немец, но он находится в структуре, детерминирующей определенные его действия, т.е. оказывается в ситуации ответственности. Можно говорить о присвоении коллективной ответственности индивидом. Таким образом, речь идет не об индивидуальном осмыслении индивидом каждой ситуации и принятии рациональной ответственности, а о социальных действиях, определяющих эту ситуацию. Другой проблемой использования выводов Янг для исследования исторической ответственности может стать то, что ее система направлена на соучастников действий в настоящем времени, независимо от того, насколько далеко в пространстве друг от друга они относятся. Историческая ответственность предполагает, что мы говорим об ответственности за действия, совершенные в прошлом, непосредственными исполнителями которых члены сообщества не являлись. Однако Янг подчеркивает, что только дополняет концепцию политической ответственности своим структурным подходом, т.е. основные постулаты политической ответственности Арендт, в т.ч. идея об ответственности «невиноватых», не противоречит ее идеям. Важным оказывается не только принадлежность к сообществу (пассивный фактор), но и оценка задач, которые исполнялись в этом сообществе.

Использование интуиций И. Канта, Х. Аренд и А. Янг, позволяет описать некоторые аспекты социальной оптики ответственности, которые мы можем применить для трактовки исторической ответственности.

1. Об ответственности, в т.ч. исторической, можно говорить только в условиях свободы. Но чтобы избежать сложностей с концептуализацией категории свободы и выявлением корреляции степени свободы и ответственности, мы будем говорить об интенции действующего, определяющей его поступки. Если в случае личной ответственности человек отвечает за совершенные им деяния (или недеяния, по Веберу), то в случае коллективной (исторической) ответственности, человек делает выбор в пользу того или иного сообщества и, оказываясь его частью, отвечает за действия сообщества, а значит, структурный подход к ответственности распространяется только на сообщества, выбор которых можно называть сознательным (например, корпорации, но не нации). Поэтому при анализе конкретного исторического кейса первоначальную интенцию личности можно опустить и говорить только о коллективном действующем.

2. Необходимо говорить не о личной ответственности, а о присвоении коллективной ответственности личностью. При этом, ответственны все индивиды, связанные со структурой (например, не только топменеджеры и владельцы предприятий, но и те, кто использует произведенные этими предприятиями продукты). В этом тезисе Янг расходится с Арендт. Если ответственны не только палачи, но и жертвы, то значит ли это, что за репрессии ответственны репрессированные? Здесь можно напомнить фразу С. Довлатова «Кто написал 4 миллиона доносов?». Мы не говорим об их вине, но в соответствии с предлагаемой теорией, должны говорить об ответственности. 
3. Ответственность, таким образом, носит распределенный характер, но это не значит, что все члены сообщества отвечают в равной степени. Отталкиваясь от идей Гудина, мы, вслед за Янг, настаиваем на том, что необходимо учитывать степень вовлеченности в структуру и качество выполняемых задач.

4. Таким образом, поставленный выше вопрос можно переформулировать в следующую задачу: позволяют ли социальные структуры создать субъект, который обладает всей степенью ответственности? От реализации этой задачи зависит постановка целей исторического исследования. Мы не ставим себе целью в рамках этой статьи предложить однозначный ответ на этот вопрос, однако можем наметить некоторые варианты разрешения. В этой ситуации ключевым оказывается вопрос возможности социальных практик, конструирующих как субъекта ответственности, так и культивирующих историческую ответственность как отношение. Практики предшествуют формированию субъекта, однако сама постановка вопроса о возможности практик предполагает, что этот вопрос уже должен кто-то задавать. Этот «кто-то» еще не является субъектом, но должна существовать определенная контингентность, в которой задается этот вопрос.

Предлагаемая схема несовершенна. Так, она не позволяет разрешить проблему измерения исторической ответственности или допустимости такой постановки вопроса вообще. Есть ли сроки давности преступлений, т.е. должны ли еще 5 поколений немцев каяться за преступления фашизма? Должны ли еще 5 поколений евреев помнить про Холокост? Мы также не можем ответить на вопрос, при каких условиях стоит говорить об ответственности, если индивид оказывается связан с разными сообществами, что может привести к ситуации множественных ответственностей, которые вступают в противоречия друг с другом.

Концептуализация исторической ответственности предполагает не возвращение к осмыслению этико-философских коннотаций содержательного поля, а возможность использования имеющихся теоретикометодологических ресурсов в осмыслении конкретных эпизодов реализации исторической ответственности. Приоритетным в этом процессе мы считаем участие субъекта исторической ответственности в организации знания об истории и формирования исторического сознания.

\section{БИБЛИОГРАФИЯ / REFERENCES}

Авдеева И.А. К проблеме определения объекта исторической ответственности. Философия и общество. 2019. № 3. С. 82-94 [Avdeeva I.A. K probleme opredelenija ob\#ekta istoricheskoj otvetstvennosti. Filosofija i obshhestvo. 2019. № 3. S. 82-94].

Арендт X. Коллективная ответственность // X. Арендт. Ответственность и суждение. М.: Издание Института Гайдара, 2013. С. 205-217 [Arendt H. Kollektivnaja otvetstvennost' // H. Arendt. Otvetstvennost' i suzhdenie. M.: Izdanie Instituta Gajdara, 2013. S. 205-217].

Арендт X. Личная ответственность при диктатуре // Арендт X. Ответственность и суждение. М.: Изд. Ин-та Гайдара, 2013. С. 47-82 [Arendt H. Lichnaja otvetstvennost' pri diktature // H. Arendt. Otvetstvennost' i suzhdenie. M.: Izd. Instituta Gajdara, 2013. S. 47-82].

Зиновьева O.М. Этика, политика и историческая ответственность // Вестник Московского университета. Глобалистика и геополитика. 2015. № 1/2. C. 32-34 [Zinov'eva O.M. Jetika, 
politika i istoricheskaja otvetstvennost' // Vestnik Moskovskogo universiteta. Serija 27. Globalistika i geopolitika. 2015. № 1/2. S. 32-34].

Историческая ответственность / под ред. Д.А. Томильцевой. Екатеринбург: Деловая книга, 2016 [Istoricheskaja otvetstvennost' / pod red. D.A. Tomil'cevoj. Ekaterinburg: Delovaja kniga, 2016].

Кант И. Метафизика нравов в двух частях // Основы метафизики нравственности. М.: Мысль, 1999. С. 563-894 [Kant I. Metafizika nravov v dvuh chastjah // Osnovy metafiziki nravstvennosti. M.: Mysl', 1999. S. 563-894].

Лаврухина И.М., Тимошенко С. А. Вина как социально-культурный образ: многообразие подходов // Вестник Донского государственного аграрного университета. 2014. № 2 (12). C. 135-142 [Lavruhina I.M., Timoshenko S. A. Vina kak social'no-kul'turnyj obraz: mnogoobrazie podhodov // Vestnik Donskogo gosudarstvennogo agrarnogo universiteta. 2014. № 2 (12). S. 135-142].

Переходько Я. Историческая вина и историческая ответственность // Medium. URL: https:// medium.com/@yaroslavperekhodko/историческая-вина-и-историческая-ответственность174d16b7e16b [Perehod'ko Ja. Istoricheskaja vina i istoricheskaja otvetstvennost'. URL: https://medium.com/@yaroslavperekhodko/istoricheskaja-vina-i-istoricheskajaotvetstvennost'-174d16b7e16b].

Smith S.G. What We Have Time for: Historical Responsibility on the Largest Scale // Journal of the Philosophy of History. 2019. Vol. 13. Is. 2. P. 163-182.

Young I.M. Political Responsibility and Structural Justice // The Lindley Lecture. 2003. Vol. 41. University of Kansas. URL: https://kuscholarworks.ku.edu/bitstream/handle/1808/12416/ Political\%20Responsibility\%20and\%20Structural\%20Injustice-2003.pdf?sequence=1\&isAllowed=y

Young I. M. Responsibility and Global Justice: A Social Connection Model // Anales de la Cátedra Francisco Suárez. 2005. № 39. Pp. 709-726.

Young I.M. Responsibility and Global Labor Justice // The Journal of Political Philosophy. 2004. Volume 12. Number 4. Pp. 365-388.

Головашина Оксана Владимировна, доктор философских наук, ведущий научный сотрудник Уральского федерального университета, научный сотрудник Томского государственного университета, ovgolovashina@mail.ru

\section{Social Framework of Historical Responsibility: in Search of Rational Grounds for Historical Estimates}

In the proposed article, the author insists on the need to determine the grounds of social responsibility, since this will avoid appeals to emotions and moral discourse when evaluating historical events. At the first step, the author turns to the ideas of I. Kant, showing that the resources of his theory do not allow solving the problems of responsibility outside of freedom and conceptualizing collective responsibility. The author finds some solutions in X. Arendt, conceptualizing political responsibility as a collective one. A.M. Young's structural approach allows us to shift the focus to depersonalization in the conditions of a large number of intermediaries, the consequences of whose actions cannot be calculated, and to assess responsibility in the categories of causality. Thus, the author speaks about the assignment of collective responsibility by an individual; while assessing the degree of responsibility, it is necessary to take into account the level of involvement in the structure and quality of the tasks performed. This allows us to understand the role of historical dynamics actors without emotional and moral assessments.

Keyword: historical responsibility, collective responsibility, political responsibility, structural approach, Arendt, Young.

Golovashina Oksana V., Ph.D., leading research fellow at the Ural Institute of Humanities atUral Federal University, researcher of Tomsk state University, ovgolovashina@mail.ru 


\section{ЦВЕТЫ И МОНЕТЫ: НЕКОТОРЫЕ ОБРАЗЫ АВТОРИТЕТА ТЕКСТА В ПРОИЗВЕДЕНИЯХ ИСИДОРА СЕВИЛЬСКОГО}

В статье обсуждается значение авторитета цитируемого текста в свете дихотомии авторитет текста / авторитет личности в культуре последних веков Поздней Античности на Латинском Западе на материале наследия Исидора Севильского. На основании анализа метафор, связанных с фигурой благоразумного читателя (prudens lector), а именно - собирания цветов и экспертизы монет, делаются следующие выводы: 1) авторитет цитируемых текстов позволяет произведению репрезентировать традицию, а его автору-епископу - «образ отцов церкви». Это определяет символический характер авторитета личности церковного учителя, требующий, в то же время, воспроизведения первообраза; 2) цитируемые тексты образуют поле возможных альтернатив, из которых «разумный компилятор» осмысленно выбирает необходимые для воздействия на читателя; 3) читатель при этом, применяя монашеское искусство памяти, на основании накопленных коннотации использовал авторитетные высказывания для созидания новых смыслов. Таким образом, авторитет текста на рубеже Поздней Античности - Раннего Средневековья скорее оказывается средством обоснования и производства новых смыслов, чем ограничивающей их рамкой.

Ключевые слова: авторитет, Исидор Севильский, благоразумный читатель, компиляция, репрезентация, Поздняя Античность

По замечанию Г. Струмсы, религиозный авторитет в Поздней Античности диалектически выстраивается между текстами и личностями ${ }^{1}$. Характерной чертой эпохи становится то, что божество начинает репрезентироваться в определенных людях (философах, праведниках, священниках $)^{2}$. Они становятся авторами текстов и участниками интеллектуальной культуры, сосредотачивая в руках и определенную власть. В то же время - и в некотором пределе мы видим это в Вестготской Испании - в текстах нивелируются индивидуальные/оригинальные «авторские» черты, они все больше и в большой мере буквально следуют образцам. Нивелируется как саморепрезентация авторов в своих текстах, так и описываемых личностей. Так, пересечения деталей в жизнеописаниях Мартина Турского и Мартина Брагского (автора VI в.) позволяют предположить, что его современник Венанций Фортунат в целом описал жизнь Брагского епископа по образу его покровителя, не интересуясь деталями «реальной» биографии ${ }^{3}$.

Вопрос отношений авторитета текста и личности может рассматриваться в разных плоскостях (Кто мог писать текст? Кто мог толковать Писание (с очевидностью, самый авторитетный текст) и как это влияло на авторитет личности? Как в текстах представлялся авторитет личностей? Существовала ли иерархия авторов? и т.д.). В культуре, где цита-

\footnotetext{
${ }^{1}$ Stroumsa 2016: 170.

${ }^{2}$ Brown 1978: 12.

${ }^{3}$ Nascimento 2006: 87-104, особенно: 90.
} 
ты и аллюзии в разных формах составляют основу и ткань создаваемых текстов, особое значение и особое «звучание» получает вопрос о значении авторитета цитаты, которая становится «единицей» текста («компиляции»). Речь пойдет об авторитете текста в особой ситуации. Составитель, строя на цитатах свое сочинение, выступает и как читатель, и как автор. Это отражается в своеобразном преломлении метафорики, связанной с prudens lector - благоразумным читателем. В этом исследовании оно будет рассмотрено в произведениях Исидора Севильского наиболее выдающегося представителя культуры Вестготской Испании.

\section{Чтение как собирание цветов}

Макробий в предисловии к «Сатурналиям» говорит о работе писателя как собирании пыльцы с цветов других произведений и смешении их в мед собственного текста ${ }^{4}$. Автор должен переработать множество высказываний, избрав подходящие. Исидор использует и для чтения, и для письма известный образ луга, на котором растут тернии и розы 5 . Исидор приводит метафору собирания цветов, описывая работу читателя. Он противопоставляет два модуса чтения: «пробегания» текста ${ }^{6}$ и собирания. Во втором случае цитируется Вергилий: «qui legitis flores»7. Характерно, что Беда Достопочтенный, как читатель Исидора, раскрывает эту аллюзию и приводит более полную цитату, из которой становится ясно, что речь идет о предупреждении читателя от «беспечного сбора цветов», т.е. чтения 8 . Такая манера чтения разбивала текст на высказывания (dicta/sententia ${ }^{9}$ ), которые оказывались единицей восприятия текста. Большие единства (из которых могли бы реконструироваться аргументы, «авторская позиция», «основная мысль текста») отходили на задний план. Смысл высказывания не был однозначным. Для Исидора актуально суждение Августина о множестве смыслов Писания, подающихся согласно уровню разумения каждого ${ }^{10}$. В. Ло справедливо переносит эту идею множественности смыслов, их ситуативности и зависимости от читателя и на восприятие других текстов в эту эпоху ${ }^{11}$.

Смысл текста не воспринимался как «объективный», т.е. познаваемый при условии правильного методического использования разума (что хорошо сознавалось философами эпохи Просвещения ${ }^{12}$ ). Не только еретики, по Исидору, но и «гордые читатели» и «плотские читатели»

\footnotetext{
${ }^{4}$ Macr. Sat. 1, 1, 5-6. Cfr. Sen. ep. 84, 3, где прописана более «творческая» роль автоpa (Pelttari 2014: 26-27).

${ }^{5}$ Isid. expos. pr. ueterum que ecclesiasticorum sententias congregantes, ueluti ex diuersis pratis flores lectos ad manum fecimus... Isid. etym. 10, 154.

${ }^{6}$ Isid. etym. 10, 154: Lector dicitur a legendo, id est percurrendo. Vnde et nauis dicitur legere quicquid transit. Nam "legit", transit, praeterit, ut: Crebris legimus freta concita terris. ${ }^{7}$ Ibid.: Item lector, a colligendo animo quae legit, quasi collector: sicut illud: Qui legitis flores (Verg. ecl. 3, 92).

${ }^{8}$ Beda Venerabilis. In canticum canticorum. Prol.

${ }^{9} \mathrm{CM}$. Codoñer 2014: 3-10.

${ }^{10}$ Isid. sent. 1, 18, 5 .

${ }^{11}$ Law 1995: 4.

12 Шартье 2006: 19-23.
} 
неспособны проникать в смысл Писания ${ }^{13}$. Фавст Манихей, рассуждая о пророчествах, не без иронии говорит ${ }^{14}$ об извлечении нужных фраз (используя широкий метафорический ряд, в т.ч. «избирание» рыбы, годной в пищу из морской воды, в пищу не годной) и продолжает, что пророчеств Моисея о Христе он не находит. Августин, полемизируя, указывает что Фавст не хочет этой рыбы (не может воспринять смысл выбранного отрывка), поскольку не верит Моисею из-за извращенного и гордого подхода к его пророчествам ${ }^{15}$. В качестве «объективного» условия понимания смысла оказывается определенное совершенство читателя.

Наследие авторов - это некое единство, которое у Исидора изображается в виде лугов (prata), где растут как шипы, так и розы ${ }^{16}$. Р. Стар, рассматривая традицию латинских грамматических комментариев, указывает на активную роль читателя, который должен был выбирать из тех толкований, которые предлагала традиция. Причем этот выбор не рассматривался как однократный - избирание мыслилось как длящийся процесс ${ }^{17}$. Стар, однако, в качестве исходной модели использует образ prudens lector Иеронима Стридонского ${ }^{18}$, который ориентировался не только на традицию комментариев, но и на образ чтения, восходящий к Клименту Александрийскому и Оригену в связи с аграфой «будьте хо-

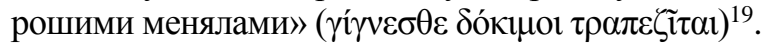

У Григория Великого видим применение метафоры цветов / шипов в отношении чтения Писания. Комментируя речь Элиуя в «Моралиях», Григорий характеризует его как человека ученого и гордого (doctus et adrogans), речь которого содержит и «то, что благоухает», и «то, что колет». Григорий использует образ не луга, а «сада учения» - в нем следует осторожно собирать цветы высказываний, не поранившись колючками нравов, указывая, что некоторые элементы речи имеют не моральный, а пророческий смысл ${ }^{20}$. Итак, «благоразумный читатель» правильным образом избирает и модус толкования, т.е. прочтение Писания ${ }^{21}$.

Итак, авторитет текстов, находящихся в распоряжении читателя и составителя нового текста, требует не пассивного согласия, а активного определения и выбора нужных, исходя из ситуации читателя, смыслов. Компилятор до определенной степени переписывает и формирует авторитетный корпус высказываний ${ }^{22}$. Р. Кастер замечает, что Сервий (известный грамматик IV-V вв., оказавший значительное влияние на Исидора) рассматривал примеры из текстов «древних» (обладающих aucto-

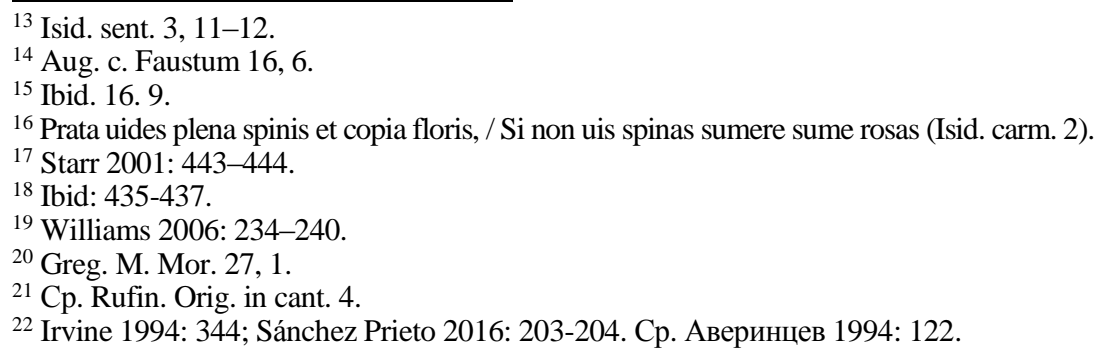


ritas) как множество, скорее контролируемое грамматиком, чем контролирующее его ${ }^{23}$. Техника чтения требовала умения избирать полезное и беречься вредного, которая в целом оказывалась составной частью добродетели благоразумия (pruden-tia) ${ }^{24}$. Исидор во второй книге «Дифференций» напрямую связывает эту добродетель с умением читать Писание и различать в нем уровни смыслов ${ }^{25}$. Высказывания должны не столько доносить конечные истины, сколько изменять читателя, и он, в свою очередь, мог их использовать для воздействия и трансформации потенциальных читателей его текста ${ }^{26}$. Процесс формирования смысла текста зависел не столько от гипотетической мысли автора, сколько от ситуации читателя ${ }^{27}$, в т.ч. от его порочности / добродетельности.

Средневековое монашеское «мастерство мысли», согласно М. Каррутерс, основывалось не на «инсайте», а на памяти, в которой «инвентаризировались» высказывания ${ }^{28}$. Цитаты из Писания служили для аккумуляции других текстов, таким образом, общие места окружались коннотациями (Каррутерс приводит пример с Мемориалом ветеранам Вьетнамской войны - общим местом, вызывающим разные индивидуальные воспоминания $)^{29}$. Авторитетные и общие высказывания, таким образом, служили «производству» мысли гораздо лучше, чем оригинальные.

Г. Струмса, говоря о традиции, приводит удачную метафору полифонии ${ }^{30}$. Разноречие авторитетных текстов в той или иной мере сохранялось в традиции комментария (грамматического и экзегетического) и предполагало выбор читателя, понимаемый как процесс, а не однократное действие в культуре, где, как пишет Р. Стар, граница между чтением и медитацией размыта ${ }^{31}$. В целом характер чтения еще в IV в. изменяется от «пробегания» к медитативному перечитыванию ${ }^{32}$. В результате читатель сосредотачивался на сентенциях - фразах.

В Вестготской Испании VII в. мы видим, что этот подход экстраполируется на разные сферы знания и определяет характер не только чтения, но и письма. Компилятор тоже «собирает цветы» и пользуется разными «партиями», создавая собственную. Происходит удвоение активного «благоразумного читателя» - это и сам компилятор, и его потенциальный читатель.

\footnotetext{
${ }^{23}$ Kaster 1980a: 221.

${ }^{24}$ Isid. etym. 2, 24, 5.

${ }^{25}$ Isid. diff. 2, 40. нию его воздействия. - Pollmann 2013: 326.

${ }^{27}$ Cp. Pucci 1998: xi.

${ }^{28}$ Carruthers 1998: 11-15.

${ }^{29}$ Ibid: 19, 35-40.

${ }^{30}$ Stroumsa 2016. P. 179.

${ }^{31}$ Starr 2001: 443.

${ }^{32}$ Кавалло, Шартье 2008: 118-121.
}

${ }^{26}$ О воздействии и применении риторики см. Habinek 2005: 61-62, 72. К. Польманн замечает, что в позднеантичной христианской поэзии было стремление не столько к более истинному высказыванию (в т.ч. антиеретических выпадах), сколько к усиле- 


\section{Письмо как соответствие образу}

Аграфа о добрых менялах, как уже говорилось, имеет прямое отношение к отбору мнений, которые рассматриваются через метафору монеты. Читатель должен отличать истинную монету от поддельной. Эта мысль от Климента Александрийского через Оригена переносится на почву латинского языка Иеронимом ${ }^{33}$. Кассиан применяет эту образность в рассуждении о различении помыслов, подробно раскрывая ее. Он разделяет определение качества сплава, различие золота / меди и выяснение подлинности изображения на монете, связывая первое с различными мнениями, происходящими не только от слова Божия, а втоpoe - с ложным пониманием Писания, из-за чего монах занимается такими трудами, которые под предлогом добродетелей ведут к порокам (среди прочего Кассиан указывает желание стать клириком). Он заключает, что такая монета (т.е. помысел) происходит не от законных монетчиков, т.е. не от отцов церкви ${ }^{34}$. По-видимому, этот ход мысли использует Григорий Великий в «Моралиях», где он также говорит о необходимости духовной «экспертизы монет» в контексте выявления проповедников, служащих Антихристу. Он акцентирует внимание на образе жизни проповедников, сравнивая его с изображением на монете, чеканенной законными монетчиками - отцами церкви ${ }^{35}$.

Исидор составляет сентенцию о церковном учителе с опорой, прежде всего, на текст Григория ${ }^{36}$. Как представляется, он учитывает коннотации, связанные и с образом жизни, и с учением, тем более что это - ключевая для «Сентенций» дихотомия. Если металл в его сентенции сравнивается с учением, а вес - через добродетель смирения с жизнью, то подобие отцам может быть отнесено и к тому, и к другому. Соотнесение подобия и изображения - не случайно. Изо всех перечисляемых Исидором признаков подлинности именно изображение имеет функцию репрезентации ${ }^{37}$. В «Этимологиях» Исидор подчеркивает значимость надписи и изображения правителя на монете ${ }^{38}$. В кодексе Феодосия указывается, что подделка лика императора является святотатством (sacrilegium) ${ }^{39}$.

\footnotetext{
${ }^{33}$ Hier. contra Ruf. 1, 16. CM. Williams 2006: 237.

${ }^{34}$ Cassian. conl. 1, 20.

35 Greg. M. Mor. 33, 35.

${ }^{36}$ Sicut in numisma metallum, et figura, et pondus inquiritur, ita in omni doctore ecclesiastico quid sequatur, quid doceat, quomodo uiuat. Per qualitatem igitur metalli, doctrina, per figuram, similitudo patrum, per pondus, humilitas designatur. Qui ergo ab his tribus discrepauerit non metallum, sed terra erit (Isid. sent. 3, 36, 5).

${ }^{37}$ См. Howgego 1995: 62-87. Отмечается, что монеты с изображениями императора могли использоваться как своего рода медальоны (и в христианскую эпоху) (Williams 2007: 158). С.С. Аверинцев, говоря о символическом мире Поздней Античности, указывал на иконичность монеты, носящей образ и надпись (Аверинцев 1997: 121).

${ }^{38}$ Isid. etym. 16, 25, 14: Ipse quoque nomisma uocatur pro eo quod nominibus principum effigiis que signetur.

${ }^{39}$ CTh 9, 38, 6 .
} 
Авторитет пишущего в определенной степени зависел от авторитета приводимых им цитат. Не стоит забывать, что для Вестготской Испании большая часть авторов - епископы, на которых была возложена обязанность учить народ ${ }^{40}$. Если через «подобие отцам» епископ и сам репрезентирует церковную традицию, метафора монеты показывает, что в этом подобии важен не только символический аспект: епископ должен соответствовать образу отцов. У Иеронима образ монеты соотнесен конкретно с толкованиями, которые он приводит в своем тексте. Таким образом, речь идет не только об абстрактных учениях, но и о текстах. В этом смысле усвоение епископом высказываний традиции служит репрезентации в его лице церковного учения.

Характерно, что, представляя Исидора Севильского как авторитетного учителя, Браулион Сарагосский указывает на то, что Исидор воспринял и представил современникам образ древности ${ }^{41}$. Р. Кастер отмечает, что уважение к авторитету древних у Сервия «Сатурналий», которое предполагает связь (societas, communio) древности и нынешнего дня, является скорее моральным качеством, а не методологическим приемом ${ }^{42}$. Таким образом, воспроизведение учения отцов связано с моральным совершенством учителя. Цитирование текстов и репрезентация оказываются тесно связаны и определяют авторитет епископа (в той перспективе, где должностное и личное трудно различимо). В то же время цитирование является следствием активного и избирательного чтения и не укладывается в оппозицию рутинного воспроизведения традиции и харизматического противостояния ей ${ }^{43}$.

\section{Заключение}

Авторитет личностей отцов церкви, причастных божественной благодати, проецировался на их тексты, что определило его значение для более поздних авторов. Необходимость соответствовать отцам для церковного учителя определяла набор не только примеров, но и высказываний, которые он мог воспроизводить. В проникнутой символизмом культуре за такими «повторами» закреплялась важная функция репрезентации: для текста - традиции, для автора - апостолов и отцов церкви. Авторитет церковного учителя, таким образом, носил символический характер, требовавший, однако, соответствия образа первообразу.

Подход такого автора к своим источникам не сводился к рецепции. Составляя свой текст, в качестве благоразумного читателя он дол-

${ }^{40}$ См. Биркин 2017.

${ }^{41}$ Braulion. Renotatio: In quo quiddam sibi antiquitas uindicauit, immo nostrum tempus antiquitatis in eo scientiam imaginauit. Браулион для описания Исидора использует прославляющее Варрона описание Цицерона, которое воспроизводит Августин. Подробнее см. Fontaine 1983.

${ }^{42}$ Kaster 1980b: 231-235.

43 Впрочем, Струмса склонен видеть в связи теологии (как вероучения) и теозиса инструменты для проявления «харизматического» авторитета праведника. Stroumsa 2016: 180-181. 
жен были избирательно подходить к высказываниям в поле традиции, использовать их как исходный материал, определяя необходимое для воздействия на своего читателя, который при этом тоже мыслился как активный и благоразумный. Таким образом, prudens compilator осмысленно (а не случайно) соединял те или иные авторитетные суждения, отбрасывая другие.

Перед читателем такой текст представлял не один из застывших образов традиции, а давал пищу для развития мысли. Общие места и аллюзии задействовали память читателя - важнейший «механизм» процесса мышления, в развитом виде предстающего в монашеской культуре Средних веков. Вокруг этих «общих мест» накапливались коннотации, необходимые для выявления новых смыслов. Процесс образования смыслов больше был ориентирован на читателя, а не на автора и его реконструируемую «мысль». Авторитетное высказывание, таким образом, не подавляло суждение, а стимулировало его.

Гадамер приходит к выводу, что авторитет связан не с повиновением, а с познанием, а его установления перенимаются в свободном акте ${ }^{44}$. Как видим, в культуре Вестготской Испании авторитет связан с «производством» знания, с ремеслом мысли. Свободный акт состоял не только в принятии суждений, но и в их выборе и осмыслении. По большому счету усвоение высказываний требовало определенной свободы обращения с ним. В то же время собственное произвольное суждение скорее отвергалось и критиковалось. В этом контексте стоит вспомнить предложенное Й. Бохеньским понятие «эпистемического авторитета». В данном случае на основании компетенции того, кому принадлежат авторитетные суждения, они обретают правдоподобие ${ }^{45}$. Для Исидора и его «наследников» путь к новой мысли лежал не через сомнение, а через усвоение и осмысление авторитета.

Это исследование позволяет сделать несколько предположений. Прежде всего, когда мы говорим, по меньшей мере, об «эпистемическом» авторитете, т.е. относящимся к области высказываний и знания, по-видимому, на протяжении истории его функции и характер меняются ${ }^{46}$. Из этого следует, что историчны и принципы и цели герменевтики авторитетных высказываний.

Попытка воспроизведения авторского тезиса, единой мысли, стоящей за текстом, в случае текстов интеллектуальной культуры Вестготской Испании, как правило, недостаточна. В таком случае легко свести эти тексты к набору ходов мысли авторитетов (Августина, Цицерона) и рассматривать их сквозь призму упрощений, непониманий, бессмысленных цитирований и отступлений в деталях ${ }^{47}$. Однако, как отмечает Х.Л. Борхес, книги пишутся не только для того, чтобы их понимали, но

\footnotetext{
${ }^{44}$ Там же: $332-333$.

45 Bochenski 1974: 59-66.

${ }^{46}$ К сходному выводу на другом материале приходит К. Польманн. Pollmann 2014: 171.

${ }^{47}$ Напр., см. Адо 2002: 250, 256; Марей 2019: 102.
} 
и чтобы «читатель продолжал размышлять» ${ }^{48}$. Рискну предположить, что рассматриваемые мною источники функционировали и в таком модусе - отсылая читателя к размышлению над высказываниями, авторитет которых объединял несколько контекстов и призван был вызывать в памяти ряды коннотаций.

\section{ИСТОЧНИКИ}

Avg. c. Faust. - Zycha J. ed. (1891) Augustini Hipponensis contra Faustum in Idem. De utilitate credendi. De duabis animabus. Contra Fortunatum Manichaeum. Contra Adimantium. Contra epistulam fundamenti. Contra Faustum Manichaeum. Contra Felicem Manichaeum. De natura boni. Epistula Secundini. Contra Secundium Manichaeum, Wien: Tempsky (CSEL; 25), pp. 251-797.

Bedae In canticum canticorum. - Hurst D. ed. (1983) Bedae Venerabilis in Cantica canticorum libri ui in Idem. Opera exegetica, Turnhout: Brepols publishers (CCSL; 119B), pp. 167-375.

Braulion. Renot. - Martín J.C. ed. (2005) Braulioni Caesaraugustani Renotatio librorum domini Isidori in Scripta de uita Isidori Turnhout: Brepols publishers (CCSL; 113B), pp. 199-207.

Cassian. conl. - Petschenig, Michael ed. (1886) Cassiani Collationes XXIII, Wein: Tempsky (CSEL; 13).

CTh - Mommsen Th., Meyer P. eds. (1904-1905) Theodosiani libri XVI cum constitutionibus Sirmondianis et Leges novellae ad Theodosianum pertinentes, Berlin: apud Weidemannos.

Greg. M. Mor. - Adriaen M. ed. (1979-1985) Gregorii Magni Moralia in Iob, Turnhout: Brepols publishers (CCSL; 143-143B).

Hier. contra Ruf. - Lardet, Pierre ed. (1982) Contra Rufinum, Turnhout: Brepols (CCSL; 79).

Isid. carm. - Sánchez Martín, Jose Maria ed. (2000) Isidori Hispalensis versus, Turnhout: Brepols publishers (CCSL; 113A).

Isid. diff. 2 - Andrés Sanz, Maria Adelaida. ed. (2006) Isidori Hispalensis Liber Differentiarum [II], Brepols, Turnhout (CCSL; 111A).

Isid. etym. - Lindsay Wallace M. ed. (1911) Isidori Hispalensis Etymologiarum sive originum libri XX. Clarendon Press, Oxford. 2 vols.

Isid. expos. - Gorman, Michael M ed. (2009) Isidorus episcopus Hispalensis Expositio in Vetus Testamentum. Genesis. Frieburg in Breisgau: Herder.

Isid. sent. - Cazier, Pierre ed. (1998) Isidori Hispalensis sententiae. Brepols, Turnhout (CCSL; 111).

Macr. Sat. - Willis J. ed. (1970) Macrobii Saturnalia, Leipzig: Teubner.

Rufin. Orig. in cant. - Baehrens, W. A. ed. (1925) Commentarium in Canticum Canticorum in Origenes Werke, Bd. 8, Leipzig: Ninrichsche Buchandlung, pp. 61-241.

Sen. ep. - Hense, Otto. ed. (1938) Senecae Epistulae morales ad Lucillium. Teubner, Leipzig.

\section{БИБЛИОГРАФИЯ / REFERENCES}

Аверинцев С. С. Авторство и авторитет // Историческая поэтика. Литературные эпохи и типы художественного сознания. М.: Наследие, 1994. С. 105-125. [Averincev S. S. Avtorstvo i avtoritet // Istoricheskaya poetika. Literaturnye epohi i tipy hudozhestvennogo soznaniya. M.: Nasledie, 1994. S. 105-125.].

Аверинцев С. С. Поэтика ранневизантийской литературы. М.: Наука, 1997. [Averincev S. S. Poetika rannevizantijskoj literatury. M.: Nauka, 1997.].

Адо И. Свободные искусства и философия в античной мысли / пер. с фр. Е.Ф. Шичалиной. М.: Греко-латинский кабинет Ю.А. Шичалина, 2002. [Ado I. Svobodnye iskusstva i filosofiya v antichnoj mysli / per. s fr. E.F. SHichalinoj. M.: Greko-latinskij kabinet YU.A. SHichalina, 2002.].

Биркин М. Социальные функции епископской проповеди в Толедском королевстве в начале VII в. // Теология и политика. Власть, Церковь и текст в королевствах вестготов (V - начало VIII в.). М.: Дело, 2017. С. 143-162. [Birkin M. Social'nye funkcii episkopskoj propovedi v Toledskom korolev-stve v nachale VII v. // Teologiya i politika. Vlast', Cerkov' i tekst v koro-levstvah vestgotov (V - nachalo VIII v.). M.: Delo, 2017. S. 143-162.].

Борхес Х. Л. Книга // Он же. Собрание сочинений. Т. 3. СПб.: Амфора, 2005. С. 501-509. [Borhes H. L. Kniga // On zhe. Sobranie sochinenij. T. 3. SPb.: Amfora, 2005. S. 501-509.].

${ }^{48}$ Бopxec 2005: 503. 
Гадамер Х.-Г. Истина и метод / пер. с нем. Б.Н. Бессонова. М.: Прогресс, 1988. [Gadamer H.-G. Istina i metod / per. s nem. B.N. Bessonova. M.: Progress, 1988.].

Кавалло Г., Шартье Р. История чтения / пер. с фр. М.А. Руновой, Н.Н. Зубкова, Т.А. Недашковской. М.: Изд-во ФАИР, 2008. [Kavallo G., SHart'e R. Istoriya chteniya / per. s fr. M.A. Runovoj, N.N. Zubkova, T.A. Nedashkovskoj. M.: «Izdatel'stvo FAIR», 2008.].

Марей A.B. Populus: рождение, смерть и воскрешение политического субъекта (от Цицерона до Гоббса) // Социология власти. 2019. Т. 31. С. 95-111. [Marej A.V. Populus: rozhdenie, smert' i voskreshenie politicheskogo sub"ekta (ot Cicerona do Gobbsa) // Sociologiya vlasti. 2019. T. 31. S. 95-111.].

Шартье Р. Письменная культура и общество / пер. с фр. и послесловие И. Стаф. М.: Новое издательство, 2006. [SHart'e R. Pis'mennaya kul'tura i obshchestvo / per. s fr. i posleslovie I. Staf. M.: Novoe izdatel'stvo, 2006.].

Bochenski J. M. (1974) Was ist Autorität? Eiführung in die Logik der Autorität, Freiburg im Breisgau: Herder.

Brown P. (1978) The Making of Late Antiquity, Cambridge, MA; L.: Harvard University Press.

Carruthers M. (1998) The Craft of Thought. Meditation, Rhetoric, and the Making of Images, 400-1200, Cambridge: Cambridge University Press.

Codoñer C. (2014) La sententia y las Sententiae de Isidoro de Sevilla Wisigothica. After M.C. Díaz y Díaz / ed. C. Codoñer Firenze: Sismel, pp. 3-48.

Fontaine J. (1983) Isidorus Varro Christianus // Bivium. Homenaje a Manuel Cecilio Díaz y Díaz. Madrid: Gredos, pp. 89-106.

Habinek T. (2005) Ancient Rhetoric and Oratory, Blackwell.

Howgego C. (1995) Ancient History from Coins, London: Routledge.

Irvine M. (1994) The Making of Textual Culture: 'Grammatica' and Literary Theory 350-1100, Cambridge: Cambridge University Press.

Kaster R. (1980a) The Grammarian's Authority in Classical Philology, Vol. 75, No. 3, pp. 216-241.

Kaster R. (1980b) Macrobius and Servius: Verecundia and the Grammarian's Function in Harvard Studies in Classical Philology, Vol. 84, pp. 219-262.

Law V. (1995). Wisdom, Authority and Grammar in the Seventh Century: Decoding Virgilius Maro Grammaticus, Cambridge University Press.

Nascimento A. (2006) A cultura bracarense no séc. VI: uma revisitação necessária // Estudos em homenagem ao professor doutor José Marques, Porto: Faculdade de letras da Univesidade de Porto,Vol. 1., pp. 87-104.

Pelttari A. (2014). The Space that Remains. Reading Latin Poetry in Late Antiquity, Cornell U.P.

Pollmann K (2013) Establishing Authority in Christian Poetry of Latin Late Antiquity, Hermes, Bd. 141, pp. 309-330.

Pollmann K. (2014) Christianity and Authority in Late Antiquity: The Transformation of the Concept of Auctoritas // Carol Harrison, Caroline Humfress, and Isabella Sandwell eds. Being Christian in Late Antiquity: A Festschrift for Gillian Clark. Oxford: O.U.P., pp. 156-174.

Pucci J. (1998) The Full-Knowing Reader: Allusion and the Power of the Reader in the Western Literary Tradition, Yale University Press.

Prieto S., A. Belén (2016) Authority and authorship, tradition and invention, reading and writing in early medieval compilation genres: the case of Hrabanus Maurus' De institutione clericorum in De Medio Aevo, Vol. 5/2, 2016, pp. 179-240.

Starr R. J. (2001) The Flexibility of Literary Meaning and the Role of the Reader in Roman Antiquity in Latomus, T. 60 (2), pp. 433-445.

Stroumsa G. G. (2016) Modes of Scriptural and Personal Authority in Late Antique Religion // Ercolani, Andrea, Giordano, Manuela (eds.). Submerged Literature in Ancient Greek Culture. Vol. 3: The Comparative Perspective. Berlin: De Gryter, pp. 169-182.

Williams M. H. (2006) The Monk and the Book, Gerome and the Making of Christian Scholarship, Chicago; London: The University of Chicago Press.

Williams J. (2007) Religion and Roman Coins in Rüpke, Jörg ed. A Companion to Roman Religion, Oxford: Blackwell, pp. 143-163.

Воронцов Сергей Александрович - кандидат философских наук, старший научныий сотрудник, Лаборатория исследований иерковных институций, Православныий Свято-Тихоновский Гуманитарный Университет (Москва) 


\section{Coins and Flowers: Some Images of the Textual Authority in the Works of Isidore of Seville}

The article considers the function of the authority of the quoted text through the lens of the dichotomy of personal / textual authority. The study is focud on the last ages of Late Antiquity and particularly on the works of Isidore of Seville. By consideration of the images related to the prudent reader (prudens lector) the article comes to the following conclusions. The extensive use of the authoritative quotations allows the text to represent the tradition, while its author as religious leader represented the Apostles and fathers of the Church. Thus, the authority of this leader turns out to be essentially symbolical. Relatively wide range of texts were considered authoritative. Making his own text, a prudent compiler (prudens compilator) as a prudent reader (prudens lector) chose the quotations not randomly, but according to the presupposed effect of the compilation. The reader of this kind of text, according to the monastic craft of the thought, produced new ideas by mediation upon the quotations, i.e. remembering all the connotations and relating them to the situation of the reader. Thus, the main function of authority of the quotations was to give an impetus to the thought in terms of tradition and not to suppress it.

Keywords: Isidore of Seville, textual authority, imitatio, compilatio, prudens lector, Late Antiquity

Sergey A. Vorontsov, PhD in Philosophy, Senior Scientist, Laboratory for Research of Church Institutions, St. Tikhon Orthodox University for the Humanities (Moscow) 


\section{M.С. ПЕТРОВА \\ ДУНГАЛ И МАКРОБИЙ \\ К ВОПРОСУ О ВОСПРИЯТИИ АНТИЧНЫХ ТЕКСТОВ СРЕДНЕВЕКОВЫМИ АВТОРАМИ}

В статье обсуждается проблема рецепции античного (натурфилософского) знания западноевропейской наукой раннего Средневековья. Отмечается возможность ее решения посредством текстуальных исследований компаративного характера, цель которых состоит не только в формировании общей «картины» усвоения предшествующего знания средневековой наукой, но и в накоплении сведений о разнообразных способах и методах его трансформации и использования. Автор анализирует текст ответного письма (811 г.) ирландского монаха Дунгала (fl. 811-828) Карлу Великому о природе солнечных затмений, основанного на античных источниках - «Естественной истории» Плиния Старшего (I в.) и «Комментария на 'Сон Сципиона'» Макробия (V в.). Выявляются цели изложения Дунгала при составлении ответа Карлу; обсуждается порядок планетарных сфер; отмечается знание Дунгалом основ античной натурфилософии; показано, как он (в зависимости от источника - Плиния или Макробия) перестраивает и перерабатывает исходный текст. Сделан вывод о попытке Дунгала ответить на вопрос Карла о солнечных затмениях и полученном результате.

Ключевые слова: текст, традиция, знание, источник, рецепџия, усвоение.

Исследователи, занимающиеся интеллектуальной историей, историей идей и историей науки в целом, все чаще обращают внимание на проблему рецепции античного натурфилософского ${ }^{1}$ знания ${ }^{2}$ в раннем Средневековье, пытаясь ответить на вопросы, как, в каком виде и каким образом оно было воспринято, трансформировано и усвоено. Очевидно, что однозначные ответы на вопросы такого рода вряд ли можно получить как из-за сложности самой проблемы, так и необъятности этого явления, но к их решению все же можно приблизиться, с одной стороны, посредством проведения микроисторических исследований, направленных на изучение сочинений средневековых авторов и их источников; с другой, благодаря реконструкции ситуаций и причин, побудивших последних к его усвоению и использованию. Мы рассмотрим частный случай восприятия и трансформации ирландским монахом Дунгалом (fl. 811-828) ${ }^{3}$ натурфилософского знания, изложенного в Макробиевом

${ }^{1} \mathrm{~B}$ латинской традиции этот термин наиболее ярко обозначен Сенекой (Sen. Ep. ad Luc. 88, 24, 1): Quemadmodum... est aliqua pars philosophiae naturalis, est aliqua moralis, est aliqua rationalis, sic et haec quoque liberalium artium turba locum sibi in philosophia vindicat - «Поскольку одна часть философии... занимается природой, другая - нравами, третья - человеческим разумом, постольку и вся толпа свободных искусств притязает занять в ней место», пер. С.А. Ошерова (1977, ad. loc.).

2 Такое знание в своих сочинениях отразили латинские авторы-энциклопедисты Поздней Античности, среди которых Марциан Капелла, Макробий и Калкидий.

${ }^{3}$ Дунгал - монах, учитель, астроном, поэт - родился в Ирландии предположительно в конце VIII в. Его происхождение неизвестно. Возможно, студенческие годы он про- 
«Комментарии на 'Сон Сципиона'» $(\mathrm{V} \text { в. })^{4}$, в его ответном письме Карлу Великому (742-814) о природе солнечных затмений5.

Заслуживает внимания «история» самого письма. В 811 г. через аббата Вальдона к Дунгалу, которого при дворе считали большим ученым и знатоком астрономии, обратился Карл Великий, чтобы Дунгал разъяснил ему явления двух солнечных затмений, случившихся годом ранее 6 , и рассказал, как можно предсказывать такие затмения. Согласившись дать Карлу объяснение необычного явления, Дунгал пишет письмо, которое начинает с отказа, мотивированного тем, что у него нет при себе философских книг, которые находятся в дворцовой библиотеке Карла, и по которым можно было бы дать исчерпывающий ответ (Dung. Ep. I // PL 105, 449B): «Поскольку у меня нет под рукой касающихся этой темы текстов, что доступны при дворе, позвольте мне показать Вам и дворцо-

вел в школе Бангора (Bangor) - города в Северном Уэльсе у побережья Ирландского моря, основанного в VI в. Покинув Ирландию, Дунгал жил в монастыре св. Дионисия неподалеку от Парижа, а также в Павии и Боббио (Laistner 1957: 214, 290-291).

${ }^{4}$ Принято считать, что значение Макробия как транслятора античного знания в Средние века необычайно велико и его «Комментарий на 'Сон Сципиона'» пользовался широкой известностью среди ученых того времени, оказав на них немалое влияние. Например, У. Рид (Reade 1931: 790) говорит об огромном долге Средневековья по отношению к Макробию. Наиболее востребованными оказались части «Комментария», посвященные астрономии и геометрии (т.е. картографии и географии) (Gersh 1986: 493-495). О влиянии Макробия на картографическую традицию в Средние века (X-XII), см.: Чекин 1999: 87-107. Что касается астрономии, то такой вывод был сделан на основе маргиналий, диаграмм и иллюстраций в сохранившихся манускриптах, а также выдержек из «Комментария» на астрономические темы, имеющих соответствующие титулы (Stahl 1990: 39-42 et al.). Например: "Ex libris Macrobii de differentia stellarum et siderum” («Из книг Макробия о различии планет и звезд») - Comm. I, 14, 21; "De circis et spera" («О кругах и сфере») - Comm. I, 14, 24; "De decem circulis" («O десяти кругах») - Comm. I, 15 8; "De solis magnitudine” («О величине солнца») Comm. I, 20, 9. Встречаются и более развернутые названия: “Ambrosii Macrobii Theodosii de mensura et magnitudine terrae et circuli per quem solis iter est” («Амвросий Феодосий Макробий об измерении и величине земли и орбиты солнца») - Comm. I, 20, 14 (Stahl 1990: 41-42). О жизни и сочинениях Макробия см.: Петрова 2007: 8-41. Однако в целом тема влияния Макробия на авторов Средних веков из-за ее обширности изучена мало. Среди уже предпринятых (хотя и неполных) обзоров следующие: Manitius 1931; Duhem 1915: 62-71; Schedler 1916: 104-139; Stahl 1990: 39-55; Courcelle 1958: 205-234; Jeauneau 1960: 3-24; Silvestre 1963: 170-180; Flamant 1977: 688-693; Gersh 1986: 493-495, n. 1. Marchetti 2001: lxvi-lxxii.

${ }^{5}$ Eastwood 1994: 117-134; Idem 1993A: 161-180; Idem 1993B: 7-26.

${ }^{6}$ Об этих затмениях упомянуто в анналах: Ann. Iuv. a. 810, p. 88; Ann. regn. Franc., a. 810, p. 133 (см. также ниже, с. 6). О затмениях как предвестниках смерти Карла Великого упоминает Эйнхард (Einh., Vita Kar. 32): «B течение трех последних лет его жизни происходили беспрерывные солнечные и лунные затмения, и на солнце целых семь дней сряду замечали темные пятна» (пер. наш); см. также примеч. 15. Солнечное затмение, во время которого Луна закрывает от находящегося на Земле наблюдателя Солнце (полностью или частично), возможно только в период новолуния, когда обращённая к Земле сторона Луны не освещена, и сама Луна не видна (см.: Цесевич 1973: VI, 68; Littmann, Espenak, Willcox 2008: 109-115; Михайлов 1954; 1960). 
вым школярам, что я смог сделать в отношении Вашего вопроса, используя наилучший авторитетный текст, который имею здесь, в монастыре св. Дионисия, названный Макробиевым «Комментарием» (перевод наш). Обезопасив себя таким образом, Дунгал замечает, что при рассмотрении поставленного вопроса, ему необходимо обосновать исходные положения в астрономии, и потому он привлекает те неболышие, «простые и легкие сочинения», которые имеются в библиотеке его монастыря. Именно из них он пытается извлечь нужные сведения, чтобы составить ответ королю, «хотя и неумелый, и слишком длинный» (Ib. 447A - 449C). Далее Дунгал, сославшись на Макробия как на толкователя Цицерона (Ib. 449C) и пользуясь Макробиевой терминологией구 , сначала описывает по тексту «Комментария» особо не относящуюся к делу структуру небес, пытаясь объяснить движение планет и их порядок от небесной сферы (Апланес) до земной, упоминая о различии в планетарных порядках между теориями «халдеев» и «египтян»; затем он обсуждает траектории движения планет по своим орбитам, скорость их движения; движение светил по широте в области Зодиака; в заключение говорит о возможности предсказания затмений в будущем.

Следует пояснить, что Дунгал мог иметь в виду, когда упоминал о различиях в теориях «халдеев» и «египтян» о порядке планет. Но прежде отметим, что в отношении очередности их следования в ранней греческой традиции единого мнения не сложилось. Так, Анаксимандр (611546 гг. до н.э.) полагал, что звезды расположены ближе к Земле, далее следовали Луна и Солнце. Анаксимен (586-526 гг. до н.э.), напротив, считал, что звезды являются самыми дальними от Земли объектами, закрепленными на внешней оболочке Вселенной (Космоса). Его мнение было принято практически всеми последующими учеными, за исключением Эмпедокла (490-430 гг. до н.э.), который придерживался взглядов Анаксимандра. В целом, в греческой традиции был принят следующий порядок расположения планет и светил: Луна - Солнце - Марс - Юпитер - Сатурн - отдельные звезды. О расположении и следовании Меркурия и Венеры существовало множество концепций. Например, Платон (429/427 - 347 гг. до н.э.) и Аристотель (384-322 гг. до н.э.) помещали их сразу за Солнцем, Птолемей - между Луной и Солнцем. Кроме того, Аристотель считал, что выше сферы неподвижных звёзд нет ничего, даже пространства; стоики полагали, что мир погружен в бесконечное

\footnotetext{
${ }^{7}$ Напр.: яркие светила, Луна и Солнце - "lumina" (lumen, inis [n] - Comm. I, 17, 6); одиночные звезды, прочие звезды, пять «блуждающих» (erraticae) планет - "stellae" (stella, ae [f] - Comm. I, 14, 21 и 23); созвездия в сочетании с другими светилами, образующие на небе некий знак, например, Овна и Тельца, Персея или Северной Короны и т.д. - "sidera" (sidus, eris [n.] - Comm. I, 14, 21); небесные сферы (круги) - “circuli caeli” (circulus, i [m] - Comm. I, 3, 13). Макробий лишь один раз употребляет термин "planities" (planities, ei [f] - Comm. I, 5, 9), но в месте, не имеющем отношения к астрономии (Eastwood 1994: 117-134).
} 
пустое пространство; атомисты, вслед за Демокритом (460-370 гг. до н.э.) придерживались мнения, что за нашим миром, ограниченным сферой неподвижных звёзд, находятся другие миры. Эту концепцию позднее поддерживали эпикурейцы ${ }^{8}$. Что касается собственно различий между «халдейской» и «египетской» концепциями о порядке планет, о которых пишет Дунгал, пересказывая Макробиев текст, то они таковы. Согласно первой, халдейской, теории (ей впоследствии следовал Цицерон), Солнце занимало четвертое место от небесной сферы, вокруг которого вращались две планеты - Венера и Меркурий; ниже находились Луна и Земля (Илл. 1). Согласно второй, которой придерживались египтяне и позднее Платон, Солнце находилось на шестом по порядку месте от Небесной сферы, а именно: Сатурн (1) - Юпитер (2) - Марс (3) - Венера (4) - Меркурий (5) - Солнце (6) - Луна (7) - Земля (8) (Илл. 2) 9

\footnotetext{
${ }^{8}$ См., напр.: Lucr. De rerum nat. // PHI 5. Подробнее о греческой космологии, см., напр.: Kahn 1960: 75-165; Burnet 1908: 83-84; Bicknell 1969: 53-85; Graham 2006; Graham 2003: 1-20; O'Brien 2008: Cornford 1937: i-x; 1-8; Nichols Jr. 1976; Clay 1984; Sedley 1998; Kouremenos 2010: 17-33; Kwok 2017: 17-24; 49-59; 143-147; 149-157; Matthen, Hankinson 1993: 417-435; Solmsen 1958: 265-282.

9 Заметим, сам Макробий (см.: Мacr. Comm. I, 12, 13) сначала принимает «халдейский» порядок, но далее (Comm. I, 19, 1-3) он следует порядку «египтян». Это рассуждение Макробия специально рассматривалось многими исследователями, с целью выявления его источников. Например, К. Мрас (Mras 1933: 25-26) сравнивает его с отрывком из «Комментраия на 'Тимей'» Прокла (см.: Procl. In Tim. III, 355, 12) и полагает, что оба автора следовали разным источникам, поскольку Макробий приводит халдейский порядок, а Прокл - египетский. Дж. Фламан (Flamant 1977: 561), изучая эту проблему, полагает, что в этом месте «Комментария» источником Макробия мог выступить опосредованный через Порфирия текст Нумения. Указывая на Порфириев «Комментарий на 'Государство'» Платона, исследователь мотивирует свой вывод тем, что сам Порфирий приводит именно халдейский порядок, который он мог позаимствовать у Нумения. По мнению Дж. Фламана, Прокл также мог следовать Порфирию, но он использовал другой его текст - «Комментарий на 'Тимей’», в котором Порфирий перелагает взятую у Нумения доктрину о порядке небесных сфер и вводит иной перечень планет - египетский. Однако отсутствие ныне двух упомянутых Порфириевых «Комментариев» делает эти выводы гипотетичными.
} 


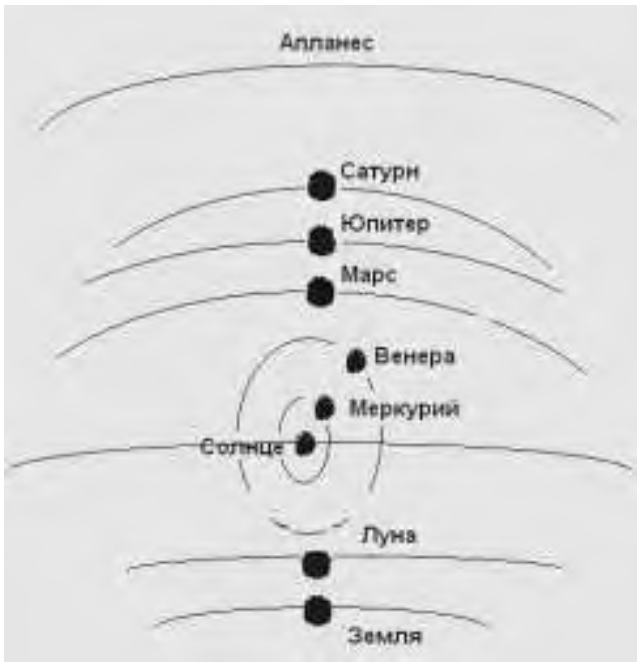

Илл. 1. Порядок планет, согласно халдеям и Цицерону. Солнце занимает четвертое место (от Сатурна сверху вниз), вокруг которого вращаются Меркурий и Венера.

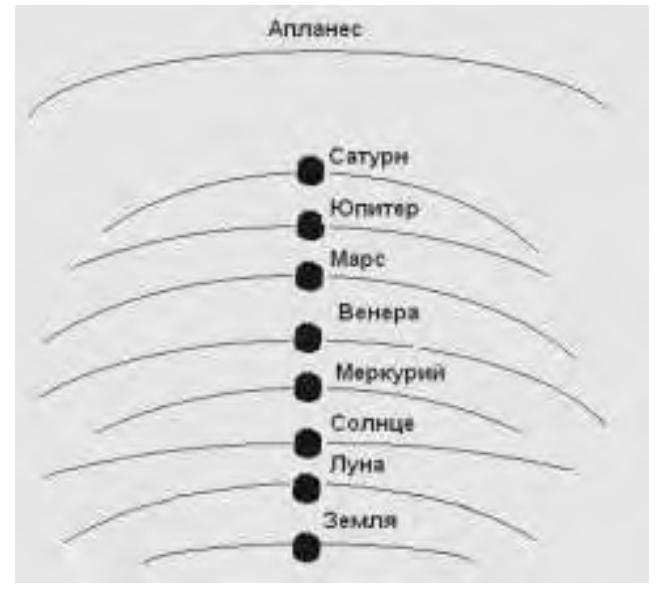

Илл. 2. Порядок планет, согласно египтянам и Платону.

Солнце занимает шестое место (сверху вниз, от Сатурна).

Метод работы Дунгала с Макробиевым «Комментарием» состоит в следующем: цитаты из него он помещает во фрагменты текста, взятые из второй книги «Естественной истории» Плиния (Plin. Nat. hist. II, 13) ${ }^{10}$, которые, по его словам, воспроизводятся им по памяти (Дунгал с сожалением отмечает, что этого сочинения у него под рукой не оказалось;

${ }^{10}$ Вторая книга этого трактата (Plin. Nat. hist. II, 1-112) служила одним из основных источников для каролингских ученых, рассматривавших планетарную астрономию, cм.: Eastwood 1994: 120; Tierney 1967: 27-29. 
Dung. Ep. 1 // PL 105, 457B). Фактически, все его рассуждение составлено из фрагментов, почерпнутых из Макробиевого текста (Macr. Comm. I, 15, 2 и 13-15; I, 20, 5; I, 17, 16; I, 19, 3-5; I, 18, 2-7 и 7-19; I, 19, 1-2 и 7-13 et cet.) ${ }^{11}$ и фраз из сочинения Плиния. Однако Дунгал, несмотря на свою зависимость от Макробия, перестраивает и перерабатывает исходный текст, о чем свидетельствуют как его пропуски при цитировании ${ }^{12}$, так и включение заимствованных у Макробия фрагментов в текст Плиния, служащий для него, как представляется, более важным источником.

Особенно ярко это проявляется в том месте послания Дунгала, где он, изменяя смысл сказанного Макробием, поддерживает порядок планет Цицерона, принятый в его время. Далее он, цитируя соответствующий фрагмент из текста Макробия, пишет, что и о другом, менее известном порядке планет, согласно которому Солнце следует сразу же за Луной (т.е. порядке планет Платона), тоже следует сказать по ряду причин. Во-первых, продолжает Дунгал, Луна, единственная из планет, которая получает весь свой свет от Солнца. Во-вторых, он полагает, что, поскольку Луна, будучи над Землей, находится выше окружающего ее беспримесного эфира, но ниже Солнца (в то время как остальные планеты располагаются выше него), можно понять, что место Луны и ее физическая природа наиболее соответствуют природе Земли ${ }^{13}$. И далее Дунгал заключает, что Меркурий и Венера не могут быть ниже Солнца, поскольку такое положение могло бы заставить их походить физически на Луну. Это, по мнению Дунгала, помогает читателю «осознать» как то, что Луна (как полагали платоники) есть эфирная Земля, так и то, что она по сравнению с Землей все же недостаточно тверда по своей природе.

Утверждения такого рода позволяют Дунгалу не только написать о Платоновском порядке планет и включить в свой ответ Карлу цитату Макробия о положении Солнца, но тем самым и отвергнуть сказанное им. В итоге, Дунгал, умолчав об отношении Луны к Солнцу в период солнечного затмения и о природе солнечного затмения, когда Луна полностью или частично закрывает / затмевает Солнце от находящегося на Земле наблюдателя, сохраняет лишь рациональное объяснение о видимости Луны и ее возможной природе, схожей с землей. Такой подход Дунгала демонстрирует его собственное, весьма поверхностное отношение к своему источнику и знание самого предмета ${ }^{14}$.

В отношении ответа Дунгала на вопрос Карла о возможности предсказания затмений в будущем следует заметить, что здесь он зависит от включенных в Макробиев «Комментарий» фрагментов из «Сна

\footnotetext{
${ }^{11} \mathrm{~B}$ отношении использования другими каролингскими учеными соответствующих разделов Макробиевого «Комментария» детальных исследований еще не существует. ${ }_{12}$ Eastwood 1994: 117-134.

${ }^{13}$ Об эфирной природе Луны пишет Плутарх в трактате «О лике, видимом на диске Луны (Plut. De facie 938-940 // TLG). Также см.: Петрова 2000: 122-131.

${ }^{14}$ Eastwood 1994: 117-134.
} 
Сципиона» Цицерона (e.g. Dung. Ep. I // PL 105, 455BC) и разъясняющего их текста (Cic. Somn. VII, 3-4 - Macr. Comm. II, 11, 2-3; II, 11, 5-15). Так, сначала Дунгал утверждает, что тот, кто намерен предсказать затмение Луны или год, когда оно произойдет, должен следовать «логическому исследованию и усердному наблюдению» (sagacem explorationem et diligentem observationem - Dung. Ep. I // PL 105, 455B), как это делали древние авторитеты (Ib. 454D; 455B). Затем он упоминает о методе предсказывания затмения через 15 тысяч земных лет после того, как оно случилось. Вслед за Цицероном (Cic. De Rep. VI, 22, 24) и Макробием (Comm. II, 11, 8; II, 11, 10-15) Дунгал пишет, что подобно тому, как у каждой планеты существует собственный период обращения («год»), так и у всей Вселенной есть такой «год» - мировой (mundanus), определяемый тем необходимым временем, за которое все звезды, светила и планеты Вселенной смогут вернуться к исходному месту и положению относительно друг друга. Согласно натурфилософам (physici), продолжает Дунгал, этот «год» равен 15-ти тысячам годам. По его завершении затмения вновь начнут происходить в то же время и среди тех же планет, как и в предыдущий мировой год. Таким образом, Дунгал, описав регулярность небесного движения в прошлом и весьма отдаленном будущем, завершает подготовленный для Карла астрономический ответ утверждением, что нет ничего удивительного в двух затмениях 810 года: ведь первое из них произошло 7 июня, а второе - 30 ноября, во время соединения Солнца и Луны. Свое изложение он завершает своего рода наставлением, говоря, что тот, кто склонен тщательно исследовать этот предмет, может с легкостью его изучить и сам предвидеть такие явления (scientiam et praescientiam), как это делали древние предсказатели.

О рассматриваемых Дунгалом двух затмениях имеются свидетельства в анналах эпохи Каролингов: «В канун декабрьских календ было затмение солнца с 4-го до 7-го часа в субботний день» ${ }^{15}$; «В том [810-м] году дважды происходили затмения Солнца и Луны, Солнца - 7 июня (выделено мною. - М.П.) и 30 ноября, Луны - 23 июля и 15 января» ${ }^{16}$.

«Каталог солнечных затмений NASA» ${ }^{17}$ даёт реконструированный перечень четырёх таких явлений, относящихся к 810 г.

ПЕРЕЧЕНЬ СОЛНЕЧНЫХ ЗАТМЕНИЙ 810 ГОДА

\footnotetext{
${ }^{15}$ Ann. Iuv. a. 810, p. 88, пер. А. Голованова с изм. Это затмение обозначено как предзнаменование смерти сына Карла Великого, Пипина. См.: Ad loc. 810 a.: Domnus Pipinus obiit 8. Idus Iulius. Pridie Kal. Dec. eclipsis solis facta est ab hora 4, usque in horam 7. die sabbata.

${ }^{16}$ Ann. regn. Franc., a. 810, p. 133, пер. А. Волынец;. См.: Ad loc. 810 a.: Eo anno sol et luna bis deffecerunt, sol XII. Idus Iun. et II. Kal. December luna XI. Kal. Jul. et XVIII Kal. Iannuar. См. также различные «истории»: Einh. Vita Car. 32 (см. выше, примеч. 6); An. Vita Hlud. 31.

${ }^{17}$ CatSE, 810 .
} 


\begin{tabular}{|c|c|c|c|l|}
\hline $\begin{array}{c}\text { Небесное } \\
\text { тело }\end{array}$ & Дата & $\begin{array}{c}\text { Динамическое мировое } \\
\text { время в момент } \\
\text { наибольшего затмения }\end{array}$ & $\begin{array}{c}\text { Тип } \\
\text { затмения }\end{array}$ & $\begin{array}{l}\text { Область наилучшей ви- } \\
\text { димости }\end{array}$ \\
\hline Солнце & 9 января & 7 час. 25 мин. & частное & $\begin{array}{l}\text { приполярные и средние } \\
\text { широты южного полу- } \\
\text { шария; соответственно, } \\
\text { невидимо из Ахена }\end{array}$ \\
\hline Солнце & 5 (7 июня) & 22 час. 12 мин. & частное & $\begin{array}{l}\text { приполярные и средние } \\
\text { широты южного полуша- } \\
\text { рия; невидимо из Ахена }\end{array}$ \\
\hline Солнце & 5 июля & 13 час. 05 мин & частное & $\begin{array}{l}\text { приполярные и средние } \\
\text { широты северного полу- } \\
\text { шария; могло быть види- } \\
\text { мо в Ахене }\end{array}$ \\
\hline Солнце & 30 ноября & 12 час. 02 мин. & полное & $\begin{array}{l}\text { средние широты северно- } \\
\text { го полушария; видимо в } \\
\text { Ахене }\end{array}$ \\
\hline
\end{tabular}

ПРИМЕЧАНИЯ: Частное (9 января, 5 июня и 5 июля 810 г.) - солнечное затмение, при котором земную поверхность пересекает только лунная полутень (конус тени и его продолжение не пересекают земную поверхность). Полное (30 ноября 810 г.) - солнечное затмение, при котором конус лунной тени пересекает земную поверхность (Луна достаточно близко к Земле, чтобы полностью закрыть Солнце). Цветом выделены сведения о затмениях, которые могли быть частично видимы в Ахене.

В этом перечне применительно к июньскому затмению указана дата - 5 июня. Двухдневное расхождение (у Дунгала и в анналах - 7 июня), вероятно, связано с тем, что такие затмения сначала были рассчитаны каролингскими учеными, а затем дополнены данными наблюдений либо собственными, либо, переданными теми, кто мог их наблюдать из других мест (Византии, Ирландии и т.д.). Кроме того, затмение 5 (7) июня ни Карл, ни его приближенные не могли увидеть в Ахене, поскольку оно было частным и видимым только в приполярных и средних широтах южного полушария, например, в Тихом океане (Илл. 3). 


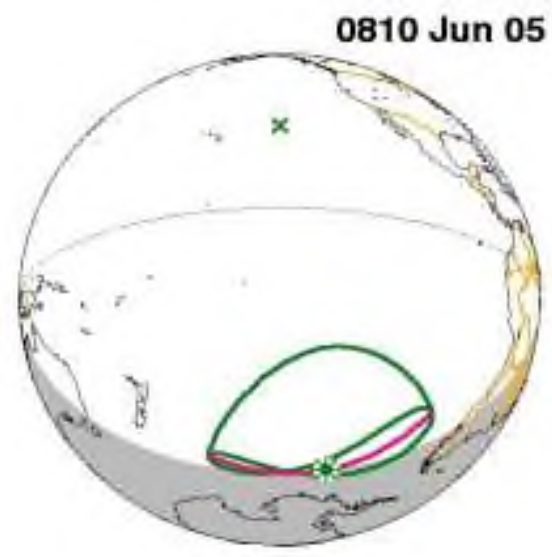

Илл. 3. Солнечное затмение 5 июня 810 г.

Зелеными линиями отмечены границы лунной полутени, звездочка соответствует точке наибольшего затмения. (CatSE 810: КатС3 810).

Затмение, датированное 30 ноября, было слишком далеко на севере и востоке европейского континента, чтобы его можно было полностью увидеть в Ахене и территории Франкского государства, но частично его все же можно было наблюдать (Илл. 4$)^{18}$.

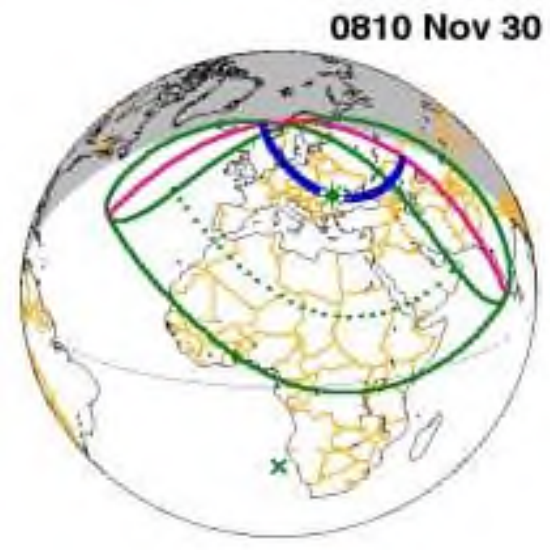

Илл. 4. Солнечное затмение 30 ноября 810 г.

Зелеными линиями отмечены границы лунной полутени, звездочка соответствует точке наибольшего затмения. Границы видимости полной фазы тени показаны синими линиями (CatSE 810: КатС3 810).

${ }^{18}$ Warntjes 2014: 108-115; MW. 
Относительно двух других указанных в «Каталоге» солнечных затмений, заметим, что одно из них (5 июля) могло быть в той или иной степени видно на территории Франкии (Илл. 5), а другое (9 января) нет (Илл. 6).

$$
* * *
$$

Очевидно, возникает целый ряд сопутствующих вопросов, а именно, почему Дунгал обсуждает темы, которые не имеют прямого отношения к природе солнечных затмений. С какой целью он использует те части Макробиевого текста, которые не относятся к солнечному затмению, игнорируя те, которые, напротив, связаны с ним. Анализ письма Дунгала позволяет сделать вывод: Дунгал сознавал, что ответ на вопрос Карла должен был последовать обязательно; он знал, что при королевском дворе имеется библиотека, по книгам которой можно проверить его выводы, и понимал, что в окружении Карла есть ученые, готовые обсудить и раскритиковать его ответ или вовсе подвергнуть его сомнению. Вероятно, что Дунгал решил не просто ответить на вопрос короля, но и продемонстрировать собственные познания ${ }^{19}$. Именно так можно объяснить вступительный абзац письма Дунгала, включающий самоуничижительную фразу о неумелом и слишком длинном ответе. В целом же, Дунгала сумел лишь выбрать подходящий текст, позволивший ему сделать свой ответ Карлу связным, убедительным и, вероятно, удовлетворительным для его окружения (хотя, по существу, он так и не смог ответить на поставленный перед ним вопрос о двух затмениях).

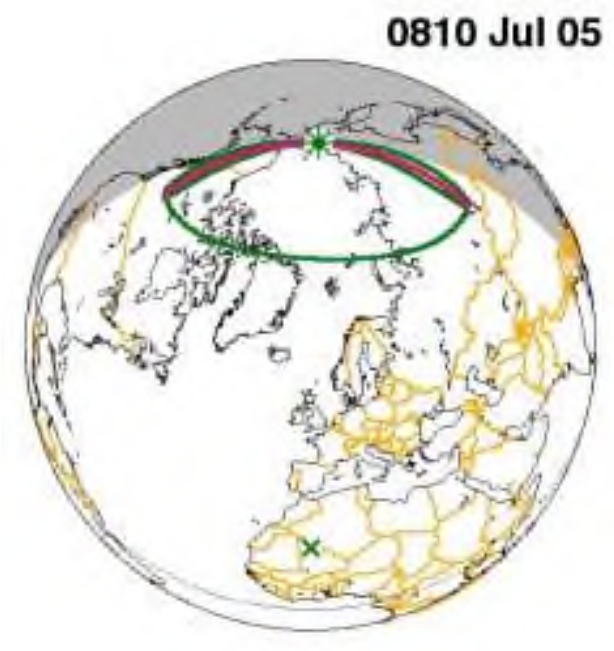

Илл. 5. Солнечное затмение 5 июля 810 г.

Зелеными линиями отмечены границы лунной полутени,

${ }^{19}$ Eastwood 1994: 117-134. 
звездочка соответствует точке наибольшего затмения.

(cм. CatSE 810: КатC3 810).

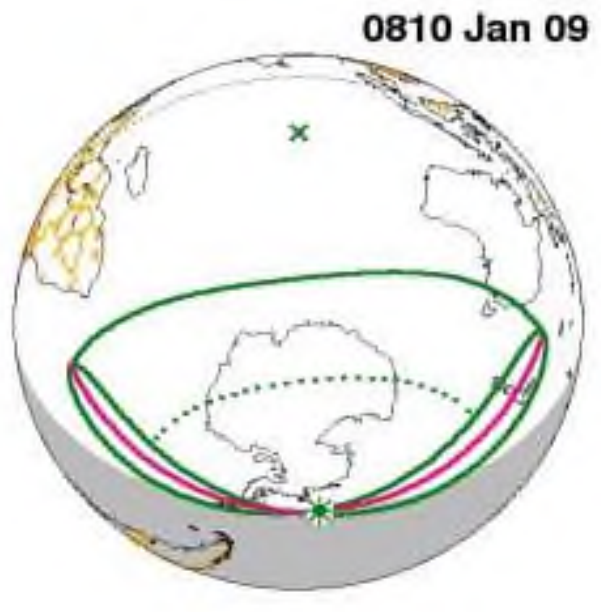

Илл. 6. Солнечное затмение 9 января 810 г.

Зелеными линиями отмечены границы лунной полутени, звездочка соответствует точке наибольшего затмения.

(cм. CatSE 810: КатC3 810).

\section{Источники, их обозначения и переводы}

\section{БИБЛИОГРАФИЯ / REFERENCES}

Оригинальные тексты, кроме случаев, оговоренных особо, см. в электронных базах данных или открытом доступе сети Интернет:

ALB Aureae Latinitatis Bibliotheca (1991)

BTL Bibliotheca Teubneriana Latina (2002)

MGH Monumenta Germaniae Historica:

MGH Ep. - Epistolae Karolini aevi II. T. IV.

https://www.dmgh.de/mgh_epp_4/index.htm\#page/(III)/mode/1up

MGH SS - Scriptores I.

https://www.dmgh.de/mgh ss 1/index.htm\#page/IV/ mode/1up (May, 2021)

PHI $5 \quad$ Packard Humanities Institute (CD version 5, 1991)

PL Patrologia Latina (CD version 1993-1995) / Patrologiae Cursus Completus Series Latina / Ed. J.-P. Migne. Parisiis, 1844-1865. T. 1-225. https://www.documentacatholicaomnia.eu/1815-1875,_Migne,__ Patrolo-

TLG

Анналы (Annales) -

gia_Latina_01._Rerum_Conspectus_Pro_Tomis_Ordinatus,_MLT.html Thesaurus Linguae Graecae (1992-2010)

Ann. Iuv. - Annales Iuvavenses maiores // MGH, SS. Bd. I. Hannover. 1826. https://www.dmgh.de/mgh ss $1 /$ index.htm\#page/88/mode/1up

Рус. пер.: Большие Ювавские анналы / Пер. А. Голованова [Rus. per.: Bol'shie Yuvavskie annaly / Per. A. Golovanova].

http://www.vostlit.info/Texts/rus17/Ann_Juv_Salz_II/ann_iuv_maiores.phtml?id=7385

Ann. regn. Franc. - Annales regni Francorum inde ab a. 741 usque ad a. 829, qui dicuntur Annales Laurissenses maiores et Einhardi // MGH, SS. rer. Germ. Bd. 6. Hannover, 1895. https://www.dmgh.de/mgh_ss_rer_germ_6/index.htm\#page/ 132/mode/1up

Рус. пер.: Анналы королевства франков, 741-829... / Пер. А. Волынец [Rus. per.: Annaly korolevstva frankov, 741-829 / Per. A. Volynets]. - $\underline{\text { http://www. vos- }}$ 
tlit.info/Texts/rus17/Annales regni francorum/frametext1.htm (May, 2021).

Аноним (Anonymus). - An. Vita Hlud.

Рус. пер.: Аноним. Жизнь императора Людовика / Пер. А.В. Тарасовой // Историки эпохи

Каролингов. М.: РОССПЭН. 1999 [Rus. per.: Anonim. Zhizn' imperatora Lyudovika /

Per. A.V. Tarasovoi // Istoriki epokhi Karolingov. M.: ROSSPEN. 1999]. http://www.vostlit.info/Texts/rus11/Astronom/ frametext1.htm

Дунгал (Dungalus) - Dung. Ep. I

Dungali Reclusi Epistola I de duplici solis eclipsi anno 810. Ad Carolum Magnum // PL 105. Cols. 447A - 458C.

Epistola I // Dungali Scotti Epistolae / Ed. E. Dümmler // MGH: Ep. Karolini aevi II. T. IV. P. 570-578.

Лукреций (Lucretius) - Lucr. De rerum nat.

Lucretius Carus, Titus. De rerum natura // ALB; BTL; PHI 5.

Рус. пер.: Лукреций Кар Тит. О природе вещей / Пер. Ф.А. Петровского. М.: АН СССР, 1958 [Rus. per.: Lukretsii Kar Tit. O prirode veshchei / Per. F.A. Petrovskogo. M.: AN SSSR, 1958]. - https://classics.nsu.ru/bibliotheca/ lucretius.htm (May, 2021).

Макробий (Macrobius) - Macr. Comm.

Ambrosii Theodosii Macrobii Commentarii in Somnium Scipionis / Ed. I. Willis. Leipzig, 1963.

Рус. пер.: Макробий Амвросий Феодосий. Комментарий на «Сон Сципиона». Кн. І. Гл. 14; 8-14 и 17. Кн. II. Гл. 12-13 и 17 / Пер. с лат. и примеч. М.С. Петровой // Петрова М.С. Макробий Феодосий и представления о душе и о мироздании в Поздней Античности. - М.: Кругъ, 2007. - 464 с. [Rus. per.: Makrobii Amvrosii Feodosii. Kommentarii na «Son Stsipiona». Kn. I. Gl. 1-4; 8-14 i 17. Kn. II. Gl. 12-13 i 17 / Per. s lat. i primech. M.S. Petrovoi // Petrova M.S. Makrobii Feodosii i predstavleniya o dushe i o mirozdanii v Pozdnei Antichnosti. - M.: Krug", 2007. - 464 s.]

Плиний (Plinius) - Plin. Nat. hist.

Plinius Secundus, Gaius. Naturalis historia // PHI 5 [0978].

Ориг. текст, англ. пер.: Pliny. Natural history in ten volumes. Vol. 1. Praefatio, libri I-II, with an English translation by H. Rackham. Cambridge, MA: Harvard University Press - London: William Heinemann Ltd., 1962. - 412 p.

Плутарх (Plutarchus) - Plut. De facie

Plutarchus. De facie in orbe lunae // TLG [0007].

Рус. пер.: Плутарх. О лике, видимом на диске Луны / Пер. с др.-греч. Г.А. Иванова, сверен и переработан В.В. Петровым, примеч. Г.А. Иванова, М.С. Петровой // Философия природы в Античности и Средние века / Общ. ред. П.П. Гайденко, В.В. Петров. М.: Прогресс-Традиция, 2000 [Rus. per.: Plutarkh. O like, vidimom na diske Luny / Per. s dr.-grech. G.A. Ivanova, sveren i pererabotan V.V. Petrovym, primech. G.A. Ivanova, M.S. Petrovoi // Filosofiya prirody v Antichnosti i Srednie veka / Obshch. red. P.P. Gaidenko, V.V. Petrov. M.: Progress-Traditsiya, 2000]. - https://facetia.ru/node/5351).

Прокл (Proclus) - Procl. In Tim.

Procli Diadochi in Platonis Timaeum commentaria / Ed. E. Diehl, 3 vols. Leipzig, 1903-1906, repr. 1965. T. III // TLG.

Сенека (Seneca) - Sen. Ep. ad Luc.

Seneca, L. Annaeus (Iunior). Epistulae Morales ad Lucilium // ALB; BTL; PHI 5 [1017].

Рус. пер.: Луций Анней Сенека. Нравственные письма к Луцилию / Пер., примеч., подг. изд. С.А. Ошерова / Отв. ред. М.Л. Гаспаров. М.: Наука, 1977 [Rus. per.: Lutsii Annei Seneka. Nravstvennye pis'ma k Lutsiliyu / Per., primech., podg. izd. S.A. Osherova / Otv. red. M.L. Gasparov. M.: Nauka, 1977]. - http://ancientrome.ru/antlitr/t.htm?a=1346570088 (May, 2021).

Цицерон (Cicero) - Cic. De Rep.

Cicero, Marcus Tullius. De Republica // PHI 5 [0474]

Русск. пер.: Цицерон. О государстве / Пер. В.О Горенштейна / Примеч. И.Н. Веселовского, В.О. Горенштейна // Цицерон. Диалоги: О государстве. О законах / Отв. ред. С.Л. Утченко. М.: Наука, 1966. - 224 с. [Russk. per.: Tsitseron. O gosudarstve / Per. V.O Gorenshteina / Primech. I.N. Veselovskogo, V.O. Gorenshteina // Tsitseron. Dialogi: O gosudarstve. O zakonakh / Otv. red. S.L. Utchenko. M.: Nauka, 1966. - 224 s.] 
Эйнхард (Einhardus) - Einh. Vita Kar.

Ориг. текст и русск. пер.: Эйнхард. Жизнь Карла Великого / Вступит. ст., перевод с лат., примеч., указат. М.С. Петровой. М.: Ин-т философии, теологии и истории св. Фомы, 2005. - 304 c. [Orig. tekst i russk. per.: Einkhard. Zhizn' Karla Velikogo / Vstupit. st., perevod s lat., primech., ukazat. M.S. Petrovoi. M.: In-t filosofii, teologii i istorii sv. Fomy, 2005. - 304 s.]

\section{Исследования / Issledovaniya}

Armisen-Marchetti, M. Introduction // Macrobe, Commentaire au Songe de Scipion. Livre I: Texte établi, traduit et commenté par Mireille Armisen-Marchetti. Paris: Les Belles Lettres, 2001. P. vii-cv.

Burnet, John. Influence of Anaximenes (23-31) // Burnet, John. Early Greek Philosophy / Ed. J. Burnet. London: A \& C Black Ltd, 2nd ed., 1908. P. 75-84. - 431 p.

Bicknell, P.J. Anaximenes’ Astronomy // Acta Classica. 1969. Vol. 12. P. 53-85.

Clay, D. Lucretius and Epicurus. Ithaca, 1984. - 361 p.

Cornford, F.M. (tr.) / Plato's Cosmology: the Timaeus of Plato / Transl. with a running commentary by F. MacDonald Cornford. L.: Routledge \& Kegan Paul, 1937; repr. 1997. 376 p.

Courcelle, P. La postèritè chrètienne du 'Songe de Scipion' // Revue des études latines 36. 1958. P. 205-234.

Duhem, P. Le système du monde; histoire des doctrines cosmologiques de Platon à Copernic. In 5 vols. Paris, 1913-1915. Vol. 3. Paris, 1915. - 549 p.

Eastwood, Bruce. The Astronomies of Pliny, Martianus Capella and Isidore of Seville in the Carolingian World // Science in Western and Eastern Civilization in Carolingian Times / Eds. Paul Leo Butzer, Dietrich Lohrmann. Basel: Birkhäuser Verlag, 1993A. P. 161-180 (Eastwood, 1993A).

Eastwood, B.S., Plato and Circumsolar Planetary Motion in the Middle Ages // Archives d'histoire doctrinale et littéraire du Moyen Age 60. 1993B. P. 7-26 (Eastwood, 1993B).

Eastwood, B.S. The Astronomy of Macrobius in Carolingian Europe: Dungal's Letter of 811 to Charles the Greate // Early Medieval Europe 3. 1994. P. 117-134.

Flamant, J. Macrobe et le Néoplatonisme Latin à la fin du IVe Siècle. Leiden, 1977. 738 p.

Gersh, St. Middle Platonism and Neoplatonism. The Latin Tradition. Vol. II. Notre Dame, Indiana, $1986.782 \mathrm{p}$.

Graham, D.W. A New Look at Anaximenes // History of Philosophy Quarterly. 2003. Vol. 20 (1). P. 1-20.

Graham, D.W. Explaining the Cosmos: the Ionian Tradition of Scientific Philosophy. Princeton, NJ: Princeton University Press, 2006. -368 p.

Hägermann, Dieter. Karl der Große. Herrscher des Abendlandes. Biografie. Berlin: Propyläen Verlag, 2000.

Jeauneau, E. Macrobe, source du platonisme chartrain // Studi Medievali III. V. 1 (1960). P. 3-24.

Laistner, M.L.W. Thought and Letters in Western Europe: A.C. 500 to 900. Ithaca: Cornell University Press, 1957; 2nd. ed. 416 p.

Kahn, Charles H. Anaximander and the Origins of Greek Cosmology. N.Y.: Columbia University Press, 1960. 249 p.

Kwok, S. Our Place in the Universe (Understanding Fundamental Astronomy from Ancient Discoveries). Springer, Cham., 2017. 375 p.

Kouremenos, T. Aristotle's Cosmology // Heavenly Stuff. The Constitution of the Celestial Objects and the Theory of Homocentric Spheres in Aristotle's Cosmology. Stuttgart: Franz Steiner, 2010. 155 p.; Aristotle's Cosmology, p. 17-33 [11-49]. https://www.weltbild.de/media/txt/pdf/9783515097338-115.027.230.pdf.

Littmann, Mark; Espenak, Fred; Willcox, Ken. Totality. Eclipses of the Sun. Oxford University Press, 1991, ${ }^{3} 2008 .-343$ p.

Manitius, M. Geschichte der lateinischen Literatur des Mittelalters. 3 vols. Muenchen, 1911-1931. Vol. 3.

Matthen, M.; Hankinson, R.J. Aristotle's Universe: Its Form and Matter // Synthese (Logic and Metaphysics in Aristotle and Early Modern Philosophy). 1993. Vol. 96, No. 3. P. 417-435.

Mras, K. Macrobius' Kommentar zu Ciceros Somnium: ein Beitrag zur Geistesgeschichte des 5. Jahrh. n. Chr. Berlin: Verlag der Akademie der Wissenschaften in Kommission bei Walter 
de Gruyter, 1933. -57 p.

Nichols Jr., J.H. Epicurean Political Philosophy. The De rerum natura of Lucretius. Ithaca, 1976. $214 \mathrm{p}$.

O'Brien, Denis. Empedocles' Cosmic Cycle: A Reconstruction from the Fragments and Secondary Sources. Cambridge: Cambridge Iniversity Press, 1969; repr. 2008. - 472 p.

Reade, W.H.V. Philosophy in the Middle Ages // The Cambridge Medieval History. In 8 vol. N.Y.; Cambridge, 1911-1936. Vol. 5: The Contest of Empire and Papacy / Ed. J.R. Tanner, C.W. Previte-Orton, Z.N. Brooke. N.Y., 1928 и 1931. P. 780-829.

Schedler, Ph.M. Die Philosophie des Macrobius und ihr Einfluss auf die Wissenschaft des Christlichen Mittelalters // Beiträge zur Geschicte der Philosophie des Mittelalters 13. 1. 1916. $190 \mathrm{p}$.

Sedley, D. Lucretius and the Transformation of Greek Wisdom. Cambridge, 1998. 256 p.

Silvestre, H. Note sur la survie de Macrobe au Moyen Âge // Classica et Mediaevalia: Revue danoise de philologie et d'histoire 24. 1963. P. 170-180.

Solmsen, Friedrich. Aristotle and Presocratic Cosmogony // Harvard Studies in Classical Philology. 1958. Vol. 63. P. 265-282.

Stahl, W.G. Introduction // Macrobius. Commentary on the 'Dream of Scipio' / Trans. and notes by W.H. Stahl. N.Y., 1952; 1990². P. 3-65.

Tierney, J.J. Introduction // Dicuili ‘Liber de mensura orbis terrae'. Dublin, 1967. P. 27-29.

Warntjes, Immo. An Irish eclipse prediction of AD 754: the earliest in the Latin West // Peritia 24-25. 2014. P. 108-115.

Михайлов, А.А. Теория затмений. М.: Изд-во технико-теоретич. лит., 1954. 272 с. [Mikhailov, A.A. Teoriya zatmenii. M.: Izd-vo tekhniko-teoretich. lit., 1954. - 272 s.]

Михайлов, А.А. (ред.) / Солнечные затмения и их наблюдения / Сост. В.А. Бронштэн, Е.Я. Богуславская, Н.Я. Богуславская и др. / Под ред. А.А. Михайлова // Всесоюзное астрономо-геодезическое общество. М.: Физматгиз, 1960. - 238 с. [Mikhailov, A.A. (red.) / Solnechnye zatmeniya i ikh nablyudeniya / Sost. V.A. Bronshten, E.Ya. Boguslavskaya, N.Ya. Boguslavskaya i dr. / Pod red. A.A. Mikhailova // Vsesoyuznoe astronomo-geodezicheskoe obshchestvo. M.: Fizmatgiz, 1960. 238 s.]

Петрова, М.С. Природа души и мира в диалоге Плутарха О лике, видимом на диске Луньь // Философия природы в Античности и в Средние века / Общ. ред. П.П. Гайденко, B.В. Петрова. М.: Прогресс-Традиция, 2000 [Petrova, M.S. Priroda dushi i mira v dialoge Plutarkha O like, vidimom na diske Luny // Filosofiya prirody v Antichnosti i v Srednie veka / Obshch. red. P.P. Gaidenko, V.V. Petrova. M.: Progress-Traditsiya, 2000]. http://www.astro-cabinet.ru/library/Plytarch/Plytarch3. htm (May, 2021).

Петрова, М.С. Макробий Феодосий и представления о душе и о мироздании в Поздней Античности. М.: Кругъ, 2007. 464 с. [Petrova, M.S. Makrobii Feodosii i predstavleniya o dushe i o mirozdanii v Pozdnei Antichnosti. M.: Krug", 2007. 464 s.]

Хэгерманн, Д. Карл Великий / Пер. с нем. В.П. Котелкина. М.: Изд-во АСТ, 2003. 684 с. [Khegermann, 2003 - Khegermann, D. Karl Velikii / Per. s nem. V.P. Kotelkina. M.: Izdvo AST, 2003. 684 s.]

Цесевич, В.П. Руководство к организации и проведению любительских наблюдений небесных светил. М.: Наука, 1973. 384 с., с илл. [Tsesevich, 1973 - Tsesevich, V.P. Rukovodstvo k organizatsii i provedeniyu lyubitel'skikh nablyudenii nebesnykh svetil. M.: Nauka, 1973. 384 s., s ill.] - http://12apr.su/books/item/f00/ s00/z0000012/st000.shtml

Чекин, А.С. Картография христианского Средневековья VIII-XIII вв. М.: Вост. литер. PAH, 1999. 366 c. [Chekin, A.S. Kartografiya khristianskogo Srednevekov'ya VIII-XIII vv. M.: Vost. liter. RAN, 1999. $366 \mathrm{c}$.]

\section{Электронные материаль и их обозначения}

CatSE - Catalog of Solar Eclipses: 0801 to 0900 // NASA GODDARD SPACE FLIGHT CENTER ECLIPSE WEB SITE. - eclipse.gsfc.nasa.gov/eclipse.html (май, 2021); https://eclipse.gsfc.nasa.gov/SEcat5/SE0801-0900.html (май, 2021).

MW - Merovingian World

Palmer, James T. On the Early Middle Ages and Other Things // The Case of the Mystery Eclipse of 811. - https://merovingianworld.com/2018/04/25/the-case-of-the-mystery-eclipse-of-811/ 
КатС3 - Каталог солнечных затмений, 810 г. // Полное солнечное затмение [Katalog solnechnykh zatmenii, 810 g. // Polnoe solnechnoe zatmenie]. - https://www.secl.ru/;

https://www.secl.ru/eclipse_catalog/810_1_9.html (May, 2021);

https://www.secl.ru/eclipse catalog/810 6 5.html (May, 2021);

https://www.secl.ru/eclipse_catalog/810_7_5.html (May, 2021);

https://www.secl.ru/eclipse catalog/810 11 30.html (May, 2021).

Петрова Майя Станиславовна, доктор исторических наук, дочент, главный научный сотрудник, Институт всеобщей истории РАH; beionyt@mail.ru

\section{Dungal and Macrobius: On the Perception of Ancient Texts by Medieval Authors}

The paper discusses the importance of the problem of perception of ancient (naturalphilosophical) knowledge by Western European science of the early Middle Ages. The possibility of its solution by means of textual comparative studies is noted. The purpose of such studies is not only the gradual and detailed formation of a general "picture" of the assimilation of previous knowledge by medieval science, but also the accumulation of information about various ways of using it. The text of the reply letter (811) of the Irish monk Dungal (fl. 811-828) to Charlemagne on the nature of solar eclipses, based on ancient sources ("Natural History" by Pliny the Elder [1st c.] and "Commentary on the 'Dream of Scipio'" by Macrobius [V c.]), is under consideration. The explicit and hidden goals of the Dungal's text are revealed; the order of the planetary spheres is discussed; Dungal's knowledge of the foundations of ancient natural philosophy is noted; it is shown how Dungal (depending on his source - Pliny or Macrobius) rebuilds and processes the original text. The conclusion is made about Dungal's attempt to answer Charlemagne's question and the result obtained.

Keywords: text, tradition, knowledge, source, reception, assimilation.

Maya Petrova, Dr. Sc. (in History), Institute of World History of the Russian Academy of Sciences; beionyt@mail.ru 


\section{РОМАНЫ О «НОВЫХ ЛЮДЯХ» РУБЕЖА 1860-1870-х гГ. В ВОСПРИЯТИИ РУССКОГО ОБЩЕСТВА}

В статье рассматриваются свидетельства о реакции общества на романы о «новых людях», выходившие на рубеже 1860-1870-х гг. Приводятся мнения и отзывы критиков, читателей, цензуры, раскрываются факты о воздействии этой литературы на реальную деятельность интеллигентов. На основе этих данных подтверждается, что романы о «новых людях» отразили запросы и настроения разночинной интеллигенции, оказывали влияние на формирование ее мировоззрения и идеологии, что доказывает ценность такой литературы как исторического источника.

Ключевые слова: интеллигенция, народничество, общественное движение, идеология разночинцев, иензура

Литература задает неслыханные, фантастические нормы героического поведения, а жизнь героев пытается их реализовать. Не литература воспроизводит жизнь, а жизнь стремится воссоздать литературу.

Ю.М. Лотман «Культура и взрыв»

1860-е гг. стали временем невиданного до тех пор в России роста общественного движения, временем формирования разночинной интеллигенции и развития ее идеологии. Важную роль в самоопределении разночинцев играла литература ${ }^{1}$, а роман Н.Г. Чернышевского «Что делать?» положил начало популярности произведений о «новых людях», игравших роль «учебников» для молодых интеллигентов. В этих произведениях в доступной форме излагались идеи, следуя которым необходимо жить «новому человеку». Среди романов о «новых людях», создававшихся в 1860-е - начале 1870-х гг. преимущественно писателямиразночинцами, отметим «Трудное время» В.А. Слепцова (1864), «Степан Рулев» Н.Ф. Бажина (1864), «Перед рассветом» Н.А. Благовещенского (1865), «Старая и юная Россия» Д.К. Гирса (1868), «Знамения времени» Д.Л. Мордовцева (1869), «Шаг за шагом» И.В. Омулевского (1870), «Николай Негорев, или Благополучный россиянин» И.А. Кущевского (1871), «Без исхода» К.М. Станюковича (1873) и др.

Несмотря на низкую художественную ценность большинства отмеченных произведений, исследователи признают несомненную историческую значимость беллетристики этого направления: в ней отразились господствующие настроения эпохи, вопросы, волновавшие мыслящих людей, популярные идеи, замыслы и цели интеллигенции. Неслучайно такую беллетристику называют тенденциозной, публицистической, просветительской ${ }^{2}$. Одна из ее характеристик - ярко выраженная идеологическая составляющая. Авторы стремились популяризировать «новые идеи», в художественно-публицистической форме убедить читателя в их правильности и перспективности, - таким образом, рома-

\footnotetext{
${ }^{1}$ Об этом см. напр.: Могильнер 1999; Колесникова 2005.

2 Замотин 1910: 131; Скабичевский., 1897: 270; Пинаев 1980: 63.
} 
ны о «новых людях» получали прямое пропагандистски-воспитательное значение для формирующейся разночинной интеллигенции ${ }^{3}$.

В центре нашего внимания - романы о «новых людях», вышедшие на рубеже 1860-1870-х гг., наиболее значительные из них - «Знамения времени» Д.Л. Мордовцева (1869) и «Шаг за шагом» И.В. Омулевского (1870). Раскрытие отзывов современников о романах, выявление свидетельств об их воздействии на читателей - позволит сделать значительный шаг в определении роли романов о «новых людях» в жизни русской интеллигенции, а значит - глубже понять источники формирования ее мировоззрения и идеологии. В историческом ракурсе выбранные романы интересны тем, что создавались на рубеже двух ярких исторических эпох: если лейтмотив деятельности шестидесятников («мыслящих пролетариев», по определению Д.И. Писарева) заключался в стремлении к личному самоопределению и саморазвитию, основанному на труде, научных знаниях, отрицании «отцовской» элитарно-дворянской культу$\mathrm{pы}^{4}$, то знаменем семидесятников стал народ, целью - служение народу.

Конец 1860-х - начало 1870-х, по свидетельству современников, время брожения и смутных настроений. Вера «мыслящего пролетариата» в «личное счастье», способное привести к счастью общественному, отступала, так как не приносила результатов и удовлетворения. «То были времена всеобщего хаотического брожения, предшествовавшего массовому социалистическому движению 73-74 годов, когда назревшие силы только еще искали бессознательно выхода», - вспоминал народник С.М. Степняк-Кравчинский, - Каракозовские погромы, снесшие все, что было живого и смелого в молодежи, успели забыться; раны, ими нанесенные, успели зажить. Подросло новое поколение, которое <..> под влиянием естественного недовольства окружающим настраивалось резко оппозиционно, жадно прислушивалось ко всяким новшествам и готово было броситься к первой бреши и даже щели, откуда блеснет луч света» ${ }^{5}$.

Обстоятельным высказыванием развитии «современной молодой литературы» стала опубликованная в «Отечественных записках» критическая статья М.Е. Салтыкова-Щедрина «Напрасные опасения» (1868). «Наше время, по справедливости, называется переходным, то есть таким, которое не столько дает готовые ответы на вопросы, сколько собирает материалы для этих ответов. Этот же переходный характер необходимо признать и за литературным движением последнего времени», - писал Салтыков-Щедрин ${ }^{6}$. Рассуждая о характере нового направления в литературе, критик подчеркивал «служение правде», которым оно «всецело проникнуто» ${ }^{7}$. Салтыков-Щедрин признавал сложность изображения «новых людей» и задавался вопросом, где в жизни искать эти «деятель-

\footnotetext{
${ }^{3}$ См. об этом: Родигина, Сабурова 2011.

${ }^{4}$ Напр.: Доронина 2004.

${ }^{5}$ Степняк-Кравчинский 2001: 235.

${ }^{6}$ Салтыков-Щедрин 1970: 30.

${ }^{7}$ Там же: 20.
} 
ные и положительные типы». Он отмечал, что в произведениях «все эти люди очень мало выражают себя в действии» и «слишком много предаются теоретизированию»; «они не поступают, а только толкуют о том, как поступать должно, и этим справедливо навлекают на себя упрек в безжизненности и невыношенности» ${ }^{8}$. Хотя рассматриваемые нами романы еще не были опубликованы к выходу этой статьи СалтыковаЩедрина, сказанное им можно вполне применить к сочинениям Мордовцева и Омулевского: критик верно уловил особенности литературы о «новых людях». По его мнению, причины затруднения в изображении «новых людей» заключаются как во внутренней сложности этого типа, так и в ограничениях внешней обстановки, в которой вынужден действовать «новый человек». Похожие рассуждения мы встретим у Омулевского: завершая роман о Светлове, писатель хочет разъяснить его замысел, объяснить, почему нет «грандиозности» в действиях главного героя (основная линия повествования - устройство Светловым народной школы в его родном сибирском городе), завязка может показаться читателю «однообразной и скучной или несколько туманной, а развязка совершенно ничтожной» (главный герой уезжает в Цюрих $)^{9}$. Автор признает, что пока не видна «широкая общественная арена», на которой деятельность Светлова «могла бы показать свои действительные силы», и с оптимизмом призывает «новых людей» «шаг за шагом» идти к цели, ведя «борьбу пролетария в подземных каменноугольных копях».

Какова была, в представлении читателей, цель деятельности героев? «Слово, которое герои Мордовцева закутывали эзоповскими намеками и шарадами, а Светлов шепнул на ухо любящей женщине, было, конечно, «революция»-писал В.Г. Короленко, вспоминая о чтении романов ${ }^{10}$. Отметим, что и цензор в докладе о романе Омулевского сделал вывод, что преследуемая главным героем задача - «освобождение молодежи от всяких общественных уз и законом установленной зависимости одних лиц от других во имя нового свободного социального порядка» ${ }^{11}$. Очевидно, цензура стесняла писателя в его намерениях представить общественно-политическую деятельность героев. В том же послесловии, в завуалированных фразах Омулевского - «суровым дыханием нашей северной непогоды задерживаются рост и краски художественного произведения», «за развязку романа никто не может поручиться в наше переходное, обильное всякими недоразумениями время», - цензурный комитет ловил намеки на то, что «автор ясно высказывает сожаление об отсутствии у нас свободы слова и деятельности без правительственной санкции» ${ }^{12}$. Показательны связанные с цензурой истории романов Мордовцева и Омулевского. Опубликованный в 1869 г. в журнале «Всемир-

\footnotetext{
${ }^{8}$ Там же: 27.

${ }^{9}$ Омулевский 1960: 438.

${ }^{10}$ Короленко 1976: 268.

11 Базанов 1941: 192.

12 Там же: 182.
} 
ный труд», роман «Знамения времени» вызвал ажиотаж среди читателей, тем самым обратив на себя внимание цензурного ведомства. Цензура причислила произведение к «опасным» в политическом отношении, отдельное издание «Знамений времени» было запрещено, конфискованы и изъяты из общественных библиотек номера журнала, содержащие главы романа. Однако спрос на эти номера журнала никогда не прекращался, все это лишь подогревало интерес молодежи к крамольному произведению ${ }^{13}$. «В те времена бывало, что книга считалась опасною потому, что ею зачитывалась пылкая молодежь, а пылкая молодежь зачитывалась ею потому, что она считалась опасною», - писал в отношении романа «Знамения времени» Н.К. Михайловский, считая, что действия цензуры, с одной стороны, и интерес со стороны читателей, с другой, находились во взаимодействии и увеличивали популярность книги ${ }^{14}$. Отдельным изданием роман вышел лишь в 1900 г.

Не осталась равнодушной цензура и к сочинению Омулевского. Роман «Шаг за шагом» выходил по частям в журнале «Дело» в 1870 г. В журнальной версии роман появился не полностью: одна из глав, где рассказывалось о бунте рабочих на фабрике, была запрещена к печати. Цензура полагала, что дальнейшее развитие действий романа «будет состоять только в бесконтрольной пропаганде так называемых гуманных идей о социализме». В 1871 г. роман был издан в Петербурге отдельной книгой под заглавием «Светлов, его взгляды, характер и деятельность». Это бесцензурное издание попало в список книг, запрещенных в библиотеках и читальнях за «вредное направление». По свидетельствам современников, роман переписывали с печатного экземпляра и распространяли в рукописном виде. Попытки его переиздать окались безуспешными. В 1874 г. роман был отпечатан в издании Н.Н. Трапезникова, но весь тираж (2200 экз.) был конфискован. В 1896 г. был арестован тираж романа (3200 экз.), напечатанный без предварительной цензуры в издательстве О.Н. Поповой ${ }^{15}$. Только после 1905 г. появилась возможность перепечатать роман в «Сочинениях» Омулевского ${ }^{16}$.

Цензурный комитет считал, что «Шаг за шагом» заключает в себе «крайне вредную тенденцию», «относясь с особым уважением к так называемым «новым» людям и крайне несочувственно к существующему административному порядку, который выставляется в самом непривлекательном виде» ${ }^{17}$, содержит «мысли самого нигилистического свойства, относительно существующего строя нашего общества» ${ }^{18}$. В цензорском докладе от 1896 г. говорилось: «роман Омулевского пропагандистами революционно-социальных идей, наравне с романом Чернышевского «Что делать?» рекомендуется молодежи в качестве наиболее

\footnotetext{
${ }_{13}^{13}$ Хаханов 1900: 243.

${ }^{14}$ Михайловский 1900: 109.

15 Базанов 1941: 176-178.

${ }^{16}$ Там же: 192.

${ }^{17}$ Там же: 181.

${ }^{18}$ Там же: 184.
} 
назидательного чтения для подготовки к революционной пропаганде» ${ }^{19}$. Официальный «Список книг, запрещенных к обращению в публичных библиотеках и читальнях» оказывал решительное влияние на формирование интеллигентского набора «обязательной» литературы. Так, один из активных пользователей библиотеки кружка самообразования владимирских гимназистов, вспоминая о списке запрещенных книг, говорил, что «раз правительство запрещает известные книги, значит, их следует читать, догадывались мы. Так список запрещенных книг превратился у нас в свою противоположность - в список рекомендуемых книг...» ${ }^{20}$.

Рецензии журнальных и газетных критиков, выходившие по «горячим следам» публикации произведений, позволяют составить представление об их восприятии читающей публикой, выявить оттенки общественного мнения. Роман Омулевского одни рецензенты встретили «с глумлением», другие «обошли его молчанием, как вещь ничего не обещающую», однако, по свидетельству литературного критика газеты «Новое время», роман «Шаг за шагом» заинтересовал многие читатели «решительно наперекор газетным судьям, видят в произведении Омулевского вещь хорошую и нечто обещающую». Рецензент отмечал правдоподобность, естественность, жизненность повествования и героев и утверждал, что роман заслуживает всеобщего внимания ${ }^{21}$.

В журнале «Дешевая библиотека для легкого чтения» С.С. Окрейц рассуждал о романе «Шаг за шагом» в контексте роста популярности тенденциозной беллетристики. Рецензент признавал, что «писателю нынче недостаточно одной художественности: необходимо сказать чтонибудь по социальным и политическим вопросам», «необходимо если не решить, то, по крайней мере, наметить путь общества; нарисовать типы, в которых сказалось наше общественное движение» ${ }^{22}$. Окрейц называл роман «бедным», «мертвым», неудобочитаемым, созданных им «новых людей» - «китайскими тенями без признака жизни». Тем не менее, этот роман - порождение времени: «Все, что продумал, слепил и написал автор «Шаг за шагом», он сделал не самопроизвольно, а под давлением своего времени и общества, под давлением читающей публики, требующей изображения общественных вопросов» ${ }^{23}$.

К «беллетристике добрых намерений» относил роман «Шаг за шагом» рецензент журнала «Вестник Европы» ${ }^{24}$. Беллетристы «добрых намерений», по его определению, обнаруживая неуменье справляться и с формой, и с содержанием романа, наполняют его рассуждениями по актуальным вопросам, тем самым знакомя читателей с полезными знаниями и оказывая влияние на общество. Критик относит роман к типу «наиболее умных и наиболее даровитых произведений такой беллетри-

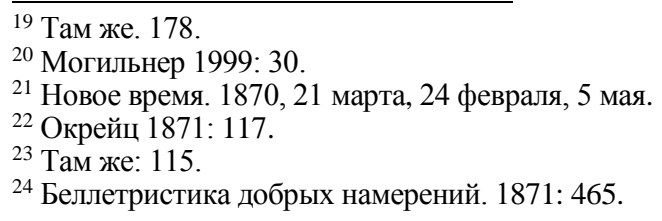


стики», это, скорее, программа для тех, кто стремится быть полезным, «внушенная искренним и горячим чувством» автора. «Это чувство примиряет читателя с недостатками романа, и он дочитывается тем легче, что у автора есть и некоторая наблюдательность, и живые, выхваченные из жизни сцены, и даже < ...> некоторые зачатки типов» ${ }^{25}$.

Положительно отозвался о сочинении Омулевского СалтыковЩедрин. По его мнению, автор «с полной добросовестностью» отнесся к насущным вопросам современности - о свободе мышления, народном образовании, женскому, рабочему вопросу. Критик признавал, что в романе о Светлове присутствует большая доля книжности, однообразность героев, вялость действия, и связывал эти недостатки с тем, что «новые идеи, которых касается автор, входят в общий обиход очень туго, а еще туже проникают в самую жизнь»; при этом со стороны автора видны «очень серьезные усилия освободиться от голословных разглагольствований и стать на дорогу образного воспроизведения жизни» ${ }^{26}$.

Поэт и критик П.В. Быков, вращавшийся в литературных кругах того времени, вспоминал, что «молодежь зачитывалась романом, делала овации автору», произведением интересовались читатели среднего круга и высшего света: после выхода отдельного издания романа на одной из встреч у писателя «весь вечер говорили об этом романе, жарко спорили о типе «нового человека», борящегося с обветшалым строем» ${ }^{27}$.

Роман Мордовцева «Знамения времени», запрещенный вскоре после выхода в свет, широкого обсуждения в печати непосредственно после публикации не получил. Отметим рецензию Окрейца в журнале «Дело». Героев произведения критик называл не людьми, а олицетворением того или другого общественного вопроса. По его мнению, писатель не связал общей идеей поставленные в романе вопросы, и само произведение - неудачное, задуманное не по силам автора. Критик отметил: «Сам Мордовцев и его писательский талант суть настоящие знамения времени: имеется кое-что, но установившейся идеи, понимания того, что бессознательно запало в голову, нет» ${ }^{28}$. Заслуживают внимания свидетельства о влиянии идей романа на конкретную деятельность интеллигентов. В 1872 г. в Одессе возник народнический кружок «сенжебунистов», которые проповедовали идеи социалистических преобразований России путем мирной пропаганды и организации хозяйственной деятельности среди крестьян. На средства от продажи имения одного из членов кружка «сен-жебунисты» хотели приобрести участок земли, чтобы устроить там опытное образцовое хозяйство ${ }^{29}$. Эти планы очень напоминают действия главных героев романа Мордовцева. Неслучайно об организаторе этого кружка Сергее Жебунове его соратник С. Чуднов-

\footnotetext{
25 Там же: 477.

${ }^{26}$ Салтыков-Щедрин 1970: 417-418.

${ }^{27}$ Быков 1909: 77.

${ }^{28}$ Окрейц 1869: 112.

${ }^{29}$ Момот 1978: 71.
} 
ский писал: «Такие цельные и непосредственные натуры мне больше в жизни не попадались, я встречал их лишь в таких романах, как «Знамения времени» Мордовцева и ему подобных» ${ }^{30}$. Вскоре члены кружка склонились к революционной программе действий.

Советский исследователь народнического движения Б.С. Итенберг, привлекая архивные материалы, в своей монографии пишет, что весной 1874 г. роман Мордовцева обсуждался в пензенском народническом кружке. Участник этого кружка П.В. Кротов пересказал содержание романа, охарактеризовал деятельность героев, стремившихся к созданию земледельческих ассоциаций. Затем он отверг подобный характер деятельности, заявив, что, по мнению современной молодежи, «ничто не в состоянии помочь русскому народу подняться из его положения, кроме революционного движения, для возбуждения которого некоторые идут в народ». В процессе обсуждения один из членов кружка Д. Рогачев говорил о том, что если герои романа «Знамения времени» рассчитывали улучшить положение народа посредством реформ сверху, то в реальности радикально настроенная молодежь не верила в легальную деятельность и в силу государственных реформ. Таким образом, радикально настроенные интеллигенты не были согласны с нереволюционной тактикой героев романа Мордовцева. Свидетельства о таких дискуссиях в народнических кружках доказывают, что роман вызвал немалую реакцию в среде интеллигенции: идеи романа анализировались, обсуждалась возможность их применения на практике. Интересно, что народник, активный пропагандист М.А. Гриценков после своего ареста, вероятно, желая создать в глазах следствия «легальный» облик своей деятельности, заявил, что герои романа Мордовцева «Знамения времени», которых он назвал примерами для идущих в деревни народников, «шли в народ не для того, чтобы делать революцию, а с намерением оказать влияние на умственное и нравственное развитие трудящихся» ${ }^{31}$.

При обыске у студента Вятского земского технического училища 3.С. Сычугова, который в 1874 г. принял участие в «хождении в народ», был арестован и судился по процессу 193-х, нашли записку, по мнению полиции, «составляющую программу партии, в которой выражалось мнение о необходимости идти в народ и сначала сеять рожь и прочие хлеба, а затем уже и идеи». В записке воспроизводилась точная цитата из «Знамений времени»: «Мы идем в курные избы, в народ, будем там жать, будем там пахать и сеять не современные идеи, а просо, рожь, ячмень, пшеницу, а после уже и идеи... Мы идем в народ не с прокламациями... мы просто идем слиться с народом». Интересно, что Сычугов стал одним из учеников А.Н. Энгельгардта в его знаменитой «интеллигентной деревне», а затем сам устроил земледельческую колонию в Уфимской губернии в конце 1870 -х, хотя она скоро и распалась ${ }^{32}$. Идеи рома-

\footnotetext{
30 Чудновский 1934: 83.

${ }^{31}$ Итенберг 1965: 102-103.

${ }^{32}$ Гордеева 2003: 41-42.
} 
на Мордовцева, несомненно, оставили след в сознании народника и, вероятно, оказали влияние на выбор путей деятельности.

В 1874 г. активный народник С.С. Голоушев писал родителям, что часто вспоминает роман «Знамения времени», на который смотрит «совсем иначе, чем прежде»: «Прочтите их хоть снова или припомните все, что говорилось о Караманове, и попробуйте прочесть кое-что и между строк. Караманов - вот тип живого, реального и действительно честного человека...». Впечатлен он был и Светловым Омулевского, о чем есть запись в его дневнике ${ }^{33}$. В Михайловском артиллерийском училище небольшая группа юнкеров, во главе с Л. Шишко и С. Кравчинским, скомплектовав нелегальную библиотеку, занялась изучением общественных вопросов. Читали и обсуждали статьи Писарева, роман Омулевского «Шаг за шагом», собирались на тайные сходки ${ }^{34}$.

Рассказывая о процессе «хождения в народ», Итенберг пишет, что часто пропагандисты из Петербурга и Москвы оседали вначале в провинциальных городах, с тем чтобы привлечь местную молодежь, активизировать работу местных кружков, а затем с полученным таким образом пополнением отправляться в народ. Так, в Нижнем Новгороде образовался кружок, организатором которого был прибывший из Петербурга А.И. Ливанов, начавший работу среди местной молодежи с чтения произведений Добролюбова, Чернышевского, Писарева, Омулевского ${ }^{35}$.

В мемуарах и письмах представителей интеллигенции фигурируют списки «обязательной литературы», которой определялось становление интеллигента. Поколения молодых людей штудировали одну и ту же беллетристику, которая формировала их мировоззрение и ценностный мир, и, таким образом, в немалой степени кодировала их сознание ${ }^{36}$.

В составленном народником А.Д. Михайловым списке книг, которые он рекомендовал для чтения своим сестрам в письме от 1876 г., наряду с книгами по истории, философии, естественным наукам и публицистике (работы Добролюбова, Писарева, Шелгунова), большое место занимает беллетристика. Михайлов советует сестрам читать «Что делать?» Чернышевского, произведения Салтыкова-Щедрина, рассказы и очерки Помяловского, романы и повести Решетникова, «Отцы и дети» Тургенева, «Знамения времени» Мордовцева ${ }^{37}$. Читали эти произведения и следующие поколения интеллигенции. Писатель Е.Н. Чириков вспоминал о годах своей гимназической юности в 1880-е: «В старших классах мы уже группировались в «кружки саморазвития» и, подчиняясь революционному духу того времени, читали Михайловского, Шелгунова, Миртова, Чернышевского, Писарева и обязательную, так сказать, для всякого мыслящего гимназиста беллетристику: Омулевского «Шаг

\footnotetext{
${ }^{33}$ Итенберг 1965: 103.

${ }^{34}$ Шишко 1906: 6-7.

${ }^{35}$ Итенберг 1965: 316-317.

${ }^{36}$ Могильнер 1999: 24.

${ }^{37}$ Момот 1978: 65.
} 
за шагом», Мордовцева «Знамения времени», «Что делать?» Чернышевского, «Эмма» Швейцера, «Между молотом и наковальней» Шпильгагена, «Кто виноват?» Герцена и др.» Его современник Г. Роков писал: «В восьмидесятых годах школьники с увлечением читали такое нехудожественное произведение как роман Чернышевского «Что делать?». В большом ходу был также тенденциозный роман Омулевского «Шаг за шагом». В библиотеке Владимирской мужской гимназии среди наиболее популярных и широко читаемых книг числились все те же «Что делать?», «Шаг за шагом», «Знамения времени», «Один в поле не воин» Шпильгагена, «Эмма» Швейцера, произведения Салтыкова-Щедрина, Глеба Успенского, К. Гаршина ${ }^{38}$. Литературный критик Н.Я. Абрамович вспоминал: «Что знала наша молодежь? На чем она воспитывалась? О чем до утра говорили на дымных сходках? «Что делать?» Чернышевского, тенденциозные романы Омулевского, Шеллера, статьи Михайловского, затрепанные томики западных утопистов-социалистов...»>

По мнению народников, чтение «тенденциозной беллетристики» в юности создавало «идеальный образ стойкого борца за новые идеи, полного новейших знаний, не отступающего ни перед какими препятствиями, не связанного предрассудками, умного и сильного “нового человека" $\rangle^{40}$. В автобиографиях народников художественная литература фигурирует как важный фактор, определивший их жизненный выбор. «Так, мало-помалу, - вспоминал народник В.К. Дебагорий-Мокриевич, - мы приблизились к революционному мировоззрению, и нужно сказать, что в этом вопросе... большую роль сыграла наша литература. Благодаря цензуре, прямой проповеди революции, конечно, не было, но было другое: сочувствие к революционным методам борьбы сквозило между строк у многих русских писателей» ${ }^{41}$.

Заслуживает отдельного внимания тот факт, что роман «Знамения времени» вызвал интерес в печати спустя тридцать лет после создания когда в 1900 г. появилось его отдельное издание. Развернулась полемика между известными публицистами А.И. Богдановичем («Мир Божий») и Н.К. Михайловским («Русское богатство»), главным образом по вопросу о том, насколько роман соответствует настроениям и взглядам интеллигенции того времени. К полемике присоединились литературные критики журналов «Вестник всемирной истории» и «Жизнь».

Богданович писал, что романы о «новых людях», среди которых упоминал и «Шаг за шагом» Омулевского, тогда «читались, «поглощались жадно и страстно и имели несомненное влияние, потому что отражали в себе настроение передовой части тогдашнего общества». Произведение Мордовцева он назвал одним из самых характерных образцов этой литературы: оно содержало «ходячие идеи того времени», «иллю-

\footnotetext{
${ }_{38}$ Могильнер 1999: 29-30.

39 Абрамович 1917: 19.

${ }^{40}$ Цит. по Колесникова 2005: 98.

${ }^{41}$ Могильнер 1999: 24-25.
} 
страции к излюбленным теориям» интеллигенции, читатели встречали в нем «живой отголосок своих чувств и мыслей» ${ }^{42}$. При этом, по мнению критика, «художественная грубость» играла положительную роль, поскольку делала идеи романа доступнее для большинства; отрицательные стороны сочинения «и тогда кидались в глаза всем», но они стушевывались и исчезали перед основной тенденцией романа. Тенденция эта, преобладавшая тогда в настроении прогрессивных кружков общества: вера в себя, в силу личности, которая может перестроить мир на разумных основаниях - концепция «критически мыслящей личности» из «Исторических писем» П.Л. Лаврова, неимоверно популярная среди народников 1870-х. По словам Богдановича, всякий, кто мнил себя «критически мыслящей личностью», с жадностью хватался за «Знамения времени», увлекался героями романа и посильно подражал им: «их речи, мысли, чувства находили себе отголосок в читателе, который, приблизительно, так же говорил, мыслил, чувствовал». Роман Мордовцева представляет «несомненный исторический интерес» для понимания бурной эпохи. В речах героев «сохранились задушевные мысли передовых людей того времени» о переустройстве общества на тех или иных основаниях, хотя в настоящее время видна «наивность» этих проектов - с «абсолютной общинностью труда, денег и всего имущества», с «переделами земли». Богданович считал, что содержащиеся в романе идеи в его время уже не актуальны, а современные мыслители, верящие в силу «критически мыслящей личности», не способны никого увлечь ${ }^{43}$.

Уловив в рассуждениях Богдановича намек на свои идеи, Михайловский опубликовал ответную статью, выступив как бы от поколения 1870-х. От отказывался признавать за этим произведением скольконибудь серьезное значение, отрицая при этом какую бы то ни было связь «Знамений времени» с идеями народнической интеллигенции той поры. Он соглашался в том, что роман в свое время «действительно, с жадностью читался известной частью общества». По его мнению, роман читался преимущественно «зеленой» молодежью, «подрастающим поколением», которому были необходимы примеры для поклонения и подражания, а «задушевные мысли» взрослых и серьезных представителей интеллигенции роман не отразил. Подлинным в романах о «новых людях» Михайловский называл только «подкладку настоятельной жажды общественной совести в великом и честном» и призывал будущего историка русского общества «суметь усмотреть эту подкладку над разнообразными вышитыми на ней комическими и нелепыми узорами» ${ }^{44}$.

Литературный критик «Вестника всемирной истории» А. Хаханов считал, что персонажи романа «Знамения времени» - «не кто иные, как олицетворения шестидесятых годов», а знакомство с такими романами, как «Знамения времени» Мордовцева, «Трудное время» Слепцова, «Шаг

\footnotetext{
42 Богданович 1900: 1-2.

${ }^{43}$ Там же: 6-7.

${ }^{44}$ Михайловский 1900: 124-125, 130.
} 
за шагом» Омулевского, «Николай Негорев» Кущевского, «Что делать?» Чернышевского и пр., несмотря на то, что они лишены художественности, стало обязательным для каждого вступившего в жизнь молодого человека: в этих романах была затронута масса животрепещущих вопросов, «которые постоянно такую молодежь волнуют и раздражают». Не соглашаясь с Богдановичем, Хаханов утверждал, что роман Мордовцева продолжает пользоваться успехом и «до сего времени читается» ${ }^{45}$.

К полемике присоединился литератор Е.А. Соловьев, под псевдонимом Андреевич выступивший в журнале «Жизнь». По его свидетельству, романом Мордовцева «упивались гимназисты 70-80-х годов, <... вздрагивая от каждого подозрительного шороха на учительской кафедре». Соловьев, как и Богданович, считал, что роман Мордовцева проникнут «духом и настроением» эпохи, а главные его герои были «знамением приближающегося народнического романтизма с огромностью нравственных требований, с ригоризмом, с хождением в народ». Критик отмечал, что несмотря на низкие художественные достоинства и большую долю публицистичности, в произведении есть «очень ценное, искупающее все недочеты по части художества» - это «историчность»: каждая строчка, каждая страница в нем «носит печать своей эпохи и тех интересов, которыми жило тогда общество» ${ }^{46}$.

Таким образом, мы видим, что роман «Знамения времени» бурно обсуждался критиками даже тридцать лет спустя. Публицисты соглашались в том, что роман в свое время пользовался большой популярностью, звучало мнение, что и к началу XX в. произведение не утратило значения. За исключением Михайловского, вступившие в полемику критики признавали, что роман отражал дух эпохи, «задушевные мысли» интеллигенции, стал «знамением» формирующегося народничества.

Будучи в конце 1860-х юношей, впоследствии видный общественный деятель и писатель В.Г. Короленко с присущей ему чуткостью уловил «дух времени». «Дорога, на которую страна так радостно выступала в начале десятилетия, упиралась в неопределенность», - вспоминал он в «Истории моего современника». Молодежь, не обнаруживая в настоящем путей для разрешения кризиса, ждала героев - «новых людей», которые бы указали ориентиры для деятельности. Литературе таких героев «приходилось не воссоздавать, а выдумывать», так как в действительной жизни их не было. Первостепенные художники за изображение «новых людей» не брались: почувствовать, созерцать творческим воображением этих необыкновенных героев было невозможно, «живость изображения приходилось «заменять одушевлением ожидания и веры». Именно тогда на сцену литературно-общественной жизни выдвигаются писатели второго плана и «величаво-мглистые очертания героев-великанов» - «новые люди». Среди литературы о «новых людях» Короленко выделял как раз «Знамения времени» Мордовцева и «Шаг за шагом» Омулевского.

${ }_{45}$ Хаханов 1900: 244-245.

46 Андреевич 1900: 306-307. 
Роман Мордовцева, по его впечатлению, был окружен смутным ореолом революционности: «Можно было подумать, что автору и его героям выход из современного положения ясен, и если бы не цензура, то они бы его, конечно, указали...». По свидетельству писателя, роман имел огромный успех: «Его зачитывали, комментировали, разгадывали намеки, которые, наверное, оставались загадкой для самого автора». Омулевского он называет гораздо более искренним писателем: «от его романа веяло молодой верой и какой-то особенной бодростью». Короленко прочитал эти романы в юношеском возрасте, когда гостил на каникулах у родственников, где собралась группа молодежи: «читали громко, и даже старики - капитан с женой - слушали с некоторым благоговением повествования о «новой молодежи»»). Сюжеты и герои казались Короленко неестественными и деланными, с «сильным привкусом антихудожественности»: героев Мордовцева он называет «деревяш-ками», а Светлова «с его отвлеченной удачливостью» - напоминавшим «хорошо вычищенный таз». Хотя «светлые личности» не овладевали воображением Короленко, он признавал, что «какой-то особый дух, просачивавшийся в этой литературе, все-таки оказывал свое влияние» ${ }^{47}$.

Ценные рассуждения о тенденциозной литературе 1860-х мы находим у Глеба Успенского. «Боже милосердный, как мучительно было мне смотреть на автора новых времен, на романиста новых людей!..» вспоминал он в автобиографическом рассказе «На старом пепелище» (1876). Необходимость создания «совсем-совсем новых людей» была продиктована тем, что у общества назрела «самая настоятельная надобность» в ориентирах, в образцах новой жизни и новых людей, «самой чистой нравственности» и «самой сущей правды». Как и Короленко, Успенский подчеркивал, что за неимением реальных условий и реальных героев, авторам приходилось выдумывать и изобретать черты «новых людей». Однако подлинным в этих романах была «настоящая жажда общественной совести в великом, сильном и честном ${ }^{48}$.

Таким образом, несмотря на художественную бедность, искусственность образов, однообразность сюжетов произведений о «новых людях», они попали в нерв запросов молодых разночинцев. Это была по-своему живая, актуальная и адекватная общественным настроениям литература. Произведения Мордовцева и Омулевского могли оказывать непосредственное влияние на конкретную деятельность интеллигентов: предпринимались попытки претворения идей романов в жизнь; они фигурируют в списках «обязательной литературы», на которой воспитывались поколения интеллигенции вплоть до XX в., и оказывались в центре внимания крупных писателей и публицистов. Подводя итоги, подчеркнем, что литература о «новых людях» заслуживает пристального внимания при изучении не только литературных процессов второй половины XIX в., но и идеологии русской разночинной интеллигенции.

${ }^{47}$ Короленко 1976: 266-269.
48 Успенский 1949: 125-126. 


\section{БИБЛИОГРАФИЯ / REFERENCES}

Абрамович Н.Я. Подполье русского интеллигентства: (О тупиках русского интеллигентского сознания). М.: Свободное слово, 1917. 43 с. [Abramovich N. Y. Podpol'e russkogo intelligentstva: (O tupikah intelligentskogo soznaniya). M.: Svobodnoye slovo, 1917. 43 s.].

Андреевич. Очерки текущей русской литературы (о людях красных, серых и ультрафиолетовых) // Жизнь. 1900. № 10. С. 297-319 [Andreevich. Ocherki tekushchey russkoy literatury (o lyudyah krasnyh, seryh i ultrafioletovyh) // Zhizn’. 1900. № 10. S. 297-319].

Базанов В.В. Из литературной полемики 60-х годов. Петрозаводск: Госиздат Карело-Фин. CCP, 1941. 194 c. [Bazanov V. V. Iz literaturnoy polemiki 60-h godov. Petrozavodsk: Gosizdat Karelo-Fin. SSR, 1941. 194 s.].

Беллетристика добрых намерений // Вестник Европы. 1871. № 5. С. 465-478 [Belletristika dobryh namereniy // Vestnik Evropy. 1871. № 5. S. 465-478].

Богданович А.И. Воскресшая книга - «Знамение времени» г. Мордовцева // Мир Божий. 1900. № 8. C. 1-6 [Bogdanovich A. I. Voskresshaya kniga - «Znamenie vremeni» g. Mordovtseva // Mir Bozhiy. 1900. № 8. S. 1-6].

Быков П.В. Последняя встреча // Нива. 1909. № 4. С. 77-78 [Bykov P. V. Poslednyaya vstrecha // Niva. 1909. № 4. S. 77-78].

Гордеева И.А. «Забытые люди»: история коммунитарного движения. М.: Науч.-исслед. центр «АИРО-XX», 2003. 240 с. [Gordeeva I. A. «Zabytye lyudi»: istoriya kommunitarnogo dvizheniya. M.: Nauch.-issled. tsentr «AIRO-XX», 2003. 240 s.].

Доронина М.В. Культура повседневности русской разночинной интеллигенции во второй половине XIX века: соотношение «идеального» и «реального»: дис. ...к.и.н.. М., 2004. 257 c. [Doronina M.V. Kul'tura povsednevnosti russkoy raznochinnoy intelligentsii vo vtoroy polovine XIX veka: dis. ... kand. ist. nauk. M., 2004. 257 s.].

Замотин И.И. Тенденциозная беллетристика 60-70-х годов // История русской литературы XIX века: в 5 т. Т. 4 / под ред. Д. Н. Овсянико-Куликовского. М.: Мир, 1910. С. 129159 [Zamotin I.I. Tendentsioznaya belletristika 60-70-h godov // Istoriya russkoy literatury XIX veka: v 5 t. T. 4 / red. D. N. Ovsyanniko-Kulikovskogo. M.: Mir, 1910. S. 129-159].

Итенберг Б.С. Движение революционного народничества: Народнические кружки и «хождение в народ» в 70-х годах XIX в. М.: Наука, 1965. 443 с. [Itenberg В. S. Dvizhenie revolyutsionnogo narodnichestva: Narodnicheskie kruzhki i «khozhdenie v narod» v 70-h godah XIX v. M.: Nauka, 1965. 443 s.].

Колесникова Л.А. Мемуары революционеров 1870-х годов об идейно-психологическом воздействии на них литературы // Вопросы истории. 2005. № 5. C. 96-105 [Kolesnikova L.A. Memuary revolyutsionerov 1870-h godov ob ideyno-psihologicheskom vozdeystvii na nih literatury // Voprosy istorii. 2005. № 5. S. 96-105].

Короленко В.Г. История моего современника: в 4 т. Т. 1-2. Л., 1976. 552 с. [Korolenko V. G. Istoriya moego sovremennika: v 4 t. T. 1-2. L.: Khudozhestvennaya lit-ra, 1976. 552 s.]

Михайловский Н.К. «Знамения времени», роман г. Мордовцева // Русское богатство. 1900. № 9. C. 108-123 [Mihaylovskiy N. K. «Znameniya vremeni», roman g. Mordovtseva // Russkoe bogatstvo. 1900. № 9. S. 108-123].

Могильнер М. Мифология «подпольного человека»: радикальный микрокосм в России в начале XX в. как предмет семиотического анализа. М.: НЛО, 1999. 208 c. [Mogil'ner M. Mifologiya «podpol'nogo cheloveka»: radikal'niy mikrokosm v Rossii v nachale XX v. kak predmet semioticheskogo analiza. M.: Novoe literaturnoe obozrenie, 1999. 208 s.].

Момот В.С. Даниил Лукич Мордовцев: Очерк жизни и творчества. Ростов: Кн. изд-во, 1978. 125 c. [Momot V. S. Daniil Lukich Mordovtsev: Ocherk zhizni i tvorchestva. Rostov: Kn. izd-vo, 1978. 125 s.].

Новое время. 1870, 21 марта, 24 февраля, 5 мая.

Окрейц С.С. Беллетристика последнего времени // Дешевая библиотека для легкого чтения. 1871. № 1. C. 111-145 [Okreyts S.S. Belletristika poslednego vremeni // Deshevaya biblioteka dlya legkogo chteniya. 1871. № 1. S. 111-145].

Окрейц С.С. Журналистика 1869 г. // Дело. 1869. № 9. С. 105-112 [Okreyts S.S. Zhurnalistika 1869 g. // Delo. 1869. № 9. S. 105-112].

Омулевский И.В. Шаг за шагом. Новосибирск: Новосибирское книж. изд-во, 1960. 444 с. [Omulevskiy I.V. Shag za shagom. Novosibirsk: Novosibirskoe knish. izd-vo, 1960. 444 s.].

Пинаев М.Т. Н.Г. Чернышевский-романист и «новые люди» в литературе 60-70-х годов // История русской литературы: в 4 т. Т. 3. Л.: Наука, 1982. С. 80-119 [Pinaev M.T. 
N.G. Chernyshevskiy-romanist i «novie lyudi» v literature 60-70-h godov // Istoriya russkoy literaury: v 4 t. T. 3 / pod. red. N.I. Prutskova i dr. L.: Nauka, 1982. S. 80-119].

Родигина Н.Н., Сабурова Т.А. Поколенческое измерение социокультурной истории России XIX века: преемственность и разрывы // Диалог со временем. 2011. Вып. 34. С. 138-157 [Rodigina N.N., Saburova T.A. Pokolencheskoe izmerenie sotsiokul'turnoy istorii Rossii XIX v.: preemstvennost' i razryvy // Dialog so vremenem. 2011. Vyp. 34. S. 138-157]. Салтыков-Щедрин М.Е. Напрасные опасения // Салтыков-Щедрин М.Е. Собрание сочинений: в 20 т. Т. 9 / под ред. С.А. Макашина и др. М.: Худож. литература, 1970. С. 7-35 [Saltykov-Shchedrin M. E. Naprasnye opaseniya // Saltykov-Shchedrin M. E. Sobranie sochineniy: v 20 t. T. 9 / pod. red. S. A. Makashina i dr. M.: Khudozh. literatura, 1970. S. 7-35].

Салтыков-Щедрин М.Е. Светлов, его взгляды, характер и деятельность // Собрание сочинений: в 20 т. Т. 9. С. 411-419 [Saltykov-Shchedrin M. E. Svetlov, ego vzglyady, kharakter i deyatel'nost' // Saltykov-Shchedrin M. E. Sobranie sochineniy: v 20 t. T. 9. S. 411-419].

Скабичевский А.М. История новейшей русской литературы 1848-1892 гг. СПб.: Павленков, 1897. 490 с. [Skabichevskiy A.M. Istoriya noveyshey russkoy literatury 1848-1892 gg. SPb.: Pavlenkov, 1897. 490 s.].

Степняк-Кравчинский С.М. С.М. Бардина // Степняк-Кравчинский С.М.Грозовая туча России. М.: Новый ключ, 2001. 480 c. [Stepnyak-Kravchinskiy S.M. S.M. Bardina // Stepnyak-Kravchinskiy S.M. Grozovaya tushcha Rossii. M.: Noviy klyuch, 2001. 480 s.].

Успенский Г.И. На старом пепелище // Успенский Г.И. Полное собрание сочинений: в 14 т. T. 4. М.: Изд-во АН CCCP, 1949. C. 108-164 [Uspenskiy G.I. Na starom pepelishche// Uspenskiy G.I. Polnoe sobranie sochineniy: v 14 t. T. 4. M.: AN SSSR, 1949. S. 108-164].

Хаханов А. Полемика о «Знамениях времени» // Вестник всемирной истории. 1900. № 1. C. 243-246 [Khahanov A. Polemika o «Znameniyah vremeni» // Vestnik vsemirnoy istorii. 1900. № 1. S. 243-246].

Чудновский С.Л. Из давних лет: Воспоминания. М.: Изд-во Всес. о-ва политкаторжан и ссыльно-поселенцев, 1934. 302 с. [Chudnovskiy S. L. Iz davnih let: Vospominaniya. M.: Izd-vo Vses. o-va politkatorzhan i ssyl'no-poselentsev, 1934. 302 s.].

Шишко Л.Э. Сергей Михайлович Кравчинский и кружок чайковцев: (Из воспоминаний и заметок старого народника). СПб.: В. Распопов, 1906. 47 c. [Shishko L.E. Sergey Mihaylovich Kravchinskiy i kruzhok chaykovtsev. SPb.: V. Raspopov, 1906. 47 s.].

Ильясова Лилия Рустамовна, аспирант кафедры истории России ХІХ - начала XX в. исторического факультета МГУ им. М. В. Ломоносова; ilyasova-lilia@mail.ru

\section{The novels about "new people" of the turn of the 1860s-70s and their reception by the Russian society}

The article discusses the evidence of the reaction of the Russian society to novels about "new people", published in the late 1860s - early 1870s. Opinions and reviews of critics, readers, censorship of works are presented, facts about the impact of this literature on the real activities of intellectuals are revealed. The study confirms the existing that novels about "new people" reflected the demands and moods of the raznochinnaya intelligentsia, influenced the formation of its worldview and ideology, which proves the value of such literature as a historical source.

Keywords: Russian intelligentsia, narodnichestvo, populism, social movement, ideology of raznochintsy, censorship

Lilia R. Iliasova, Graduate Student, Department of Russian History of the 19th - the beginning of the 20th Century, Lomonosov Moscow State University; ilyasova-lilia@mail.ru 


\title{
TРАКТАТ А.В. КАРТАШЕВА «РЕФОРМА, РЕФОРМАЦИЯ И ИСПОЛНЕНИЕ ЦЕРКВИ»
}

\begin{abstract}
Предмет исследования - сочинение А.В. Карташева «Реформа, реформация и исполнение Церкви», его речь 1916 г. в Петербургском религиозно-философском обществе о «внешнем» и «внутреннем» развитии Русской Церкви в преддверии Февральской революции. ПРФО было попыткой вернуться к Петербургским религиозно-философским собраниям (1901-1903), на которых религиозная интеллигенция выдвинула Церкви предложения по церковной реформе и начала религиозное движение. Его задачей была пропаганда нового религиозного сознания (НРС), воцерковление культуры как фактора обожения человека. Церковь призвали изменить отношение к «плоти» и слиться с общественной жизнью религиозно. Считается, что трактат направлен против церковной реформации. Реконструкция его содержания в доктринальной системе НРС показывает, что Карташев в 1916 г. верен своим взглядам начала века. Ключевые слова: Антон Владимирович Карташев, религиозно-философский трактат 1916 года, «неохристианство», иерковная реформа
\end{abstract}

Бывший доцент СПбДА, профессор, историк Церкви А.В. Карташев к 1908 г. стал признанным лидером религиозного движения наряду с основавшими его Д.С. Мережковским и Д.В. Философовым. Заинтересовавшись доктриной НРС в 1902 г., он примкнул к группе Мережковского, опубликовал статью (в журнале «Новый путь» ${ }^{1}$ в в защиту учения НРС о «святости плоти», в 1905 г. оставил кафедру в академии, в 1906 г. занялся журналистикой и ступил на путь церковного критика. Долгие годы он был известен своими публикациями в «Стране» и «Русском слове» по проблеме «паралича» Русской Церкви и ее взаимодействия с общественностью, ему заказывали статьи такие крупные газеты как «Биржевые ведомости». В 1913 г. Карташев был избран официальным председателем Петербургского (Петроградского) религиозно-философского общества. За годы его председательства тема реформы Церкви вновь была поднята на тот уровень, какой она занимала в ПРФС, здесь рождались и обсуждались спекулятивные проекты реформ. На заседании действительных членов ПРФО 28 февраля 1916 г. Карташев произнес речь, которая должна была дать ответ десятилетним вопрошаниям участников движения: «Что же должно произойти в Русской Церкви - реформа или реформация?» При публикации автор назвал речь «трактатом», и она является таковым, потому что аккумулирует все разнообразие мыслей о развитии Церкви в России в среде религиозной интеллигенции с 1901 г. Вместе с тем, в нем изложено собственное отношение кандидата богословия Карташева к роли Церкви в истории человечества и государстве.

Выступление председателя ПРФО традиционно проходило в конце обсуждений той или иной темы и подводило итог прениям по докладам. Поэтому в дополненном тексте трактата использованы мнения и имена

\footnotetext{
${ }^{1}$ Романский 1903: 262-276.
} 
докладчиков, выступивших по проблеме церковной реформы, и адресованные им замечания председателя. Речь была опубликована в издательстве, деятельность которого направлялась «неохристианами», и первый отклик поступил от Д.В. Философова: он сообщал, что Карташев выступал в ПРФО почти три часа, а заполненный зал слушал, не отвлекаясь, и был в каком-то особенном «напряжении», а выступление Карташева разрослось до «философско-исторического обсуждения судеб... исторических церквей» ${ }^{2}$. Философов считал, что Карташев «с гениальным проникновением» объяснил, почему «современному религиозному сознанию тесно в рамках ортодоксальности», и почему борьба демократии за лучшее будущее отвечает «коренным религиозным запросам человечества». Давний единомышленник, если не сказать «пестователь» ${ }^{3}$, Философов отозвался о Карташеве как о человеке, преданном «европейскому уму, европейской науке, европейской культуре», «утверждающем религиозный смысл истории и святость борьбы за социальную правду» ${ }^{4}$.

Д.С. Мережковский тоже благосклонно отнесся к трактату Карташева, назвав свой отклик «Исполнение церкви» ${ }^{5}$. Он выделил эту часть, так как она продолжала старинный спор между мережковцами и Карташевым ${ }^{6}$ о том, сохранять ли церковную преемственность, или создавать новую церковь для новой эпохи, в которой государство станет церковью, а «новое религиозное сознание» - общественной идеологией. Издание речи Карташева привлекло внимание и бывших участников религиозного движения: в собрании Киевского религиозно-философского общества 4 марта 1917 г. выступил В.В. Зеньковский с докладом «О книге Карташева "Реформа, реформация и исполнение церкви”, в газете «Утро России» опубликовал рецензию Н.А. Бердяев ${ }^{7}$. Отсутствие в рецензии критических замечаний, позволяет думать, что Бердяев поддержал выдвинутые в трактате тезисы о связи церковной реформы с политическим вопросом, отсутствии «признаков воли к церковной реформе» и «порыва к созданию свободной церкви». Последние он отнес к «религиозному течению» православной интеллигенции, указав С.Н. Булгакова, П.А. Флоренского ${ }^{8}$, Экземплярского, В. Зарина, П.П. Кудрявцева $\left.{ }^{9}\right)$. Бердяев писал:

\footnotetext{
2 Ермичев 2007: 189-190.

${ }^{3}$ Философов иногда корректировал статьи «неохристиан», и именно он помогал Карташеву на его пути в журналистику, пристраивая его статьи в газеты. РГАЛИ. Л. 54.

${ }^{4}$ Ермичев 2007: 189-190.

${ }^{5}$ Мережковский 1916: 2.

${ }^{6}$ См. подробно: Воронцова 2019; 2006.

${ }^{7}$ Бердяев 2004: 277-282.

8 «С. Булгаков, отец П. Флоренский... не могут не страдать от унижения и порабощения церкви. Но по всему духу своему они закрепляют старое и препятствуют всякому свободному порыву к религиозному обновлению. Их христианство - не религия свободы, а религия необходимости, религия смирения». - Бердяев 2004: 279. 9 «Они немного побаиваются мистики и в согласии с традицией берут церковное христианство скорее в противопоставлении мистике, чем в смешении с ней. Это делает их религиозно-застывшими, консервативными, боязливыми к новым религиозным темам, недостаточно чуткими». Бердяев 2004: 280.
} 
«настроенность их полезна для той внешней реформы православной церкви, которая неизбежна со всех точек зрения, хотя сама по себе и не есть религиозное дело»; действительная реформа связана с «творческим сдвигом в Церкви», а «религиозная новь» - с «новым откровением человека» ${ }^{10}$. В журнальной статье Бердяев отметил: докладчик «заражен всеми ядами Мережковского, заворожен его постановкой религиозных тем», но все-таки чувствуется в Карташеве «истинно православный, церковный человек» ${ }^{11}$. Если согласиться с Бердяевым, что Карташев в 1916 г. продолжал колебаться между цельностью и органичностью старой церковности и «соблазнами новшеств... Мережковского»" 12 (а он действительно колебался в выборе в 1906-1908 гг. ${ }^{13}$ ), то упустим главное, чем отличалась позиция Карташева в НРС после 1908 г. Трактат помогает отследить этот важный момент и понять, почему Бердяев назвал его автора-«неохристианина» истинно церковным человеком.

Еще два важных сочинения А.В. Карташева имели отзывы в зарубежных эмигрантских журналах ${ }^{14}$. В России трактат в контексте НРС не анализировался. Специфика вопроса требует погружения в содержание доктрины НРС: лексику, приемы умолчаний, иносказаний, понятийные формулы и пр. Несколько диссертаций, упоминавших трактат, были посвящены интеллектуальной эволюции и биографии Карташева как последнего обер-прокурора Святейшего Синода и историка Русской Церкви. С.С. Бычков Карташева как церковного историка ${ }^{15}$; А.Л. Золаев и А.А. Пешков интересовались его философией истории ${ }^{16}$; А.В. Антощенко рассматривал творчество Карташева в контексте разработки в русской эмиграции концепции «Россия - новая Святая Русь» ${ }^{17}$, а в рамках научного проекта под его руководством был в 2019 г. опубликован еще ряд работ ${ }^{18}$. Мы посвятили несколько статей Карташеву как журналисту и церковному критику, рассмотрев причины его увлечения НРС и особенности понимания им «неохристианской» доктрины в 1902-1905 гг. ${ }^{19}$ Трактат, пока не получивший должного внимания, является частью духовной эволюции Карташева и позволяет понять, с какими установками он подошел к 1916 г., в т.ч. как один из лидеров НРС. Анализ трактата о церковной модернизации в России призван помочь историкам сориентироваться в том наследии, которое НРС оставило после себя накануне «обновленческого» раскола в Православной Российской Церкви.

${ }^{10} \mathrm{OH}$ также подтвердил тезис Карташева о присутствии во «внешней реформе» религиозного аспекта. - Бердяев 2004: 281-282.

${ }^{11}$ Бердяев 1917: 71.

12 Бердяев 1917: 71.

${ }^{13}$ Воронцова 2006; Воронцова 2019.

14 Оболенский 1956; Шмеман, 1960.

${ }^{15}$ Бычков 1999; 2005.

16 Золаев 2014.

17 Антощенко 2004.

18 Антощенко 2019; Бычков 2019; Воронцова 2019.

${ }^{19}$ Воронцова 2006; 2020. 
Карташев предлагал рассмотреть возможности церковной модернизации в России: через внешнюю реформу, социально-религиозную реформацию (подобно Реформации в католическом мире) и новый путь - пополнение церковного учения и изменения отношения к культурному прогрессу. При переходе к каждой части трактата он рассуждал о перспективах применения этих форм церковного реформирования в России, разъяснял их содержание, аргументировал неприятие или полезность, и готовился определить исходную точку нового действия.

Начало трактата обращено к событиям 1913-1915 и первого полугодия 1916 г., когда шла борьба за реформу прихода в IV Думе, и можно предположить, что дополнения к речи относились к вопросу обсуждаемых в те годы церковных реформ. Четыре законодательных предложения были внесены депутатами в первую сессию IV Думы, обсуждение в ней вопроса о преобразовании прихода было отмечено тремя блестящими докладами: В.Н. Львова (о необходимости государственной поддержки пастыря и прихода), В.П. Шеина (он заявил от имени Комиссии по делам православной Церкви, что предложенные законопроекты соответствуют цели воссоздать приход и обеспечить духовенство) и Е.П. Ковалевского, указавшего в 1915 г. на медлительность Синода в проведении реформ. Вместо того, чтобы овладеть религиозными народными движениями, «иерархия отталкивает от себя тех, кто пытается не формально и внешне, но сознательно и глубоко войти в общение с Богом», сказал Е.П. Ковалевский, заявивший в Думе, что говорит от лица тех людей, которые любят Россию и готовы к ее религиозному просвещению, сознательному формулированию народом своего религиозного миропонимания ${ }^{20}$. После назначения на пост обер-прокурора А.Д. Самарина думское духовенство, чтобы ускорить реформу прихода, подало 4 августа записку, где отмечалось оскудение в Церкви религиозного духа. После записки предложенный для утверждения Думы проект Устава православного прихода был изъят, видимо для внесения поправок, а при новом прокуроре был внесен снова (13 декабря) без изменений. В феврале 1916 г. Дума собралась после длительного перерыва, и вопрос реформы прихода был возобновлен. После заявления митрополита Киевского Владимира (Богоявленского) и сообщений в прессе, что Комиссия по делам православной церкви постановила внести ряд поправок в ведомственный проект, Синод 29 апреля вынес определение просить Государственную думу передать проект в духовное ведомство. Но передаче препятствовал бюрократический механизм прохождения документа через Совет министров, а министры после доклада обер-прокурора А.Н. Волжина высказались против изъятия проекта. В самой Комиссии священники были связаны позицией, занятой Синодом, дело не двигалось, и рассмотрение реформы прихода было отложено ${ }^{21}$. Начало трактата Кар-

${ }^{20}$ Рожков 2004: 270.

${ }^{21} \mathrm{~B}$ прессе появились сообщения, что проект будет переработан членом Синода митрополитом Петроградским Питиримом и новым обер-прокурором. 
ташева с замечаниями в адрес думских депутатов и позиции В.Н. Львова по отношению к институту обер-прокурорства, вероятнее всего и содержало дополнения к речи, чтобы на фактах показать реальные возможности «практического» пути церковного развития, или реформы.

Центральная идея трактата сфокусирована на обличении автором «вавилонской башни социального устроения людей без Бога». Карташев видел три пути реставрации религиозного сознания в обществе: политический, реформационный и религиозный («обогащение объема религиозной жизни» исторической Церкви). Политический одним концом касался внешних реформ, другим упирался в вопрос о связи православия и самодержавия. НРС с 1905 г. декларировало необходимость религиозно расторгнуть союз Церкви с самодержавием. Карташев подчеркнул, что задание это не утратило своего значения: реформа Церкви - дело людей «политически прозревших», а «вещи, о которых говорят в Государственной думе политики, иногда вовсе безрелигиозные» ${ }^{22}$. Реформа была обозначена как действие, имеющее результатом внешние и частичные перемены: с начала века реформой Русской Церкви интересовались «люди безрелигиозные, либо религиозно неопределенного типа», которым реформа была интересна лишь с точки зрения «практической организации церковной жизни на лучших началах». Внешняя реформа административного типа всегда была чужда НРС. «Ничего религиозного нет в том, чтобы организовать приход на началах юридического лица, в том, чтобы реформировать консисторию и бракоразводный процесс, чтобы реорганизовать Синод, урегулировать положение обер-прокурора, учредить патриаршество, снять государственный запрет с функции соборности» ${ }^{23}$. С точки зрения НРС, попытки ввести «новое церковно-практическое законодательство» как усовершенствование внешней организации были необходимы, но как усовершенствование Церкви, создававшее социальное пространство благоприятное для религиозной реформы, которая устроит народ настолько, что он более не будет «разбегаться по сектам». Внешние действия открывали дорогу к реформе внутренней, и когда «уста» Церкви будут распечатаны», а «ноги и руки развязаны», будет «ясно, каков ее религиозный предел (курсив мой. - И.В.)». И «мы утверждаем... эту косвенную связь их [внешних реформ] с настоящим религиозным вопросом» ${ }^{24}$. Религиозная часть реформы Церкви определялась для Карташева следующими вопросами: а) новая церковность, при которой «масса, если и будет создавать расколы и секты, то более высокого, близкого к Церкви... типа» ${ }^{25}$; б) Церковь при государстве или государство при Церкви? Освобождение Церкви от «служебных, узко понятых национальных и правительственных целей»; в) отказ граждан от «абсо-

\footnotetext{
22 Карташев 1916: 8.

${ }^{23}$ Карташев 1916: 8.

${ }^{24}$ Карташев 1916: 10. «Религиозным вопросом» лидеры групп, участвовавших в движении, обозначали изменения в церковном сознании. Степень радикальности этих изменений различалась и зависела от реформационных «программ» группы.

${ }^{25}$ Карташев 1916: 11.
} 
лютной бесцерковности» как «псевдохристианского индивидуализма» ${ }^{26}$; г) проблема раскола в «политически освобожденной» Русской Церкви.

Рассмотрим подробней пункт «Г» об опасности церковных расколов: «Существует мнение, что в результате церковной реформы освободительного характера консервативные элементы церкви ${ }^{27}$, стоящие за старый принцип автократии, не пойдут за реформой. Илиодоры, Гермогены, Антонии, Серафимы - люди этого закала останутся на старых позициях, в расколе с новым течением, идущим вслед за жизнью общественно-политической», а «из нового течения составится покровительствуемое обновленной государственной властью большинство, господствующая Церковь, которая и вступит на умеренно-либеральный путь». Исторический опыт православных церквей «мирно сожительствующих с государственными конституциями» имеется: в Болгарии, Сербии, Румынии, Греции, Австрии. Но дело не в сосуществовании, призвание православия - в «мистико-догматическом опыте... церковного самосознания». «Православие в его максимуме и расцвете дорожит... связью с религиозным носителем власти государственной, с Помазанником-Кесарем... [и] не в силу только морально-бытового консерватизма, но в силу того же инстинкта... религиозно владычествовать над миром... в силу теократических задач церкви» ${ }^{28}$. «Нетеократическая церковь» не есть собственно церковь, православную Русскую Церковь можно внешними политическими реформами разлучить с ее «теократическим стилем», но это означало бы сдать ее в архив. К тому же «никакая внешняя разлука в наиболее глубоких носителях традиционного православного самосознания не убьет ни теократических стремлений, ни тяготений к самодержавию». Для политически освобожденной Церкви данных для раскола нет. «Раскол мог бы произойти, если бы уже не было в церковной массе той теплохладности, которая создалась в ней последним церковно мертвым периодом русской истории» ${ }^{29}$. По Карташеву, после старообрядчества расколы в Русской Церкви стали невозможны, потому что запасы «церковной православной энергии» оскудели: в ней осталось «все равнодушное, примиренческое, не способное массовым образом реагировать ни на деятельность иерархических верхов, ни на вопросы, выдвигаемые совестью отдельных религиозных искателей» ${ }^{30}$, То есть в Русской Церкви необходим творческий взрыв, но на что ему опереться? На «те-

\footnotetext{
${ }^{26}$ Подразумевается, что отношение церкви к государству безразлично христианину («Я верю во Христа, и мне все равно, как они относятся друг к другу, все равно: по католической, по протестантской или по православной схеме, - вся эта схема внехристианская»). Считающего, что «не надо... реформировать, поднимать и исправлять какое-то упавшее учреждение... потому, что где двое или трое собрались во Имя Его, там и Он - без всяких реформ и исправлений». Карташев 1916: 11-12.

${ }^{27}$ В оригинале с маленькой буквы. - И.В.

${ }^{28}$ Карташев 1916: 13-15.

${ }^{29}$ Карташев 1916: 15-16.

${ }^{30}$ Карташев 1916: 16-17.
} 
чение большинства» («покровительствуемая и приветствуемая либеральным обществом Церковь, которая забудет о своем теократическом призвании... будет церковью выдохшейся») или течение «любителей православной мистики» («не имеющих вкуса ни к какому общественному служению: ни консервативному, ни либеральному»)? Реформа даст Церкви только внешний, культурный колорит, но не будет «глубоким внутренним обновлением ее по существу». Возможно среди «государственных церковников... ретроградных групп, тоскующих о прошлом», возникнет новое церковное течение - чутких к запросам жизни людей, которые, «оказавшись в обстановке освобожденной церкви, отвернутся от старого теократического воплощения, уже осужденного судом истории и... будут искать новых, более демократических путей воплощения теократического идеала», и тогда есть некоторая надежда: «церковные либералы, мистики-созерцатели, теократы-реакционеры и церковные демократы, вот те течения», которые обозначатся в реформированной Церкви ${ }^{31}$. Появление этих течений Карташев считал показателем освобождения «подавленного церковного сознания», перед некоторыми течениями откроется выход к новому творчеству, к такого рода начинаниям, которые перейдут «грани простой реформы» в перспективах реформации.

Рассматривая во второй части вопрос «Как соприкоснется Русская Церковь с реформацией?», автор сразу заявлял: повторение «классической реформации» невозможно. «Пафос, с которым была связана Реформация, - ...возрождения и гуманизма и даже пафос просвещения - уже изжит» ${ }^{32}$. Но плоды Реформации усвоены, и ее «достояние» перспективно в плане «права личного религиозного отношения к Богу, вне авторитета» церковного, и в плане права научного разума «изучать и осмысливать христианские догматы» ${ }^{33}$. «Потребность в религиозной автономии личности, выношенная Реформацией, слилась теперь, так сказать, с самым воздухом современности, и ее присутствие сказывается и в нашем церковно-обновленческом либеральном движении» ${ }^{34}$. Его борьба против «засилия епископата, против монашества за привилегии белого духовенства, за выборные права прихожан и т.п., эта явная тенденция к демократизации церковного строя», и в будущем может быть признана «отражением реформационного принципа автономии личности в жизни Русской Церкви» ${ }^{35}$. Потребность «в современном обновленческом течении ...рационализации догматов... заявит о себе в условиях свободы с большей силой, подобно тому, как она выявилась в самом организованном вероисповедании, в римском католицизме, в форме модернизма». Есть основание ожидать «некоторой эволюции в реформационном духе» ${ }^{36}$ и

\footnotetext{
${ }^{31}$ Карташев 1916: 17-18.

32 Карташев 1916: 19.

${ }^{33}$ Оба указанные докладчиком пункта были в числе тех перспектив, которые предложил модернизм в римо-католицизме в 1890-е гг.

${ }^{34}$ Карташев 1916: 19.

${ }^{35}$ Карташев 1916: 19. Курсив мой, - И.В.

${ }^{36}$ Карташев 1916: 20.
} 
для Русской Церкви. Удивляет, что «неохристианин» Карташев отдал т.н. догматический вопрос либеральному церковному течению, тогда как в начале века он был поднят религиозной интеллигенцией. Но НРС хотело развития догмы, и лишь немногие из либерал-реформаторов допускали такое развитие. Карташев писал о «рационализации догматов» (историко-философском осмыслении их) носителями церковного сознания, потому что помнил, что в 1905-1907 гг. церковное реформаторство не смогло выдвинуть системных предложений по «религиозному вопросу» ${ }^{37}$. «Религиозный вопрос» - это изменение сознания, разворот учения Церкви в сторону общественности и культуры. Предложенный церковными реформаторами в 1905 г. лозунг «назад, к христианству первых веков» Карташев считает неприемлемым. «Первохристианство сплошь мистично, церковно, теократично, хилиастично. В нем не было никакого рационального ограничения, отграничения религии от каких-то светских нейтральных областей. Оно сознавало себя универсальной теократией не по признаку связи с государством, а в хилиастическом порыве, [стремясь] творчески, духовно упразднить... всю языческую культуру, подчинив ее... власти Царя-Мессии, преобразив ее в новую тварь». Сегодня заинтересованные в церковной модернизации имеют дело с исторической Церковью, которая «покоряла себе мир культуры и истории... более механическим... способом». Итак, «предполагаемая частичная эволюция Русской Церкви в духе реформационном», с одной стороны, должна внести в Церковь плодотворную модернизацию мысли, психики и практики, и эта модернизация приспособит русскую освобожденную Церковь к новой жизни, а с другой, рационализация догматов может вести к «величайшему обеднению Церкви, к упразднению ее теократической души, т.е. выбросит за борт весь запас социальных заданий христианства. Тогда получится умиротворенная, очень удобная для светской безрелигиозной культуры, национальная русская Церковь как одна из ничтожных восточных Церквей, навеки бесплодная» ${ }^{38}$. Карташев не принимает те исторические формы, в которые вылилась реформация в католицизме и откликнулась в России (штунда, толстовство), и считает, что движение обязано «разойтись с... распространенным взглядом на протестантскую форму христианства как на высшую и дающую разрешение современным запросам человечества», но и не должно испытывать «того страха», какой вызывает протестантизм у «консерваторов» ${ }^{39}$. Он считает, что принцип реформации - «полное одиночество религиозной личности пред Богом» - лишает религию ее организующей силы. Он апофатически ведет читателя к мысли: русская реформация должна быть глубже, религиознее, духовнее.

Главное в русской реформации - это сохранение Церкви, в т.ч. как коллектива, ее иерархической структуры, вершиной которой является

\footnotetext{
${ }^{37}$ Воронцова 1917.

38 Карташев 1916: 20-22.

${ }^{39}$ Карташев 1916: 25.
} 
власть Иисуса Христа. «Мы выдвигаем идею Церкви», в глубине догмата которой должны сойтись все пути к разрешению вопросов «человеческого общежития и космоса» ${ }^{40}$. Без сомнения, писал он, «ориентируясь на эту идею, будут написаны и теория познания, и логика, и этика, и философия религии, и все другие философские дисциплины», но современникам Карташева суть русской реформации остается недоступной. Она - в существе «религиозной природы, религиозном качестве» ряда вопросов, регулирующих проблему духовного разрыва с Церковью тех, кто не находит в ней «удовлетворения своему разуму, своей свободе, своему творчеству и освобождению общественному» ${ }^{41}$. Внешними аргументами это понимание не передаваемо потому, что в основе его должно лежать новое ощущение, новый опыт, с точки зрения которых единственно и виден «весь ужас трагического разрыва между Церковью и жизнью». Старый религиозный опыт иерархов и богословов не позволяет им понять запросы современного сознания, которые считаются ими внерелигиозными, «следовательно, надо поставить эти вопросы как вопросы религиозной совести», или веры. И Карташев препринимает попытку обосновать «религиозность» мучающих интеллигенцию вопросов. Он предлагает рассматривать тварное бытие («плоть») в единстве категорий «космос-человек-общество», последняя составляющая этого единства есть коллективное человеческое «Я», «полуличность», а в комплекте с противостоящими личной свободе «Я» «космическими законами количества, законами механики, законами биологии», оно - метафизически антиномичный «полуорганизм» ${ }^{42}$; и в нем он видит «неслучайную параллель догмату Богочеловечества» ${ }^{43}$. Изложенное здесь Карташев обозначает «проблемой общества». Традиционные религии оперируют двумя категориями - Бог и человек, пишет он, и для них нет проблемы общества. Понять общественное историческое строение человечества как религиозное могла только религия, мистически переживающая проблему космоса. Обогащенное эллинизмом христианство приняло в себя тайну космоса, но отвратившееся от древней Церкви религиозное сознание утратило ее, космос стал «рисоваться» антиподом Бога, а соглашение с духом «космических и общественных явлений» - кощунством. До Реформации христианская Церковь знала «проблему космоса», но решала эту проблему «аскетически», т.е. «отрицательно». Церковь не была нейтральной и к энергии общественного самоустроения. Она враждовала с ней как с грехом, как с «хождением по стихиям мира сего», и на место ее стремилась водворить «аскетическую чистоту политического воздержания, квиетизм лояльности»; так же она не раскрыла и религиозных заслуг истории, а значит, не ответила на вопрос о смысле

${ }^{40}$ Карташев 1916: 27-28.

${ }^{41}$ Карташев 1916: 32.

42 Карташев 1916: 33.

43 Карташев 1916: 34. «Из свободы личности и необходимости космоса образуется человеко-космос, как из Божеской и человеческой природы антиномично, сверхразумно и в то же время фактически реально образуется Богочеловек». 
человеческого существования. «Ведь не для того же существует на земле человечество после Христа, чтобы только вновь и вновь каяться», непонятно для чего увеличивая населенность Земли, писал, видимо, не согласный со «школьным богословием», Карташев.

Как религиозный мыслитель, он смотрел на историю как на непрекращающийся «боготворческий процесс» продолжающегося после Христа божественного откровения и действия Бога в мире (после седьмого дня творения). Церковь ранее «пользовалась» историей, формулируя догматы, отчего бы, спрашивал он, человечеству не продолжить богословскую практику вселенских соборов, в любом случае, «все усложнения общечеловеческого сознания приносят положительный вклад в постановку христианских проблем, преображают их иногда до неузнаваемости» ${ }^{44}$. Перед христианством и Церковью, считал Карташев, стоят новые задачи, решению которых не помогут древние святоотеческие творения и полуученые справки с документами патристики и каноники.

Возвращаясь к плодам исторической Реформации по отношению к личной, не регламентированной церковным авторитетом веры, Карташев показывает открывающиеся новые возможности: «личность в наш век сознала свое достоинство не только как пассивная... заслуживающая спасения у Бога-Отца, прощающего ее тварные немощи и вольные прегрешения, но и сознала себя имеющей религиозное право на то стремление к абсолютному достоинству, к абсолютной самооценке, к абсолютной свободе, к автономии, которое она приобрела в процессе культуры» ${ }^{45}$. Положительная оценка личности - «проблема религиозная», и ее также невозможно решить справками и цитатами из св. отцов, здесь проблема человеческого общества приобрела «глубины абсолютные», «богоподобные», «царственно-свободные в Боге».

Таким образом, по Карташеву, приблизилось преображение представлений об «обществе» - в переоценке человека, общественности, общения, вероисповедания и пр., «преобразование духа и строя церквей» без «грубого разделения» на пасущих и пасомых, учащих и учащихся. Но как кандидат богословия, автор понимал необходимость для всего этого церковного благословения. «Религиозный смысл общественного строительства... не мыслим без религиозной санкции материальных космических уз, органически связующих общество». Пока в носителях ортодоксального церковного сознания, - писал он, - не произойдет «преодоления аскетической исключительности в отношении к космосу, ничто новое, творческое в христианстве не будет возможно». В «новом чувстве космоса... в религиозном его восприятии, лежит центральный секрет» новых судеб религии в дальнейшей истории человечества. Выявление этого секрета - теократия, которая основана на «автономной личности... соединенной церковными органическими узами с другими ...и со всем космосом», теократия, с «новой живостью» открывающая

\footnotetext{
${ }^{44}$ Карташев 1916: 40.

${ }^{45}$ Карташев 1916: 42.
} 
Божество Святой Троицы». Карташев считал, что «догматическометафизическая схема мировых запросов, предъявляемых христианству историей... явно превышает мыслимые возможности не только реформы Церкви, но и реформации» и сказывается «на том догмате, который кажется абсолютно неподвижным, отчеканенным раз навсегда... [догмате] о Боге в Самом Себе и в Его отношении к миру» ${ }^{46}$. Он не уточнил, как должно измениться церковное учение о Боге в Самом Себе и Его отношении к миру, но можно предположить, что концептуальная мысль Карташева лежала в русле русской софиологии.

Четвертая часть начиналась обращением к наличным возможностям конкретной, исторической Русской Церкви: что дала бы реформа Русской Церкви («от реформы Русской Церкви было бы наивно ждать непосредственного раскрытия каких-либо мировых вопросов христианства», ожидаемые ответы может дать Церковь вселенская). И какой может стать церковная модернизации в России. Здесь Карташев высказывался о том, что традиционными приемами Церкви проблему не решить ${ }^{47}$. Только внеся в Церковь «все приобретения человеческого сознания в истории, все углубление и обновление стоящих пред ним философских, социальных и религиозных задач», все растущие требования «человеческого духа», она выполнит свой долг, и откроется новая эра церковной жизни. По Карташеву, это единственный способ не остаться на задворках «большого исторического пути», - признать историческую трагедию разрыва христианства с культурой, «взять на себя бремя кровавых исканий и мук человечества». Под первым, очевидно, имеется в виду кровь социальных смут и революций, под вторым - страдания души, ищущей отражения в повседневности абсолютной истины).

Внерелигиозная интеллигенция и светская общественность предъявляют ей обвинения «морально-общественного свойства», но Церковь не реагирует, оптимисты считают: если бы с ней говорили на ее языке, т.е. религиозном, она бы приблизилась к осознанию своего долга и новой религиозной эры в ее жизни ${ }^{48}$. Карташев говорит, что Церковь спасет только глубокая «мистическая переделка» ее сознания, которая под силу пророкам. Пророчества есть, писал он, пророков уже слышно, и одним них Карташев называет В.С. Соловьева. Но в целом, пророчество в последние века истории сконцентрировалось в области внецерковной культуры, верной эсхатологическим ожиданиям первохристианства. Религиозная норма требует слить его в одно русло с «церковным томлением о пророчестве», а пока человечество без религии перестраивает землю. «У культуры человечества есть своя духовность», убеждал Карташев, и оно «пророчески грезит о царстве свободных личностей, свобод-

\footnotetext{
46 Карташев 1916: 47.

47 «Нельзя же, в самом деле, возлагать надежды в беде на то, что усовершенствованные пастырские училища, ...новый вид миссионеров, ...энер-гия библейских и других религиозных обществ, ... реформированный приход возвратят Церкви... власть творить историю». - Карташев 1916: 52.

${ }^{48}$ Карташев 1916: 53.
} 
ных в мысли, в познании, во всяком творчестве, не зависимых от социальной неправды и от страданий стихийного хаоса» ${ }^{49}$.

Так, из речи А.В. Карташева, признавшего внешнюю церковную реформу, не только не исчез акцент на ее религиозности, но и было подчеркнуто: модернизация церковная - это «критическое религиозное искомое». И если речь Карташева в ПРФО соответствовала строению его трактата, то очевидно, что она шла к выводу о том, что же, наконец, должно предпринять в отношении исторической христианской Церкви.

По сравнению с установками, с которыми «неохристиане» вышли на собеседования с Русской Церковью в ПРФС в 1901 г., Карташев, проведший в «неохристианстве» 14 лет, не сказал ничего нового. Он принимал, что вдохновение новых пророков (от интеллигенции), не благословленное Церковью, рискует стать «духом лжи», но оставался оптимистичен, как и Д.С. Мережковский, писавший в начале века на эту тему. По Карташеву, ошибка церковной истории в том, что весть о Царстве Божьем - в истории поглощена Церковью ${ }^{50}$. Царство Божие, в отличие от христианских социалистов, он не рассматривал утилитарно, как царство земное, но как «измерение религиозной воли в опыте религиозного действия». Оно нисходит свыше навстречу ищущему его человечеству. Он поднял вопрос метафизики и показал, что необходимо расширение христианской догмы. Отказав святоотеческому богословию в способности выразить единство двух сфер - «земной и небесной, Карташев в последней части трактата применил ранее не встречавшееся в философии НРС понятие - «Силы ${ }^{51}$. Во имя «Сил» и должно, по Карташеву, совершаться все земное, преображаясь изнутри. «Сила» конкретизируется им, как сходящая свыше «Сила Царства» (Царства Божьего), навстречу которому восходит снизу, от земли «творчество человека во плоти». В трактате образ не разъяснен и, возможно, он мелькнул как чужой ${ }^{52}$, или авторский из незавершенной теологемы о богочеловеческом единстве «по-Карташеву». Подразумевалось ли им персонифицированная предержащая мир «Сила Божья»? Так или иначе, в нарисованном им движении навстречу двух сфер бытия - небесного и земного, нет упоминаний Личного Бога. Как и в том случае, когда, отметая возможные подозрения в несторианстве и монофизитстве ${ }^{53}$, он пояснял, что рационально понять «тайну духа и плоти в Царстве Божием, в Церкви, в истории и в каждом нашем частном деянии» возможно по «иррацио-

\footnotetext{
${ }^{49}$ Карташев 1916: 56-57.

${ }^{50}$ Карташев 1916: 58.

51 У Карташева - с большой буквы, как обозначение религиозного понятия.

52 Напр., в диссертации выпускника МДА Туберовского, выведшего образ Любви как силы Божьей творящей многоступенчатый природный мир, в котором произошло «оплототворение» Бога. Туберовский А. Воскресение Христово: Опыт мистической идеологии догмата: Посад, 1916: 223.

53 « был бы монофизитом, если бы все человеческое творчество по плоти, все достижение власти над материей ...презрел как фактор, исходящий от земли навстречу ...силе Царства, сходящей свыше...». - Карташев 1916: 62.
} 
нальной схеме: “нераздельно, неслиянно, неизменно, неразлучно”». Схемой названо богословское определение, вынесенное отцами Церкви на вселенском соборе по отношению к Личности воплотившегося Бога. ****

Сочинение Карташева апофатическим методом расставляло точки над «і» по проблеме церковной модернизации в России - в том виде, в каком проблема была поставлена в начале века на ПРФС (1901-1903). Однако был и небольшой шаг вперед: оставшихся верными идее теперь нельзя было упрекнуть в том, что им чужды внешние, административноправовые и другие реформы в исторической Русской Церкви, или в том, что они были про-протестантствующим движением и стремятся к повторению Реформации. Прозвучала и отличавшая Карташева от кружка Мережковского вера в историческую Церковь. Она соединялась с надеждой на будущую теократию и общество, охваченное единым религиозным сознанием и строящим Царство Божие; а также с верой Карташева в то, что человечество - часть космоса, и одновременно является богочеловеческим организмом, Телом Христовым. Таким образом, в трактате критиком официальной Церкви в России впервые ясно было заявлено, что главной ценностью является историческая Церковь, которую новое поколение пророков перенаправит на ее соответствие культурным запросам человечества, в т.ч. через восполнение ее метафизики, и тем самым вернет ей власть над душами и над миром. Т.е., в 1916 г. Антон Владимирович подтвердил свою верность идее исторической Церкви (со всеми ее Таинствами), но эта церковь должна была еще созреть на стебле вселенского христианства как плод богочеловеческой истории.

Изданный тонкой книжкой трактат после эмиграции А.В. Карташева был переиздан еще два раза - в первом и втором сборнике евразийцев «На путях» (1922) в Берлине. Архиерейский Синод русских епископов составил по поводу этого сочинения послание, и Карташеву был послан запрос от управляющего русскими православными приходами Московской патриархии в Западной Европе митрополита Евлогия (Георгиевского). Карташев отвечал, что его сочинение никак не может быть и не является призывом к реформации, и был искренен, потому что трактат, как мы видели, и в самом деле разъяснял, почему реформация в ее отложившейся исторической схеме не пригодна для православной Церкви в России («Счесть меня сторонником реформации, - восклицал он, значит не понять в статье ничего»). Сочинение (автор называет его статьей) было и «ярким отрицанием» реформы, по причине ее низкой оценки автором: «Я в своей статье не проповедую (отмежевываясь от патетических либералов) [реформу], а просто как историк описываю и предсказываю (что и сбылось - положительно в Соборе 1917-1918 г., и отрицательно - в живоцерковничестве)» ${ }^{54}$. В пояснении он ушел от вопроса о «новой метафизике» и пояснял, что имел в виду исключительно «мощное научно-богословское и общее просвещение всех учащих и управля-

${ }^{54}$ Карташев 1927: 16. 
ющих сил церкви» ${ }^{55}$. Вместе с этим объяснением в его жизни был навсегда «похоронен» вопрос о религиозных основаниях освящения Церковью культуры человечества как процесса духовного, проблемы «духа и плоти», и концепт о единстве космоса-человека-общества-космоса как полуорганизма, стремящегося в историческом процессе к «неслиянному и нераздельному» единению с божественным Бытием.

\section{ИСТОЧнИКИ}

Бердяев Н. Реформа Церкви // Мутные лики. М., Канон, 2004.

Бердяев Н. Идеи и жизнь. Теократические иллюзии и религиозное творчество // Русская мысль. 1917. Кн. 3-4. Пагин. II. С. 95-107.

Ермичев А.А. Религиозно-философское общество в Петербурге (1907-1917): Хроника заседаний. СПб., 2007.

Карташев А.В. Реформа, реформация и исполнение Церкви. СПб., 1916.

Карташев А.В. Объяснение. Его Высокопреосвященству Высокопреосвященнейшему Евлогию, митрополиту Западно-Европейских Русских Православных Церквей // Церковный вестник Западно-Европейской епархии. 1927. № 5. С. 14-21.

Мережковский Д. Исполнение Церкви // Русское слово. 1916. № 127. 24 дек. С. 2.

Письмо Д.В. Философова в редакцию газеты «Речь» // РГАЛИ. Ф. 1666. Оп. 1. Ед. хр. 810. Л. 54.

Романский Т. [Карташев] «Не все же» // Новый путь. 1903. Июль. С. 262-276.

\section{БИБЛИОГРАФИЯ / REFERENCES}

Антощенко А.В. «Евразия» или «Святая Русь»? Российские эмигранты «первой волны» в поисках исторического самосознания. Дис. ... д-ра ист. наук. СПб.: СПбГУ, 2004. [Antoshchenko A.V. «Evraziya» ili «Svyataya Rus'»? Rossijskie emigranty «pervoj volny» v poiskah istoricheskogo samosoznaniya. Dis. ... d-ra ist. nauk. SPb.: SPbGU, 2004]

Антощенко А.В. «Я был обязан заклеймить самый факт». Письма А.В. Карташева Г.И. Новицкому // Вестник Омского университета. 2019. № 4. С. 282-290. [Antoshchenko A.V. «Ya byl obyazan zaklejmit' samyj fakt». Pis'ma A.V. Kartasheva G.I. Novickomu // Vestnik Omskogo universiteta. 2019. № 4. S. 282-2901

Бычков С.П. Антон Владимирович Карташев - историк Русской Православной Церкви: Дис. ... канд. ист. наук. Омск, 1999. [Bychkov S.P. Anton Vladimirovich Kartashev - istorik Russkoi Pravoslavnoi Cerkvi: Dis. ... kand. ist. nauk. Omsk, 1999]

Бычков С.П. Жизнь историка в переписке с другом (А.В. Карташев - С.П. Каблуков, 19091917) Письмо 13 от 30.7.1911 / вст. ст., сост. коммент. // Мир историка. Историкобографический сборник. Омск, 2005. C. 329-330. [Bychkov S.P. Zhizn' istorika v perepiske s drugom (A.V. Kartashev - S.P. Kablukov, 1909-1917 gg.) Pis'mo 13 ot 30.7. 1911 / vst. st., sost. komment. // Mir istorika. Istorikobograficheskij sbornik. Omsk, 2005. S. 329-330.]

Бычков С.П. «Можно пустить действенную стрелу в сознание церкви лишь став на общую с ней почву...» Карташев как аналитик событий церковной жизни в России в 19111917 гг. в газете «Русское слово» // Вестник Омского университета. 2019. № 4. С. 69 80. [Bychkov S.P. «Mozhno pustit' dejstvennuyu strelu v soznanie cerkvi lish' stav na obshchuyu s nej pochvu...» Kartashev kak analitik sobytij cerkovnoj zhizni k Rossii v 19111917 gg. v gazete «Russkoe slovo». // Vestnik Omskogo universiteta. 2019. № 4. S. 69-80]

Воронцова И.В. А.В. Карташев и «неохристианство»: интеллектуальная биография историка // Ученые записки Петрозаводского госуниверситета. 2019. № 8 (185). С. 65-71. [Voroncova I.V. A.V. Kartashev i «neohristianstvo»: intellektual'naya biografiya istorika // Uchenye zapiski Petrozavodskogo gosudarstvennogo universiteta. 2019. № 8 (185). S. 65-71]

Воронцова И.В. Участие А.В. Карташева в религиозном движении «неохристиан» и эволюция его взглядов на «историческую» Церковь (по письмам 1906-1907 гг.) // Вестник ПСТГУ. М., 2006. Вып. 20. С. 27-46. [Voroncova I.V. Uchastie A.V. Kartasheva v religioznom dvizhenii «neohristian» i evolyuciya ego vzglyadov na «istoricheskuyu» Cerkov' (po pis'mam 1906-1907 gg.) // Vestnik PSTGU. M., 2006. Vyp. 20. S. 27-46]

Воронцова И.В. Тематика статей А.В. Карташева в газете «Страна» 1906-1907 гг. в свете программных аспектов движения религиозной интеллигенции за церковную реформу // Вестник ПСТГУ (II). 2019. № 5-6. С. 11-24. [Voroncova I.V. Tematika statej A.V. Kar-

${ }^{55}$ Карташев 1927: 17. 
tasheva v gazete «Strana» 1906-1907 gg. v svete programmnyh aspektov dvizheniya religioznoj intelligencii za cerkovnuyu reformu // Vestnik PSTGU (II). 2019. № 5-6. S. 11-24]

Воронцова И.В. Антон Владимирович Карташев как религиозный реформатор (19031910-е гг.) // Диалог со временем. 2020. Вып. 70. С. 99-111. [Voroncova I.V. Anton Vladimirovich Kartashev kak religioznyj reformator (1903-1910 gg.) // Dialog so vremenem. 2020. Vyp. 70. S. 99-111]

Воронцова И.В «Реформа» или «реформация»: движение за церковное обновление в России начала XX в. // Вестник Московского университета. Сер. 8. № 4. 2017. С. 46-63.

Золаев А.Л. Исторические воззрения А.В. Карташева и историография русского зарубежья. Дисс. ... канд. ист. наук. М.: РУДН, 2005 [Zolaev A.L. Istoricheskie vozzreniya A.V. Kartasheva i istoriografiya russkogo zarubezh'ya. Diss. ... kand. ist. nauk. M.: RUDN, 2005]

Оболенский С.С. Среди книг и журналов. А. В. Карташев «Воссоздание Святой Руси» // Возрождение. 1956. № 54. С. 139-142. [Obolenskij S.S. Sredi knig i zhurnalov. A. V. Kartashev «Vossozdanie Svyatoj Rusi» // Vozrozhdenie. 1956. № 54. S. 139-142]

Пешков А.А. Философия истории П.Н. Милюкова и А.В. Карташева: сравнительный анализ. Дис. ... канд. филос. наук: 09.00.03 Н. Новгород: НГПУ, 2014.; Peshkov А.А. Filosofiya istorii P.N. Milyukova i A.V. Kartasheva: sravnitel'nyj analiz. Dis. ... kand. filos. nauk: 09.00.03 N. Novgorod: NGPU, 2014]

Пешков А.А. Философия истории П.Н. Милюкова и А.В. Карташева: сравнительный анализ. Дис. ... канд. филос. наук: 09.00.03 Н. Новгород: НГПУ, 2014.; Peshkov A.А. Filosofiya istorii P.N. Milyukova i A.V. Kartasheva: sravnitel'nyj analiz. Dis. ... kand. filos. nauk: 09.00.03 N. Novgorod: NGPU, 2014]

Рожков В., прот. Церковные вопросы в Государственной думе. Материалы по истории Церкви. Кн. 23. М., 2004. [Rozhkov V., prot. Cerkovnye voprosy v Gosudarstvennoj dume. Materialy po istorii Cerkvi. Kn. 23. M., 2004]

Шмеман А.Д. Церковь, государство, теократия. По поводу «Очерков по истории Русской Церкви» А. В. Карташева // Новый журнал. 1960. № 59. С. 275. [Shmeman A.D. Cerkov', gosudarstvo, teokratiya. Po povodu «Ocherkov po istorii Russkoj Cerkvi» A. V. Kartasheva // Novyj zhurnal. 1960. № 59. S. 275]

Воронцова Ирина Владимировна, кандидат богословия, кандидат исторических наук, стариий научный сотрудник Православного Свято-Тихоновского гуманитарного университета, irinavoronc@yandex.ru

\section{«Reform, reformation and replenishment of the Church». Historical and analytical review of A.V. Kartashev's treatise}

The subject of the research is the work of A.V. Kartashev «Reform, reformation and replenishment of the Church». This is Kartashev's speech at the St. Petersburg religious and philosophical society (1907-1917) about the «external» and «internal» development of the Russian Church on the eve of The February bourgeois-democratic revolution. PRFO was an attempt to return to the St. Petersburg religious and philosophical meetings (1901-1903), at which the religious intelligentsia in the context of the historical modernization of the country put forward proposals for Church reform to the Church and started a religious movement. Its task was to promote a new religious consciousness (NRC), and to establish culture as a factor of human deification. The Church was called to change its attitude to the «flesh» and merge with public life religiously. It is believed that in the treatise Kartashev opposed the Church reformation in Russia. Reconstruction of the content of the treatise in the doctrinal system of the NRC shows that Kartashev in 1916 was true to his views of the beginning of the century.

Keywords: Anton V. Kartashev, religious and philosophical treatise of 1916, «newChristianity", Church reform in Russia

Irina Vorontsova, candidate in Theology, candidate in History, Senior research fellow, Saint Tikhon's Orthodox University of Humanities; irinavoronc@yandex.ru 


\section{РУССКИЕ МАРКСИСТЫ О БЛИЖНЕВОСТОЧНОЙ ДРЕВНОСТИ ${ }^{1}$}

Дореволюционный марксизм - забытая страница предыстории советского исторического нарратива. Советские историки почти полностью игнорировали таких авторов, как Г.В. Плеханов, Н.А. Рожков, А.А. Богданов в качестве предшественников своей науки. В статье сделана попытка исследовать взгляды указанных авторов на историю древнего Ближнего Востока и сформулировать ряд обобщений, касающихся их влияния на советское историописание. Русские марксисты использовали упрощение как приём для того, чтобы показать, что одни и те же принципы материалистического анализа действуют и на примере древнейших обществ Востока, что частично смягчалось как признанием вариативности исторического развития восточных обществ, так и наличествующей конкуренцией разных вариантов этого развития. Но это сочетание было утрачено при формировании советской исторической науки в начале $1930-\mathrm{x} \mathrm{гг.}$

Ключевые слова: русский марксизм, историософия, раннесоветская историография

Если подводить промежуточные итоги развития интеллектуальной истории нашей науки в текущем столетии, то можно обратить внимание на две неизолированных друг от друга тенденции: во-первых, произошло осознание ценности советского опыта (ценность может быть как позитивной, так и негативной, но фактическим консенсусом стало то, что сам этот опыт не может быть проигнорирован), во-вторых, в последние годы начал формироваться запрос на выяснение и прояснение используемой историками терминологии, в т.ч. через анализ её генетики, что, опять же, во многом возвращает нас к проблеме советского опыта.

При этом в происхождении советской историографии оказываются учтены далеко не все моменты, что отчасти также объясняется спецификой нашего наследия. Советская наука - не всегда сознательно - камуфлировала свои корни, сводя дело их поиска к вопросу о наличии соответствующих терминов и идей, с одной стороны, в дореволюционной историографии, а с другой - в работах «классиков» марксистской теории. В первом случае было отобрано несколько фигур «прогрессивных» историков, которых можно было, при умеренной критике, считать предтечами. Во втором случае советская наука сформировала устойчивый стереотип, согласно которому именно труды Маркса, Энгельса и Ленина заложили основы её отношения к историческому процессу. Соответственно, если первый стереотип в настоящее время в целом подвергся пересмотру, то в отношении второго сделано гораздо меньше.

Устойчивость второго стереотипа поддерживается и сакральной привязанностью даты отсчёта советской историографии к политическому 1917 г. Поскольку перипетии политической борьбы привели к тому, что из всего круга русских марксистских интеллектуалов конца XIX -

\footnotetext{
${ }^{1}$ Исследование выполнено при поддержке гранта РФФИ (проект № 20-09-41014) «От Святой Земли до рабовладельческой формации: история Древнего Ближнего Востока в российской исторической науке XX в.».
} 
первой трети XX в. полностью легитимным мыслителем остался только Ленин, то представления всех остальных об истории оказались в той или иной мере изъяты из предыстории советской науки. Между тем, исследование этих взглядов способно послужить одной из искомых точек отсчёта для выяснения истинных условий формирования советских исторических воззрений (другая относится к профессиональным историкам, «обратившимся» в марксизм в конце 1920-х - начале 1930-х гг.).

В статье рассмотрены взгляды на ближневосточную древность трёх марксистов, которые пользовались заметным влиянием в среде левой интеллигенции в первой трети ХХ в.: Г.В. Плеханова (1856-1918), Н.А. Рожкова (1856-1927), А.А. Богданова (1873-1928). Их роднит то, что они задумали и стали создавать свои главные труды задолго до революционных событий 1917 г., при этом на протяжении 1920-х гг. их работы продолжали издаваться или переиздаваться. Изучение воззрений русских марксистов именно на ближневосточную древность обусловлено, помимо понятной необходимости правомерного сужения материала $^{2}$, тем, что ни для одного из них она не была предметом профессионального интереса; при этом прогресс знаний об истории древнего Ближнего Востока, которым знаменовалось время творческой активности наших героев, оставил свой отпечаток на их деятельности.

\section{Истоки и источники}

Реальное воздействие гегелевской системы на марксистскую философию истории не только не исчерпывается её очевидными характеристиками - т.е. европоцентризмом, эволюционизмом и прогрессизмом, но, можно предположить даже, что в них и не заключается, ведь в той или иной мере эти идеи были общеразделяемыми в историческом мышлении XIX в. и могли быть, в принципе, выражены многими другими философами. Поэтому укажем на более специфические характеристики гегелевской историософии: органичность фактора природно-географической среды при описании конкретных сообществ (что стало как раз проблемой для марксизма во всех его версиях), отделение Ближнего Востока как в большей мере «исторического» от практически «неисторических» Китая и Индии, строгая убеждённость во внутренних причинах любых принципиальных перемен в жизни каждого сообщества ${ }^{3}$.

Хорошо известно, что изучение Гегеля входило как в университетские курсы, так и в круг общего чтения интеллектуалов того времени; Плеханов посвятил разбору «Философии истории» ряд страниц, равно как уделил внимание книге Л.И. Мечникова (1838-1888) о цивилизациях - подчеркнув, кстати, принадлежность того к материализму4. В книге

\footnotetext{
${ }^{2}$ Впрочем, можно присоединиться и к тем авторам, которые осознают концентрацию современных исследований рецепции на античности и предлагают дополнить её исследованием рецепции ближневосточных цивилизаций: Verderame 2020: 1-2.

${ }^{3}$ Гегель 2000: 122: «Народ может умереть насильственной смертью лишь в том случае, если он естественно сам по себе стал мёртвым...».

${ }^{4}$ По политическим взглядам Мечников был анархист; собственно, это отражалось и в его работах по географии. McDonald 2017: 120.
} 
Мечникова была отчётливо сформулирована тогда наиболее обоснованная фактически версия о том, что первичной цивилизацией следует пока признавать египетскую, хотя допускалась вероятность такой же характеристики для ассиро-вавилонской ${ }^{5}$, а вообще выделялись «четыре древнейшие великие культуры» (включая индийскую и китайскую ${ }^{6}$ ). Мечникову принадлежит и подробное обоснование роли ирригации в функционировании древнейших цивилизаций; наконец, он не упускает значения финикийской истории, относя её к началу морского этапа согласно собственной классификации мирового исторического процесса ${ }^{7}$.

Следует уточнить, что если Плеханов и Рожков так или иначе ссылаются на источники своей информации, то в работах Богданова избранный им и его соавтором И.И. Скворцовым-Степановым (1870-1928) стиль максимального обобщения предполагает практически полное отсутствие не только библиографии, но даже упоминаний трудов историков или исторических источников. Чтение Плехановым работ по древней истории Востока было если и не систематическим, то целенаправленным и, пожалуй, галлоцентричным; он ссылался на обобщающие труды $\Gamma$. Масперо, но мог обратиться и к специальной статье Э. Куга по отношениям собственности в Халдее на основании камней кудурру, был хорошо знаком как с довольно старым сочинением о нравах и обычаях египтян Дж.Г. Вилкинсона, так и с новой для тех лет «Историей Лагидов» О. Буше-Леклерка. Рожкова отличает последовательная ориентация на базовую литературу студента-историка: Г. Масперо, учебники Б.А. Тураева и Р.Ю. Виппера, переводы книг Д. Брэстеда, А. Морэ, «История древности» Э. Мейера; в случае истории Восточного Средиземноморья он обращался и к книгам профессиональных авторов (Ю. Вельсгаузен, А. Иеремиас, И. Гольдциер и т.д.). По отдельным странам Рожков использовал считавшиеся тогда лучшими специальные исследования, например, «Историю карфагенян» О. Мельцера, работы М.В. Никольского по истории Месопотамии ${ }^{8}$, книгу Л. Хёзэ и Ф. Тюро-Данжена о стеле коршунов, книгу М. Ястрова по религии, немецкое издание «Истории религий в древности» К.П. Тиле. Источники знаний Богданова, вероятно, лежали примерно в той же плоскости, но вряд ли он знакомился со специальными трудами.

Наконец, ещё один источник представлений о ближневосточной истории - текст Библии. В наибольшей мере отсылки к Библии заметны в творчестве Плеханова, отсылки эти по большей части вполне обычны:

\footnotetext{
${ }^{5}$ Мечников 2013: 177, 171-172.

${ }^{6}$ Поэтому нельзя полностью согласиться с мнением И.А. Ладынина, согласно которому недостаток знаний о древнейшей Индии и Китае подталкивал исследователей рубежа XIX-XX вв. к тому, чтобы относить их историю к средневековой - это могло иметь значение для историков-специалистов, но мало смущало всех остальных, включавших ранние периоды Индии и Китая в древность. Ладынин 2019: 777.

${ }^{7}$ Мечников 2013: 180-181.

${ }^{8}$ Рожков даже планировал посвятить отдельное исследование хозяйственной истории времени Урукагины. Рожков I: 409.
} 
истребление египетским фараоном младенцев ${ }^{9}$, бегство от него евреев и их скитание в пустыне ${ }^{10}$, сон фараона о тучных и тощих коровах ${ }^{11}$, «вавилонская тоска» ${ }^{12}$, притчи Соломона ${ }^{13}$. Есть, впрочем, и примеры более оригинального использования «вечной книги», указывающие на хорошее знакомство автора с её текстом (в церковнославянском переводе): «Во время свидания Моисея с Иеговой на горе Синае, сварливый еврейский бог стоял, как известно, спиною к своему верному слуге, так что почтенный вождь Израиля видел только “заднюю его”. Наши сторонники "экономического" направления в этом отношении похожи на Моисея: они видят только “заднюю” нашего пролетариата» ${ }^{14}$.

Тематика работ Рожкова и Богданова предоставляла им меньше возможностей для апелляции к библейским сюжетам, а в случае с Богдановым можно предполагать и сознательную дистанцию от религиозной культуры. Несколько раз Богданов повторяет пример анализа моисеевых заповедей для иллюстрации «права теократически-патриархального мира» ${ }^{15}$, упоминает израильские примеры при анализе развития дарообмена $^{16}$, но всё это на максимально общем уровне. Единственный пример активного использования библейского текста, который мне удалось обнаружить ${ }^{17}$, весьма показателен: в знаменитой «Тектологии» Богданов излагает сюжет отбора Гедеоном трёхсот воинов для битвы с мадианитянами (Суд. 6: 2-7). Если в библейской истории отбор совершается исключительно по совету Бога, то Богданов говорит о рациональных (хотя и недостаточно качественных) принципах отбора, применённых Гедеоном, производя перекодирование библейского сюжета, который в таком виде должен был служить иллюстрацией не божественной воли, а принципов прагматического подбора кадров ${ }^{18}$.

\section{Восточный деспотизм и его аналоги: Г.В. Плеханов}

Устойчивое представление о Плеханове как первом русском систематически мыслящем марксисте, чья деятельность была направлена на строго ортодоксальную разработку материалистической теории, в принципе может быть принято за точку отсчёта при рассмотрении его взглядов и на историю Востока ${ }^{19}$. Тем не менее, как всякий более или менее серьёзный автор, Плеханов и во второстепенных вопросах не может считаться только лишь толкователем Маркса и Энгельса. С одной стороны,

\footnotetext{
${ }^{9}$ Плеханов 1923-1927. IV: 240.

${ }^{10}$ Плеханов 1923-1927. III: 179; VI: 19.

${ }^{11}$ Плеханов 1923-1927. XV: 289; XVII: 261; XIX: 107.

${ }^{12}$ Плеханов 1923-1927. XIV: 285.

${ }^{13}$ Плеханов 1923-1927. XIX: 165.

${ }^{14}$ Плеханов 1923-1927. XII: 17.

${ }^{15}$ Богданов 2010b: 39. Сp. Богданов 2010b: 83, Богданов 1990: 55.

${ }^{16}$ Например: Богданов, Скворцов-Степанов 2011: 154-155.

17 Пример с тем, что в войске Саула было всего два железных меча (1 Цар. 13: 22), принадлежит, видимо, соавтору Богданова. Богданов, Скворцов-Степанов 2011: 42.

${ }^{18}$ Богданов 1989. II: 169.

${ }^{19}$ Из работ о Плеханове, позволяющих получить предварительное представление о его жизни и творчестве в контексте обозначенной темы: Baron 1995; Тютюкин 1997.
} 
он вполне усвоил те высказывания немецких теоретиков, которые к тому времени были опубликованы и наиболее близко относились к делу: а именно постоянное выделение Энгельсом античности, средневековья и буржуазной эпохи как основных типов эксплуатации в истории ${ }^{20}$. Но поскольку Плеханов выбрал путь обращения к достаточно широкому кругу исторического чтения и, кроме того, его главным интересом была судьба России, то взгляды на древнюю историю Востока оказались органично встроены в концепцию русской истории, наиболее полно раскрытую в его главной книге «История русской общественной мысли», а это в свою очередь потребовало более гибкого отношения к прямолинейной энгельсовой схеме общественной эволюции.

Суть обозначенной концепции сводится к тому, что, с одной стороны, история России не является абсолютно своеобразной (потому полностью подвластна марксистскому анализу), с другой - являет собой сочетание западных и восточных элементов общественного строя. Изначально русская история идёт по типичному пути восточных деспотий, основанных на создании крупных государств на «широком пространстве равнин и бассейнах больших рек» ${ }^{21}$; здесь Плеханов был бо́льшим сторонником географического детерминизма, чем повлиявший на него Мечников: он заявлял, что деспотический путь развития неизбежно следовал из нужд ирригации ${ }^{22}$. Деспотизм характеризуется Плехановым не столько через понятие неограниченной власти монарха, сколько через представление об абсолютном бесправии жителей его государства, исходящего из фактического отсутствия у них частной собственности: «Восточному деспоту принадлежит право по произволу распоряжаться имуществом своих подданных» ${ }^{23}$. Такое представление развилось далеко не во всех восточных обществах. Будучи свойственным Египту, Месопотамии, Китаю, Персии, Индии, оно достигло наибольшей степени лишь в Китае и Египте 24 ; соответственно, Плеханов против стереотипа об одинаковом и абсолютном порабощении подданных в деспотиях ${ }^{25}$.

Оформлению монархии восточного типа способствовала опричнина $^{26}$. Россия, однако, не успела войти в классическую фазу: «некоторые деспотии Востока, - древний Египет или древняя Халдея, - тоже закрепощавшие государству все народные силы, были более цивилизованы, нежели Московская Русь XVII столетия. ...Позволительно предположить, что она, в конце концов, почти сравнялась бы с древним Египтом или с древней Халдеей» ${ }^{27}$. Петровская модернизация не отменила восточный деспотизм, а дополнила его рациональными западными метода-

\footnotetext{
20 Энгельс 1961: 224; Плеханов 1923-1927. IV: 206-207.

${ }^{21}$ Плеханов 1923-1927. X: 25.

${ }^{22}$ Плеханов 1923-1927. VII: 26; XX: 77.

${ }^{23}$ Плеханов 1923-1927. XXI: 35.

24 Плеханов 1923-1927. XX: 57.

${ }^{25}$ Плеханов 1923-1927. XX: 243.

${ }^{26}$ Плеханов 1923-1927. XX: 193.

${ }^{27}$ Плеханов 1923-1927. XX: 121.
} 
ми управления: «государство это отличалось от западных тем, что закрепостило себе не только низший, земледельческий, но и высший, служилый класс, а от восточных, на которые оно очень походило с этой стороны, - тем, что вынуждено было наложить гораздо более тяжёлое иго на своё закрепощённое население» ${ }^{28}$. История России, тем самым, не полностью аналогична истории восточных деспотий, хотя некоторые совпадения могут быть показательными - так, Плеханов не удерживается от сравнения нападения гиксосов на Египет с татаро-монгольским нашествием ${ }^{29}$, но тут же указывает на то, что Египет был окружён лишь варварскими племенами, и это в целом требовало меньших усилий на самооборону, чем в случае Московского государства, которое должно было оборонять не только восточную границу, но и западную, за которой находились развитые соседи. Эти факторы способствовали усилению русского деспотизма взамен нужды в ирригационных работах.

Впрочем, для читателей имела значение, надо полагать, не сама по себе теоретическая рамка исторического процесса, в которую были вплетены восточные мотивы, а собственно публицистические приёмы, которые автор умело разворачивал благодаря принятой им конструкции. Следует признать, что здесь Плеханов не ограничивается банальными сопоставлениями ${ }^{30}$, но иногда строит эффектный образный ряд, стремясь показать, что психология крестьянской массы имеет своим источником общественное устройство восточных деспотий. Так, обсуждая творчество писателя Гл. Успенского (1843-1902), Плеханов уцепляется за использованный тем образ «Ивана Ермолаевича», мужика от сохи, ушедшего в солдаты, подавлявшего польский мятеж и с наслаждением пересказывавшего знакомому на богомолье, как они давали залпы по недовольным крестьянам в западных губерниях. «На французском языке, - продолжает Плеханов, - есть интересная книга Мэнана “Annales des rois d'Assyrie". Книга эта представляет перевод подлинных надписей ассирийских царей на различных ниневийских памятниках». Цари нестерпимо хвастаются своими победами, в частности, один из них гордится тем, что перебил уйму бунтовщиков, и тела их плыли по реке подобно брёвнам. Но ведь не лично цари убивали повстанцев, отмечает автор. «Ассирийским Иванам Ермолаевичам давали в руки лук и стрелы, ассирийские Муравьёвы кричали им - “ну-ко!”, и они “усмиряли”, не мудрствуя лукаво, и трупы усмиряемых “плыли по реке, как брёвна”»"31.

Судя по всему, Плеханов давал это место из Менана по памяти, поскольку наиболее близкий по содержанию отрывок в этой книге относится к походу Ашшурабанипала на Элам (собственно, не являвшийся частью Ассирийской державы) и передан в следующих словах (с характерным сомнением переводчика в окончании фразы): «Я убил многих из

\footnotetext{
${ }^{28}$ Плеханов 1923-1927. XX: 88, тж. 118.

${ }^{29}$ Плеханов 1923-1927. XX: 87.

${ }^{30}$ Вроде «на "мужичке" целые тысячелетия непоколебимо держались восточные деспотии». Плеханов 1923-1927. III: 383; ср. Плеханов 1923-1927. XX: 74.

${ }^{31}$ Плеханов 1923-1927. Х: 30-31.
} 
его солдат; его воины попали живыми в мои руки; их жёны, подобно наконечникам стрел, заполонили окрестности Суз, трупы заполнили реку Улай и плыли как обломки деревьев (?)» ${ }^{32}$. В книге есть и другой похожий отрывок, но уже из надписи Саргона II: «Воды каналов несли тела мятежников на своих волнах подобно стволам деревьев» ${ }^{33}$. Надо думать, два близких текста сложились в памяти автора в общий образ подавления восстаний ассирийскими правителями, а практика сплава деревьев по русским рекам сделала его естественно запоминающимся.

Публицистический подход позволяет Плеханову избежать также противоречия с ассоциацией древности и рабовладения, которую использовал Энгельс. С одной стороны, Плеханов вполне однозначно ассоциирует основной эксплуатируемый класс восточных деспотий с «мужичками», а сами эти государства относит к феодальным ${ }^{34}$. С другой, неоднократно говорит о рабовладении - но употребляет это понятие не в узком смысле, а приблизительно в том, в котором в дореформенной России «рабами» называли крепостных крестьян ${ }^{35}$. Если же говорить об общественном строе, то все или почти все «культурные страны Востока» прошли через «фазу феодализма» - как Россия и Западная Европа ${ }^{36}$, хотя это вовсе не тождественные феодализмы ${ }^{37}$.

Можно добавить к этому, что, несмотря на некоторое внимание к месопотамским сюжетам, текст Плеханова в аспекте ближневосточной истории предсказуемо египтоцентричен. Почти всякий раз, когда необходимо проиллюстрировать свою мысль отсылкой к Востоку, ему приходят на ум именно египетские образы ${ }^{38}$. В одном из партийных споров, рисуя для примера некоего абстрактного интеллектуала, который может отказаться от открытого вступления в ряды социал-демократов, он выразился так: «Если какой-нибудь профессор египтологии, на том основании, что он помнит наизусть имена всех фараонов и знает все требования, которые предъявлялись египтянами быку Апису, сочтёт, что вступление в нашу организацию ниже его достоинства, то нам не нужно этого профессора» ${ }^{39}$. Как часто бывает с пафосными заявлениями, оно дезавуирует само себя: из-за показного презрения к «профессору египтологии» выглядывает подавляемая мечта оказаться на его месте.

\footnotetext{
${ }^{32}$ Menant 1874: 260. В поздних переводах вообще отсутствует сравнение с брёвнами. См. Piepkorn 1933: 69.

${ }^{33}$ Menant 1874: 188.

${ }^{34}$ Плеханов 1923-1927. XX: 11.

${ }^{35}$ Плеханов 1923-1927. XXI: 61; XXII: 301.

36 Плеханов 1923-1927. XX: 11.

${ }^{37}$ Плеханов 1923-1927. ХХІІІ: 183. Важное отличие заключалось в том, что в восточных деспотиях «держателям земли, несмотря на их усилия, не удалось обратить лёны в свою наследственную собственность». Плеханов 1923-1927. ХХ: 79. См. также Плеханов 1923-1927. ХІІ: 344: о круговой поруке и земельных переделах как неотъемлемой основе «са́мого варварского деспотизма».

${ }^{38}$ Показательный пример - воображаемое путешествие ожившей мумии египетского писца в Московию. Плеханов 1923-1927. ХХ: 79. Ср.: Плеханов 1923-1927. XX: 259.

${ }^{39}$ Плеханов 1923-1927. XII: 426-427.
} 


\section{В царстве отражсений: Н.А. Рожкков}

Восточная история оказалась частью иллюстративного материала, включённого Рожковым в его главное произведение «Русская история в сравнительно-историческом освещении (основы социальной динамики)» ${ }^{40}$. Как и Плеханов, Рожков стремился раскрыть историю России в контексте мирового процесса, а для реализации поставленной цели выбрал путь сравнительной характеристики обществ на каждом из основных выделенных им исторических этапов (первобытное общество - феодальная революция - феодализм и его падение - дворянская революция старый порядок (господство дворянства) - буржуазно-демократическая революция - производственный капитализм - финансовый капитализм), при этом наиболее подробный обзор русских событий он дополнял более сжатым материалом других стран. Очевидно, что при таком сопоставительном расположении материала залогом успеха были ориентация автора на поиск совпадающих характеристик и тенденция к игнорированию различий. Это легко можно было характеризовать как главный недостаток подхода автора, что он прекрасно сознавал: «“Это схематично", “это чересчур схематично" - вот критические замечания, какие пишущему эти строки приходилось не раз сльшать и читать по поводу своих исторических работ. В устах критиков эти замечания звучали порицанием, но мне они казались бессознательной похвалой» ${ }^{41}$. В качестве компенсации потенциальному упрощению историк полагал важным учитывать историческое развитие психологии общественных классов ${ }^{42}$.

История древних стран фигурирует только в части указанной цепочки преемственных форм, завершаясь эпохой «старого порядка». Если говорить о Ближнем Востоке, то автором были использованы примеры из истории египтян, Месопотамии (шумеры, вавилоняне, ассирийцы), Крита, Израиля, Финикии (и отдельно Карфагена), доисламской Аравии, хеттов и Персии. Основная цель автора - показать, что в древних обществах проходили те же процессы, которые он определил ранее в России и Западной Европе: «В общем номы - те же марки древних германцев, кланы кельтов, задруги и верви славян ${ }^{43}$. Показателен порядок сопоставлений, при котором переворачивается хронология: не верви славян оказываются подобны египетским номам догосударственного периода, а ровно наоборот. Это не случайность, а постоянно повторяемый приём: формирование государства (феодального) в Египте, происходит «в стиле Карла Великого, Владимира Святого, Альфреда Великого и т.п.» ${ }^{44}$, ряд

\footnotetext{
${ }^{40}$ Наиболее значимые обзорные работы о Рожкове последних лет: Волобуев 2012; González 2017.

${ }^{41}$ Рожков 1925-1928. I: 21.

42 «Психология общества есть всегда в сущности психология его отдельных классов». Рожков 1925-1928. I: 13.

${ }^{43}$ Рожков 1925-1928. I: 121.

${ }^{44}$ Рожков 1925-1928. I: 406. Характеристики управления Персидской империей также маркируются как «живо напоминающие историю Карла Великого». Рожков 1925 1928. I: 420.
} 
черт в экономике «сближают древний Карфаген с Флоренцией» ${ }^{45}$, Хатшепсут как «руководительница феодальной реакции» подобна Василию Шуйскому или «некоторым из последних Валуа», а египетская «реформация» особенно близка английской ${ }^{46}$. Главы по древности размещаются после разделов о Руси и Западной Европе.

В каждой фазе развития идентичны основные характеристики общественного и политического устройства, духовной жизни и той самой психологии. У всех народов в ранней фазе развития Рожков находит «хаотический конкретизм психологии» ${ }^{47}$, всюду отмечает анимистический и фетишистский характер ранних религий. Всюду доминирует феодализм, переходящий в ряде случаев в старый порядок, а основывается ли он на крепостничестве или рабовладении - в сущности, не принципиально ${ }^{48}$. Рабовладение при Хаммурапи трактуется историком как фактически переродившееся в крепостничество, так как у рабов была собственность, а долговое рабство ограничивалось тремя годами ${ }^{49}$.

Отчасти это сравнение более древнего с более поздним как образцовым объясняется состоянием исходных данных: Рожков не только подчёркивал недостаточность сведений о древневосточных обществах, но, видимо, искренне исходил из этого тезиса; во всяком случае, освещение европейских обществ проводится им с большим количеством тех самых деталей и подробностей, которых обычно лишены разделы по древнему миру. Но здесь легко переставить причину и следствие: не находя в литературе достаточных сведений, подтверждающих его аналогии, автор начинает апеллировать к скудости данных.

Расцвет феодализма у Рожкова непременно связывается с тем, что «в искусстве не было сделано особых успехов» ${ }^{50}$, поскольку он считал его временем господства психологического типа активного эгоиста, который «не имеет развитого эстетического вкуса, потому что вся его эмоциональная жизнь отличается большой бедностью, крайним убожеством

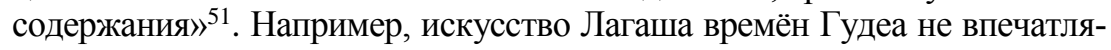
ет историка потому, что при тонкой обработке голов скульпторы не справлялись с пропорциями ${ }^{52}$. При этом Рожков ограничился фактически цитированием одной фразы из учебника Тураева (у которого, однако, не было таких оценок ${ }^{53}$ ), хотя ему была знакома и более пространная характеристика Э. Мейера, к которой, в свою очередь, восходит и тураевский рассказ. Именно Мейер формулировал эстетическое противоре-

\footnotetext{
45 Рожков 1925-1928. II: 405.

${ }^{46}$ Рожков 1925-1928. VI: 201.

48 Рожков 1925-1928. VII: 268, 282.

50 Рожков 1925-1928. II: 269.

${ }^{51}$ Рожков 1925-1928. II: 264.

52 Рожков 1925-1928. II: 269.

53 Тураев 1913: 94.
}

${ }^{47}$ Рожков 1925-1928. I: 123, 125, 126.

49 Рожков 1925-1928. VI: 207. Конечно, существующее в Законах Хаммурапи различение долгового и постоянного рабства было замечено и в современной Рожкову литературе, так что в данном случае он отбирает те оценки, которые были удобны ему. 
чие между тонкой обработкой голов и нарушенными пропорциями, изза чего статуя Гудеа представлялась ему подобной изображению «карлика-переростка». Тем не менее, немецкий историк оценивал этот период как вершину шумерского искусства ${ }^{54}$.

Но если определения, даваемые стадиям развития искусства, могут считаться делом впечатления, то и в вопросах экономики Рожков спешит делать большие умозаключения на основе скромных данных: введение Дарием I золотой монеты даёт ему возможность утверждать, что «Персидская империя была первой попыткой устройства мировой почти монархии на основе товарного хозяйства, торгового капитала» ${ }^{55}$, а анализ данных об имуществе храма Амона-Ра при XX династии служит основанием для утверждения о том, что храмовая экономика работала не только на внутренний, но и на международный рынок ${ }^{56}$.

В целом, корректно излагая отдельные факты из работ специалистов по периоду, Рожков более или менее сознательно манипулирует с их трактовкой: либо добавляет, как очевидное то, чему свидетельств не найдено, либо игнорирует часть оценок профессионалов, сосредоточиваясь на том, что подтверждает его изначальную схему.

\section{Жрец науки о жрецах прошлого: А.А. Богданов}

По степени оригинальности мировоззрения Богданов может считаться лидером среди всех обозначенных нами марксистов - его теория, развивавшаяся от эмпириомонизма к тектологии, являясь материалистической, не во всём равна марксизму (во второй половине 1920-х гг. учёный стал скрывать это обстоятельство $)^{57}$. Поскольку теория эта общенаучная, степень использования в ней конкретных исторических данных оказалась заведомо ниже, чем у Плеханова и Рожкова. Тем не менее, взгляды Богданова на отдельные эпохи и культуры выражены более или менее определённо; известную роль в этом сыграло то, что он был одним из авторов учебника по политэкономии (популярный в раннем СССР жанр); нередко его соавтором выступал И.И. Скворцов-Степанов.

Неизбежный социологизм таких работ авторы старались смягчить как отсылкой к тому, что выделяемые ими типы обществ являются лишь научными абстракциями, не имевшими чистых форм в реальной истории, так и вариативностью путей их развития. На выходе из первобытного состояния переходной формой им виделись патриархальные общины, при трансформации которых появляются феодальные отношения ${ }^{58}$. Из них, в свою очередь, могут выйти различные формы менового хозяйства: рабовладельческая, крепостническая, ремесленная и торгово-капи-

\footnotetext{
${ }^{54}$ Meyer 1909: 490.

${ }^{55}$ Рожков 1925-1928. I: 419.

${ }^{56}$ Рожков 1925-1928. VII: 238.

57 Литература по Богданову огромна, уместно указать лишь некоторые обобщающие работы: Jensen 1978; Локтионов 2018.

${ }^{58}$ Ввиду невозможности датировать их определённо, Богданов пояснял, что «феодальные отношения складывались на Востоке и в классическом мире за много столетий до P.X., а в Западной Европе приблизительно с V века до IX...». Богданов 1923: 47.
} 
талистическая ${ }^{59}$. Эти формы соотносятся также со стадиями человеческого мышления (конкретно, понимания человеком причинной связи): начальной стадии недифференцированной родовой группы (мировоззрение фактически отсутствует); второй стадии авторитарной общины «сначала патриархального, потом феодального типа; всё более глубокое разделение труда исполнительного и организаторского» (зарождение религиозного мировоззрения); третьей стадии менового, индивидуалистического общества (отвлечённые философские системы) и четвёртой стадии «нового трудового коллектива», при которой формируется социалистическое общество ${ }^{60}$. Древний мир знал первую и вторую стадии (вторая начинается с создания централизованных государств на Востоке и оформления полисного строя в Греции), поэтому в его мировоззрении преобладало консервативное приспособление к реальности.

Основная характеристика восточных обществ оказывается у Богданова вполне тривиальной - это «бессмысленно-тупой восточный деспотизм ${ }^{61}$, причём это его главное и интеллектуальное, и эмоциональное представление о древнем Востоке. Такое политическое устройство столь же узнаваемо связывается с долинами великих рек. Отличие восточных обществ от античных заключается в том, что они возникли раньше и, по сути, были простейшим типом рабовладельческих систем. Причины заключались в том, что «потрясаемое мелкими внутренними войнами» 62 феодальное общество не могло выполнять функции систематической ирригации и достойно защищаться от внешнего вторжения. В итоге складывается предельно авторитарная форма общества.

Деспотическое государство формируется через отвержение ряда прежних принципов: усиливается эксплуатация крестьянства (в т.ч. через ростовщичество ${ }^{63}$ ) и отменяется наследственность чиновников, пропасть отделяет обожествлённого восточного деспота от «последнего из рабов его государства» ${ }^{64}$. Нарастающий контроль за прежними общинами делает власть государства над человеком неограниченной: «действие государственного механизма деспотии окончательно уравнивает человека с продуктами его труда, а в этом и состоит сущность рабства»; появляется тенденция к объединению всей массы рабочих сил в рамках гигантского государственного ойкоса - Египет «в известной фазе своей истории успел подойти близко к этому пределу» ${ }^{65}$, некоторая независимость остаётся только у жрецов. Меновым такое хозяйство является не потому, что оно преодолевает свою натуральную основу, а потому что почти каждый член общества является потенциальным товаром ${ }^{66}$.

\footnotetext{
${ }^{59}$ Богданов; Скворцов-Степанов 2011: 186.

${ }^{60}$ Богданов 2010а: 227.

61 Богданов 1990: 33.

62 Богданов; Скворцов-Степанов 2011: 187.

${ }^{63}$ Богданов; Скворцов-Степанов 2011: 169. Ср. Богданов 1923: 71-72.

${ }^{64}$ Богданов 2010b: 45-46.

${ }^{65}$ Богданов; Скворцов-Степанов 2011: 191.

${ }^{66}$ Богданов; Скворцов-Степанов 2011: 192.
} 
Но рабовладение, как самый грубый механизм действия менового общества, неизбежно возникающий в случае «натурально-хозяйственного базиса» ${ }^{67}$, оказывается в итоге наименее жизнеспособным ${ }^{68}$, причём его самые предельные формы являют собой именно восточные рабовладельческие деспотии. Объяснение кризиса рабовладения лежит в принципе в русле марксистского понимания (восходящего к логике А. Валлона), но дано со специфической богдановской акцентуацией на социальноорганизационных аспектах: первоначально рабовладельцы были важны для функционирования всей системы труда, поскольку реально управляли трудом рабов; при дальнейшем росте числа рабов, эту функцию стала исполнять отдельная прослойка (рабы-распорядители, управляющие поместий), а рабовладельцы, отрываясь от организационной деятельности, превращались в социальных паразитов, предаваясь безделью и разврату (в этом аспекте характеристика разложения высших классов в древнем мире вполне стандартна ${ }^{69}$ ), выжимая из экономики последние соки на роскошную жизнь. С другой стороны, низшие классы оказывались настолько истощены сверхэксплуатацией, что у них не оставалось сил для сопротивления - более того, рабы фактически не оформились как класс ${ }^{70}$ и не обрели идеологию для сопротивления, которое проявлялось поэтому только в пассивных формах ${ }^{71}$. Подробно рассказывая о причинах гибели рабовладельческих обществ на примере Римской империи (впрочем, тоже на минимуме фактического материала), Богданов замечает при этом, что судьба народов Востока «оказалась чуть ли не хуже судьбы классического мира ${ }^{72}$, но нигде не развивает эту мысль ${ }^{73}$.

Наибольшей силы рассуждения Богданова достигают там, где он рассказывает об эволюции мировоззрения общественных классов в связи с историческим развитием. «В долинах Евфрата, Нила, Янцзы-Кианга жрецы халдейские, египетские, китайские, стремясь к точному разделению времени и к точному знанию направлений в пространстве, сознательно приводили в порядок переданные от предков астрономические сведения, систематически проверяли и дополняли их новыми наблюдениями, оформляли $u x$ с помощью постепенно выработанных способов измерения и исчисления, закрепляли посредством записей» ${ }^{74}$. Нужно помнить о том почтении, которое учёный питал к процессу получения

${ }^{67}$ Богданов 1906: 117.

${ }^{68}$ Богданов 1989. I: 233: «консервативно сформированные организмы устойчивы только в консервативной среде».

${ }^{69}$ Богданов 1989. II: 116.

70 Богданов 1906: 95-96.

${ }^{71}$ Богданов 1906: 110.

72 Богданов 1906: 117.

${ }^{73}$ Вероятно, под худшей участью Богданов подразумевал то, что восточные культуры находились в длительном состоянии упадка, не погибая окончательно, и это не давало возможности восточным народам перейти к новым общественным формам. Об упадке «восточных культур» см. Богданов 1990: 446; о переходе от деспотизма к капитализму «мировой цивилизации»: Богданов; Скворцов-Степанов 2011: 193.

${ }^{74}$ Богданов 1990: 360. Курсив автора. 
знания в принципе, чтобы понять, насколько такого рода описания были внутренне позитивны с его стороны, ведь жрецов он прямо называл «тогдашними интеллигентами» ${ }^{75}$. Причем сама по себе религиозная оболочка для знаний не вызывает у Богданова неприятия или порыва к богоборчеству - он достаточно спокойно квалифицирует её как исторически обусловленную форму ${ }^{76}$. Проблема знания и его носителей на этапах и авторитарной общины, и индивидуалистического общества состоит в том, что оно целиком встроено в авторитарную систему мировосприятия, носит статический характер ${ }^{77}$ и поэтому перестаёт эволюционировать: консервативное знание оберегается узким кругом его носителей, навязывается остальным как набор неизменных истин и в итоге не может служить более сложным задачам. «История знает примеры, когда целая культура становилась неспособной к развитию благодаря тому, что вырабатывала идеологию, исключающую социальный прогресс. Так было с рабовладельческой культурой древнего мира...» ${ }^{78}$. Именно эти соображения лежали в основе выступлений Богданова против тех последователей Маркса, которые относятся к его учению как к авторитарному, раз и навсегда данному и непоколебимому в своих основах ${ }^{79}$.

\section{Восточное прошлое и предвестия будущего}

Несмотря на определённые расхождения, взгляды русских марксистов на древнюю историю вообще и Ближнего Востока в частности несли и черты существенного сходства. Оно не может быть сведено лишь к отдельным внешним совпадениям, хотя они вполне значимы, так как указывают на общие источники вдохновения, знакомство с трудами друг друга, элементы полемики. Так, Рожков и Богданов считали, что на Востоке в ранний период, как и повсюду, власть воплощалась во фракциях светских и духовных феодалов ${ }^{80}$, они оба считали нужным выделять историю городов-государств в качестве отдельного подтипа общественного развития. Рожков рекомендовал Богданову и СкворцовуСтепанову убрать из учебника характеристику рабовладельческого этапа - ведь тот отсутствовал в его представлениях об исторических эпо$\mathrm{xax}^{81}$. В «Красной звезде» Богданова родина главного героя характеризуется как азиатское государство, которое «пользуется европейскими способами сообщения и средствами истребления, чтобы подавлять и искоренять всё, что есть у вас живого и прогрессивного» ${ }^{82},-$ чисто пле-

\footnotetext{
75 Богданов 1990: 363. Более того, в религиозном мышлении «далёкого прошлого» Богданов видит зачатки собственной науки - «народную тектологию». Богданов 1989. II: 195.

76 Религиозность доменовой эпохи даже характеризует как «могучую, боевую». Богданов 2010b: 84, прим. 1. Ср. Богданов; Скворцов-Степанов 2011: 58 (курсив автора): «Исторически религия зарождается из культа предков-организаторов».

77 Богданов 2010b: 144.

${ }^{78}$ Богданов 1906: 65.

${ }^{79}$ Богданов 2010b: 116-117.

${ }^{80}$ Богданов 1989. II: 119.

${ }^{81}$ Богданов; Скворцов-Степанов 2011: XXX.

82 Богданов 2014: 28.
} 
хановская мысль ${ }^{83}$. Так или иначе, это была определённая интеллектуальная среда, в которой могли обращаться разные трактовки. Объединяло их, очевидно, стремление к материалистическому пониманию сути социальных процессов, желание показать, что общее видение истории применимо ко всем историческим сообществам и всюду работает одинаково. Склонность к простоте была скорее побочным следствием этой изначальной задачи и смягчалась теми моментами, которые были затем отвергнуты советским марксизмом: отсутствовала строгая привязка форм развития к хронологии, признавалось преобладание смешанных форм и допускалось наличие разных подтипов у сходных сообществ.

****

Может показаться, что всё вышеизложенное не имеет особого значения в контексте последующей традиции - все эти рассуждения могут быть положены в копилку позабытых идей отечественной мысли, не востребованных советским поколением и ещё менее актуальных сейчас ${ }^{84}$. Но, во-первых, это не совсем так: советские авторы 1930-х гг. были недавними читателями именно разобранных выше сочинений. Одним из таких авторов, внимательно читавших учебники, был Сталин. Нельзя говорить о бесспорном влиянии именно учебника Богданова и Скворцова-Степанова на такие замечания в «Истории ВКП (б)» как наличие у древнего рабовладения двух источников (военнопленных и закабаляемых собственных подданных ${ }^{85}$ ), но и отмахиваться от этой версии также не стоит. Наконец, и сама мысль о том, что рабство есть не юридическое состояние, а социально-экономическая характеристика, как и сведение социального статуса человека к функции его труда - это фактический прототип идеи В.В. Струве о рабстве в экономическом смысле слова.

Во-вторых, есть и более важный вопрос: насколько развитие советской науки (в частности, востоковедения) было подготовлено этим предшествующим этапом? Проистекали ли особенности советского видения древневосточной истории из русской марксистской мысли или строились на её отвержении? Хотелось бы высказать некоторые соображения.

У всех рассмотренных авторов «идеально-типическим» воплощением древней истории была античность, а восточная история (несмотря на признание исключительной древности египетской и месопотамской культур) оказывалась локальным вариантом. Это, в частности, говорит о том, что преодоление европоцентризма, которое попыталась реализовать ранняя советская историография в конце 1920-х - начале 1930-х гг., совершенно не было подготовлено марксистской историософией. По-

${ }^{83}$ Естественно, это не отменяет принципиальных расхождений между Плехановым и Богдановым, но линия раскола проходила совсем не по древней истории. См. Sadovsky, Kelle 1996: VII-IX.

${ }^{84}$ О том, что Плеханов предвосхитил ряд идей К.А. Витфогеля: Baron 1995: 18 f.; Sawer 1997: 115 f. См. также мнение Дж. Гонзалеза о причинах отторжения Рожкова в советской историографии: González 2013: 112-115.

${ }^{85}$ Богданов; Скворцов-Степанов 2011: 189; Богданов 1923: 71; История ВКП (б) 1938: 119. 
этому описание особенностей восточных обществ, по сравнению с античными, имело очень немного возможностей быть основанным на каких-либо оригинальных идеях и проигрывало тенденции к обобщённой характеристике древней истории.

Следует обратить внимание и на другой момент: становление советской науки было во многом построено на отвержении учебных пособий и исторических трудов 1920-х гг. как слишком схематичных, при этом продукция 1930-х гг. сама в итоге оказалась подчинена более ригидной, к тому же единственной схеме исторического процесса, которая идеально сочеталась с сугубой фактологией. Косвенную роль в этом торжестве сталинской модели историописания сыграло то, что работы таких авторов, как Плеханов, Рожков, Богданов, несмотря на очевидное упрощение в них исторических сведений, могли быть адекватно поняты и прочитаны только таким читателем, который имел базис дореволюционного гимназического образования - и это ему они могли казаться простыми и схематичными. Советский читатель, обладавший куда более скромным запасом знаний, должен был совершенно теряться в потоке хронологически неупорядоченных примеров, который лился на него параллельно с всеохватывающей исторической теорией, причём именно такое сочетание дезориентировало в наиболышей мере. На материале ближневосточной истории, с её обилием нерасхожих сюжетов и малоизвестных персонажей, это должно было быть особенно заметно. Таким образом, рождение советского востоковедения было в том числе реакцией на кризис русского марксистского историописания.

\section{БИБЛИОГРАФИЯ / REFERENCES}

Богданов А. Краткий курс экономической науки. М.-Пг.: Государственное издательство, 1923. 264 c. [Bogdanov A. Kratkij kurs jekonomicheskoj nauki Moscow - Petrograd: Gosudarstvennoe izdatel'stvo, 1923. 264 p.]

Богданов А. Праздник бессмертия. Избранные произведения. СПб.: Издат. группа «Лениздат», «Команда А», 2014. 384 с. [Bogdanov A. Prazdnik bessmertija. Izbrannye proizvedenija. Saint Petersburg: Izdatel'skaja gruppa «Lenizdat», «Komanda A», 2014. 384 p.]

Богданов А. Эмпириомонизм. Книга III. СПб.: Электропечатня товарищества «Дело», 1906. 160 c. [Bogdanov A. 1906: Empiriomonizm. Book III. Saint Petersburg: Jelektropechatnja tovarishhestva «Delo», 1906. 160 p.]

Богданов А.А. Вопросы социализма. Работы разных лет. М.: Политиздат, 1990. 479 с. [Bogdanov A.A. Voprosy socializma. Raboty raznyh let. Moscow: Politizdat, 1990. 479 p.]

Богданов А.А. Падение великого фетишизма. Современный кризис идеологии. М.: КРАСАНД, 2010 (b). 224 c. [Bogdanov A. Padenie velikogo fetishizma. Sovremennyj krizis ideologii. Moscow: KRASAND, 2010 (b). 224 p.]

Богданов А.А. Тектология. Всеобщая организационная наука. М.: Экономика, 1989. Кн. I. 304 c.; Кн. II. 351 c. [Bogdanov A.A. Tektologija. Vseobshhaja organizacionnaja nauka. III. Moscow: Jekonomika, 1989. Vol. I. 304 p.; Vol. 2. 351 p.]

Богданов А.А. Философия живого опыта. Материализм, эмпириокритицизм, диалектический материализм, эмпириомонизм, наука будущего. Популярные очерки. М: КРАСАНД, 2010 (a). 272 c. [Bogdanov A. Filosofija zhivogo opyta. Materializm, jempiriokriticizm, dialekticheskij materializm, jempiriomonizm, nauka budushhego. Populjarnye ocherki. Moscow: KRASAND, 2010 (a). 272 p.]

Богданов А.А., Скворцов-Степанов И.И. Курс политической экономии докапиталистической эпохи. М.: Книжный дом «Либроком», 2011. 378 с. [Bogdanov, A.A.; Skvortsov- 
Stepanov, I.I.: Kurs politicheskoj jekonomii dokapitalisticheskoj jepohi. Moscow: Knizhnyj dom «Librokom», 2011.378 p.]

Волобуев О.В. Н.А. Рожков: историк и общественный деятель. М.: Собрание, 2012. 320 с. [Volobuev O.V. N.A. Rozhkov: istorik i obshhestvennyj dejatel'. M.: Sobranie, 2012. 320 p.]

Гегель Г.В.Ф. Лекции по философии истории. СПб.: Наука, 2000. 480 c. [Hegel, G.W. Fr. Lektsii po filosofii istorii. Saint Petersburg: Nauka, 2000. 480 p.]

История Всесоюзной Коммунистической партии (большевиков). Краткий курс. М.: Издательство ЦК ВКП(б) «Правда», 1938. 352 с. [Istoriia Vsesoiuznoi Kommunisticheskoi partii (bol'shevikov). Kratkii kurs. Moscow: Izdatel'stvo CK VKP(b) «Pravda», 1938. 352 p.]

Ладынин И.А. Понятие «древний Восток» в отечественной историографии XX в. // ВДИ. 2019. T. 79. № 3. C. 772-796 [Ladynin I.A. Ponjatie «drevnij Vostok» v otechestvennoj istoriografii XX v. // Vestnik drevney istorii. 2019 (a). Vol. 79. No 3. P. 772-796].

Локтионов М.В. Александр Богданов между марксизмом и позитивизмом. М.: ИФ РАН, 2018. 135 c. [Loktionov M.V. 2018: Aleksandr Bogdanov mezhdu marksizmom i pozitivizmom. Moscow: IF RAN, 2018. 135 p.]

Мечников Л.И. Цивилизация и великие исторические реки. М.: Айрис-пресс, 2013. 320 с. [Metchnikoff L.I. 2013: Civilizacija i velikie istoricheskie reki. M.: Ajris-press, 2013. 320 p.]

Плеханов Г.В. Сочинения. Тт. I-XXIV. Москва-Петроград/Ленинград, 1923-1927 [Plekhanov G.V. Sochinenija. Vol. I-XXIV. Moscow - Petrograd/Leningrad1923-1927].

Рожков Н.А. Русская история в сравнительно-историческом освещении (Основы социальной динамики). Тт. I-XII. Л.-M., 1925-1928 [Rozhkov N.A.: Russkaja istorija v sravnitel'no-istoricheskom osveshhenii (Osnovy social'noj dinamiki) Vol. I-XII. L.; M.,1925-1928].

Тураев Б.А. История древнего Востока. Ч. І. СПб.: Тип. В. Безобразова и К우 1913. 414 с. [Turaev B.A. Istoriya drevnego Vostoka. Part I. SPb.: Tip. V. Bezobrazova i K, 1913. 414 p.]

Тютюкин С.В. Г.В. Плеханов. Судьба русского марксиста. М.: РОССПЭН, 1997. 376 с. [Tjutjukin S.V. G.V. Plehanov. Sud'ba russkogo marksista. M.: ROSSPJeN, 1997. 376 p.]

Энгельс Ф. Развитие социализма от утопии к науке // Маркс К., Энгельс Ф. Сочинения. М.: Государственное издание политической литературы, 1961. Т. 19. С. 185-230 [Engels F. Razvitie socializma ot utopii k nauke // Marx K., Engels F. Sochinenija. Moscow: Gosudarstvennoe izdanie politicheskoj literatury, 1961. Vol. 19. P. 185-230].

Baron S.H. Plekhanov in Russian History and Soviet Historiography. Pittsburgh; London: University of Pittsburgh Press,1995. 298 p.

González J. An Intellectual Biography of N.A. Rozhkov (1868-1927): Life in a Bell Jar. Leiden: Brill, 2017. 380 p.

González J. From Historicism to Historical Sociology: An Examiniation of Nikolai Aleksandrovich Rozhkov's Nomothetis Scheme of Historical Evolution // Journal of Modern Russian History and Historiography. 2013. Vol. 6. P. 90-115.

Jensen K.M. Beyond Marx and Mach. Aleksandr Bogdanov's Philosopy of Living Experience. Dordrecht: D. Reidel Publishing Company, 1978. IX+189 p.

McDonald P.D. Artefacts of Writing. Ideas of the State and Communities of Letters from Mattew Arnold to Xu Bing. Oxford: Oxford University Press, 2017. 328 p.

Ménant M.J. Annales des rois d'Assyrie. Traduites et mises en ordre sur le texte Assyrien. Paris: Maisonneuve et CIE, Éditeurs, 1874. 312 p.

Meyer E. Geschichte des Altertums. Erster Band. Zweite Hälfte. Die Altesten Geschichtlichen Völker und Kulturen bis zum Sechzehnten Jahrhundert. Stuttgart-Berlin: J.G. Gotta'sche Buchhandlung Nachfogler, 1909. $894 \mathrm{~s}$.

Piepkorn A.K. Historical Prism Inscriptions of Ashurbanipal. Vol. I. Edition E, B 1-5, D, and K. Chicago: The University of Chicago Press, 1933. 109 p.

Sadovsky V.N.; Kelle V.V. Foreword // Bogdanov's Tektology. Book 1. Hull: Centre for System Studies Press, 1996. P. III-XXIX.

Sawer M. Marxism and the Question of the Asiatic Mode of Production. Hague: Martinus Nijhoff, 1977. $252 \mathrm{p}$.

Verderame L., Garcia-Ventura A. Preliminary Considerations // Receptions of the Ancient Near East in Popular Culture and Beyond / Eds. L. Verderame, A. Garcia-Ventura. Atlanta: Lockwood Press, 2020. P. 1-9.

Крих Сергей Борисович, доктор исторических наук, профессор, Омский государственньй университет им. Ф.М. Достоевского; krikh@rambler.ru 


\section{The Russian Marxists and the Ancient Near East}

Marxism in pre-revolutionary Russia is one of the forgotten pages for prehistory of the Soviet historical narrative. Soviet historians speaking large about Lenin (either Marx and Engels) as a predecessor of the Soviet scholarship, but mostly ignored such authors like Georgii Plekhanov, Nikolai Rozhkov and Alexander Bogdanov. All named Russian Marxist has similar background in their historical education and in their handing of facts. All of them also used simplification as a technique to show how the same principles of materialistic analysis worked on the examples many of ancient societies of the East. This general simplification was partly smoothed out by both the recognition of the variability of the historical development of ancient societies and the mutual competition of different versions of their development. But this combination was lost during the genesis of Soviet historical scholarship in the early 1930s.

Keywords: Russian Marxism, history of the ancient Near East, early Soviet historiography

Sergey Krikh, Dr. Sc. (History), Professor, Department of World History, Omsk State University named after Dostoevsky; krikh@ rambler.ru 


\section{Н.Ю. НИКОЛАЕВ \\ «РАЗОЧАРОВАННЫЙ ПАЦИФИСТ» \\ ПРОБЛЕМАТИКА ВОЙНЫ И МИРА \\ В ПУБЛИЦИСТИКЕ П.Н. МИЛЮКОВА В НАЧАЛЕ ХХ ВЕКА}

В статье рассмотрены взгляды П.Н. Милюкова на проблемы войны и мира в 1910-е гг. Выявлено его отношение к вооруженным конфликтам, пацифистскому движению, милитаризму, разоружению и перспективам достижения всеобщего (вечного) мира. Определены причины и характер мировоззренческой эволюции Милюкова и его отказа от прежних антивоенных убеждений. Отдельно рассмотрена общественно-политическая позиция, занятая Милюковым в период Первой Мировой войны.

Ключевые слова: война, мир, милитаризм, пацифизм, милитаризм, международное гуманитарное право, Первая Мировая война

Научному сообществу Павел Николаевич Милюков (1859-1943) известен прежде всего своим участием в либеральном движении дореволюционной России и политической активностью в 1917 г. Значительно реже обсуждают Милюкова-историка - ученика В.О. Ключевского, автора оригинальных работ по петровскому времени и истории русской культуры. И уже совсем на периферии исследовательского внимания оказались его антивоенные взгляды. В советской историографии критика Милюковым современного ему милитаризма и вооруженных конфликтов практически не рассматривалась. Напротив, констатировался шовинистический и экспансионистский характер его воззрений в годы Первой Мировой войны ${ }^{1}$. Лишь в последние два десятилетия возрос интерес к его миротворческой деятельности заметно усилился ${ }^{2}$. По словам Р.М. Илюхиной и Д.А. Сдвижкова, пацифистские взгляды Милюкова в полной мере отразили противоречивую историю отечественного миротворчества начала XX века ${ }^{3}$. Действительно, публицистика Милюкова тех лет представляла собой удивительный пример идейной эволюции - стремительной и на первый взгляд парадоксальной. Убежденный противник межгосударственных конфликтов и гонки вооружений за довольно короткий промежуток времени изменил свою позицию фактически на противоположную. Думается, что анализ причин столь резкого изменения взглядов позволит не только по-новому оценить противоречивую фигуру одного из столпов отечественного либерализма, но и выявить особенности развития антивоенной мысли в России начала XX в.

В своих воспоминаниях Милюков отмечал, что давно интересовался миротворческими идеями. Будучи депутатом I Государственной Думы, он являлся членом межпарламентского Союза мира, в рамках кото-

\footnotetext{
${ }^{1}$ Думова 1988: 11-15, 22-23; Дякин 1967: 47, 49, 51.

2 Воронкова 2007: 11-13; Илюхина 1992: 23-24; Нигметзянов 2003: 84; Новиков 2000: 319-321.

${ }^{3}$ Илюхина, Сдвижков 1997: 180.
} 
рого работал в комиссии об ограничении вооружений ${ }^{4}$. Сочувствуя идеям политического (государственного) миротворчества, ученый внимательно следил за Гаагской мирной конференцией 1907 г. В то время он был горячим поборником кодификации международного права, считая ее высшим проявлением повсеместное развитие и распространение третейского разбирательства ${ }^{5}$. Милюков выступал за сокращение вооружений, которое должно было происходить посредством обязывающего межгосударственного соглашения. «Теперь уже никто не думает, - писал он в передовице газете «Речь», - чтобы в один прекрасный день люди из злых станут добрыми, преисполнившись любви к друг другу, сложили оружие, сдали в музей пушки и броненосцы и обратили на культурные нужды суммы военных и морских бюджетов. Зато мысль о международном соглашении, об ограничении темпа или силы вооружений, становится все более и более привычной, доступной и приемлемой» ${ }^{6}$.

Именно в этот период Милюков создал свое самое известное произведение, направленное на пропаганду миротворческих идей. Речь идет о написанной в 1911 г. по заказу петербургского отделения Общества мира брошюре «Вооруженный мир и ограничение вооружений» ${ }^{7}$. Идейным фундаментом этого сочинения послужил нашумевший труд известного английского общественно-политического деятеля Н. Энджелла «Великая иллюзия/The Great Illusion» (в русских переводах - «Великое заблуждение»), где автор стремился доказать, что в условиях нараставшей экономической взаимозависимости войны одинаково разрушительны, как для проигравших, так и для победителей. Энджелл предлагал подходить к межгосударственным конфликтам с утилитарной точки зрения и оценивать их, прежде всего, как убыточное, а потому бессмысленное предприятие ${ }^{8}$. Современные исследователи относят Энджелла к родоначальникам нового «ревизионистского» пацифизма, основанного не на толстовском антивоенном «морализаторстве», а на прагматизме и экономической выгоде 9 . В России сторонником схожих идей был известный промышленник и филантроп И.С. Блиох. В 1898 г. он издал шести томный труд «Будущая война в техническом, экономическом и политическом отношениях», переведенный практически на все основные европейские языки ${ }^{10}$. Основная мысль этого поистине монументального произведения состояла в доказательстве пагубного воздействия военных конфликтов и гонки вооружений на финансовую систему и торговлю.

\footnotetext{
${ }^{4}$ Ефремов 1913: 3.

${ }^{5}$ Милюков 1991: 310-311.

${ }^{6}$ Милюков В поисках... 1910: 1.

${ }^{7}$ Милюков 1991: 311.

${ }^{8}$ Angell 1910; Энджель 1912.

9 Лакеева 2006: 12; Сдвижков 1999: 75, 82-83, 115. Для подобных взглядов, вполне допускавших также оборонительные или даже колониальные войны, по мнению автора, более уместен термин «пацифицизм».

${ }^{10}$ Bloch 1899.
} 
Свою главную авторскую задачу Милюков видел в предоставлении обществу четких и понятных аргументов в пользу мира. Именно их отсутствие снискало миротворчеству репутацию отвлеченного и сугубо теоретического движения ${ }^{11}$. Поэтому уже на первых страницах своего труда он старательно пытался выявить основное содержание антивоенных идей, которые продолжали вызывать у общественности «противоречивые чувства». Приверженцы всеобщего мира нередко воспринимались обществом либо как обманщики и лицемеры, либо в не менее неприятном качестве ограниченных мечтателей и праздных болтунов. Однако общий скептицизм не помешал миротворческому движению становиться все более популярным и востребованным, заставляя прислушиваться к требованиям разоружения и всеобщего умиротворения уже и политические круги. Распространению антивоенных идей, считал Милюков, способствовала прежде всего заинтересованность общества в снижении непереносимого бремени гонки вооружений ${ }^{12}$.

Определенный интерес представляла предложенная автором социологическая теория развития милитаризма. Состояние «вооруженного мира», господствовавшее в международных отношениях начала XX в., Милюков считал лишь одной из исторических стадий отношения к войне и миру, критериями которого выступало развитие социальной организации, политических институтов и степень экономического прогресса. В предгосударственный период человечество существовало в условиях бесконечных междоусобиц, полностью стиравших грань между миром и войной. Связь войны и экономики в это время была самой элементарной и выражалась принципом «война кормит войну». Грабежи побежденных, как правило, покрывали сопутствующие издержки, что позволяло считать конфликты весьма выгодным занятием. С появлением централизованного государственного механизма ситуация стала постепенно меняться. Война становилась профессией, привилегией правящего класса. На данном этапе «вновь складывающаяся государственная машина берет войну в свои руки и дарует мир подчиненному населению». Однако лишь с появлением современных политических институтов и усложнением народнохозяйственной жизни государство потеряло возможность беспрепятственно эксплуатировать население для реализации своих воинственных замыслов. Соответственно заметно возросли негативные экономические последствия межгосударственных столкновений. Война превратилась в своеобразное «промышленное, капиталистическое предприятие», обусловленное насущными национальными интересами ${ }^{13}$. Наибольшую выгоду от международных конфликтов стали получать военно-промышленные предприятия, которые развивались при активной государственной поддержке. «Промышленники заинтересованы в войне и военных осложнениях, - писал Милюков, - потому что это дает им

\footnotetext{
${ }^{11}$ Милюков 1911: 3-4.

12 Там же: 6-7.

13 Там же: $13-16$.
} 
возможность сбыть залежавшиеся товары, вышедшие из моды военные орудия и получить новые заказы» ${ }^{14}$. Однако гонка вооружений лишь усиливала негативные социально-экономические последствия для населения. Увеличение налогов, бюджетный дефицит, отток капитала, ухудшение положения рабочего класса, рост безработицы и преступности - таков неполный перечень проблем ${ }^{15}$. Опираясь на сведения Блиоха, Милюков стремился доказать, что война в будущем исчезнет как раз в силу собственной разрушительности и разорительности. Даже военнотехнический прогресс лишь увеличивал социально-экономические тяготы конфликтов. Появление магазинных винтовок, скорострельных артиллерийских орудий и шрапнельных снарядов кардинально изменило тактику сражений. Отказавшись от прежних скоротечных битв, противники перешли к долговременным, изматывающим окопным сидениям. Победить в такой войне, прозорливо считал автор, сможет не более многочисленная армия, а та, что «окажется выносливее и сможет долее выдержать необходимое напряжение». В конечном счете, важнейшим вопросом будущих столкновений станет состояние экономики и финансового хозяйства противоборствующих сторон ${ }^{16}$.

Милюков пытался найти то, что могло бы препятствовать межгосударственным столкновениям и способствовать развитию мирного человеческого общежития. Грядущее умиротворение он связывал прежде всего с социальным прогрессом. Общественно-политическое развитие на рубеже XIX-XX вв. способствовало постепенному отказу от демонстрации открытой силы и ускорило переход к состоянию «необходимой обороны». Тысячелетняя борьба народов за жизненное пространство, полагал Милюков, подходила к концу. Прогресс науки и техники, рост национального самосознания, климатические условия и общее культурное развитие Африки и особенно Азии поставили предел дальнейшей экспансии представителей белой расы. Так был положен естественный рубеж колониальным захватам, а значит, создавалось необходимое условие «для торжества идеи мира и для установления между народами взаимного равновесия на каком-либо ином начале, чем открытая физическая борьба за первенство, за мировое преобладание». На рубеже XIX$\mathrm{XX}$ вв. в Европе возникла неведомая прежде ситуация международной стабильности и политического равновесия, которая «обещала» сделать достижение мира не только возможным, но и вполне реальным ${ }^{17}$.

Лишь на Балканах можно было ожидать всплеска напряженности, вызванного ростом национально-освободительного движения и соперничеством великих держав за влияние в регионе. Впрочем, эта гипотетическая война виделась Милюкову локальной, не способной заметно нарушить европейское равновесие. Наступательные войны, с целью но-

\footnotetext{
14 Там же: $17-18$.

15 Там же: $20-32$.

16 Там же: 42-44.

17 Там же: $77-83$.
} 
вых территориальных захватов еще возможны были в колониях, но на континенте подобные конфликты уже ушли в прошлое ${ }^{18}$. В то же время вероятность случайного столкновения, причинами которого могли быть произвол, капризы правителей, политические амбиции и интриги, продолжала беспокоить автора. Надежным средством недопущения таких конфликтов стал бы общественный контроль над внешней политикой ${ }^{19}$.

Успеху разоружения должно было способствовать распространение миротворческих идей в обществе и политических кругах. В своей работе Милюков предложил собственную классификацию антивоенного движения. К первому направлению он относил сторонников «непротивления злу», которых критиковал за отрицание силы закона и государственной власти. Их идейными антагонистами являлись приверженцы утверждения мира силой, через завоевания и создание «мировых» империй. Милюков признавал подобные взгляды не меньшей утопией, чем мир «непротивленцев», основанный на совести, братстве и добровольном единении всего человечества. Но утопией гораздо более опасной, так как в международных отношениях начала XX в. уже было невозможно демонстративное национально-государственное доминирование, и мировое сообщество требовало признания, пусть и в чем-то формальное, всеобщего равенства и независимости ${ }^{20}$. Выступая против мира, основанного на совести и свободе, отвергая мир, порожденный насилием и порабощением, Милюков видел возможность реального прекращения войн лишь «путем добровольного согласия» (курсив мой - Н.Н.), и именно таким должен быть настоящий, действенный пацифизм.

Однако с предложенной Милюковым классификацией антивоенного движения можно согласиться лишь отчасти. Едва ли справедливо относить к миротворцам захватчиков и поработителей, какими бы целями они ни руководствовались. Потому логичнее было бы разделить миротворческое движение на умеренное крыло («интернационалисты», «пацифицисты») и радикальное, отрицавшее войны в любой форме.

Какие практические меры предлагал Милюков для борьбы с милитаризмом и гонкой вооружений? По его мнению, всеобщее умиротворение могло быть достигнуто только через создание «правовой международной организации цивилизованных наций». Всеобщему объединению способствовал происходивший рост торговых связей, развитие коммуникаций и общий социально-экономически прогресс ${ }^{21}$. Милюков считал, что процесс постепенного создания международной организации давно уже шел полным ходом. Ее фундаментом стали многочисленные «общества мира», которые стали появляться с начала XIX в., а с середи-

\footnotetext{
18 Там же: 82. Обратим внимание, что сбывшийся вскоре политический прогноз Милюкова, предвосхитившего балканские войны, парадоксальным образом соседствовал с «близорукостью» в оценке перспектив общеевропейского конфликта.

${ }^{19}$ Там же: 83.

${ }^{20}$ Там же: 86-88.

${ }^{21}$ Там же: 88-94.
} 
ны столетия их деятельность стала координироваться периодически созываемыми конгрессами и расположенным в Берне секретариатом. Более реальную, политическую плоскость миротворческая деятельность приобрела с образованием в 1889 г. «межпарламентского союза третейского суда и мира». Автор именовал межпарламентский союз «вторым этажом» будущей международной организации ${ }^{22}$.

Отметим, что деятельный поборник мира и старший современник Милюкова М.М. Ковалевский также рассматривал создание международного союза как важнейшее условие победы над милитаризмом. Однако, если для Ковалевского объединение человечества было завершающим актом солидарности и замирения, то в интеграционных проектах Милюкова основной упор делался на политико-правовой аспект организации. Иными словами, у него прекращение войны обеспечивалось прежде всего социально-правовыми механизмами, в то время как Ковалевский отдавал предпочтение социально-гуманитарному развитию. Поразному понимали они и глубинные причины уменьшения войн. Если для Милюкова движение к миру было связано прежде всего с возраставшим осознанием невыгодности международных конфликтов, то для Ковалевского этот процесс основывался на поступательном расширении основанной на договорных отношениях «пространства замирения» ${ }^{23}$.

Вместе с тем Милюков отстаивал идеи прагматизма в международных отношениях. Он призывал задуматься над тем, насколько межгосударственные конфликты действительно прибыльны. В отличие от прежних эпох, завоевание одного государства другим уже не несло ощутимой материальной и/или политической выгоды. Усложнение финансово-экономического хозяйства европейских государств, делало невозможным конфискацию банковских средств или разрушение национальной торговли противника. Выплата контрибуции, вопреки распространенному мнению, вела бы к сокращению внешней торговли и промышленного производства не столько у побежденного, сколько у победителя. Не меньше проблем, в условиях роста национально-освободительного движения, принесло бы и присоединение чужих колоний. Таким образом, резюмировал Милюков, захват чужих богатств и территорий «оказывается так невыгоден, что не стоит к нему стремиться» ${ }^{24}$.

Проблему милитаризма и сопутствующей ему гонки вооружений Милюков предлагал рассмотреть с позиции поступательного культурного, социального и нравственного прогресса человечества. Он полагал, что милитаризм в общественном сознании просвещенной Европы постепенно вытеснялся идеями миролюбия и добрососедства: «Сила и значение государств соответствуют не степени сохранности в них старых военных инстинктов, а степени просвещения и “индустриализации”

\footnotetext{
22 Там же: 98-99.

${ }^{23}$ Николаев 2014: 7-8.

${ }^{24}$ Милюков 1911: 144-151.
} 
их» ${ }^{25}$. Изменение эмоциональной природы человечества, сказалось и на социальных отношениях. Грубая физическая сила все реже выступала инструментом решения политических проблем. Волюнтаризм и импульсивность, столь часто в прошлом приводившие к межгосударственным столкновениям, сменились рациональным подходом. В итоге война «потеряла прежнюю романтическую привлекательность и сделалась самой прозаической профессией». Общему умиротворению способствовало преодоление воинствующего национализма и религиозного сектантства. Национальности и религии давно перешагнули тесные рамки государственных границ. Сближение на основе общих культурных ценностей и единого мировоззрения коснулось всех без исключения классов и социальных групп: пролетариата, интеллигенции, аристократии. Как результат, в международных отношениях другое государство перестало быть объектом иррациональной ненависти и вражды. Теперь оно представлялось «сложным агрегатом всевозможных интересов и настроений, среди которых есть враждебные, но есть и дружественные» ${ }^{26}$.

Вопрос демилитаризации России Милюков увязывал с общей либерализацией всей социально-политической системы. Решающую роль в этом процессе должно было сыграть расширение общественного контроля в сфере государственных финансов, внешней политики и обороны. Подобная демократизация избавила бы государственную политику от «покрова» приватности, освободила от случайностей и придала ей истинно национальный характер. «Только та страна может вести постоянную, последовательную политику, - категорически утверждал он, независимую от этих случайных личных усмотрений, в которой национальные интересы понятны и проникли в сознание широкой массы» ${ }^{27}$.

В требованиях Милюкова усилить общественный контроль за деятельностью правительства не следует видеть призывы к кардинальному сокращению расходов на вооружения и проведению исключительно миролюбивой политики. Скорее автор указывал на необходимость сбалансированности военных ассигнований, а также соотнесения их объема с общим финансовым положением страны, ее внешнеполитическим курсом и потребностями обороны. Подтверждением очевидной умеренности антивоенных взглядов автора стала оценка им «боснийского кризиса», который Милюков рассматривал как печальную демонстрацию несоответствия международных амбиций России с ее военными возможностями. Неслучайным нам видится и отказ Милюкова от анализа российского миротворчества. Он ограничился описанием того, как «подобные вопросы ставятся и решаются образованным мнением Европы» ${ }^{28}$. Вместе с тем Милюков признавал позитивное отношение русского общества к антивоенным идеям, а степень восприятия и проникнове-

\footnotetext{
25 Там же: 157.

26 Там же: $158-161$.

27 Там же: 9.

${ }^{28}$ Там же. С 10-12.
} 
ния миротворческих идей в «толщу» общественного сознания, напрямую увязывал с просвещением народа. И в этой благородной и многотрудной миссии важнейшая роль, по его мнению, принадлежала именно отечественной интеллигенции ${ }^{29}$.

Работа «Вооруженный мир и ограничение вооружений» являлась крупнейшим произведением Милюкова, написанным на антивоенную тематику. Однако, при ближайшем рассмотрении она оставляет впечатление довольно эклектичного сочинения, грешащего повторами и моральными сентенциями ${ }^{30}$. Автор прилежно, но не всегда доказательно стремился подвести читателя к мысли о неизбежности установления международного мира, по крайней мере, в рамках «цивилизованных государств Европы». Работа представляла собой обширную компиляцию трудов ряда известных социологов и экономистов конца XIX - начала XX в.: Н. Энджелла, А. Фрида, Ж. Бланделя, О. Шлифа Я.А. Новикова, И.С. Блиоха и др. В то же время следует помнить, что сочинение Милюкова носило популярный характер, являя пример своеобразного «non-fiction», изначально рассчитанного на широкий круг читателей. Кроме того, говорить об отсутствии в нем авторского мнения и идейной самостоятельности было бы несправедливо. В данной работе нашли отражение собственные взгляды Милюкова на состояние международных отношений, проблему роста вооружений и способы борьбы с милитаризмом. Нетрудно обнаружить в этом сочинении и субъективные предпочтения автора, его общественно-политические идеалы Так, заметны идеализация Англии и стремление обвинить в росте международной напряженности прежде всего Германию. Сам Милюков не слишком высоко оценивал свое сочинение. «То были идеалистические времена, вспоминал он, - когда правила международного права казались неприкосновенной святыней, когда Европа наслаждалась долголетним миром, колониальная борьба на время затихла, национальные претензии не поощрялись, «империализм» был почти бранным словом, и вечный мир вовсе не казался недостижимой перспективой». По его словам, уже во время написания работы у него возникли сомнения в безупречности аргументов английского миротворца. Доводы Энджелла выглядели неопровержимыми лишь в случае признания того, что мир или хотя бы его европейская часть стояли на том же уровне цивилизации и культуры, что и Англия. К сожалению, отмечал Милюков, ситуация накануне Первой Мировой войны, и в особенности агрессивная политика Германии противоречили выводам Энджелла и, в конечном счете, его «великая иллюзия» обернулась всеобщим горьким разочарованием ${ }^{31}$.

29 Там же: $162-165$.

${ }^{30}$ В Петербургском «Вестнике мира» был помещен краткий обзор труда Милюкова (Милюков 1912: 29-30). Отмечалось, что «книга захватывает внимание читателя как животрепещущим интересом темы», с чем, безусловно, следует согласиться, «так и новизной постановки самого вопроса», что справедливо лишь отчасти.

${ }^{31}$ Милюков 1991: 311. 
Интерес к проблематике войны и мира в публицистике Милюкова естественным образом соотносился с важными для России внешнеполитическими событиями. Так, в начале 1910-х гг. его пристальное внимание привлек Балканский полуостров, ставший ареной двух кровопролитных конфликтов. Российскую внешнюю политику в этом регионе Милюков рассматривал прежде всего через призму национальных интересов. «...Если мы что-нибудь должны делать на Балканах, - писал он еще в 1910 г., - то должны делать это в интересах России» ${ }^{32}$. Милюков не ставил под сомнение право «христианских народностей на окончательное освобождение от турецкого владычества», но указывал на необходимость энергичных усилий российского правительства, чтобы «побудить воюющие стороны принять посредничество для заключения мира» ${ }^{33}$. Целями Санкт-Петербурга, по его мнению, было сохранение европейского мира и поддержка «балканского союза». И если в своем стремлении сохранить континентальный мир отечественная дипломатия преуспела, то отстоять интересы балканских союзников перед великими державами не смогла. В итоге созданный с таким трудом балканский союз «был разрушен в самом основании», а в регионе началась новая фаза русско-австрийского соперничества ${ }^{34}$. Милюков горько сожалел о расколе между недавними союзниками и неудаче русского мирного посредничества. Винил он в этом прежде всего «военную партию», имевшую большое влияние в правительствах балканских государств ${ }^{35}$.

Между тем деятельность Милюкова в рамках межпарламентского Союза мира и его активная антивоенная позиция, сникали ему репутацию миротворца не только в России, но и за ее пределами. В 1913 г. его пригласили в составе международной комиссии участвовать в расследовании военных преступлений, совершенных в период балканских войн ${ }^{36}$. По словам Милюкова, увиденные зверства отрезвляюще повлияли на его увлечение абстрактным миротворчеством. «Вера в высшие идеалы, - писал он, - казалась слепой; гладкая терминология пацифизма - добровольным заблуждением неведения; жар проповеди - профессиональным лицемерием». Вместе с тем Милюков продолжал верить в идеалы антивоенного движения и надеяться на мирное разрешение международных противоречий вплоть до лета 1914 г. ${ }^{37}$

\footnotetext{
32 Милюков Балканский кризис... 1910: 56.

${ }^{33}$ Милюков 1913: 10-12.

${ }^{34}$ Милюков 1914: 1.

35 Там же: 8-9.

${ }^{36}$ М.М. Ковалевский в своих воспоминаниях утверждал, что именно он порекомендовал Милюкова вместо себя членом в «Международную комиссию по расследованию причин и ведения Балканских войн» (т.н. «комиссию Карнеги»). Причиной тому стал содержательный доклад, прочитанный лидером кадетов на заседании Петербургского отделения общества мира на тему нарушения принципов международного права в период балканских войн (Ковалевский 2005: 416).

${ }^{37}$ Милюков 1991: 364-365.
} 
Еще более важным событием, повлиявшим на миротворческую позицию Милюкова, стала I Мировая война. С момента августовской катастрофы многие либеральные публицисты стали оперировать понятиями, которые были призваны подчеркнуть справедливость или даже необходимость участия России в данном конфликте ${ }^{38}$. Вчерашние «пасифисты», еще в начале 1914 года призывавшие остановить безумную гонку вооружений и пресечь милитаристские устремления европейских правительств, с первых месяцев войны наперебой бросились доказывать необходимость обуздания агрессивных поползновений Центральных держав. В этом потоке «священного единения» позиция Милюкова не выглядела исключением, хотя необходимо признать, что до вооруженной фазы конфликта он призывал к его «локализации» и скептически относился к «моральным обязанностям России по отношению к славянству» ${ }^{39}$. Однако с началом войны Милюков занял совершенно четкую позицию, отстаивая ее национальный и оборонительный для России характер. Свою задачу он видел в том, чтобы объяснить «навязанную нам войну, ее происхождение, ее достижимые последствия» ${ }^{40}$. По его мнению, вся полнота вины за развязывание конфликта лежала на Германии. Национальное высокомерие, жажда мирового господства, авантюрная внешняя политика Вильгельма II, милитаризация немецкой культуры все эти факторы в совокупности «толкали» Берлин к развязыванию мировой войны ${ }^{41}$. Но более всего Милюков негодовал относительно нарушения бельгийского нейтралитета, в котором усматривал вопиющее нарушение основ международного права и пример неразборчивости в выборе средств германской дипломатией ${ }^{42}$.

Возмущенный агрессией Центральных держав он признавал допустимым реализацию «vae victis» в отношении вражеских территорий. Одновременно Милюков с негодованием писал о планах немецких шовинистов построить «Великую Германию», которые подразумевали, в том числе, и расчленение Российской империи ${ }^{43}$. В 1915 г. он выступил с масштабной программой национально-государственного переустройства Европы, обосновывая необходимость будущих территориальных приобретений для России ${ }^{44}$. Так, присоединение Восточной Галиции представлялось ему лишь завершением собирательной политики московских князей, т.е. «объединением русских народностей в их этнографических границах». Интересы «прочного мира», заявлял Милюков, требовали воссоздания объединенной Польши в ее этнических пределах,

\footnotetext{
38 Шелохаев 1993: 29.

${ }^{39}$ Милюков 1991: 385.

40 Там же: 392.

${ }^{41}$ Милюков Происхождение войны... 1915: 1-17.

42 Милюков Дипломатическая история... 1915: 106-121.

${ }^{43}$ Милюков Происхождение войны... 1915: 9.

44 По словам В.В. Шелохаева в этой статье Милюкова территориальные претензии российской либеральной буржуазии были изложены «в наиболее концентрированном виде» (Шелохаев 1993: 29).
} 
под «скипетром русского царя» ${ }^{45}$. По его мнению, отчуждение польских земель из состава Австро-Венгрии и Германии стало бы «делом справедливости и делом политического благоразумия». Учитывая автономный статус будущей Польши, Милюков не без лукавства заявлял, что исправления границ в ее пользу «не должны, конечно, считаться непосредственными приобретениями России». Еще более решительно Милюков определял послевоенную судьбу Турцию. Интересы российской государственности требовали передачи ей Босфора, Дарданелл и Константинополя с прилегающей территорией. В Закавказье предлагалось возвратиться к границам, установленным Сан-Стефанским договором 1878 г. Помимо этого следовало отогнуть Турецкую Армению, образовав на этой территории автономное государство, под контролем Османской империи или России. При этом Милюков рассматривал реализацию своих геополитических прожектов как необходимое условие установления прочного европейского мира, укрощения гегемонистских устремлений Германии, прекращения гонки вооружений и обеспечения национально-государственного развития малых народов ${ }^{46}$.

Более детально планы послевоенного территориального разграничения стран Центрального блока, с картами, таблицами, подробным анализом различных мнений, он представил в ежегоднике газеты «Речь» на 1916 г. Милюков призывал отказаться от шовинистических крайностей, например, возвращение раздробленного состояния Германии, видя в реализации подобных проектов источник «новых осложнений». Тем не менее, согласно его «программе», Германия лишалась ЭльзасЛотарингии, части территорий на Рейне (Саaр) и своих колоний ${ }^{47}$. Он безоговорочно приветствовал состоявшиеся между союзниками договоренности 1915 г. относительно будущего присоединения к России проливов и Константинополя ${ }^{48}$. Турецкий суверенитет над автономной, населенной армянами провинцией полностью исключался и устанавливался за Россией. Собственно турецкую государственность следовало ограничить Западной Анатолией, а ближневосточные владения Оттоманской империи передавались союзникам ${ }^{49}$. Судьбу Австро-Венгрии Милюков рассматривал через призму освобождения малых народов. Предполагалось слияние Сербии с Хорватией-Славонией и образование Югославии. Создавалось Чехословацкое государство, связанное специальным «соединительным коридором» с Югославией, который не только отрезал Венгрию от Австрии, но и «давал бы выход славянским това-

\footnotetext{
${ }^{45}$ Милюков Территориальные приобретения... 1915: 53-60.

46 Там же: 61-66.

${ }^{47}$ Милюков 1916 (б): 109-128.

${ }^{48}$ Милюков и в дальнейшем развивал идеи о необходимости отторжения от Турции черноморских проливов, за что получил от политических оппонентов язвительное прозвище «Милюков-Дарданелльский». (Милюков «Нейтрализация» ... 1915; Милюков Константинополь... № 1, 2, 4-6. 1917).

${ }^{49}$ Милюков 1916 (б): 38-56.
} 
рам к Адриатике». Польша восстанавливалась в своих этнических границах. Италии передавались Южный Тироль, Триест, Истрия, Далмация и учитывались ее интересы при разделе Турции ${ }^{50}$.

Начало войны изобиловало случаями нарушения международного права. Пока Россия, по мнению Милюкова, энергично способствовала кодификации гуманитарного права, Германия «стояла в стороне от этой практики и от этого развития международных идей». Немецкие войска постоянно нарушали гаагские конвенции, совершая грабежи, насилия, убийства мирных жителей, подвергая бомбардировке незащищенные города, расстреливая без суда и следствия партизан и военнопленных, разрушая памятники искусства и архитектуры ${ }^{51}$. В то же время Милюков не разделял пессимизма многих современников, утверждавших, что война «поставила крест на развитии международного права». Напротив, из данного кризиса «право войны» должно выйти более «усовершенствованным и усиленным». Прежние его нормы не предусматривали возможность стремительного военно-технического прогресса, миллионных армий, высокой степени государственного вмешательства в процесс организации обороны и пр. В результате действовавшие нормы гуманитарного права не могли использоваться в полной мере, так как не соответствовали существовавшей военно-политической ситуации ${ }^{52}$.

Главным итогом войны Милюков видел установление «прочного $u$ длительного (курсив мой - Н.Н.) мира». Этому могло помочь усовершенствование и развитие международного права в двух направлениях. Во-первых, следовало расширить компетенцию третейского международного суда «на самые важные спорные случаи... из-за которых происходят войны между народами». Во-вторых, необходимо создать силы международного принуждения, которые контролировали бы выполнения принятых судом решений. В результате международное право получило бы обязательную силу, что гарантировало бы прекращение конфликтов и установление мира ${ }^{53}$. Создание «мировой правовой общественной жизни» мыслилось Милюковым в качестве высшей политической задачи, однако ее достижение было невозможно без решения ближайших целей войны. К ним он относил восстановление Бельгии, Сербии, Черногории с «надлежащими для них компенсациями», освобождение захваченных территорий Франции, России, Румынии «со справедливым вознаграждением», изгнание Турции из Европы «как решительно чуждой западной цивилизации», освобождение итальянцев, славян, румын, чехо-словаков от австрийского владычества ${ }^{54}$.

\footnotetext{
50 Там же: $56-108$.

${ }^{51}$ Милюков 1916 (а): 131-135. По мнению Милюкова, во всех случаях нарушения международного гуманитарного права была повинна исключительно Германия.

52 Там же: $129-130$.

${ }^{53}$ Милюков. Почему и зачем... 1917: 39-41.

${ }^{54}$ Там же: 41-44.
} 
Эти призывы Милюкова продолжать войну до победного конца ради будущих территориальных приобретений и его жесткая критика сторонников заключения сепаратного мира, контрастировали с идеями, изложенными им в работе «Вооруженный мир и ограничение вооружений». Однако сам Милюков считал занятую им позицию глубоко патриотической и отвечающей задачам стратегического развития Российского государства ${ }^{55}$. Он критиковал ту часть пацифистски настроенной общественности, что, приемля войну, стремилась оправдать российское в ней участие возвышенными и благородными помыслами. В попытках примирить голос совести с оправданием массового убийства, ему виделся пример идейного лицемерия, выродившегося в популярные вскоре лозунги: «война против войны», «война без победителей», «война без аннексий и контрибуций» и пр. ${ }^{56}$ Еще более категорично Милюков отзывался о социалистическом интернационализме, чья антивоенная пропаганда разлагала армию и общество. При непосредственной помощи Германии и посредничестве швейцарских социалистов «циммервальдская и кинтальская зараза» широко распространилась среди общественных и политических кругов России, и главной задачей армии и правительства было переломить эти псевдомиролюбивые настроения ${ }^{57}$.

Возглавив министерство иностранных дел во Временном правительстве Г.Е. Львова, Милюков еще более активно требовал продолжения войны, клеймя пораженчество и взывая к союзническому долгу. «Пока на фронте царит проповедь непротивления, - писал он весной 1917 г., - усердно подогреваемая теоретиками пораженчества, и пока в то же время “главный приз всей войны” (т.е. Босфор и Дарданеллы H.H.), по выражению наших союзников, признается неценным и ненужным для нации, - мы не в состоянии ни делать усилий в пользу других, ни требовать, чтобы другие совершали эти усилия в нашу пользу... Вместо того, чтобы рассуждать, отдаляет ли приобретение проливов конец войны, нужно воевать и добиваться общей с союзниками победы» ${ }^{58}$.

В качестве заключения попробуем оценить характер и масштабы идейной метаморфозы П.Н. Милюкова в вопросах войны и мира. Для начала укажем, что обвинения Милюкова в лицемерии и тем более беспринципности нам кажутся безосновательными. Его взгляды на проблемы войны и мира в начале 1910-х гг. претерпели сложную и последовательную (хотя и довольно быструю) эволюцию, связанную прежде всего с изменением международной обстановки.

Важными событиями, повлиявшими на миротворческие убеждения Милюкова, стали балканские войны и Мировая война. Однако здесь он

\footnotetext{
55 Нельзя не отметить, что оба сына Милюкова в годы Первой мировой войны находились на фронте, а младший - Сергей погиб в 1915 г. в кровопролитных сражениях за австрийскую Галицию (Милюков 1991: 398-399).

56 Там же: 392-393.

${ }^{57}$ Милюков Россия... 1917: 3-40.

${ }^{58}$ Милюков Константинополь... № 4-6: 547.
} 
не был исключением. Дилемма выбора между патриотизмом и пацифизмом в августе 1914 г. возникла перед многими искренними противниками войны. Просто в случае с Милюковым контраст между идеями, высказанными в работе «Вооруженный мир и ограничение вооружений», и позицией занятой им с начала мирового конфликта особенно заметен. Вместе с тем следует помнить, что его «прагматичный пацифизм» был всегда далек от полного отрицания войны. Милюков признавал неискоренимость вооруженных конфликтов, но полагал, что развитие политической культуры, правосознания и общей образованности постепенно уменьшали вероятность насильственного разрешения межгосударственных споров. Еще одним важным условием, способствовавшим повсеместному росту миролюбия, он считал рост интернационального общения, который, в конечном счете, должен был воплотиться в учреждение «правовой международной организации цивилизованных наций». При этом Милюков не отрицал оборонительные войны, и даже в отдельных случаях конфликты с целью достижения насущных государственных задач. Разумеется, подобные рода столкновения должны были быть санкционированы обществом и в полной мере отвечать национальным интересам. Тем не менее, незадолго до начала Первой мировой войны Милюков разочаровался даже в такой, достаточно умеренной форме миротворчества, по причине несоответствия политической ситуации ценностям «абстрактного пацифизма». Потому неудивительно, что Милюков в 1914 г. занял позицию, заметно отличавшуюся от его прежних антивоенных призывов. Разразившийся конфликт он рассматривал как оборонительный и требовал от соотечественников участия в войне «до победного конца». По ее окончанию, следовало удовлетворить территориальные притязания России и стран Антанты, что наряду с созданием развитой международно-правовой системы способствовало бы установлению общего мира и предотвращению будущих межгосударственных столкновений.

\section{БИБЛИОГРАФИЯ / REFERENCES}

Воронкова И.Е. «Вооруженный мир» и идеи пацифизма начала XX века во внешнеполитической доктрине конституционных демократов // Гуманитарные науки в начале третьего тысячелетия. Монография. СПб.: ИНФО-ДА, 2007. С. 8-23. [Voronkova I.Е. «Vooruzhennyj mir» i idei pacifizma nachala XX veka vo vneshnepoliticheskoj doktrine konstitucionnyh demokratov // Gumanitarnye nauki v nachale tret'ego tysyacheletiya. Monografiya. SPb.: INFO-DA, 2007. S. 8-23.].

Думова Н.Г. Кадетская партия в период первой мировой войны и Февральской революции. М.: Наука, 1988. 244 с. [Dumova N.G. Kadetskaya partiya v period pervoj mirovoj vojny i Fevral'skoj revolyucii. M.: Nauka, 1988. 244 s.].

Дякин В.С. Русская буржуазия и царизм в годы первой мировой войны (1914-1917). М.: Наука, 1967. 372 c. [Dyakin V.S. Russkaya burzhuaziya i carizm v gody pervoj mirovoj vojny (1914-1917). M.: Nauka, 1967. 372 s.].

Ефремов И.Н. Русская группа Междупарламентского Союза // Вестник мира (Le Massager de la Paix). Орган международного права и культуры. 1913. № 2. С. 1-6. [Efremov I.N. Russkaya gruppa Mezhduparlamentskogo Soyuza // Vestnik mira (Le Massager de la Paix). Organ mezhdunarodnogo prava i kul'tury. 1913. № 2. S. 1-6.]. 
Илюхина Р.М. Российский пацифизм вчера и сегодня. М.: ИВИ РАН, 1992. 106 с. [Ilyuhina R.M. Rossijskij pacifizm vchera i segodnya. M.: IVI RAN, 1992. 106 s.].

Илюхина P.M., Сдвижков С.Д. Российский пацифизм и западное миротворчество в начале XX в. (Становление и деятельность российских обществ мира) // Долгий путь российского пацифизма: Идеал международного и внутреннего мира в религиознофилософской и общественно- политической мысли России. М.: ИВИ РАН, 1997. С. 179-201. [Ilyuhina R.M., Sdvizhkov S.D. Rossijskij pacifizm i zapadnoe mirotvorchestvo v nachale XX v. (Stanovlenie i deyatel'nost' rossijskih obshchestv mira) // Dolgij put' rossijskogo pacifizma: Ideal mezhdunarodnogo i vnutrennego mira v religiozno-filosofskoj i obshchestvenno- politicheskoj mysli Rossii. M.: IVI RAN, 1997. S. 179-201.].

Ковалевский М.M. Моя жизнь: Воспоминания. М.: «Российская политическая энциклопедия» (РОССПЭН), 2005. 784 с. [Kovalevskij M.M. Moya zhizn': Vospominaniya. M.: «Rossijskaya politicheskaya enciklopediya» (ROSSPEN), 2005. 784 s.].

Лакеева А.Р. Норман Эйнджелл и развитие пацифистского движения в Великобритании (1900-1930-е годы): автореф. дис. ... канд. ист. наук. Томск, 2006. 27 с. [Lakeeva A.R. Norman Ejndzhell i razvitie pacifistskogo dvizheniya v Velikobritanii (1900-1930-e gody): avtoref. dis. ... kand. ist. nauk. Tomsk, 2006. 27 s.].

Милюков П.Н. Балканский кризис и политика А. П. Извольского. СПб.: Тип. тов. «Общественная польза», 1910. 404 с. [Milyukov P.N. Balkanskij krizis i politika A. P. Izvol'skogo. SPb.: Tip. tov. «Obshchestvennaya pol'za», 1910. 404 s.].

Милюков П.Н. Внешняя политика России // Ежегодник газеты «Речь» на 1913 год. СПб.: Изд. Редакции газеты «Речь», 1913. C. 1-17 [Milyukov P.N. Vneshnyaya politika Rossii // Ezhegodnik gazety «Rech'» na 1913 god. SPb.: Izd. Redakcii gazety «Rech'», 1913. S. 1-17].

Милюков П.Н. Внешняя политика России // Ежегодник газеты «Речь» на 1914 год. СПб.: Изд. Редакции газеты «Речь», 1914. C. 1-20 [Milyukov P.N. Vneshnyaya politika Rossii // Ezhegodnik gazety «Rech'» na 1914 g. SPb.: Izd. Redakcii gazety «Rech'», 1914. S. 1-20].

Милюков П.Н. Война и международное право // Ежегодник газеты «Речь» на 1916 год. СПб.: Тип. Петрогр. Т-ва печ. и изд. дела «Труд», 1916 (a). C. 129-196. [Milyukov P.N. Vojna i mezhdunarodnoe pravo // Ezhegodnik gazety «Rech'» na 1916 god. SPb.: Tip. Petrogr. T-va pech. i izd. dela «Trud», 1916 (a). S. 129-196.].

Милюков П.Н. Вооруженный мир и ограничение вооружений. СПб.: Тип. Б. М. Вольфа, 1911. 178 c. [Milyukov P.N. Vooruzhennyj mir i ogranichenie vooruzhenij. SPb.: Tip. B. M. Vol'fa, 1911. 178 s.].

Милюков П.Н. «Вооруженный мир и ограничение вооружений» // Вестник мира (Le Massager de la Paix). Орган международного права и культуры. 1912. № 1. С. 29-30. [Milyukov P.N. «Vooruzhennyj mir i ogranichenie vooruzhenij» // Vestnik mira (Le Massager de la Paix). Organ mezhdunarodnogo prava i kul'tury. 1912. № 1. S. 29-30.].

Милюков П.Н. Воспоминания. М.: Политиздат, 1991. 528 с. [Milyukov P.N. Vospominaniya. M.: Politizdat, 1991. 528 s.].

Милюков П.Н. В поисках всеобщего мира // Речь. 1910. № 203 (1441). 27 июля (9 августа). [Milyukov P.N. V poiskah vseobshchego mira // Rech'. 1910. № 203 (1441). 27 iyulya (9 avgusta).].

Милюков П.Н. Дипломатическая история войны // Ежегодник газеты «Речь» на 1915 год. СПб.: Изд. Редакции газеты «Речь», 1915. C. 43-121. [Milyukov P.N. Diplomaticheskaya istoriya vojny // Ezhegodnik gazety «Rech'» na 1915 god. SPb.: Izd. Redakcii gazety «Rech'», 1915. S. 43-121.].

Милюков П.Н. Константинополь и проливы // Вестник Европы. 1917. № 1. С. 354-381. [Milyukov P.N. Konstantinopol' i prolivy // Vestnik Evropy. 1917. № 1. S. 354-381.].

Милюков П.Н. Константинополь и проливы // Вестник Европы. 1917. № 2. С. 227-259. [Milyukov P.N. Konstantinopol' i prolivy // Vestnik Evropy. 1917. № 2. S. 227-259.].

Милюков П.Н. Константинополь и проливы // Вестник Европы. 1917. № 4-6. С. 525-547. [Milyukov P.N. Konstantinopol' i prolivy // Vestnik Evropy. 1917. № 4-6. S. 525-547.].

Милюков П.Н. «Нейтрализация» Дарданелл и Босфора // Вопросы мировой войны: Сборник комитета по устройству этапного лазарета имени Высших учебных заведений Петрограда / Под ред. Проф. М.И. Туган-Барановского. Пг.: Право, 1915. С. 532 548. [Milyukov P.N. «Nejtralizaciya» Dardanell i Bosfora // Voprosy mirovoj vojny: Sbornik komiteta po ustrojstvu etapnogo lazareta imeni Vysshih uchebnyh zavedenij Petrograda / Pod red. Prof. M.I. Tugan-Baranovskogo. Pg.: Pravo, 1915. S. 532-548.]. 
Милюков П.Н. Почему и зачем мы воюем? (война, ее происхождение, цели и последствия). Пг.: Скоропечатня «Свобода», 1917. 59 с. [Milyukov P.N. Pochemu i zachem my voyuem? (vojna, ee proiskhozhdenie, celi i posledstviya). Pg.: Skoropechatnya «Svoboda», 1917. $59 \mathrm{~s}$.].

Милюков П.Н. Россия в плену у Циммервальда. Две речи П. Н. Милюкова. Пг.: Скоропечатня «Свобода», 1917. 44 c. [Milyukov P.N. Rossiya v plenu u Cimmerval'da. Dve rechi P. N. Milyukova. Pg.: Skoropechatnya «Svoboda», 1917. 44 s.].

Милюков П.Н. Цели войны // Ежегодник газеты «Речь» на 1916 год. СПб.: Тип. Петрогр. Т-ва печ. и изд. дела «Труд», 1916 (б). С. 29-128. [Milyukov P.N. Celi vojny // Ezhegodnik gazety «Rech'» na 1916 god. SPb.: Tip. Petrogr. T-va pech. i izd. dela «Trud», 1916 (b). S. 29-128.].

Нигметзянов Т.И. Отечественная интеллигенция и пацифизм в России (конец XIX-XX вв.) // Интеллигенция и мир. 2003. № 1. С. 76-85. [Nigmetzyanov T.I. Otechestvennaya intelligenciya i pacifizm v Rossii (konec XIX-XX v.) // Intelligenciya i mir. 2003. № 1. S. 76-85].

Николаев Н.Ю. Миротворческие взгляды М.М. Ковалевского в начале ХХ века // Вестник Волгоградского государственного университета. Сер. 4, История. Регионоведение. Международные отношения. 2014. № 3. С. 6-15. [Nikolaev N.Yu. Mirotvorcheskie vzglyady M.M. Kovalevskogo v nachale XX veka // Vestnik Volgogradskogo gosudarstvennogo universiteta. Ser. 4, Istoriya. Regionovedenie. Mezhdunarodnye otnosheniya. 2014. № 3. S. 6-15.].

Новиков Д.Е. П.Н. Милюков о внешней политике России (1906-1914) // П.Н. Милюков: историк, политик, дипломат. Материалы международной научной конференции. М.: «Российская политическая энциклопедия» (РОССПЭН), 2000. С. 318-333. [Novikov D.E. P.N. Milyukov o vneshnej politike Rossii (1906-1914) // P.N. Milyukov: istorik, politik, diplomat. Materialy mezhdunarodnoj nauchnoj konferencii. M.: «Rossijskaya politicheskaya enciklopediya» (ROSSPEN), 2000. S. 318-333.].

Сдвижков Д.А. Против «железа и крови». Пацифизм в Германской империи. М.: ИВИ PAH, 1999. 333 c. [Sdvizhkov D.A. Protiv «zheleza i krovi». Pacifizm v Germanskoj imperii. M.: IVI RAN, 1999. 333 s.].

Шелохаев В.В. Российские либералы в годы первой мировой войны // Вопросы истории. 1993. № 8. C. 27-39. [Shelohaev V.V. Rossijskie liberaly v gody pervoj mirovoj vojny // Voprosy istorii. 1993. № 8. S. 27-39.].

Энджель Н. Великое заблуждение. Этюд о взаимоотношениях военной мощи наций к их экономическому и социальному прогрессу. М.: Тип. А.П. Поплавского, 1912. 320 с. [Endzhel' N. Velikoe zabluzhdenie. Etyud o vzaimootnosheniyah voennoj moshchi nacij k ih ekonomicheskomu i social'nomu progressu. M.: Tip. A. P. Poplavskogo, 1912. 320 s.].

Angell N. The Great Illusion: A Study of the Relation of Military Power in Nations to their Economic and Social Advantage. New York: G.P. Putnam's \& Sons, 1910. 335 p.

Bloch I.S. The Future of War in Its Technical, Economic, and Political Relations: Is War Now Impossible? New York: Doubleday \& McClure C ${ }^{\circ} ., 1899.380$ p.

Николаев Николай Юрьевич, кандидат исторических наук, дочент, кафедра сочиально-гуманитарных дисциилин, Волжский политехнический институт; nikcam@mail.ru

\section{"The disappointed pacifist": Problems of war and peace in P.N. Milyukov's journalism at the beginning of the XX century}

The article examines the views of P.N. Milyukov on the problems of war and peace in the 1910s. His attitude to armed conflicts, pacifist movement, militarism, disarmament, and prospects for achieving universal (eternal) peace is Revealed. The reasons and nature of Milyukov's worldview evolution and his rejection of previous anti-war beliefs are determined. The socio-political position taken by Milyukov during the First World war is considered separately.

Key words: war, peace, militarism, pacifism, pacificism, militarism, international humanitarian law, first world war.

Nikolai Y. Nikolaev, PhD in History, Associate Professor, Volzhsky Polytechnic Institute (Branch) of Volgograd State Technical University; nikcam@mail.ru 


\section{РАЗОЧАРОВАНИЕ В «РУССКОМ АМЕРИКАНЦЕ» ПРЕССА США 1917-1918 гГ. О ПОЛИТИЧЕСКОЙ ДЕЯТЕЛЬНОСТИ П.Н.МИЛЮКОВА}

Статья содержит анализ представлений американской прессы 1917-1918 гг. о политической деятельности известного российского либерального политика П.Н. Милюкова, который после Февральской революции получил почетное прозвище «русского американца». В ходе исследования выясняется, каким образом из любимого персонажа политических репортажей лидер кадетов превращается в персону нон-грата.

Ключевые слова: пресса США, П.Н. Милюков, политическая деятельность

Еще в дофевральский период имя П.Н. Милюкова часто появлялось на страницах американских газет, в первую очередь - в связи с его энергичной деятельностью в качестве одного из лидеров российской думской оппозиции. Мощный поток информации о событиях в России и о роли в ней лидера Прогрессивного блока приходит в США в марте 1917 г. Причем, если поначалу американские СМИ, по инерции, рекламируют оппозиционную активность Милюкова еще до свержения самодержавия, то в последующие недели и месяцы они довольно подробно освещают его дела на посту министра Временного правительства.

Один из ярких примеров - издававшаяся в штате Монтана газета «The Butte Daily Post»: 22 марта 1917 г. ${ }^{*}$ на ее страницах появляется заметка Милтона Броннера «Новые лидеры России, которые помогли народу сбросить ярмо царя», с портретами Г.Е. Львова, П.Н. Милюкова и М.В. Родзянко. Под портретом лидера кадетов поместили надпись: «Герой российской демократии, который боролся против тирании в России в течение десятилетия». Первая часть статьи содержала краткие журналистские заметки о «лидерах революции» (Г.Е. Львове, М.В. Родзянко, А.И. Гучкове, А.И. Шингареве, М.И. Терещенко, А.Ф. Керенском и др.), в т.ч.: «Проф. Павел Милюков, наряду с Львовым, является одним из величайших людей России. Он лидер конституционных демократов и специально подходит для поста министра иностранных дел, так как он не только глубокий исследователь международной политики, но и побывал во всех великих демократиях и изучал их на практике» ${ }^{1}$.

Однако этим высказыванием американский журналист не ограничился и во второй части статьи дал развернутую характеристику Милюкова как «Немезиды царя» (раздел так и называется): «В качестве лидера Прогрессивного блока Думы он создавал царю бесконечные проблемы и настойчиво отстаивал народные интересы вопреки противодействию императора. Царь закрывал сессии Думы каждый раз, когда Милюков был близок к победе в борьбе за конституционную реформу и особенно

\footnotetext{
* Все даты приводятся по григорианскому календарю.

${ }^{1}$ The Butte Daily Post. Butte (Montana). 1917, March 22: 5.
} 
за справедливое отношение к евреям в России. Когда Дума возобновляла свою работу, Милюков вновь возвращался к требованиям реформ. Бесстрашная прямота Милюкова, с которой он сообщал миру об угнетенности своего народа при царском режиме, неоднократно ставила под угрозу его жизнь». В следующем разделе статьи повествуется о примеpax фантастической самоотверженности лидера российских кадетов. $\mathrm{B}$ частности, еще на заре XX века он «поведал американской аудитории о тысячах ссыльных, ежегодно направляемых в Сибирь, и по возвращении в Россию был арестован и приговорен за критику правительства к отбыванию наказания на сибирских шахтах». «Он бежал в Соединенные Штаты». Позднее вернулся и получил должность редактора петроградской газеты «Речь». «Публикации в этой газете стали для него причиной неоднократных тюремных заключений, но он продолжил свою деятельность до тех пор, пока правительство не стало его бояться». «Благодаря огромному доверию петроградского населения Милюков был избран в Думу, где быстро стал руководителем Прогрессивной группы. С начала войны он выражал страстное желание народа с полной силой вести войну против Германии, однако встретил оппозицию со стороны царя и его монархистской группы» ${ }^{2}$.

Такая же смесь достоверной информации и причудливого вымысла появляется на страницах газеты «Evening capital news» (штат Айдахо). 23 марта 1917 г. на первой странице была опубликована статья с портретом П.Н. Милюкова под заголовком «Российский герой дня назван “американцем”, так как его методы имеют американский оттенок (Russia's Man of the Hour Called "The American" Because Methods Appear to Have a Yankee Tinge)». Перечисляя статусные достижения нового российского главы МИДа: известный историк, редактор, основатель и лидер Прогрессивного блока, кадетской партии, «решительный борец за прогресс в России», «высоко ценится в странах-союзницах и, вероятно, понимает международные дела и отношения России с ее союзниками лучше, чем почти кто-либо другой», - газета выделяет то, что должно было в наибольшей степени импонировать американской публике: «То обстоятельство, что Милюков возглавил революцию, придало ей настоящий американский оттенок, поскольку он проникнут многими американскими идеями и идеалами, которые изучил и усвоил во время своего лекционного тура по Америке в 1907 г. Его приверженность американским институтам была так ярко выражена, что по возвращении в Россию реакционеры в Думе освистали его как “американца”» ${ }^{3}$.

Газета проговорилась и об истинной цели участия «честного патриота» в круизе думской делегации по странам Северной и Западной Европы в апреле-июне 1916 г. ${ }^{4}$ По сведениям издания, «еще в мае про-

\footnotetext{
${ }^{2}$ Ibidem.

${ }^{3}$ Evening capital news. Boise (Idaho). 1917, March 23: 1. При этом он тут же, ничтоже сумняшеся, назван «честным патриотом».

${ }^{4}$ Подробнее об этом эпизоде см.: Милюков 1991; Алексеева 1990; Кустов 2010.
} 
шлого года Милюков попытался выяснить отношение британского и французского правительствам к революции в России. В Лондоне и Париже эту идею встретили холодно. Он вернулся домой убежденный, что час революции еще не настал. Тем не менее, он продолжал свои выступления в Думе против врагов русской демократии». Отметив, что Милюков «несет ответственность за смещение прогерманского премьера Штюрмера, которого он осудил в своей знаменитой речи в Думе», газета закончила биографическую презентацию «героя дня» еще одним горячим «фактом»: «В январе [1917 г.] Берлин, которому каким-то образом удалось сохранить тесную связь с Петроградом, разослал сообщение о том, что демократический лидер Думы вынужден был бежать из столицы. Предполагалось, что это связано с политическим переворотом, последовавшим за убийством Распутина. “Темные силы” стремились смутить Милюкова, распространяя от его имени прокламации, подстрекающие фабричных и других рабочих к публичным демонстрациям» ${ }^{5}$.

К началу мая события в революционной России создали вокруг имени Милюкова тревожный контекст, который с озабоченностью был воспринят в странах-союзницах, не исключая США. 5 мая 1917 г. министр иностранных дел России дал эксклюзивное интервью корреспонденту агентства «Юнайтед Пресс» Уильяму Шеферду (William G. Shepherd). Американский журналист увидел в Павле Николаевиче «человека, который в течение двух предыдущих дней держал в своих руках судьбу новой России, встретив упрямую оппозицию и восторжествовав над внезапным бунтом рабочих и солдат» ${ }^{6}$. Интервьюер, разумеется, был особенно заинтересован в милюковских оценках международной ситуации. Раскрывая суть договора между Россией и союзными странами, Павел Николаевич подчеркнул, что упомянутые договоренности «включают в себя планы по созданию новых национальных границ, корректировке карты Европы на основе [интересов] национальностей и рас и закладыванию фундамента для длительного мира». По мнению министра, лишь тот факт, что указанный пакт был одобрен новым правительством без консультации с депутатами рабочих и солдат, стал причиной затруднений, случившихся в последние два дня. Милюков не стал раскрывать детали соглашения, заключенного еще при царе, поскольку они являются «не только царскими секретами и не могут быть опубликованы без согласия всех союзных держав». Он выразил убеждение, что массовые выступления в столице были вызваны германским влиянием: «за антиправительственными демонстрациями стояли темные силы», поскольку первая и вторая ноты Временного правительства не противоречили друг другу. Американский корреспондент отметил, что Милюков принял его

\footnotetext{
${ }^{5}$ Evening capital news. 1917, March 23: 1.

${ }^{6}$ Evening Capital News. 1917, May 6: 1. - Над интервью были помещены следующие заголовки: «Situation now well in hand; Russians will keep up fight to the finish». «Foreign Minister Sends Message of Cheer to the American People and Declares Battle for Democracy Will Be Won ». «Pact with Allies Not Czar’s Making».
} 
после ночи, в течение которой слова российского министра иностранных дел, «вероятно, изменили все направление войны, предотвратив внутренние разногласия, которые могли бы привести Россию к отдалению от союзников в критический час мировой истории». Милюков во время встречи был «по-прежнему силен, энергичен и решителен» ${ }^{7}$.

Возвращаясь к теме межсоюзнических договоренностей, американец спросил русского политика, считает ли тот их «недемократичными и порочными» ${ }^{8}$. Милюков дипломатично ответил, что договоренности были разработаны Великобританией, Францией и другими союзниками, царь лишь принял их. «Если бы они были собственностью свергнутого царя и только его тайной, я мог бы обнародовать их. Но они принадлежат нашим союзникам, и я не могу опубликовать их без согласия союзников”, - подчеркнул он. Министр не обращался за соответствующим разрешением к союзникам, поскольку «в этом не было необходимости», ведь указанные договоренности совпадают со всеми демократическими планами всех демократических народов Земли по созданию национальных границ и корректировке карты Европы на основе национальностей и рас, закладывая тем самым прочный фундамент прочного мира». Российский политик передал личное послание Североамериканским Штатам: «Вы можете сказать американскому народу, что ситуация в России под контролем. Мы особенно рады тому, что президент Вильсон, заявив, что не может быть мира без борьбы, поддержал наше решение о том, что подлинный мир может быть достигнут только путем борьбы» 9.

Однако другие сообщения из революционной России не подтвердили этого оптимистического утверждения. Одна из газет сообщала, что 3-4 мая 1917 г. возмущенные рабочие и солдаты прошли «маршем» по улицам Петрограда, а затем собрались у резиденции Временного правительства с требованием отставки Милюкова. Недовольство было вызвано убеждением масс в том, что «министр не вполне симпатизирует взглядам рабочих и солдат». В свою очередь, Исполком Петроградского совета рабочих и солдатских депутатов решил, что следует принять меры, однако «нет никаких причин требовать отставки Временного правительства». По сведениям издания, социал-демократический печатный орган «Новая жизнь» и другие «крайне левые» газеты резко критикуют адресованную союзникам ноту Милюкова, подтверждающую решимость России энергично продолжать войну против Германии ${ }^{10}$.

Другая газета опубликовала суть речи, которую Милюков произнес 4 мая 1917 г. перед митингующими рабоче-солдатскими массами у резиденции МИДа. Он решительно отказался «предавать союзников» и удалять Россию из «списка союзных держав». «“Даже если большинство россиян предпочитают такой курс, - заявил он, - правительство не

\footnotetext{
${ }^{7}$ Evening Capital News. 1917, May 6: 1.

${ }^{8}$ Ibidem.

${ }^{9}$ Ibid: 2.

${ }^{10}$ The Commonwealth. Greenwood (Missouri). 1917, May 9: 7.
} 
может принять эту точку зрения. Мы будем отстаивать свою позицию таким образом, чтобы ни у кого не было оснований обвинять Россию в измене. Россия никогда не согласится на сепаратный мир, если Временное правительство или я могу это предотвратить". Он также заявил, что правительство не изменит своей позиции, как это было сделано в его первомайской ноте, адресованной рабочим и солдатам» ${ }^{11}$.

Прошло еще несколько дней, и в США узнали, что Милюков оставил кресло министра иностранных дел, не получив во Временном правительстве никакого другого поста. Решение политика уйти в отставку было озвучено на правительственном заседании 15 мая 1917 г., причиной стало якобы «различие во взглядах на реорганизацию кабинета» ${ }^{12}$. Показательно, что официальный Вашингтон не выразил особого сожаления по поводу отставки «русского американца». Как гласила специальная заметка, «реорганизация российского кабинета была расценена там, с одной стороны, как расширение власти радикалов, и, с другой стороны, как [перспектива достижения] большей степени единства. Все полагают, что приход во власть радикальной партии более желателен, чем ситуация, когда власть разделена между радикалами и умеренными, причем обе [силы] практически не имеют полномочий действовать» ${ }^{13}$. Администрация США расценила отставку Милюкова как «цену, которую потребовали радикалы за их активное сотрудничество с правительством»: «Милюков навлек на себя большую вражду, когда, не посоветовавшись с радикалами, поручился, что Россия не заключит сепаратного мира. Он также был непопулярен в некоторых кругах за его энергичное требование передачи Константинополя России, что противоречило антианнексионистским декларациям. Отставка министра Милюкова значительно более опасна, чем политические подвижки власти, поскольку могут быть затронуты сама дисциплина и боевой дух армии» ${ }^{14}$.

Рассуждая о перемещениях в первом составе Временного правительства, газета «Hickory Daily Record» (Северная Каролина) указала на позитивный, с американской точки зрения, факт: «Милюков уходит, а Львов остается. Если бы оба последовали за Гучковым, это показалось бы зловещим, но Львов считается одним из сильнейших людей в России, и, хотя об отставке Милюкова будут сожалеть в странах Антанты, это могло бы быть необходимым». Издание напомнило, что Милюков был «активным лидером мартовского переворота», но «как представитель “буржуазной” партии, как презрительно называли либералов социалисты, он быстро навлек на себя враждебность и подозрения, в частности, объявлением военных целей свободной России. Другой член правительства, Керенский, который теперь занимает место военного министра

\footnotetext{
${ }^{11}$ The Alaska Citizen. Fairbanks (Alaska). 1917, May 7: 1.

${ }^{12}$ El Nuevo Mexicano. Santa Fe (New Mexico). 1917, May 17: 5; The Omaha Daily Bee. Omaha (Nebraska). 1917, May 17: 2.

${ }_{13}^{13}$ El Nuevo Mexicano. 1917, May 17: 5.

${ }^{14}$ El Nuevo Mexicano. 1917, May 17: 5; The Omaha Daily Bee. 1917, May 17: 2.
} 
Гучкова, тотчас же выступил со своим заявлением, что Россия не воюет за Галицию и Константинополь, как утверждал Милюков. Возобладала точка зрения Керенского, и поскольку Милюков едва ли мог забрать свои слова обратно, его отставка представляется необходимой, хотя можно надеяться, что, когда будет сформировано постоянное правительство, можно будет найти место для человека, ценного своими знаниями и способностями, а также своим влиянием на группу, которой якобинское правительство могло бы легко противостоять» ${ }^{15}$.

Еще два возвращения имени кадетского лидера и «одного из главных двигателей революции» ${ }^{16}$ на страницы американской прессы 1917 г. были связаны с корниловским мятежом и Октябрьской революцией. В первом случае отмечалось, что профессор Милюков предпринял «неудачную попытку предотвратить гражданскую войну»: «Сначала он по телефону предложил свои услуги в качестве посредника генералу Корнилову, а затем провел личную встречу с премьером Керенским, на которой присутствовал бывший главнокомандующий русской армией генерал Алексеев. Милюков рассказал, что несколько дней назад Корнилов пригласил его к себе в штаб, но Милюков отказался» ${ }^{17}$. Во втором случае в газетах промелькнуло сообщение, что профессор Милюков, наряду с генералом Л.Г. Корниловым, бывшим «гетманом» донских казаков А.М. Калединым и председателем Думы М.В. Родзянко, занимается «реформированием правительства в Москве» ${ }^{18}$.

Еще несколько полуфантастических фактов дошли до американских читателей весной и летом 1918 г. Так, по версии ряда газет, Германский МИД, заявив, что слухи о смене правительства в России «не звучат совсем уж неправдоподобно», поручил своему послу в нашей стране собрать информацию о происходящих с целью монархической реставрации беспорядках в Петрограде. В Берлине якобы уже получены сведения о том, что «лидеры российских конституционных демократов» - Милюков, Гучков и Родзянко, а также генерал Алексеев - находятся в Петрограде и оказывают содействие движению за реставрацию ${ }^{19}$. Прошло еще два месяца, и американская пресса проинформировала общественность о том, что лидер российских конституционных демократов Павел Милюков и лидер октябристов Александр Гучков прибыли в Харбин и «возглавили контрреволюционное движение» ${ }^{20}$.

\footnotetext{
${ }^{15}$ Hickory Daily Record. Hickory (North Carolina). 1917, May 19: 3.

${ }^{16}$ Evening Star. Washington (Washington D.C.). 1917, September 12: 7.

17 «Милюков сказал, что он предложил ему поехать в штаб-квартиру с полномочиями от правительства вести переговоры о мире между фракциями. Керенский, однако, заявил, что примирение невозможно и получил поддержку других членов правительства в своем требовании о безоговорочной капитуляции Корнилова» (ibid.).

${ }^{18}$ Evening Times - Republican. Marshalltown (Iowa). 1917, November 12: 1.

${ }^{19}$ The Ogden Standard. Ogden City (Utah). 1918, April 30: 1; The Topeka State Journal. Topeka (Kansas) 1918, April 30: 2.

20 Arizona Republican. Phoenix (Arizona). 1918, June 29: 2; The Daily Banner. Cambridge (Maryland). 1918, June 29: 4; The Omaha Daily Bee. 1918, June 29: 1.
} 
Однако с началом гражданской войны в России главным пунктом милюковской темы в американских СМИ стала радикальная внешнеполитическая переориентация лидера кадетов. В середине июля 1918 г. газеты процитировали слова Милюкова: он принадлежит к той части кадетской партии, которая стремится «ориентироваться на центральные державы», при этом приписываемую ему идею о создании формального протектората Германии над Россией профессор назвал недоразумени$\mathrm{eм}^{21}$. Через две недели в США, из французской газеты «Матен», стало известно, что бывший министр иностранных дел буржуазно-демократической России «подозревается в укреплении пронемецкой ориентации своей партии», в связи с чем ему предстоит дать разъяснения на следующем съезде Конституционно-демократической партии ${ }^{22}$. Прошло совсем немного времени, и американская пресса уже без тени сомнения объявила об измене своего недавнего любимца союзническому делу: профессор Павел Милюков «перешел на сторону немцев, заявив, что предпочел бы единую Россию под защитой Германии стране, распавшейся на множество правительств» ${ }^{23}$.

Заокеанские СМИ предложили и собственное, весьма любопытное, объяснение поразительной перемены политических предпочтений кадетского деятеля: оказывается, американский народ «терпит последствия» совершенной некогда грубой выходки президента Теодора Рузвельта. Якобы дело в том, что Милюков, который в свое время читал лекции в США и был связан с Чикагским университетом, «заехал в Вашингтон и попросил встречи с тогдашним президентом. Ему было сказано в сравнительно немногих словах - а-ля Рузвельт, конечно, - что его присутствие будет более желательным в его родной стране, чем здесь. [Подразумевалось,] что его присутствие там нежелательно никому, кроме нескольких революционеров-вспышкопускателей (lightning-bug revolutionists). Это был страшный упрек для Павла, ибо он был известен не как нигилист, а как консервативный, хорошо образованный русский, не имеющий ничего общего с радикальными тенденциями». Согласно автору этой истории, Милюков так и не смог простить «рузвельтовскую оплеуху» (Rooseveltian slam) и ждал случая, чтобы поквитаться со страной, в которой с ним так обошлись, поэтому он и основал «прогуннскую» (pro-Hun) партию, цель которой «тесно сотрудничать с немцами и создавать как можно больше проблем для Америки и ее союзников» ${ }^{24}$.

Осенью того же года Милюков вернулся в лоно антантофильства. В середине декабря 1918 г. из Константинополя пришло известие, что прибывший туда Милюков, наряду с другими российскими политиками,

${ }^{21}$ Evening Star. 1918, July 13: 4.

${ }^{22}$ Grand Forks Herald. Grand Forks (North Dakota). 1918, July 26: 1.

23 The Middletown Transcript. Middletown (Delaware). 1918, July 27: 2; Iron County News. Hurley (Wisconsin). 1918, July 27: 3; The Pickens Sentinel. Pickens (South Carolina). 1918, August 1: 7.

${ }^{24}$ The Washington Herald. 1918, September 27: 6. 
намерен отправиться в Париж, чтобы призвать страны Антанты к интервенции в Россию. «Единственное возможное лекарство от нынешней проблемы заключается в том, чтобы союзные силы немедленно высадились на юге [России], - сказал он. - Соединенные Штаты, вероятно, в состоянии оказать наибольшую помощь» 25 .

Однако, когда он прибыл в Париж с целью «заинтересовать страны Антанты в восстановлении порядка в России», его без промедления выдворили из страны ${ }^{26}$. В прессе подчеркивалось, что «его присутствие здесь посчитали излишним»: паспорт, полученный им в Константинополе, «был выдан по ошибке», сам же Милюков подозревался «в чрезмерных прогерманских наклонностях, и предполагалось, что его присутствие в Париже было организовано с дурной целью» ${ }^{27}$.

Отдельные голоса в американских СМИ в защиту «русского американца» прозвучали довольно робко ${ }^{28}$, для большинства же заокеанских служителей «четвертой власти» Милюков, хотя и «был активен против большевиков», но - в первую очередь и преимущественно! «обвинялся в германофильских наклонностях» 29 .

Павел Николаевич Милюков еще в царский период фактически стал агентом влияния стран «Сердечного согласия», консультируясь с правящими кругами Британии и Франции по вопросам «решительного штурма» на правящий в его стране режим. (Впрочем, одновременно с этим он вызывал беспокойство западных демократий постоянным педалированием темы «проливов».) После Февраля «честный патриот» оказал солидные дружеские услуги правительствам Антанты и администрации США на посту главы российского МИДа, не побоявшись вступить в прямой конфликт с пацифистски настроенными народными массами. После Октября профессор получил всемирную известность как принципиальный и энергичный борец с большевиками. Однако все былые заслуги либерального политика были перечеркнуты его неожиданной, хотя и краткосрочной, изменой общему «союзническому» делу. «Русский американец», любимый персонаж политических репортажей, в либерально ориентированном общественном мнении стремительно превратился в политического отщепенца и изгоя.

\footnotetext{
25 The Pensacola Journal. Pensacola (Florida). 1918, December 17: 2.

26 The Pensacola Journal. 1918, December 23: 1.

27 The Commonwealth. Scotland Neck (N.C.). 1918, Dec. 24: 1; Evening Star. 1918, Dec. 25: 6. См. также: The Watchman and Southron. Sumter (South Carolina). 1918, Dec. 28: 6; Little Falls Herald. Little Falls, Morrison County (Minnesota). 1919, Jan. 3: 8.

${ }^{28}$ Сообщение из Парижа о срочной высылке российского политика «вызывает удивление, так как Милюков до сих пор считался принципиальным антибольшевиком. Несколько раз его имя было связано с сообщениями о движении против радикального правительства в Москве. Но полного понимания сложностей русского лабиринта нет. Возможно, парижские власти решили не рисковать. Высылка предполагает, что русский вопрос может быть осложнен обстоятельствами, которые в настоящее время не полностью понятны общественности» (Evening Star. 1918, December 25: 6).

${ }^{29}$ Little Falls Herald. 1919, January 3: 8.
} 


\section{БИБЛИОГРАФИЯ / REFERENCES}

Алексеева И.В. Агония Сердечного Согласия: Царизм, буржуазия и их союзники по Антанте. 1914-1917. Л.: Лениздат, 1990. С. 172-194. 「Alekseyeva I.V. Agoniya Serdechnogo Soglasiya: Tsarizm, burzhuaziya i ikh soyuzniki po Antante. 1914-1917. L.: Lenizdat, 1990. S. 172-194].

Кустов В.А. Думская дипломатия: визит русской парламентской делегации в страны Антанты (апрель-июнь 1916) // Вестник Саратовского государственного социальноэкономического университета. № 4 (33). 2010. C. 129-133. [Kustov V.A. Dumskaya diplomatiya: vizit russkoi parlamentskoj delegatsii v strany Antanty (aprel' - iyun' 1916) // Vestnik Saratovskogo gosudarstvennogo sotsial'no-ekonomicheskogo universiteta. № 4 (33). 2010. S. 129-133].

Милюков П.Н. Воспоминания. М.: Политиздат, 1991. С. 418-433. [Milyukov P.N. Vospominaniya. M.: Politizdat, 1991. S. 418-433].

Arizona Republican. Phoenix (Arizona.). 1918, June 29. P. 2;

El Nuevo Mexicano. Santa Fe (New Mexico). 1917, May 17. P. 5.

Evening Capital News. Boise (Idaho). 1917, March 23. P. 1; 1917, May 6. P. 1-2.

Evening Star. Washington (Washington D.C.). 1917, September 12. P. 7; 1918, July 13. P. 4; 1918, December 25. P. 6.

Evening Times - Republican. Marshalltown (Iowa). 1917, November 12. P. 1.

Grand Forks Herald. Grand Forks (North Dakota). 1918, July 26. P. 1.

Hickory Daily Record. Hickory (North Carolina). 1917, May 19. P. 3.

Iron County News. Hurley (Wisconsin). 1918, July 27. P. 3;

Little Falls Herald. Little Falls, Morrison County (Minnesota). 1919, January 3. P. 8.

The Alaska Citizen. Fairbanks (Alaska). 1917, May 7. P. 1.

The Butte Daily Post. Butte (Montana). 1917, March 22. P. 5.

The Commonwealth. Greenwood (Mississippi). 1917, May 9. P. 7.

The Commonwealth. Scotland Neck (North Carolina). 1918, December 24. P. 1.

The Daily Banner. Cambridge (Maryland). 1918, June 29. P. 4;

The Middletown Transcript. Middletown (Delaware). 1918, July 27. P. 2;

The Ogden Standard. Ogden City (Utah). 1918, April 30. P. 1;

The Omaha Daily Bee. Omaha (Nebraska). 1917, May 17. P. 2; 1918, June 29. P. 1.

The Pensacola Journal. Pensacola (Florida). 1918, December 17. P. 2; 1918, December 23. P. 1.

The Pickens Sentinel. Pickens (South Carolina). 1918, August 1. P. 7.

The Topeka State Journal. Topeka (Kansas) 1918, April 30. P. 2.

The Washington Herald. 1918, September 27. P. 6.

The Watchman and Southron. Sumter (South Carolina). 1918, December 28. P. 6.

Сапон Владимир Петрович, д.и.н., профессор, кафедра истории России и вспомогательных исторических дисииплин, Нижегородский государственный педагогический университет им. Козьмы Минина

\section{Disappointment in the "Russian American": the US press of 1917-1918 on political activities of P.N. Milukoff}

The article contains an analysis of the views of the US press in 1917-1918 on the political activities of the famous Russian liberal politician P.N. Milukoff, who after the February Revolution got the honorary nickname of "Russian American". The research reveals in what way the Cadet leader turned from a favorite character of political reporting into a persona non-grata.

Keywords: US mass media, P.N. Milukoff, political activities, 1917-1918.

Sapon Vladimir, Doctor of History, Professor, Department of Russian History and Auxiliary Historical Disciplines, Kozma Minin's Nizhniy Novgorod State Pedagogical University 


\section{А.Ю. СуСЛОВ \\ ПАМЯТИ ИСТОРИКА И ПЕДАГОГА \\ ВЛАДИМИР ПЕТРОВИЧ САПОН (1969-2020)}

Статья посвящена памяти профессора Нижегородского государственного педагогического университета им. Козьмы Минина В.П. Сапона. Рассматривается биография и основные труды ученого, его вклад в развитие исторической науки.

Ключевые слова: В.П. Сапон, история России, револючия, либертарное движение, анархизм, А. Корелин, Нижегородский край

16 апреля 2020 г. ушел из жизни замечательный историк и человек, педагог, популяризатор науки - профессор кафедры Истории России и вспомогательных исторических дисциплин Нижегородского государственного педагогического университета им. Козьмы Минина, доктор исторических наук Владимир Петрович Сапон.

Владимир Петрович родился 8 марта 1969 г. в поселке Каинда Калининского района Киргизской ССР. В 1986 г. с серебряной медалью окончил среднюю школу № 27 г. Павлодара (Казахская ССР). В 19871989 гг. проходил срочную службу в войсках Гражданской обороны. В 1990-1991 гг. работал учителем, затем сторожем, бетонщиком, каменщиком, плотником, преподавателем техникума. В 1991 г. поступил на исторический факультет Алтайского госуниверситета (г. Барнаул), а в 1992 г. перевелся в Нижегородский госуниверситет имени Н.И. Лобачевского (ННГУ), который закончил в 1997 г.

Научные интересы В.П. Сапона были связаны с историей Российской революции, революционной мысли, изучением либертаристских аспектов теории и практики российских леворадикальных партий и организаций, антиглобалистским (альтерглобалистским) движением конца XX - начала XXI в. Своим учителем В.П.Сапон считал доктора исторических наук, заслуженного профессора ННГУ Григория Васильевича Набатова. Под его руководством 29 января 2002 г. в диссертационном совете ННГУ он защитил кандидатскую диссертацию на тему «Антиэтатизм в российской леворадикальной идеологии (1840-е - 1917 г.)».

В апреле 2002 г. В.П. Сапон был принят на работу ассистентом кафедры истории политических партий и общественных движений ННГУ. С марта 2003 г. - старший преподаватель, с июня 2005 г. - доцент той же кафедры. Читал лекционные курсы «История политических партий и общественных движений России», «Современные партии России», «Политическая риторика, «Либертаризм в российской леворадикальной идеологии». В 2009 г. защитил в Чувашском государственном университете докторскую диссертацию «Концепция революционного освобождения общества в теоретических воззрениях и политической практике российских левых радикалов: конец XIX в. - 1918 г.». Затем В.П. Сапон работал в ННГУ, одно время заведовал кафедрой истории России. 
Научное наследие В.П. Сапона довольно обширно. В своих книгах, и многочисленных статьях, опубликованных в ведущих российских и зарубежных журналах он реконструировал и анализировал либертарные проекты ведущих отечественных леворадикальных течений (анархистов, левых неонародников и большевиков), рассматривал попытки реализации этих проектов, давал свое объяснение исторического успеха авторитарно-централистской традиции в российском обществе ${ }^{1}$. Сапон определял либертарианство как «теоретические разработки и социальнополитические практики, направленные на освобождение личности и коллектива от всех видов социального гнета и эксплуатации». По его мнению, во второй половине XIX в. в рамках радикально-революционного направления российской политической мысли формируется идейный комплекс либертарного социализма, ключевыми целями которого являются ликвидация политического угнетения путем распределения общественной власти в широких слоях трудящихся, а также устранение экономической эксплуатации за счет передачи контроля над производством и распределением в руки производителей.

Сапон рассматривал промежуток времени между февралем 1917 г. и осенью 1918 г. как «Великую русскую либертарианскую революцию». Эта перспектива позволяет увидеть непрерывность, а не разрывы между Февралем и Октябрем. Сапон подчеркивал, что следует все-таки говорить о единстве революционного процесса в России в 1917-1918 гг., о единстве его стратегической либертарной направленности. Либертарный характер Великой российской революции заключался в том, что различные социальные, политические, экономические, национальные силы стремились к достижению оптимальных условий жизнедеятельности, которые предоставляют высокую степень индивидуальной и коллективной свободы, при этом представления о свободе в разных клетках и органах общественного организма имели весьма своеобразные черты. И только после того как самодержавный политический режим был ликвидирован, после того как уже на ранней стадии социального переворота закладываются основы для созидания нового, свободного общества, в России начинается напряженная конкуренция между сторонниками разных либертарных проектов. При этом соперничество за право направлять революционные преобразования разворачивается не только между социальными «низами», приверженными традиционным ценностям мирского общежития, и «верхами», радеющими за последовательный прогресс и всеобщую эмансипацию, но и между различными идейными направлениями в «верхах», борющимися за преобладающее влияние в массах и - в конечном итоге - за политическую гегемонию в обществе 2 .

Касаясь событий 6 июля 1918 г. - выступления партии левых эсеров, Сапон приходил к выводу, что ленинское правительство опасалось не столько возобновления военных действий с войсками Германской

${ }^{1}$ Сапон 2005; 2008-2; 2008-3.

${ }^{2}$ Сапон 2008-2: 235-236. 
империи, которая, как вскоре выяснилось, находилась на пороге своего краха и была уже не способна к полномасштабным активным действиям на фронтах мировой войны, сколько дальнейшего укрепления политического статуса левых эсеров в случае их непосредственного обращения к крестьянским массам, демонстрировавшим явное недовольство внешней и особенно внутренней политикой правящей «пролетарской» партии. Поскольку они представляли собой реальную угрозу политической «гегемонии» большевиков, одним из политических приоритетов которых являлось сохранение собственной власти - именно по этой причине Ленин и его соратники воспользовались «акцией 6 июля 1918 года».

По мнению В.П. Сапона, основной пафос трагедии левых неонародников заключался в том, что они оказались жертвой «цивилизационной ловушки»: будучи проводниками идеалов аграрной («сельской», «крестьянской») цивилизации, они стремились во всех сферах жизни российского общества внедрять начала децентрализации и федерации, которые в условиях войны не были столь эффективны, как централизация и авторитаризм, на которые опиралась индустриальная («городская», «пролетарская») цивилизация, и на которые с начала 1918 г. сделала основную ставку руководящая группа правящей партии большевиков. Сапон подчеркивал, что в случае установления экономической, а вслед за ней и политической гегемонии «селянства», пусть даже поначалу возглавляемого левыми неонародниками, вполне вероятным был бы сценарий деиндустриализации страны, архаизации экономических и социальных отношений и последующей автономизации крестьянских общин без оглядки на какие-либо партийные схемы. К осени 1918 г. вопрос стоял уже не о продолжении либертарных преобразований, а о создании авторитарного механизма управления и распределения ресурсов в условиях гражданской войны. Наиболее подготовленной к этой роли оказалась партия большевиков, в которой авторитаристская традиция имела более глубокие корни, чем в других леворадикальных партиях.

Значительное внимание в творчестве В.П. Сапона уделено биографическим сюжетам, в частности, изучению жизни и деятельности Аполлона Андреевича Карелина (1863-1926), «легендарной» и «таинственной» фигуры российской истории, публициста, революционера, идеолога и теоретика анархистского движения. А.А. Карелину Сапон посвятил ряд публикаций, в т.ч. две монографии (вторая, в расширенной версии вышла в свет на английском языке в США) 3 . Перу Сапона принадлежат статьи о П.А. Кропоткине, М.А. Бакунине, А.И. Герцене, А.А. Богданове, А.Ф. Лосеве, М.И. Воронкове и др.

Другим направлением научной деятельности В.П. Сапона было исследование общественно-политической истории Нижегородского края, попытка создания обобщенной картины развития многопартийности в регионе накануне, а также в период Первой мировой войны, завершившейся Февральской революцией 1917 г. Исследователь отмечал, что

\footnotetext{
${ }^{3}$ Сапон 2009; Sapon 2015 (см. рец: Кадиков 2017).
} 
в последние годы имперского периода в Нижегородской губернии существовала и развивалась самочинная «партийная система», в которой наиболее динамичными и активными оказались элементы внесистемной оппозиции. Либеральные и особенно социалистические партийные организации не имели возможность участия в политических процессах, в силу чего их цели и задачи носили вполне выраженный деструктивный характер в отношении существующих институтов власти. В.П. Сапон проявил себя и как публикатор документов ${ }^{4}$, и как кропотливый исследователь, стремящийся дать полноценную научную картину общественно-политической жизни края в переломный период истории ${ }^{5}$.

В январе-феврале 2020 г. мы общались с Владимиром по поводу подготовленного им сборника документов и материалов «Сормовские меньшевики в 1917-1918 гг.». Я согласился быть рецензентом этого сборника, куда вошли документы и материалы, раскрывающие историю общественно-политической деятельности социал-демократов меньшевиков на Сормовском заводе в период с весны 1917 г. до лета 1918 г. Документы и материалы, большая часть которых публикуется впервые, дают представление о том, как сормовские меньшевики из небольшой группы в марте 1917 г., пройдя через сотрудничество с большевиками и активную работу в органах местной власти, в послеоктябрьский период превратились в оппозиционную организацию, которая успешно конкурировала с правящей партией в борьбе за влияние на рабочих, но в конечном итоге потерпела поражение. Хочется надеяться, что эта публикация - последний крупный проект В.П. Сапона - увидит свет.

\section{БИБЛИОГРАФИЯ / REFERENCES}

Идейно-политическая оппозиция в Нижегородском крае в период Гражданской войны и НЭПа: учебно-методическое пособие / авт.-сост. В.П. Сапон, ред.колл. А.П. Арефьев, О.А. Колобов, Г.В. Набатов, В.А. Харламов. Ниж. Новгород: Изд-во НГУ, 2006. 97 с. [Idejno-politicheskaya oppoziciya v Nizhegorodskom krae v period Grazhdanskoj vojny i NEPa: uchebno-metodicheskoe posobie / avt.-sost. V.P. Sapon, red.koll. A.P. Arefev, O.A. Kolobov, G.V. Nabatov, V.A. Harlamov. Nizh. Novgorod: Izd-vo NGU, 2006. 97 s.].

Кадиков Э.Р. Рецензия на монографию В.П. Сапона «Либертарный социалист Аполлон Карелин». Рец.: Sapon V. Libertarian Socialist Apollon Karelin. Raleigh, North Carolina, USA: Lulu Press, 2015. 214 p. // Историческая экспертиза. 2017. № 1. С. 186-194. [Kadikov E.R. Recenziya na monografiyu V.P. Sapona «Libertarnyj socialist Apollon Karelin». Rec.: Sapon V. Libertarian Socialist Apollon Karelin. Raleigh, North Carolina, USA: Lulu Press, 2015. 214 p. // Istoricheskaya ekspertiza. 2017. № 1. S. 186-194].

«Мы очень просим не посылать к нам больше политиков таких...». Перевыборы Сормовского Совета: Весна 1918 г. / публ. подгот. В. П. Сапон // Исторический архив. 2019. № 3. C. 28-36. [«My ochen' prosim ne posylat' k nam bol'she politikov takih...». Perevybory Sormovskogo Soveta: Vesna 1918 g. / publ. podgot. V. P. Sapon // Istoricheskij arhiv. 2019. № 3. S. 28-36].

Сапон 2014 - Нижегородская губерния в годы первой мировой войны (дофевральский период): сборник документов и материалов / ГТ.Л. Грачева и др.; науч. ред. и сост.: В.П. Сапон]; Ун-т Российской акад. образования, Нижегородский фил. Нижний Новгород: [б. и.], 2014. 407 с. [Nizhegorodskaya guberniya v gody pervoj mirovoj vojny (dofevral'skij period): sbornik dokumentov i materialov / [T.L. Gracheva i dr.; nauch. red. i

\footnotetext{
${ }^{4}$ Сапон 2006; Сапон 2014; Сапон 2019.

${ }^{5}$ Сапон 2014-2; Сапон 20167; Сапон 2017.
} 
sost.: V P. Sapon]; Un-t Rossijskoj akad. obrazovaniya, Nizhegorodskij fil. Nizhnij Novgorod, 2014. $407 \mathrm{~s}$.].

Сапон В.П. Аполлон Андреевич Карелин: Очерк жизни. Нижний Новгород: Изд. А.Ю. Николаев, 2009. 120 с. [Sapon V.P. Apollon Andreevich Karelin: Ocherk zhizni. Nizhnij Novgorod: Izd. A.YU. Nikolaev, 2009. 120 s.].

Сапон В.П. Лики либертаризма // Свободная мысль. 2010. № 2 (1609). С. 167-172. [Sapon V.P. Liki libertarizma // Svobodnaya mysl'. 2010. № 2 (1609). S. 167-172].

Сапон В.П. Нижегородская губерния в 1916-1917 гг.: от «феврализма» к большевизму: монография. Отделение Российского исторического общества в Нижнем Новгороде. Нижний Новгород: [б. и.], 2017. 310 c. [Sapon V.P. Nizhegorodskaya guberniya v 19161917 gg.: ot «fevralizma» k bol'shevizmu: monografiya. Otdelenie Rossijskogo istoricheskogo obshchestva v Nizhnem Novgorode. Nizhnij Novgorod, 2017. 310 s.].

Сапон 2014-2 - Сапон В.П. Опыт развития многопартийности в Нижегородской губернии в годы Первой мировой войны (дофевральский период): монография. Нижний Новгород: УРАО, 2014. 135 с. [Sapon V.P. Opyt razvitiya mnogopartijnosti v Nizhegorodskoj gubernii v gody Pervoj mirovoj vojny (dofevral'skij period): monografiya. Nizhnij Novgorod: URAO, 2014. 135 s.].

Сапон В.П. Руководство Нижегородской губернии в 1917-1918 гг.: национальное, общественное, личное // Российская история. 2016. № 3. С. 139-149. [Sapon V.P. Rukovodstvo Nizhegorodskoj gubernii v 1917-1918 gg.: nacional'noe, obshchestvennoe, lichnoe // Rossijskaya istoriya. 2016. № 3. S. 139-149].

Сапон В.П. Терновый венец свободы. Либертаризм в теории и революционной практике российских левых радикалов (1917 - 1918 гг.): монография. Нижний Новгород: Издво Нижегород.ун-та, 2008. 332 c. [Sapon V.P. Ternovyj venec svobody. Libertarizm v teorii i revolyucionnoj praktike rossijskih levyh radikalov (1917 - 1918 gg.): monografiya. Nizhnij Novgorod: Izd-vo Nizhegorod.un-ta, 2008. 332 s.].

Сапон 2008-2 - Сапон В.П. Философия пробудившегося человека. Либертаризм в российской леворадикальной идеологии (1840-е - 1917 гг.): монография. Н. Новгород: Изд-во ННГУ, 2005. 334 с. [Sapon V.P. Filosofiya probudivshegosya cheloveka. Libertarizm v rossijskoj levoradikal'noj ideologii (1840-e - 1917 gg.): monografiya. N. Novgorod: Izd-vo NNGU, 2005. 334 s.].

Сапон 2008-3 - Сапон В. П. Русский либертарий А. А. Карелин // Отечественная история. 2008. № 2. C. 160-169. [Sapon V. P. Russkij libertarij A. A. Karelin // Otechestvennaya istoriya. 2008. № 2. S. 160-169. Sapon V. P. Russkij libertarij A. A. Karelin // Otechestvennaya istoriya. 2008. № 2. S. 160-169]

Sapon V. Libertarian Socialist Apollon Karelin. Raleigh, North Carolina, USA: Lulu Press, 2015. $214 \mathrm{p}$.

Суслов Алексей Юрьевич: доктор исторических наук, профессор, Казанский национальный исследовательский технологический университет; plusha131333@yandex.ru

In memory of Vladimir Petrovich Sapon (1969-2020) - historian and teacher

The article is dedicated to the memory of the Nizhny Novgorod historian and teacher, Professor of the Kozma Minin state pedagogical University, doctor of historical Sciences Vladimir Petrovich Sapon. The author considers the biography of the scientist, his main works, and his contribution to the development of historical science.

Keywords: V.P. Sapon, history of Russia, revolution, libertarian movement, anarchism, A. Korelin, Nizhny Novgorod region

Aleksei Suslov, Dr.Sc. (History), Kazan national research technological University, Professor; plusha131333@yandex.ru 


\section{В.П. ОРЛОВ, Э.В. РУНГ \\ ТЕРМИН «АРИСТОКРАТИЯ» И ЕГО ПРИМЕНЕНИЕ
ДЛЯ ОБОЗНАЧЕНИЯ ЗНАТИ В АХЕМЕНИДСКОЙ ИМПЕРИИ*}

В статье рассматривается правомерность использования термина «аристократия» применительно к истории Древнего Востока в целом и Ахеменидской державы, в частности. Авторы статьи на ряде примеров демонстрируют, в каких контекстах встречался термин «аристократия» в трудах зарубежных и отечественных востоковедов и эллинистов, а в завершении дают краткую характеристику персидской аристократии, которая приводится ими с учетом как древнегреческого понимания этого феномена, и так и древнеперсидских реалий, на основании источников.

Ключевые слова: аристократия, знать, элита, греки, персы, Ахемениды

В поле зрения современных историков, занимающихся изучением социальной организации в государствах Древнего Востока, попадают проблемы как конкретно-исторического, так и теоретического плана. Среди них особого внимания заслуживает вопрос о применении терминов, описывающих явления одного периода для характеристики другого или используемых в условиях одного общественного строя для описания социальных реалий другого. В их числе - термин «аристократия»; он восходит своими истоками к Древней Греции, но сфера его применения уже давно вышла за пределы конкретного географического ареала и хронологического периода. Примечательно, что зарубежные историки конца XIX - середины XX в., изучавшие историю Ахеменидской державы, предлагали различные определения для обозначения персидской политической верхушки, однако термина «аристократия» среди них не было. Очевидно, это было связано с тем, что исследователи при обращении к древнеперсидской истории сознательно стремились дистанцироваться от термина, характеризующего социальные реалии в Элладе. Такая позиция, вероятно, была непосредственно связана с признанием греко-персидского противостояния в качестве основополагающего фактора в развитии как Ахеменидской империи, так и Древней Греции.

К примеру, Ю. Прашек в работе, посвященной истории мидийских и персидских племен до завоеваний Александра Македонского, использовал не термин «аристократия», а немецкое понятие adel, аналогом которого в русском языке является слово «знать»${ }^{1}$ Ф.Х. Вайсбах также применяет термин adel при переводе одного из спорных пассажей Бехистунской надписи (DB. I. 61-71) 2 . В книге В. Юдайха, посвященной гре-

\footnotetext{
* Работа выполнена при финансовой поддержке РНФ, проект № 20-18-00374 «Имперское Средиземноморье: модели, дискурсы и практики империализма от Античности до раннего Нового времени».

${ }^{1}$ Prášek 1910: 32.

${ }^{2}$ Weissbach 1911: 21 (при этом сам Вайсбах считает, что термин adel не подходит для перевода фрагмента и заменяет его термином народ - das Volk).
} 
ко-персидским отношениям в Малой Азии, термин «аристократия» ${ }^{3}$ тоже не встречается. П.М. Сайкс в книге «История Персии» описывает мидийцев и персов при помощи слова noble $e^{4}$, а также словосочетания the Persian grandees - «персидские вельможи» ${ }^{5}$. В труде «Персия» он использует словосочетание a Persian nobleman, описывая знатных персов как времен Ахеменидской империи ${ }^{6}$, так и Арабского халифата ${ }^{7}$. Кроме того, он употребляет уже знакомое нам словосочетание the Persian grandees $^{8}$, когда речь заходит о реалиях Сефевидского Ирана. Ни в одной из двух книг автора не встречается термин «аристократия», а, например, афинского реформатора Клисфена он называет членом благородной семьи Алкмеонидов ${ }^{9}$, но не аристократом. В работе А.Т. Джонса, посвященной древним империям, в т.ч. Ахеменидской и Римской, автор использует термин «аристократия» только в главах, посвященных истории Рима. Сообщая о персах времен Ахеменидской державы, он применяет словосочетание the Persian grandees $^{10}$, а также the noblest Persians $^{11}$ и the noblest families ${ }^{12}$, когда говорит о семье, из которой вышла царица Парисатида. В англоязычной книге Э. Герцфельда «Археологическая история Ирана» вовсе не встречаются обозначенные выше термины. Исследователь лишь однажды вводит выражение the men of high rank ${ }^{13}$, описывая армию Шапура I, изображенную на рельефе из Бишапура. В работе Дж. Кэмерона «Ранняя история Ирана» термин «аристократия» встречается трижды ${ }^{14}$, но ни разу по отношению к персам. Понятие nobles отмечено единожды в отношении эламитов. Строго говоря, исследователь вообще не применял к персам термины «знать», «вельможа» и «аристократия», с помощью которых можно было бы охарактеризовать степень их социального расслоения. Аналогичная ситуация наблюдается и в книге Э.Ф. Шмидта, посвященной археологическим изысканиям в Персеполе. Единожды автор употребляет словосочетание the persons of high rank, описывая барельеф в Персеполе ${ }^{15}$.

В фундаментальной книге А.Т. Олмстеда «История Персидской империи» термин grandees, который ранее нередко встречался у европейских исследователей, не используется, зато можно найти словосочетание feudal nobles ${ }^{16}$, которым он обозначает прослойку, недовольную

\footnotetext{
${ }^{3}$ Judeich 1892.

${ }^{4}$ Sykes 1915: 139, 157, 325.

${ }^{5}$ Ibid: 207.

${ }^{6}$ Sykes 1922: 8 .

${ }^{7}$ Ibid: 49 .

${ }^{8}$ Ibid.: 89.

${ }^{9}$ Ibid.: 199.

${ }^{10}$ Jones 1898: 165.

11 Ibid.: 88 .

12 Ibid.: 180.

${ }^{13}$ Herzfeld 1935: 84.

${ }^{14}$ Cameron 1936: 91, 139, 140.

15 Schmidt 1939: 30.

${ }^{16}$ Olmstead 1948: 93.
} 
реформами Бардии, а также feudal chiefs $^{17}$ для обозначения неких сил, выступивших против фараона Нектанеба, сотрудничавшего со спартанским царем Агесилаем в Египте. Помимо этого, автор использует термин «аристократия» для обозначения представителей греческой знати ${ }^{18}$, a также для описания индоиранских завоевателей Митанни ${ }^{19}$ и именитых родов из Месопотамии ${ }^{20}$. Персов Олмстед термином «аристократия» не описывает, а оперирует словосочетаниями the Persian nobles ${ }^{21}$ и the Aryan nobility 22 . Когда автор использует термин «аристократия» по отношению к представителям знати из городов Двуречья, он указывает на то, что они скрупулезно следили за составлением своей генеалогии. На наш взгляд, это один из важных показателей, который характеризует аристократию, как особую прослойку общества. Выражение a Persian nobleman также встречается в книге Р. Кента «Древнеперсидский язык: грамматика, тексты, лексика». Автор применяет это словосочетание для описания знатного перса Отана, который помог Дарию I организовать заговор против Гауматы. Других терминов для обозначения социального статуса представителей персидской властной верхушки в книге нет.

Исходя из сказанного, можно констатировать, что многие выдающиеся зарубежные иранисты и специалисты по истории Древнего Востока XIX - первой половины XX века не называли персидскую правящую верхушку аристократией. Однако во второй половине XX в. ситуация начинает кардинально меняться: термин «аристократия» уже постоянно используется ${ }^{23}$ по отношению к знати Ахеменидской империи, что может объясняться более активным обращением современных исследователей к материалу античных авторов (прежде всего, Геродота и Ксенофонта), которые в духе эллиноцентризма проводили явные параллели между древнегреческим обществом и древнеперсидским.

Уже в фундаментальной работе «Обзор персидского искусства от доисторических времен по настоящее время» можно найти словосочетания the Persian aristocracy и the Old Iranian aristocracy ${ }^{24}$. М. Рут же пишет, что Геродот по ошибке называет Аспатина персидским аристократом, хотя, по ее мнению, он был мидийцем ${ }^{25}$. В дальнейшем все больше исследователей используют выражение «персидские аристократы». Оно неоднократно встречается у таких специалистов как Р. Фрай, Дж. Балсер, К. Таплин, Й. Везихофер, П. Бриан, А. Курт ${ }^{26}$ и др. Таким

${ }^{17}$ Ibid.: 420.

${ }^{18}$ Ibid.: 302.

${ }^{19}$ Ibid.: 11.

${ }^{20}$ Ibid.: 74 .

${ }^{21}$ Ibid.: 497.

${ }^{22}$ Ibid.: 29.

${ }^{23}$ См. напр.: Fox 1973: 49; Hammond 1989: 238, 288.

${ }^{24}$ Pope, Ackerman, Besterman 1964: 65, 84.

${ }^{25}$ Root 1979: 282.

${ }^{26}$ Frye 1983: 97, 99, 134; Balcer 1984: 254; 1995: 125; Tuplin 1996: 138; Wiesehöfer 2001: 3, 37, 58, 106, 108; Briant 2002: 82, 103, 105, 352, 769; Kuhrt 2007: 312, 349, 421. 
образом, сегодня в исследовательской среде словосочетание «персидская аристократия» является вполне приемлемым и общеупотребимым. На наш взгляд, в первую очередь это связано с тем, что слово aristocracy зачастую может выступать синонимом понятий «знать» или «привилегированная часть общества» ${ }^{27}$. Сложно сказать, какое точно значение тот или иной зарубежный исследователь вкладывал в понятие «аристократия», применяя его к древним персам, однако можно отметить, что историки, несомненно, следовали древнегреческой традиции, хотя и употребляли этот термин просто в качестве синонима таких определений как elite, noble, nobility, royal, high-class, upper class и т.д.

В отечественной историография имеется собственная традиция употребления термина «аристократия». Для начала приведем несколько примеров его из работ дореволюционных историков. В «Истории Ассирии» 3.А. Рагозиной ${ }^{28}$ термин встречается как минимум дважды. В первом случае она рассуждала о генезисе филистимлян и полагала, что они могли произойти от неких «искателей приключений», захвативших семитские земли и образовавших там «военную аристократию» или «владетельное сословие». Во втором случае речь идет об арийских племенах, которые после завоевания некоторых народов образовали «надменную аристократию». Даже, исходя из этих двух примеров, можно с осторожностью констатировать, что в тексте Рагозиной термин «аристократия» имеет некоторую негативную коннотацию и описывает слой общества, образующийся после захватнической деятельности, а затем стремящийся изолироваться от покоренного населения.

Выдающийся антиковед М.И. Ростовцев в работе «Эллинство и иранство на юге России», Анализируя социальный строй Скифии, констатирует наличие в этом кочевом обществе «господствующего класса конной аристократии», причем, по его наблюдениям, представители скифской аристократии много тренировались и участвовали в боях, а также огромную роль в их жизни играла охота ${ }^{29}$. Ростовцев использует понятие «аристократия» в отношении сарматов и заключает, что аристократов отличало наличие лучшего вооружения и экипировки. Эти выводы историка относятся к эпохе эллинизма, однако нельзя отрицать колоссальное влияние Ахеменидской державы на развитие различных племенных образований, в том числе, скифов.

Итак, для 3.А. Рагозиной аристократы - надменные завоеватели, управляющие покоренными народами, а для М.И. Ростовцева - социальная прослойка в обществе, имеющая более высокий статус за счет особого образа жизни, обеспечивающего наилучшую боевую выучку ${ }^{30}$.

${ }^{27}$ Николаев 1995: 39.

${ }_{28}^{8}$ Рагозина 1902: 162, 397.

${ }^{29}$ Ростовцев 2002: 52.

${ }^{30}$ М.И. Ростовцев, описывая скифскую аристократию, использует термин «рыцарь». Этот же термин, а также понятие «аристократия» использует и В.В. Бартольд в одном из текстов о сасанидском и исламском Иране. См.: Бартольд 1971: 371-373. 
В работах же советских исследователей истории древних обществ термин «аристократия» применяется для описания различных исторических реалий. Уже А.А. Фрейман использует понятие «военная аристократия» для описания представителей политической верхушки Ахеменидской державы ${ }^{31}$. В труде Б.А. Тураева «История Древнего Востока» встречаются термины «военная касситская аристократия», «феодальная аристократия» (применительно к истории Древнего Египта) и «коренная местная аристократия» в рядах Яфетидов, которую исследователь обозначает как представителей божественного или благородного сословия $^{32}$. То есть, Б.А. Тураев включает в понятие «аристократия» военнополитическую, экономическую и религиозную составляющие.

Многократно термин «аристократия» используется В.И. Авдиевым в егоработах по истории Египта XVI-XV вв. до н.э. Исследователь выделяет понятия «номовая аристократия» и «рабовладельческая аристократия», в которую входят представители старой родовой знати, новой придворной и служилой знати, чиновники, жрецы и военные командиры $^{33}$. По его мнению, рабовладельческая аристократия выступала опорой царской власти, и фараон был вынужден раздать крупные земельные наделы отдельным влиятельным аристократам. Историк выделял наличие у аристократов титулов, например, «великий вождь», а также экономического могущества, позволяющего строить собственные города и вступать в конфликт с фараоном для защиты своих привилегий. По мнению Авдиева, усиление «номовой аристократии» приводило к смуте и даже распаду страны ${ }^{34}$. Таким образом, в его представлении египетская аристократия являлась слоем крупных землевладельцев, которые могли конкурировать между собой за сферы влияния, а иногда и выступать против центральной власти. Несмотря на это, «номовая аристократия» была опорой царской власти. В таком наборе функциональных особенностей между строк читается определенное противоречие, так как, с одной стороны, аристократия выступает опорой центральной власти, а с другой, стремится расширить свои привилегии и влияние на местах до уровня, позволяющего уверенно выступить против царской власти. Такое диалектическое понимание взаимодействия царя и аристократии достаточно часто встречается в работах советских исследователей. В учебнике по истории Древнего Востока под редакцией В.И. Авдиева термин «аристократия» встречается более 150 раз и фактически используется для описания властной прослойки общества, которая эксплуатировала рабов и зачастую могла передавать звания, титулы, и должности по наследству, а также активно боролась за политическое влияние с верховной властью в лице царя. Учебник применительно к истории Древнего Востока однозначно закреплял за термином «аристо-

\footnotetext{
31 Фрейман 1946: 378.

32 Тураев 1935: 68, 159, 192, 297.

33 Авдиев 1948: 45

${ }^{34}$ Авдиев 1939: 39.
} 
кратия» яркие негативные коннотации, которые ассоциировались с тотальной эксплуатацией населения, сепаратизмом и экономическим доминированием. В дальнейшем многие исследователи с осторожностью будут применять термин «аристократия» или вовсе откажутся от него.

К примеру, И.М. Дьяконов в работе «Развитие земельных отношений в Ассирии» совсем не использует термин «аристократия», а оперирует такими понятиями, как «родовая знать», «военная и служилая знать», а также «торгово-ростовщическая знать» 35 . Однако именно он одним из первых употребляет понятие «персидская аристократия» применительно к Киру Младшему, который, по его мнению, был достаточно прогрессивным политическим деятелем в Ахеменидской державе ${ }^{36}$. Анализируя социальный строй мидийского общества, исследователь использует понятие «аристократическая олигархия», которым он обозначает visspati («владыку viss'a») ${ }^{37}$ в условиях формирования классового общества и понятие «родовая аристократия», представляющая из себя прослойку рабовладельцев ${ }^{38}$. В схожем смысле термин «аристократия» зафиксирован у Н.М. Никольского, рассуждающего о существовании в Лагаше господствующего класса родовой аристократии, которая занималась наращиванием своих доходов за счет местного населения ${ }^{39}$. Аналогично историк использует термин «аристократия» при изучении истории Финикии ${ }^{40}$. Применительно к истории Ахеменидской державы термин «аристократия» упоминает и М.М. Дьяконов ${ }^{41}$, описывая с его помощью родовую и жреческую знать, против которой мог быть направлен антидэвовский поход Ксеркса I.

К концу 1950-х гг. в советской историографии термин «аристократия» постепенно выходит из употребления у ряда специалистов по истории Древнего Востока (за исключением исследователей истории Древнего Китая). Эта тенденция хорошо прослеживается и в работах, посвященных Ахеменидской державе. Так, в трудах М.А. Дандамаева термин «аристократия» ${ }^{42}$ полностью замещен понятиями «знать» и «вельможа». Аналогичная ситуация наблюдается в учебнике по истории Древнего Востока под редакцией В.И. Кузищина, первое издание которого вышло в 1979 г. В этой книге термин «аристократия» не раз применяется при описании разных государств и обществ Древнего Востока, однако абсолютно не встречается в главах, которые посвящены истории Ахеменидской державы и принадлежат перу М.А. Дандамаева. Это же утверждение справедливо и для трехтомного учебника истории Древнего мира

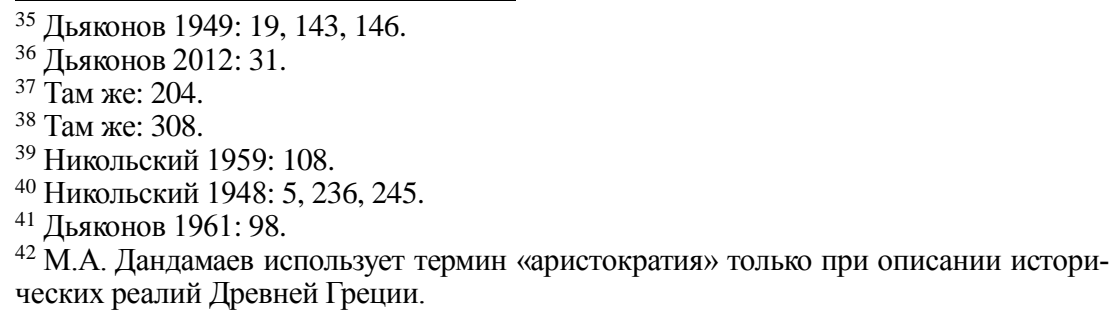


под редакцией И.М. Дьяконова, В.Д. Нероновой, И.С. Свенцицкой. Во всех трех книгах термин «аристократия» неоднократно используется, однако крайне редко употребляется по отношению к государствам, расположенным в Месопотамии ${ }^{43}$, и вовсе не встречается при описании персидской знати времен Ахеменидской державы. Исходя из вышесказанного, мы можем предположить, что в советской историографии под влиянием И.М. Дьяконова и М.А. Дандамаева, а возможно и всей ленинградской школы востоковедения сложилась крайне осторожная практика использования термина «аристократия» среди специалистов, обращающихся к истории Ахеменидской державы.

При этом в целом необычно, что Б.Г. Гафуров в преамбуле к сборнику «История Иранского государства и культуры. К 2500-летию Иранского государства» упоминает словосочетание «ахеменидская аристократия», которое наделяется резко негативной семантикой ${ }^{44}$. Гафуров неоднократно использует термин «аристократия» в изданной на излете существования СССР двухтомной работе «Таджики. Древнейшая, древняя и средневековая история» ${ }^{45}$, наделяя его вереницей отрицательных смыслов. Персидскую империю он описывает следующим образом: «Ахеменидское государство было ярко выраженным рабовладельческим военно-аристократическим государством, привилегированные и правящие слои которого состояли из персов и частично из мидян» ${ }^{46}$. Надо сказать, что на нынешнем этапе развития отечественной исторической науки наблюдается отход от выше обозначенной традиции. Показательным примером произошедших изменений является неоднократное использование словосочетания «персидская аристократия» в новейшем учебнике по истории Древнего Востока ${ }^{47}$.

Если в дореволюционных изданиях термин «аристократия» ещё не обладает ярко выраженной отрицательной семантикой, то в СССР ситуация меняется коренным образом. По мнению Э.Д. Фролова, в советское время термин «аристократия» приобретает явные негативные коннотации. Исследователь был справедливо убежден, что в число актуальных задач отечественной историографии входит преодоление стереотипов, которые утвердились из-за господства догматического марксизма, в том числе стереотипа, согласно которому аристократия играла сугубо негативную роль в историческом процессе ${ }^{48}$. Это влияние марксистской парадигмы сохранится на протяжении практически всего периода существования СССР. К примеру, в «Философском энциклопедическом словаре» отмечается, что аристократия как форма правления «основывается на идее о политической неполноценности большинства людей, которы-

\footnotetext{
${ }^{43}$ К примеру, В.А. Якобсон заявлял о несостоятельности понятия «касситская аристократия», которое употребляется в учебнике Б.А. Тураева. (Якобсон 1989: 203).

${ }^{44}$ Гафуров 1971: 6.

${ }^{45}$ Гафуров 1989: 71, 79, 118, 123, 124, 136.

46 Там же: 94.

47 Древний Восток 2008: 427, 429, 430.

48 Фролов 2007: 202.
} 
ми призвана править аристократическая элита» ${ }^{49}$. В конечном итоге в советское время термин «аристократия» продолжают активно применять антиковеды и специалисты по истории Древнего Китая ${ }^{50}$.

Обратимся к краткой характеристике эллинского понимания аристократии. Во-первых, это связано с тем, что сам термин «аристократия» - древнегреческого происхождения, а во-вторых, именно через призму восприятия античных авторов мы зачастую узнаем о том, какими качествами обладали носители высшей политической власти в Ахеменидской державе. Поэтому необходимо выделить ряд черт, присущих греческой аристократии, которые могли быть справедливо или же наоборот необоснованно экстраполированы античными авторами при описании представителей персидской властной верхушки. И.Е. Суриков, описывая афинскую аристократию архаического периода, фиксирует ряд факторов $^{51}$, на которых базировалась власть аристократов. Во-первых, исследователь выделяет экономическое доминирование, которое заключалось в наличие у аристократов крупных земельных владений; во-вторых, влияние на религиозную жизнь полиса посредством контроля над культовыми центрами; в-третьих, т.н. престиж аристократии (складывающийся из наличия возводимой к богам генеалогии, монополии на административные должности в полисе и на участие в панэллинских играх); в-четвертых, прерогативой аристократии являются ксении, помогавшие устанавливать дипломатические связи между полисами и варварскими государствами. Другими словами, аристократия представляет собой слой греческого общества, который стремится играть ведущую роль в экономической, религиозной, политической и культурной сферах жизни общества. Однако, несмотря на это, отмечает И.Е. Суриков, аристократия ни в коей мере не является некой закрытой кастой 52 . Э.Д. Фролов отмечает, что формированию аристократических качеств способствовало, «во-первых, наличие материально обеспеченного досуга, во-вторых, сохранение унаследованного от героической (гомеровской) эпохи состязательного принципа жизни и, в-третьих, укоренившееся с эпохи сложения у греков гражданских городских общин-полисов (т.е. с эпохи архаики, VIII-VI вв. до н. э.) представление об обязательности для активной части гражданства, к каковой знать относила себя, не только военной службы, но и политической деятельности и сопряженных с последней интеллектуальных занятий, таких как философия и риторика» ${ }^{53}$.

Несмотря на достаточно конкретную характеристику, данную выше, понятие «аристократия», на наш взгляд, все ещё смешивается с определениями «знать» и «элита». М. Блок, рассуждая о средневековой аристократии, выделяет два признака, которые отделяют искомую про-

\footnotetext{
49 ФЭС 1983: 33.

${ }^{50}$ См. напр.: Крюков, Софронов, Чебоксаров 1978: 169, 172, 181, 259-260, 264, 273.

${ }^{51}$ Суриков 2009: 57-61.

52 Там же: 59.

53 Фролов 2007: 204.
} 
слойку от всех остальных. Во-первых, аристократия обладает юридическим статусом, т.е. её положение в обществе закреплено законодательно, а во-вторых, данный статус должен существовать долгое время и передаваться по наследству ${ }^{54}$. После того, как мы отметили основные признаки аристократии, необходимо на ряде примеров обосновать возможность применения этого термина для обозначения персидской властной верхушки в Ахеменидской державе. Прежде всего, это прямое следование древнегреческой традиции, уподоблявшей знатных персов греческим аристократам по ряду критериев, из коих наиболее значимыми были происхождение, воспитание и личные качества.

Геродот сообщает, что свой род Кир возводит к Ахемену (Hdt. III. 75). У «отца истории» также обнаруживаем сведение, согласно которому персы якобы являются сородичами жителям Аргоса, так как считают себя отпрысками Персея и Андромеды, дочери Кефея, сына Данаи (Hdt. VII. 150). Ксенофонт отмечает, что Камбиз I, отец Кира Великого, возводит происхождение к Персею (Xen. Cyr. I. 2. 1). В диалоге Платона «Алкивиад І» говорится, что персы ведут свой род от Ахемена, который в свою очередь восходит к Персею, сыну Зевса (Plato. Alcib. 120e). При этом отмечается, что Ахемениды и Гераклиды имеют единое происхождение. Ксенофонт и Платон, повествуя о происхождении персов, опираются на греческий этиологический миф, но даже сквозь мифологическую призму у Платона ощущается стремление найти общее между персами и эллинами. Любопытное сведение сообщает Клавдий Элиан. Он пишет, что перс Ахемен, от которого происходят благородные персы, был вскормлен орлом (Aelian. Nat. Anim. 12. 21). При этом известно, что орел является атрибутом Зевса ${ }^{55}$. Соответственно пассажи Элиана и других античных авторов перекликаются относительно происхождения Ахеменидов от Зевса. Николай Дамасский пишет, что «Ахемен - герой, по имени которого персы называются Ахеменидами. Он был сыном Персея; назван был так потому, что его предок был из Ахеи» (F.15. 6; 13). Кроме того, начиная с Геродота, греческие авторы наделяют персов качествами, которые присущи аристократам. К примеру, «отец истории» пишет: «Главная доблесть персов - мужество. После военной доблести большой заслугой считается иметь как можно больше сыновей»; «Детей с пяти до двадцатилетнего возраста они обучают только трем вещам: верховой езде, стрельбе из лука и правдивости» (Hdt. I. 136).

Таким образом, уже Геродот выделяет некоторые черты, которые составят аристократический этос персов. «Отцу истории» вторит Ксенофонт, сообщая, что Кир Великий при дворе Астиага учился верховой езде, стрельбе из лука и послушанию (Xen. Cyr. I. 3). В диалоге Платона «Алкивиад I» автор сообщает: «Затем царский сын воспитывается не никудышной женщиной, но избранными евнухами из приближенных царя. При этом им поручается всевозможная забота о новорожденном, в т.ч. и

\footnotetext{
${ }^{54}$ Блок 2003: 277.

${ }^{55}$ Скржинская 2009: 190.
} 
умелое формирование мальчишеских членов и фигуры: благодаря этой своей задаче они находятся в особой чести. Когда же наследникам исполняется семь лет, они обучаются верховой езде и к ним приставляют для этого учителей; кроме того, они начинают ходить на охоту. После того как им стукнет четырнадцать, мальчиков отдают в руки тех, что именуются у них царскими наставниками; это - четверо избранных достойнейших людей среди персов, достигших преклонного возраста: наимудрейший, наисправедливейший, наирассудительнейший и наихрабрейший. Один из них преподает магию Зороастра, сына Ормузда: суть ее в почитании богов. Кроме того, он преподает царскую науку. Самый справедливый учит правдивости в течение всей жизни». Таким образом, мы видим, что античные авторы очень подробно рассказывают о воспитании знатных персов, которое соотносится с эллинской пайдейей. При этом может закрасться подозрение, что греческие авторы передают не реальные особенности жизни персидской знати, а всего лишь представления, сформированные на основе собственных паттернов поведения. Однако Б. Линкольн провел тщательный анализ сведений античных авторов и древнеперсидских надписей и пришел к выводу, что персидская система образования и воспитания, описанная греками, нашла свое отражение в древнеперсидских царских надписях ${ }^{56}$. В частности, он показал, какими моральными качествами и физическими навыками должен обладать знатный перс и как это отражено у античных авторов. По сути, у Линкольна речь идет о своеобразной персидской калокагатии, базирующейся с духовной точки зрения на мудрости, разумении и принадлежности к царскому дому, а с физической точки зрения - на мощи / энергии, умении командовать/управлять, умении быть хорошим воином, а также на навыках наездника, лучника и копьеметателя. При этом духовные качества необходимо активно проявлять в мирное время и среди своих соплеменников, а физические во время войны на чужбине.

Подтверждения античным сведениям можно найти в древнеперсидских надписях. Прежде всего, во всех них содержатся генеалогические сведения, а в надписи Ариарамны, прадеда Дария I, говорится, что он является внуком Ахемена $(\mathrm{Amh})^{57}$. Кроме того, в ряде надписей неоднократно сообщается, что Персия обладает «хорошими мужами» (AMh, DPd, DSf, DZc) или «хорошими мужами и «хорошими лошадьми» (ASh), или же «хорошими колесничими, хорошими лошадьми, хорошими мужами» (DSs, DSp). В Накши-Рустамской надписи Дария I $(\mathrm{DNb})$ и надписи Ксеркса I из Персеполя $(\mathrm{XPl})$ эти цари сообщают о том, что они отличные всадники, а также хороши в стрельбе из лука и метании копья, как в пешем, так и конном строю ${ }^{58}$. Выдающимися физическими способностями монархи обязаны Ахурамазде. Эти два пассажа

\footnotetext{
${ }^{56}$ Lincoln 2012: 335-354.

${ }^{57}$ Скорее всего, данная надпись была создана гораздо позже, но это не умаляет желание её создателя возвести происхождение Ариарамны к Ахемену.

58 Об этом см.: Рунг, Чиглинцев 2018: 700.
} 
подтверждают сообщения античных авторов, согласно которым персы много времени уделяют верховой езде и стрельбе из лука, ибо лучшим можно стать только при условии постоянных тренировок.

Таким образом, исходя из сведений царских надписей, можно заключить, что знатные персы, сродни греческим аристократам, уделяли большое внимание своему происхождению, физическому воспитанию и личным качествам. Кроме того, в персидских царских надписях можно найти пассажи, которые, на наш взгляд, свидетельствуют о наличии даже агонального поведения в рядах персидской военной знати. Также надо отметить, что у знатных персов была развита система статусных атрибутов: особая одежда ${ }^{59}$, украшения, например, серьги. Не менее важно наличие у них особого мировоззрения и представления о справедливости, которое формировалось, в т.ч. под влиянием теологической концепции зороастризма. Кроме того, материал источников позволяет проследить привилегированное положение шести знатных семейств, возводивших происхождение к персам, свергнувшим мага Гаумату и способствовавшим воцарению Дария I, которые получили особый статус в Ахеменидской империи и право породниться с царем ${ }^{60}$.

На примере изучения Ахеменидской империи рельефно прослеживается, как исследователи меняли свое отношение к категории «аристократия»: от синонима слова «знать» до высшей прослойки общества, имеющей аристократический этос. Такой терминологический поворот обоснован данными источников, но также очень полезен с методологической точки зрения, так как позволяет по-новому взглянуть на проблемы не только истории Ахеменидской Державы, но и Древней Греции.

\section{БИБЛИОГРАФИЯ / REFERENCES}

Авдиев В.И. Военная история Древнего Египта. Т. 1. М.: «Советская наука», 1948. 240 с. [Avdiev V.I. Voennaya istoriya Drevnego Egipta. T. 1. M.: «Sovetskaya nauka», 1948. 240 s.]

Авдиев В.И. Военная политика Египта в эпоху Среднего Царства // Вестник древней истории. 1939. № 1. C. 34-51 [Avdiev V. I. Voennaya politika Egipta v epokhu Srednego Tsarstva // Vestnik drevney istorii. 1939. № 1. S. 34-51].

Бартольд В.В. Рыцарство и городская жизнь в Персии при Сасанидах и при Исламе // Сочинения. Т. VII. М.: ИВЛ, 1971. С. 371-373 [Bartol'd V. V. Rytsarstvo i gorodskaya zhizn' v Persii pri Sasanidakh i pri Islame // Sochineniya. T. VII. M.: IVL, 1971. S. 371-373].

Блок М. Феодальное общество / Пер. с фр. М.Ю. Кожевниковой. М.: Изд. им. Сабашниковых, 2003. 504 с. [Blok M. Feodal'noe obshchestvo / Per. s fr. M. Yu. Kozhevnikovoy. M.: Izd. im. Sabashnikovykh, 2003. 504 s.]

Гафуров Б.А. К 2500-летию иранского государства // История Иранского государства и культуры. (к 2500-летию Иранского государства). М.: Наука, 1971. С. 5-37 [Gafurov B.A. K 2500-letiyu iranskogo gosudarstva // Istoriya Iranskogo gosudarstva i kul'tury. (k 2500-letiyu Iranskogo gosudarstva). M.: Nauka, 1971. S. 5-37.]

Гафуров Б.А. Таджики. Древнейшая, древняя и средневековая история. Кн. І. Изд. 2. Душанбе: Ирфон, 1989. 479 с. [Gafurov B. A. Tadzhiki. Drevneyshaya, drevnyaya i srednevekovaya istoriya. Kn. I. Izd. 2. Dushanbe: Irfon, 1989. 479 s.]

Древний Восток: учеб. пос. для вузов / Н.В. Александрова, И.А. Ладынин, А.А. Немировский, В.М. Яковлев. М.: АСТ, 2008. 656 c. [Drevniy Vostok: ucheb, pos. dlya vuzov / N.V. Aleksandrova, I.A. Ladynin, A.A. Nemirovskiy, V.M. Yakovlev. M.: AST, 2008. 656 c.]

59 Подробнее об этом см.: Shahbazi 1992: 723-737.

${ }^{60}$ См.: Орлов 2016: 776-784. 
Дьяконов И.М. Развитие земельных отношений в Ассирии. Л.: Ленингр. гос. ордена Ленина ун-та им. А.А. Жданова, 1949. 152 с. [D'yakonov I. M. Razvitie zemel'nykh otnosheniy v Assirii. L.: Izd-vo Leningr. gos. ordena Lenina un-ta im. A.A. Zhdanova, 1949. 152 s.]

Дьяконов И.М. История Мидии. Кн.I. Баку: Изд-во «Нагыл Еви», 2012. 332 с. [D'yakonov I. M. Istoriya Midii. Kn.I. Baku: Izd-vo «Nagyl Evi», 2012. 332 s.]

Дьяконов М.М. Очерки истории Древнего Ирана. М.: ИВЛ, 1961. 444 с. [D'yakonov M. М. Ocherki istorii Drevnego Irana. M.: IVL, 1961. 444 s.]

Крюков М.В., Софронов М.В., Чебоксаров Н.Н. Древние китайцы: проблема этногенеза. М.: Наука, 1978. 344 с. [Kryukov M. V., Sofronov M.V., Cheboksarov N.N. Drevnie kitaytsy: problema etnogeneza. M.: Nauka, 1978. 344 s.]

Луконин В.Г. Древний и раннесредневековый Иран. М: Наука, 1987. 295 с. [Lukonin V.G. Drevniy i rannesrednevekovyy Iran. M: Nauka, 1987. 295 s.]

Никольский Н.М. Этюды по истории финикийских общинных и земледельческих культов. Минск: Гос. изд-во БССР, Ред. политической лит-ры, 1948. 426 с. [Nikol'skiy N.M. Etyudy po istorii finikiyskikh obshchinnykh i zemledel'cheskikh kul'tov. Minsk: Gosudarstvennoe izdatel'stvo BSSR, Redaktsiya politicheskoy lit-ry, 1948. 426 s.]

Никольский Н.М. Культура Древней Вавилонии. Минск: Изд-во АН БССР, 1959. 183 с. [Nikol'skiy N.M. Kul'tura Drevney Vavilonii. Minsk: Izd-vo AN BSSR, 1959. 183 s.]

Орлов В.П. Шесть знатных персов и их потомки при Дарии I: положение персидской аристократии в Ахеменидской империи. // Ученые записки Казанского университета. Сер. Гуманит. науки. 2016. Т. 158. Кн. 3. С. 776-784 [Orlov V.P. Shest' znatnykh persov i ikh potomki pri Darii I: polozhenie persidskoy aristokratii v Akhemenidskoy imperii. // Uchenye zapiski Kazanskogo universiteta. Ser. Gumanit. nauki. 2016. T. 158. Kn. 3. S. 776-784].

Рагозина 3.А. История Ассирии. СПб: Изд. А.Ф. Маркс, 1902. 500 с. [Ragozina Z.A. Istoriya Assirii. SPb: Izd. A. F. Marks, 1902.500 s.]

Ростовцев М.И. Эллинство и иранство на юге России. М. Издательский дом «Книжная находка», 2002. 160 c. [Rostovtsev M.I. Ellinstvo i iranstvo na yuge Rossii. M. Izdatel'skiy dom «Knizhnaya nakhodka», 2002. 160 s.]

Рунг Э.В., Чиглинцев Е.А. Darius versus Xerxem: образы Дария I и Ксеркса в древнеперсидских текстах и в произведениях Эсхила и Геродота // Вестник древней истории. 2017. № 3. C. 696-719 [Rung E. V., Chiglintsev E. A. Darius versus Xerxem: obrazy Dariya I i Kserk-sa v drevnepersidskikh tekstakh i v proizvedeniyakh Eskhila i Gerodota // Vestnik drevney istorii. 2017. № 3. S. 696-719.]

Скржинская М.В. Древнегреческие праздники в Элладе и Северном Причерноморье. СПб: Алетейя, 2009. 464 с. [Skrzhinskaya M.V. Drevnegrecheskie prazdniki v Ellade i Severnom Prichernomor'e. SPb: Aleteyya, 2009. 464 s.]

Струве В.В. История Древнего Востока. М.: ОГИЗ, Госполитиздат, 1941. 484 с. [Struve V.V. Istoriya Drevnego Vostoka. M.: OGIZ, Gospolitizdat, 1941. 484 s.]

Суриков И.Е. Аристократия и демос: политическая элита архаических и классических Афин. Учеб. пособ. по спецкурсу для исторических факультетов вузов. М.: Русский фонд содействия образованию и науке, 2009. 256 c. [Surikov I.E. Aristokratiya i demos: politicheskaya elita arkhaicheskikh i klassicheskikh Afin. Ucheb. posob. po spetskursu dlya istoricheskikh fakul'tetov vuzov. M.: Russkiy fond sodeystviya obrazovaniyu i nauke, 2009. 256 s.]

Тураев Б.А. История Древнего Востока. Т. 1 / Под ред. В.В. Струве, И.П. Снегирева. Л.: Социально-экономическое изд., 1935. 340 с. [Turaev B.A. Istoriya Drevnego Vostoka. T. 1 / Pod red. V.V. Struve, I.P. Snegireva. L.: Sotsial'no-ekonomicheskoe izd., 1935. 340 s.]

Фрейман А.А. Задачи иранской филологии // Известия Академии наук СССР. Отделение литературы и языка. 1946. Т. V. Вып. 5. C. 373-386 [Freyman A. A. Zadachi iranskoy filologii // Izvestiya Akademii nauk SSSR. Otdelenie literatury i yazyka. 1946. T. V. Vyp. 5. S. 373-386.]

Фролов Э.Д. Аристократия в античном мире // Вестник Санкт-Петербургского университета. 2007. Cep. 2. Вып. 4. C. 202-206 [Frolov E. D. Aristokratiya v antichnom mire // Vestnik Sankt-Peterburgskogo universiteta. 2007. Ser. 2. Vyp. 4. C. 202-206.]

Якобсон В.А. Месопотамия в XVI-XI вв. до н.э. // История древнего мира. Расцвет древних обществ / Под ред. И.М. Дьяконова, В.Д. Нероновой, И.С. Свенцицкой. М.: Глав. ред. вост. лит-ры, 1989. С. 198-212 [Yakobson V. A. Mesopotamiya v XVI-XI vv. do n.e. // Istoriya drevnego mira. Rastsvet drevnikh obshchestv / Pod red. I.M. D'yakonova, V.D. Neronovoy, I.S. Sventsitskoy. M.: Izd-vo glav. red. vost. lit-ry, 1989. S. 198-212]. 
Balcer J.M. The Persian Conquest of the Greeks 545-450 B.C. Konstaz: Universitätsverlag Konstanz, 1995. 229 p.

Balcer J.M. Sparda by the Bitter Sea. Imperial Interaction in Western Anatolia. Chico: Calif, Scholars Press, 1984. 359 p.

Briant P. From Cyrus to Alexander. A History of the Persian Empire. Winona Lake: Winona Lake (Indiana): Eisenbrauns, 2002. 1196 p.

Cameron G.G. History of Early Iran. Chicago, Illinois: University of Chicago Press, 1936. 260 p.

Fox R.L. Alexander the Great. Harmondsworth: Pinguin, 1973. 568 p.

Frye R.N. The history of ancient Iran. München: Verlag C.H. Beck, 1983. 411 p.

Hammond N.G.L. The Macedonian State: origins, institutions, and history. Oxford: U.P., 1989. $414 \mathrm{p}$.

Herzfeld E.E. Archaeological History of Iran (Schweich Lectures for 1934). London: The British Academy, 1935. $260 \mathrm{p}$.

Jones A.T. The Great Empires of Prophecy, from Babylon to the Fall of Rome. Chicago, Illinois: Review and Herald Publishing Company, 1898. 696 p.

Judeich W. Kleinasiatischen Studien. Untersuchungen zu griechisch-persischen Geschichte des IV Jahrhunderts v. Ch. Marburg: N. G. Elwertsche Verlagsbuchhandlung, 1892. 209 S.

Kuhrt A. The Persian Empire: A Corpus of Sources of the Achaemenid Period. London: Routledge, 2007. 496 p.

Lincoln B. Happiness for Mankind: Achaemenian Religion and the Imperial Project (Acta Iranica). Leuven: Peeters Publishers, 2012. 554 p.

Olmstead A.T. History of the Persian Empire. Chicago: University of Chicago Press, 1948. 670 p.

Pope A.U., Ackerman P., Besterman T. A survey of Persian Art: From Prehistoric Times to the Present. Oxford: O.U.P., 1964.

Prášek J.V. Geschichte der Meder und Perser bis zur makedonischen Eroberung: Bd. II: Die Blütezeit und der Verfall des Reiches der Achämeniden. Gotha: Friedrich Andreas Perthes, 1910. $274 \mathrm{~S}$.

Root M.C. The King and Kingship in Achaemenid Art: Essays on the Creation of an Iconography of Empire. Leiden: Brill, 1979. 357 p.

Schmidt E.F. The Treasury of Persepolis and Other Discoveries in the Homeland of the Achaemenians. Chicago: University of Chicago Press, 1939. $139 \mathrm{p}$.

Shahbazi S. Clothing II. In the Median and Achaemenid periods // Encyclopaedia Iranica. 1992. Vol. V. Fasc. 7. P. 723-737.

Sykes P.M. A history of Persia. London; Chicago, Illinois: Macmillan and Co, 1915. 804 p.

Tuplin C.J. Achaemenid Studies (Historia Einzelschrift. 99). Stuttgart: Franz Steiner, 1996. 226 p. Weissbach F.H. Die Keilinschriften der Achämeniden. Leipzig: Hinrichs, 1911. 160 S.

Wiesehöfer J. Ancient Persia from 550 BC to 650 AD. London; New York: Tauris, 1996. 344 p.

Орлов Василий Павлович, кандидат исторических наук, независимый исследователь, Казань; vasiliy_orlov_historian@mail.ru

Рунг Эдуард Валерьевич, доктор исторических наук, профессор, заведуюший кафедрой всеобщей истории, Казанский (Приволюский) федеральньій университета; eduard_rung@mail.ru

\section{The term "Aristocracy" and its Use for Nobility in the Achaemenid Empire}

This article discusses the use of the term "aristocracy" for the history of the Ancient East as a whole, and of the Achaemenid Empire, in particular. Turning to this issue, the authors demonstrate, in a number of examples, in what contexts the term "aristocracy" was used in the works of foreign and Russian orientalists and Hellenists, and finally they give a brief description of the Persian aristocracy, which they consider on the basis of the ancient Greek understanding of this phenomenon, and of ancient Persian realities reconstructed from sources.

Keywords: aristocracy, nobility, elite, Greeks, Persians, Achaemenids

Vasily Orlov, candidate of historical sciences, independent researcher, Kazan; vasiliy_orlov_historian@mail.ru

Eduard Rung, Doctor of Historical Sciences, Professor, Head of the Department of General History, Kazan Federal University; eduard_rung@mail.ru 


\author{
Д.В. СУХИНО-ХОМЕНКО
}

\title{
«АНГЛО-САКСОНСКАЯ СХИЗМА» терминологическая дискуссия в англоязычном медиа-пространстве и вызовы сообщества медиевистов *
}

Статья исследует публичную дискуссию по вопросу о допустимости академического использования термина «Anglo-Saxon». После выхода М. Рамбаран-Ольм из Международного Общества англо-саксонистов в сентябре 2019 г. медиевистическое сообщество раскололось. Критики термина «Anglo-Saxon» апеллируют к его расовым коннотациям и злоупотреблениям, защитники - к его историчности и устоявшейся традиции. Размежевание во многом связано с географией и локальным общественным дискурсом. Примирение сторон вряд ли достижимо в ближайшем будущем.

Ключевые слова: историография, англо-саксы, медиевистика, расовый дискурс, дискриминачия, идеология, культурная гегемония

Вспыхнувшая в 2019 г. публичная дискуссия о правомочности использования термина «Anglo-Saxon» в профессиональной среде глубоко расколола англоязычное сообщество медиевистов. Пока в академическом пространстве не предпринимались попытки всесторонне обобщить эту полемику ${ }^{1}$, которая находится на стыке методологии, академической демографии и публичного дискурса. Настоящая статья преследует цель восполнить этот пробел в новейшей историографии, а также представить возможный прогноз дальнейшего развития этой острой ситуации.

19 сентября 2019 г. Международное Общество англо-саксонистов (International Society of Anglo-Saxonists, ISAS) объявило о своём решении изменить название, изъяв слово «англо-саксонисты» в целях «отражения демографического состава Общества и его экспертного совета» ${ }^{2}$. Решение было принято 60\% голосов, а из 582 членов Общества в голосовании приняли участие $75 \%{ }^{3}$. В опубликованном коммюнике среди причин подчеркивались две: злоупотребления термином «Anglo-Saxon» в расистском дискурсе и отрицательная роль этого термина в создании инклюзивного сообщества медиевистов. Решение стало реакцией на уход с поста высокопоставленного члена ISAS M. Рамбаран-Ольм, публично оглашенный ею 7 сентября на конференции RaceB4Race в Baшингтоне. Стенограмма, видимо, не велась, поэтому аргументация известна только в пересказах. Х. Нэйтансон указывает, что, являясь активным членом MCO (Medievalists of Color Organization), Рамбаран-Ольм, два года настаивала на смене названия ISAS и добилась вынесения вопроса на голосование в мае 2019 г. Подобные идеи были впервые озву-

\footnotetext{
* Автор выражает признательность Д.С. Сегал, Е.О. Владимирцевой и Е.А. Мельниковой за их ценные замечания к рукописи данной статьи.

${ }^{1}$ Наиболее полно на момент подготовки статьи проблема была освещена в: Allen 2019b; Flaherty 2019; Natanson 2019; Wood 2019.

${ }^{2}$ Stephenson 2019. Здесь и далее перевод выполнен автором.

${ }^{3}$ Natanson 2019.
} 
чены ещё в 2017 г. А. Мияширо. Не скрывая, что поводом к публикации стал отказ со стороны ISAS в выступлении на конференции в Гонолулу летом того же года, автор, «потомок мультиэтничного союза между азиатскими, полинезийскими и гаитянскими народами и культурами», упрекал Общество в консервативной программе встречи ${ }^{4}$ и «игнорировании местного уроженца» (erasure of the native) ${ }^{5}$.

Вклад термина «Anglo-Saxon» в т.н. англо-саксонский миф не является новостью в академическом дискурсе ${ }^{6}$. Его «расистские коннотации» также давно известны. Но именно уход с поста Рамбаран-Ольм, вызванный, по её словам, ригидностью и имплицитным сопротивлением ISAS, ускорил процесс переименования. В последовавшем обсуждении иногда упускают из вида, что еще 27 июля 2018 г. за авторством Рамбаран-Ольм вышла онлайн-колонка с описанием трудностей, с которыми сталкиваются историки с не-белым цветом кожи, включая и автора. Там же она обращала внимание на присвоение радикалами и шовинистами элементов медиевистического дискурса. Статья заканчивалась конструктивным призывом быть открытыми к диалогу ${ }^{7}$.

Едва ли удивительно, что эскалация дискуссии по скорости напоминала лесной пожар, и разгоревшийся скандал, если называть вещи своими именами, уже успел нанести косвенный ущерб. Как точно подметила Ш. Аллен: «Термин “Anglo-Saxon” удачно сосредоточил в себе недовольство академических левых, а равно смущение и сомнения тех учёных, кто полагает себя толерантными либералами и подспудно стыдится преобладания белых мужчин в рядах интересующихся англосаксонскими темами» ${ }^{8}$. Показателен пример радикализации в текстах самой Рамбаран-Ольм. Несмотря на будущие оговорки вплоть до недавнего времени она сохраняла обсуждаемый термин в собственном лексиконе 9 . Упомянутая колонка 2018 г. была написана в умеренном тоне, а замена «Anglo-Saxon» на «Early English» в названии, согласно сноске, была проведена только во второй редакции статьи. Но уже через два месяца после своей добровольной отставки Рамбаран-Ольм сменила стиль изложения, допуская визуальный argumentum ad Hitlerum и осуждая призыв британских коллег сохранить термин «Anglo-Saxon» как «тошнотворную попытку затушевать его неточное использование даже в историческом контексте» ${ }^{10}$. Одна из убедительных объяснительных моделей этой радикализации предложена М. Докрэй-Миллер. В качестве примера выхода из профессионального употребления некогда считавшихся допустимых лексем она приводит афроамериканские сюжеты

\footnotetext{
${ }^{4}$ Программа конференции опубликована в: Foys, Irvine 2018.

${ }^{5}$ Miyashiro 2017.

${ }^{6}$ Niles 1997; Niles 2015: 34; 278-286; Sayer et al. 2016: 3; Shippey 2000. Также тема рассматривается в монографии Karkov 2020.

${ }^{7}$ Rambaran-Olm 2018.

${ }^{8}$ Allen 2019b.

${ }_{9}^{9}$ См., напр., Rambaran-Olm 2014.

${ }^{10}$ Rambaran-Olm 2019.
} 
в США: «coloured» (1909) $\rightarrow$ «negro» (1944) $\rightarrow$ «black» (1968) $\rightarrow$ «African-American» (2003). Термин «Anglo-Saxon» отличается в трёх положениях. Во-первых, временно́й компрессией дискуссии и её освещением в СМИ. Во-вторых, его приложением доминирующей группой к себе, а не к дискриминируемым ${ }^{11}$. В-третьих, изрядной подогретостью публичного дискурса о социальной инклюзии к началу полемики. Дорогу к ней в равной мере проложили как критические высказывания о гомогенности в цехе медиевистов и её возможной расовой (расистской?) подоплё$\mathrm{\kappa e}^{12}$, так и, предположительно, публичная ажитация в ходе недавнего обсуждения расового состава населения римской Британии. К концу 2019 г. можно констатировать три итога развернувшейся дискуссии.

Во-первых, это ожесточённость публикаций и последовавший быстрый переход на личности. Яркий пример апелляций ad hominem можно видеть в обмене репликами между Г. Уильямсом с одной стороны и Х. Янг и К. Калиендо с другой. Последние предъявили первому не только отсутствие оригинальности, но и «белый либеральный расизм, замаскированный под разумное и рациональное обсуждение», «нехватку профессионализма и игнорирование коллег, что свидетельствует об открытой враждебности», попытки «пристыдить и контролировать высказывания магистрантов», а также искажение фактов ${ }^{13}$. Не упоминая Янг и Калиендо открыто, Уильямс не остался в долгу, заявив, что «единственный оставшийся путь для них - продолжать шельмовать несогласных как расистов или поборников белого превосходства» ${ }^{14}$. Аналогичным образом британский историк-любитель Т. Холланд, идентифицируя себя «наполовину ютом», не нашёл ничего оскорбительного в термине «Anglo-Saxon», спровоцировав осуждение со стороны Рамбаран-Ольм его «шутливого тона» как «показателя, насколько британские учёные не воспринимают проблему белого превосходства всерьёз» ${ }^{15}$.

Второй итог - стремительное развитие событий, когда ISAS не только приняло решение о смене названия, выбранного при создании общества в 1983 г., но и не досчиталось своих членов. «Для некоторых изменения были запоздалыми, для иных - слишком поспешными. [...] Из девяти членов экспертного совета осталось только четверо» ${ }^{16}$. Рамбаран-Ольм была поддержана МСО и Обществом учёных-феминистов (Society for Medieval Feminist Scholarship) ${ }^{17}$.

B-третьих, спор обнажил по меньшей мере две этические проблемы в раннесредневековых штудиях. Первая - корректность, применимость и адекватность лексемы «Anglo-Saxon» в академическом дискурсе. Вторая - консервативный демографический состав «англо-саксони-

\footnotetext{
${ }^{11}$ Dockray-Miller 2019.

${ }^{12}$ Allen 2019a-b; Dockray-Miller 2017; Kim 2019; Lomuto 2019.

${ }^{13}$ Young, Caliendo 2019.

${ }^{14}$ Williams 2019b. См. также другие записи Уильямса в этом же блоге.

${ }^{15}$ Bridge 2019.

${ }^{16}$ Natanson 2019.

${ }^{17}$ Elmes 2019; Medievalists of Color 2019.
} 
стов». Смешение этих вызовов, как и нежелание рассматривать их по отдельности, сделало дискуссию особенно легко воспламеняемой.

Для критиков термина «Anglo-Saxon» (в основном из академической среды в США) причиной недопустимости его использования является его возникновение и циркуляция в расистском дискурсе, что, по их мнению, наносит ущерб профессиональному сообществу. Они настаивают, что термин невозможно очистить от отрицательных ассоциаций, так что «для студентов-медиевистов с не-белым цветом кожи термин, неся расистские коннотации, не является репрезентативным ${ }^{18}$. Противники такой точки зрения (большей частью британские и европейские учёные) частично признают анахронизм обсуждаемой лексемы, но фокусируются на её академической допустимости. Защитники указывают, что языковые злоупотребления на вненаучном поле сами по себе не должны вести к цензуре, особенно в свете устоявшегося употребления.

\section{«Англо-саксонский» спор в более широкой перспективе}

В своей статье в ноябре 2019 г. М. Рамбаран-Ольм, ссылаясь на готовившуюся публикацию Д. Уилтона ${ }^{19}$, утверждает, что «население раннесредневековой Англии или "Englelond"20 не называло себя "англосаксами”. Термин использовался лишь спорадически, и большей частью сами люди определяли себя как "Englisc" или “Anglecynn"»»". Анти«англо-саксонисты», большинство из которых не специализируется на ранних Средних веках, взяли этот тезис на вооружение как вполне самодостаточный. Напротив, их противники, в основном специалисты по донормандской Англии, выбрали его главной мишенью своей критики.

Точное происхождение и первоначальное значение лексемы являются темой дискуссии, но в форме «Anglisaxones» она, видимо, впервые зафиксирована в «Истории лангобардов» Павла Диакона в конце VIII в. Любопытно, что Павел допускал и перестановку элементов компаунда $^{22}$, из чего родилось распространённое объяснение, что так он отделял континентальных от «английских» саксов. Согласно одному из толкований, та же идея проявилась в титуле короля Альфреда (прав. 871-899) в одной из его грамот: «Ego Ælfredus gratia Dei Angulsaxonum rex» ${ }^{23}$. Та-

\footnotetext{
${ }^{18}$ Wood 2019.

${ }^{19}$ Wilton 2020.

${ }^{20}$ Авторская орфография сохранена. Орфограмма «Anglecynn» в корпусе нам не встретилась. Написание «Englelond» встречается в корпусе лишь однажды.

${ }^{21}$ Rambaran-Olm 2019. Последнюю лексему можно перевести «английский (на)род».

${ }^{22}$ Книга 4, глава 22: «Vestimenta vero eis erant laxa et maxime linea, qualia Anglisaxones habere solent, ornata institis latioribus vario colore contextis» («Одежда у них была свободная и в основном льняная, как у англосаксов, украшенная широким разноцветным поясом»); книга 5, глава 37: «At vero Cunincpert rex Hermelindam ex Saxonum Anglorum genere duxit uxorem» («Король же Куникперт взял в жёны Хермелинду из племени англосаксов»; Waitz 1878. S. 155; 201; Циркин 2008: 125; 169).

23 «Я, Альфред, божьей милостью король англо-саксов» (S 354). Ссылки на англосаксонские грамоты приводятся по изданию: Sawyer 1968. Оригинальный текст опубликован в: Birch 1887: 205-207. В древнеанглийских текстах также проводится различие между «британскими» и «континентальными», или «старыми», саксами.
} 
кой же титул ему приписывает его биограф и современник, епископ Ас$\mathrm{cep}^{24}$. С другой стороны, крупнейший современный специалист по древнеанглийской дипломатике С. Кейнз выдвигает иное объяснение: Альфред претендовал на власть над всеми англоговорящими жителями низинной Британии, не подчинявшимися скандинавским правителями ${ }^{25}$.

В контексте настоящей дискуссии большинство авторов обычно ссылаются на Оксфордский словарь английского языка, приводящий лишь четыре примера, два из которых упомянуты выше. В преддверии заявленной статьи Уилтона мы провели собственный контекстуальный анализ употреблений и сочетаний вариаций этнонимов «саксы» и «англы» на основе корпуса древнеанглийского языка ${ }^{26}$.

Критики, бесспорно, правы в том, что касается чисто количественного доминирования древнеанглийской лексемы «Angelcynn»: она встречается 230 раз, а «Angelseaxe» - лишь четырежды ${ }^{27}$. Вопреки саксонскому ядру королевства не подлежит сомнению и преимущественно «англская» идентичность низинной Британии, созданная во многом под влиянием труда Беды Достопочтенного (ок. 672-735) «Церковная история народа англов» и его древнеанглийского перевода конца IX в. ${ }^{28}$ Она подтверждается и внешними источниками. Так, около 30 скандинавских рунических камней содержат топоним «England», в то время как «Saxland» прилагается к современной Северной Германии ${ }^{29}$. Интересно и возникновение компаунда «Angelcynig» («король англов»; вероятно, по модели «Angelcynn»). Он встретился нам в восьми грамотах (ap-

${ }^{24}$ Главы 1, 13, 21, 64, 67, 71, 73, 83, 87 (Stevenson 1904: 1; 12; 19; 49; 50; 53; 54; 69; 73). Данный источник не учтён Д. Уилтоном.

${ }^{25}$ Niles 2015: 34.

${ }^{26}$ Dictionary of Old English Web Corpus. Цифры включают результаты поиска по всем возможным орфограммам. Поиск латинских форм облегчается ресурсом Британской академии Dictionary of Medieval Latin from British Source, но он не предлагает исчерпывающий список вхождений лексемы в корпус. Подготовка настоящей статьи предшествовала публикации текста Уилтона. Этот обзор на данный момент следует признать наиболее полным лексикографическим исследованием данного вопроса.

${ }^{27}$ В анонимном прологе к «De virginitate» авторства Альдхельма, епископа Шербурна (705-709) и аббата Мальмсбери (675-709), этот прелат назван «благородным поэтом в земле англо-саксов, епископом бриттов» («Ealdelm, æpele sceop, etiam fuit ipselos on æðele Angolsexna, byscop on Brettene»; Dobbie 1942: 97). Текст известен в рукописи, широко датируемой X-XI вв. В переводе папских привилегий для аббатств под руководством Альдхельма, Мальмсбери назван местом, лежащим в «области англосаксов» («on angelsexena scire»; в латинском «оригинале», сохранившемся лишь в сочинении Уильяма Мальсмберийского «Деяния английских епископов» ок. 1125 г., речь идёт о «provintia Saxonia»; Birch 1885: 154-156). Д. Уилтон, по не совсем понятным причинам, не учитывает это упоминание в своём списке. В грамоте 934 г. Этельстан (прав. 924-939) назван «королем англо-саксов и бретвальдой всего острова» («Ongolsaxna cyning and brytænwalda eallæs ðyses iglandæs»; S 427; Birch 1887. P. 410). Похожим образом в грамоте 955 г. Эадред (прав. 946-955) носит титул «короля англо-саксов и императора всей Британии» («Angulseaxna Eadred cyning and casere totius Brittannię»; S 566; Birch 1893: 70).

${ }^{28}$ Foot 1996; Frazer, Tyrrell 2000: 69-90; Lavelle, Roffey 2016; Timofeeva 2013; и др.

${ }^{29}$ Jesch 2001: 70-78; 80-83. Лексема «Englaland» встретилась нам 189 раз. 
хи)епископа Освальда между 962 и 987 гг. ${ }^{30}$, одной королевской хартии $^{31}$, в древнеанглийском переводе Беды ${ }^{32}$, и одной поздней гомилии ${ }^{33}$. Напротив, субстантивация прилагательного «Englisc» в значении этнонима нетипична. Количественно доминирует значение «английский язык», особенно в выражении «on Englisc» («по-английски»), крайне распространённом в контексте перевода с латыни. «Англичане» иногда обозначаются как «Englisce menn» (также и в единственном числе), реже — «Englisc folc». В данном случае мы склонны подозревать невольную контаминацию с современным словоупотреблением.

Два из четырёх древнеанглийских употребления «Angelseaxe» приходятся на XI в. Добавим к ним обозначение жителей Британии «англосаксами» («Angli(-)saxones»), упоминание «англо-саксонского обыкновения» («mos Anglosaxonum/Anglis-Saxonibus») королевских наместников путешествовать с пышной свитой, а также «разные края англо-саксов» («diversi Anglisaxonum fines») в трех латинских житиях Св. Свитхуна 970-990-х гг. ${ }^{34}$ Выражение «англы и саксы» известно из перевода Беды, поэм «Битва при Брунанбурге» (937) и «Смерть короля Эдуарда» (1065), месяцеслова XI в., а также в латинских текстах ${ }^{35}$. Латинский титул «короля англо-саксов», встречавшийся уже в грамотах Альфреда, известен в хартиях X в., ${ }^{36}$ некоторые из которых, однако, вызывают сомнения в своей принадлежности указанным в них датам составления. Уэссекские короли этого времени носят и титул «короля англов» («rex Anglorum»), но только контролируя все бывшие независимые германские королевства. Этот титул также хорошо известен на королевских монетах.

Итак, утверждение, что термин «англо-саксы» был чужд современникам, нельзя принять безапелляционно. Несомненно, он был менее

${ }^{30}$ S 1299, 1309, 1326, 1332, 1369, 1372, 1373 (Birch 1893. P. 317; 443; Robertson 1956. P. 96, 114; 116; 120; 124).

${ }^{31} \mathrm{~S} 914$.

${ }^{32}$ Miller 1890: 176.

${ }^{33}$ Napier 1883: 215.

${ }^{34}$ Lapidge 2003: 256-258, 306, 319-320, 530-532, 564. Примечательно, что автор самого раннего из житий, Лантфред, выходец из французского аббатства Флёри, в Англии был «иностранцем». Епископ Ассер был валлийцем. Хронист Ордерик Виталий (1075-ок. 1142), приводит письмо нормандца Гуитмонда Аверсского (ум. ок. 10901095) королю Вильгельму I (прав. 1066-1087), датированное 1070 г. Среди перечисленных завоевателей прошлого упомянуты и «англо-саксы, ведомые Хенгистом и Хорсой» («Angli-Saxones ducibus Hengist et Horsa»; Chibnall 1969: 276).

35 «Angelpeode and Seaxum», «Angel peod and Seaxna», «Ongle and Seaxan», «Engle and Seaxe», «omnes Angli et Saxones», «rex Saxonum et Anglorum» (Miller 1890: 2; 50; 408; Dobbie 1942: 20, 25; Karasawa 2015: 82; Stevenson 1904: 69; S 394). Cp. перечисление трёх «английских плёмен» на континенте в переводе Беды: «Пришли они от трёх сильнейших народов Германии, то есть от саксов, англов и ютов» («Comon hi of prim folcum ðam strangestan Germanie, pæt of Seaxum and of Angle and of Geatum»; Miller 1890: 52).

${ }^{36}$ S 392, 396, 397, 590, 624, 1417. Примечательно, что в S 1417 и 392 «англо-саксы» противопоставлены данам и нортумбрийцам, что, вероятно, свидетельствует о контаминации политической и этнической идентичностей в компаунде «англо-саксы». 
популярен, чем вариации на основе «англской» идентичности, однако здесь мы вступаем на почву источниковедческой критики и этногенеза. Аргумент, что «англо-саксы» были порождением «книжной учёности», вызывает вопрос, насколько та же природа была присуща и терминам «Angelcynn» или «Engla peod» ${ }^{37}$, которые критиками полагаются более «аутентичными». Обе стороны признают, что современное прилагательное «Anglo-Saxon» появилось в XVIII в. в работах Н. Тиндаля (16871774) и победило в конкуренции с такими альтернативами, как «English(-)Saxon», лишь к исходу века, когда его популяризовал Ш. Тёрнер $(1768-1847)^{38}$. В этой связи уместна обширная цитата из статьи А. Герро: «В любом исследовании средневекового общества в действие вовлечены по меньшей мере четыре объекта: 1 . средневековое общество; 2. представления о нём историков начиная с 1750 г.; 3. представления этих историков о собственном обществе; 4. общество, к которому они принадлежат. Ни один из этих элементов нельзя исключить. Особенно важным представляется анализ отношений между пунктами 3 и 4, иначе говоря, того, как в разное время внутренние проблемы и стимулы общества определяли представления о нём историков» ${ }^{39}$. И критики, и защитники термина «Anglo-Saxon» опускают проблему представленности в нём третьего германского племени, переселившегося в Британию в V-VI вв., а именно ютов. Кажется, лишь Т. Холланд заметил, что если кто-то и должен быть «оскорблён» словом «англо-саксы», то именно они.

Аргументация анти-«англо-саксонистов» дополнительно подрывается тем, что почти все современные профессиональные термины так или иначе анахронистичны. В качестве примера можно привести проблему «феодализма». Существительное «féodalité» и прилагательное «féodal» появились в Новое время, а сама концепция «феодализма» сформировалась в эпоху Французской революции. В 1974 г. Э. Браун призвала отказаться от термина ${ }^{40}$, и позже эта идея была развита С. Рейнольдс ${ }^{41}$. Обе исследовательницы доказывали, что «феодализм» - не более чем эталонная модель и упрощение исторической реальности. Академическое сообщество живо отозвалось на эту критику ${ }^{42}$, но всё же сошлось во мнении, что слово «феодализм» имеет право на существование как удобное и проверенное временем определение многих доиндустриальных обществ и политических институтов ${ }^{43}$. Как обобщил Р. Абельс: «Медиеви-

${ }^{37}$ Выражение (букв. «народ англов»; вероятно, калька с латинского «gens Anglorum») встретилось нам 74 раза, чаще всего в переводе Беды.

${ }^{38}$ Niles 2015: 34; 174.

${ }^{39}$ Гeppo 2006: 98.

${ }^{40}$ Brown 1974.

${ }^{41}$ Reynolds 1994. См. критику в: Филиппов 2015.

42 Abels 2009; Bagge et al. 2011; Cheyette 2010; Filippov 2004; Reuter 2006: 72-88. См. также «Одиссей: Человек в истории. Феодализм перед судом историков» за 2006 г. ${ }^{43}$ Параллельно шла дискуссия о других базовых понятиях, включая «Средние века» (напр., Reuter 2006: 19-37), и таких аналитических терминах, как «государство» применительно к доиндустриальным обществам (Davies 2003; Foot 2005). См. также статью о ранней советской историографии Древнего Востока (Ладынин 2019). 
сты согласны, что ответ на вопрос: "Было ли это общество феодальным?”, - менее значим, чем понимание институтов и отношений в этом обществе в историческом контексте» ${ }^{44}$. Авторы «Коллективного заявления об ответственном употреблении термина "Anglo-Saxon"» стоят на близкой позиции: «Термин “Anglo-Saxon”... отражает некоторый уровень обобщения. Способность перемещаться между более широким и узким уровнями необходима для точного представления и толкования источников» ${ }^{45}$. На это можно возразить, что титул «rex Angelsaxonum» появился практически одновременно с «Angelcynn», но не получил широкого распространения. В свете наблюдения С. Фут, что «англо-саксы были способны и проявляли интерес к отражению в языке изменений в [этно-политических - Д.С.-X.] реалиях» ${ }^{46}$, редкость употребления термина свидетельствует о его неактуальности для современников. С точки зрения методологии, аргументация заходит в тупик: да, исходя из имеющихся источников, англоговорящее население Британии в I тысячелетии н.э., видимо, не определяло себя как «англо-саксы», но многие исторические народы в современной историографии проходят под «псевдонимами» ${ }^{47}$, и тем самым вопрос выходит за рамки англо-саксонистики.

Проблема институциональной дискриминации гораздо сложнее и щепетильнее, поэтому мы вступаем на это поле с большой осторожностью. Насколько нам известно, на текущий момент в этой области не проводились массовые исследования, поэтому обсуждение велось в основном вокруг отдельных зафиксированных инцидентов. Их правдивость не вызывает сомнения ${ }^{48}$, и каждый случай расовой (как и любой другой) дискриминации должен быть всесторонне осуждён и требует реакции сообщества. Не разделяя имплицитного уклонения от обсуждения этой проблемы многими про-«англо-саксонистами», предлагаем, однако, вновь обратить внимание на более полную картину.

Отдельные описания подобных случаев дискриминации и иных примеров несправедливого отношения могут создать у читателя ощущение сознательной стратегии у академического «истеблишмента» ${ }^{49}$.

\footnotetext{
${ }^{44}$ Abels 2009: 1025. Схожую идею ранее высказывал А.А. Горский (2008: 25).

45 Hines et al. 2020: 4.

${ }^{46}$ Foot 2005: 129-130.

47 См., напр., схожие обсуждения таких «псевдонимов», как «Viking», «HibernoNorse» или «Anglo-Danes» (Jesch 2001: 44-54; Downham 2009).

${ }^{48}$ Напр.: Chan 2017; Pyke 2018; Sian 2019.

${ }^{49}$ Напр.: «Более всего поражает, насколько “белая” эта конференция. За исключением нескольких учёных с Дальнего Востока, почти все заявленные доклады принадлежат белым учёным» (Miyashiro 2017); «Многие годы доктор Рамбаран-Ольм безустанно работала [...], чтобы вскрыть глубоко укоренившееся белое превосходство в английском литературоведении в её области и в ISAS. Она осуществляла этот труд вопреки своей уязвимости женщины с не-белым цветом кожи в организации, настолько доминируемой “белостью” (whiteness), что та по-прежнему придерживается названия, привлекающего и придающего сил белым супрематистам» (Medievalists of Color 2019); «Дисциплину традиционно представляли белые, и неудивительно, что она по-прежнему привлекает больше белых студентов в силу заложенной в неё
} 
Ни в коей мере не оправдывая подобные ситуации, мы берём на себя смелость рассматривать их лишь как вершину айсберга, а именно печальное наследие модернистского дискурса с его расовыми предрассудками, европоцентризмом, эксплуатаций автохтонных народов, агрессивным национализмом, антигуманными социал-дарвинистскими учениями, сегрегаций, мизогинией, ксенофобией и проч. Написанная более 120 лет назад «Теория праздного класса» Т. Веблена ${ }^{50}$ предлагает не менее допустимое объяснение текущего положения дел, чем собственное толкование Рамбаран-Ольм: «...увековечиваемый ложный нарратив попрежнему стоит на пути у исследователей с не-белым цветом кожи, короче говоря, он отпугивает и их, и студентов» ${ }^{51}$. Несомненно верно её наблюдение о глубокой связи между «имплицитными предрассудками о “британских" корнях» и изучением древнеанглийского языка. Но численное преобладание белых (мужчин) может проистекать не из чьей-то злой воли, а из подспудной коллективной систематической предрасположенности, также называемой «привилегией белых» ${ }^{52}$. К этому стоит добавить, что «медиевистика - очень техническая и оттого консервативная дисциплина, требующая подготовки в древних языках и палеографии, а также других навыков» ${ }^{53}$. Приобретение подобных «непрактических» умений, или демонстративная праздность в теории Веблена, невозможно без определённого уровня экономического и социального благополучия. Отсюда понятно противостояние исторически менее представленных и более уязвимых групп этой грамшистской культурной гегемонии. Тем не менее, мы склонны видеть эту проблему как показатель гораздо более широких социальных вызовов в сфере инклюзии. Очевидно, дополнительную пищу для размышления могло бы представить исследование корреляции между словом «Anglo-Saxon» в университетских учебных программах и составом студентов этих направлений.

Апроприация лексемы «Anglo-Saxon» разного рода радикалами, к сожалению, не требует дополнительных доказательств. Перед обществом встаёт, следовательно, вопрос реакции на подобные действия. Критики непреклонны и настаивают на забвении термина, указывая на подобный прецедент с выражением «Dark Ages». Напротив, их оппо-

“белости” (whiteness)» (Rambaran-Olm 2019); «Чернокожих учёных систематически не допускали до исследования древнеанглийской литературы. Поскольку пока нет критической массы чернокожих интеллектуалов, писателей и поэтов, которые могли бы вести диалог с ранней английской литературой [...] очерк Тони Морисон о "Беовульфе" может стать первым шагом. Поскольку она пишет о "Беовульфе", расе и том, как избавиться от белого взгляда на текст, её эссе адресовано не только читателям "Беовульфа", но и английским литературоведам, которые превратили англосаксонистику в поле непрерывного белого превосходства» (Kim 2019); и т.д.

${ }^{50}$ Веблен 1984.

${ }^{51}$ Rambaran-Olm 2018.

52 См. критику этого положения: Harinam, Henderson 2019. Автор уклоняется от дискуссии о «привилегии белых», не обладая для неё достаточной компетенцией.

${ }^{53}$ Allen 2019a. 
ненты апеллируют к ответственности научного сообщества не только за общее просвещение, но и за противостояние любым попыткам злоупотреблений научными достижениями. На текущий момент, судя по всему, позиции непримиримы, поскольку у сторон просто разные повестки дня. Если Ч. Уэст считает, что: «Как бы вы ни относились к средневековой истории, она разворачивалась очень давно: она безразлична (или должна таковой быть) для современных политических вызовов.... ${ }^{54}$, то Рамбаран-Ольм с ним не согласна: «Обсуждаемый термин не нейтрален. Невозможно в принципе сохранять нейтралитет перед лицом расизма. Научная деятельность, в том числе изучение истории, никогда не может быть отделима от текущих общественных и политических реалий ${ }^{55}$.

Злоупотребление интерпретацией прошлого - отнюдь не новое явление ${ }^{56}$, и некоторое удивление вызывает фиксация исключительно на слове «Anglo-Saxon». Можно указать, например, на этноним «галлы» и его значение для французских правых с одним из их лозунгов «Nos ancêtres les Gaulois» («Наши предки галлы»), включая его использование и в политической полемике ${ }^{57}$. В XIX столетии в России развернулась полемика по печально знаменитому «варяжскому вопросу». Изначальная профессиональная дискуссия была взята на вооружение советской идеологией в 1930-1950-е гг., что, как известно, поломало не одну судьбу ${ }^{58}$ и оказалось питательной средой для современного восточнославянского шовинизма. Наконец, ни один другой термин не пострадал так сильно, как «германцы» от рук нацистских идеологов ${ }^{59}$. Однако ни «галлы», ни «варяги» или «славяне», ни «германцы» не были до сих пор изъяты из академического лексикона ${ }^{60}$. Отсюда возникает вопрос, во-первых, не станет ли подобное удаление «англо-саксов» прецедентом, и, во-вторых, не развяжет ли оно руки тем самым радикалам. С другой стороны, после выхода из научного обращения таких (псевдо)этнонимов, как «тевтоны» или «арийцы», их появление немедленно маркирует дискурс как ангажированный. Повторимся, что разнообразные этические вызовы, обнаруженные в ходе дискуссии об «Anglo-Saxon», очевидным образом выходят за рамки англо-саксонистики.

Комментаторы неоднократно отмечали размежёвывающую роль Атлантического океана в развернувшемся споре, хотя линии раскола пролегают глубже. Показательно, что стороны группируются вокруг

\footnotetext{
54 West 2019.

${ }^{55}$ Rambaran-Olm 2019.

${ }^{56}$ Wood 2007.
}

${ }^{57}$ Viallaneix, Ehrard 1982; Bernard 2017; Forcari 2006. Автор выражает признательность С. Яцык за указание на две последние публикации.

58 Детали и последствия дискуссии см., например, в: Клейн 2009 (nota bene не нейтральный взгляд автора, участника описываемых событий).

59 Тема неоднократно рассматривалась в историографии. Из недавних работ можно отметить: Hoppenbrouwers 2007.

${ }^{60} \mathrm{O}$ противоположных взглядах на применимость термина «германцы» см.: Jarnut 2004 и Pohl 2004. 
изданий той или иной направленности (см. библиографию). На этом фоне небезынтересны размышления Ч. Уэста. Он указывает, что британский политический ландшафт отнюдь не страдает от отсутствия правых радикалов, но, в отличие от США: «...ультраправые в Соединённом Королевстве и особенно Англии [...] используют в первую очередь дискурс исключительной “английскости” ${ }^{61}$. Ф. Сванберг продемонстрировал, как использование современных этнических терминов облегчает «колонизацию прошлого» ${ }^{62}$, против чего выступает, например, А. Мияширо. Дж. Молинью подверг критике вообще само представление об «Англии» как исторической онтологии до рубежа тысячелетий и особенно традиционный дискурс её «объединения» или «отвоевания» уэссекскими королями ${ }^{63}$. Д. Хадли наглядно проследила бытование «датской» идентичности в зоне скандинавского расселения (Денло ${ }^{64}$.

Сторонний наблюдатель вправе задаться вопросом, насколько безвредной в британском контексте стала бы замена «Anglo-Saxon» на предлагаемое выражение «early English». Учитывая последние исследования в области исторического этногенеза ${ }^{65}$, не станут ли «ранние англичане» не менее пагубным анахронизмом, чем «англо-саксы»? Нельзя обойти стороной и коннотации к последнему компаунду за пределами англоязычного мира, где, насколько мы можем судить, слово «англо(-)саксы», даже не являясь полностью нейтральным, тем не менее лишено выраженных расовых ассоциаций. Сообщество англосаксонистов за пределами Британии и США, естественно, находится в численном меньшинстве, однако также могло бы противостоять уже упомянутой грамшистской гегемонии, включая чьё-либо стремление регулировать словоупотребление.

\section{«Англо-саксы» - новые «германцы» или «арийцы»??}

Едва ли было бы преувеличением назвать текущее положение кризисом. Конструктивными нам представляются два идеальных сценария дальнейшего развития. В первом случае вопреки длительной традиции «англо-саксы» присоединятся к вышедшим после Второй Мировой Войны из научного оборота «тевтонам» и «арийцам» и, вероятно, останутся только в ангажированном дискурсе. С учётом ожесточённости идеологического противостояния это был бы, возможно, наименее болезненный вариант. Но в свете уже проявившейся оппозиции, «англосаксы» могли бы последовать за «германцами», сохранившими status quo лишь в профессиональном употреблении. Увы, в современных условиях обе перспективы выглядят благими пожеланиями. Более вероятно, что обнажившаяся бескомпромиссность сторон приведёт к идеологической «схизме» внутри исторического цеха.

\footnotetext{
61 West 2019.

${ }^{62}$ Svanberg 2003. См. также: Lowenthal 1985.

63 Molyneaux 2015.

${ }^{64}$ Social Identity... 2000. P. 111-135.

${ }^{65}$ Например: Стефанович 2018; Gillet 2002; Reuter 2006: 100-108.
} 
Значение любого слова - социальный конструкт и предмет договорённостей, что спор вокруг «Anglo-Saxon» дополнительно и подтвердил. Как минимум, одно положение не вызывает разногласий, а именно отторжение праворадикальных идеологий. Они «основаны на мифе, в котором вырванные термины, символы и искажённые нарративы используются для нагнетания ненависти и создания белой идентичности», пишет Рамбаран-Ольм ${ }^{66}$. Ей вторит Ч. Уэст: «...главная проблема фашистов XXI в., играющих в средневековых англо-саксов или викингов, не в том, что они неверно толкуют Беду Достопочтенного или Гильду Мудрого, а в том, что они фашисты» ${ }^{67}$. В условиях обозначившегося раскола хотя бы это согласие должно обнадёживать.

\section{БИБЛИОГРАФИЯ / REFERENCES}

\section{Источники}

Павел Диакон. История лангобардов / Пер. с лат. Ю.Б. Циркина. СПб.: Азбука-классика, 2008. 320 c. [Pavel Diakon. Istoriya langobardov / Per. s lat. Ju.B. Tsirkina. SPb.: Azbukaklassika, 2008. 320 s.].

Anglo-Saxon Charters / Ed. and transl. A.J. Robertson. Cambridge: U.P., 1956 [2011]. 555 p.

The Anglo-Saxon Minor Poems / Ed. E. van Kirk Dobbie. N.Y.: Columbia Univ. Press, 1942. 220 p. Asser's Life of King Alfred / Ed. W.H. Stevenson. Oxford: Clarendon Press, 1904. 383 p.

Cartularium Saxonicum: A Collection of Charters Relating to Anglo-Saxon History / Ed. W. de Gray Birch. Vol. I-III. L.: Whiting \& Company, 1885, 1887, 1893.

The Cult of St Swithun / Ed. M. Lapidge. Oxford: Clarendon Press, 2003. 811 p.

The Ecclesiastical History of Orderic Vitalis / Ed. and transl. M. Chibnall. Vol. II. Oxford: Clarendon Press, 1969.

The Old English Metrical Calendar (Menologium) / Ed. and transl. K. Karasawa. Cambridge: D. S. Brewer, 2015. $228 \mathrm{p}$.

The Old English Version of Bede's Ecclesiastical History of the English People / Ed. and transl. T. Miller. Vol. I. L.: N. Trübner \& Co., 1890. 488 p.

Paulus Diaconus. Historia Langobardorum / Hrgs. G. Waitz. Hannover: Impensis bibliopolii Hahniani, 1878. 268 p.

Sawyer P.H. Anglo-Saxon Charters: An Annotated List and Bibliography. L.: Offices of the Royal Historical Society, 1968. 538 p.

Wulfstan: Sammlung der ihm zugeschriebenen Homilien nebst Unterschungen über ihre Echtheit / Hrgs. A. Napier. Berlin, 1883 [1966]. 318 s.

\section{Лumepamypa}

Веблен Т. Теория праздного класса. М.: Прогресс, 1984. 367 с. [Veblen T. Teoriya prazdnogo klassa. M.: Progress, 1984. 367 s.].

Герро А. Фьеф, феодальность, феодализм. Социальный заказ и историческое мышление // Одиссей. Человек в истории. 2006. С. 77-113 [Gerro A. Fief, feodal'nost', feodalizm. Sotsialny zakaz i istoricheskoye myshleniye // Odissey. Chelovek v istorii. 2006. S. 77-113].

Горский А.А. О «феодализме»: «русском» и не только // Средние века. 2008. Т. 69. № 4. C. 9-26 [Gorskiy A.A. O «feodalizme»: russkom i ne tol'ko // Sredniye veka. 2008. T. 69. № 4. S. 9-26.].

Клейн Л.С. Спор о варягах. История противостояния и аргументы сторон. СПб.: Евразия, 2009. 400 c. [Klein L.S. Spor o varyagakh. Istoriya protivostoyaniya i argumenty storon. $\mathrm{SPb}$.: Evrasia, 2009. 400 s.].

Ладынин И.А. Концепция феодализма на древнем Востоке и работы В.В. Струве 1910-х начала 1930-х гг. // Диалог со временем. 2019. Т. 69. С. 251-267 [Ladynin I.A. Kontseptsiya feodalizma na drevnem Vostoke i raboty V.V. Struve 1910 - nachala 1930-kh gg. // Dialog so vremenem. 2019. T. 69. S. 251-267].

Стефанович П.С. Новые подходы к этничности в медиевистике: взгляд из «древнерусской перспективы» // Историческая память и российская идентичность / Под ред. В.А. Тиш-

66 Rambaran-Olm 2019.

${ }^{67}$ West 2019. 
кова, Е.А. Пивневой. М., 2018. С. 467-486 [Stefanovich P.S. Novye podkhody k etnichnosti v mevievistike: vzglyad iz «drevnerusskoj perspektivy» // Istoricheskaya pamyat' i rossijskaya identichnost' / Pod red. V.A. Tishkova, E.A. Pivnevoj. M., 2018. S. 467-486].

Филиппов И.С. Размышления о книге С. Рейнольдс «Феоды и вассалы» и её восприятии в современной медиевистике // Средние века. 2015. Т. 76. № 3-4. C. 8-57 [Filippov I.S. Razmyshleniya o knige S. Reynolds «Fiefy i vassaly» i eyo vospriyatii v sovremennoj medievistike // Sredniye veka. 2015. T. 76. S. 8-57].

Abels R. The Historiography of a Construct: "Feudalism" and the Medieval Historian // Historical Compass. 2009. Vol. 7. № 3. P. 1008-1031.

Feudalism: New Landscapes of Debate / Ed. S. Bagge, M.H. Gelting, T. Lindkvist. Turnhout: Brepols, 2011.232 p.

Bernard G. Roma Aeterna: l'Antiquité Romaine et l'Extrême Droite Française // Cahiers d'histoire. Revue d'histoire critique. 2017. T. 135. P. 147-166.

Brown E. The Tyranny of a Construct: Feudalism and Historians of Medieval Europe // The American Historical Review. 1974. Vol. 79. № 4. P. 1063-1088.

Cheyette F. 'Feudalism': A Memoir and an Assessment // Feud, Violence and Practice / Ed. B.S. Tuten, T.L. Billado. Farnham - Burlington: Ashgate, 2010. P. 119-133.

Davies R. The Medieval State: The Tyranny of a Concept? // Journal of Historical Sociology. 2003. Vol. 16. № 2. P. 280-300.

Downham C. 'Hiberno-Norwegians' and 'Anglo-Danes': Anachronistic Ethnicities and VikingAge England // Medieval Scandinavia. 2009. Vol. 19. P. 139-169.

Filippov I. The Notion of Feudalism in Russian Historiography // El temps i l'espai del Feudalisme. Reunió científica VI Curs d'Estiu. Comtat d'Urgell (Balaguer, 11, 12 i 13 de juliol de 2001) / Red. F. Sabaté, J. Farré. Lleida: Pages editors, 2004. P. 149-168.

Foot S. The Historiography of the Anglo-Saxon 'Nation-State' // Power and the Nation in European History / Ed. L. Scales, O. Zimmer. N.Y.: Cambridge Un-ty Press, 2005. P. 125-142.

Foot S. The Making of Angelcynn: English Identity before the Norman Conquest // Transactions of the Royal Historical Society. 1996. Sixth Series. Vol. 6. P. 25-49.

Foys M., Irvine S. Record of the Eighteenth Conference of the International Society of AngloSaxonists, at the University of Hawai'i at Mānoa, Honolulu, 31 July - 4 August 2017 // Anglo-Saxon England. 2018. Vol. 47. P. 1-6.

Hoppenbrouwers P. Medieval Peoples Imagined // Imagology: The Cultural Construction and Literary Representation of National Characters. A Critical Survey / Ed. M. Beller, J. Leerssen. Amsterdam: BRILL, 2007. P. 45-61.

Jarnut J. Germanisch. Plädoyer für die Abschaffung eines obsoleten Zentralbegriffes der Frühmittelalterforschung // Die Suche nach den Ursprüngen. Von der Bedeutung des frühen Mittelalters / Hrgs. W. Pohl. Wien: Verlag der Österreichischen Akademie der Wissenschaften, 2004. S. 107-113.

Jesch J. Ships and Men in the Late Viking Age: The Vocabulary of Runic Inscriptions and Skaldic Verse. Woodbridge: The Boydell Press, 2001. 330 p.

Karkov C. Imagining Anglo-Saxon England: Utopia, Heterotopia, Dystopia. Woodbridge: The Boydell Press, 2020. 282 p.

Lavelle R., Roffey S. West Saxons and Danes: Negotiating Early Medieval Identities // Danes in Wessex / Ed. R. Lavelle, S. Roffey. Oxford - Philadelphia: Oxbow Books, 2016. P. 7-35.

Lowenthal D. The Past is a Foreign Country. Cambridge: C.U.P., 1985. 489 p.

Molyneaux G. The Formation of the English Kingdom in the Tenth Century. N.Y.: Oxford University Press, 2015. 302 p.

Niles J. Appropriations: A Concept of Culture // Anglo-Saxonism and the Construction of Social Identity / Ed. A. Frantzen, J. Niles. Gainesville: Un-ty Press of Florida, 1997. P. 202-228.

Niles J. The Idea of Anglo-Saxon England 1066-1901. Chichester: John Wiley\&Sons, 2015. 425 p.

Nos ancêtres les Gaulois: Actes du Colloque International de Clermont-Ferrand 23-25 juin 1980 / Éd. par P. Viallaneix, J. Ehrard. Clermont-Ferrand: Faculté des lettres et sciences humaines, 1982. $492 \mathrm{p}$.

On Barbarian Identity: Critical Approaches to Ethnicity in the Early Middle Ages / Ed. A. Gillett. Turnhout: Brepols, 2002. 265 p.

Pohl W. Vom Nutzen des Germanenbegriffs zwischen Antike und Mittelalter: Eine forschungsgeschichtliche Perspektive // Akkulturation. Probleme der germanisch-romanischen Kultursynthese in Spätantike und frühem Mittelalter / Hrgs. D. Hägermann, W. Haubrichs, J. Jarnut. Berlin: Walter de Gruyter, 2004. S. 18-34. 
Pyke K. Institutional Betrayal: Inequity, Discrimination, Bullying, and Retaliation in Academia // Sociological Perspectives. 2018. Vol. 61. № 1. P. 5-13.

Rambaran-Olm M. Trial History's Jury: Examining II Æthelred's Legislative and Literary Legacy, AD 993-1006 // English Studies. 2014. Vol. 95. № 7. P. 777-802.

Reuter T. Medieval Polities and Modern Mentalities / Ed. J. Nelson. N.Y.: Cambridge University Press, 2006. 483 p.

Reynolds S. Fiefs and Vassals: The Medieval Evidence Reinterpreted. Oxford: Clarendon Press, 1994. $554 \mathrm{p}$.

Sayer D. et al. Iron Age and Anglo-Saxon Genomes from East England Reveal British Migration History // Nature Communications. 2016. Vol. 7.

Shippey T. The Undeveloped Image: Anglo- Saxon in Popular Consciousness from Turner to Tolkien // Literary Appropriations of the Anglo- Saxons from the Thirteenth to the Twentieth Century / Ed. D. Scragg, C. Weinberg. Cambridge: C.U.P., 2000. P. 215-236.

Social Identity in Early Medieval Britain Studies in the Early History of Britain / Ed. W.O. Frazer, A. Tyrrell. L.; N.Y.: Leicester University Press, 2000. 283 p.

Svanberg F. Decolonizing the Viking Age 1. Stockholm: Almqvist \& Wiksell International, 2003. 217 p.

Timofeeva O. Of Ledenum Bocum to Engliscum Gereorde: Bilingual Communities of Practice in Anglo-Saxon England // Communities of Practice in the History of English. 2013. Vol. 235. P. 201-224.

Wilton D. What Do We Mean by Anglo-Saxon? Pre-Conquest to the Present // The Journal of English and Germanic Philology. 2020. Vol. 119. № 4. P. 425-456.

Wood I. The Use and Abuse of the Early Middle Ages // The Making of the Middle Ages: Liverpool Essays / Ed. M. Costambeys, A. Hamer. Liverpool: University Press, 2007. P. 36-53.

\section{Материаль Интернета}

Allen Ch. In the Academic Sandox // First Things. June 2019. URL: https://www.firstthings.com/article/2019/06/in-the-academic-sandbox (a).

Allen Ch. Higher Education's Medievalist Moral Panic // Quillette. 22.10.2019. URL: https://quillette.com/2019/10/22/higher-educations-medievalist-moral-panic (b).

Dictionary of Medieval Latin from British Sources // Database of Latin Dictionaries / compiled by Richard Ashdowne, David Howlett, R.E. Latham, with Tom Wrobel. [Brepols: Turnhout, 2015]. URL: http://clt.brepolis.net/dmlbs

Dictionary of Old English Web Corpus // Dictionary of Old English Project / comp. by Antonette diPaolo Healey, J. Price Wilkin, Xin Xiang. Toronto, 2009. URL: https://www.doe.utoronto.ca

Bridge M. Drop the Term Anglo-Saxon as it is 'Bound up with White Supremacy', Say Academics // The Times. 08.11.2019. URL: https://www.thetimes.co.uk/article/drop-theterm-anglo-saxon-as-it-is-bound-up-with-white-supremacy-say-academics-d66dlztfj

Chan J. Medievalists, Recoiling From White Supremacy, Try to Diversify the Field // The Chronicle of Higher Education. 07.7.2017. https://www.chronicle.com/article/MedievalistsRecoiling-From/240666

Dockray-Miller M. The Massachusetts Medievalist Thinks about the Power Dynamics of "Anglo-Saxon" // The Massachusetts Medievalist. 17.12.2019. URL: https://mdockraymiller. hcommons.org/2019/12/17/the-massachusetts-medievalist-thinks-about-the-powerdynamics-of-anglo-saxon

Elmes M. SMFS Statement in Support of Dr. Mary Rambaran-Olm // Society for Medieval Feminist Scholarship. 16/17.9.2019. URL: http://smfsweb.org/\%EF\%BB\%BFsmfsstatement-in-support-of-dr-mary-rambaran-olm

Flaherty C. It's About More Than a Name // Inside Higher Ed. 20.9.2019. URL: https://www.insidehighered.com/news/2019/09/20/anglo-saxon-studies-group-says-it-willchange-its-name-amid-bigger-complaints-about

Forcari Ch. L'extrême droite célèbre la défaite de Bleus trop noirs // Liberation. 12.7.2006. URL: https://www.liberation.fr/france/2006/07/12/l-extreme-droite-celebre-ladefaite-de-bleus-trop-noirs_45857

Harinam V., Henderson R. Why White Privilege is Wrong // Quillette. 19.8.2019. URL: https://quillette.com/2019/08/22/why-white-privilege-is-wrong-part-1/

Hines J. et al. The Responsible Use of the Term 'Anglo-Saxon' // A Forum for Multidisciplinary Anglo-Saxon Studies. 03.1.2020. URL: http://www.fmass.eu/uploads/pdf/responsible_use_of $\% 20$ the\%20term\%20_Anglo-Saxon.pdf 
Kim D. The Question of Race in Beowulf // JSTOR Daily. 22.9.2019. URL: https://daily.jstor.org/the-question-of-race-in-beowulf

Lomuto S. Public Medievalism and the Rigor of Anti-Racist Critique // In the Medieval Middle. 04.4.2019. URL: http://www.inthemedievalmiddle.com/2019/04/public-medievalism-andrigor-of-anti.html

Statement of Support for Dr. Mary Rambaran-Olm // Medievalists of Color. 10.9.2019. URL: https://medievalistsofcolor.com/race-in-the-profession/statement-of-support-for-dr-maryrambaran-olm

Miyashiro A. Decolonizing Anglo-Saxon Studies: A Response to ISAS in Honolulu // In the Medieval Middle. 28.7.2017. URL: http://www.inthemedievalmiddle.com/2017/07/decolonizinganglo-saxon-studies.html

Natanson H. 'It's all white people': Allegations of White Supremacy are Tearing Apart a Prestigious Medieval Studies Group // Washington Post. 19.9.2019. URL: https://www.washingtonpost.com/education/2019/09/19/its-all-white-people-allegationswhite-supremacy-are-tearing-apart-prestigious-medieval-studies-group

Rambaran-Olm M. Anglo-Saxon Studies [Early English Studies], Academia and White Supremacy // Medium. 27.7.2018. URL: https://medium.com/@mrambaranolm/anglosaxon-studies-academia-and-white-supremacy-17c87b360bf3

Rambaran-Olm M. Misnaming the Medieval: Rejecting "Anglo-Saxon" Studies // History Workshop. 04.11.2019. URL: http://www.historyworkshop.org.uk/misnaming-the-medievalrejecting-anglo-saxon-studies

Sian K. Racism in UK Universities is Blocking BAME Academics from the Top // The Guardian. 10.7.2019. URL: https://www.theguardian.com/education/2019/jul/10/racism-inuk-universities-is-blocking-bame-academics-from-the-top

Stephenson R. Message from the Advisory Board (19 Sept. 2019) // International Society for the Study of Early Medieval England. 19.9.2019. URL: http://www.isasweb.net/AB091919.html

West Ch. Reflections on the 'Anglo-Saxon' Debate // Turbulent Priest. 11.11.2019. URL: http://turbulentpriests.group.shef.ac.uk/reflections-on-the-anglo-saxon-debate

Williams H. Should 'British Archaeology' Stop Using 'Anglo-Saxon'? // ARCHAEOdeath. 12.12.2019. URL: https://howardwilliamsblog.wordpress.com/2019/12/12/should-britisharchaeology-stop-using-anglo-saxon

Wood M. As a Racism Row Rumbles on, Is it Time to Retire the Term ‘Anglo-Saxon'? // History Extra. 04.11.2019. URL: https://www.historyextra.com/period/anglo-saxon/professormichael-wood-anglo-saxon-name-debate-is-term-racist

Young H., Caliendo K. The Monster They Have Created: Tone-Policing, Victim Blaming, and the Toxicity of White Medieval Studies // In the Medieval Middle. 14.10.2019. URL: http://www.inthemedievalmiddle.com/2019/10/the-monster-they-have-created-tone.html

Сухино-Хоменко Денис Владимирович, аспирант, Институт исторических исследований, Университет Гётеборга (Швеция); denis.sukhino-khomenko@gu.se

\section{The "Anglo-Saxon schism": a terminological discussion in the Anglophone mass media and current challenges to the medieval academic community}

The article aims at summarizing the recent debate concerning the term 'Anglo-Saxon' in the academic discourse. Following the resignation of Dr Mary Rambaran-Olm from the (former) International Society of Anglo-Saxonists in September 2019, the English-speaking medieval scholarly community split into critics of the continuous use of 'Anglo-Saxon' and its defenders. The former appeal to the term's racist connotations and misuse, the latter point out the historical adequacy and long-standing tradition. The divide has a lot to do with geography and regional public discourses. No reconciliation seems likely in the nearest future.

Keywords: historiography, Anglo-Saxon, medieval studies, racial discourse, discrimination, ideology, cultural hegemony

Denis Sukhino-Khomenko, PhD-student at the Department of Historical Studies, University of Gothenburg (Sweden); denis.sukhino-khomenko@gu.se 


\section{Л.К. НОВОСЕЛЬЦЕВА \\ ОСМЫСЛЕНИЕ НАЦИОНАЛЬНОГО ОПЫТА ВЗАИМОДЕЙСТВИЯ С ВЕНГЕРСКИМИ ПОЛИТИЧЕСКИМИ ЭЛИТАМИ В СЕРБСКОЙ ЛИБЕРАЛЬНОЙ ПУБЛИЦИСТИКЕ (1861-1872)1}

Национальная самоорганизация сербов в Австрийской монархии с 1690 по 1867 гг. претерпела значительные изменения в ходе взаимодействия с венгерскими элитами. В статье показано, как затяжной сербо-мадьярский конфликт при вмешательстве в него австрийских властей сформировал стратегию выживания в условиях полиэтничного государства и политическую культуру сербов, базировавшуюся на устойчивой антипатии к осуществляемой концепции развития в Венгерском королевстве единой политической нации. Представлен новый взгляд на мобилизацию сербского сообщества в условиях принудительной интеграции, наиболее действенными средствами которой являлись популяризация травмирующего опыта взаимоотношений с титульным этносом и его стигматизация путем применения «языка вражды» в пропагандистской компании, развернутой сербскими либералами в 1866-1872 гг.

Ключевые слова: этнические стереотипь, «язык вражды» в прессе, сербское национальное движение в монархии Габсбургов, венгерская супремачия

Использование манипулятивных приемов в медиа - одна из наиболее разрабатываемых тем в психологии, социологии и лингвистике. К ней все чаще обращаются и историки, рассматривая процессы воздействия на массовое сознание в прессе, в т.ч. в контексте формирования наций в моно- и полиэтничных государствах. Особый интерес вызывает проблема использования этнических стереотипов в национальной пропаганде, когда исторический материал позволяет провести лонгитюдное исследование их формирования и функционирования в рамках определенного этнического сообщества. Кроме того, стереотипы определяют характер коммуникации, основанной на предубеждении и дискриминации, наиболее яркой формой которой является т.н. «язык вражды» ${ }^{2}$. Такие тексты появились в раннее Новое время, их широкое распространение в XIX в. было связано с развитием «печатного капитализма», позволявшего транслировать информацию на массового адресата ${ }^{3}$.

Показателен пример многонациональной монархии Габсбургов в силу различного опыта взаимодействия народов, населявших владения Австрийского дома. Если рассматривать Соглашение (Ausgleich) 1867 г. как механизм/алгоритм урегулирования межнациональных отношений, то сосредоточение на компромиссе между правящей династией и венгерской политической элитой уводит от ключевого для композитарной

\footnotetext{
${ }^{1}$ Работа выполнена в рамках проекта РФФИ № 19-59-23005 «Монархия Габсбургов: новые направления в изучении экономического, социально-политического и национального развития композитарного государства Центральной Европы».

2 Подробно об определении см.: Гладилин 2013.

${ }^{3}$ Евстафьева 2009: 3.
} 
монархии вопроса: как реагировали на конституционные преобразования в государстве привилегированные слои «малых народов». Будучи не менее истеблишмента заинтересованными в стабильном развитии Отечества, политические элиты этнических меньшинств не преминули воспользоваться призрачной возможностью повлиять на ход переговоров будущих титульных наций Австро-Венгрии и упрочить свои позиции в двуедином государстве. Разочаровавшее их в итоге Соглашение 1867 г. стало отправной точкой для разработки новых национальных программ.

Сербское сообщество в 1866 г. фактически вернулось к своей проверенной стратегии: с момента массового переселения в 1690 г. из Османской империи на территорию Венгерского королевства оно пыталось узаконить свой этнический статус. Обновление алгоритмов взаимодействия с властями было связано с деятельностью политиков либерального толка во главе со Светозаром Милетичем (1826-1901), разработавших программы переустройства монархии Габсбургов с учетом интересов нетитульных наций, в первую очередь самих сербов. Либералы первыми уловили необходимость привлечения масс в борьбу за национальные интересы. С этой целью Милетичем в 1866 г. была основана газета «Застава» («Знамя»), в которой помимо информационно-разъяснительного публиковался и агитационный материал с призывами к читателям поддержать либеральное крыло сербского политического спектра в борьбе за национальные права в Венгерском королевстве. Пропагандистская программа базировалась на использовании стереотипных когнитивных схем, негативных установок и предубеждений. Важно отметить, что в сербской прессе речь не шла о бытовой дискриминации мадьяр ${ }^{4}-$ стигматизации были подвергнуты единая и неделимая венгерская нация (natio Hungarica) и политическая элита как ее воплощение.

В статье на примере взаимодействия сербского сообщества монархии Габсбургов с венграми (при вмешательстве австрийских правящих кругов) рассматривается, как возникали и функционировали в пропаганде стереотипы об инонациональной политической власти в условиях полиэтнического государства. Задача исследования - проследить этапы взаимоотношений с конца XVII в., выделить фазы сближения и прямого столкновения, которые по-разному были зафиксированы и интерпретированы в исторической памяти народов, что стало почвой для формирования взаимных предубеждений. Особого внимания заслуживают проекты сербских либералов по мирному урегулированию конфликта в начале 1860-х гг., спровоцированного упразднением провинции Сербская Воеводина и Темешский Банат и возвратом этой территории венгерской короне, а также серия статей антивенгерской тематики, опубликованная в печатном органе Либеральной партии газете «Застава» ввиду отсутствия компромисса между противодействующими сторонами.

\footnotetext{
${ }^{4}$ В статье термином «венгры» обозначаются все жители Венгерского королевства (подданные венгерского короля), «мадьярами» называются этнические венгры.
} 


\section{«Привилегии» сербам и венгерская конституция}

Вызванная войнами «Священной лиги» и освобождением Среднего Подунавья от османов в ходе кампании 1683-1699 гг. масштабная миграция сербов во главе с патриархом Арсением III Черноевичем (1633-1706) в 1690 г. на территорию владений Австрийского дома стала причиной глобальных изменений в запустевшей Южной Венгрии. Беженцы составили значительную часть населения и должны были нести пограничную службу и способствовать экономическому восстановлению региона. Статус сербского народа, регулируемый согласно манифесту «Litterae invitatorie» (6 апреля) и дарованными императором-королем Леопольдом I (1654-1705) «Привилегиями сербам» (1690, 16911695 гг.), стал сложным вопросом сразу же после первой волны переселения народных масс из-за Дуная и Савы. «Привилегии» предоставляли сербам право исповедовать православие и придерживаться юлианского календаря, свободно и самостоятельно выбирать архиепископа с соответствующими полномочиями, а также гарантировали защиту от посягательств иных светских и церковных властей, что было закреплено в отдельном «охранительном дипломе» 1695 г. Как отмечает Т.А. Лебер: «Основной задачей данного документа было донести волю императора до венгерских властей и избежать (или снизить напряженность существующих) конфликтов между сербами и светскими и церковными властями Венгерского королевства» ${ }^{5}$. Привилегии 1690 и 1691 гг. были адресованы Леопольдом I патриарху Черноевичу и подтверждены Венгерской королевской канцелярией, но при этом силу закона на землях короны св. Стефана не получили, поскольку решение императора-короля так и не было одобрено венгерскими сословиями, которые стремились отнести сербов к компетенции Государственного собрания и превратить их в кметов. Присоединилась к этому процессу и католическая церковь, насильно обращая православное население в униатство и требуя уплаты обязательной десятины. Сербы сопротивлялись натиску, уповая на защиту императора, считая, что они добровольно подчиняются только династии. Не имея атрибутов государственности, они сохранили память о средневековой сербской державе, а вместе с ней и политические воззрения о неограниченности власти монарха, который один был источником национальных прав ${ }^{6}$. Впоследствии в сербской политической культуре сложилась когнитивная схема о том, что заступничество Габсбургов в любой ситуации позволит им «обойти» венгерский закон.

Первые столкновения с венгерскими властями сподвигли сербов на требования отдельной национальной территории в рамках монархии Габсбургов, основанием для получения которой они считали привилегии. Переселенцы воспринимали дипломы Габсбургов как гарантию лучшей жизни и особого статуса в государстве. Центральное правитель-

\footnotetext{
5 Лебер 2016: 120-121.

${ }^{6}$ Einrichtungswerk 2010.
} 
ство в свою очередь постепенно сужало круг вопросов, регулируемых привилегиями, и окончательно трансформировало их в формат церковно-школьной автономии в правление Марии Терезии (1740-1780) и Иосифа II (1780-1790). Сербы, сопротивляясь переменам, все же не рисковали кусать «кормящую руку» Вены и провоцировать новые санкции, источник своих бед они видели в кознях венгерских сословий, хотя те могли повлиять на сокращение сербских привилегий лишь косвенно ${ }^{7}$.

Развитие венгерского национального движения на рубеже 1780 1790-х гг. принесло кардинальные изменения в статусе сербского населения королевства. В условиях очередной массовой миграции соплеменников в ходе австро-турецкой войны (1787-1791), сербы вновь подняли вопрос о ратификации габсбургских дипломов Государственным собранием Венгрии и закреплении их в ранге закона, что означало бы признание их «исторических прав» на землях короны св. Стефана. Но очередное вмешательство Вены изменило ход событий: одобрив проведение сербского сабора в Темешваре в августе 1790 г. до дозволения этого мероприятия венгерскими властями и придав ему явно антимадьярский характер, австрийские власти попытались изменить соотношение сил в королевстве. Из затребованных условий, а именно территориальной автономии под личным управлением Габсбургов, гарантий безопасности сербского населения и создания национального органа управления в государственном аппарате, удовлетворено было последнее в виде создания Иллирской придворной канцелярии, поскольку выполнение других условий означало бы нарушение договоренностей династии с венгерскими сословиями. Компромисс 1791 г. повлиял на решение сербского вопроса: Государственное собрание предоставило сербам гражданские права в королевстве, включая свободное использование привилегий 1690 г., касавшихся церковной иерархии в той мере, в какой это не противоречило венгерскому законодательству ${ }^{8}$. Логично предположить, что с точки зрения венгерских сословий, вернувшихся после краха йозефинизма (как принято именовать программу преобразований Иосифа II) к прежним политико-нравственным и культурным ценностям, предоставление гражданских прав значительно улучшило положение сербов, поскольку те, выйдя из-под опеки Вены, оказались под покровительством «святой короны» и должны были ощутить дух «святой Свободы» 9 .

Игнорирование первой сербской национальной программы, разработанной на Темешварском саборе и бескомпромиссность Государственного собрания в нежелании признать за привилегиями Габсбургов силу закона о нации разрушило иллюзию об исключительности сербов, поддерживаемую Габсбургами по мере необходимости использования

\footnotetext{
${ }^{7}$ Костяшов 1997: 79.

${ }^{8}$ Краткая история Венгрии 1991: 161; Шемякин 2004: 295; Костяшов 1997: 87.

${ }^{9}$ Подробнее: Хаванова 2000: 56.
} 
этого народа в качестве «самой дешевой» армии или противовеса антиавстрийским настроениям Венгерском королевстве. Посчитавшие такую позицию оскорблением православные иерархи выступили главными выразителями и вдохновителями стойкого предубеждения против венгерской политической элиты в сербской среде ${ }^{10}$. Митрополит и несколько епископов, единственные представители народа в Государственном собрании, принимали участие в заседаниях его верхней палаты. Однако их деятельность, ориентированная на восстановление полагающихся привилегий, была мало результативной, поскольку в условиях «эпохи реформ» (1825-1848) рассматривалась венгерской политической элитой как анахронизм. Как полагает сербский историк 3. Джере, венгерские либералы имели лишь общие представления об этнической структуре страны и, не осознавая глубину и сложность национального вопроса в королевстве, в духе романтизма считали, что его возможно разрешить интеграцией немадьярских народов в единую гражданскую венгерскую нацию ${ }^{11}$. «Позиционная война мнений» вылилась в открытое кровопролитное противостояние в годы революции и национальноосвободительной войны 1848-1849 гг.

\section{Сербские либералы и венгерский либерализм}

Программа венгерского правительства сокрушила чаяния немадьярских народов королевства, поскольку революционные лидеры отклонили даже самые скромные требования, посчитав их угрозой целостности страны. Сербо-венгерские переговоры завершились фактически объявлением войны: революционеры сочли требования сербов изменой «святой короне» и были намерены пресечь распространение национального движения, основной силой которого стала торгово-ремесленная буржуазия, ранее не игравшая существенной роли в политике. Сербы не скрывали в ответ полуторавековой неприязни: «Во всем, что плохого случалось с сербами за это столетие, виноваты венгры; в том, что народ страдает под феодальным гнетом, виноваты венгры, что граница (военная - Л.Н.) в тисках, виноваты венгры, и даже в том, что натворил Меттерних, виноваты венгры» ${ }^{12}$. Шанс на осуществление своих национальных чаяний они увидели в очередном обещании Габсбургов и участии в подавлении революции «оголтелых мадьяр» ${ }^{13}$. Австрийские власти не преминули воспользоваться этой возможностью. Согласно патенту императора Франца Иосифа I (1848-1916) от 18 ноября 1849 г. из бывших южно-венгерских комитатов, включающих территории Баната, Бачки и части Срема, была сформирована провинция Сербская Воеводина и Темешский банат с центром в г. Темешвар (совр. Тимишоара в Румынии) ${ }^{14}$.

\footnotetext{
${ }^{10}$ Срби 2016: 361-362.

11 Ђepe 2009: 89.

12 Игњатовић 1966: 148-149.

${ }^{13}$ Стратимировић 1848 .

${ }^{14}$ Cp.: Clewing 2005.
} 
Это была своеобразная награда от Вены за верную службу в годы революции, так как сербы получили меньшую, чем требовали, территорию, где они не составляли большинства населения, и церковную, но не национальную автономию. Удивительно, но «баховский» (по имени министра внутренних дел Александра Баха) абсолютизм способствовал сербо-венгерскому сближению, так как оба народа в равной мере столкнулись с политикой централизации и германизации, проводимой венским двором ${ }^{15}$. Кроме того, широко распространилось «запоздалое» мнение о том, что, поддержав венгерскую революцию, сербы добились бы больших успехов в реализации своих национальных прав ${ }^{16}$.

В 1860 г. для урегулирования отношений с венграми австрийские власти упразднили провинцию Сербская Воеводина и Темешский Банат. Это поставило перед сербами задачу разработать программу национальной автономии в рамках обновленной монархии Габсбургов, поскольку, как выразился бывший королевский комиссар, венгерский политик сербского происхождения Петар Черноевич (1810-1892): «У сербов и венгров одна судьба - быть несчастными до тех пор, пока не договорятся» ${ }^{17}$. На фоне сербо-венгерского сближения в годы неоабсолютизма финальным аккордом существования национального мифа о всесилии императора была программа сербского консервативно-клерикального течения в первой половине 1860 -х гг. и обращение к авторитету Франца Иосифа. В условиях переустройства монархии Габсбургов на принципах дуализма «всемилостивейший государь» сербов не защитил, а иерархи и светские политики лишились поддержки народных масс за свои неуместные верноподданнические убеждения, так как большинство населения Воеводины поддерживало союз с венграми ${ }^{18}$.

Возглавляемые С. Милетичем сербские либералы всерьез надеялись на сотрудничество и поддержку венгров, за что заслужили от оппонентов ярлык «мадьяронов» ${ }^{19}$. Михаил Полит-Десанчич (1833-1910) в 1861 г. представил свой проект преобразований монархии Габсбургов в цикле статей о проблемах национальностей в Венгерском королевстве, опубликованных по-немецки в журнале «Ost und West» («Восток и Запад»), а также на страницах газеты «Србски дневник» («Сербский ежедневник» $)^{20}$. Идею о преобразовании Австрийской монархии в преимущественно славянскую страну Полит считал утопией ${ }^{21}$, потому его про-

\footnotetext{
15 Deák 2008; Политические партии 2018: 43-50.

16 Полит-Десанчић 1883: 2.

17 Ђepe 2000: 243.

${ }^{18}$ Новосельцева 2018.

${ }^{19}$ Мадьяроны - представители немадьярских народов (хорваты, сербы, словаки), связывавшие развитие своего народа с венгерской политической нацией.

${ }^{20}$ Материал статей был позднее переработан автором в брошюру «Этнос и его национально-правовая основа», изданную на немецком и сербском языках в 1862 г.

${ }^{21}$ Микавица 2007: 60.
} 
ект был больше ориентирован на преобразования в Венгерском королевстве. Не рассматривая привилегии Габсбургов как единственный источник коллективных прав сербов, автор полагал, что решение национального вопроса возможно в условиях компромисса венгров с немадьярскими народами, которых он призывал не возлагать больших надежд на династию, поскольку сербский опыт сотрудничества с двором стал «одним большим разочарованием» ${ }^{22}$. Разработанная Политом программа преобразований предполагала расширение прав комитатов Венгрии до статуса, сопоставимого со швейцарскими кантонами: ведь в стране, где титульная нация составляет едва ли треть всего населения, должны быть обеспечены индивидуальные права каждой народности, что достигается национальным самоуправлением конкретной области ${ }^{23}$. Согласно этой концепции, немадьярские народы королевства могли получить национальную автономию, не нарушая единства земель короны св. Стефана, поскольку, по мнению автора, народы в Венгрии в меньшей степени рассредоточены по территории страны и в большей степени консолидированы духовно, чем в Швейцарии. Согласно его плану, области Бачка и Банат, заселенные преимущественно сербами, могли бы объединиться в Воеводину, которая по своему статусу являлась бы крупным комитатом ${ }^{24}$, но не провинцией, чего опасались венгерские политики. Обеспокоенность венгерской элиты наиболее четко в 1862 г. сформулировал находившийся в эмиграции Лайош Кошут (1802-1894), который утверждал: на такое решение можно пойти только в крайнем случае, «если с ними не договориться по-другому, но такое развитие событий стало бы национальной бедой» ${ }^{25}$. Полит считал эти страхи необоснованными, поскольку основной закон и границы местного самоуправления определялись бы Государственным собранием с пропорциональным национальным представительством. Впрочем, он отмечал, что для венгерских политиков одно название «Воеводина» звучало как угроза единству королевства ${ }^{26}$, хотя считал, что идея ее воссоздания не противоречила стремлениям Пешта обновить конституционный порядок и декларировать новое государственно-правовое устройство Венгрии.

В 1861 г. по предложению Йожефа Этвеша (1813-1871) Государственное собрание избрало 15 депутатов-венгров и 12 - из представителей немадьярских народов королевства, поручив им разработку проекта закона о национальностях. Комиссия, однако, могла рекомендовать лишь такие предложения о расширении национальных прав, которые были совместимы с целостностью государства, т.е. не выходя за рамки цер-

${ }^{22}$ Срббски дневник, 30.06.1861. № 55.

${ }^{23}$ Полит-Десанчић 1883: 7.

${ }^{24}$ Комитат - не только основная административно-территориальная единица королевства, но и символ венгерского доминирования, и оплот противостояния централизаторским устремлениям Вены.

${ }^{25}$ Katus 2000. 14. old.

${ }^{26}$ Милутиновић 1936: 54-55. 
ковно-школьной автономии. В основу курса Пешта лег принцип, гласивший что в политическом отношении все граждане королевства независимо от происхождения составляют единую и неделимую нацию, соответствующую историческому понятию и смыслу венгерского государства $^{27}$. Полит считал, что «генетическая идентификация мадьярского народа с венгерской государственностью» ${ }^{28}$, есть главное заблуждение политической элиты, поскольку только консолидация всех народностей королевства на высшем уровне могла обеспечить целостность государства и предотвратить его распад ${ }^{29}$. С роспуском парламента 22 августа 1861 г. разработка нового национального законодательства была приостановлена и возобновлена только в 1866 г. в изменившихся условиях. Венгерские либералы, оказавшиеся у руля власти, предпочли включить разрешение конфликта с немадьярскими народами в сложный комплекс разногласий, которые необходимо было преодолеть на пути к Соглашению 1867 г. с австрийской частью монархии. Компромисс с Веной в будущем обеспечивал венграм супремацию (превосходство) в политической, экономической и культурной сферах жизни королевства.

Автором обновленной программы сербского национального движения выступил Милетич. Согласно плану, «монархия Габсбургов будет разделена на две государственные единицы, каждая из которых будет организована на федеральной основе, и каждая из них будет предоставлять автономию, проживающим в ней народностям» ${ }^{30}$. В каждой федерации Милетич признавал ведущую роль немцев и мадьяр в политической сфере. Для сербов в Венгрии он не требовал ничего больше отдельного комитата с преобладанием сербского населения, где действовала бы административная автономия с гарантиями национальных прав, а другим народам обеспечивалось бы гражданское и национальное равноправие $^{31}$. Стратегия сербских либералов во время подготовки австровенгерского Соглашения базировалась на высказывании С. Милетича: «Мы и сербы, и граждане», и представляла собой в большей степени лавирование между этими условиями. По мнению Милетича, существование единого «венгерского народа» на внутриполитической сцене уникальный в отрицательном смысле случай. Он был бы согласен, если бы эта конструкция функционировала как в Великобритании: шотландцы, ирландцы внутри страны являются британцами вне ее пределов. Ссылаясь на то, что принципы «сuius regio eius religio» («чья страна, того и вера») и «сujus nominis regio, ilivit [sic!] nominis et natio» («кто дал имя стране, тот дал его и народу») устарели, Милетич предлагал заменить

\footnotetext{
${ }^{27}$ Исламов 1967: 240.

${ }^{28}$ Polit // Ost und West. 1861. № 94.

${ }^{29}$ Полит-Десанчић 1862: 40.

${ }^{30}$ Светозар Милетић и Народна странка: 113.

${ }^{31}$ Попов 1997: 41.
} 
формулировку «венгерский народ» на «народ страны» и таким образом привнести в соглашение долю федерализма ${ }^{32}$. Указывая на то, что судьба Венгрии зависит от славян, он посоветовал парламенту внести ряд изменений в свои планы. Ференц Деак (1803-1876) в феврале 1866 г. на заседании Государственного собрания выступил с непримиримой позиции, указав, что политическая элита Венгрии возражает против переустройства земель короны св. Стефана и может наложить вето на попытки добиться реформирования со стороны немадьяр.

Стратегия сербского либерального течения развернулась от сотрудничества к открытой вражде с венграми, поэтому возникла необходимость переориентировать сочувствующую аудиторию с помощью, говоря современным языком, политических технологий, в частности путем открытой антивенгерской пропаганды в прессе. На наш взгляд, для интерпретации сложившейся коллизии между сербскими либералами и венгерской политической элитой, применимы идеи социолога С. Бенеш $^{33}$. Согласно ее концепции, обращение к «языку вражды» в этой ситуации стало закономерным, так как было обусловлено изменением политических условий в связи с переустройством монархии Габсбургов на дуалистических началах, когда было нарушено иллюзорное равенство венгров и сербов, достигнутое в годы неоабсолютизма и подпитываемое скорее дежурным интересом венгерского истеблишмента к проектам преобразований в королевстве, разработанным воеводинскими либералами. Новый опыт взаимодействия сербского сообщества с венгерскими властями показал, что те не склонны к компромиссам, как и в 1790 г., и в 1848-1849 гг. Такая позиция объяснялась тем, что мадьяры создали эту державу и веками обороняли ее от многочисленных захватчиков. Наделение немадьяр автономией в рамках королевства означало бы утрату его венгерского характера и угрозу его существованию ${ }^{34}$. Однако сербская либеральная пресса через призму стереотипов представила иной образ венгерской политической элиты, как источник этих убеждений.

\section{«Язык вражды» в сербской либеральной пропаганде}

В связи с этим особого внимания заслуживают статьи политика и поэта Лазы Костича (1841-1910), опубликованные в газете «Застава». Привлечение Костича как одного из основных авторов, по мнению историка М. Лесковца, было обусловлено тем, что ни главный редактор издания Милетич, ни ведущий теоретик партии Полит-Десанчич не обладали достаточным литературным талантом, чтобы доступно излагать актуальную информацию и расширять читательскую аудиторию ${ }^{35}$.

Дебютной публикацией Костича стал фельетон «Мадьярский мир наступает. Сверху и снизу. Внизу, кстати, кто-то бунтует. Уведомляем!» в номере от 16 февраля 1866 г., содержание которого было призвано

\footnotetext{
32 Застава. 1866, № 2.

${ }^{33}$ Benesch 2012.

${ }^{34}$ Szalay 1862: 147.

${ }^{35}$ Костић 1990: 10.
} 
убедить читателей, главным образом венгерских политиков, в необходимости уступок немадьярским народам, и сербам, в частности. Автор начал повествование с занимательного каламбура: он обратился к чтению газеты «Magyar világ» («Венгерский мир») и задумался, как правильно перевести венгерское слово «világ». В первую очередь ему на ум пришло сербское слово «свет» - «мир», но тут же вспомнил, что у слова «свет» есть созвучное «освета» - «месть». Костич продолжил в метафорическом ключе. Опираясь на содержание статей в «Magyar világ» он высказал ряд претензий «мадьярскому миру». В первую очередь он пояснил, что имел в виду под наступлением сверху и снизу. Сверху «мадьярский мир» наступал на немцев. Костич обвинил венгерскую политическую элиту в гипертрофированной эксплуатации проблем Австрии и Габсбургов в свою, «великомадьярскую» пользу ${ }^{36}$. Внизу были немадьярские народы королевства, на которых мадьяры наступали, заручившись поддержкой Вены. Но, с другой стороны, он сравнил все «угнетаемые» народы монархии Габсбургов с плотным слоем пороха, и если не найдется «факела», то сербы, по крайней мере, либеральное крыло, согласны сыграть эту ответственную роль ${ }^{37}$. Фельетон - пример коммуникации на основе предубеждения и дискриминации, которая реализуется в речевом жанре порицания как в завуалированной, так и в открытой форме. В качестве кульминации статьи Костич предложил своеобразную метаграмму: «међер ви лажете» («итак, вы врете») он заменил на «мађар-вилажете» - глагол, образованный от названия «Magyar világ», записанного кириллицей. Очевидно, авторский неологизм обозначал осуществление концепции о единой политической венгерской нации и являлся поэтическим выражением отношения сербских либералов к этому процессу. Более того фразой: «Мы в вас не переплавимся, не дай то бог!», Костич обозначил намерение сопротивляться мадьяризации ${ }^{38}$.

В статье «Пасхальные размышления» (1866) Костич сравнил великое переселение сербов в Габсбургскую монархию с исходом сынов Израиля из Египта, а патриарха Арсения Чарноевича, возглавлявшего беженцев, с Моисеем. В надежде найти в южных комитатах Венгрии свой Ханаан, сербы, однако, попали в Вавилонский плен, поскольку современный автору режим был ничуть не лучше тирании Навуходоносора $\mathrm{II}^{39}$. Костич выражал уверенность в том, что сербы, угнетаемые и Турцией-Египтом, и Венгрией-Вавилоном, отринут рабство и, объеди-

\footnotetext{
36 Застава. 1866, № 3.

${ }^{37}$ Как отмечает В. Фишер, Костич, пользуясь эзоповым языком, буквально поэтапно расписывает действия сербов в борьбе за право влиять на политическое развитие страны, гражданами которой они являются. Fischer 2002: 22-23.

38 Застава. 1866, № 3.

${ }^{39}$ Сравнение Костичем Венгрии с Вавилоном представляется аллюзией на в свое время знаменитый памфлет «Вавилон» (1790) журналиста и тайного агента австрийской тайной полиции Л.А. Хофмана (1760-1806). См.: Хаванова 2000: 136-138.
} 
нив усилия, возродят сербскую славу по обе стороны Дуная ${ }^{40}$. Представляется логичным, что обращение к библейскому сюжету в жанре сравнения было использовано в целях речевой манипуляции, поскольку отсылало к конфессиональному измерению сербо-венгерского конфликта. Эта тема в меньшей степени затронута в полемических сочинениях Костича ввиду его антиклерикальных взглядов и сложных отношений с сербским иерархами, но тем не менее проявляется в статьях.

В работе «События в мире и венгры» (1870) он вкратце изложил политическую историю венгерского народа (тут лучше подошел бы этноним «мадьярского») как постоянное лавирование между славянским и германским мирами. Вплоть до XIX в. преобладал славянский элемент, особенно в административно-политическом устройстве - в жупаниях (сербск. жупанија). До Нового времени жупании, или комитаты (лат. comitatus, нем. Komitat) лежали в основе венгерского уклада жизни, хотя и были приняты вопреки традициям монгольских племен, к которым якобы относились венгры. В доказательство Костич приводил венгерское слово «ispán» образованное от славяского «жупан». Более того, славянские заимствования преобладали в венгерском языке в целом. Современная венгерская аристократия по большей части имела славянское происхождение, крови вождя древних венгерских племен Арпада в ней еще меньше, чем крови султана Сулеймана в боснийских беях ${ }^{41}$.

Принципы западной культуры долго не могли укорениться в сознании венгерского народа, они достигли широких масс только после того, как перед всем немецким стали преклоняться государственные деятели и церковь. Причиной того, что высшие слои общества переняли западные политические традиции, по мнению Костича, является врожденная монгольская жажда власти. Он с сожалением замечал, что во время первых контактов с немцами, мадьяры не были еще достаточно «размонголены» славянами, а потому не утратили своего главного недостатка, наоборот, усилив, передали его будущим поколениям. Эта порочная черта настолько была сильна, что со временем стала проявляться даже у представителей тех кругов, которые у других народов ей сопротивляются больше всего, а именно у интеллигенции, особенно у юристов. После войн с турками в Венгрию устремились немецкие переселенцы. Сначала они подчинили своим интересам общественную жизнь, постепенно проникая при поддержке венского двора в ряды венгерской аристократии. Затем взялись за сферу культуры, задавив наплывом немецких книг «бедную сиротку» - венгерскую литературу. Венгры, ученые и писатели стали не только говорить, но и думать по-немецки. Удержать на плаву венгерский язык помогла только поэзия, подпитываемая народным разговорным языком. И в этом велика заслуга серба Петровича-Петёфи ${ }^{42}$.

\footnotetext{
${ }^{40}$ Костић 1990: 51-55.

${ }^{41}$ Костић 1990: 145.

${ }^{42}$ Один из ярчайших поэтов Венгрии, трагически погибший в 1849 г., родился, вопреки широко распространенному заблуждению, не в сербской, а в словацкой семье.
} 
Желая отречься от монгольского происхождения, утверждал Костич, венгерские политики всеми силами старались заключить союз с австрийскими немцами, так как славяне, «простецы, у которых нет аристократии», в этом отношении бесполезны. В то же время в Пеште рассуждали так: «Заключив в 1867 г. Соглашение, венгры в один момент из подмастерьев станут компаньонами Вены и тем самым обезопасят себя от многочисленных славян королевства. После поражения при Садовой /Кениггреце $(1866)^{43}$, австрийские немцы сильно сдали, им хватало проблем со своими славянами, монархия начала дряхлеть, а потому открывалась перспектива стать не только ее партнером, но и наследником. Автор удивлялся тому, что венгры как будто не замечают, что не сегодня-завтра состоится объединение Германии, которого так ждут австрийские немцы. Шанс ли это для венгров стать союзниками Великой Германии? Костич считал, что мадьяр ждет превращение в немецкую политическую периферию.

Сделав неверный выбор в пользу германского мира, венгры последовательно разрушали исторические связи со славянством. Костич призывал сограждан-венгров отказаться от заискивания перед немцами и Западом и обратить взор на славян земель короны св. Стефана. До тех пор, пока нарушенные связи не восстановлены, некогда дружно жившие народы останутся чужими. В этом случае венгры выступали только как объект конфронтации, Костич заведомо не рассматривал их как «субъект встречи» в силу существования стереотипа о неспособности венгров заключать компромиссы. Это означает, что славяне/сербы, сами не были готовы идти на контакт, но вину за отдаление возлагали на визави.

Яркий признак «языка вражды» в данном материале - использование этнофолизма «монголы» в отношении мадьяр. Очевидно, что, прикрепляя этот этнический ярлык, Костич связал увлечение венграми поиска прародины на Востоке и представление себя как потомков гунновкочевников, которых исследователи XVIII-XIX вв. относили к монгольским племенам ${ }^{44}$. Однако стоит отметить, что «наследуемая» жестокость как государствообразующий фактор трактовалась Костичем ситуативно. Так, в статье «Санкт-Петербург и Москва» он, будучи славянофилом, оправдывал беспощадность русского царизма, перенятую у монголо-татар для того, чтобы «клин клином избавиться от рабства и иноземный абсолютизм прогнать силами отечественного самодержавия» ${ }^{45}$.

Односторонняя негативная, даже агрессивная оценка неадекватности выбора, сделанного мадьярами в пользу германского мира, сначала

\footnotetext{
${ }^{43}$ В сражении при Садовой/Кениггреце в 1866 г. австрийская армия потерпела сокрушительное поражение от пруссаков, что в известной мере предопределило готовность Вены на заключение компромиссного соглашения с венграми.

${ }^{44}$ Иностранцев 1926: 17-50.

${ }^{45}$ Костич 1990: 91.
} 
заставляет усомниться в компетентности автора. Однако образование Костича позволяет сделать вывод о том, что он хорошо понимал суть проблемы. Наиболее логичным представляется применение автором стереотипа о «генетическом» невежестве мадьяр. По мнению автора, именно из-за своего невежества венгры - «несамостоятельная» нация, которая зависит на заре политической истории от славян, а потом от немцев. Это прямо противоречило положительному автостереотипу венгров, считавших себя уникальным буфером между Востоком и Западом, между «германским миром» и славянством, обиду которого Костич выносил на первый план. Инкриминируя современной ему венгерской элите как «дезертирство» прогерманскую ориентацию, он значительно преувеличивал роль славянского фактора в развитии национальной политической культуры, базировавшейся на достижениях западной духовной мысли и отечественных традиция ${ }^{46}$. Но таким образом он формировал у читательской аудитории чувство превосходства автора, а в его лице всего сербского либерального течения, над изображаемой венгерской элитой, которую уничижительно назвал «политическим междометием», что можно классифицировать как проявление речевой агрессии.

В статье «Венгерская "Реформа" и призрак Московской войны» (1870) Костич вспоминал о своей поездке Москву в 1867 г. на II Славянский съезд: «Один очень умный русский человек сказал мне, что какойто патологоанатом установил: у поляков мозг устроен иначе, чем у всех людей в мире. Это открытие совершилось после того, как поляк стрелял в царя Александра в Париже. - И неудивительно! После того, что польский народ выдержал, сохранить прежний рассудок означало бы лишиться прежнего сердца. Но есть одна польская пословица: "Венгр и поляк - два брата, вместе дерутся, вместе надираются!"». В таком случае, по мнению автора, заключение русского патологоанатома вполне применимо и для венгров, особенно для парламентского большинства Государственного собрания. Костич считал, что любой, кто прочитает правительственную газету «Reform», согласится, что с мозгами «у них» непорядок. Дело, конечно, не в пережитых бедах, как у поляков, а в излишней нагрузке на желудок ${ }^{47}$.

Причиной такой желчности автора стала статья на первой полосе «Reform» от 19 ноября 1870 г., декларировавшая венгерскую супремацию и соответствовавшую ей картину совместного проживания народов на землях короны св. Стефана. Костич вступил с редакцией в полемику и попытался продемонстрировать читателям, что текст является неприкрытой пропагандой и имеет мало общего с действительностью. Выявляя несоответствие между реальностью и описанными в статье примерами разрешения спорных ситуаций между венгерскими властями и национальными меньшинствами, он доказывал, что конфликты

\footnotetext{
46 Тевес 2014: 3.

${ }^{47}$ Костић 1990: 154-155.
} 
лишь приостановлены. Как бы ни старалась правительственная пропаганда создать иллюзию единения народов королевства, разобщенность между титульной нацией и другими была очевидна. Не раз уличая венгерскую политическую элиту в неадекватности, Костич таким образом ставил под сомнение ее право на супремацию.

Провокационные статьи Костича и нарушение им депутатской этики на заседаниях Государственного собрания стали основанием для его ареста в Пеште в 1872 г. Публикация работ антимадьярской направленности в «Заставе» была временно приостановлена, однако к сотрудничеству с изданием он после отбывания наказания не вернулся из-за политических разногласий с главным редактором. Вместе с тем, на наш взгляд, в рассмотренном цикле статей Костичу удалось решить поставленные задачи. Во-первых, стереть следы былого «мадьяронства» и вычеркнуть из социальной памяти сербов Южной Венгрии связь либерального течения с венгерской политической элитой, что было реализовано в фельетоне «Мадьярский мир». Во-вторых, в статьях Костича была представлена интерпретация взаимодействия сербского сообщества с венгерскими властями согласно стратегии сербского либерального течения. Полученный в этих взаимоотношениях и зафиксированный в национальном сознании травмирующий опыт автор попытался объяснить политически неподкованной аудитории неизменной человеческой природой венгров, а не стабильностью венгерской концепции нации, поколебать которую на протяжении полутора веков пыталась сербская элита. Примечательным, на наш взгляд, является предъявленное венграм обвинение в предательстве мифологических общих со славянством идеалов прошлого, поскольку противопоставление автором вымышленного «золотого века» дружбы реальной вражде формирует алгоритмы негативного восприятия действительности, что является примером использования исторических мифов в политической борьбе ${ }^{48}$. Еще одним действенным манипулятивным приемом можно назвать делегитимизацию, представленную Костичем через призму стереотипов о жестокости, недалекости, недальновидности и эпигонстве венгров, потому что «такая» власть не может привести королевство к миру и процветанию. Таким образом была достигнута конечная цель пропагандистской кампании либералов - партии, образованной в 1869 г., удалось заручиться поддержкой большинства сербского сообщества Венгрии ${ }^{49}$.

Негативный имидж венгерской политической элиты, созданный сербской либеральной пропагандой в условиях конфликта интересов, благодаря широкому распространению через прессу лег в основу стереотипного отношения к конструкту «natio Hungarica» среди населения Воеводины. Таким образом, из политического антагониста венгры пре-

${ }^{48}$ Репина 2012: 6.

49 Политические партии 2018: 142. 
вратились в «вечного врага», ответственного за нереализованность национальных прав сербов Австро-Венгрии. В современных обстоятельствах стереотип о венграх как «злых господах» также обладает завидной устойчивостью ${ }^{50}$. Мадьяры, являющиеся самым многочисленным этническим меньшинством автономного края Воеводина, так или иначе подвергаются делегитимизации в пропаганде со стороны правых сил политического спектра Сербии при отсутствии бытовой дискриминации.

На наш взгляд, описанное противостояние сербов венгерским политическим элитам (комитатским властям, католическому духовенству, в рамках представительства в Государственном собрании) демонстрирует, условно говоря, признаки идеально-типической дихотомии гражданской и этнической наций. В условиях «разлома сербского этнического пространства ${ }^{51}$ и принудительной межнациональной интеграции в Венгерском королевстве, попытки получения сербами национальных прав и свобод различными способами - от идиллических требований автономии на основании привилегий Габсбургов до масштабных проектов преобразований Австрийской монархии - необходимо характеризовать как «стратегию выживания» в полиэтничном государстве, а национальную пропаганду и конструируемые ей историческую память и этнические предубеждения как средства мобилизации сообщества против осуществления концепции развития в Венгрии единой политической нации.

\section{БИБЛИОГРАФИЯ / REFERENCES}

Гладилин А.В. «Язык вражды» в традиционных и новых медиа //Вестник ЧелГУ. 2013. № 21 (312). C. 114-153 [Gladilin A.V. «Iazyk vrazhdy» v traditsionnykh i novykh media // Vestnik CHelGU. 2013. № 21 (312). S. 114-153].

Ђере 3. Дневник краљевског комесара Петра Чарнојевића из 1848. године // Зборник Матице српске за историју. 2000. № 61-62. С. 241-244 [Đere Z. Dnevnik kraljevskog komesara Petra Čarnojevića iz 1848. godine. Zbornik Matice srpske za istoriju. 2000. № 61-62. S. 241-244].

Ђере 3. Концепција „усаглашавања интереса” као основа реформне политике у Vormärzу" // Истраживања. № 20. Нови Сад, 2009. С. 73-107 [Đere Z. Koncepcija „,usaglašavanja interesa” kao osnova reformne politike u Vormärz-u”. // Istraživanja. № 20. Novi Sad, 2009. S. 73-107.]

Евстафьева А.В. «Язык вражды» в средствах массовой информации: лингвистические и экстралингвистические факторы функционирования: дис. ...канд. филол. наук. Тамбов, 2009 (рукопись) [Evstaf'eva A.V. «Iazyk vrazhdy» v sredstvakh massovoi informatsii: lingvisticheskie i èkstralingvisticheskie faktory funktsionirovaniia: dis. ...kand. filol. nauk. Tambov, 2009 (rukopis')].

Застава. 1866. № 2, № 3 [Zastava. 1866. № 2, № 3].

Игњатовић J. Мемоари: рапсодије из прошлог српског живота. Београд, 1966 [Ignjatović J. Memoari: rapsodije iz prošlog srpskog života. Beograd, 1966].

Иностранцев К.А. Хунну и гунны. Л., 1926 [Inostrantsev K.A. Hunnu i gunny. L., 1926].

Исламов Т.М. Австро-венгерское Соглашение. Внутриполитические и внешнеполитические предпосылки // Der Österreichisch-Ungarische Ausgleich 1867. Materialen (Referate und Diskussion) der internationalen Konferenz in Bratislava 28.8-1.9.1967. / Hrsg. A. Vantuch, L. Holotík. Bratislava, 1971 [Islamov T.M. Avstro-vengerskoe Soglashenie. Vnutripoliticheskie i vneshnepoliticheskie predposylki // Der Österreichisch-Ungarische Ausgleich 1867. Materialen (Referate und Diskussion) der internationalen Konferenz in Bratislava 28.8-1.9.1967. / Hrsg. A. Vantuch, L. Holotík. Bratislava, 1971].

${ }^{50}$ Калуђеровић 2016: 53.

51 Термин А.Л. Шемякина. См.: Шемякин 2004: 289-330 
Калуђеровић Г. Етнички стереотипи у програмима цивилне и политичке деснице у Војводини, 2000-2012. Докт. дисс. Београд, 2012 [Kaluđerović G. Etnički stereotipi u programima civilne i političke desnice u Vojvodini, 2000-2012. Dokt. dis. Beograd, 2012].

Костић Л. О политици, о уметности. Т. 1. Нови Сад, 1990 [Kostić L. O politici, o umetnosti. T. 1. Novi Sad, 1990].

Костяшов Ю.В. Сербы в Австрийской монархии в XVIII веке. Калининград, 1997 [Kostiashov IU.V. Serby v Avstriiskoi monarkhii v XVIII veke. Kaliningrad, 1997].

Краткая история Венгрии. М., 1991 [Kratkaia istoriia Vengrii. M., 1991].

Лебер Т.А. Правовой статус сербов как коллективного субъектра монархии Габсбургов, 1690-1792 // Взаимодействия и конфликты на конфессионально и этнически смешанных территориях Центральной и Восточной Европы, 1517-1918 гг. / редколл.: К.А. Кочегаров, Л.К.Новосельцева, А. Форго, О.В. Хаванова (отв. ред.). М., СПб.: Нестор-История, 2016. С. 115-133 [Leber T.A. Pravovoi status serbov kak kollektivnogo sub'ektra monarkhii Gabsburgov, 1690-1792 // Vzaimoderstviia i konflikty na konfessional'no i ètnicheski smeshannykh territoriiakh Tsentral'noi i Vostochnoi Evropy, 1517-1918 gg. / redkoll.: K.A. Kochegarov, L.K.Novosel'tseva, A. Forgo, O.V. Khavanova (otv. red.). M., SPb.: Nestor-Istoriia, 2016. S. 115-133].

Микавица Д. Михајло Полит Десанчић. Вођа српских либерала у Аустроугарској. Нови Сад, 2007 [Mikavica D. Mihajlo Polit Desanchić. Vođa srpskih liberala u Austrougarskoj. Novi Sad, 2007].

Милутиновић К. Михајло Полит-Десанчић као историчар. Нови Сад, 193 [Milutinović K. Mihajlo Polit-Desanchić kao istoričar. Novi Sad, 1936].

Новосельцева Л.К. «Кто в молодости не был либералом»: к политической биографии Джордже Стратимировича // Славянский альманах. 2018. № 3-4. С. 60-6 [Novosel'tseva L.K. «Kto $\mathrm{v}$ molodosti ne byl liberalom»: $\mathrm{k}$ politicheskoi biografii Dzhordzhe Stratimirovicha // Slavianskii al'manakh. 2018. №3-4. S. 60-69].

Полит Десанчић М. Беседе. Књ. 1. Нови Сад, 1883 [Polit Desanchić M. Besede. Knj. 1. Novi Sad, 1883].

Полит-Десанчић М. Народност и њен државноправни основ. Нови Сад, 1862 [PolitDesanchić M. Narodnost i njen državnopravni osnov. Novi Sad, 1862].

Политические партии и общественные движения в монархии Габсбургов 1848-1914 гг. Очерки / Под ред. Л.А. Кирилиной, А.С. Стыкалина, О.В. Хавановой (отв. ред.). М., 2018 [Politicheskie partii i obshchestvennye dvizheniia v monarkhii Gabsburgov 1848-1914 gg. Ocherki / Pod red. L.A. Kirilinoi, A.S. Stykalina, O.V. Khavanovoi (otv. red.). M., 2018].

Попов Ч. Српски национални програм Светозара Милетића // Актуелност мисли Светозара Милетића. Београд, 1997. С. 41. С. 33-47 [Popov Č. Srpski nacionalni program Svetozara Miletića // Aktuelnost misli Svetozara Miletića. Beograd, 1997. S. 41. C. 33-47].

Репина Л. П. Опыт социальных кризисов в исторической памяти // Кризисы переломных эпох в исторической памяти. 2012. C. 3-37 [Repina L. P. Opyt sotsial'nykh krizisov v istoricheskoi pamiati // Krizisy perelomnykh èpokh v istoricheskol pamiati. 2012. S. 3-37].

Светозар Милетић и Народна странка. Грађа 1860 - 1885. Књ. I. 1860-1869. Сремски Карловци, 1968 [Svetozar Miletić i Narodna stranka. Građa 1860-1885. Knj. I. 18601869. Sremski Karlovci, 1968].

Срби у Хабзбуршкој монархији од 1526. до 1918. Књ. 1. Од Мохачке битке до Благовештенског сабора (1526-1861). Нови Сад, 2016 [Srbi u Habzburškoj monarhiji od 1526. do 1918. Kn. 1. Od Mohažke bitke do Blagoveštenskog sabora (1526-1861). Novi Sad, 2016].

Србски дневник, 1861. № 55 [Srbski dnevnik, 1861. № 55].

Стратимировић Ђ. Проглас генерала Ђорђа Стратимировића са заседања Главног одбора и позив свим способним родољупцима да узму оружје и помогну српском народу у борби против Мађара. Сремски Карловци, 1848 [Stratimirović Đ. Proglas generala Đorđa Stratimirovića sa zasedanja Glavnog odbora i poziv svim sposobnim rodoljupcima da uzmu oružje i pomognu srpskom narodu u borbi protiv Mađara. Sremski Karlovci, 1848]. URL: http://digital.bms.rs/ebiblioteka/publications/view/1803

Тевес Л. Концепция национальной политики Йожефа Этвеша и конституционнонациональная традиция «Партии» Ференца Деака, 1860-1868 годы // Славяноведение. М. 2014. № 6. С. 3-14 [Teves L. Kontseptsiia natsional'noi politiki Iozhefa Ėtvesha i 
konstitutsionno-natsional'naia traditsiia «Partii» Ferentsa Deaka, 1860-1868 gody // Slavianovedenie. M. 2014. № 6. S.3-14].

Хаванова О.В. Нация, отечество, патриотизм в венгерской политической культуре: движение 1790 г. М., 2000 [Khavanova O.V. Natsiia, otechestvo, patriotizm v vengerskoi politicheskoi kul'ture: dvizhenie 1790 g. M., 2000].

Шемякин А.Л. Сербы в условиях разлома сербского этнического пространства // История Балкан. Век восемнадцатый / Отв. ред. В.Н. Виноградов. М., 2004. С. 289-330 [Shemiakin A.L. Serby v usloviiakh razloma serbskogo ètnicheskogo prostranstva // Istoriia Balkan. Vek vosemnadtsatyı̌ / Otv. red. V.V. Vinogradov. M., 2004. S. 289-330].

Benesch S. Words as Weapons // World Policy Journal. 2012. 29 (1). pp. 7-12. URL: https://www.jstor.org/stable/41510486

Clewing K. Die doppelte Begründung der Serbischen Wojwodschaft 1848-1851. Ethnopolitik im Habsburgerreich // Südosteuropa. Von vormoderner Vielfalt und nationalstaatlicher Vereinheitlichung. Festschrift für Edgar Hösch. München, 2005, S. 253-302.

Deák A. From Habsburg neo-absolutism to the Compromise, 1849-1867. New York, 2008.

Einrichtungswerk des Königreichs Hungarn (1688-1690) / Hrsg. von J. Kalmár, J.J. Varga. Stuttgart, 2010 (Forschungen Zur Geschichte Und Kultur Des Östlichen Mitteleuropa, Bd. 39.)

Fischer W. Zwischen Anpassung und Wiederstand. Stationen der Entstehung einer GegenHegemonie im Diskurs der serbisch-vojvodinischen Eliten (1848-1905). Wien, 2002.

Katus L. Deák és a nemzetisegi kérdés // Deák Ferenc és a polgári átalákulás Magyarországon/ szerk. E. Balogh, Cs.M. Sarnyai. Szeged, 2000.

Polit M. Das Integrität Ungarns und die Nationalitäten // Ost und West. 1861. № 94.

Szalay L. Das Rechtsverhältniss der Serbischen Niederlassungen zum Staate in den Ländern der ungarischen Krone. Pest, 1862.

Новосельцева Людмила Константиновна, младший научный сотрудник, Институт славяноведения РАH; mnovoseltseva91@ gmail.com

\section{Comprehension of the national experience of interaction with Hungarian political elites in Serbian liberal journalism (1861-1872)}

The Serbs' national self-organisation in the Habsburg monarchy from 1690 to 1867 underwent significant changes in the course of interaction with the Hungarian elites (county administrations, the Catholic clergy, deputies of the Diet). Periodicals, political writings, ego-documents and other sources demonstrate how the Serbian-Magyar conflict against the background of the Austrian authorities' interference into the inter-ethnic relations resulted in the making of a "survival strategy" in the composite monarchy and crystallisation of a specific political culture of the Serbs, based on a stable antipathy to the triumph of the concept of "natio Hungarica". The article presents a new look at mobilisation of the Serbian community in the context of forced integration, the most effective means of which were the popularisation of traumatic experience of relationships with the titular nation and its stigmatisation by using the "hate speech" in the propaganda campaign launched by Serbian liberals in 1866-1872.

Keywords: ethnic stereotypes, "hate speech" in the media, Serb national movement in the Habsburg monarchy, Hungarian supremacy

Novoseltseva Liudmila Konstantinovna, Junior Research Fellow, Institute of Slavic Studies of the Russian Academy of Sciences; mnovoseltseva91@ gmail.com 


\title{
НА ПУТЯХ ОТ ВНУТРИЭТНИЧЕСКОЙ ПОЛИФОНИИ К ЭТНОНАЦИОНАЛЬНОЙ «СИМФОНИИ» КОСОВСКИЙ МИФ И СЕРБСКИЕ ИСТОРИКИ ${ }^{1}$
}

\begin{abstract}
Этно-исторические мифы признаны одним из важнейших факторов формирования национальной памяти, конструирования идентичности и разжигания межэтнических конфликтов. При этом исследователи часто сосредотачиваются на межгрупповом противостоянии мифотворцев-интеллектуалов и войнах памяти. Такой подход нивелирует внутриэтническое многоголосие и создает представление о национальной памяти как едином целом. Развитие косовского мифа в среде сербских историков партийно-югославистского, национально-патриотического и скептического течений 1980-1990-х гг. иллюстрирует процессы формирования внутрицехового разноречия. Оно также помогает понять, как внутриэтническое разноголосие эволюционирует в этнонациональное единогласие при встрече с Другим.
\end{abstract}

Ключевые слова: Битва на Косовом поле; институциональные детерминанты; интеллектуалы и власть; косовский миф; мифопоэтическая полифония; начиональная память; сербская историография; сербский национализм.

«Война интеллектуалов в СФРЮ, к сожалению, началась гораздо раньше войны военачальников», - отмечает С.А. Романенко ${ }^{2}$. Большинство отечественных балканистов усматривают в этно-исторических мифах и войнах памяти важные факторы распада Югославии и последовавших этно-гражданских войн ${ }^{3}$. Роли интеллектуалов в идеологическом оправдании межэтнических столкновений в Восточной Европе также посвящено немало работ. П.Е. Кандель обобщает: «[В]сегда находятся силы, которые способны довести процесс "национального возрождения" до логического предела - межнационального конфликта. Его провозвестники в идейно-культурной сфере могут потом и быть шокированы “крайностями”, и оказаться не у дел при дележе плодов победы» ${ }^{4}$.

Разделяя сложившиеся оценки участия интеллектуалов в разжигании межэтнической вражды, хотелось бы дополнить их с учетом разработок по проблемам социальной памяти и мнемонических практик. Вопервых, обращая пристальное внимание на межэтнические «войны памяти», исследователи часто нивелируют различия внутри этнических групп. Я рассматриваю идейные противоречия внутри интеллектуального сообщества соотечественников, а с другой стороны, показываю, почему и как внутригрупповое разноречие ${ }^{5}$ приобретает своеобразное «симфоническое» звучание в условиях политического транзита, отягощен-

\footnotetext{
${ }^{1}$ Статья подготовлена при поддержке гранта РНФ № 19-78-10125 «Как «работают» национализмы? Сравнительный анализ факторов и механизмов распространения националистических мифологий в постконфликтных Украине и Сербии».

2 Романенко 1997: 58.

${ }^{3}$ См., напр.: Докучаева 2016: 60; Мартынова 2008: 36-38; Ermolin 2014.

${ }^{4}$ Кандель 1994: 13.

${ }^{5}$ См.: Бахтин 1975: 113-116, 121-128, 131-144.
} 
ного межэтническим конфликтом. Во-вторых, в имеющихся работах изучение этно-исторических мифов зачастую сводится к рассмотрению точек зрения тех или иных интеллектуалов. Но, на мой взгляд, сложно понять, как формируется внутригрупповое многоголосие и как оно трансформируется в этнонациональное единогласие при встрече с Другим, без учета социального положения, институционального контекста и идеологических предпочтений мифотворцев.

В фокусе исследования - национальное мифотворчество сербских историков 1980-х - конца 1990-х гг., а именно их вклад в развитие и популяризацию косовского мифа. Балканистами разных стран косовский миф признан одним из самых ярких примеров политизации истории 6 . Сформировавшийся в XIX в. нарратив рассматривает Косово «сердцем средневековой сербской империи», согласно ему, в июне 1389 г. на «святой земле» сербский народ потерпел «мученическое поражение» от «турецких полчищ», но одержал «моральную победу». «Косовские герои» оставили потомкам, обреченным судьбой на многовековое «турецкое рабство», «завет [битвы на] Косово». Завет гласит, что сама история наделила сербов «метафизическим ядром» высших духовных ценностей и предопределила их конечную победу в борьбе с исторической несправедливостью. Для этого сербы должны преодолеть внутренний раскол, такой как «предательство» участника битвы на Косовом поле Вука Бранковича, и быть готовыми к длительным испытаниям.

Историческое мифотворчество вокруг драматических событий средневековой истории Косово привлекло заслуженное внимание отечественных исследователей. Усилия П.А. Искендерова направлены на опровержение крайних точек зрения сербской и албанской сторон в просветительском ключе и построение собственной альтернативы истории края ${ }^{7}$. Е.А. Колосков предлагает более нюансированный обзор сербской и албанской историографии битвы на Косовом поле ${ }^{8}$, но лишь вскользь упоминает о существовании «двух историографических направлений сербской академической среды» - «представителей патриотического лагеря» и «критиков», ограничиваясь перечислением разных взглядов. Оба автора не уделяют большого внимания анализу идейного противостояния внутри сербского интеллектуального сообщества.

Теоретики подчеркивают необходимость отказа от понимания «национальной памяти» как всеохватывающего мнемонического явления, «воображаемой, целостной и непротиворечивой памяти о национальном прошлом, которую разделяют почти все» члены сообщества. Фактически единого, «ядерного национального нарратива... не существует» ${ }^{9}$. Д. Белл предлагает говорить о «национальном мифологическом ландшафте», дискурсивном пространстве, в котором «мифы нации фор-

\footnotetext{
${ }^{6}$ См., напр.: Bieber 2002; Popović 1998; Белов 2007: 479-511; Чоловић 2016: 9-31.

${ }^{7}$ Искендеров 2010.

${ }^{8}$ Колосков 2016.

${ }^{9}$ Bell 2004: 74.
} 
мируются, распространяются, реконструируются и оспариваются», а нарративы групп элит сталкиваются с «органической памятью» низовых сообществ ${ }^{10}$. Обращаясь к анализу конкурирующих националистических нарративов, необходимо учитывать, что они производятся интеллектуалами, помещенными в рамки различных социальных институтов. Р. Тоштендаль подчеркивает, что социальные установления следует рассматривать двояко: как нормативные системы и как основанные на этих системах конкретные организации и сообщества ${ }^{11}$. Социальные установления формируют индивидуальный выбор человека, погружая его решения в собственную историю, ограничивая их устоявшимися правилами.

В конце XX в. сербское научное сообщество внесло весомый вклад в возрождение косовского мифа, его культивирование и распространение в массах, но неверно полагать, что республиканские научные и образовательные институты попросту превратились в приводные ремни государственной пропагандистской машины. Давление политического руководства Югославии и Сербии имело несистематический характер ${ }^{12}$. Отношения сербских интеллектуалов 1980-1990-х гг. характеризовались скрытой конфронтацией трех нормативно-ценностных сообществ: партийно-югославистского, национально-патриотического и скептического.

Близкие партийным структурам интеллектуалы, храня верность лозунгам югославского братства и единства, рассматривали историю как инструмент патриотического воспитания, пропаганды ценностей многоэтничной социалистической Югославии и борьбы против «крайностей» национализмов разных народов. Другая группа - по большей части филологи, культурологи, историки и антропологи из Сербской академии наук и искусств - занимая позиции сербского этнического национализма, возвеличивала национальный исторический опыт, обращалась к публике с призывами следовать заветам предков.. Важно отметить, что подобно представителям «патриотического» и «художественного» направлений русской историографии XIX в., сербские национал-патриоты считали себя защитниками народных традиций, стражами памяти, пестунами национальной идентичности, а то и «спасителями нации» ${ }^{13}$. Методологически они сближались с интуитивистской историографией, постулируя истину путем экзистенциального «вчувствования» в исторические обстоятельства существования своих героев ${ }^{14}$. Как и приверженцы партийно-югославистского течения, они придерживались социально-ориентированной модели историописания, но критически относились к социалистической Югославии. Многие историки национально-патриотического направления активно участвовали в политике, занимая посты в националистических оппозиционных партиях.

\footnotetext{
${ }^{10}$ Ibidem: 75.

11 Тоштендаль 2010: 17.

${ }^{12}$ Marković, Ković and Mićević 2004: 289.

13 Маловичко 2014: 141-142; Репина 2016: 12.

${ }^{14}$ См.: Савельева, Полетаев 2007: 284-286.
} 
Третья группа, включавшая профессиональных историков и правоведов, работавших в обособленном от САНИ Историческом институте и на гуманитарных кафедрах Белградского и Новосадского университетов, если и разделяла национальную идею, считала, что достижение общих целей возможно лишь через критическое переосмысление исторического опыта. Для них были характерны «технократические» ориентации на профессионализм, позитивизм и корреспондентскую концепцию истины.

Нормативно-ценностная и организационная фрагментация исследователей битвы на Косовом поле отражала историю сербского интеллектуального класса. Как показал С. Малешевич, уже в югославский период от государственных интеллектуалов откололись этнонационалисты $^{15}$. При этом и государственные и этнонационалистические мыслители были интеллектуалами «органическими», т.е. разделяли ценности коллективизма и лояльности к группе: к рабочему классу либо к своей нации. Интеллектуальный ландшафт 1980-1990-х гг. обнаружил разные степени дрейфа бывших «государственников-югославистов» в сторону этнонационализма. Противостоящим этому дрейфу было другое традиционное деление сербских историков, которые на рубеже XIX-XX вв. были представлены не только «романтической школой» Пантелии Сречковича, но и «критической школой» Илариона Рувараца ${ }^{16}$.

\section{От борьбы за «братство и единство» к борьбе за «национальное существование}

В послевоенной социалистической Сербии косовский миф надолго отступил на второй план, а его место в публичной сфере заняли нарративы о героической партизанской борьбе югославских народов. В 19601970-е гг. исследования битвы на Косовом поле развивались в русле критики и опровержения косовского мифа. Толчком к возрождению национального нарратива послужили выступления албанцев марта-мая 1981 г., которые переросли из протеста студентов против бытовых условий в массовые акции с требованием создания Республики Косово. Руководство Югославии ввело в крае чрезвычайное положение и объявило выступления антисоциалистической контрреволюцией. В республиканской и федеральной прессе началась шумная кампания против краевого руководства и историков, которые изобличались в потворстве ирредентизму и мегаломанским романтическим теориям ${ }^{17}$. Стала муссироваться тема выдавливания и массового исхода сербов из Косово. Поскольку актуальным стал вопрос об исторической принадлежности Косово, под огонь критики попала теория об автохтонности албанцев в крае. Ей была противопоставлена средневековая история Косово.

В первой половине 1980-х гг., которая позднее будет названа националистическими идеологами временем «сербского пробуждения», атмосфера в республике становилась напряжённой из года в год. Партий-

\footnotetext{
${ }^{15}$ Malešević 2002.

${ }^{16}$ Marković, Ković and Milićević 2004: 277-278.

${ }^{17}$ Ramet 2006: 300-306.
} 
ные элиты интенсивно работали над поиском новой формулы реорганизации конституционного устройства страны и решения проблемы Косово. В сербской научной печати то и дело появлялись противоречивые публикации. Партией был частично уграчен контроль над СМИ ${ }^{18}$. В этих условиях средневековая история Косово стала предметом интерпретаций ученых разных идейных течений. Одним из первых ее политизировал близкий к партии историк - научный сотрудник Института рабочего движения и специалист в области партизанского сопротивления (святая святых югославской мифологии) Спасое Джакович. В его монументальном труде «Столкновения в Косово», вышедшем в 1984 г. теория континуитета между доримским иллирийским населением и косовскими албанцами была подвергнута жесткой критике. В подтверждение исторических прав сербов на южную территорию автор приводил данные старославянских церковных грамот и первых османских переписей. По подсчетам С. Джаковича получалось, что численность албанцев в средневековом Косово составляла считанные проценты. Более того, они признавались маргинальной группой горцев, занимавшихся отгонным скотоводством. Косово изображалось центром сербского средневекового государства. Несмотря на разоблачительный характер публикации, в деле возрождения косовского мифа Джакович остановился на полпути. Его книга лишь поверхностно рассматривала средневековую сербскую государственность и Косовскую битву. Партийный историк рассуждал в русле концепции «братства и единства», трактуя текущие сербско-албанские противоречия как досадное исключение. Он возлагал ответственность за искажение прошлого на отдельных недобросовестных политиков и исследователей, не заботящихся о югославском патриотизме албанской молодежи. Следуя старым заветам сербских социал-демократов, Джакович подчеркивал репрессивный характер режимов королевской Сербии и довоенной Югославии по отношению к албанцам.

В тот самый год, когда книга Джаковича вышла из печати, общее собрание Отделения языка и литературы Сербской академии наук и искусств одобрило куда более далеко идущее произведение, которое ознаменовало собой переход части академического сообщества на позиции этнического национализма. «Книга о Косово» Дмитрие Богдановича вышла в свет в 1985 г. За годы своей академической карьеры Д. Богданович опубликовал ряд работ о средневековых княжествах, монографию по истории ранней сербской литературы, приобрел большой авторитет и был удостоен звания члена-корреспондента. После кризиса 1981 г. ученый активно включился в работу ряда неформальных комитетов академии, занимавшихся обсуждением будущего Сербии. Очень скоро эти дискуссии приобрели тональность, характерную для риторики неформального лидера национально-патриотических интеллектуалов, сербского писателя Добрицы Чосича, которого в 1968 г. исключили из партии за национализм и критику югославской политики в Косово.

${ }^{18}$ Ibid.: $319-320$. 
Публикация «Книги о Косово» имела в Югославии большой резонанс. Автор не только критиковал действия косоварских лидеров, но и открыто говорил о неразрешенности в стране национального вопроса. Он призывал к публичному обсуждению сербско-албанских отношений без прикрас. По его мнению, текущий кризис не ограничивался «ни проблемой конституционно-правового статуса САК Косово, ни проблемой положения албанской народности в Югославии» ${ }^{19}$. «Косовский исход» представлял угрозу существованию сербов как единого народа. Средневековая история должна была подсказать ответы на вызовы современности. Отодвигая позитивистский подход к интерпретации фактов прошлого на второй план, автор обратился к экзистенциалистской риторике.

Для Д. Богдановича центральным становился вопрос о «положении и самом существовании сербского народа - в Косово, Югославии, на Балканах». Во многих случаях тон его повествования оставался спокойным, сдержанным. В частях, посвященных средневековой Сербии, он признавал достижения критической историографической школы и не отрицал присутствия албанского населения в южно-сербских землях. В то же время край был представлен как центральная область мощной средневековой империи, очаг сербской культуры, населенный однородным сербским населением, с ничтожными вкраплениями (2\%) иноплеменников. Косовская битва, по мнению автора, если и не положила конец средневековой государственности, тем не менее, явилась пограничной вехой «между эпохой свободы сербства и турецкой неволи».

Утверждая, что авторы ранних письменных источников были неспособны адекватно оценить значение и смысл сражения 1389 г., сербский историк литературы подчеркивал, что Битва на Косовом поле в стратегическом смысле стала военным и политическим поражением сербского народа. Несмотря на это, сербы одержали моральную победу, «духовный триумф в своей приверженности идеалам христианской цивилизации». Косовская битва как символ самых высоких моральных ценностей на века врезалась в народное сознание, выражением которого стали эпос и церковная литература. Соответственно, по мнению автора «Книги о Косово», речь шла не «о некоем «косовском мифе», а об «историческом сознании, связывающем настоящее с реальным прошлым». «Живая память о своем средневековом государстве была важнейшим фактором в борьбе сербского народа за свободу и объединение...».

Другими словами, в своей интерпретации Косовской битвы Богданович следовал ретроспективному детерминизму и post hoc оценкам. Если, в конце концов, пусть даже спустя 70 лет, сербская полития прекратила существование, а национальными идеологами XIX в. сражение стало восприниматься как «моральная победа», значит, битва изначально и была военно-стратегическим поражением и духовным триумфом, что бы ни говорили источники. Именно вдохновляющая, мобилизующая сила символа событий 1389 г., сюжеты средневековой истории как ору${ }^{19}$ Богдановић 1985. 
дие борьбы за формирование и права сербской нации, а не фактографические детали балканского прошлого интересовали Богдановича. Нарратив о славной средневековой истории Косово дополнялся в «Книге» повествованием о вековых гонениях на автохтонное сербское население и поэтапной албанизации края. Гнев ученого вызывали замалчивание фактов «насилия и геноцида, чинимого над сербским народом в Косово» и безразличие партийного руководства на всех уровнях.

Именно превозношение «моральной победы» 1389 г. как «метафизической основы», живительной силы борьбы «сербского народа за существование» стало отличительной чертой исторического воображения представителей национально-патриотического направления. Поворотным моментом в оформлении и публичной легитимации их подхода была публикация «Меморандума» Сербской академии наук и искусств. «Книга о Косово» стала его предвестником. Первые попытки подтолкнуть академических ученых предложить свой план решения накопившихся «социальных и национальных проблем» были предприняты Чосичем в 1984 г. Группа, включавшая 23 члена академии, среди которых были историки, филологи, экономисты, естественники и литераторы, начала работу над документом в июне 1986 г. Уже в сентябре отдельные его части были опубликованы в газете «Вечерне новости» ${ }^{20}$.

Риторика академиков была насыщена экзистенциалистскими аргументами. Югославская политика, которая, по мнению авторов меморандума, потворствовала эгоистическим аппетитам малых народов, поставила под вопрос само существование сербов как единой нации. Вместо обещанной стабилизации конституционные изменения 1970-х вылились в фактическую дезинтеграцию и экономическую эксплуатацию Сербии. Повышение статуса Автономного Края Косово привело к эскалации сепаратизма и трагическому исходу - геноциду сербского населения и его вытеснению с «исконных территорий». Дабы придать драматизма текущей ситуации, авторы обращались к истории, противопоставляя жизненную важность Косово для нации преступному безразличию современного партийного руководства: «Не только прошлое сербов, олицетворенное в бесценных культурно-исторических памятниках, [коренится] в Косово и Метохии. Их живые духовные, культурные и моральные ценности [находятся] в Косово и Метохии. Прародина самого их исторического бытия в Косово и Метохии. Насилие, которое в течение веков терпело сербское население [края], уже в настоящее, в наше с вами время подходит к своему трагическому исходу» ${ }^{21}$.

Далеко не все ученые согласились с выводами «Меморандума». Он был детищем довольно узкой группы академиков: большинство принадлежали к старшему поколению (за 60 лет) или считались диссидентами ${ }^{22}$.

${ }^{20}$ Ramet 2006: 319-322.

${ }^{21}$ Mihajlović and Krestić 1995: 129. См. также: Pavković 1997: 513-515.

${ }^{22} \mathrm{O}$ разнообразии мнений о сербских национальных целях в среде сербской интеллигенции 1980-1990-х гг. см.: Pavković 1997: 515-524. 
В конце 1986 - начале 1987 г. близкие к партии академики, такие как отказавшийся от сербского национализма и занимавший высокие государственные посты историк Васа Чубрилович и бывший руководитель Института ядерных наук Павле Симич открестились от документа, назвав его политическим памфлетом и выразив опасения насчет тенденции политизации прошлого. Их поддержал академик С. Чиркович, непризнанный лидер историков-скептиков из Белградского университета и Исторического института. Но несмотря на попытки партийной верхушки и многих интеллектуалов ограничить влияние Меморандума в публичной сфере, он возымел каскадный эффект. Вскоре интеллектуальное сообщество страны погрузилось в череду ожесточенных дискуссий на исторические темы. В этих баталиях представители каждой республики рассматривали именно «свой народ» жертвой югославского проекта.

В такой наэлектризованной атмосфере страна готовилась к празднованию 600-летия Косовской битвы. В 1989 г. прошла серия научных конференций, посвященных косовскому бою. На них тон задавали социально-ориентированные представители национально-патриотического течения. Однако скептически настроенные историки не уставали настаивать на своих интерпретациях. Трудно предсказать, чем бы могла закончиться внутринаучная дискуссия, если бы она состоялась. Дело в том, что скептики не вступали в открытую полемику с воспевателями сербской славы. В октябре интеллектуалы национально-патриотического лагеря созвали международный симпозиум «Косовская битва и ее последствия». В процессе его организации представители Института балканистики САНИ, который стал пристанищем сторонников этнонационалистических интерпретаций истории, объединили усилия с деятелями Западноевропейской епархии Сербской православной церкви, с начала 1980-х гг. окончательно принявшей на себя роль «народной защитницы и воспитательницы». Организационный комитет мероприятия характеризовал Косовскую битву как «наиболее важное событие сербской истории». Подчеркивалось, что память о героических событиях 1389 г. составила «метафизическое ядро» сербского народа, позволив ему выжить в «наиболее тяжкие дни».

Основное внимание участников конференции было сосредоточено на моральном смысле сражения как «духовного триумфа массового мученичества». Тон конференции задал секретарь Отделения исторических наук и директор Института балканистики САНИ Радован Самарджич, с начала 1980-х, поддерживавший тесные дружеские отношения с Чосичем и сербскими диссидентами-националистами. Его программная речь «За Царство Небесное» была проникнута риторикой сербского национализма XIX в. и церковным дискурсом последних лет. Самарджич изображал сербов особым, избранным народом, воспитанным на самых высоких идеалах. По его мнению, проиграв военное сражение в 1389 г., сербы выиграли морально. Понеся физические потери, они навеки сделали выбор в пользу своих национальных ценностей: резкого неприятия 
чужеземного рабства, непримиримой борьбы за свободу, православную веру и духовные ориентиры средневековой сербской державы. Короче, Завет битвы на Косовом поле стал «духовной вертикалью» всей сербской истории и предопределил «возрождение царства земного» в Новое время $^{23}$. Участники симпозиума, выступавщие после Р. Самарджича (Д. Батакович, В. Джуретич), говорили о «Косово» как «цивилизационном выборе» в пользу христианства, национальном ответе на «исторический вызов неволи и Зла», повествовали о продолжающейся трагедии сербов Косова и Метохии. В атмосфере идеологического триумфа социально-ориентированных истолкователей прошлого критически настроенные ученые (О. Зироевич, Й. Калич, Й. Реджеп) открыто не противостояли праздничной риторике конференции. Те, кто описывал использование косовской легенды в государственном строительстве XIX в., отмечали ее глубоко позитивную роль в «национально-освободительной борьбе», характеризуя саму битву как момент большого «морального, исторического, цивилизационного и государственнического выбора».

Национал-просветительская повестка преобладала и на другом научном мероприятии «Святой князь Лазарь: В память о 600-летии Косовского боя», организованном в 1989 г. по благословению косовского архиепископа Павле Архиерейским Синодом СПЦ. Конференция открылась рассуждениями церковных иерархов о сербской Голгофе и сосредоточилась на символизме личности православного мученика. Превозносилось идеологическое значение Косовской битвы. Й. Бойович отметил, что наследие «решающей битвы между Сербией и Турцией», после которой «части сербской империи одна за другой попадали под турецкую власть и иго», имело огромное значение для всех сербов. «Косовская мысль» о «героях во главе с Милошем Обиличем» утвердила «великие освободительные идеи» в сознании черногорских иерархов и позволила им возглавить «национально-освободительную борьбу» XVIII-XIX вв. ${ }^{24}$ Л. Дуркович-Якшич подчеркнул роль культа князя Лазаря для «воскресшей Сербии». Исторические реконструкции средневековья, предложенные историками-критиками, отошли на второй план.

В декабре 1989 г. сотрудники Исторического института и гуманитарных кафедр университетов в Белграде и Новом Саде организовали круглый стол «Косовская битва в историографии». Мероприятие было поддержано сравнительно либерально ориентированной Академией науки и искусств Воеводины. Оно стало ответом скептиков сторонникам национально-патриотических интерпретаций, хотя прямая критика в адрес этнонационалистов не звучала, общий тон конференции существенно отличался. Признавая «большое значение» памяти о Косовской битве для «сербского общества», председатель конференции видный исследователь средневековья Сима Чиркович призывал к критическому анализу исторических источников, поставил под вопрос капсулирование истори-

\footnotetext{
${ }^{23}$ Самарџић 1991: 9-10, 12, 14.

${ }^{24}$ Бојовић 1989: 393.
} 
ческой мысли в национальных рамках, использование устаревшей литературы и недоучет достижений югославской исторической науки последних десятилетий. Чиркович дистанцировался от косовского мифа, недоумевая «почему люди часть своего внимания и времени посвящают вещам, которые были и прошли, которые не имеют никакой связи или только опосредованную связь с их повседневной реальностью» ${ }^{25}$. Одни из наиболее ярких представителей критической историографии - Раде Михальчич и Милош Благоевич, -предостерегали аудиторию от депрофессионализации истории. Михальчич сожалел, что на фоне последних политических событий стало модным игнорировать достижения науки, окончательно развенчавшей миф о «национальном предательстве» Вука Бранковича. В противовес вновь становившемуся популярным мнению Благоевич отметил, что самые ранние упоминания о Косовской битве говорят о ничейном исходе, а не о сокрушительном поражении сербов. Все докладчики, твердо следуя критической традиции, сконцентрировали внимание на анализе новых источников и историографии вопроса.

Три противоположные по духу конференции 1989 г. явились своего рода водоразделом в исторической мысли сербских историков о событиях 1389 г. На протяжении 1990-х гг. ученое сообщество раскололось на два лагеря. Представители национально-патриотического течения стали играть еще более заметную роль. Их противники уходили в тень, нередко меняли тему исследований.

В начале 1990-х гг. Радован Самарджич, стяжавший к этому времени славу декана сербской исторической науки, выразил свои идеи о «косовском выборе» сербов в одноименной монографии. Поскольку книга представляла собой научный труд, сербский ученый вынужден был посвятить отдельную главу работам предшественников и отметить их заслуги в области реконструкции сражения и отделении данных первоначальных источников от их последующих недостоверных интерпретаций. Однако Самарджич, следуя линии социально-ориентированных истолкователей, делал акцент на духовном значении 1389 г.

По его мнению, несмотря на имеющиеся расхождения с фактами, по своей сути, эпическая традиция и церковная легенда о князе Лазаре были верными. Даже если сербская государственность продолжала существовать на Балканах в более поздний период, Битва на Косовом поле «опустила занавес» двух веков славной истории державы Неманичей. И если сам Вук Бранкович не предавал сербский народ, существовал раскол в среде корыстолюбивой знати, часть из которой придерживалась антипатриотических позиций. Не фактографическая, а глубинная, сущностная истинность воспоминаний о Косово позволила им стать «животворным ядром» сербского народа, выражением его «самых высоких моральных качеств», залогом цивилизационного выбора в пользу свободы, которую неприятели всегда хотели отнять ${ }^{26}$.

\footnotetext{
25 Ћирковић. Косовска битка... 1991: 109; Ћирковић. Уводна... 1991: 7-8.

${ }^{26}$ Самарџић 1990: 8-27, 181-185.
} 
В 1992 г. вышла в свет книга другого участника национал-просветительских конференций 1989 г., сотрудника Института балканистики Душана Батаковича. «Косовская хроника» вышла на английском языке и была адресована в первую очередь иностранному читателю ${ }^{27}$, но вскоре обрела большую популярность в среде сербской образованной публики. Аргументация автора очень напоминала идеи Самарджича. С одной стороны, Батакович полностью признавал ложность народных представлений о Косовском сражении, с другой - отмечал, что на протяжении веков Косово по сути являлось центром сербских земель, «сердцем сербской культуры», духовным «фундаментом, на котором национальная и государственная идентичность удержались во времена несчастий и были воздвигнуты на пьедестал во времена свободы». Автор отстаивал исторические права сербов, которых он считал жертвой порой негласного, порой открытого сговора косовских албанцев и руководства СФРЮ.

Диссонировала с оценками национал-патриотических историков монография Й. Калич «Сербы в позднем Средневековье» (1994). Ожидаемо книгу характеризовал критический взгляд на события рубежа $\mathrm{XIV}-\mathrm{XV}$ вв. В разрез с мифологическими представлениями, здесь говорилось о «ключевой» роли битвы на р. Марице (1371) как точке невозврата, после которой восстановление Сербского царства стало невозможным. Калич подчеркивала, что территория «земли Лазаря» не выходила за границы Сербии конца XIII в. - таким образом, ни о какой «сербской империи» не могло быть и речи. Славянское воинство на Косовом поле немногим уступало по численности османскому и не терпело сокрушительного поражения. Ни «Лазарев небесный выбор», ни раскол в стане эгоистичных феодалов, ни «косовский завет» в книге не упоминались, а легенда о предательстве Вука напрямую отвергалась. Особое внимание было уделено расцвету сербской культуры и государственности во времена Деспотовины (1402-1459), что опровергало представление о «крушении сербской государственности» в 1389 г. ${ }^{28}$

Оказавшись в обстоятельствах, когда риторика деятелей национал-патриотического направления становилась все более экзальтированной, историки-скептики предпочитали вести себя сдержанно. Общая социально-политическая атмосфера и вооруженное противостояние на территории Югославии не способствовали работе представителей скептического течения, тем более их публичной критике национальных нарративов. Из-за финансовых трудностей были существенно сокращены гуманитарные кафедры Новосадского университета - одного из прибежищ скептического течения. Многие медиевисты, среди которых С. Чиркович, Р. Михальчич, и Й. Калич, постепенно отходили от политической и обращались к социальной и культурной истории ${ }^{29}$.

\footnotetext{
${ }^{27}$ Bataković 1992.

${ }^{28}$ Калић 1994: 27-28, 55-64.

${ }^{29}$ См.: Marković, Ković and Milićevic 2004: 286-287, 297-298.
} 


\section{На путях к этно-национальной «симфонии»}

Три нормативно-ценностных сообщества сербских историков 1980-1990-х гг. происходили из рядов государственных органических интеллектуалов Югославии, но руководствовались разными целями и ценностями, но ряд социальных механизмов приводил к постепенному преобразованию внутрицеховой полифонии в этнонациональную «симфонию» при встрече с Другим. Внешнее политическое давление на интеллектуальное сообщество имело место, однако не менее важную роль играли другие факторы: плотность внутриреспубликанских интеллектуальных связей, межэтническое отчуждение и укрепление социальных границ между интеллектуалами разных национальностей, и, в конце концов, непреднамеренные последствия действий историков.

Политические ограничения наиболее ярко проявились в тех сферах издательской деятельности, где государство сохраняло контроль: публикация научно-популярных работ для широкой публики в больших государственных издательствах, издание школьных учебников. В условиях внешних ограничений и самоцензуры происходил дрейф скептического течения в сторону национально-патриотического. Примечательно, что авторами школьных учебников 1990-х гг., подвергшихся влиянию косовского мифа, были как представители социально-ориентированного направления, так и ученые-скептики (Д. Батакович, Р. Михальчич) ${ }^{30}$. Помимо политического давления такое положение наглядно иллюстрирует силу сочиальных сетей. Их формирование и упрочение было связано с историей административно-территориальных реформ Югославии, приведших в середине 1970-х к трансформации федерации в де-факто конфедерацию и укреплению внутриреспубликанских социальных связей историков ${ }^{31}$. Будучи представителями сербской интеллектуальной элиты, консервативные сторонники компартии с ее лозунгом «братства и единства», приверженцы национально-патриотического истолкования истории и скептики были тесно связаны. Они посещали мероприятия друг друга, поддерживали коммуникацию. Охраняя сложившийся молчаливый консенсус, который позволял совместно работать над отдельными конкретными проектами, представители трех нормативных сообществ почти никогда не критиковали друг друга открыто. Именно поэтому уместно говорить скорее о разноречии сербской историографии Косовской битвы в 1980-1990-е годы, а не о противоречиях.

Сползание влиятельных общественных институтов, организаций и политических игроков в сторону этнонационализма, разрыв межреспубликанских научных связей и, в конце концов, полномасштабные боевые действия привели к упрочению сочиальных грании между представителями интеллектуальных элит разных национальностей, нередко к полному этническому размежеванию. Так, активное участие ученых-критиков (С. Чирковича, Р. Михальчича) в научных мероприятиях, организу-

\footnotetext{
${ }^{30}$ Nakarada and Vasović 2012.

${ }^{31}$ Repe 2012: 22-31.
} 
емых косовскими коллегами, во второй половине 1980-х гг. воспринималось неоднозначно по обе стороны межэтнических «баррикад» ${ }^{32}$. Албанские коллеги нередко видели в них, прежде всего, представителей сербского режима даже когда ученые-скептики стремились к диалогу и понижению градуса дискуссии. Это наводит на мысль, что непреднамеренные последствия деятельности интеллектуалов играли немаловажную роль в трансформации внутриэтнической полифонии трех направлений в национальную «симфонию». Включение авторитетных ученых из числа сторонников социалистического югославизма и скептического подхода в многочисленные научные мероприятия и проекты, даже массовое издание медиевистами-скептиками образцовых сборников источников по Косовской битве лишь легитимировали проникновение одобряемого правящим классом историцизма во все сферы жизни общества.

Говоря о значительной роли историков и этно-исторических мифов в разжигании межэтнических конфликтов последних десятилетий на Балканах, в Восточной Европе и Евразии и акцентируя внимание на межэтническом противостоянии интеллектуалов, специальная литература недооценивает внутриэтнические и внутрицеховые разногласия. Кроме того, анализ националистической историографии зачастую ограничивается перечислением точек зрения отдельных авторов, оставляя за кадром обстоятельства их появления. В статье проанализированы как взгляды на средневековую историю Косово, так и институциональный, нормативный и идеологический контекст работы сербских интеллектуалов. Показано, как в 1980-1990-х гг. многоголосие в среде сербских исследователей средневековья трансформировалось в этнонациональное единогласие, способствуя возрождению и популяризации косовского мифа XIX - начала XIX в. Другими словами, я объясняю, за счет чего «национальный мифологический ландшафт» все же остается «национальным», как мощные, доминирующие национальные нарративы черпают свою силу из существующего многоголосия исторического сознания.

Исследователи подчас склонны преувеличивать роль политического фактора в формировании предвзятого «национального» взгляда на прошлое и унификации позиций историков, особенно если под политическим фактором подразумевается прямое административное давление или «примитивная схема “заказчики - исполнители”»"33. Как я показал выше, важную роль в трансформации внутрицеховой полифонии сербских исследователей средневековья в национальную «симфонию» играли другие, социальные обстоятельства. Оказавшись в этих обстоятельствах, ведомые собственными целями, ценностями и интересами, не только убежденные националисты, но и приверженцы социалистического югославизма, а также «умеренного патриотизма» включались в национальное мифотворчество относительно средневекового Косово.

\footnotetext{
32 Реджа 2017; Arkivi i Kosoves. F. 130. Skënder Rizaj. Nr. 7.

${ }^{33}$ Кореняко 2014: 53.
} 
Национальные нарративы, как правило, базируются на стандартной мифологической модели, которая предполагает «вечное возвращение» в «золотой век». Давнее прошлое предстает в ней неким кладезем национальных ценностей и идеалов и служит путеводителем к светлому будущему. Психологическая сила национальной мифологии заключается в создании серии когнитивных диссонансов через противопоставление славного прошлого постыдному настоящему и, затем, противопоставление очерненного настоящего воодушевляющему будущему ${ }^{34}$. Сербские историк всех трех нормативно-ценностных сообществ в той или иной мере приближались в своих работах к идеально-типическому национальному нарративу и, таким образом, вносили вклад в усиление косовского мифа в сербском обществе 1980-1990-х гг.

Интеллектуалы национально-патриотического направления, сосредоточенные в административных структурах, Отделение языка и литературы и Институт балканистики САНИ, зашли дальше всех в националистическом мифотворчестве. Воображая себя «народной интеллигенцией» и не отрицая своей социально-ориентированной повестки, они не чурались антисциентизма, всемерно продвигали националистический историцизм, драматизировали исторический процесс, прославляли прошлое сербского Косово, чернили «албанский геноцид сербов» в XX в., предлагали собственную программу решения югославского кризиса. Близкие к компартии консервативные ученые, стоявшие на позициях социалистического югославизма, были готовы драматизировать историю и противопоставлять славное прошлое постыдному настоящему. Однако использование прошлого в пропагандистских целях одобрялось ими лишь в той мере, в которой оно могло помочь борьбе с республиканскими национализмами и сохранению единой, относительно централизованной Югославии. Они являлись приверженцами интернационалистического историцизма. Наконец, группировавшиеся вокруг сравнительно независимого Института истории и гуманитарных кафедр Белградского и Новосадского университетов, медиевисты-скептики, активно популяризировали прошлое, хотя и не были сторонниками использования исторических аргументов в текущей политике и сторонились императива патриотического воспитания. Над ними сильно довлели профессиональные ценности, осознание себя технократическими интеллек-туалами и сциентистские ориентации. Увлеченные конкретными проблемами средневековой истории, поисками «трещин» в изображении исторических деталей косовского мифа и критикой наивных народных представлений, они, тем не менее, активно не препятствовали «властителям дум» извлекать из истории «глубокий национальный смысл».

\section{БИБЛИОГРАФИЯ / REFERENCES}

Arkivi i Kosoves (Prishtina). F. 130. Skënder Rizaj. Nr. 7.

Бахтин М.M. Вопросы литературы и эстетики. М.: Худлит, 1975. [Bahtin M.M. Voprosy literatury i estetiki. M.: Hudlit, 1975].

${ }^{34}$ Levinger and Franklin Lyttle 2001. 
Белов М.В. У истоков сербской национальной идеологии: механизмы формирования и специфика развития (конец XVIII - середина 30-х гг. XIX вв.). СПб.: Алетейа, 2007. [Belov M.V. U istokov serbskoj nacional'noj ideologii: mekhanizmy formirovaniya i specifika razvitiya (konec XVIII - seredina 30-h gg. XIX vv.). SPb.: Aleteja, 2007.].

Богдановић Д. Књига о Косову. Београд: САНУ, 1985_[Bogdanović D. Knjiga o Kosovu. Beograd: SANU, 1985. URL: www.kosovo.net/sk/rastko-kosovo/istorija/knjiga_o_kosovu/ bogdanovic-kosovo_1.html].

Бојовић J. О Видовдану у Црној Гори // Свети кнез Лазар: споменица о шестој стогодишњици косовског боја, 1389-1989, уредили епископ Павле и др. Београд: Свети архијерејски синод СПЦ, 1989. С. 392-403. [Bojović J. O Vidovdanu u Crnoj Gori // Sveti knez Lazar: spomenica o šestoj stogodišnjici kosovskog boja, 1389-1989, uredili episkop Pavle i dr. Beograd: Sveti arhijerejski sinod SPC, 1989. S. 392-403].

Докучаева Н.А. Роль интеллектуалов в становлении современной Черногории // Лабиринт, 2016. T.1. № 2, C. 55-64. [Dokuchaeva N.A. Rol' intellektualov v stanovlenii sovremennoj Chernogorii // Labirint, 2016. T.1. No. 2. S. 55-64.].

Искендеров П.А. История Косово в прицеле дискуссий // Вопросы истории. 2010. №3. С. 3854 [Iskenderov P.A. Istoriya Kosovo v pricele diskussij // Voprosy istorii. 2010. No.3. C. 38-54]

Кандель П.Е. Национализм и проблема модернизации в посттоталитарном мире // Полис, 1994. №6. C. 6-15. [Kandel' P.E. Nacionalizm i problema modernizacii v posttotalitarnom mire. Polis, 1994. No.6. S. 6-15.].

Колосков E.A. Косовский миф в современной сербской и албанской историографии: этапы и основные тенденции // Studia slavica et balkanica petropolitana, 2016. №2. C. 152168. [Koloskov E.A. Kosovskij mif v sovremennoj serbskoj i albanskoj istoriografii: etapy i osnovnye tendencii // Studia slavica et balkanica petropolitana, 2016. No.2. C. 152-168.].

Кореняко B.A. Этнонационализм, квазиисториография и академическая наука // Историческая экспертиза, 2016. №3. C. 49-71. [Korenyako V. A. Etnonacionalizm, kvaziistoriografiya i akademicheskaya nauka // Istoricheskaya ekspertiza, 2016. No. 3. S. 49-71.].

Маловичко С.И. Непонимание как форма сосуществования разных типов исторического знания //Диалог со временем. 2014. №46. C. 129-145. [Malovichko S.I. Neponimanie kak forma sosushchestvovaniya raznyh tipov istoricheskogo znaniya // Dialog so vremenem, 2014. No. 46. S. 129-145.].

Мартынова М.Ю. Косовский узел: этнический фактор. М.: ИЭА РАН, 2008. [Martynova M.Yu. Kosovskij uzel: etnicheskij faktor. M.: IEA RAN, 2008].

Реджа И. Албанский историк из Косово. Интервью. Приштина, август 2017 г., 90 мин. [Rexha, Iliaz. Albanian historian from Kosovo. Interview. Pristina, August 2017, 90 min.].

Репина Л.П. Историческая память и национальная идентичность: подходы и методы исследования // Диалог со временем. 2016. № 54. C. 9-15. [Repina L.P. Istoricheskaya pamyat' i nacional'naya identichnost': podhody i metody issledovaniya // Dialog so vremenem. 2016. No.54. S. 9-15].

Романенко С.А. История и историки в межэтнических конфликтах (Югославия конца 80-х - начала 90-х годов) // Общественные науки и современность, 1997. №5. С. 54-62. [Romanenko S.A. Istoriya i istoriki v mezhetnicheskih konfliktah (Yugoslaviya konca 80-hnachala 90-h godov) // Obshchestvennye nauki i sovremennost', 1997. No.5. S. 54-62].

Савельева И.М., Полетаев А.В. Теория исторического знания. СПб.: Алетейя, 2007. [Savel'eva I.M., Poletaev A.V. Teoriya istoricheskogo znaniya. SPb.: Aletejya, 2007.].

Самариић P. За Царство Небеско // Косовска битка 1389. године и њене последице, уредили Н. Тасић и В. Ђуретић. Београд: САНУ, 1991. С. 9-14. [Samardžić R. Za Carstvo Nebesko // Kosovska bitka 1389. godine i njene posledice, uredili Nikola Tasić i Veselin Đuretić. Beograd: SANU, 1991. S. 9-14.].

Самариић P. Косовско опредељење: историјски огледи. Београд: СКЗ, 1990. [Samardžić R. Kosovsko opredeljenje: istorijski ogledi. Beograd: SKZ, 1990.].

Тоштендаль P. Возвращение историзма? Нео-институционализм и “исторический поворот” в социальных науках // Диалог со временем, 2010. №. 30. C. 14-25. [Toshtendal' R. Vozvrashchenie istorizma? Neo-institucionalizm i "istoricheskij povorot" v social'nyh naukah // Dialog so vremenem, 2010. No.30. S. 14-25.].

Ћирковић C. Косовска битка као историјски проблем // Косовска битка у историографији: Зборник радова округлог стола, уредио С. Ћирковић. Београд: Историјски институт, 1990. C. 109-118. [Ćirković S. Kosovska bitka kao istorijski problem // Kosovska bitka u 
istoriografiji: Zbornik radova okruglog stola, urdio S. Ćirković. Beograd: Istorijski institut SANU, 1990. S. 109-118.].

Ћирковић C. Уводна реч// Косовска битка у историографији. Београд: Историјски институт, 1990. C. 7-10. [Ćirković S. Uvodna reč // Kosovska bitka u istoriografiji. Beograd: Istorijski institut, 1990. S. 7-10.].

Чоловић И. Смрт на Косовом пољу: Историја косовског мита. Београд: Библиотека XX век, 2016. [Čolović I. Smrt na Kosovom polju: Istorija kosovskog mita. Beograd: Biblioteka XX vek, 2016.].

Bataković D. The Kosovo Chronicles. Belgrade: Knjižara Plato, 1992. URL: https://www.rastko.rs/ kosovo/istorija/kosovo_chronicles/kc_partlb.html

Bell D.S. Mythscapes: Memory, mythology, and national identity // The British Journal of Sociology. 2003. Vol. 54. No 1. P. 63-81.

Bieber F. Nationalist Mobilization and Stories of Serb Suffering: The Kosovo Myth from the 600th anniversary of the present // Rethinking History, 2002. Vol. 6. No. 1. P. 95-110.

Ermolin D.S. When Skanderbeg meets Clinton: cultural landscape and commemorative strategies in postwar Kosovo // Politička Misao, 2014. Vol. 51. No. 05. P. 157-173.

Levinger M. and P.F. Lyttle. Myth and Mobilization: The Triadic Structure of Nationalist Rhetoric // Nations and Nationalism, 2001. Vol.7. No.2. P.175-194.

Malešević S. From 'Organic'Legislators to 'Organicistic'Interpreters: Intellectuals in Yugoslavia and Post- Yugoslav States // Government and Opposition, 2002. Vol. 37. No.1. P. 55-75.

Marković P., Ković M. and Milićević N. Developments in Serbian Historiography since 1989 // (Re) Writing History. Historiography in Southeast Europe after Socialism, edited by U. Brunnbauer. Munster: Lit Verlag, 2004. P. 277-316.

Mihajlović K. and Krestić V. Memorandum of the Serbian Academy of Sciences and Arts: Answers to criticism. Belgrade: SANU, 1995.

Nakarada, R., Vasović, M. et al. Etnički stereotipi i nacionalni mtovi kao prepreke pomirenju: albansko-srpski odnosi. Izveštaj projekata. Belgrade: Center for Peace Studies, 2012. Unpublished manuscript.

Pavković A. The Fragmentation of Yugoslavia: Nationalism in a Multinational State. London: MacMillan Press, 1997.

Popović M. Vidovdan i časni krst. Beograd: Čigoja štampa, 1998.

Ramet S.P. The Three Yugoslavias: State-building and legitimation, 1918-2005. Bloomington: Indiana University Press, 2006.

Repe B. Between Myths and Ideology: Some views on Slovene contemporary historiography. Ljubljana: University of Ljubljana, 2010.

Ломоносов Матвей Юрьевич, PhD (Sociology, McGill), профессор, Школа перспективных исследований, Тюменский государственный университет; m.lomonosov@utmn.ru

\section{On the Roads from Intra-Ethnic Polyphony to Ethno-National "Symphony" The Kosovo Myth and Serbian Historians in the 1980s and 1990s}

The scholars of nationalism and memory see ethno-historical myths as important factors in forging national memory, constructing cultural identity, and fueling ethnic conflicts. However, the literature tends to focus on the inter-communal competition between intellectuals, memory wars, and the incompatibility of ethnic claims. This approach neglects intra-ethnic polyphony, thus, contributing to the tendency of seeing "national memory" as a single whole. The case of the famous Kosovo myth in the ranks of Serbian intellectuals of the 1980s-1990s, who belonged to the party-Yugoslavist, Serbian ethno-nationalist and skeptical currents of historical thought, illustrates how intra-ethnic mythopoeic polyphony develops. It also helps to understand how the intra-ethnic polyphony evolves into an ethno-national "symphony" in face of the Other.

Keywords: Kosovo battle; institutional constraints; intellectuals and state power; Kosovo myth; national memory; Serbian historiography; Serbian nationalism

Matvey Lomonosov, PhD in Sociology from McGill, Professor, School of Advanced Studies, University of Tyumen, Russia; m.lomonosov@utmn.ru 


\title{
ЯЗЫК ИМПЕРИИ И ОБРАЗ «БЛАГОРОДНОГО ДИКАРЯ» ВО ФРАНЦУЗСКИХ ОЧЕРКАХ О КРУГОСВЕТНЫХ ПУТЕШЕСТВИЯХ ВТОРОЙ ПОЛОВИНЫ ХУІІ ВЕКА
}

\begin{abstract}
В статье рассмотрен образ «благородного дикаря» на примере очерков о кругосветных плаваниях - «Кругосветном путешествии на фрегате "Будёз” и транспорте “Этуаль"» Луи Антуана де Бугенвиля и «Путешествии по всему миру на "Буссоли" и “Астролябии”» Жан-Франсуа де Лаперуза. Показано, как межкультурный контакт привел к возникновению шаблонов восприятия европейцами «других» народов. Отмечено, что эти очерки способствовали определению места и роли европейцев в мире. Данный шаблон включал как положительные, так и отрицательные элементы. Империя могла извлекать пользу из романтизированного образа «благородного дикаря», тем самым стимулируя новые колониальные захваты. В то же время на практике европейцы находили варваров агрессивными, лживыми и недалекими. Автор приходит к выводу, что межкультурный диалог, показанный во французских очерках о кругосветных путешествиях второй половины XVIII в., вряд ли можно назвать успешным, так как эти травелоги привели к возникновению очередного шаблона, рассматривающего «других» сквозь высоту европейского знания, основанного на привычной для европейского мира системе ценностей.
\end{abstract}

Ключевые слова: колонизация, XVIII век, колониальная политика Франичии, экспансия, образ «благородного дикаря», Лаперуз, Бугенвиль

Открыв для себя Новый свет, наряду с новыми территориями европейцы столкнулись с его жителями, столь непохожими на представителей Старого света. Образ «другого» стал предметом изучения, начиная с раннего Нового времени ${ }^{1}$. Наиболее заметный вклад в его развитие принадлежит эпохе Просвещения ${ }^{2}$ Вольтер, Дидро, Руссо и другие французские мыслители прославляли образ «благородного дикаря», подчеркивали его естественность и связь с природой ${ }^{3}$. Часто представители французского Просвещения использовали этот образ, чтобы подвергать нападкам устои колониальной империи. Вместе с тем, не стоит забывать, что просветители в основном были кабинетными мыслителями. Некоторые исследователи 4 сомневались в том, что наследие эпохи Просвещения может быть рациональным в своем познании, поскольку эти философы никогда не покидали метрополию. Обращение к заметкам путешественников позволяет создать более адекватную картину.

В современных исследованиях ${ }^{5}$ прослеживается связь травелогов с политическими и социальными событиями эпохи, отмечается наличие

\footnotetext{
1 Лac Кacac 1968; Cartier 1867. чительно наследия французских авторов второй половины XVIII века.

${ }^{3}$ Voltaire 1759, 1768; Diderot 1875; Rousseau 1755, 1762.

${ }^{4}$ Lilti 2009: 204.

5 Thomson 2011: 255; Howells 2012: 771.
}

2 Периодизация эпохи Просвещения является одним из наиболее интересных и спорных моментов в историографии. В данном исследовании мы касаемся исклю- 
у колониальных империй характерных фигур речи и аргументов, изучается язык и риторика империи ${ }^{6}$. Очерки о путешествиях содействовали продвижению веры европейцев в необходимость цивилизовать дикие народы. Дорис Гэррауэй называет это идеями «просвещенного колониализма» ${ }^{7}$, который олицетворял коммерцию и личную свободу.

Пол Артур ${ }^{8}$ рассматривал травелоги как ценный источник межкультурного дискурса, который способствовал принятию европейцами колониальной экспансии и вел к возникновению очередного увлекательного шаблона, рассматривающего «других» сквозь высоту европейского знания. Он подмечал, что к концу XVIII в. травелоги содержали смесь фактов и фантастики ${ }^{9}$. Тот факт, что европейцы использовали исключенных «других» как пример естественного состояния, чтобы критиковать свою собственную историю, а также исключать или включать по своему усмотрению других из этой системы, подчеркивал Джон Покок ${ }^{10}$. Многие авторы испытывали влияние теории Э. Саида ${ }^{11}$, который на основе анализа художественных и научных текстов, исторических фактов и общественных институтов показал, как, начиная с эпохи Просвещения в европейских державах формировался дискурс, призванный закрепить идею цивилизационного превосходства Запада над Востоком и тем самым оправдать колониальную экспансию. В западной историографии репрезентация колониальных империй в трудах представителей французского Просвещения нашла отражение и в рамках постколониальных исследований ${ }^{12}$. Цель нашего исследования состоит не только в том, чтобы рассмотреть язык описания «других» народов, но более точно обрисовать контуры очерков о путешествиях и оценить их реальное влияние на имперскую политику и восприятие колониальной империи.

Мы обратились к материалам первых французских кругосветных плаваний Луи Антуана де Бугенвиля и Жан-Франсуа де Лаперуза. Их уникальность состоит в том, что целью этих путешествий, которые поддерживались французским королем, были исключительно сами экспедиции, а не поиск новых колоний, военных баз и торговых путей. Они должны были продемонстрировать морскую мощь Франции и поднять престиж страны, пошатнувшийся после Семилетней войны. Плавания были инициированы королевской властью, а значит, путешественники, в некотором роде, были проводниками имперской воли и должны были решать имперские задачи.

Кругосветное плавание Бугенвиля стало первым в истории «пиарпроектом» подобного масштаба и первым французским кругосветным плаванием. Оно началось в 1766 г. и заняло два с половиной года. От-

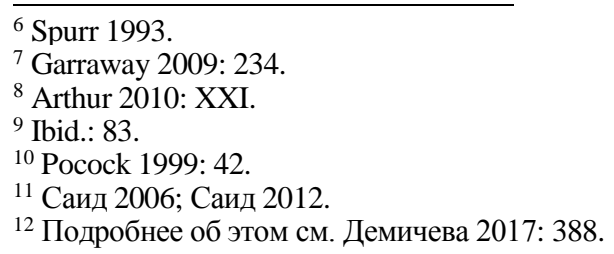


плыв из Бреста, Бугенвиль прошел Магелланов пролив, посетил Таити, Самоа и Новые Гебриды, Новую Бретань (о-ва Бисмарка), Новую Гвинею, Маврикий; пройдя мыс Доброй Надежды, он вернулся в Сен-Мало.

Плавание Лаперуза, которое тоже должно было стать кругосветным, началось в 1785 г., но ему не суждено было удачно завершиться. Корабли обогнули мыс Горн, побывали в Чили, на острове Пасхи, в Гавайском архипелаге, на Аляске, в Калифорнии, в Макао, на Филиппинах, на Сахалине, на Камчатке, на Самоа, в Ботаническом заливе в Австралии. После чего в марте 1788 года их следы были потеряны. Однако Лаперуз периодически отправлял корреспонденцию во Францию, благодаря чему известны подробности его плавания. Экспедиция Лаперуза была экипирована самым тщательным образом учеными (ботаниками, зоологами, астрономами, математиками), художниками и другими специалистами, которые должны были собирать описания флоры и фауны, астрономические, картографические данные и иные научные знания.

Травелоги сообщали жителям метрополии о других странах и народах. Основываясь на этих данных, которые производили колоссальное впечатление на общественность, философы и писатели Нового времени создавали свои произведения. Известно, что, вдохновившись травелогом Бугенвиля, Дидро написал свое знаменитое «Добавление к "Путешествию” Бугенвиля». Но это было влияние в обе стороны. Так, Е.Е. Шведе в предисловии к русскому изданию «Добавления» отмечал, что на формирование политических взглядов Бугенвиля оказал влияние его наставник Д'Аламбер, руководивший его математическим образованием ${ }^{13}$.

Очерки о путешествиях сочетали в себе ежедневные наблюдения и планомерные отчеты о естественной истории с обширными рассуждениями и изображениями власти. Конечно, стоит относиться к ним критически, поскольку они представляли собой выжимки из корреспонденции, часто отправленной на материк с целью публикации. Лаперуз знал о принятой в то время практике литературной редактуры травелогов и выступал против того, чтобы его редактировал литератор, который мог пожертвовать точными терминами, необходимыми мореплавателю, и заместить реальные события, чтобы получить увлекательный роман, как это произошло с очерком Кука. Вместе с тем Лаперуз не имел ничего против редактора, сведущего в точных науках ${ }^{14}$. Он также предусматривал возможность публикации дневника до своего возвращения.

Интересно, что французское правительство долгое время не хотело издавать имевшиеся в распоряжении части журнала Лаперуза, пока была еще надежда на благополучное завершение экспедиции. В итоге окончательный отчет Лаперуза, состоящий из писем и судового журнала, был опубликован в 1797 г. генералом Миле де Мюро. Тогда публике в большей степени было интересно, что ж случилось с мореплавателем, она мало обращала внимания на отдельные факты.

\footnotetext{
${ }^{13}$ Бугенвиль 1960: 9.

14 Лаперуз 2014: 60.
} 
Читающая публика с интересом относилась к подобным проектам. Аббат Ленгле-Дюфренуа отмечал: «чтение литературы о путешествиях, особенно когда она точна и рассудительна, радует всех; она используется обычно в качестве забавы, но умелые люди применяют ее в географии, истории, и торговле». Он указывал, что эта литература была адресована двум основным категориям читателей: в первую очередь тем, кто хотел развлечься, т.е. интересовался природными диковинками и чудесами, иностранными обычаями, приключениями и даже катастрофами. Помимо этой «широкой публики» специалисты - историки, моралисты, географы, натуралисты и др. - ожидали от путешественника в меньшей степени повествования о его приключениях и в большей - новую информацию и точные знания, которые могли бы обогатить науку ${ }^{15}$. Бугенвиль в ответ отмечал ложные суждения у людей, движимых лишь праздным любопытством и подверженных предрассудкам: «после моего возвращения многие из тех, кого считали образованными, уверяли, что я вовсе не совершил кругосветного путешествия, поскольку не был в Китае. Они, никогда не выезжавшие из столицы, легко впадающие во всякого рода заблуждение и не стремящиеся углубить свои знания, не задумываясь, выносят, однако, строгие и безапелляционные решения» ${ }^{16}$.

Французские философы не были снисходительны к путешественникам. Руссо восклицал: «Я провел жизнь в чтении описаний путешествий и никогда не находил хоть двух описаний, которые давали бы мне одинаковое понятие об одном и том же народе. Сравнивая немногие, вынесенные мною наблюдения со всем прочитанным, я кончил тем, что забросил путешественников и пожалел о времени, вполне убедившись, что когда дело касается наблюдений какого бы то ни было рода, то нужно не читать, а видеть» ${ }^{17}$. Вольтер упрекал путешественников в недостаточности описания топографии открытых земель, нравов, законов и обычаев новых народов ${ }^{18}$. Маркиз де Кондорсе писал: «путешественники почти всегда не точные наблюдатели; они рассматривают вещи со слишком большой поспешностью, через призму предрассудков своей страны и часто глазами людей объезжаемой ими местности» ${ }^{19}$. Мы видим, что упреки в адрес путешественников, как правило, заключались в неточности, противоречиях, ошибках, которые были результатом отсутствия культуры или слишком поверхностных замечаний, а также в использовании языка колонизатора при описании открытых земель.

Путешественники отвечали на нападки философов. Задал тон Бугенвиль: «Я путешественник и моряк, то есть лгун и глупец в глазах той клики ленивых и надменных писателей, которые в тени своих кабинетов бесконечно философствуют о мире и его обитателях и упорно пытаются

\footnotetext{
${ }^{15}$ Broc 1969: 137-138.

${ }_{17}^{16}$ Bougainville 1771: 224-225 (Бугенвиль 1960: 182).

${ }^{17}$ Rousseau 1866: 528 (Pycco 1981: 555).

${ }^{18}$ Diderot 1765: 225.

${ }^{19}$ Condorcet 1794-1795: 324 (Кондорсе 1936: 217-218).
} 
подчинить природу своим вымыслам. Весьма странен метод этих людей, которые, сами ничего не видев, пишут и догматизируют только лишь на основании наблюдений, заимствованных у тех самых путешественников, которым они отказывают в способностях видеть и мыслить ${ }^{20}$. Известный путешественник и писатель Бернарден де Сен-Пьер удивлялся, что «до сих пор нет никакого очерка о путешествиях, опубликованного теми нашими писателями, которые стали наиболее знаменитыми в литературе и философии. Нам не хватает примера в этом занимательном жанре и не хватает уже давно, потому что господа Вольтер, Д'Аламбер, Буффон и Руссо его нам не дали» ${ }^{21}$. Жалобы Лаперуза были более точны и касались кабинетных ученых: «географы, которые не были моряками, обычно столь несведущи в гидрографии [...] они наносят на карты острова, которых не существует и которые исчезают, словно призраки, при приближении современных мореплавателей» ${ }^{22}$.

Свидетельства путешественников отличались двойственностью. Травелоги показывали сообщества, которые могли быть одновременно представлены как хорошими, так и плохими, что позволяло высмеивать недостатки метрополии с разных сторон. Распространено было убеждение, что все дикари - дети природы, тот идеал, к которому европейцы, погрязшие в пороках, должны стремиться. Лаперуз отмечал: «Познания просвещенного класса европейцев, разумеется, во всем превосходят знания двадцати одного островитянина, с кем мы встретились в заливе ДеЛангля. Однако среди народа этого острова самые разнообразные сведения распространены более чем среди низших классов народов Европы» ${ }^{23}$. Бугенвиль отмечал доверчивость островитян, которая свидетельствовала об их добродушии ${ }^{24}$. Путешественники щедро одаривали дикарей разными мелочами, что позволяет нам рассматривать их отношение к «другим» как к детям, которым вручали подарки. В целом это представление о дикарях, как о «естественном человеке», было хорошо закреплено в умах путешественников благодаря стараниям философов. Лаперуз века отмечал, что «из сообщений разных мореплавателей я слишком хорошо знал, что эти туземцы подобны большим детям» ${ }^{25}$.

У Руссо в «Рассуждении о происхождении и основаниях неравенства между людьми» дикари хорошо сложены, крепки, тело было их единственным оружием, они имели прекрасное здоровье. Туземцам «не составляло «столь большого несчастья, ни, даже, столь большого препятствия для их самосохранения, нагота, отсутствие жилища и всех тех ненужностей, которые считаем мы столь необходимыми» ${ }^{26}$. Их единственной заботой являлась забота о самосохранении, их бедами - боль и

\footnotetext{
${ }^{20}$ Bougainville 1771: 17 (Бугенвиль 1960: 31-32).

${ }^{21}$ Bernardin de Saint-Pierre 1835: 75.

${ }^{22}$ Lapérouse 1798. T. II: 60 (Лаперуз 2014: 90).

${ }^{23}$ Lapérouse 1798. T. III: 74 (Лаперуз 2014: 292).

${ }^{24}$ Bougainville 1771: 187.

${ }^{25}$ Lapérouse 1798. T. II: 91 (Лаперуз 2014: 103).

${ }^{26}$ Rousseau 1775: 29 (Pycco 1998: 80).
} 
голод. Они не были злыми потому, что они не знали, «что значит быть добрыми», а безмятежность страстей и неведение порока мешали им совершать 3 ло $^{27}$, они не обладали какими-то познаниями, а лишь способностью познания. Ранее Монтескье в «Духе законов» отмечал, что таким людям чуждо стремление нападать друг на друга и что они были крайне боязливы ${ }^{28}$. Грубоватый образ естественного человека виден и в философских сказках: у Вольтера в повести «Простодушный» (1767), у Дидро - в «Добавлении к “Путешествию Бугенвиля”» (1772). У Вольтера портрет дикаря - идеальный образ человека, обладающего качествами, которых был лишен европеец Нового времени: дикари хоть и были варварами, но никогда не притесняли друзей ${ }^{29}$ и всегда говорили чистосердечно то, что думали, делали все, что хотели ${ }^{30}$, сочетали в себе воинственность и кротость ${ }^{31}$. У Дидро дикари подчинялись только инстинктам природы, они были невинны ${ }^{32}$. «Таитяне находятся у начала мира, а европейцы у конца его. Расстояние, отделяющее их от нас, больше, чем расстояние от новорожденного ребенка до дряхлого старца» ${ }^{33}$.

В исследуемых травелогах при описании образа «благородного дикаря» использовались схожие признаки: хорошее питание, мягкая речь, мягкие манеры, физическое развитие тела, жизнь на лоне природы в безмятежном покое, птицы, которые не боятся сесть на плечи. Это были характерные признаки «нежестокости» народа ${ }^{34}$. На Таити местные женщины были красивы, они «красотой не уступали большинству европейских женщин, а стройностью фигур могли бы даже с успехом поспорить с ними» ${ }^{35}$. Важно, что при сравнении дикарей с европейцами путешественники стремились оперировать знакомыми им понятиями.

Примечательны случаи признания путешественниками своих пороков, например, высокомерия, которое могло навредить «детям природы», оттолкнуть вновь обращенных от христианства ${ }^{36}$. Руссо полагал, что человек должен был оставаться вечно в подобном состоянии, поскольку цивилизация вела лишь к одряхлению человеческого рода ${ }^{37}$. Гольбах в «Энциклопедии» утверждает, что изначально все народы на земле управлялись по образу и подобию мелких американских племен, однако, со временем это состояние было утрачено ${ }^{38}$.

С другой стороны, описание дикарей Таити, данное Бугенвилем, ставило под сомнение их естественность. Их благородство проявлялось

\footnotetext{
${ }^{27}$ Ibid.: 73 .

${ }^{28}$ Montesquieu 1757: 7-8.

${ }^{29}$ Voltaire 1768: 90.

${ }^{30}$ Ibid.: 6-7.

${ }^{31}$ Ibid.: 4.

${ }^{32}$ Diderot 1875: 214.

${ }^{33}$ Diderot 1875: 212 (Дидро 1956: 182).

${ }^{34}$ Bougainville 1771: 50; Lapérouse 1798. T. III: 237.

${ }_{35}$ Bougainville 1771: 190 (Бугенвиль 1960: 158).

${ }^{36}$ Ibid.: 95.

${ }^{37}$ Rousseau 1755: 124-125.

${ }^{38}$ Diderot 1757. T. VII: 788.
} 
в искусственно смоделированных ситуациях. В свою очередь, империя извлекала из этого пользу, романтизировав «благородного дикаря» через концепт невинности и беспомощности. Взгляды французских просветителей (например, критика аббатом Рейналем колониальных империй в «Истории обеих Индий», которая была одной из самых популярных книг своего столетия и выдержала 49 переизданий с 1770 по 1843 г.) $)^{39}$, не способствовали тому, чтобы замедлить колониальные предприятия. Они вели лишь к возникновению очередного увлекательного шаблона, рассматривающего «других» сквозь высоту европейского знания ${ }^{40}$. Так, например, маркиз Кондорсе полагал, что приближается то время, когда европейцы станут для диких народов освободителями.

Однако образ «благородного дикаря» не был исключительно положительным. Переворот сознания хорошо заметен у кругосветных путешественников. Примечателен конфликт команды Лаперуза с туземцами, в результате чего погибла часть команды. Если вначале Лаперуз придерживался гуманности и миролюбия, то позднее он признал свою ошибку в отношении к туземцам: «Причиной его смерти [одного из офицеров - Т.Д.] стала его человечность. Если бы он позволил себе выстрелить в первых туземцев, вошедших в воду, чтобы окружить баркасы, он предотвратил бы собственную смерть и гибель еще одиннадцати жертв варварской жестокости». В письмах, написанных в Ботаническом заливе, Лаперуз признавался, что в будущих сношениях с нецивилизованными народами будет прибегать к более решительным мерам, поскольку опыт научил его, что недостаточная твердость воспринимается ими как слабость, а «разум и здравый смысл подсказывали нам, что мы имеем право применять силу против человека, который, как нам известно, стал бы нашим убийцей, если бы его не сдерживал страх» ${ }^{41}$. Он сожалел, что пришел к ним с принципами мягкости и терпения.

И Лаперуз, и Бугенвиль отмечали агрессивность местных жителей, которые часто воевали или ссорились друг с другом. Однако путешественники не упрекали их в этом и не хотели платить злом за зло. Наряду с образом ребенка можно обнаружить образ дикого зверя: «человек почти дикий в состоянии анархии - существо более злобное, чем самый кровожадный зверь» ${ }^{42}$. В целом данное представление о туземцах подводит к возникновению элементов расовой политики и иных предрассудков - согласно наблюдениям, островитяне с черной кожей были злее, чем те, у которых кожа по цвету приближалась к белой ${ }^{43}$.

Французами было отмечено много случаев воровства и недобросовестности в торговле, особенно со стороны народов островов Южного моря $^{44}$. И дело зачастую было не в самом факте воровства, а в способе

\footnotetext{
${ }^{39}$ Барышников 2016: 14.

${ }^{40}$ Arthur 2010: 82.

${ }^{41}$ Lapérouse 1798. T. III: 251, 289 (Лаперуз 2014: 383, 403).

${ }^{42}$ Lapérouse 1798. T. III: 237-238 (Лаперуз 2014: 378); Bougainville 1771: 269, 287-288.

${ }^{43}$ Bougainville 1771: 269.

${ }^{44}$ Lapérouse 1798. T. III: 224.
} 
его совершения. Лаперуз отмечал, что самые отъявленные мошенники Европы были меньшими лицемерами, нежели островитяне с их притворными ласками и отсутствием каких-либо искренних чувств ${ }^{45}$. Они постоянно грабили европейцев, и было невозможно построить общество с человеком в его естественном состоянии, поскольку этот человек был «злобным и лживым варваром» ${ }^{46}$. Европейцы не считали, что надо применить силу, чтобы ответить на подобную несправедливость со стороны туземцев, и, возможно, именно это увеличивало их дерзость ${ }^{47}$.

Кроме агрессии и случаев воровства неприятный образ «другого» дополнялся описанием недалеких людей, которые использовали небольшое число слов и отвлеченных понятий в языке, что свидетельствовало о невысоком развитии их интеллекта ${ }^{48}$, и разум которых не мог подняться выше детского ${ }^{49}$. Снисходительное отношение со стороны французов соседствовало со слабостью и чувством жалости. Это можно проследить на примере аборигенов Магелланова пролива, которых «не удивляли ни корабли, ни различные предметы, которые они видели впервые», поскольку необходимо было иметь элементарное представление об искусстве, чтобы ему удивляться ${ }^{50}$, или обитателях Огненной земли, которым малейшее усилие мысли казалось невыносимой работой, поэтому они старались не утомлять свои мозг и тело ${ }^{51}$. Лекари дикарей в представлении путешественников были варварами, формы правления зачастую порочны, люди были равнодушны к собственным детям; они были подлинными тиранами своих женщин, которых обрекали на самый тяжелый труд ${ }^{52}$. В заметках Лаперуза видно влияние, произведенное путешествием Бугенвиля, с легкой руки которого, доступные женщины стали сравниваться с жительницами Таити.

Все это вело к пренебрежительному отношению, которое проявлялось в том, что труды туземцев французы оплачивали «пустяками» ${ }^{53}$, а нрав некоторых островитян можно было укротить лишь страхом ${ }^{54}$. Наряду с этим ограниченность и ригидность мышления островитян вела к тому, что с ними было необходимо обращаться, как с детьми, иначе они бежали бы от тех, кто взял на себя труд их наставлять ${ }^{55}$. Власти Испании полагали, что, так как рассуждения почти не действовали на коренное население в Калифорнии, то на чувства местных жителей нужно было воздействовать силой, например, прибегать к телесным

\footnotetext{
${ }^{45}$ Ibid. T. II: 105.

${ }^{46}$ Ibid.: 217.

${ }^{47}$ Lapérouse 1798. T. II: 178.

${ }^{48}$ Ibid.: 324.

${ }^{49}$ Bougainville 1771: 101-102.

${ }^{50}$ Ibid. 155 .

${ }^{51}$ Ibid.: 220-221.

${ }^{52}$ Lapérouse 1798. T. II: 219.

${ }^{53}$ Bougainville 1771: 196.

${ }_{54}^{54}$ Lapérouse 1798. T.II: 272.

${ }^{55}$ Ibid.: 289.
} 
наказаниям. В качестве возможного способа смягчения нравов туземцев и превращения их в «общественных существ» Лаперуз видел развитие сельского хозяйства, которое превращало человека в домоседа, не желавшего видеть свою землю разоренной ${ }^{56}$.

В метрополии мнение о туземцах часто также складывалось не в их пользу. Бугенвиль, привезя таитянина Аотуру в Париж, отмечал, что во Франции о нем распространили дурное мнение, «потому что, проведя два года среди французов, он еле-еле научился неправильно произносить несколько слов на нашем языке» ${ }^{57}$. В статье Энциклопедии «Канадцы» отмечалось, что большая часть жителей метрополии полагала, будто бы туземцы рождаются покрытые шерстью и живут в лесах подобно зверям. Автор статьи, Жан Пестрее, стремился опровергнуть данные мифы, заявляя, что дикари при рождении выглядели как европейцы, верили в божественное начало и бессмертную душу ${ }^{58}$.

В итоге образ «естественного человека» оказался несостоятелен. Лаперуз писал: «Философы могут сколько угодно возмущаться таким портретом. Они сочиняют свои книги в уютных кабинетах, я же путешествую в течение тридцати лет. Я был свидетелем несправедливости и обмана этих людей, которых философы изображают столь праведными, потому что они очень близки к природе. Однако природа возвышенна лишь как целое, но она небрежна во всех подробностях» ${ }^{59}$.

Европейцы, считая себя носителями высших ценностей, стремились просвещать людей. Путешественники были твердо уверены, что они совершали добро по отношению к местному населению. Как отмечал Лаперуз, они «желали от этих людей [дикарей - Т.Д.] лишь одного: чтобы они позволили нам помочь им. Мы привезли им коз, овец и свиней. У нас были для них семена апельсина, лимона, хлопчатника, маиса и, вообще говоря, всех видов растений, которые могли бы прижиться на их острове» ${ }^{60}$. Бугенвиль, рассказывая о таитянине, которого он взял с собой в Париж, отмечал, что тот «не любил признавать наше превосходство над его народом. Трудно передать, до какой степени он был горд» ${ }^{61}$. Разумеется, путешественники судили со своей позиции народа, который нес благо, свет и цивилизацию, а таитянин был слишком горд по сравнению с европейцем и совсем не уважал последнего. Это было вполне в духе традиции того времени, ведь, например, основополагающее положение западных колонизаторов в защиту их вторжения на африканский континент состояло в том, чтобы цивилизовать народы Африки, которые на протяжении веков представлялись как «нечеловеческие», «грубые», «дикие» и инфантильные в своем мышлении.

\footnotetext{
${ }^{56}$ Ibid.: 233.

${ }^{57}$ Bougainville 1771: 225 (Бугенвиль 1960: 182).

${ }^{58}$ Diderot 1752: 581-582.

${ }^{59}$ Lapérouse 1798. T. II: 217 (Лаперуз 2014: 166).

${ }^{60}$ Ibid.: 94 (Там же: 109).

${ }^{61}$ Bougainville 1771: 281 (Бугенвиль 1960: 226).
} 
Восприятие образа «другого» шло через привычную для европейцев систему ценностей, а именно через понятия личной свободы, частной собственности, торговли и права. Так, Лаперуз отмечал, что порядки в поселениях индейцев, обращенных в христианство, были бы более благоприятны, если бы в их основании лежала частная собственность и некая степень свободы ${ }^{62}$. Он полагал, что необходимо «донести до небольшого числа семей преимущества общества, основанного на правах человека, установить среди них право собственности, столь соблазнительное для всех людей, и, посредством этого нового порядка вещей, привлечь каждого к соревнованию в возделывании полей или другом полезном занятии ${ }^{63}$ ». Рассказывая о жителях острова Мауи, он отмечал их честность в торговле ${ }^{64}$. Бугенвиль дополнял к этой системе ценностей религию: «приобщая их [индейцев $-T$.Д.] к католической церкви, они несли дикарям цивилизацию и в то же время становились хозяевами обширной и богатой страны; это означало для метрополии новый источник доходов и новых последователей истинного бога» ${ }^{65}$. Однако сами туземцы не жили европейскими ценностями, что вызывало искреннее непонимание со стороны европейцев: «Мы же, напротив, высадились на остров единственно для того, чтобы сделать им добро. Мы осыпали их подарками, обласкали всех старых и малых, в особенности грудных детей. Мы засеяли их угодья всеми видами полезных семян. Мы оставили в их селениях свиней, коз и овец, которые, вероятно, расплодятся. И мы ничего не потребовали взамен. При всем том, они забросали нас камнями и украли у нас все, что только смогли унести» ${ }^{66}$.

Еще раз подчеркнем, что европейцы рассматривали «других», используя привычную им систему ценностей (личную свободу, частную собственность, торговлю, право), которая не соответствовала образу жизни дикарей. Европейцы не задавались вопросом о необходимости привития «другим» этих ценностей. Хотя еще Вольтер отмечал, что необходимо было отойти от европоцентричности, не судить и не изображать историю чужой страны «точно таким же образом, как историю своей родины» ${ }^{67}$. В этих очерках мы можем наблюдать как «общее благо» замещалось национальными и практическими нуждами (в случае с мореплавателями - это распространение имперского влияния) ${ }^{68}$.

С другой стороны, Лаперуз сетовал, что европейская культура несла бедствия коренному населению и нарушала права человека ${ }^{69}$. Отмечались случаи распространения венерических заболеваний на остро-

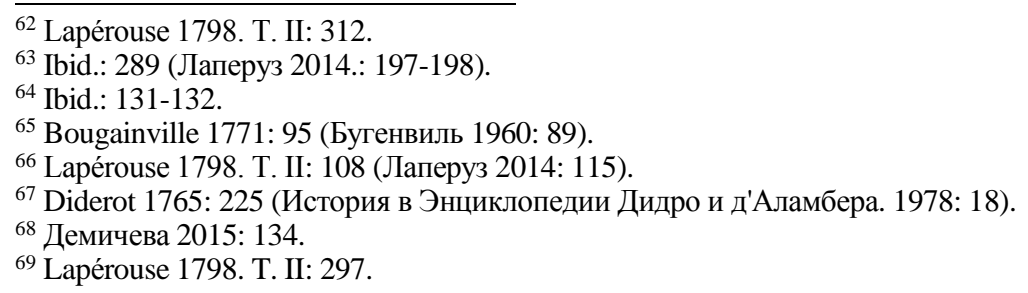


вах, отказы местного населения от своих древних обычаев ${ }^{70}$. Путешественник полагал странным и нелепым обычай объявлять остров собственностью короля в случае первой высадки, опираясь только на свое превосходство и оружие и попирая священное право местных жителей на землю. Лаперуз полагал, что задача всех мореплавателей состояла в описании нравов далеких народов, что способствовало заполнению пробелов в истории человечества и просвещению ${ }^{71}$. Вместе с тем опять подчеркнем, что стоит осторожно и критически относиться к этому «просвещению», поскольку оно подразумевало под собой необходимость «сделать посещаемые ими народы более счастливыми, укрепив их средства существования» ${ }^{72}$. Однако, понятие счастья с европейской точки зрения не всегда соответствовало понятию счастья у островитян.

Неевропейские народы часто представали на контрасте с цивилизованными народами Старого Света. Редко, когда Америку показывали как креольское общество, впитавшее культуры американских индейцев, европейцев и африканских рабов ${ }^{73}$. Образ «благородного дикаря» был ближе и выше для европейца, нежели образ раба. До конца XVIII в. рабов не воспринимали как жертв европейской имперской политики. Народы Азии, которые, хотя и отличались от европейцев нравами, обычаями, религией, составляли общество, сравнимое с европейским ${ }^{74}$, отмечал Бугенвиль. Иными словами, теоретические положения эпохи Просвещения о равенстве всех людей, господствовавшие среди просвещенных людей в то время, мало соответствовали дискурсу травелогов.

Вряд ли можно говорить об успехе межкультурного диалога, представленного в исследуемых травелогах: на первый взгляд доброжелательные намерения представителей колониальных предприятий не всегда таковыми являлись. Для европейцев при описании дикарей было характерно использовать стандартные и близкие для них понятия. Использование привычной системы ценностей показывало пропасть различий между народами, несоответствие «других» принятым в Старом Свете стандартам. Это вело к продвижению идеи колониального господства и к возникновению шаблона, где колониализм часто проистекал из жестокого конфликта и отношений, изначально основанных на неравенстве. Очерки о путешествиях, как часть культуры эпохи Просвещения, сочетали двойственность представления идей, что вело к сложному и мозаичному представлению о «другом»: путешественники рассматривали открытые народы близкими к естественному состоянию человека, прославляемому просветителями, однако эти народы воспринимались негативно, как нецивилизованные и варварские.

\footnotetext{
70 Ibid.: $77,140$.

${ }^{71}$ Lapérouse 1798. T. II: 142.

72 Ibid.: 142 (Лаперуз 2014: 130-131).

${ }^{73}$ Dobie 2010: 10.

${ }^{74}$ Bougainville 1771: 353-354.
} 


\section{БИБЛИОГРАФИЯ / REFERENCES}

Барышников В.Н., Борисенко В.Н., Демичева Т.М. Колониализм и империя в «Истории обеих Индий» аббата Рейналя // Клио. 2016. №6 (114). С. 13-22 [Baryshnikov V.N., Borisenko V.N., Demicheva T.M. Kolonializm i imperija v «Istorii obeih Indij» abbata Rejnalja // Klio. 2016. №6 (114). S. 13-22].

Бугенвиль Л.А. Кругосветное путешествие на фрегате «Будёз» и транспорте «Этуаль» в 1766, 1767, 1768 и 1769 годах. Москва: Глав. Изд. геогр. литературы, 1960. 359 с. [Bugenvil' L.-A. Krugosvetnoe puteshestvie na fregate «Budyoz» i transporte «EHtual'» v 1766, 1767, 1768 i 1769 godakh. Moscow: Glav. Izd. geogr. literatury Publ., 1960. 359 s.]

Демичева T.M. «Великий проект» Генриха IV как средство предотвращения войн в Европе // Труды кафедры истории Нового и новейшего времени. 2015. № 14. С. 126-136 [Demicheva T.M. «Velikij proekt» Genriha IV kak sredstvo predotvrashhenija vojn v Evrope // Trudy kafedry istorii Novogo i novejshego vremeni. 2015. № 14. S. 126-136].

Демичева Т.М., Барышников В.Н., Борисенко В.Н. Право и теория империи в представлениях европейских просветителей второй половины XVIII в. // Былые годы. 2017. Vol. 44. Is. 2. C. 387-395. [Demicheva T.M., Baryshnikov V.N., Borisenko V.N. Pravo i teorija imperii v predstavlenijah evropejskih prosvetitelej vtoroj poloviny XVIII v. // Bylye gody. 2017. Vol. 44. Is. 2. S. 387-395]

История в Энциклопедии Дидро и д'Аламбера. / под общ. ред. А.Д. Люблинской. Л.: Наука, 1978. 312 с. [Istorija v Jenciklopedii Didro i d'Alambera. / pod obshh. red. A.D. Ljublinskoj. Leningrad: Nauka, 1978. 312 s.].

Кондорсе Ж.А. Эскиз исторической картины прогресса человеческого разума. М.: Соцэкгиз, 1936. XII +265 с. [Kondorse Zh.A. Jeskiz istoricheskoj kartiny progressa chelovecheskogo razuma. Moskva: Socjekgiz, 1936. XII + 265 s.].

Лаперуз Ж.-Ф. Путешествие по всему миру на «Буссоли» и «Астролябии». М.: Эксмо, 2014. 480 c. [Laperuz Zh.-F. Puteshestvie po vsemu miru na «Bussoli» i «Astrolyabii». Moscow: Eksmo Publ., 2014. 480 s.]

Лас Касас Б. де. История Индий. Л.: Наука, 1968. 471 с. [Las Kasas B. de. Istorija Indij. Leningrad : Nauka, 1968. 471 s.].

Руссо Ж.-Ж. Рассуждение о происхождении и основаниях неравенства между людьми. // Об Общественном договоре: Трактаты. Москва: Канон-Пресс-Ц, 1998. 414 с. [Russo Zh.-Zh. Rassuzhdenie o proishozhdenii i osnovanijah neravenstva mezhdu ljud'mi. // Ob Obshhestvennom dogovore: Traktaty. Moskva: Kanon-Press-C, 1998. 414 s.].

Руссо Ж.-Ж. Эмиль, или о воспитании // Педагогические сочинения: в 2-х томах. Т. 1. М.: Педагогика, 1981. 656 c. [Russo Zh.-Zh. Jemil', ili o vospitanii // Pedagogicheskie sochinenija: v 2-h tomah. T. 1. Moskva : Pedagogika, 1981. 656 s.].

Саид Э.В. Культура и империализм. СПб.: Владимир Даль, 2012. 733 с. [Said Je.V. Kul'tura i imperializm. Sankt-Peterburg: Vladimir Dal', 2012. 733 s.].

Саид Э.В. Ориентализм. Западные концепции Востока. СПб.: Русский Міръ, 2006. 636 с. [Said Je.V. Orientalizm. Zapadnye koncepcii Vostoka. SPb.: Russkij Mir, 2006. 636 s.].

Arthur P.L. Virtual Voyages: Travel Writing and the Antipodes 1605-1837. L.: Anthem Press, 2010. $216 \mathrm{p}$.

Bernardin de Saint-Pierre J.-H. Voyage à l'Ile-de-France. T. II. Paris: Hiard, 1835. 197 p.

Bougainville L.A. Voyage autour du monde par la frégate la Boudeuse et la flûte l'Étoile: en 1766, 1767, 1768 \& 1769. Paris: Saillant \& Nyon, 1771. 417 p.

Broc N. Voyages et géographie au XVIIIe siècle // Revue d'histoire des sciences et de leurs applications. 1969. T.22. № 2. P. 137-154.

Cartier, Jacques. Relation originale du voyage de Jacques Cartier au Canada en 1534. Paris: Libr. Tross $1867.76+54 \mathrm{p}$.

Condorcet, M.J.A.N.C. Esquisse d'un tableau historique des progres de l'esprit humain. Paris: Agasse, 1794-1795. 389 p.

Dobie M. Trading Places: Colonization and Slavery in Eighteenth-century French Culture. Ithaca: Cornell University Press, 2010. 336 p.

Diderot D. Encyclopédie ou Dictionnaire raisonné des sciences, des arts et des métiers: 17 tomes. Paris : Briasson, 1752. T. II. P. 581.

Diderot D. Encyclopédie ou Dictionnaire raisonné des sciences, des arts et des métiers: 17 tomes. Paris: Briasson, 1757. T. VII. 1030 p. 
Diderot D. Encyclopédie ou Dictionnaire raisonné des sciences, des arts et des métiers: 17 tomes. Paris : Briasson, 1765. T. VIII. 936 p.

Diderot D. Supplément au voyage de Bougainville ou Dialogue entre A. et B. sur l'inconvénient d'attacher des idées morales à certaines actions physiques qui n'en comportent pas // Oeuvres complètes. Paris : Garnier Frères, 1875. T. II. P. 193-250.

Howells R. Bernardin de Saint-Pierre's Founding Work: The Voyage a L'île de France // Modern Language Review. 2012. Vol. 107. № 3. P. 756-771.

Garraway D. Of Speaking Natives and Hybrid Philosophers: The French Enlightenment Critique of Colonialism // The Postcolonial Enlightenment: Eighteenth-Century Colonialism and Postcolonial Theory. P. 207-239.

Lapérouse J.F. Voyage de La Pérouse autour du monde : 3 t. P.: chez Plassan, 1798. T. II. 414 p.

Lilti A. Comment écrit-on l'histoire intellectuelle des Lumières? Spinozisme, radicalisme et philosophie // Annales HSS. 2009. №1. P. 171-206.

Montesquieu, Ch.-L. De l'esprit des loix : in 4-vol. Londres, 1757. T. I. CXVII, 430 p.

Pocock J.G.A. Nature and History, Self and Other: European Perceptions of World History in the Age of Enlightenment // Voyages and Beaches: Pacific Encounters, 1769-1840 / ed. by Alex Calder, Jonathan Lamb, Bridget Orr. Honolulu: University of Hawai'i Press, 1999. P. 25-44.

Rousseau J.-J. Émile, ou De l'éducation. Paris: Garnier, 1866. 565 p.

Rousseau J.-J. Discours sur l'origine \& les fondements de l'inégalité parmi les hommes. Amsterdam : Marc Michel Rey, 1755. LXXXVII, 299 p.

Rousseau J.-J. Du contrat social. Amsterdam: Marc Michel Rey, 1762. 324 p.

Spurr D. The Rhetoric of Empire: Colonial Discourse in Journalism, Travel, Writing, and Imperial Administration. Durham, N.C.: Duke University Press, 1993. 212 p.

Thomson A. Thinking about the history of Africa in the eighteenth century // Cromohs. 2011. Vol 16. P. 253-265.

Voltaire. Candide, ou l'Optimisme. Londres (s.n.), 1759. 175 p.

Voltaire. L'Ingénu: histoire veritable tirée des manuscrits de P. Quesnel. Utrecht (s.n.), 1768. 124 p.

Таисия Максимовна Демичева, кандидат исторических наук, Российская национальная библиотека, отдел библиографии и краеведения, demicheva_taja@mail.ru

\section{The language of the empire and the image of the "noble savage" in French travel essays of the second half of the 18th century}

In the article we use the round-the-world travel essays "Around-the-world trip on the frigate "Boudez" and the transport" Etoile" by Louis Antoine de Bougainville and "Travel all over the world to "Bussoli" and "Astrolabe" by Jean- Francois de La Perouse to show the image of the "noble savage". These travelogues show that the intercultural contact led to the emergence of patterns of perception of "Others" by Europeans. It is noted that travelogues contributed to self-examination and determined the place and the role of Europeans in the world. Moreover, this pattern includes positive and negative elements as well. The empire could have a benefit from a romanticized image of the "noble savage" thereby stimulating new colonial conquests. At the same time, travel essays could contradict the Enlightenment ideas, when Europeans found barbarians to be aggressive, deceitful and dimwitted. The purpose of this study is to consider the problematic aspects of describing "Others" and to define the role of travelogues in imperial politics. We will argue that the intercultural dialogue shown in French round-the-world travel essays of the second half of the 18th century can hardly be called successful. These travelogues led to the appearance of fascinating pattern of "other". That pattern looked at the "others" through the European knowledge based on system of values typical for the European world.

Keywords: colonization, XVIII century, France's colonial policy, expansion, the image of the "noble savage", La Perouse, Bougainville

Taisiia Demicheva, Ph.D. (History), the National Library of Russia,demicheva_taja@mail.ru 


\title{
ГЕРМАНИЯ В ЖИЗНИ РОССИЙСКИХ ПИСАТЕЛЕЙ И ПОЭТОВ ПЕРВОЙ ПОЛОВИНЫ ХІХ В.
}

\begin{abstract}
Помимо плодотворного взаимодействия в решении политических вопросов Россию и Германию в первой половине XIX в. связывали тесные культурные связи, в выстраивании которых ключевую роль играла литература. Германия являлась в определенном смысле фильтром, через который Россия знакомилась с европейской литературой. Образы немецкого мира, находившие отражение в русской литературе, возникали не в последнюю очередь благодаря личному опыту общения российских писателей с Германией и немцами. Вследствие этого Германия нередко приобретала свое особенное значение в их жизни и творчестве, чему и посвящена настоящая статья.

Ключевые слова: Россия, Германия, литература, романтизм, В.А. Жуковский, А.С. Пушкин, М.Ю. Лермонтов, Н.В. Гоголь, Ф.И. Тютчев, А.А. Фет. И.С. Тургенев, И.В. фон Гёте, Ф. Шиллер, К. А. Фарнхаген фон Энзе, Ф. М. фон Боденштедт
\end{abstract}

Взаимоотношения России и германских государств очень часто определяли политический вектор развития европейского континента, вносили изменения в уже сложившиеся схемы международного сотрудничества, выстраивали новые линии взаимодействия. Богатым по своему многообразию для истории отношений России и Германии стал XIX в., в течение которого двум государствам предстояло столкнуться со сложными историческими вызовами, пройти трудный путь общественно-политической трансформации, что накладывало свой отпечаток на контакты между ними. Наряду с политической историей взаимоотношений Российской империи с германскими государствами, а с 1871 г. - с Германской империей, - российские историки традиционно обращают внимание на исследование других сфер взаимодействия России и Германии в XIX в. ${ }^{1}$, что позволяет более полно представить и лучше понять связи двух народов накануне трагического XX столетия. Такая проблема является актуальной для современной историографии, о чем, например, свидетельствует деятельность Совместной комиссии по изучению новейшей истории российско-германских отношений, под руководством которой в 2019 г. была завершена работа над публикацией трехтомного проекта «Россия - Германия. Вехи совместной истории в коллективной памяти. XVIII - XX вв.»². Это исследование подтверждает, что ученые двух стран проявляют устойчивый интерес к изучению различных эпизодов, имеющих отношение к истории России и Германии.

Целью настоящей статьи является освещение некоторых сюжетов, связанных с ролью и местом Германии в жизни и творчестве российских писателей первой половины XIX в., линиями взаимодействия российской и германской традиций в литературе.

\footnotetext{
${ }^{1}$ См., напр.: Петров 1997; Кириков 2002; Немцы в России 2003; Быт и культура 2003; Губкина 2003; Андреев 2005; Немцы Санкт-Петербурга 2005;

${ }^{2}$ Россия - Германия. Вехи совместной истории... 2015, 2018, 2019.
} 
Период конца XVIII в. - начала XIX в. прочно связан с таким литературным направлением как романтизм, жизнь которому дали писатели и философы т.н. Йенской школы ${ }^{3}$ в Германии. Ее идеи были поддержаны представителями Гейдельбергского романтизма ${ }^{4}$, с его обращением к национальному прошлому, мифологическим формам, народу и его подлинному языку - фольклору. Разгоравшаяся в Европе в начале XIX в. борьба с Наполеоном способствовала утверждению этих форм, в которых идеологи немецкого романтизма видели определенный протест, неприятие государственных реформ, насаждаемых Наполеоном на захваченных им территориях.

Эти литературные веяния не могли остаться без внимания в России, где благодаря В.А. Жуковскому появился такой феномен как «немецкая школа» русских поэтов. Под впечатлением от знаменитой баллады Г. Бюргера «Ленора» Жуковский создал обладавшие определенной литературной новизной баллады «Людмила» (1808) и «Светлана» (1812), имевшие большой успех у читателя. В.В. Набоков в своих комментариях к «Евгению Онегину» отмечал: «Меня всегда интересовало, не повлияла ли разработка Жуковским этой сонетной формы в «Светлане» на выбор Пушкиным размера для $\mathrm{E}<$ вгения> $\mathrm{O}<$ негина>, хотя, конечно, мелодика поэмы Жуковского < ..> производит иной эффект, нежели мелодика $\mathrm{E}<$ вгения $>\mathrm{O}<$ негина $>»^{5}$. Если принять точку зрения Набокова, через творчество Жуковского можно проследить определенную взаимосвязь немецкой литературы с построением стихотворного размера «Евгения Онегина». Спустя годы, Жуковский вернулся к балладе Г. Бюргера, выполнив в 1831 г. ее точный перевод на русский язык. Переводы с немецкого языка составляют большую часть творческого наследия Жуковского. Он перевел более десятка стихотворений И.В. фон Гёте, около 30 произведений Ф. Шиллера, стихотворения и поэмы поэта и естествоиспытателя А. фон Шамиссо, представителя «швабской школы поэтов» Л. Уланда, одного из важных выразителей идей европейского сентиментализма Ф.Г. Клопштока. Эти переводы оказали большое влияние на отечественную литературу первой половины XIX в., вследствие чего русский читатель познакомился с лучшими явлениями европейского литературного творчества. По словам В.Г. Белинского, «великая заслуга русскому обществу со стороны Жуковского: благодаря ему немецкая поэзия - нам родная, и мы умеем понимать ее без того усилия, которое условливается чуждою национальностию» ${ }^{6}$.

Сложный труд соединения двух культур предстоял Жуковскому в деле обучения русскому языку Фридерики Луизы Шарлотты Вильгельмины Прусской, прибывшей в июне 1817 г. в Россию для обручения с великим князем Николаем Павловичем, будущим российским импера-

\footnotetext{
${ }^{3}$ Behler 2010; Frank 1998; Pikulik 2000.

${ }^{4}$ Schlechter 2007; Ziolkowski 2009; Иванова 2007.

${ }^{5}$ См.: Комментарий к Главе III, V, 2-4// Набоков 1998: 290 - 291.

${ }^{6}$ Белинский 1955: 222.
} 
тором Николаем I. Справедливости ради нужно отметить, что прусской принцессе обучение давалось довольно сложно из-за особенностей поэтического образа мыслей ее учителя. В своих мемуарах императрица вспоминала: «Я принялась серьезно за уроки русского языка; в учителя мне был дан Василий Андреевич Жуковский, в то время уже известный поэт, слишком поэтичный, чтобы быть хорошим учителем. Вместо того чтобы корпеть над изучением грамматики, какое-нибудь отдельное слово рождало идею, идея заставляла искать поэму, а поэма служила предметом для беседы; таким образом проходили уроки. Поэтому русский язык я постигала плохо, и, несмотря на мое страстное желание изучить его, он оказывался настолько трудным, что я в продолжение многих лет не имела духу произносить на нем цельных фраз» ${ }^{7}$. Будучи придворным учителем (в 1825 г. он стал воспитателем наследника цесаревича Александра Николаевича), Жуковский неоднократно сопровождал своих венценосных воспитанников в поездках как по России, так и за рубеж, в частности в Германию. Российский поэт был лично знаком с Гёте и в 1820-е гг. дважды посещал его в Йене и Веймаре, крупнейших центрах немецкого романтизма того времени.

Выдающееся произведение Гёте «Фауст», первая часть которого была опубликована в 1808 г. во время беспощадной ломки наполеоновской Францией Старого порядка в Европе, было встречено в России с большим вниманием и интересом. В 1825 г. томившийся в ссылке в Михайловском А.С. Пушкин заинтересовался этим образом и написал «Сцену из Фауста», где сам Фауст «впервые в истории мировой литературы $<\ldots>$ был раскрыт реалистически» ${ }^{8}$. Несмотря на сходство образов, пушкинский Фауст отличается от своего прототипа у Гёте. У Пушкина он менее сосредоточен на постижении запретных знаний или погружении в мистицизм. Герой томится от нестерпимой скуки и угнетающей его тоски, о чем свидетельствуют слова, которыми Пушкин начинает свое стихотворение: «Мне скучно, бес». В этом образе тоскующего философа эпохи Вольтера Фауст более похож на главного героя романа в стихах «Евгений Онегин». Вместе с тем, Пушкин считал «великого Гёте» «нашим германским патриархом ${ }^{9} »$, а в статье 1827 г. «О Байроне» называл «Фауста» «величайшим созданием XVIII века», который «служит фаросом новейших времен, так точно как «Илиада» есть великолепный памятник древности» ${ }^{10}$. Есть легенда о том, что в знак признательности «великий Гёте, разговорившись с одним путешественником о России и, услышав о Пушкине, сказал: «Передайте моему собрату вот мое перо». Пером этим он только что писал. Гусиное перо великого поэта было доставлено Пушкину. Он сделал для него красный сафьянный футляр, на котором было <надписано> напечатано: Перо Гёте, и доро-

\footnotetext{
${ }^{7}$ Императрица Александра Федоровна в своих воспоминаниях 1896: 32 - 33.

${ }^{8}$ Макогоненко 1975: 286.

${ }^{9}$ Пушкин 1965: 247.

${ }^{10}$ Сочинения Пушкина 1929: 77.
} 
жил им» ${ }^{11}$, хотя «достоверность этой трогательной истории подвергается сомнению» ${ }^{12}$. Признанием славы творчества Гёте в России стало избрание его в 1826 г. почетным членом Императорской академии наук.

О Пушкине в Германии заговорили с начала 1820-х гг. В авторитетном литературном журнале «Zeitung für die elegante Welt», издававшемся с 1801 г. в Лейпциге, так отзывались об известном российском поэте: «Пушкин - это редкое литературное явление. Одаренный природой всеми качествами прекрасного поэта, он начал свою карьеру так, что многие решили считать его счастливчиком». Отмечалось, что к своим 25 годам Пушкин «снискал славу у муз» ${ }^{13}$. В этом же 1824 г. вышел перевод знаменитой поэмы Пушкина «Кавказский пленник», со вторым изданием которой был знаком и Гёте ${ }^{14}$. Благодаря появившимся спустя десятилетие переводам произведений Пушкина в прозе - «Пиковая дама», «История пугачевского бунта», «Дубровский», «Арап Петра Великого» - немецкие читатели познакомились с российскими традициями и интересными сюжетами российской истории. Переведенную за короткое время четырежды на немецкий язык трагедию «Борис Годунов» журнал «Blätter für literarische Unterhaltung» называл «одним из самых сильных и самобытных творений русской музы», сравнивая по силе воздействия с произведениями Шиллера и Шекспира ${ }^{15}$. На смерть российского поэта известная немецкая газета «Allgemeine Zeitung» отозвалась несколькими экстренными выпусками, в которых рассказывала о жизни Александра Сергеевича, его вкладе в российскую литературу ${ }^{16}$.

В отличие от А.С. Пушкина, совершенно не говорившего по-немецки, немецким языком прекрасно владел М.Ю. Лермонтов. В письме В.П. Боткину Белинский отмечал, что Лермонтов «славно знает по-немецки и Гёте почти всего наизусть дует» ${ }^{17}$. Это стало возможным во многом благодаря Христине Осиповне Ремер, няне Лермонтова. Детский и юношеский мир поэта формировался под влиянием не столько русских народных сказок, сколько сказок братьев Гримм, произведений Гёте и баллад Шиллера. «Наша литература так бедна, что я из нее ничего не могу заимствовать; в 15 же лет ум не так быстро принимает впечатления, как в детстве; но тогда я почти ничего не читал. - Однако же, если захочу вдаться в поэзию народную, то, верно, нигде больше не буду ее искать, как в русских песнях. - Как жалко, что у меня была мамушкой немка, а не русская - я не слыхал сказок народных; - в них, верно, больше поэзии, чем во всей французской словесности», - так отзывался о своих юношеских впечатлениях Лермонтов ${ }^{18}$.

\footnotetext{
${ }^{11}$ Рассказы о Пушкине 1925: 43.

${ }^{12}$ Гильманов, Копцев 2015: 65.

${ }^{13}$ Der russische Dichter Puschkin 1824: 1869.

${ }^{14}$ Henning 1987: 304.

${ }^{15}$ Knorring 1833: 174.

${ }^{16}$ Außerordentliche Beilage zur Allgemeinen Zeitung 1837.

${ }^{17}$ Белинский 1989: 301.

${ }^{18}$ Дудышкин 1859: 248.
} 
В 15-летнем возрасте Лермонтов перевел балладу Гёте «Рыбак». В 1829 г. после просмотра театральных постановок «Разбойники» и «Коварство и любовь» Шиллера у него являются собственные драматические планы и замыслы в духе трагедий Шиллера. В 1830 г. он написал одну из своих ранних драм «Menschen und Leidenschaften» («Люди и страсти»). Следование традиции прозаической драмы Шиллера заметно здесь не только в стилизации названия произведения, но и в трактовке семейного сюжета как высокой трагедии, сильном эмоциональном строе драмы, в употреблении броских фраз, афоризмов. Интересна история с первым творческим псевдонимом поэта. После того как на страницах драматической поэмы Шиллера «Дон Карлос, инфант испанский» ему встретился один из персонажей драмы, граф Франсиско Лерма, испанский государственный деятель, фаворит короля Филиппа III, Лермонтов сочинил легенду о том, что знаменитый граф был его предком. Вскоре поэт начал использовать подпись «M. Lerma» ${ }^{19}$, а иногда писал свою фамилию в документах через букву «а» ${ }^{20}$.

Лермонтов был известен в Германии еще при жизни. Именно в Германии вышел первый перевод его прозы на иностранный язык. В первом номере журнала «Der Freihafen» за 1841 г. был размещен выполненный немецким писателем и критиком, популяризатором русской литературы в Германии, К.А. Фарнхагеном фон Энзе перевод повести «Бэла» под заголовком: «Бела. Из записок российского офицера о Кавказе. С русского языка, по Михаилу Лермонтову» ${ }^{21}$. Фарнхаген фон Энзе так отзывался о Лермонтове: «Наиболее блестящее и наиболее обещающее явление новой русской поэзии <..> Молодой поэт, который обладает величайшим вдохновением <...> В его стихотворениях проявляется и мощь прежних времен, и свобода, и мастерство нынешних. На Лермонтова, по справедливости, обращены взоры, полные ожидания» ${ }^{22}$. Годом позже знаменитый востоковед и филолог Вильгельм Шотт сопровождал перевод на немецкий язык поэмы «Песня про царя Ивана Васильевича, молодого опричника и удалого купца Калашникова» такими восторженными словами: «Немногие поэты отличаются таким жаром и такой глубокой искренностью чувства; немногие обладают бо́льшим и более разнообразным богатством фантазии и более пышной красочностью, которую делает еще очаровательнее благозвучие прекраснейших стихов» ${ }^{23}$.

Впоследствии «Герой нашего времени» Лермонтова неоднократно переводился на немецкий язык ${ }^{24}$. Так, в одной из своих статей, опубликованной под псевдонимом Iskender, А.И. Герцен писал: «На немецком языке есть очень точный перевод (поэмы - В.Д.) «Мцыри» («Черкесский

\footnotetext{
19 Российская национальная библиотека.

${ }^{20}$ ИРЛИ; НИОКР РГБ; Бородино. М. Лермантова1837.

${ }^{21}$ Bela1841.

22 Varnhagen von Ense 1841: 235.

${ }^{23}$ Schott Wilhelm 1842: 441.

${ }^{24}$ Кандель 1962: 209 - 210.
} 
юноша»). Прочтите ее, чтобы понять эту раскаленную душу, которая борется, будучи скованной цепями, которая скорее становится диким зверем, змеей, дабы стать свободной, удалиться от людей» ${ }^{25}$. Эта тема жизни вдали от людей с большей силой проявилась в двух стихотворениях, написанных Лермонтовым незадолго до смерти: «Из Гёте» (1840) и «Сосна» (1841), у них были прообразы: «Über allen Gipfeln» (1780) Гёте и «Ein Fichtenbaum steht einsam» (1823) Гейне. Эти стихотворения Лермонтова, в которых были сохранены и точно переданы содержание и эмоциональная напряженность прообразов, было бы правильно назвать все же не переводами, а своеобразными переложениями, в чем и заключается особенность переводов Лермонтова. Эти стихи проникнуты особой грустью и мотивом одиночества. «Когда известие о гибели Лермонтова пришло 2 августа в Петербург, обнаружилась вся сила ненависти к поэту не только Николая, но и всего двора» ${ }^{26},-$ писала Э.Г. Герштейн. Лишь супруга российского императора Александра Федоровна, урожденная принцесса Фридерика Луиза Шарлотта Вильгельмина Прусская, писала С.А. Бобринской: «Вздох о Лермонтове, об его разбитой лире, которая обещала русской литературе стать ее выдающейся звездой» ${ }^{27}$.

Процесс взаимопроникновения двух культур в поэзии был бы трудным и едва ли возможным без профессионализма и точной работы переводчиков, среди которых важное место принадлежит немецкому писателю, поэту Фридриху Мартину фон Боденштедту. Благодаря его переводам немецкий читатель познакомился с произведениями Пушкина, Тургенева и особенно Лермонтова ${ }^{28}$. «Я перечитывал Лермонтова, чтобы сравнить перевод Боденштедта с оригиналами. Переводчик, в самом деле, добился чрезвычайных успехов, бо́льших, чем я считал возможным; он соединяет мощь с закругленностью и гладкостью» ${ }^{29},-$ так 29 июня 1852 г. характеризовал уровень переводов Боденштедта в своем дневнике Фарнхаген фон Энзе. «Перевод Лермонтова, сделанный Боденштедтом, признавался и рекомендовался современной ему немецкой критикой не менее, чем и переведенный им русский поэт», - позднее отмечал известный исследователь Ф. Дукмайер ${ }^{30}$.

Однако для российского литературного мира Германия стала не только родиной романтических литературных героев. После публикации на страницах «Московского журнала» в 1791-1792 гг. «Писем русского путешественника» Н.М. Карамзина германские государства на длительное время превратились в важное направление русских литературных путешествий XIX века. Германия стала первой заграницей для

\footnotetext{
${ }^{25}$ Von der Entwicklung der revolutionären Ideen in Russland 1851: 375.

${ }^{26}$ Герштейн 1986: 69

${ }^{27}$ Герштейн 1986: 72.

28 Боденштедт поведал немецкому читателю об известном русском поэте в послесловии к двухтомному переводу стихов Лермонтова (Bodenstedt 1852) и в собственных мемуарах (Bodenstedt 1888 - 1890).

${ }^{29}$ Assing 1868: 273.

${ }^{30}$ Dukmeyer 1913: 110.
} 
Н.В. Гоголя. Находясь под впечатлением от немецкой литературы и философии, Гоголь создал в своем представлении романтизированный образ Германии. Подражая идиллии немецкого поэта И.Г. Фосса «Луиза», он под псевдонимом В. Алов написал в 1827 г. поэму «Ганс Кюхельгартен», «идиллию в картинках», где нередки описания повседневных сцен, быта немцев, переданные в светлых, романтических тонах. Личное знакомство Гоголя с Германией началось в 1829 г. в Любеке, куда он прибыл на лечение ради целебных вод Травемюнда, расположенного неподалеку от Любека. В письме матери, М.И. Гоголь, 1 (13) августа 1829 г. писатель даже несмотря на неважное самочувствие нашел силы для того, чтобы красочно описать увиденную им в Любеке картину жизни:

«Чистота в домах необыкновенная; неприятного запаху нет вовсе в целом городе, как обыкновенно бывает в Петербурге, в котором мимо иного дома нельзя бывает пройти. Крестьянки девушки в красивых корсетиках, с зонтиком в руках толпятся с утра до вечера по рынкам и чистым улицам. Экипажей здесь вовсе не употребляют: добрые немцы обыкновенно отправляются пешком, и даже за город на несколько верст. Извозчиков нет в помине $<\ldots>$ Лошади здоровы и жирны, как волы $<\ldots>$ В городе шуму почти вовсе незаметно, хотя движения довольно $<\ldots>>$ Места, окружающие Любек, недурны < ..> Домики, разбросанные за городом, увитые и усаженные деревьями, кустарниками и цветами, прелестны и очень похожи на петербургские дачи; воздух довольно здоров, а климат немного подходит к нашему, т. е. полтавскому <... > Учтивость и какая-то прелесть обращения здешних жителей мне нравится. Простая крестьянка, у которой вы купите на рынке за какой-нибудь шиллинг фруктов или зелени, отвесит вам с такою приятностью кникс, которому позавидовала бы и наша горожанка» ${ }^{31}$.

Интересно, что наблюдения Гоголя за готической архитектурой легли в основу его статьи «Об архитектуре нынешнего времени» 32 (1833), а впечатления от описанной им ${ }^{33}$, предположительно, церкви Marienkirche - в основу заключения статьи «О средних веках» ${ }^{34}$. Приятные впечатления Германия оставила у Гоголя и в 1836 г., когда он путешествовал по стране из Любека в Гамбург, «прекрасный город», в котором жить «очень весело», затем в «старинный город» Бремен, где его удивил один «погреб, который имеет такое странное свойство, что все тела, которые похоронены там, не тлеют», и потом в Ахен, где «есть воды, то есть ручьи, которые текут и кипят вместе и такие горячие, что в них с трудом можно купаться; однако же кто купается в них, тот выздоравливает, в какой бы ни был болезни» ${ }^{35}$. После этого Гоголь направился в Кёльн, «в котором катедраль считается первым в Европе по своей архитектуре», а уже из этого города его ожидало «самое приятное путешествие на пароходе по реке Рейну» ${ }^{36}$. Из Франкфурта, этого «Парижа Германии», он направился в Баден-Баден. Находясь здесь, Гоголь

${ }^{31}$ Гоголь Н.В. - Гоголь М.И. 1 (13) августа 1829 г.// Гоголь 1940: 153 - 154.

${ }^{32}$ Гоголь Н.В. Об архитектуре нынешнего времени// Гоголь 1952. Т. 8: 56 - 75.

${ }^{33}$ Гоголь Н.В. - Гоголь М.И. 25 августа 1829 г.// Гоголь 1940: 156.

${ }^{34}$ Гоголь Н.В. О средних веках// Гоголь. 1952. Т. 8: $14-25$.

${ }^{35}$ Гоголь Н.В. - Гоголь А.В. и Е.В. 17 июля 1836// Гоголь 1952. Т. 11: 52 - 54.

${ }^{36}$ Гоголь Н.В. - Гоголь М.И. 17/ 5 июля 1836// Гоголь 1952. Т. 11: 56. 
писал: «Заехал только на три дня и откуда уже три недели не могу выбраться» ${ }^{37}$. Затем его путь вел в Швейцарию.

Жизнь Гоголя в течение первой половины 1837 г. в Италии, где он с большим вдохновением работал над поэмой «Мертвые души», ухудшение здоровья и личные переживания в связи с гибелью Пушкина все это оказало влияние на его последующее восприятие Европы в целом и Германии в частности. Вынужденный отправиться на лечение минеральными водами, Гоголь отзывается теперь о поражавших его некогда Швейцарии и Германии совсем по-иному: прежние теплые чувства к Германии исчезли, кажется, совершенно. В Германии ему становится душно, теперь жизнь поддерживают в нем мысли об Италии. В письме Н.Я. Прокоповичу из Баден-Бадена в июле 1837 г. он жаловался: «Какое гадкое, какое ужасное время! Дождь, слякоть, Сердце мое тоскует по Риме и по моей Италии!» ${ }^{38}$. Путешествие на пароходе по Рейну теперь уже не радовало его. Раздраженно Гоголь писал: «Все пассажиры столпились в одну каюту, и немецкий запах сделался до такой степени густ, что можно было 700 топоров повесить <...> тоска проходила меня насквозь от головы и до пяток» ${ }^{39}$. Уже осенью 1837 г. в Риме Гоголь в письме Жуковскому сделает одно из своих самых жестких признаний: «Вы говорили мне о Швейцарии, о Германии и всегда вспоминали о них с восторгом. Моя душа также приняла их живо <.. > Но теперь, когда я побывал в них после Италии, низкими, пошлыми, гадкими, серыми, холодными показались мне они со всеми их горами и видами, и мне кажется как будто я был в Олонецкой губернии и слышал медвежее дыхание северного океана» ${ }^{40}$. Несмотря на это, Германия вскоре обрела новое место в жизни Гоголя. Период высшего развития его религиозного настроения, вторая половина 1844 г. - начало 1845 г., прошел во Франкфурте. Гоголь выбрал этот «пуп Европы, куда сходятся все дороги» ${ }^{41}$, для своей работы, поселившись у Жуковского. Прежние оценки Германии и немцев в личной корреспонденции Гоголя уже не встречаются. Писателя поглотила работа над продолжением «Мертвых душ», он был занят собственными духовными поисками.

В это время Гоголя начали активно переводить на немецкий язык. Первоначально немецкие издатели были заинтересованы в публикации переводов повестей из сборников «Вечера на хуторе близ Диканьки» и «Миргород», поскольку в них наиболее ярко был выражен национальный «русский» колорит. Уже в 1844 г. в Германии увидела свет повесть «Тарас Бульба», а в 1846 г. - первый перевод поэмы «Мертвые души» ${ }^{42}$. Вышедший в Берлине в 1854 г. из-под пера известного литератора и пе-

\footnotetext{
${ }^{37}$ Гоголь Н.В. - Гоголь М.И. 26/ 14 июля 1836// Гоголь 1952. Т. 11: 57.

${ }^{38}$ Гоголь Н.В. - Прокоповичу Н.Я. 21/ 9 июля 1837// Гоголь 1952. Т. 11: 107.

${ }^{39}$ Гоголь Н. В. - Н.М. Смирнову. 3 сентября 1837// Гоголь 1952. Т. 11: 108.

${ }^{40}$ Гоголь Н. В. - В.А. Жуковскому. 30 октября 1837// Гоголь. 1952. Т. 11: 111.

${ }^{41}$ Гоголь Н. В. - А.А. Иванову. 9 января 1845// Гоголь. 1952. Т. 12: 451.

${ }^{42}$ Die todten Seelen 1846.
} 
реводчика Августа фон Фидерта первый перевод «Ревизора» в Германии стал одним из лучших переводов не только XIX в., но и XX в. ${ }^{43}$

Своеобразную роль сыграла Германия в жизни и личных переживаниях Ф.И. Тютчева и А.А. Фета. В 1821 г. по окончании Московского университета молодой Тютчев поступил на службу в Министерство иностранных дел и вскоре был определен в качестве внештатного атташе Российской дипломатической миссии в столицу Баварского королевства - Мюнхен. В этом важном центре европейской культуры, средоточии музеев, картинных галерей и библиотек одаренный юноша в скором времени познакомился с Гейне, с которым его надолго связала крепкая дружба, и с Шеллингом. В Мюнхене Тютчев с увлечением занимался поэзией, литературными переводами. Именно он открыл русскому читателю поэзию Гейне. Перевод его знаменитого «Ein Fichtenbaum steht einsam» Тютчев опубликовал в 1827 г. в альманахе «Северная лира» ${ }^{44}$, задолго до лермонтовской «Сосны».

С Мюнхеном была связана личная драма молодого российского дипломата. В 1824 г. у него случился бурный роман с Амалией фон Лерхенфельд, двоюродной сестрой российской императрицы Александры Федоровны по материнской линии и, по слухам, дочерью прусского короля Фридриха-Вильгельма III. Молодые даже приняли решение о свадьбе, с чем, однако, оказались не согласны родственники как самого Тютчева, так и Амалии. В итоге юную красавицу отдали замуж за непосредственного начальника Тютчева по службе: первого секретаря русской миссии в Мюнхене барона А.С. Крюденера, который был старше ее на 22 года. Вскоре Тютчев женился на немке, вдове российского дипломата, секретаря миссии в Мюнхене А.Х. Петерсона, Эмилии Элеоноре фон Ботмер. Для Тютчева этот период был богатым с точки зрения его литературной работы. В 1836 г. в 3 и 4 томах издаваемого Пушкиным журнала «Современник» было опубликовано 24 стихотворения Тютчева ${ }^{45}$. Н.А. Некрасов напишет позже: «Хотя они и присылаемы были из Германии, но не подлежало никакому сомнению, что автор - русский: все они написаны были чистым и прекрасным языком, и многие носили на себе живой отпечаток русского ума, русской души» ${ }^{46}$. В конце 1837 г. Тютчев в ранге камергера и статского советника получил назначение старшего секретаря российского дипломатического представительства в Турине. После скоропостижной смерти супруги в 1838 г. он в 1839 г. женился во второй раз на немке, богатой баронессе Эрнестине фон Пфеффель, с которой познакомился еще в 1833 г. Несогласованный с Петербургом отъезд в 1839 г. в Швейцарию стал причиной лишения Тютчева звания камергера и отставки - ему пришлось вновь поселиться в Мюнхене, где поэт прожил еще четыре года.

\footnotetext{
${ }^{43}$ Der Revisor 1854.

${ }^{44}$ Тютчев 1984: 175.

${ }^{45}$ Стихотворения, присланные из Германии Ф.Т. 1836. Т. 3., Т. 4.

${ }^{46}$ Некрасов 1850: 56.
} 
Во многом благодаря помощи и ходатайству давней знакомой, петербургской красавицы баронессы Амалии Крюденер, которой помимо Гейне, Пушкина, Вяземского, Тургенева, баварского короля Людвига I восторгались также А.X. Бенкендорф и император Николай I, Тютчев был «восстановлен» в обществе, чему во многом способствовало то, что в российской столице положительно отзывались о работе поэта по созданию позитивного образа России на Западе. Опубликованная им (без указания своего авторства) в 1844 г. политическая статья «Россия и Германия» («Письмо к г-ну доктору Кольбу») 47 была с большим интересом воспринята в Петербурге, а сам император «нашёл в ней все свои мысли и будто бы поинтересовался, кто её автор» ${ }^{48}$. Во многом благодаря этим изменениям Тютчева ожидал дружелюбный прием в обществе после того как он окончательно возвратился в 1844 г. из Германии в Россию.

Германия оставила значительный след и в семейных перипетиях А.А. Фета. Так, отец поэта Афанасий Неофитович Шеншин, представитель древнего русского дворянского рода, находясь в Дармштадте на лечении, женился в 1819 г. на дочери обер-кригс-комиссара К. Беккера Шарлотте, которая по первому мужу носила фамилию Фёт (Foeth), после чего молодожены переехали в Россию, где в 1822 г. венчались по православному обряду. В 1834 г. духовная консистория пересмотрела законность признания Афанасия сыном Шеншина и отменила соответствующую крещальную запись, поскольку полученное в Дармштадте лютеранское благословение на брак в России не признавалось законным, а православное венчание произошло уже после рождения Афанасия. В этой связи юноша определялся сыном первого мужа Шарлотты Иоганна-Петера-Карла-Вильгельма Фёта - исключался из рода Шеншиных, лишался русского подданства и потомственного дворянства, что оказало огромное влияние на его дальнейшую жизнь ${ }^{49}$. Несмотря на то, что в 1873 г. он официально вернул себе родовую фамилию Шеншин и дворянство, свои литературные произведения и переводы он продолжал подписывать фамилией Фет (через «е»).

Современники Фета отмечали в его характере присущие немецкому менталитету особенности. Так, И.С. Тургенев в письме своему приятелю И.П. Борисову отмечал: «Вы совершенно верно определили его характер - недаром в нем частица немецкой крови - он деятелен и последователен в своих предприятиях, при всей поэтической безалаберщине - и я уверен, что, конец концов, - его лирическое хозяйство принесет ему больше пользы, чем множество других, прозаических и практических ${ }^{50}$. Германия присутствовала и в творчестве Афанасия Афанасьевича, особенно в его поздний период. В конце 1870-х - начале 1880-х

\footnotetext{
${ }^{47}$ Lettre à Monsieur le D-r Gustave Kolb 1844, также: Тютчев 1912: 431 - 455.

${ }^{48}$ Ф. И. Тютчев - И. Н. и Е. Л. Тютчевым. 27 октября 1844 г.// Тютчев 1980: 30 - 31.

${ }^{49}$ Страхов 1912: 3 - 10.

50 Тургенев И.С. - Борисову И.П. 21 февраля (3 марта) 1862 г.// Щукинский сборник. 1909: $361-362$.
} 
он работал над переводом «Фауста» Гёте (опубликован в 1889 г. $\left.{ }^{51}\right)$. Он также перевел на русский язык сочинения Шопенгауэра: «Мир как воля и представление» (1880) и «О четверояком корне закона достаточного основания» и «О воле в природе» (1886) - и даже задумывался о переводе «Критики чистого разума» И. Канта.

Германия оставила особый след в жизни И.С. Тургенева. «Я столь многим обязан Германии, что не могу не любить и не почитать ее, как свою вторую родину», - писал он в 1869 г. в предисловии к первому переводу на немецкий язык романа «Отцы и дети» ${ }^{52}$. Знакомство с немецкими традициями, обычаями и правилами началось для юного Ивана Тургенева и его брата Николая в пансионе Вейденгаммера в Москве, куда переехала семья Тургеневых, чтобы дать детям образование, а затем продолжилось в известном пансионе директора Лазаревского института немца И.Ф. Краузе. Здесь он получил практику разговорного немецкого языка и познакомился с первыми книгами на немецком. Немецкая литература навсегда вошла в круг чтения писателя. После учебы в Московском университете и окончания Петербургского университета Тургенев в 1838 г. переехал в столицу Прусского королевства, где поступил в престижный Берлинский университет. Знакомство с миром немецкой литературы, чтение «Фауста» Гёте, первую часть которого он знал наизусть, «Философии и христианства» Л. Фейербаха и лирики А. Шамиссо подтолкнули Тургенева к первым пробам пера на немецком. Большим успехом для студента Тургенева было знакомство с выдающимся немецким ученым А. фон Гумбольдтом, известными писателями Б. фон Арним и Фарнхаген фон Энзе. Жизнь в Германии настолько захватила его, что даже Италия не смогла переломить это чувство, как, например, у Гоголя. «Я приехал сюда, почти не останавливаясь, из Неаполя (в 15 дней), и так велико во мне было стремленье вернуться в Берлин - что я покинул Италию без большого сожаленья» ${ }^{53},-$ писал Тургенев Т.Н. Грановскому в мае 1840 г. Именно в Берлине завязалась дружба Тургенева с Н.В. Станкевичем, Т.Н. Грановским и М.А. Бакуниным.

В 1847 г. через семь лет жизни в России Тургенев вернулся в Берлин, где быстро вошел в берлинское общество, представители которого отмечали блестящее владение Тургенева немецким языком, как и его талант рассказчика. Германия в этот период переживала предреволюционную ситуацию, которая назревала в стране уже с начала 1840-х гг. Прекрасное знание Германии и немецкого общества помогло Тургеневу приступить к работе над серией «Писем из Берлина», но из-за преждевременного выезда писателя из Берлина было опубликовано только одно письмо. Используя «эзопов язык», Тургенев в «Письмах из Берлина» намеками, иносказательно подверг критике современную Германию. Несмотря на небольшой объем и лаконичность, письмо насыщено глу-

${ }^{51}$ Гёте И. В. Фауст 1889.

52 Vorrede // Turgenjew 1869: 6.

${ }^{53}$ Тургенев И. - Грановскому Т. Н., 18 (30) мая 1840 г. // Тургенев 1982: 153. 
боким содержанием и общественно-политическими смыслами. Читателя «Первого письма» может насторожить тревожное ощущение предстоящих перемен, которым делился русский писатель. «Наружность Берлина не изменилась с сорокового года $<\ldots>$ но большие внутренние перемены совершились < ..> Особенно теперь все здесь исполнены ожиданья, - писал Тургенев. - Повторяю: я нашел в Берлине перемену большую, коренную, но незаметную для поверхностного наблюдателя: здесь как будто ждут чего-то, все глядят вперед» ${ }^{54}$. В этих важных строках проявился определенный дар предвиденья Тургенева. Через год Германию опалила захлестнувшая Европу Революция 1848 г., а берлинцы вышли на баррикады. Определенным следствием революционных событий 1848 г. стал запуск новых внутриполитических и международных механизмов в общеконтинентальном масштабе. Это привело к значительным изменениям в самой Европе и дальнейшему углублению российскогерманских отношений, что нашло интересное отражение в русской литературе второй половины XIX в.

Колыбель европейского романтизма, Германия накануне и в годы борьбы с нашествием Наполеона привлекала европейские страны пробуждением национально-патриотического движения и той ролью, которую в этом процессе играли философия и литература. На этом фоне она увлекала русских писателей и поэтов новыми стихотворными формами, литературными сюжетами и философскими рассуждениями. Германия являлась источником, но в то же время и своеобразным фильтром, через который в России распространялись достижения европейской культуры. С другой стороны, благодаря кропотливому труду немецких переводчиков, литературным «посольствам» русских писателей во время их путешествий по Германии достижения русской литературы стали известны и в Европе. Такой опыт плодотворного сотрудничества в области литературы обогащал культуру России и германских государств, укреплял развитие общеевропейских культурных интеграционных процессов.

1840-е годы, на фоне которых утверждался реализм как новое литературное направление, пришедшее на смену романтизму, ставили новые задачи и проблемы, с которыми предстояло столкнуться Европе во второй половине столетия. В середине XIX столетия перед Германией и Россией возникла острая необходимость решения своих национальных задач: решение германского вопроса, преодоление последствий Крымской войны, внутриполитическое реформирование, ликвидация экономической отсталости, выход из дипломатической изоляции. На этом фоне личные переживания русских писателей второй половины XIX в. и их собственный опыт познания Германии и немцев оказали влияние на трансформацию образа Германии и германского мира в русской литературе, во многом отражая изменившиеся настроения и отношение российского общества к Германии.

${ }^{54}$ Письма из Берлина. Письмо первое, 1 марта н. ст. 1847 // Тургенев 1933: 316-319. 


\section{БИБЛИОГРАФИЯ / REFERENCES}

Андреев А.Ю. Русские студенты в немецких университетах XVIII - первой половины XIX века. М.: Знак, 2005. 432 с. [Andreev A.Y. Russkie studenty v nemeckih universitetah XVIII - pervoj poloviny XIX veka. M.: Znak, 2005. 432 s.]

Белинский В.Г. Выдержки из писем и статей [о Лермонтове] // М.Ю. Лермонтов в воспоминаниях современников / Редкол.: В. Вацуро, Н. Гей, Г. Елизаветина и др. М.: Художественная литература, 1989. 672 с. [Belinskij V.G. Vyderzhki iz pisem i statej [o Lermontove] // M.Y. Lermontov v vospominaniyah sovremennikov / Redkol.: V. Vacuro, N. Gej, G. Elizavetina i dr. M.: Hudozhestvennaya literatura, 1989. 672 s.].

Белинский В.Г. Полное собрание сочинений: В 13 т. М.: Изд-во АН СССР, 1955. - Т. 7. Статьи и рецензии. 1843. Статьи от Пушкине. 1843-1846. 799 с.; 2 л. ил. [Belinskij V.G. Polnoe sobranie sochinenij: V 13 t. M.: Izd-vo AN SSSR, 1955. - T. 7. Stat'i i recenzii. 1843. Stat'i ot Pushkine. 1843-1846. 799 c.; 2 1. il.]

Бородино. М. Лермантова // Современник, литературный журнал А.С. Пушкина, изданный по смерти его. Т. 6, СПб.: Гуттенбергова типография, 1837. С. 207-211. [Borodino. M. Lermantova // Sovremennik, literaturnyj zhurnal A.S. Pushkina, izdannyj po smerti ego. T. 6, SPb.: Guttenbergova tipografiya, 1837. S. 207-211].

Быт и культура российских немцев в музеях Санкт-Петербурга $=$ Alltag und kultur der russlanddeutschen in museen von Sankt Petersburg. СПб.: Наука, 2003. 142, [2] с.: ил., портр., факс. [Byt i kul'tura rossijskih nemcev v muzeyah Sankt-Peterburga $=$ Alltag und kultur der russlanddeutschen in museen von Sankt Petersburg. SPb.: Nauka, 2003. 142, [2] s.: il., portr., faks.].

Герштейн Э.Г. Судьба Лермонтова. 2-е изд. испр. и доп. М.: Худож. лит-ра, 1986. 351 с. [Gershtejn E.G. Sud'ba Lermontova. 2-e izd. ispr. i dop. M.: Hudozh. lit-ra, 1986. 351 s.]

Гёте И.В. Фауст / пер. А. Фета; с рис. Э. Зейбертца. Ч. 1-[2]. СПб.: А.Ф. Маркс, 1889. 173, [2], 218, [2], XXIX с., [27] л. ил.: ил.; 46. [Gyote I.V. Faust / per. A. Feta; s ris. E. Zejbertca. Ch. 1-[2]. SPb.: A.F. Marks, 1889. - 173, [2], 218, [2], XXIX s., [27] 1. il.: il.; 46.].

Гильманов В.Х., Копцев И.Д. «Зона Фауста» в творчестве Гёте и Пушкина // Вестник Балтийского федерального университета им. И. Канта. 2015. Вып. 8. с. 65-71. [Gil'manov V.H., Kopcev I.D. «Zona Fausta» v tvorchestve Gyote i Pushkina// Vestnik Baltijskogo federal'nogo universiteta im. I. Kanta. 2015. Vyp. 8. s. 65-71].

Гоголь Н.В. Полное собрание сочинений. М.: Изд-во АН СССР, 1952. Т. 8. Статьи. 816 с. [Gogol' N.V. Polnoe sobranie sochinenij. M.: Izd-vo AN SSSR, 1952. T. 8. Stat'i. 816 s.].

Гоголь Н.В. Полное собрание сочинений. М.: Изд-во АН СССР, 1940. Т. 10. Письма. 1820-1835 / ред. В.В. Гиппиус. 540 с. [Gogol' N.V. Polnoe sobranie sochinenij. M.: Izdvo AN SSSR, 1940. T. 10. Pis'ma. 1820-1835/ red. V.V. Gippius. 540 s.].

Гоголь Н.В. Полное собрание сочинений. М.: Изд-во АН СССР, 1952. Т. 11. Письма. 1836-1841/ ред. Б.П. Городецкий. 484 с. [Gogol' N.V. Polnoe sobranie sochinenij. M.: Izd-vo AN SSSR, 1952. T. 11. Pis'ma. 1836-1841/ red. B.P. Gorodeckij. 484 s.].

Гоголь Н.В. Полное собрание сочинений. М.: Изд-во АН СССР, 1952. Т. 12. Письма. 1842-1845/ ред. Г.М. Фридлендер. 720 с. [Gogol' N.V. Polnoe sobranie sochinenij. M.: Izd-vo AN SSSR, 1952. T. 12. Pis'ma. 1842-1845/ red. G.M. Fridlender. 720 s.].

Губкина Н.В. Немецкий музыкальный театр в Петербурге в первой трети XIX века. СПб.: Дмитрий Буланин, 2003. 563, [1] с., [8] л. ил. [Gubkina N.V. Nemeckij muzykal'nyj teatr v Peterburge v pervoj treti XIX veka. SPb.: Dmitrij Bulanin, 2003. 563, [1] s., [8] 1. il.].

Дудышкин С.С. Ученические тетради Лермонтова. Статья вторая и последняя // Отечественные записки. СПб.: Тип. И.И. Глазунова и К, 1859. № 11. С. 245 -270. [Dudyshkin S.S. Uchenicheskie tetradi Lermontova. Stat'ya vtoraya i poslednyaya// Otechestvennye zapiski. SPb.: Tip. I.I. Glazunova i K, 1859. № 11. S. 245-270].

Иванова Е.Р. Романтизм и бидермейер в немецкой литературе XIX века // Преподаватель XXI век. M., 2007. № 2. C. 118-125. [Ivanova E.R. Romantizm i bidermejer v nemeckoj literature XIX veka // Prepodavatel' XXI vek. M., 2007. № 2. S. 118-125.].

Императрица Александра Федоровна в своих воспоминаниях // Русская старина. Т. 88. СПБ: Типография Высочайше утвержд. Товарищ. «Общественная польза», 1896. 703, [5], 45 с., [3] л. портр. : ил. [Imperatrica Aleksandra Fedorovna v svoih vospominaniyah// Russkaya starina. T. 88. SPB: Tipografiya Vysochajshe utverzhd. Tovarishch. «Obshchestvennaya pol'za», 1896. - 703, [5], 45 s., [3] 1. portr.: ill.]. 
ИРЛИ, оп. 1, № 1 (переплетенная тетр.). Кавказский пленник. Сочинение М. Лермантова. M., 1828. [IRLI, op. 1, № 1 (perepletennaya tetr.). Kavkazskij plennik. Sochinenie M. Lermantova. M., 1828.].

Кандель Б.Л. Библиография переводов романа «Герой нашего времени» на иностранные языки // Лермонтов М.Ю. Герой нашего времени. М.: Изд-во АН СССР, 1962. С. 203218 [Kandel' B.L. Bibliografiya perevodov romana «Geroj nashego vremeni» na inostrannye yazyki // Lermontov M.Y. Geroj nashego vremeni. M.: Izd-vo AN SSSR, 1962. S. 203-218].

Кириков Б.М. Петербург немецких архитекторов: От Барокко до авангарда. СПб.: Чистый лист, 2002. 414, [1] с.: ил. [Kirikov B.M. Peterburg nemeckih arhitektorov: Ot Barokko do avangarda. SPb.: CHistyj list, 2002. 414, [1] s.: il.].

Макогоненко Г.П. Пушкин и Гёте: (К истории истолкования пушкинской «Сцены из Фауста») // XVIII век. Л.: Наука, 1975. Сб. 10: Русская литература XVIII века и ее международные связи: Памяти чл.-кор. АН СССР П.Н. Беркова. С. 284-291 [Makogonenko G.P. Pushkin i Gyote: (K istorii istolkovaniya pushkinskoj «Sceny iz Fausta») // XVIII vek. L.: Nauka, 1975. Sb. 10: Russkaya literatura XVIII veka i ee mezhdunarodnye svyazi: Pamyati chl.-kor. AN SSSR P. N. Berkova. S. 284-291.].

Набоков В. Комментарий к роману А.С. Пушкина «Евгений Онегин». СПб.: ИскусствоСПБ: Набоковский фонд, 1998. 924 с.: илл. [Nabokov V. Kommentarij k romanu A.S. Pushkina «Evgenij Onegin». SPb.: Iskusstvo-SPB: Nabokovskij fond, 1998. 924 s.: ill.].

Некрасов Н.А. Русские второстепенные поэты // Современник. Т. ХІХ. СПб.: Тип. Эдуарда Праца, 1850. C. 42-74. [Nekrasov N.A. Russkie vtorostepennye poety // Sovremennik . T. XIX. SPb.: Tip. Eduarda Praca, 1850. S. 42-74.].

Немцы в России $=$ Die Deutschen in Russland: три века научного сотрудничества / отв. ред. Г. Смагина. СПб.: Дмитрий Буланин, 2003. 604 с. [Nemcy v Rossii = Die Deutschen in Russland: tri veka nauchnogo sotrudnichestva / otv. red. G. Smagina. SPb.: Dmitrij Bulanin, 2003. 604 s.].

Немцы Санкт-Петербурга: наука, культура, образование $=$ Die Deutschen in SanktPetersburg: Wissenschaft, Kultur, Bildung / отв. ред. Г. Смагина. СПб.: Росток, 2005. 637 c. [Nemcy Sankt-Peterburga: nauka, kul'tura, obrazovanie = Die Deutschen in Sankt-Petersburg: Wissenschaft, Kultur, Bildung / otv. red. G. Smagina. SPb.: Rostok, 2005. 637 s.].

НИОКР РГБ. Ф.500, к.1, ед. 5. М.Ю. Лермонтов. Письмо к М.А. Шан-Гирей [1831]. 2лл. [NIOKR RGB. F.500, k.1, ed. 5. M.YU. Lermontov. Pis'mo k M.A.Shan-Girej [1831]. 211.].

Петров Ю.А. Немецкие предприниматели в Москве XIX - начала XX в. // Немцы Москвы: исторический вклад в культуру столицы. Международная научная конференция, посвященная 850-летию Москвы. Сборник докладов. М.: Общественная Академия наук российских немцев, 1997. С. 132-152. [Petrov Y.A. Nemeckie predprinimateli v Moskve XIX- nachala XX v. // Nemcy Moskvy: istoricheskij vklad v kul'turu stolicy. Mezhdunarodnaya nauchnaya konferenciya, posvyashchennaya 850-letiyu Moskvy. Sbornik dokladov. M.: Obshchestvennaya Akademiya nauk rossijskih nemcev, 1997. S. 132-152].

Пушкин А.С. Полное собрание сочинений: В 10 т. 3-е изд. Л.: Наука, 1963-1965. Т. 10. Письма / Текст проверен и примеч. сост. проф. Л.Б. Модзалевским и И.М. Семенко под ред. проф. Б.В. Томашевского. 904 с. [Pushkin A.S. Polnoe sobranie sochinenij: V 10 t. 3-e izd. L.: Nauka, 1963-1965. T. 10. Pis'ma / Tekst proveren i primech. sostavleny prof. L.B. Modzalevskim i I.M. Semenko pod red. prof. B.V. Tomashevskogo. 904 s.].

Рассказы о Пушкине, записанные со слов его друзей П.И. Бартеневым в 1851-1860 годах / вступ. статья и примеч. М. Цявловского. М.: М. и С. Сабашниковы, 1925. 140 с. [Rasskazy o Pushkine, zapisannye so slov ego druzej P.I. Bartenevym v 1851-1860 godah / vstup. stat'ya i primech. M. Cyavlovskogo. M.: M. i S. Sabashnikovy, 1925. 140 s.].

Российская национальная библиотека. Ф. 429 (Лермонтов). № 40. «Скачущая неоседланная лошадь», рисунок. <1833-1834>. Бумага, перо, чернила, 14,7 × 20,4. [Rossijskaya nacional'naya biblioteka. F. 429 (Lermontov). № 40. «Skachushchaya neosedlannaya loshad'», risunok. <1833-1834>. Bumaga, pero, chernila, $14,7 \times 20,4$.].

Россия - Германия. Вехи совместной истории в коллективной памяти. Т. 1. XVIII в. / под ред. В.С. Дударева, М.Б. Лавринович, Х. Мёллера, К. Шарфа. М.: ГАУГН-Пресс, 2018. 421 с.: илл. [Rossiya - Germaniya. Vekhi sovmestnoj istorii v kollektivnoj pamyati. T. 1. XVIII v. / pod red. V.S. Dudareva, M.B. Lavrinovich, H. Myollera, K. SHarfa. M.: GAUGN-Press, 2018. 421 s.: ill.]. 
Россия - Германия. Вехи совместной истории в коллективной памяти. Т. 2. XIX в. / под ред. В.С. Дударева, А.Г. Матвеевой, Х. Альтрихтера, Н. Катцера. М.: ГАУГН-Пресс, 2019. 368 с.: илл. [Rossiya - Germaniya. Vekhi sovmestnoj istorii v kollektivnoj pamyati. T. 2. XIX v. / pod red. V.S. Dudareva, A.G. Matveevoj, H. Al'trihtera, N. Katcera. M.: GAUGN-Press, 2019. 368 s.: ill.].

Россия - Германия. Вехи совместной истории в коллективной памяти. Т. 3. XXв. / под ред. А.О. Чубарьяна, Х. Мёллера. М.: ГАУГН-Пресс, 2015. 398 с.: илл. [Rossiya Germaniya. Vekhi sovmestnoj istorii v kollektivnoj pamyati. T. 3. XX v. / pod red. A.O. CHubar'yana, H. Myollera. M.: GAUGN-Press, 2015. 398 s.: ill.].

Сочинения Пушкина. Издание Академии наук СССР. Том IX. Кн. 2: Примечания к историко-литературным, критическим, публицистическим и полемическим статьям и заметкам/ под ред. Н.К. Козмина. Л., 1929. 1046 с. [Sochineniya Pushkina. Izdanie Akademii nauk SSSR. Tom IX. Kn. 2: Primechaniya k istoriko-literaturnym, kriticheskim, publicisticheskim i polemicheskim stat'yam i zametkam/ Pod red. N.K. Kozmina. L., 1929. 1046 s.].

Стихотворения, присланные из Германии Ф.Т. // Современник, литературный журнал А.С. Пушкина. Т. 3. СПб.: Гуттенбергова типография, 1836. С. 5-22. [Stihotvoreniya, prislannye iz Germanii F.T. // Sovremennik, literaturnyj zhurnal A.S. Pushkina. T. 3, SPb.: Guttenbergova tipografiya, 1836. S. 5-22.].

Стихотворения, присланные из Германии (Ф.Т.) // Современник, литературный журнал А.С. Пушкина. Т. 4. СПб.: Гуттенбергова типография, 1836. С. 32-41. [Stihotvoreniya, prislannye iz Germanii (F.T.) // Sovremennik, literaturnyj zhurnal A.S. Pushkina. T. 4, SPb.: Guttenbergova tipografiya, 1836. S. 32-41].

Страхов Н.Н. А.А. Фет. Биографический очерк // Полное собрание стихотворений А.А. Фета. Т. 1. Прилож. к журналу «Нива» на 1912 г. СПб.: Изд. Т-ва А.Ф. Маркс, 1912. 470 c. [Strahov N.N. A.A. Fet. Biograficheskij ocherk// Polnoe sobranie stihotvorenij A.A. Feta. T. 1. Prilozh. k zhurnalu «Niva» na 1912 g. SPb.: Izd. T-va A.F. Marks, 1912. 470 s.].

Тургенев И.С. Полное собрание сочинений и писем. В 30 т. Письма. В 18 т. М.: Наука, 1982. T. 1. Письма, 1831-1849. 607 c. [Turgenev I.S. Polnoe sobranie sochinenij i pisem. V 30 t. Pis'ma. V 18 t. M.: Nauka, 1982. T. 1. Pis'ma, 1831-1849. 607 s.].

Тургенев И.С. Сочинения / ред. К. Халабаева и Б. Эйхенбаума. М., Л.: Гос. изд-во, 19281934. В 12 т. Т. 12. Статьи, речи, предисловия, корреспонденции, письма в редакцию. 1933. 754 c. [Turgenev I.S. Sochineniya / red. K. Halabaeva i B. Ejhenbauma. M., L.: Gos. izd-vo, 1928-1934. V 12 t. T. 12. Stat'i, rechi, predisloviya, korrespondencii, pis'ma v redakciyu. $1933.754 \mathrm{~s}$.$] .$

Тютчев Ф.И. Полное собрание сочинений / ред. изд. П.В. Быкова. 6-е изд., испр. и доп. СПб.: Т-во А.Ф. Маркс, 1912. XLVIII, 694 с. [Tyutchev F.I. Polnoe sobranie sochinenij/ red. izd. P.V. Bykova. 6-e izd., ispr. i dop. SPb.: T-vo A.F. Marks, 1912. XLVIII, 694 s.].

Тютчев Ф.И. С Чужой стороны// Северная лира на 1827 год/ АН СССР; изд. подгот. Т.М. Гольц, А.Л. Гришунин. М.: Наука, 1984. - 415 с.: 4 л. ил. [Tyutchev F.I. S Chuzhoj storony// Severnaya lira na 1827 god/ AN SSSR; izd. podgot. T. M. Gol'c, A. L. Grishunin. M.: Nauka, 1984. -415 s.: 4 1. ill.].

Тютчев Ф.И. Сочинения: в 2 томах / сост. и подгот. текста А.А. Николаева. Т. 2. Письма. М.: Правда, 1980. 351 с., 4 л. ил. [Tyutchev F.I. Sochineniya: v 2 tomah/ sost. i podgot. teksta A.A. Nikolaeva. T. 2. Pis'ma. M.: Pravda, 1980. 351 s., 4 1. ill.].

Щукинский сборник. Отделение Императорского Российского исторического музея им. императора Александра III - Музей П.И. Щукина. Вып. 8. М.: Синодальная типография, 1909. 461 c. [Shchukinskij sbornik. Otdelenie Imperatorskogo Rossijskogo istoricheskogo muzeya im. imperatora Aleksandra III - Muzej P.I. Shchukina. Vyp. 8. M.: Sinodal'naya tipografiya, 1909. $461 \mathrm{~s}$.$] .$

Assing L. Tagebücher von K.A. Varnhagen von Ense. 14 Bände. Leipzig, Zürich, Hamburg 1861-1870. Bd. 9. Hamburg: Hoffmann \& Campe, 1868.

Außerordentliche Beilage zur Allgemeinen Zeitung. № 105. den. 7. März. 1837. S. 417.

Außerordentliche Beilage zur Allgemeinen Zeitung. № 113 und 114. den. 12. März. 1837. S. 449-450.

Behler E. Frühromantik. Berlin u. a.: de Gruyter, 2010. 311 S.

Bela. Aus den Papieren eines russischen Offiziers über den Kaukasus. (Aus dem Russischen des Michael Lermontoff)// Freihafen. Galerie von Unterhaltungsbildern aus den Kreisen der Literatur, Gesellschaft und Wissenschaft. Altona: Hammerich, 1841. № 1. S. 45-86. 
Bodenstedt F. Erinnerungen aus meinem Leben. 2 Bde. Berlin, 1888-1890.

Bodenstedt F. Michail Lermontoff's Poetischer Nachlaß. 2 Bde. Berlin: Decker, 1852.

Der russische Dichter Puschkin // Zeitung für die elegante Welt. № 233. den 26. November 1824. S. 1869-1870.

Der Revisor. Lustspiel in 5 Acten/ Bearb. von A. von Viedert. Berlin: Trowitsch, 1854.

Die todten Seelen: Ein satyrisch-komisches Zeitgemälde/ Aus dem Russ. übertr., mit Anm. vers. und bevorwortet von Philipp Löbenstein. Leipzig: Philipp Reclam jun., 1846. VI, 268 S.

Dukmeyer F. Лермонтов у немцев // Полное собрание сочинений М.Ю. Лермонтова. Т. 5. СПб.: Издание Разряда изящной словесности Императорской Академии Наук, 1913. C. $102-115$.

Frank M. „Unendliche Annäherung“. Die Anfänge der philosophischen Frühromantik. Frankfurt am Main: Suhrkamp, 1998. 963 S.

Henning J. Goethes Europakunde. Goethes Kenntnisse des nichtdeutschsprachigen Europas. Amsterdam. 1987. 402 S.

Kirikov B.M. Peterburg nemeckih arhitektorov: Ot Barokko do avangarda. SPb.: CHistyj list, 2002. 414, [1] s. : il.

Knorring K. von. Russische Bibliothek für Deutsche// Blätter für literarische Unterhaltung. № 43. den 12. Februar 1833. S. 173-175.

Lettre à Monsieur le D-r Gustave Kolb, rédacteur de la Gazette Universelle. Munich: Imprimerie de G. Franz, 1844. 32 p.

Pikulik L. Frühromantik. Epoche, Werke, Wirkung. München: Beck, 2000. 345 S.

Schlechter A. Die Romantik in Heidelberg. Brentano, Arnim und Görres am Neckar. Heidelberg: Universitätsverlag Winter, 2007. 200 S.: ill.

Schott Wilhelm. Lermontows Gedichte// Archiv für wissenschaftliche Kunde von Russland. Berlin: Reimer, 1842. S. 439-458.

Turgenjew I. Ausgewählte Werke. Autorisierte Ausgabe. 1. Bd.: Väter und Söhne. Mitau: E. Behre's Verlag, 1869. $383 \mathrm{~S}$.

Varnhagen von Ense Karl August. Neueste russische Literatur // Archiv für wissenschaftliche Kunde von Russland. Berlin: Reimer, 1841. S. 231-238.

Von der Entwicklung der revolutionären Ideen in Russland. Aus dem russischen Manuskript // Deutsche Monatsschrift für Politik, Wissenschaft, Kunst und Leben. Bremen: Schünemann's Buchhandlung, 1851. Drittes Heft. Erste Hälfte. S. 358-380.

Ziolkowski T. Heidelberger Romantik. Mythos und Symbol. Heidelberg: Universitätsverlag Winter, 2009. VIII, $241 \mathrm{~S}$.

Дударев Василий Сергеевич, кандидат исторических наук, старший научный сотрудник, Институт всеобщей истории РАH; wdudareff@gmail.com

\section{Germany in the life of Russian writers and poets of the first half of the 19th century}

In addition to fruitful interaction in solving political issues in the first half of the 19th century, Russia and Germany were linked by close cultural ties, in the building of which literature played a key role. Germany was a kind of filter through which Russia got acquainted with European literature. Images of the German world, reflected in the Russian literature, arose not least due to the personal experience of Russian writers with Germany and the Germans. In this regard, Germany often acquired its special significance in the life and work of Russian writers. This will be discussed in this article.

Keywords: The Russian Empire, German States, literature, romanticism, V.A. Zhukovsky, A.S. Pushkin, M.Yu. Lermontov, N.V. Gogol, F.I. Tyutchev, A.A. Fet. I.S. Turgenev, J.W. von Goethe, F. Schiller, K.A. Varngagen von Enze, F.M. von Bodenstedt

Vasily S. Dudarev, PhD (History), Senior Researcher, Institute of World History, Russian Academy of Sciences, wdudareff@gmail.com 


\section{Р.А. КОНДРАШУК \\ ОБРАЗ РИМСКОЙ ИМПЕРИИ В АМЕРИКАНСКОЙ ПРЕССЕ КОНЦА ХІХ ВЕКА}

Конец XIX века стал для США эпохой многочисленных перемен. Это отразилось на переосмыслении образа Римской империи в американской культуре. В данной статье на материале американских газет конца XIX в. показано, какие сюжеты из истории Римской империи использовались в периодической печати, и как они актуализировались для читателей. Основное внимание сосредоточено на полемике по поводу главных общественных проблем: морального облика американцев, социального расслоения, империализма. Анализируется влияние географии издания, предполагаемой аудитории и политических пристрастий редакторов на использование римского опыта при оценке событий настоящего. Благодаря этому можно увидеть, какой образ Римской империи транслировали своим читателям разные американские газеты.

Ключевые слова: История США, Позолоченный век, массовая печать, сочиальное расслоение, империализм, Римская империя, рецепция античности

Образ Древнего Рима всегда играл большую роль в американской культуре. Довольно часто к этому образу обращались для сопоставления событий древней истории с актуальными проблемами настоящего. Попытки сравнения США и Рима предпринимаются и сегодня ${ }^{1}$. Богатая римская история содержит в себе множество противоречивых событий, поэтому она могла использоваться как в качестве положительного примера, так и отрицательного. В Соединённых Штатах устойчиво закрепилось полярное разделение образов практически эталонной республики и порочной, деградирующей империи ${ }^{2}$. В эпоху становления США американцы чаще обращались к сравнениям с периодом Римской республики. Это происходило не только из-за позитивного восприятия образа этой эпохи, но и по причине внешнего сходства тех проблем, которые стояли перед обоими государствами. Многочисленные перемены во внутренней и внешней политике, произошедшие в Америке на исходе XIX века, изменили баланс в пользу сравнения с Римской империей.

Процесс актуализации знаний о Римской империи хорошо изучен. Но исследователи рассматривали источники и сферы деятельности, для большинства американцев недоступные или не представшие особого интереса: К. Аллерфелдт обращается к историческим сочинениям, письмам политиков и учёных ${ }^{3}, \mathrm{M}$. Маламуд рассматривает главным образом памфлеты идеологов левого движения ${ }^{4}$, М. Меклер анализирует речи американских сенаторов ${ }^{5}$, книга К. Уинтерер посвящена преподаванию классических дисциплин в американских университетах ${ }^{6}$. В то же самое

\footnotetext{
${ }^{1}$ Murphy: 2007; Polm 2016.

${ }^{2}$ Malamud 2009: 3-4; 253-259.

${ }^{3}$ Allerfeldt 2008; Allerfeldt 2009.

${ }^{4}$ Malamud 2009: 98-121.

${ }^{5}$ Meckler 2006: 68-82.

${ }^{6}$ Winterer 2002.
} 
время, в конце XIX в. происходит становление общедоступного источника информации - массовой периодической печати. Рост промышленности и урбанизация привели к появлению большого числа предпринимателей и потребителей, а пресса стала посредником между ними. Теперь издания начали получать основной доход за счёт рекламы, а не от реализации газет. Это послужило стимулом для привлечения как можно более широкой читательской аудитории: цены за выпуск опускались до минимально возможных, а тиражи увеличивались до сотен тысяч экземпляров. Среди той информации, которая стала доступной широким массам американцев, были и знания об античности вообще и имперском Риме в частности. Тем не менее, мы до сих пор не имеем представления о том, какие сюжеты из истории Римской империи представали перед читателями американской прессы, как и для чего эта информация использовалась журналистами, наконец, какой образ древнего государства вырисовывался на страницах печатных изданий.

Изменения, которые произошли в американской периодике конца XIX века, имели не просто количественный, но и качественный характер. В первой половине века пресса ещё не стала самостоятельной формой бизнеса, а большинство газет являлись партийными и содержались за счёт политических организаций ${ }^{7}$. Основной целью таких изданий была поддержка партии и пропаганда её взглядов. Однако во второй половине XIX в. всё больше распространялось убеждение в том, что голос человека должен основываться не на преданности определённой партии, а на рациональном выборе ${ }^{8}$. Одним из пионеров нового подхода стал главный редактор «New-York Tribune» и кандидат от Демократической партии на президентских выборах 1872 г. - Хорэс Грили. ${ }^{9}$ Грили и его единомышленники стали делать более глубокие материалы, в которых они не просто призывали поддержать определённую политику, но и старались объяснить читателю, почему он должен это сделать. Как будет показано в дальнейшем, такое различие сказалось и на использовании примеров из истории Римской империи.

Появление массовой печати изменило представление о потребителе прессы. Если раныше в основном читателями газет были избиратели из сельской местности, то теперь ими стали покупатели из крупных городов ${ }^{10}$. Эта перемена отразилась на содержании периодики, внимание которой постепенно распределялось с политики на множество разных тем, призванных заинтересовать широкую публику. На основе количественном анализе материалов американских газет, современник рассматриваемых событий Д.Ф. Уилкокс выделял два типа массовых изданий: жёлтые и консервативные. Консервативная пресса продолжала тенденции времён Грили и чаще была представлена политическими и деловы-

\footnotetext{
${ }^{7}$ Baldasty 1992. passim.

${ }^{8}$ McGerr 1988: 63-65.

${ }^{9}$ Ibid: $113-115$.

${ }^{10}$ Baldasty 1992: 129.
} 
ми известиями, в то время как в жёлтой журналистике преобладали скандальные новости и иллюстрации. Газеты первого типа оставались элитарным видом прессы, рассчитанным на более состоятельную аудиторию, тогда как вторые ориентировались на самые широкие слои населения. Именно поэтому Уилкокс отмечал, что два указанных типа изданий - это не столько количественная, сколько качественная характеристика предоставляемой читателям информации ${ }^{11}$.

Несмотря на то, что массовая печать развивалась быстро, крупные ежедневные издания были распространены только в больших городах; в некоторых штатах они ещё даже не появились. Региональная пресса была представлена преимущественно еженедельниками с достаточно скромными тиражами. Основным содержанием большинства подобных изданий были местные новости, хотя другие известия и необычные факты там тоже публиковались, но главным образом в виде перепечаток из центральных журналов и газет. Кроме того, в провинции появился ещё один тип периодики, который отличался от остальных. В 1890 г. около тысячи разных изданий учредили Национальную Ассоциацию Реформаторской Прессы (далее НАРП). Её основателями были сторонники популистского движения, стремительно приобретавшего влияние в конце XIX в. Популизм наследовал фермерскому движению, поэтому неудивительно, что подавляющее большинство реформаторских изданий были с Юга и Среднего Запада США. Популисты обращали внимание на усиливающийся разрыв между богатыми и бедными, тяжёлое положение фермеров и рабочих. Они считали, что имеющиеся проблемы можно решить путём реформ, но для того, чтобы они состоялись, требовалось обратить внимание избирателей на эти вопросы и доказать, что их игнорирование может привести к серьёзным последствиям для американского общества. Стоит отметить, что НАРП была создана не только для пропаганды популистских идей, но и для просвещения народа ${ }^{12}$.

Таким образом, в провинции всё ещё были распространены партийные газеты, пропагандировавшие политические взгляды своего спонсора. Образовательного подхода придерживалась реформаторская пресса и некоторые консервативные издания. Жёлтая журналистика была относительно аполитичной и стремилась к нейтралитету, поскольку ярко выраженная приверженность какой-либо партии могла отпугнуть её оппонентов. Если же там и встречалась агитация, то в виде обсуждения личности политиков, а не глубоких экскурсов в историю ${ }^{13}$.

Не случайно, что среди тех зол, которые несёт массовая печать, Уилкокс выделял, в первую очередь, то, что люди стали тратить много времени и сил на ознакомление с неважными новостями или некомпетентными мнениями. Для увеличения аудитории журналисты стремились найти информацию способную изумить читателей, для этого они

\footnotetext{
${ }^{11}$ Wilcox 1900: 77.

12 Clevenger 1945.

${ }^{13}$ McGerr 1988: 145.
} 
не только выискивали сенсационные истории в настоящем, но и обращались к необычным событиям из прошлого. Уилкокс описывал опыт потребителя таких газет как «серию незначительных восторгов» ${ }^{14}$.

Учитывая довольно хаотичный характер расположения материала на страницах американских газет, заметка о Римской империи могла оказаться среди текущих новостей или других сообщений об актуальных событиях. В периодике того времени вообще не было особого раздела, посвящённого истории; в рамках одного выпуска подобных материалов, даже по американскому прошлому, было не так много, чтобы их как-то выделять. Поэтому информация о Риме могла попасться на глаза человеку, который вряд ли стал бы целенаправленно её искать. Тем самым, такие факты выдёргивались из исторического контекста, что могло приводить к их превратному восприятию.

Заметки о Римской империи встречались в прессе довольно часто. Подобный факт был вызван не только интересом самих читателей или журналистов к этой эпохе, но и доступностью информации о ней. Кроме непосредственно классических сочинений и перепечаток из других газет и журналов, в прессе также использовали отрывки с упоминанием античности из публичных лекций или речей политиков и общественных деятелей. Вместе с тем, источниками им служили научно-популярные книги или даже художественные произведения, вроде «Камо грядеши» или «Последние дни Помпеи». Подавляющая часть таких примеров поверхностные заметки, в которых просто упоминаются необычные факты из прошлого, которые должны были вызвать тот самый «незначительный восторг». Такое сообщение могло занимать буквально пару строк, как например, короткая вставка в «The Press» о том, что свинина была самым ценным мясом на римском столе ${ }^{15}$.

Впрочем, узость тематики компенсировалась разнообразием выбоpa. В газетах можно встретить материалы о том, как в Римской империи ели $^{16}$, одевались ${ }^{17}$, наносили макияж ${ }^{18}$, красили волосы ${ }^{19}$, целовались ${ }^{20}$. Подобный перечень тем не случаен. Поскольку потребителями прессы теперь становились не избиратели, а покупатели, то газеты начали обращать внимание на женскую аудиторию. Во многих газетах существовали колонки либо целые полосы, посвященные материалам для женщин. Размещение в них занимательных материалов из истории антично-

\footnotetext{
${ }^{14}$ Wilcox 1900: 57.

15 The Press. 1898. Aug. 4: 4.

${ }^{16}$ A Roman Banquet // Yakima Herald. 1891. Mar. 5: 2; The Ancient Roman Way // Rock Island Daily Argus. 1892. Nov. 22: 3; Insects as Food // Waterbury Democrat. 1897. Jul. 19: 5 .

${ }^{17}$ About Women's Waist // Helena Weekly Herald. 1887. Jul. 7: 1; A Roman Woman's Dress // Arizona Weekly Journal-Miner. 1892. Feb.17: 1.

${ }^{18}$ Painting the Face in Ovid's Day // Alexandria Gazette. 1890. Jun. 10: 2; Richmond Dispatch. 1890. Oct. 15: 6; A Roman Lady // The Omaha Daily Bee. 1897. Dec. 20: 2.

${ }^{19}$ Hair Dyeing an Ancient Art // Crawford Avalanche. 1894. Mar. 29: 6.

${ }^{20}$ Exegesis on Kissing // The Evening Star. 1888. Sep.15: 3.
} 
сти преследовало цель не только развлечь читательниц, но и создать соответствующий рекламе контент ${ }^{21}$. Так, рядом с заметкой о том, как одевались римлянки, могло быть размещено объявление ателье для женщин ${ }^{22}$. Образ Империи мог использоваться и в самой рекламе: компания «Flint's Fine Furniture» обещала покупателям такую же мебель, как у Цезаря и Клеопатры ${ }^{23}$; в другом объявлении говорилось, что Гиббон показал миру закат Римской империи, а «Рaine's Furniture Сo.» продемонстрировали потомкам возвышение античного стиля в дизайне мебели ${ }^{24}$.

Предметный интерес к вещам в древнеримском стиле мог быть вызван многочисленными материалами об имперской роскоши, огромных состояниях римской аристократии и их непомерных тратах. Благо, многие конкретные цифры сохранились благодаря древним авторам. Все эти суммы, для лучшей наглядности, переводились в доллары, что давало возможность не только представить себе богатства римлян ${ }^{25}$, но и сравнить их с современными миллионерами вроде Корнелиуса Вандербилта или Эндрю Карнеги. ${ }^{26}$ Конечно, пересчёт денег сильно зависит от выбранной методики. Так, в одной статье, знаменитому своим богатством Крёзу, насчитали всего лишь три миллиона долларов ${ }^{27}$, а в другой одно только пожертвование дельфийскому оракулу оценили в четыре миллиона ${ }^{28}$. Особенности выбранного способа могли оказать влияние и на оценку состояний древних магнатов. В той газете, где один доллар приравнивали приблизительно к двадцати сестерциям, говорили, что современные богачи не уступают римским. Там, где курс был один к трём, античные состояния оценивали как недосягаемые ${ }^{29}$.

Однако главное внимание в таких заметках было направлено на экстравагантность трат римлян. Многих американцев впечатляло, что жёны Цезаря и Калигулы носили украшения на сумму, превышающую полтора миллиона долларов ${ }^{30}$. Наряд второй, Лоллии Паулины, сравнивали с костюмом популярной французской актрисы Сары Бернар, платье которой назвали скромным и ничтожным в сравнении с одеяниями жены римского императора ${ }^{31}$. Прибытие Бернар в США стало довольно

${ }^{21}$ Baldasty 1992: 71-74.

22 St. Johnsbury Caledonian. 1897. May 28: 6.

${ }^{23}$ New York Tribune. 1894. Apr. 10: 3.

${ }^{24}$ St. Johnsbury Caledonian. 1889. Dec.12: 4; Essex County Herald. 1889. Dec. 13: 3; Herald and News 1889. Dec. 19: 6.

${ }^{25}$ См. напр.: Millionaires of Ancient Times // The Wichita Daily Eagle. 1890. Jun. 15: 3; They Had Money to Burn // Watertown Republican. 1898. Mar. 16: 3.

${ }^{26}$ Columbian. 1881. April 15: 4; Old-Time Fortunes // Condon Globe. 1896. Nov. 6: 4; Fortunes of Ancient Days // Waterbury Evening Democrat. 1899. Jul. 8: 10.

${ }^{27}$ Old-Time Fortunes // Condon Globe. 1896. Nov. 6: 4.

${ }^{28}$ Columbian. 1881. April 15: 4.

29 Old-Time Fortunes // Condon Globe. 1896. Nov. 6: 4. Стоит заметить, что за 15 лет реальная стоимость доллара лишь незначительно выросла в результате дефляции The Value of a Dollar: Prices and Incomes in the United States, 1860-2009. 2009: XIX.

${ }^{30}$ Ancient Extravagance // Catoctin Clarion. 1896. Dec. 17: 4

${ }^{31}$ The Extravagance of Roman Women // Jersey City News. 1891. Mar. 14: 2. 
обсуждаемым событием, особенно американцев удивлял её богатый гардероб, насчитывавший около ста платьев. Видимо, журналисты решили, что если уж это производит впечатление на публику, то надо представить им факт, который сумеет затмить эту новость ${ }^{32}$.

Информация о вычурных тратах использовалась не только для того, чтобы удивить читателей, но и в качестве морализаторской критики. Осуждению подвергались практически все стороны подобного образа жизни, даже причудливая кухня нобилитета критиковалась за излишество $^{33}$. Многих представителей американской элиты сравнивали с римской аристократией. Замечания могли делаться в отношении праздного досуга толстосумов ${ }^{34}$ или моды на создание собственных парков с экзотическими животными ${ }^{35}$. Порицались не только способы распоряжения своими богатствами, но и моральный облик сограждан. Наиболее яркий пример - это шумиха вокруг марафона поцелуев Анны Хелд и Джулиуса Стегера. Многие газеты в деталях описывали, как известная бродвейская актриса смогла выдержать 156 поцелуев подряд ${ }^{36}$. Возмущение ряда изданий вызвало как само событие, так и факт его подробного освещения в прессе. Обличительный пафос статей подкреплялся сравнениями с падением нравов Рима времён цезарей ${ }^{37}$.

В стремлении разоблачить общественные пороки авторы порой доходили до апокалиптических пророчеств. Сопоставление с Римской империей позволяло предсказать печальный исход, который ждёт американское общество, если не остановить моральное падение. Так, в статье, посвящённой Помпеям, извержение вулкана называлось божественным наказанием римлян за их образ жизни. Автор возмущался их жестокостью, идолопоклонничеством и развращённостью. При этом моральные установки колумниста даже не позволяли ему описывать то, за что он так презирает римлян. Например, он писал, что такие статуи и рисунки, которые он встретил в Помпеях, не могут быть делом рук высокоморальных людей. В то же время, о римской жестокости автор статьи писал более детально, и основной пыл критики был направлен на распространившуюся в Нью-Йорке моду на кулачные бои, которые он сравнивал с состязаниями гладиаторов. Землетрясение в Нью-Йорке 1884 года представляется как знак того, что потворство низменным устремлениям может привести к гибели и американские города ${ }^{38}$.

\footnotetext{
${ }^{32}$ Многие газеты, перепечатывая этот материал, вообще убирали оттуда информацию о французской актрисе. - Morning Journal and Courier. 1891. Mar. 19: 1; The Indianapolis Journal. 1891. Mar. 21: 4; The Anderson Intelligencer. Mar. 26. 1891:2.

33 Their Laws and Cookery // The Helena Independent. 1891. Feb. 4: 6.

${ }^{34}$ Plutarch's Philosophy // The Progressive Farmer. 1892. Nov. 15:1

${ }^{35}$ Yorkville Enquirer. 1894. Sep. 19: 1.

${ }^{36}$ См. напр.: Anna Held Kissed to a Standstill // New York Journal and Advertiser. Oct. 31. 1897: 17, 31; Brenham Weekly Banner. Nov. 1897. 11: 6.

${ }^{37}$ Long Live Fake // Jersey City News. 1897. Nov. 2: 2; Newspapers in Schools // The Dalles Daily Chronicle. 1897. Nov. 18: 2.

${ }^{38}$ Lessons of Pompeii // Orleans County Monitor. 1893. Oct. 9: 2.
} 
Однако обличительные материалы были распространены в провинциальной периодике. Морализаторские порицания смотрелись бы явно чужеродно в развлекательном и скандальном окружении жёлтой прессы. Там преобладали статьи, рисовавшие картины невероятной роскоши нобилитета. Желание приобщиться к имперскому великолепию было так велико, что знаменитый цирк «Величайшее шоу на Земле» Барнума и Бейли представил масштабный спектакль «Нерон, или Разрушение Рима». Активно рекламировалось грандиозное зрелище с батальными сценами, триумфальными шествиями, пышными пирами ${ }^{39}$.

Образ жизни римской аристократии порицался, но, вместе с тем, обладал невероятной притягательной силой. Выходом из этого противоречия становится допущение, что причиной нравственного разложения квиритов стало не богатство само по себе, а неправильное распоряжение своим состоянием. Американцы не повторят судьбу римлян, потому что превосходят их в моральном отношении. Воспитанные на христианских ценностях, они смогут устоять перед теми соблазнами, которые несёт обладание богатством ${ }^{40}$. В этом плане характерна заметка, в которой сравнили празднование дня рождения экс-президента США У. Гаррисона и императора Коммода. На фоне грандиозного представления с кучей голодных львов и тигров, убитых лично римским правителем, тихая рыбалка американского политика смотрелась более чем скромно ${ }^{41}$.

Апокалиптический подход с масштабными сопоставлениями судеб Рима и США был более популярен при обсуждении социальных проблем Америки. К такой риторике обращались ещё во времена Джефферсона, к ней также прибегали многие радикальные американские движения, например, фрисойлеры и гринбекеры ${ }^{42}$. В конце XIX в. её начали использовать и популисты, основным рупором которых стали издания НАРП. На первых полосах этих газет выходили большие авторские материалы, в которых поднимались вопросы устройства американского общества. В этих статьях поздняя Римская республика и империя были примерами коррупции, монополизации, социального расслоения, властного произвола. Чтобы убедить избирателей в необходимости перемен, популисты, как и морализаторы, пытались показать, что современному американскому обществу свойственны те же недостатки, которые когдато были характерными чертами декадентского Рима ${ }^{43}$. Более того, некоторые даже связывали социально-экономические вопросы с упадком морали ${ }^{44}$. Печальная участь древнего государства представлялась как неизбежное следствие описанных проблем, а их решение должно было

\footnotetext{
${ }^{39}$ См. напр.: Richmond Dispatch. 1890. May. 6: 2; The Sun. 1891. Mar. 24: 10; Evening Journal. 1891. Oct. 5: 4.

${ }^{40}$ Malamud 2009: 141-146.

${ }^{41}$ Yakima Herald. 1895. Aug. 29: 2.

42 Malamud 2009: 108.

${ }^{43}$ History Repeating // The Louisiana Populist. 1895. Jun. 7: 1; A Suicidal Policy // The Advocate 1896. Mar. 18: 2; Second Valley Forge // Roanoke Daily Times. 1896 May 23: 7.

${ }^{44}$ Plutarch's Philosophy // The Progressive Farmer. 1892. Nov. 15: 1
} 
предотвратить повторение судьбы Рима. Выпады популистов были направлены не только в сторону политической системы, но и против её служителей. Такие сопоставления требовали упоминания конкретных действий исторических личностей, а не перечисления социальных процессов. В качестве примеров как нельзя лучше подходили известные выходки римских императоров. Так, конгрессменов от ведущих партий могли сравнить с конём Калигулы, которого хозяин сделал сенатором ${ }^{45}$ Эта аналогия позволяла подчеркнуть как лоббизм политиков, так и скудость их умственных способностей. Действующего американского президента от демократической партии - Гровера Кливленда уподобляли Нерону. Если император Рима играл на скрипке, пока Вечный город был объят пламенем, то глава США предавался рыбалке, в то время как страна переживала тяжелейший экономический кризис ${ }^{46}$.

Успех популистов на президентских выборах 1892 г. привлёк внимание основных политических сил страны к их программе. Среди её положений большой популярностью пользовалась идея чеканки дешёвых серебряных денег. На тот момент в США был монометаллический золотой стандарт, и данная мера, по мнению её сторонников, должна была вызвать инфляцию. Эта идея была популярна среди фермеров, потому что подъём цен на продукцию сельского хозяйства должен был помочь заработать им больше денег и рассчитаться с накопившимися долгами.

Кандидат от Демократической партии Уильям Брайан включил это положение в свою программу на президентских выборах 1896 г. Вопрос о форме денежной системы стал одним из основных в политических дискуссиях. Однако у популистов введение биметаллического стандарта было лишь частью большой программы преобразования американского общества, в своих они выступлениях предлагали большой комплекс мер. Демократы переняли только предложение чеканки дешёвого серебра.

Партийные газеты часто обращались к «Истории Европы» сэра Арчибальда Алисона. Сочинение полувековой давности переживало новый виток популярности благодаря тезису историка о том, что подлинной причиной падения Рима стало истощение рудников с драгоценными металлами в Испании и Греции, а не деградация морали, язычество или рабовладение, как это писали ранее ${ }^{47}$. Перед самими выборами 1896 года в изданиях демократов по всей стране можно было встретить статью «Выгоды расширения [денежной массы]» («The Benefits of Expansion»), в которой пассаж из «Истории Европы» приводился как доказательство заявленного в названии тезиса, и сама цитата, для пущей убедительности, выделена заглавными буквами ${ }^{48}$. В демократической прессе также ${ }^{45}$ The Public Liar // The Great West. 1890. May.23: 1; Vox Populi, Vox Dei // The Great West. 1890. Jun. 20: 1.

${ }^{46}$ The Representative. 1894. Jan. 10: 4; Kansas Agitator. 1894. Mar. 29: 4; Grover vs. Nero // The Advocate. 1896 Jan. 8: 6.

${ }^{47}$ Alison 1852: 31.

${ }^{48}$ См. напр.: The Democratic Advocate. 1896. Sep. 19: 6; Sonoma Democrat. 1896. Sept. 26: 8; Democratic Northwest and Henry County News. 1896. Oct. 1: 2. 
любили прибегать к использованию образов римских императоров. Конечно, они не называли своего президента Нероном, зато сравнивали лидера республиканской партии Марка Ханну с Калигулой. По их мнению, Калигула был даже лучше: он сделал сенатором коня, тогда как Ханна продвигает в американский Конгресс ослов ${ }^{49}$.

Риторику демократов поддерживали не только их собственные газеты, но и некоторые массовые издания. Консервативные издания помещали развёрнутые статьи по поводу денежной системы, но пример Рима там не использовался. Республиканцы вообще не считали вопрос о денежном стандарте достойным внимания. Так, автор статьи в «New-York Evening Post», разбирая аргументацию демократов, написал, что объяснять падение Римской империи истощением рудников в Испании и Греции такая же нелепость, как свести все проблемы Америки конца XIX в. к тому, что серебро не чеканилось в нужной пропорции к золоту ${ }^{50}$.

На выборах 1896 г. победу одержали республиканцы. Риторика Брайана оказала влияние на жителей Среднего Запада и Юга США, но не снискала популярности в других частях страны. К тому же США стали преодолевать последствия кризиса 1893 г., что сделало апокалиптические пророчества и сравнения с Римом ещё менее действенными. Многие реформаторские издания продолжили писать о вреде золотого стандарта и социальном расслоении после поражения Брайана, но эта тема в условиях экономического роста потеряла свою актуальность.

В самом конце XIX в. произошло событие, которое сделало образ Рима востребованным в новом контексте. Победа в Испано-Американской войне 1898 г. принесла США контроль над заморскими территориями, в т.ч. над Кубой и Филиппинами. Эти приобретения сразу вызвали дискуссии относительно того, встала ли Америка на путь империализма и чем это ей может грозить. Вообще американцев мало волновала судьба самих присоединённых стран и их населения, основные беспокойства были связаны с возможными переменами внутри США. Ещё со времён отцов-основателей был распространён страх перед империализмом, который сформировался под влиянием античной истории. Считалось, что именно многочисленные заморские завоевания Рима сгубили республику, а господство над другими народами привело к тирании над собственным. Юлий Цезарь воспринимался американцами как могильщик республики, поэтому, когда политика хотели уличить в стремлении к единоличной власти, его называли «Цезарем» ${ }^{5}$. Такое прозвище давали, например, Эндрю Джексону и Улиссу Гранту ${ }^{52}$.

На выборах 1900 г. демократы вновь выдвинули кандидатом в президенты Брайана, который прибавил к своей сильверитской программе антиимперскую риторику. На первый взгляд, это был довольно логич-

\footnotetext{
${ }^{49}$ Do Descent People Respect Mark Hanna // Stark County Democrat. 1897. Sep.16: 7.

${ }^{50}$ New-York Evening Post. 1893. Sep. 22: 4.

${ }^{51}$ Malamud 2008: 10-11.

${ }^{52}$ Ibid: 18-25; Presidential Nicknames // The Scranton Tribune. 1896. Oct. 7: 4.
} 
ный шаг: на прошлых выборах он выступал против тирании капитала, а теперь мог прибавить сюда и выпад в сторону возможной политической диктатуры. Однако страх цезаризма традиционно был присущ скорее образованным слоям Новой Англии. Они боялись не только диктатуры, но и простого народа, который мог такую диктатуру поддержать. По этой причине пристальное внимание проблеме империализма уделялось главным образом в серьёзных изданиях Северо-Востока и Западного побережья США. Основной упор делался на то, что экспансия неизбежно приведёт к деспотизму и ограничению гражданских свобод, как это произошло с Римом ${ }^{53}$. Такой процесс называли столь же неизменным правилом как закон тяготения ${ }^{54}$. К антиимперским выпадам присоединились даже некоторые прореспубликанские газеты, и они тоже прибегали к этому сравнению ${ }^{55}$. В отличие от биметаллизма, вопрос об империализме был для республиканцев куда весомее. Среди тех изданий, которые не признавали эту угрозу, сложилось несколько стратегий аргументации, которые не исключали, а иногда даже дополняли друг друга. В газетах пытались показать, что империализм сам по себе - это не путь к диктатуре. Печальный пример Рима и других великих держав древности - вина самого народа; США, в силу своей исключительности, не повторят этих ошибок ${ }^{56}$. Даже если американский империализм и существует, то в виде экспансии свободы и демократии, тогда как римляне лишь выкачивали все ресурсы из провинций ${ }^{57}$. Кое-кто вспоминал, что обвинения в империализме и сравнения с Цезарем звучали уже не первый раз, но с республикой всё по-прежнему в порядке ${ }^{58}$. Некоторые и вовсе пытались перейти в контратаку и назвать Цезарем самого Брайана ${ }^{59}$. Наконец, многие прореспубликанские газеты по-прежнему не желали вступать в дебаты и заявляли, что вопрос об империализме мёртв ${ }^{60}$.

Такая полемика свидетельствует о том, что этот вопрос действительно волновал население крупных американских городов, в отличие от идеи о биметаллизме, которая была популярна среди сельского населения. Многие политики предлагали Брайану отказаться от сильверитской риторики и сосредоточиться на проблеме империализма, однако сам демократический кандидат считал эти вопросы неразрывно связан-

${ }^{53}$ Is the Empire Impossible // The Delawarean. 1900. Jul. 18: 2; Virginian-Pilot. 1900. Mar. 18: 4; History's Teaching // The St. Louis Republic. 1900. Aug. 26: 6.

${ }^{54}$ War and Despotism // New-York Times. 1898. Jun. 12: 17.

55 The Saint Paul Globe. 1900. Sep. 7: 6.

${ }^{56}$ Comparison of the Roman and American Republics // The Record-Union. 1899. Oct. 30: 7; Striking Parallels // The San Francisco Call. 1899. Jul. 22: 6

${ }^{57}$ National Stewardship // Cambridge Tribune. 1899. Mar. 4: 7; Imperialism Defined by Joe Bristow // Wichita Daily Eagle. 1898. Oct. 21: 8; Genuine Imperialism // The Caldwell Tribune. 1899. Sept. 30: 1.

${ }^{58}$ Should Vote for McKinley // The Indianapolis Journal. 1900. Aug 28: 8; Reasons for Opposing Bryan // The Brooklyn Daily Eagle. 1900. Oct 3: 10; Visions of Caesar // The Record-Union. 1899. Dec. 12: 2.

${ }^{59}$ Amador Ledger. 1900. July 6: 2; The Indianapolis Journal. 1900. Jul. 9: 4.

${ }^{60}$ Evening Times-Republican. 1900. Sep. 14: 4; The Arizona Republican. 1900. Oct. 27: 2. 
ными $^{61}$. Такой взгляд тоже нашёл отражение в прессе, но разделяли его лишь некоторые провинциальные газеты. Образ Рима в их статьях был показательным примером того, как завоевания далёких земель могут отразиться на внутреннем состоянии общества и привести к кризису политических институтов. По мнению авторов таких теорий, социальное расслоение уже создало класс плутократов, которые постепенно прибирали власть к рукам, а империализм ещё больше разжигал их аппетиты и создавал опасный прецедент попрания чужих прав и свобод, что могло привести к пренебрежению к собственному народу ${ }^{62}$.

Большинство избирателей так и не увидели глубинной связи основных вопросов программы Брайана и восприняли ее как нагромождение разрозненных положений. Попытка охватить широкий спектр проблем в одной кампании не стала успешной в то время, когда выборы обычно посвящались одной конкретной теме. На обложке журнала «Harper's Weekly» появилась карикатура, где Брайана изобразили как таксидермиста, который сшил из разных животных странное существо под именем «Демопоптам», державшего в своих лапах имперскую корону ${ }^{63}$.

Основной упор в своей программе республиканцы делали на успехи в настоящем. Слоган их кампании был «Ещё четыре года полных обеденных котелков». Растущие зарплаты и цены на продукцию сельского хозяйства оказались куда более убедительными, чем эфемерная риторика о вероятных опасностях. Как и в случае с моральным падением римлян, распространялось убеждение в том, что империя сама по себе не плоха и США не повторят судьбу Рима. Большинство американцев оптимистично смотрели на настоящее и устремляли свой взор в будущее, а не искали дурные предзнаменования в прошлом. Это ярко иллюстрирует небольшая заметка в газете «The Lamar Register» по поводу статьи, где труд «Упадок и разложение Римской империи» использовался как предупреждение для американцев. В ней написали, что Гиббон умер сотни лет назад, а автор статьи - это очередной старый пессимист, вспомнивший одну из его книг, о которых никто никогда не слышал ${ }^{64}$.

Появление массовой прессы сделало возможным распространение информации о Римской империи среди широких слоёв населения, но новая журналистика не была нацелена на просвещение. Реформаторская пресса и некоторые консервативные издания ещё пытались проводить масштабные сопоставления событий римской истории и проблем современных им США, причем ориентация на несхожую аудиторию вынуждала по-разному проводить эти сравнения: если образованные читатели консервативной периодики имели представление об античной истории

61 Tompkins 1967: 151-156.

${ }^{62}$ Reign of Mammon // The Nebraska Independent. 1898. Jul. 21: 7; Froode's Lessons for America // People's Voice. 1900. Jun. 14: 2; True Democracy vs. Torey-Federal Imperialism // Graham Guardian. 1900. Oct. 12: 4.

${ }^{63}$ Harper's Weekly. 1900. Aug. 11.

${ }^{64}$ The Lamar Register. 1900. Nov. 21: 4. 
по другим источникам, то простые фермеры и рабочие такими знаниями чаще всего не располагали. Именно поэтому статьи в изданиях НАРП не только отсылали к некоторым фактам, но и подробно объясняли их суть и значение для последующего развития событий. Кроме того, связанная с популизмом реформаторская пресса была гораздо радикальнее в своих выводах и с большим рвением бичевала пороки римского общества.

Так или иначе, и реформатские, и консервативные издания выстраивали перед своими читателями цельный, хотя и несколько упрощённый образ Римской империи. В то время как во всё ещё существовавших партийных газетах и только возникающей желтой журналистике он использовался непоследовательно и фрагментарно. В первом случае это были единичные параллели, на основании которых могли делаться самые широкие обобщения, во втором - занимательные факты из истории Рима, призванные удивить читателей диковинными обычаями древнего народа. Такое обрывочное знакомство с событиями, вырванными из их исторического контекста, вряд ли способствовало пониманию опыта Римской империи. Это приводило к соседству противоречащих друг другу материалов. Газеты по-прежнему страшили читателей образом Цезаря и одновременно призывали обставить свой дом как его дворец.

\section{БИБЛИОГРАФИЯ / REFERENCES}

\begin{tabular}{|c|c|}
\hline \begin{tabular}{l} 
Alexandria Gazette. 1890. \\
Amador Ledger. 1900. \\
Arizona Weekly Journal-Miner. 1892. \\
Brenham Weekly Banner. 1897. \\
Cambridge Tribune. 1899. \\
Catoctin Clarion. 1896. \\
Columbian. 1881. \\
Condon Globe. 1896. \\
Crawford Avalanche. 1894. \\
Democratic Northwest \& Henry County News. \\
\multicolumn{1}{c}{1896.} \\
Essex County Herald. 1889. \\
Evening Journal. 1891. \\
Evening Times-Republican. 1900. \\
Graham Guardian. 1900. \\
Harper's Weekly. 1900. \\
Helena Weekly Herald. 1887. \\
Herald and News. 1889. \\
Jersey City News. $1897,1891$. \\
Kansas Agitator 1894. \\
Morning Journal and Courier. 1891. \\
New-York Evening Post. 1893. \\
New-York Journal and Advertiser. 1897. \\
New-York Times. 1898. \\
Orleans County Monitor. 1893. \\
People's Voice. 1900. \\
Richmond Dispatch. 1890. \\
Roanoke Daily Times. 1896. \\
Rock Island Daily Argus. 1892 \\
Sonoma Democrat. 1896. \\
St. Johnsbury Caledonian. 1889,1897
\end{tabular} & 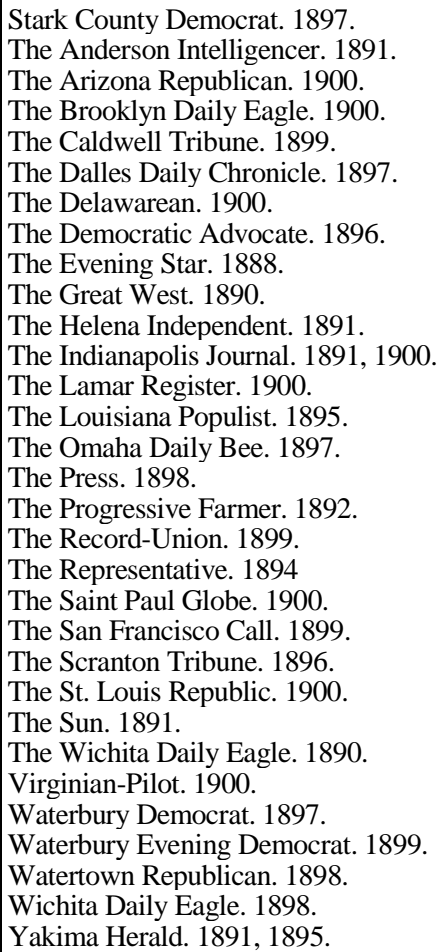 \\
\hline
\end{tabular}


Alison A. History of Europe. Vol. I. Edinburgh; London: W. Blackwood and sons, 1852. 650 p.

Allerfeldt K. Rome, Race, and the Republic: Progressive America and the Fall of the Roman Empire, 1890-1920 // The Journal of the Gilded Age and Progressive Era. Vol. 7. № 3. 2008. P. 297-323.

Allerfeldt K. Two Wars, Rome and America // Comparative Civilizations Review. Vol. 60. №. 60. 2009. P. 99-119.

Bailey T.A. Was the Presidential Election of 1900 A Mandate on Imperialism? // The Mississippi Valley Historical Review. Vol. 24. № 1. 1937. p. 43-52.

Baldasty G.J. The Commercialization of News in the Nineteenth Century. Madison. 1992.

Clevenger H. The Teaching Techniques of the Farmers' Alliance: An Experiment in Adult Education // The Journal of Southern History. Vol. 11. № 4. 1945. P. 504-518.

Malamud M. Ancient Rome and Modern America. Chichester: Wiley-Blackwell, 2009. 312 p.

McGerr M.E. The Decline of Popular Politics: The American North, 1865-1928. N.Y.; Oxford: Oxford University Press, 1988. 322 p.

Meckler M. Classical Antiquity and the Politics of America. From George Washington to George W. Bush. Waco: Baylor University Press, 2006. 225 p.

Murphy C. Are We Rome?: The Fall of an Empire and the Fate of America. Boston, N.Y. 2007. $272 \mathrm{p}$.

Polm M. Comparisons with imperial Rome in early twentieth-century Britain and in the US during the Bush Jr. administration. Aggressive foreign policy by unipolar powers and the lure of the Roman Empire. 2016.

The Value of a Dollar: Prices and Incomes in the United States, 1860-2009. Ed. by S. Derks Grey House Pub. 2009.

Tompkins E.B. Scylla and Charybdis: The Anti-Imperialist Dilemma in the Election of $1900 / /$ Pacific Historical Review. Vol. 36. № 2. 1967.

Wilcox D.F. The American Newspaper: A Study in Social Psychology // The Annals of the American Academy of Political and Social Science. Vol. 16. 1900.

Winterer C. The Culture of Classicism: Ancient Greece and Rome in American Intellectual Life 1780-1910. NY. 2002. 272 p.

Кондрашук Руслан Андреевич, магистр истории, аспирант АШИН НИУ ВШЭ, RuslanKondrashuk1992@gmail.com.

\section{The image of the Roman Empire in American newspapers at the end of $19^{\text {th }}$ century}

The end of the $19^{\text {th }}$ century had been the era of multiple changes for the United States. This was reflected in the rethinking of the Roman Empire's image in American culture. However, there have been no attempts to analyze widely available sources in historiography. This article considers the materials of various American newspapers of the late XIX century. On their basis, the research shows what examples from the Roman Empire's history were used by journalists, and how they were updated this information for readers. The main focus is on the debates over the main social issues: the moral character of Americans, social inequality, imperialism. The survey analyzes the influence of the publication's geography, intended audience and political views of editors on the use of the Roman experience in evaluating the current events. This could help to see the different forms Roman Empire's image which presented to readers of the various American newspapers.

Keywords: American history, Gilded Age, Progressive Era, Mass media, Reception of Antiquity, Ancient Rome, Imperialism, Social inequality.

Kondrashuk Ruslan Andreyevich, master's Degree in History, graduate student in Doctoral School of History National Research University HSE 


\section{А.А. АВДАШКИН, И.В. СИБИРЯКОВ \\ «НАВЕКИ ВМЕСТЕ»: ДРУЖБА СССР И КНР
В ОПТИКЕ СОВЕТСКОЙ ПРОВИНЦИАЛЬНОЙ ПЕЧАТИ}

Статья посвящена изображению советско-китайской дружбы в провинциальной печати на примере газет Челябинска и Магнитогорска. При работе с этими источниками, большая часть которых впервые введена в научный оборот, авторы использовали имагологический метод и дискурс-анализ. Этот инструментарий позволил проанализировать ведущие образы советско-китайской дружбы, транслировавшиеся в советской провинциальной периодике в исследуемый период. Они складывались из описаний китайских практикантов на промышленных предприятиях, презентации ведущей роли СССР в построении социализма в Китае и демонстраций крепких дружеских связей, возникших между уральцами и китайскими тружениками.

Ключевые слова: советско-китайская дружба, образы, советская пресса, мигранты, образ Китая, межкультурные связи

История взаимоотношений России и Китая насчитывает несколько столетий, отличается сложным и противоречивым характером, поэтому вызывает все более пристальный интерес со стороны представителей научного сообщества. В годы советско-китайской дружбы (середина 1950-х - начало 1960-х) сотрудничество двух государств приобрело особые формы практически во всех сферах: от военной до культурной. Важную роль в их становлении играли контакты между разными группами населения СССР и Китая. К преобладающим связям многие эксперты относят: обучение китайских студентов и практикантов в советских вузах и на промышленных предприятиях, работу советских специалистов на строительстве и реконструкции китайских предприятий, переписку и обмен научно-техническими знаниями, обмен делегациями, гастроли театров, цирковых трупп, организация выставок и кинопоказов ${ }^{2}$.

1950-е гг. дают интересный пример насыщенных культурных коммуникаций в ограниченном временном континууме. Именно в это время у населения двух стран формируются новые образы Советского Союза и Китая, которые сыграли важную роль в развитии политического, экономического, культурного сотрудничества между странами. Не случайно, в последние годы вышел целый ряд публикаций об образах советскокитайской дружбы в кинематографе ${ }^{3}$, журнальных карикатурах ${ }^{4}$, плака$\operatorname{Tax}^{5}$ и прессе ${ }^{6}$ В центре внимания многих авторов находятся образы социалистической интеграции, которые транслировались в СССР: позицио-

\footnotetext{
1 За ценные рекомендации по поводу более ранних вариантов рукописи авторы благодарят сотрудников кафедры отечественной и зарубежной истории ЮУрГУ доцента Т.В. Раеву и профессора В.С. Балакина.

2 Дружба навеки... 2018.

3 Tina Mai Ch. 2004; Gamsa 2012.

${ }^{4}$ Гулева 2015.

5 Федосов 2017; Он же. 2019.

${ }^{6}$ Павлюкевич 2011; Urbansky, Trecker 2018.
} 
нирование социалистического единства, «брендинг» отдельных явлений и персоналий в истории и современности Советского Союза и Китая.

Однако сегодня мы располагаем довольно мозаичной картиной истории советско-китайского сотрудничества со множеством содержательных и территориальных лакун. К таким пробелам относится и медиа дискурс о советско-китайской дружбе. В российской историографии практически нет исследований о том, как пресса, в особенности провинциальная, презентовала населению динамику развития и упадка советскокитайского альянса. Звучат настойчивые призывы к отказу от шаблонного подхода и к более детальному изучению истории социалистической интеграции в экономическом, социальном и культурном ракурсах ${ }^{7}$.

Современные тенденции развития историографии демонстрируют очевидное движение к регионализации объекта исследования. Интерес исследователей смещается от глобальных сюжетов к отдельным районам страны, участвовавшим в развитии экономики КНР, в обучении квалифицированных кадров для нее и пр. ${ }^{8}$ Примером такого района без сомнения является Урал 9 . При этом и здесь мы не располагаем достаточно полной картиной. Южноуральский регион с такими важными гигантами индустрии как Челябинск и Магнитогорск остается белым пятном ${ }^{10}$. Цель статьи - анализ дискурса дружбы СССР с Китаем в газетах Челябинска и Магнитогорска во второй половине 1950-х - начале 1960-х гг. Глубокое изучение технологии изображения разных аспектов советско-китайской дружбы в провинциальной печати позволит ответить на ряд вопросов: насколько дифференцированным был создаваемый в советской прессе образ китайцев, прибывших для трудового обучения в СССР; как презентации коммунистического Китая легитимировали советскую идеологическую экспансию; как имидж советско-китайской дружбы преломлялся в локальном измерении (регион, город, завод и др.). Хронологические рамки охватывают период насыщенных презентаций советско-китайской дружбы в печати (1950-1963). Нижняя граница исходит из подписания договора о дружбе СССР и КНР, открывшего фазу активного наполнения информационного пространства образами дружественного Китая. Верхняя граница знаменует начало открытой полемики между советским и китайским руководством. С началом этой полемики тема дружбы исчезает со страниц прессы, видоизменяется круг друзей Советского государства.

В качестве методологической основы использовались приемы, разработанные отечественными и зарубежными учеными в рамках междисциплинарного направления, получившего название имагологии. «Образ другого» стал ключевой категорией для данного проекта. Этот образ, как

${ }^{7}$ См.: Нагорная 2015.

${ }^{8}$ Каменских 2013; Нагорных 2017; Дацышен, Сюй 2019.

${ }^{9}$ Гоцинь, Каменских 2015; Каменских 2019.

10 Пока о присутствии китайцев в Челябинске и Магнитогорске и периоде «большой дружбы» на материалах Челябинской области подготовлена лишь одна небольшая статья см.: Волошина, Юдина 2005. 
«сложная, синтетическая конструкция являет собой динамическую систему представлений и мнений, обладающую как стереотипными, так и дифференцированными чертами, как рациональными, так и эмоциональными компонентами» ${ }^{11}$. Представления населения об акторах международных отношений организованы в схемы, или образы, состоящие из определенным образом упорядоченных когнитивных элементов. Они включают в себя набор когниций, убеждений и установок относительно какого-либо народа, его национальной, политической и культурной специфики, а также исторического опыта отношений. Интерпретация этих образов требует понимания контекста межгрупповых взаимоотношений, который оказывает непосредственное влияние на возникновение, воспроизводство и угасание стереотипов и установок ${ }^{12}$.

Кроме того, в рамках данной работы комплекс представлений о советско-китайской дружбе изучается с помощью дискурс-анализа ${ }^{13} \mathrm{Hac}$ интересует не только то, «что», но и в первую очередь «как» писала пресса о советско-китайской дружбе (образы, язык описания и символы).

Основу источниковой базы составили материалы периодической печати двух крупных промышленных центров Урала - Челябинска и Магнитогорска - за вторую половину 1950-х - начало 1960-х гг. Газеты «Челябинский рабочий», «Магнитогорский рабочий», «Магнитстрой» и «Трубопрокатчик» содержали разнообразную информацию о китайских практикантах, делегациях из КНР и связях, сложившихся между населением промышленных центров Южного Урала и Китаем. Газета «Челябинский рабочий» являлась в исследуемый период печатным органом обкома партии и издавалась максимальными тиражами. На ее страницах сконцентрировался основной массив интересующих нас публикаций. Остальные издания «локализовали» пропагандистский эффект для более узкой аудитории на уровне города, треста или завода, максимально сближая рядового труженика и его китайских друзей. Некоторые сюжеты почерпнуты нами на страницах центральных газет «Правда» и «Известия».

Пресса, тем более советская, как исторический источник обладает рядом особенностей и познавательных ограничений. В СССР представление о «врагах» и «друзьях» формировалось и транслировалось с помощью развитой машины пропаганды. Ее основу составляли центральные газеты, журналы, плакаты, радиопередачи и киноленты. Все они погружали обывателя в общегосударственный и международный событийный контекст. Плакаты и кинохроника давали готовые и яркие образы, но именно газетные сообщения в силу своей интенсивности, повторяемости, особого их восприятия жителями провинции, закрепляли данные образы в сознании людей, проживающих в регионах. Пресса органично дополняла агитационные плакаты, радиопередачи, киноленты и кинохроники.

\footnotetext{
${ }_{11}^{11}$ Поршнева 2014.

12 Stein, Welch 1997; Herrmann 2003.

13 Подробнее о применении дискурс-анализа см.: Wodak 2009; Van Dijk 2014; Fairclough 2015.
} 
Полностью контролируемое советское информационное пространство позволяло государственным институтам унифицировать информацию, подчиняя ее политическим задачам. Одной из технологий была работа с региональными газетными сообщениями. Тексты на одну и ту же тему публиковались массированно в разных изданиях. Однотипные тексты неоднократно повторялись, транслируя единую точку зрения, что позволяло формировать в сознании читателей ощущение истинности предлагаемых оценок и суждений. Журналисты, редакторы газет, формировавшие редакционную политику, могли выбрать несколько сюжетов и путем многократного повторения словесных конструкций и образов перенести, казалось бы, частные выводы на значительный объем событий.

Первоначально перед редакторами газет и корреспондентами ставилась задача сформировать положительный образ восточного соседа. Этот образ должен был быть близок и понятен населению, подчеркивать ведущую роль советского государства и труженика в социалистическом лагере. Не случайно на протяжении 1950-х гг. сохранялась стабильно высокая частотность публикаций на «китайскую тематику» (она отражалась практически в каждом номере). Начиная с 1960 г. происходит постепенное сокращение количества публикаций о Китае.

Это подтверждают и результаты контент-анализа. Хотя мы и не ставили цели отследить количественные показатели языка дружбы и руководствовались скорее качественными методиками, представим некоторые выкладки. Если в 1950-1959 гг. в «Челябинском рабочем» стабильно выходило от 60 до 100 публикаций, причем по нарастающей, могли меняться только тематика и акценты, то с 1960 г. мы видим эффект умолчания. Число заметок сокращается до нескольких десятков (10-30) и сюжеты о дружбе оказывались далеко не в большинстве. Скорее преобладала констатация факта, что КНР остается на когнитивной карте советского человека, входит в круг друзей Советского государства, но уже не на первых ролях. Языковые приемы, которые ранее использовались применительно к Китаю теперь широко применялись для описания нового круга друзей.

Важной группой источников стали также фонды Челябинского областного и городского партийных комитетов (Ф. П-288 и П-92).

\section{Китайские практиканты и студенты в зеркале местной прессы}

В СССР получили высшее образование более 11000 китайских юношей и девушек, а свыше 10000 инженеров, техников и рабочих прошли производственное обучение и практику на советских предприятиях ${ }^{14}$. В Челябинскую область планировалось направить 6200 китайских рабочих ${ }^{15}$. В областном центре для них даже возвели несколько жилых домов. Однако руководство СССР признало целесообразным отложить прием китайцев ${ }^{16}$. После длительных переговоров Москвы и Пекина рабочих

${ }^{14}$ Борисов, Колосков 1980: 49.

15 ОГАЧО. Ф. П-288. Оп. 19. Д. 21. Л. 12, 51.

${ }_{16}$ Распоряжением Совета министров СССР от 8 апреля 1955 прибытие китайских рабочих отсрочили до 1956 г. ОГАЧО. Ф. П-288. ОП. 19. Д. 88. Л. 29. 
прибыло в 1955 г. намного меньше, но они оставили заметный след в повседневной жизни горожан. Отрывочные сведения, опубликованные в газетах, позволяют говорить о нескольких сотнях китайцев, прошедших практику на заводах области. Срок их пребывания составлял от нескольких месяцев до года. Региональная пресса презентовала читателю две категории китайцев. Первая - рабочие и практиканты. Советские люди чаще всего контактировали с ними в цехах и лабораториях, где передавали им свой опыт и знания. Не случайно отправной точкой в формировании и развитии образа китайца в южноуральских газетах становился завод как одна из первооснов советского социального, культурного и хозяйственного строя. Китаец воспринимался в таком контексте, в первую очередь, как человек труда - такой же «созидатель», как и советский человек.

Вторая категория - студенты ${ }^{17}$. Один из главных лозунгов тех лет, которым руководствовались китайцы, приезжавшие в СССР, провозгласил М. Цзэдун: «Мы все должны учиться у Советского союза» ${ }^{18}$. Китайская пропаганда много раз обращалась к теме производственного сотрудничества между Китаем и СССР. Достаточно вспомнить известный плакат «Учиться у СССР передовому опыту и строить нашу родину» (худ. Дин Хао, 1953). А в газете «Правда» в статье о студентах-гидротехниках Дальневосточного политехнического института содержалось такое высказывание китайских студентов: «Мы учимся у советской молодежи... Мы никогда не забудем ленинского завета: “учиться, учиться и учиться"» ${ }^{19}$. Командировка на учебу и практику в СССР была очень престижна и влияла на повышение социального статуса и карьерный рост человека.

Основная роль, которой наделялись китайцы в южноуральской печати 1950-х гг., это роль активного, прилежного и упорного ученика, а советский человек в свою очередь представлялся как бескорыстный, мудрый наставник и учитель ${ }^{20}$. Старание ученика могло привести к быстрым результатам. Например, некоторых практикантов, обучавшихся на Бакальских рудниках, уже через три года после возвращения из СССР выдвинули на руководящие должности ${ }^{21}$. Многие китайские «ученики», прошедшие курс обучения в СССР, сделали хорошую карьеру и со временем заняли видные посты в руководстве КНР²2.

\footnotetext{
${ }^{17}$ На Урале основным центром притяжения образовательной миграции из Китая являлся УПИ. (Каменских 2011). На промышленных предприятиях Челябинской области проходили производственную практику китайские студенты Московского института стали, Уральского, Харьковского и Ленинградского политехнических институтов. (Челябинский рабочий. 1954. 1 октября; 1958. 3 октября; 1959. 10 марта; Магнитогорский рабочий. 1955. 8 июля; 1957. 24 сентября). Кроме того, китайские студенты УПИ совершали дружеские визиты к своим сверстникам в Челябинск, с экскурсиями посещали ММК. (Челябинский рабочий. 1958. 14 января; 1958. 6 февраля; За политехнические кадры. 1958. 13 февраля; 28 февраля).

18 Правда. 1953. 9 февраля; Челябинский рабочий. 1955. 20 сентября.

19 Правда. 1954. 29 августа.

20 Челябинский рабочий. 1955. 1 мая; 1956. 20 июня; 1957. 14 февраля.

21 Челябинский рабочий. 1959. 9 октября.

22 В Политбюро их число увеличилось с 28\% в 1987 г. до 57\% в 1997 г. Han 2013: 1119.
} 
Еще одним приемом изображения китайских мигрантов в провинциальных средствах массовой информации 1950-х гг. стала персонификация. Если в российской традиции восприятия и изображения китайцев людей не было вообще, а существовала только «масса», «толпа», «саранча» ${ }^{23}$, то в советской послевоенной традиции многие китайцы представали в глазах читателя уже как самостоятельная личность. Помимо общей с советским человеком цели - построить коммунизм - китаец в газетных текстах всегда назывался по имени, имел биографию, характер и эмоции. Многие тексты посвящались отдельному человеку или небольшим группам, но, как правило, даже в этом случае личность не растворялась в коллективе. Немало внимания уделялось отношениям между советским наставником и его учеником из КНР. В газетах присутствовали сюжеты, посвященные дружескому общению советских людей с китайцами ${ }^{24}$. Так, газета «Магнитогорский рабочий» в мае 1956 г. опубликовала материал, в котором содержался следующий текст: «Дружба! Это прекрасное слово часто упоминается в интернате молодых рабочих Магнитогорского металлургического комбината, где живут русские, китайцы, украинцы, казахи - люди разных национальностей и их зарубежные друзья» 25 .

Некоторые заголовки начинались с китайских имен ${ }^{26}$. Биографическая информация соответствовала мысли: «Судьба каждого из нас - это судьба человека нового Китая». Человек имел свою собственную, но достаточно типичную биографическую траекторию: происхождение из бедной крестьянской или рабочей семьи, затем «массовая» и непрерывная учеба, служба в армии, вступление в Коммунистическую партию Китая. Эмоциональная составляющая публикаций помимо обязательных атрибутов языка дружбы строилась вокруг желания овладеть профессией (опять же отсылка к роли ученика) и быть полезным родине ${ }^{27}$.

Обучение в СССР оказало сильное влияние на картину мира части китайской элиты. Длительное пребывание в состоянии межкультурного контакта способствовало размыванию национальных образцов толкования действительности и формированию т.н. гибридных идентичностей в сознании китайских практикантов, студентов и советских людей, контактировавших с ними. Эти акторы, «переходя» границы между двумя реальностями, превращались в культурных посредников, которые не только транслировали социалистический дискурс, но и демонстрировали друг другу отдельные элементы этнокультурной идентичности.

В начале 1960-х гг. тема дружбы в печати пошла на спад. Последние сведения о пребывании китайских практикантов на ММК датированы $1963 \Gamma^{28}$. В этом же году китайцы стали массово покидать СССР.

23 Дятлов 2014: 31.

24 Челябинский рабочий. 1954. 1 октября; 3 ноября.

${ }^{25}$ Магнитогорский рабочий. 1956. 1 мая.

${ }^{26}$ К примеру «Наш друг Ван». - Челябинский рабочий. 1959. 1 марта.

27 Челябинский рабочий. 1954. 1 октября; 1955. 1 мая.

${ }^{28}$ ОГАЧО. Ф. Р-1613. ОП. 44. Д. 8. Л. 93, 128-129. 


\section{Успехи социалистического строительства: образы КНР}

Известные агитационные плакаты тех лет гласили «Наша цель коммунизм» (худ. В. Каленский, И. Каленская, 1959), «Вперед к великой цели» (худ. М.М. Соловьев, 1959). Но относительно путей прихода к этой цели согласия у советского и китайского руководства не было. Идеологические разногласия, вызревавшие несколько лет, сыграли важную роль в советско-китайском расколе. Эти непростые обстоятельства по-своему преломлялись в текстах периодической печати 1950-х гг., где редко открыто говорили о том какие роли играют оба государства в этом совместном деле. За образами «непобедимых братьев-великанов» в виде Китая и Советского союза скрывались признаки грядущего раскола ${ }^{29}$. При этом советская печать вплоть до 1960-х гг. изображала позитивный образ китайского государства, вставшего на социалистический путь развития.

Советский Союз в центральной и региональной советской прессе безальтернативно позиционировался в роли учителя (иногда лидера), а Китай наделялся положением ведомого. Показательным примером служит освещение XX съезда КПСС. В феврале 1956 г. «Правда» пестрела заголовками «Нерушимая дружба», «Дружба навек» ${ }^{30}$. Приведем выдержку из интервью секретаря Пекинского горкома партии Пэн Чжэня, адресованного по радио к советским людям: «Мы горячо приветствуем открытие XX съезда КПСС. Великие достижения СССР освещают нашей стране путь вперед... ${ }^{31}$. Схожие сюжеты и образы можно обнаружить и в провинциальной печати. Подшивки прессы буквально пестрят разнообразными материалами о Китае. От торжеств в Пекине в честь 140-летия дня рождения К. Маркса и успехов в развитии китайской металлургии до улучшения жизни китайских трудящихся и советской выставки по мирному атому в Шанхае ${ }^{32}$. Советскому провинциальному читателю подробно сообщались статистические данные о приросте китайского промышленного и сельскохозяйственного производства, заработной платы рабочих и расширении ассортимента выпускаемых товаров народного потребления ${ }^{33}$. СССР выступал как вдохновитель успехов строительства социализма в Китае. Вот краткая выдержка из заметки по случаю 10-летия создания КНР: «Успехи социалистического строительства нашей страны связаны с помощью нашего великого союзника - Советского Союза ${ }^{34}$.

Другая часть текстов презентовала Китай непосредственно в Челябинске и городах области, на заводах, которые вносили существенный вклад в поставки оборудования или в обучение китайских практикантов.

\footnotetext{
29 О советско-китайском альянсе и расколе см.: Рябченко 2016, Lüthi 2008; Jersild, 2014. 30 Правда. 1956. 12 февраля; 13 февраля.

31 Правда. 1956. 16 февраля.

32 Челябинский рабочий. 1958. 16 января; 11 февраля; 11 марта; 12 марта; 6 мая; 10 июня; 11 июля; 13 ноября. 27 декабря. 1959. 16 апреля; 7 мая; 13 мая; 8 июля; 15 июля; 12 августа; 27 августа; 2 сентября; 17 сентября; 1 октября; 23 декабря.

33 Челябинский рабочий. 1957. 17 января. Предполагалось, что эти успехи достигались благодаря советским методам управления. См.: Kaple 2016.

34 Челябинский рабочий. 1959. 3 октября.
} 
Примером служат сообщения о выходе на экраны Челябинских кинотеатров новых фильмов китайского производства ${ }^{35}$. В 1955 г. в Челябинске даже прошел фестиваль китайского кино. Его подготовка включала беседы и лекции с трудящимися об успехах строительства социализма в Китае, выступлениями музыкантов с репертуаром китайских композиторов, выставками в честь пятилетней годовщины образования КНР, распространением литературы и периодики о Китае ${ }^{36}$.

В честь юбилеев создания КНР проводились красочные выставки достижений народного хозяйства Китая, экспозиции китайского искусства и пропагандистских плакатов, фестивали китайского кино ${ }^{37}$. Плакаты китайских художников изображали ключевые для того времени сюжеты. В их числе «Борьба за мир», советско-китайская дружба, промышленные предприятия, построенные или реконструированные при помощи советской стороны ${ }^{38}$. Так презентовались успехи, достигнутые «учеником» под чутким руководством «наставника». Подчеркивался контраст между послевоенной разрухой и ошеломительными результатами, достигнутыми уже после первых лет преобразований на «социалистический лад». Лекторы на предприятиях уделяли этому немалое внимание ${ }^{39}$.

Пресса публиковала много материалов об успехах в строительстве социализма в народном Китае ${ }^{40}$. Достижения трактовались как успех социалистической модели развития, прочного союза. Надо сказать, что многие мероприятия действительно вызывали неподдельный интерес, поскольку общество открывало для себя не только современный Китай, но и его древнюю культуру. Так в честь 10-летия создания КНР и 42 годовщины Октябрьской революции на сцене Челябинского оперного театр по мотивам китайских народных сказок поставили спектакль «Цветок счастья». Неоценимую помощь коллективу театра, как подчеркивал южноуральский журналист, оказал балетмейстер Ван Сисянь ${ }^{41}$.

\section{«Большая дружба» в локальном измерении}

Значительную поддержку имиджу «Большой дружбы» оказывало освещение визитов в СССР важных китайских делегаций и медийных лиц - политиков, спортсменов, ученых и деятелей искусства. В качестве примера из центральной печати приведем освещение визита Чжу Дэ в Харьков. Высокому гостю показали главный конвейер предприятия, он встретился и с китайскими практикантами на заводе. Как писала «Правда» ${ }^{42}$ : «Харьковские тракторостроители горячо, от всего сердца приветствовали

\footnotetext{
35 Челябинский рабочий. 1950. 11 октября; 16 сентября;

${ }^{36}$ ОГАЧО. Ф. П-92. ОП.13. Д. 51. Л. 2

37 Челябинский рабочий. 1958. 7 марта; 1959. 22 сентября; 25 сентября; 6 октября; Магнитогорский рабочий. 1955. 20 января; 1957. 1 октября; 1958. 1 октября.

38 Челябинский рабочий. 1954. 1 октября.

39 ОГАЧО. Ф. П-288. Оп. 21. Д. 140. Л. 36.

40 Челябинский рабочий. 1958. 28 сентября; 1 октября; 9 октября; 23 октября; 26 октября; 1959. 19 февраля.

41 Челябинский рабочий. 1959. 6 ноября.

42 Правда. 1956. 13 марта.
} 
представителей великого китайского народа. В 1955 г. в Челябинск и Магнитогорск с целью изучения опыта проектирования и строительства объектов городов металлургов приехал министр строительства КНР Лю Сюфын ${ }^{43}$. В 1956 г. большая группа журналистов ведущих китайских изданий посетила ММК, ЧТЗ, Уральский автозавод, Челябинский политехнический институт и Ильменский заповедник ${ }^{44}$. В 1957 г., когда СССР посетила команда китайских футболистов, в Челябинске они сыграли товарищеский матч с местным «Локомотивом» ${ }^{45}$. В Ильменском государственном заповеднике некоторое время работал заведующий отделом петрографии Китайской академии наук профессор Ли Пу и аспирант МГУ им. М.В. Ломоносова Ли Веньсянь ${ }^{46}$.

Прессой создавался эффект присутствия Китая в повседневной жизни уральцев. Известны случаи, когда китайские практиканты, уехав в Китай, уже там создавали семью. Коллектив ЧМЗ отправил одной из таких молодых пар свадебный подарок - набор столовых приборов. Уральцы отправляли китайским коллегам необходимые книги, а те в ответ присылали зеленый китайский чай и памятные подарки ${ }^{47}$. Кстати, о внимательном отношении китайской стороны к технической литературе на русском языке говорит такой факт. Книгу известного металлурга А. Шатилина «На домнах Магнитки», где он изложил свой многолетний опыт работы, в КНР перевели на китайский язык и издали большим тиражом ${ }^{48}$. Как признавался позже один из китайских инженеров: «Магнитка всегда служила нам знаменем технического прогресса. Мы учились у нее на расстоянии, жадно вчитываясь во всю литературу о ней» ${ }^{49}$.

Советские специалисты, приезжавшие в Китай с целью оказания помощи в развитии промышленности, являлись важными акторами советской культурной дипломатии. Челябинские тракторостроители помогали китайским механизаторам эксплуатировать трактор «Сталинец$80 »^{50}$. Например, бригадир тракторной бригады колхоза «Победа» (Сосновский р-он) М. Аксенов посетил Всекитайское совещание механизаторов и после этого визита состоял в дружеской переписке с китайскими коллегами. За самоотверженный труд Китайское правительство наградило М. Аксенова орденом Трудовой Славы ${ }^{51}$. Для многих китайских руководителей механизация сельского хозяйства была настолько важной за-

\footnotetext{
43 Челябинский рабочий. 1955. 20 сентября; 27 сентября; Магнитстрой. 1955. 30 сентября. - Красочные представления дали артисты Пекинского государственного цирка - участники V Всемирного фестиваля молодежи и студентов в Варшаве. - Челябинский рабочий. 1955. 24 сентября; Ф. Р-1282. Оп. 2. Д. 90. Л. 42-45; 97-99.

44 Челябинский рабочий. 1956. 2 июня; 10 июня; Магнитогорский рабочий. 1956. 5 июня.

45 Челябинский рабочий. 1957. 9 июля; 10 июля; 12 июля.

46 Челябинский рабочий. 1958. 15 июня.

47 Челябинский рабочий. 1959. 6 ноября; Магнитогорский рабочий. 1957. 23 октября.

${ }^{48}$ Магнитогорский рабочий. 1955. 18 апреля.

49 Челябинский рабочий. 1957. 27 января

50 Челябинский рабочий. 1954. 9 мая; 1956. 20 июня; 1958. 20 ноября.

${ }^{51}$ ОГАЧО. Ф. П-288. ОП. 21. Д. 83. Л. 162
} 
дачей, что сюжет о том, как советские специалисты помогают в освоении тракторов запустили даже на растиражированные китайские лубки ${ }^{52}$.

Немало внимания уделялось в печати путевым заметкам, сделанным во время поездок советских туристов и инженеров в Китай, рассказам о красотах Пекина и о том, как «китайский народ под руководством своей Коммунистической партии строит социализм» ${ }^{53}$. Публикация отзывов и очерков от первого лица создавала эффект «достоверности» событий.

Одним из способов визуализации советско-китайской дружбы стали памятные подарки и различные «артефакты». Здесь мы вновь прослеживаем параллели с центральными советскими изданиями, которые, например, много писали о том, что в память о посещении Харьковского тракторного завода маршалу Чжу Дэ преподнесли модель гусеничного дизельного трактора ${ }^{54}$. Аналогичные подарки преподносились и другим руководителям делегаций разного уровня, как в центре, так и на местах. Руководители, а иногда и рядовые участники делегаций дарили в ответ подарки. В 1957 г. корреспондент газеты «Магнитогорский рабочий» подчеркивал: «В отделе технического обучения ММК хранится немало знаков благодарности китайских металлургов: красные знамена, грамоты, приветственные адреса» ${ }^{55}$. Металлурги Аньшаня подарили своим коллегам в Магнитогорске памятное знамя, на котором было написано: «Коллективу доменного цеха ММК. Да здравствует дружба между народами Китая и Советского Союза. От доменщиков Анышаня» ${ }^{56}$. В лекционном зале партийного комитета ЧТЗ после одного из визитов в КНР появились вытканные на шелке портреты К. Маркса, Ф. Энгельса, В. Ленина, И. Сталина, Г. Маленкова и Мао Цзэдуна. Памятная надпись гласила: «Тракторостроителям - от китайского народа» ${ }^{57}$.

Листая подшивки прессы, мы видим, как осуществлялась демонстрация прочных связей между предприятиями, отдельными людьми и учреждениями по обе стороны границы. В знак надежд на дружбу будущих поколений китайцев и советских людей активно публиковалась дружеская переписка детей и молодежи ${ }^{58}$. В 1958 г. газета «Челябинский рабочий» писала: «Летят письма с челябинским штампом в разные города Китая. "Самыми дорогими друзьями” называют ребят китайские школьники» ${ }^{59}$. В газете «Магнитогорский рабочий» в 1956 г. появилось интересное письмо учащихся одного из технических училищ Магнитогорска: «Мы никогда не встречали тех, с кем переписываемся. Тысячи километров отделяют Магнитогорск от провинции Хунань. Но что значит рассто-

52 Подробнее см.: Муриан 1958.

53 Трубоппокатчик. 1958. 18 января; Челябинский рабочий. 1959. 19 февраля; 23 февраля.

${ }_{54}^{54}$ Известия. 1956. 11 марта.

${ }_{55}^{5}$ Магнитогорский рабочий. 1957. 16 ноября.

56 Челябинский рабочий. 1956. 6 сентября.

57 Челябинский рабочий. 1954. 1 октября.

58 Челябинский рабочий. 1957. 16 апреля; 1 мая; Магнитогорский рабочий. 1957. 16 ноября; Трубопрокатчик. 1957. 16 ноября.

59 Челябинский рабочий. 1958. 19 февраля. 
яние перед силой дружбы!» ${ }^{60}$. Для создания эффекта активных межкультурных обменов местные корреспонденты и журналисты использовали любой информационный повод. Так, например, некоторые южноуральцы собирали и систематизировали китайские почтовые марки ${ }^{61}$. А житель Карабаша К. Кузьмин стал победителем викторины китайского радио ${ }^{62}$. Любое событие, связанное с контактами между уральцами и Китаем, позиционировалось как проявление глубокого и плодотворного сотрудничества, имеющее перспективы в будущем, а взаимоотношения между советским и китайским народами описывались как «нерушимая дружба», «вечная дружба», «дружба на век» и т.д.

В начале 1960-х гг. публикации о Китае стали появляться в советской региональной прессе заметно реже. Тот язык, который ранее применялся для описания советско-китайской дружбы теперь использовался в текстах о других союзниках - о Кубе, Югославии, Чехословакии, Румынии (заголовки «Чехословацкая дружба нерушима» или «Нерушимая дружба советского и румынского народов» все чаще появлялись в центральных и провинциальных печатных изданиях ${ }^{63}$. Материалы о Китае помещались на фоне освещения дружбы Советского Союза с кем-то «другим», словно оттеняя и отводя на второй план еще недавно основного союзника. Разумеется, никуда не исчезали со страниц прессы «дежурные» поздравления с очередной годовщиной создания КНР. Однако они уже не вызывали никакой, даже формальной, реакции населения.

В 1963-1964 гг., когда между руководителями двух государств разгорелась открытая ожесточенная полемика, оптика провинциальных изданий стала перенастраиваться на другие темы. В одной из немногочисленных заметок, появившейся в газете «Челябинский рабочий» осенью 1963 г. осуждалась «антиленинская, раскольническая позиция КПК по важнейшим международным вопросам» ${ }^{64}$. Но эта публикация уже не играла заметной роли в процессе формирования нового образа Китая в сознании жителей Южного Урала. Новые тренды в презентации советскокитайских отношений формировались теперь полностью на страницах центральной печати. Именно там появились и первые реакции советской общественности на разногласия между КПК и КПСС. Например, отклик слесаря Московского завода В. Ермилова о том, что после публикации «Открытого письма ЦК КПСС» о сущности разногласий между КПСС и КПК стало известно всему советскому народу ${ }^{65}$. Тональность отзывов общественности приобретала все более негодующий характер. Работник Уралмашзавода А.И. Храмцов сетовал на то, что китайское руководство

${ }^{60}$ Магнитогорский рабочий. 1956. 20 октября.

${ }^{61}$ Челябинский рабочий. 1958. 15 января; 17 января; 1 мая; 2 декабря; 1959. 18 января; Магнитогорский рабочий. 1956. 14 апреля; 30 апреля; 20 октября; 1957. 3 ноября. 31 января.

62 Челябинский рабочий. 1958. 23 марта

63 Челябинский рабочий. 1961. 6 ноября; 26 сентября; 1962. 8 июня, 22 июня.

${ }^{64}$ Челябинский рабочий. 1963. 22 октября.

${ }^{65}$ Правда. 1963. 15 июля. 
предпочло забыть о помощи, которую оказывал Китаю Советский Сою3 ${ }^{66}$. Однако такие мнения публиковались нечасто: в «Правде» с 14 июля 1963 г. по 14 октября 1964 г. опубликовано 87 сообщений, содержащих такие отклики, в «Известиях - не более 25-30. На наш взгляд, это вызвано нежеланием Советского руководства СССР обострять ситуацию. Появление откликов, как правило, происходило после публикации официальных сообщений по поводу отношений Москвы и Пекина.

Многие отзывы посвящались помощи советской стороны Китаю. С точки зрения обывателя, китайский ученик оказался неблагодарным по отношению к своему учителю. Аналогичную позицию заняли и некоторые высокопоставленные партийные и советские чиновники. Например, первый секретарь Ташкентского горкома партии К. Муртазаев в своем письме в газету «Известия» выразил возмущение тем, что китайское руководство отрицает факт советской помощи. Ведь советский народ бескорыстно делился всем с КНР, при том что сам СССР еще не оправился от последствий недавней разрушительной войны ${ }^{67}$.

В этих условиях началось критическое переосмысление не только прежних практик советско-китайских отношений, но и многих базовых идеологических установок. Непостоянство казалось бы верного союзника, очевидное разочарование от нерациональности израсходованных ресурсов для его стремительного развития давали веское основание скептически оценивать массово пропагандируемую ранее советско-китайскую дружбу ${ }^{68}$. В преддверии уже открытой вооруженной конфронтации между двумя государствами, советская пропагандистская машина приступила к созданию образа непримиримого противника ${ }^{69}$. В результате у советских людей на долгие годы сместились акценты в восприятии китайцев и Китая, от круга друзей (in-group), до круга врагов (out-group).

\section{Выводы}

Приведенные из центральных и местных изданий примеры показывают, что в советской периодической печати в 1950-е гг., как правило, использовался один набор приемов для формирования положительного образа Китая и китайцев в сознании советских граждан. Советско-китайская дружба в оптике провинциальной печати предстает продолжением тех образов и смыслов, которые транслировались в центральных изданиях. Изученные нами газеты с разной степенью успешности «привязывали» их к местным реалиям, «встраивали» в повседневную жизнь конкретного города или отдельного завода.

Кратковременный период тесного сближения СССР и КНР оставил заметный след в жизни крупных советских индустриальных центров, изменив для многих жителей и работников эмоциональное восприятие целой эпохи. Описание китайских мигрантов являлось важной составляю-

\footnotetext{
${ }^{66}$ Известия. 1963. 16 июля.

${ }^{67}$ Известия. 1964. 7 апреля.

68 Федосов 2019: 216.

${ }^{69}$ Подробнее см.: Урбански 2018.
} 
щей дискурса советско-китайской дружбы. Гуманное восприятие образов Китая и китайцев на несколько лет стало доминирующим приемом советской пропаганды. Пресса персонифицировала образ китайцев, показала читателю, что представитель «других» - такой же человек, как и «человек советский», т.е. прилежный студент, труженик и созидатель общей цели (коммунизм, борьба за мир и др.). Он имеет имя, его изображают в производственной обстановке во взаимодействии с конкретными людьми, бригадами, мастерами, коллективами заводов, цехов и др.

Созданный на страницах советской прессы образ государства Китай, с одной стороны, формировал позитивное отношение к основному союзнику, с другой - легитимировал лидирующие позиции СССР в советскокитайском взаимодействии. Положительные показатели преобразований всех сторон жизни китайского общества, достигнутые с помощью «старшего брата», призваны были подтвердить верность модели развития самого Советского Союза. Энтузиазм и добровольная готовность руководства и населения КНР следовать советским шаблонам развития служила дополнительным маркером управляемости процессов и демонстрировала превосходство советской общественно-политической парадигмы. Предполагалось, что массированная презентация социалистических достижений в периодической печати будет оказывать влияние на внутриполитическую ситуацию в стране и направит общественное мнение в нужном для правящей элиты русле.

Демонстрация насыщенных и разнообразных связей уральцев с Китаем сформировала эффект «переднего края» межкультурного взаимодействия и созидания нового коммунистического общества. Так труженики и жители крупнейших индустриальных центров Южного Урала приобщались к ключевым общегосударственным и международным процессам. Тем самым судьбы людей и государств, несмотря на наличие глубоких культурных и до поры скрытых идеологических различий, развивались в общем коммуникативном пространстве.

Несмотря на то, что некоторые важные аспекты генерации «дружбы» в провинциальной печати нам выявить удалось, подготовленная рукопись оставляет ряд вопросов для дальнейшего осмысления. Практически нет региональных кейсов о моделях презентации советско-китайской дружбы, поэтому сравнить полученный нами материал с другими случаями мы возможности не имеем. До конца не ясно, как же в действительности формировалась матрица образов Китая и китайцев, происходило ли это под жестким контролем из центра или все же от региона к региону наблюдалась своя специфика в зависимости от близости/удаленности от фронтира, интенсивности контактов с китайскими мигрантами и т.д. Как могли различаться эти образы, созданные в информационном пространстве Урала, Москвы или Дальневосточного края и каким образом происходила их деконструкция? Ответы на эти вопросы мы попытаемся дать в следующих текстах. 


\section{БИБЛИОГРАФИЯ / REFERENCES}

Борисов О.Б., Колосков Б.Т. Советско-китайские отношения. М.: Мысль, 1980. 635 с. [Borisov O.B., Koloskov B.T. Sovetsko-kitajskie otnosheniya. M.: Mysl', 1980. 635 s].

Волошина Н.Н., Юдина Л.С. Китайские специалисты в Челябинске в пятидесятые годы XX века / гл. ред. М. Г. Смирнов // Россия и Китай в меняющемся мире. Челябинск, Челяб. гос. ун-т, 2005. C. 287-292. [Voloshina N. N., YUdina L. S. Kitajskie specialisty v CHelyabinske v pyatidesyatye gody XX veka / gl. red. M. G. Smirnov // Rossiya i Kitaj v menyayushchemsya mire. CHelyabinsk, CHelyab. gos. un-t, 2005. S. 287-292].

Гоцинь Ч., Каменских М.С. О реализации исследовательского проекта «эпоха советскокитайской дружбы в историко-культурном наследии Прикамья» // Вестник Пермского университета. История. 2015. Вып. 4 (31). С. 227-233. [Gocin' CH., Kamenskih M.S. O realizacii issledovatel'skogo proekta «epoha sovetsko-kitajskoj druzhby v istoriko-kul'turnom nasledii Prikam'ya // Vestnik Permskogo universiteta. Istoriya. 2015. Vyp. 4 (31). S. 227-233].

Гулева М.А. «Руки прочь от Китая!»: китайские друзья и враги на страницах журнала «Крокодил» (1922-1950 гг.) // Общество и государство в Китае. 2015. Т. 45. № 2. С. 706-729 [Guleva M. A. «Ruki proch' ot Kitaya!»: kitajskie druz'ya i vragi na stranicah zhurnala «Krokodil» (1922-1950 gg.) // Obshchestvo i gosudarstvo v Kitae. 2015. T. 45. № 2. S. 706-729].

Дацышен В.Г., Сюй Х. Отправка рабочих из провинции Хэбэй в СССР в 1955 г. Из истории русско-китайских отношений // Вестник Томского государственного университета. 2019. № 445. C. 102-106 [Dacyshen V. G., Syuj H. Otpravka rabochih iz provincii Hebej v SSSR v $1955 \mathrm{~g}$. Iz istorii russko-kitajskih otnoshenij // Vestnik Tomskogo gosudarstvennogo universiteta. 2019. № 445. S. 102-106].

Дружба навеки: Очерки истории сотрудничества Советского Союза и Китайской Народной Республики (1949-1960 гг.) / Отв. ред. И.В. Турицын. М.: НИИ ИЭП, 2018. 250 с. [Druzhba naveki: Ocherki istorii sotrudnichestva Sovetskogo Soyuza i Kitajskoj Narodnoj Respubliki (1949-1960 gg.) /Otv. red. I.V. Turicyn. M.: NII IEP, 2018. $250 \mathrm{~s}]$.

Дятлов В.И. Экзотизация и «образ врага»: синдром «желтой опасности» в дореволюционной России // Идеи и идеалы. № 2 (20). 2014. С. 23-41. [Dyatlov V. I. Ekzotizaciya i «obraz vraga»: sindrom «zheltoj opasnosti» v dorevolyucionnoj Rossii // Idei i idealy. № 2 (20). 2014. S. 23-41].

Каменских М.С. Китайцы на Среднем Урале в конце XIX - начале XXI в. СПб.: Изд-во «Маматов», 2011. 351 c. [Kamenskih M.S. Kitajcy na Srednem Urale v konce XIX - nachale XXI v. SPb.: Izd-vo «Mamatov», 2011.351 s].

Каменских М.С. Китайские рабочие в Прикамье в период советско-китайской дружбы: проблемы быта и адаптации // Вестник Пермского ун-та. История. 2013. Вып. 3 (23). С. 34-43. [Kamenskih M.S. Kitajskie rabochie v Prikam'e v period sovetsko-kitajskoj druzhby: problemy byta i adaptacii // Vestnik Permskogo un-ta. Istoriya. 2013. Vyp. 3 (23). S. 34-43].

Каменских М.С. Советско-китайская дружба 1950 - середины 1960-х годов: региональный опыт переосмысления // Российско-китайские отношения в условиях глобализации: общие вызовы и возможности для сотрудничества. М.: ИДВ РАН, 2019. С. 219-232. [Kamenskih M.S. Sovetsko-kitajskaya druzhba 1950 - serediny 1960-h godov: regional'nyj opyt pereosmysleniya // Rossijsko-kitajskie otnosheniya v usloviyah globalizacii: obshchie vyzovy i vozmozhnosti dlya sotrudnichestva. M.: IDV RAN, 2019. S. 219-232].

Муриан И.Ф. Современный китайский лубок. М.: Государственное издательство современного изобразительного искусства. 1958. 63 с. [Murian I.F. Sovremennyj kitajskij lubok. M.: Gosudarstvennoe izdatel'stvo sovremennogo izobrazitel'nogo iskusstva. 1958. 63 s.].

Нагорная О.С. «Когда СССР стал сильным и могучим... многие народы нуждаются в нашей дружбе»: аспекты изучения культурной дипломатии в социалистическом лагере (19491989) // Диалог со временем. 2015. № 4 (53). C. 268-278. [Nagornaya O.S. «Kogda SSSR stal sil'nym i moguchim... mnogie narody nuzhdayutsya v nashej druzhbe»: aspekty izucheniya kul'turnoj diplomatii v socialisticheskom lagere (1949-1989) // Dialog so vremenem. 2015. № 4 (53). S. 268-278].

Нагорных О.С. К биографии профессора В. Г. Вогралика: метод иглорефлексотерапии и аспекты советско-китайских отношений в 1950-е годы // История медицины 2017. Т. 4. № 4. C. 437-446. [Nagornyh O.S. K biografii professora V.G. Vogralika: metod iglorefleksoterapii i aspekty sovetsko-kitajskih otnoshenij v 1950-e gody // Istoriya mediciny 2017. T. 4. № 4. S. 437-446]. 
Павлюкевич Р.В. Китай - от «жертвы милитаристов» до «брата пролетария» (эволюция образа Китая в советских СМИ. 1946-1953 гг.) // Известия Иркутского гос. ун-та. Политология. Религиоведение. 2011. №2 (7). C.117-124 [Pavlyukevich R.V. Kitaj - ot «zhertvy militaristov» do «brata proletariya» (evolyuciya obraza Kitaya v sovetskih SMI. 1946-1953 gg.) // Izvestiya Irkutskogo gos. un-ta. Politologiya. Religiovedenie. 2011. № 2 (7). S. 117-124].

Поршнева O.C. Историческая имагология в современной российской историографии // Урал индустриальный. Бакунинские чтения: индустриальная модернизация Урала в XVIIIXXI вв. Екатеринбург, 2014. C. 126-129. [Porshneva O.S. Istoricheskaya imagologiya v sovremennoj rossijskoj istoriografii // Ural industrial'nyj. Bakuninskie chteniya: industrial'naya modernizaciya Urala v XVIII-XXI vv. Ekaterinburg, 2014. S. 126-129].

Рябченко Н.П. О Китае и российско-китайских отношениях. Владивосток: Дальнаука, 2016. [Ryabchenko N. P. O Kitae i rossijsko-kitajskih otnosheniyah. Vladivostok: Dal'nauka, 2016].

Урбански C. Непримиримый противник. Создание образа врага на советско-китайской границе в 1969-1982 гг. // Россия и АТР. 2018. № 2. С. 34-52. [Urbanski S. Neprimirimyj protivnik. Sozdanie obraza vraga na sovetsko-kitajskoj granice v 1969-1982 gg. // Rossiya i ATR. 2018. № 2. S. 34-52].

Федосов Е.А. «Вперед к великой цели!»: образ СССР и Китая в агитационных плакатах 1940-х - 1960-х гг. // Вестник Томского гос. ун-та. История. 2017. № 48. С. 144-137. [Fedosov E. A. «Vpered k velikoj celi!»: obraz SSSR i Kitaya v agitacionnyh plakatah 1940-h 1960-h gg. // Vestnik Tomskogo gos. un-ta. Istoriya. 2017. № 48. S. 144-137].

Федосов Е.А. Глобализация советской повседневности глазами политического плаката периода 1946-1964 гг. // Вестник Томского гос. ун-та. 2019. № 443. С. 209-218. [Fedosov E.A. Globalizaciya sovetskoj povsednevnosti glazami politicheskogo plakata perioda 1946-1964 gg. // Vestnik Tomskogo gos. un-ta. 2019. № 443. S. 209-218].

Fairclough N. Language and Power. London: Routledge, 2015. 264 p.

Gamsa M. The Cultural and the Social in Chinese-Russian Relations // Cultural and Social History. 2012. Vol. 9. Issue 3. P. 391-405.

Han D. Returnees and their Political Impact: evidence from returned students and trainees from the Soviet Union in China, 1950-1966 // Journal of Contemporary China. 2013. Vol. 22. Issue 84. P. 1106-1123.

Herrmann R.K. Image theory and strategic interaction in international relations // Oxford handbook of political psychology / D.O. Sears, L. Huddy, R. Jervis. Oxford: U.P., 2003. P. 285-314.

Jersild A. The Sino-Soviet Alliance: An International History. Chapel Hill: University of North Carolina Press, 2014. 352 p.

Kaple D. Soviet Advisers and High Stalinist Management in China, 1949-1960 // Journal of Cold War Studies. 2016. Vol. 18. No. 1. P. 5-30.

Li J. Gained in translation: The reception of foreign cinema in Mao's China // Journal of Chinese Cinemas. 2019. Vol. 13. Issue 1. P. 61-75.

Lüthi L.M. The Sino-Soviet Split: Cold War in the Communist World. New Jersey: Princeton U.P., 2008. 375 p.

Stein J.G., Welch D.A. Rational and psychological approaches to the study of international conflict: Comparative strengths and weaknesses // Decision making on war and peace: The cognitiverational debate / eds. N. Geva, \& A. Mintz. Boulder: Lynne Rienner Publ., Inc. 1997. P. 51-80.

Tina Mai Ch. Internationalism and Cultural Experience: Soviet Films and Popular Chinese Understandings of the Future in the 1950s. // Cultural Critique. 2004. No. 58. P. 82-114.

Urbansky S. \& Trecker M. Kremlinology revisited: the nuances of reporting on China in the Eastern bloc press // Cold War History. 2018. Vol. 18. Issue 3. P. 307-324.

Van Dijk T. Discourse and Knowledge A Sociocognitive Approach. Cambridge: U.P., 2014. 407 p. Wodak R. The Discourse-Historical Approach // Methods of Critical Discourse Analysis / ed. by R. Wodak, M. Meyer. London: Sage, 2009. P. 63-94.

Авдашкин Андрей Александрович, кандидат исторических наук, стариий научный сотрудник, лаборатория миграционных исследований, Южно-Уральский государственный университет; adrianmaricka@mail.ru

Сибиряков Игорь Вячеславович, доктор исторических наук, профессор, кафедра отечественной и зарубежной истории, Южно-Уральский государственньій универcumem, sibirjkovig@mail.ru 


\section{"Together Forever": friendship of The USSR and PRC in the optics of the Soviet provincial newspapers}

The article is devoted to the image of Soviet-Chinese friendship in the provincial press on the example of the newspapers of Chelyabinsk and Magnitogorsk. Most of the sources are first introduced into scientific circulation. The authors used the imagological method and discourse analysis. Using this toolkit, we analyzed the basic images of Soviet-Chinese friendship, which were broadcast in the Soviet provincial periodicals. The images of friendship developed on the basis of descriptions of Chinese trainees at industrial enterprises, a presentation of the leading role of the USSR in building socialism in China, and demonstrations of the strong friendly ties that arose between the Urals and Chinese workers.

Keywords: Soviet-Chinese friendship, images, the Soviet press, migrants, the image of China, intercultural relations

Avdashkin Andrey Alexandrovich, Candidate of Historical Sciences, Senior Researcher, South Ural State University, adrianmaricka@mail.ru

Sibiryakov Igor Vyacheslavovich, Doctor of History, professor, Professor of the Department of National and Foreign History, South Ural State University, sibirjkovig@mail.ru 


\section{ОСМЫСЛЕНИЕ НАЦИОНАЛЬНОГО ПРОШЛОГО В МУЗЫКАЛЬНОЙ КУЛЬТУРЕ ЗАПАДНОГО БЕРЛИНА 1980-Х ГГ. ${ }^{1}$}

Статья посвящена роли популярной музыки в процессах осмысления и проработки нацистского прошлого в Западной Германии в 1980-х гг. Популярная музыка рассматривается на примере музыкальной сцены Западного Берлина, а именно группы «Einstürzende Neubauten». Рассмотрены политический, экономический и социальный контекст функционирования сцены Западного Берлина, проанализированы различные способы репрезентации национального прошлого в музыке «Einstürzende Neu-bauten». Сделан вывод о том, что в музыкальной культуре Западного Берлина происходило восстановление преемственности разных периодов немецкой культуры и вписывание проблемного прошлого в публичный исторический нарратив.

Ключевые слова: Западный Берлин, популярная музыка, музыкальная сцена, нацистское прошлое, культурная идентичность, образы прошлого

В настоящее время, как иронично замечает А. Ассманн, Германия «чемпион мира по памяти» ${ }^{2}$. Несмотря на то, что в мемориальной культуре страны, безусловно, и сейчас есть спорные места, немцы проделали путь от замалчивания своего прошлого к признанию вины за нацистские преступления и коммеморации всех групп жертв. Осмысление и преодоление трудного прошлого происходило постепенно и на разных уровнях, в т.ч. в популярной культуре. Достаточно часто в качестве примеров репрезентации национального прошлого и следующего за ним изменения отношения к нему анализируются фильмы и сериалы, художественная литература и публицистические работы. Однако популярная музыка была не менее важным способом говорить о прошлом, но она гораздо реже рассматривается с точки зрения культуры памяти.

В популярной музыке отражались, прежде всего, проблемы национальной идентичности, которые возникли у первого поколения немцев, родившихся после войны. Студенческие протесты 1968 г. подняли проблему замалчивания нацистских преступлений, но не решили ее. Молодые немцы не ассоциировали себя с национальным культурным наследием и пытались отстраниться от истории своей страны, молодые немецкие музыканты предпочитали следовать образцам англо-американской музыки, не использовали немецкий язык в своих песнях. Обращение к немецкому языку и немецкой музыкальной культуре в популярной музыке происходило только в рамках политического высказывания, а самый массовый жанр - шлягер - вообще не касался каких-либо проблематичных тем ${ }^{3}$. Но с середины 1970-х - начала 1980-х гг. музыканты Западной Германии ста-

${ }^{1}$ Статья подготовлена в ходе работы в рамках Программы фундаментальных исследований НИУ «Высшая школа экономики» и с использованием средств субсидии в рамках государственной поддержки ведущих университетов РФ "5-100".

2 Assmann 2013: 59.

3 Подробнее об особенностях послевоенной популярной музыки в ФРГ и (не)артикулировании национальной идентичности в ней: Larkey 2002. 
вили своей целью создание именно немецкой музыки, пели на немецком языке. Изменение отношения к национальной идентичности было невозможно без изменения отношения к национальному прошлому. Из этого возникает исследовательский вопрос: как воспринималось прошлое в популярной музыке ФРГ в 1980-х гг.? В данной работе рассмотрено место популярной музыки в осмыслении национального прошлого послевоенной Германии и способы представления различных исторических сюжетов в музыкальной культуре Западного Берлина.

Исследование динамики образов прошлого во всем многообразии популярной музыки в ФРГ было бы слишком обширным, к тому же, в немецкой популярной музыке часто проявляется не национальная, а региональная идентичность музыкантов, влияние которой также следует учитывать. По этой причине статья посвящена периоду с 1979 по 1989 г., когда ФРГ пришлось столкнуться с последствиями мирового экономического кризиса и внутреннего политического кризиса, связанного с леворадикальным терроризмом. Основной фокус сделан на это время в Западном Берлине, поскольку в те годы этот город благодаря своему особому положению стал «законодателем моды» в популярной музыке. К началу 1980-х там возникла специфическая музыкальная сцена, участники которой не воспроизводили каноны жанров, зародившихся в США и Великобритании, а стремились экспериментировать и развивать свою музыкальную идентичность. История этой сцены стала важной частью как мифологии города, так и истории немецкой музыки ${ }^{4}$. Ее изучение проливает свет не только на то, как происходил сдвиг в отношении к национальному прошлому, но и на то, как он закрепился в коллективном сознании современных немцев, обращающихся к 1980-м гг. как к собственной истории.

Как кейс для анализа представлений о прошлом в немецкой музыке была выбрана музыкальная группа «Einstürzende Neubauten» («Разрушающиеся новостройки») $)^{5}$, созданная в 1980 г. в Западном Берлине Бликсой Баргельдом и Эндрю Унру6. Для этого есть несколько причин: во-первых, группа считается одним из самых ярких представителей сцены не только музыкальными журналистами и исследователями музыки, но и современниками ${ }^{7}$; во-вторых, как отмечает исследователь немецкой панксубкультуры Д. Хэйтон, именно представители сцены Западного Берлина,

${ }^{4}$ Подробнее о Западном Берлине 1980 -х, его мифологизации и роли в истории немецкой популярной музыки и культуры см.: Shahan, Howes, Hall 2016; Eisenhuth, Sabrow 2014; Hayton 2014: 209-10; Clarkson 2012; Teipel 2012; Hornberger 2011; Siebenhaar 2006; Lang 1994.

5 Здесь и далее переводы с немецкого сделаны автором.

${ }^{6}$ Blixa Bargeld (наст. имя Christian Emmerich), вокалист и автор всех текстов песен, p. 1959; N.U. Unruh/Andrew Chudy, перкуссионист, p. 1957; В 1981 г. к составу также присоединились Александр Хаке, Марк Чунг и ФМ Айнхайт (Alexander Hacke, басгитара и перкуссия, p. 1965; Mark Chung, перкуссионист, p. 1957; FM Einheit (наст. имя Frank Martin Strauss), перкуссионист, p. 1958).

${ }^{7}$ Müller 2013; Kruse 2017; Teipel 2011; Diederichsen 1981; Schneider 2008. Также документальные фильмы: B-Movie: Lust and Sound in West Berlin (2015), No Wave - Underground '80: Berlin - New York (2009). 
в т.ч. «Einstürzende Neubauten», сейчас контролируют публичную память о 1980-х гг. в популярной культуре ${ }^{8}$; в-третьих, репрезентируя прошлое, музыканты обращаются к разным периодам истории немецкой музыки, используют различные музыкальные приемы и даже теоретические философские работы, чтобы объяснить смысл своего высказывания, что делает их творчество любопытным для исследования.

\section{Музыкальная сцена Западного Берлина}

В работе используется термин „музыкальная сцена“, а не „субкультура“ или просто „музыкальные группы“. Исследователи популярной музыки Э. Беннетт и Р. Петерсон определяют локальную музыкальную сцену как «сфокусированную социальную активность», основными характеристиками которой является реализация общего музыкального вкуса производителями и потребителями музыки, а также отличения себя от других с помощью музыки и культурных знаков 9 .

Формирование музыкальной сцены Западного Берлина опиралось на появление новых институтов музыкальной индустрии и изменение тех, что существовали до этого. Изменилась музыкальная пресса, которая стала уделять больше внимания немецким музыкантам, чем британским и американским, появился ряд независимых рекорд-лейблов, в т.ч. записывающих музыку на кассеты, а не на виниловые пластинки, открылись новые площадки для встречи музыкантов и фанатов (бары, клубы, сквоты), а также возникли новые музыкальные фестивали, с помощью которых участники сцены получали представление друг о друге и о тех музыкантах, которые жили за пределами Западного Берлина.

Основным событием, определившим то, как себя позиционировала сцена, стал музыкальный фестиваль «Geniale Dilletanten» (sic!), прошедший в здании бывшего цирка Темподром в 1981 г. В нем приняли участие такие группы, как «Wir und das Menschliche E.V.», «Sprung Aus Den Wolken», «DIN A Testbild», «Die Tödliche Doris», «Einstürzende Neubauten», «Sentimentale Jugend», «Deutsch-Polnische Aggression» и отдельные исполнители - Гудрун Гут (Gudrun Gut), Макс Мюллер (Max Müller), Padeluun и Марк Ридер (Mark Reeder), и др. Название фестиваля было намеренно написано с ошибкой и выражало творческую позицию участников сцены: ошибки, некачественное исполнение и запись музыки, незавершенность только приветствовались и считались новаторскими художественными методами. Это было попыткой демократизации музыки, утверждением, что музыкантом может быть любой. Как вспоминает В. Мюллер о фестивале, «актеры на сцене казались настолько же безразличны к тому, был ли шум приятным или неприятным, как и зрители. Внимание было приковано к неоформленному, неготовому и непосредственному» ${ }^{10}$. Это стремление выражалось в отказе от музыкальной структуры, обычных музыкальных инструментов, от ясных и простых текстов. Тем не менее «Гениаль-

\footnotetext{
${ }^{8}$ Hayton 2013: 538; Müller 2013: 38.

${ }^{9}$ Bennett, Peterson 2004: 8.

${ }^{10}$ Müller 2013: 221-22.
} 
ных диллетантов» можно назвать радикальной интерпретацией панкрока $^{11}$, ставшего популярного в ФРГ в 1970-х: «отказ от владения музыкальным инструментом, непосредственное выражение своего отношения к жизни, «No-Future»-ощущение и связанный с ним нигилистический гламур» - эти принципы разделяли панк-сцены ФРГ и экспериментальная сцена Западного Берлина ${ }^{12}$, но ключевым различием этих сцен было то, что музыка западноберлинских групп, во-первых, из-за нестандартного подхода к ее производству была гораздо более сложной для прослушивания, чем панк-рок; во-вторых, она не выражала радикальной политической позиции в явном виде. По этим причинам в других городах Западной Германии не всегда положительно принимали музыкантов сцены: тур «Berliner Krankheit» с группами «Einstürzende Neubauten», «Sprung aus den Wolken» и «Mekanik Destruktiw Komandoh» сопровождался в основном негативными рецензиями в фанатских журналах (фэнзинах $)^{13}$.

Отношение к прошлому внутри сцены также отличалось от его использования другими немецкими панк-рок группами. Западноберлинские музыканты не обращались к образам прошлого для открытой провокации: в биографических источниках, фотографиях и видеозаписях о жизни западноберлинской сцены и «гениальных диллетантов» не встречаются упоминания о ношении значков или повязок со свастикой, упоминании имен нацистских лидеров ${ }^{14}$. Использование прошлого западноберлинскими музыкантами было связано не с агрессией и провокацией, а с критикой проблем настоящего и прошлого, а также с протестом против музыкальной индустрии. Например, песня группы «Sentimentale Jugend» под названием «Hiroshima» стилизована под шлягер, в припеве повторяется фраза «Hiroshima - wie schön es war» ${ }^{15}$. Сочетание музыкальной стилизации и провокационного текста - это ирония над бессмысленностью текстов шлягера и обращение к чувству страха перед ядерным апокалипсисом. Предчувствие апокалипсиса и конца света часто встречается в пес-

\footnotetext{
${ }^{11}$ Ключевыми характеристиками британского панк-рока, оказавшего наибольшее влияние на немецкие панк-сцены, являются «оппозиция воспринимаемому статус-кво (культурному, социальному или политическому); игнорирование символов власти и установленных иерархий; притязания предоставить голос маргинализованным или недовольным социальным группам; акцент на самодостаточности и преодолении препятствий, мешающих доступу, самовыражению или автономии» (Worley 2017: 11). Слоган «No Future» («Будущего нет»), принадлежащий группе «The Sex Pistols», выражал нигилизм молодежной субкультуры и разочарование в британской политике тэтчеризма. В панк-роке целенаправленно используются примитивные музыкальные структуры, грубый, хриплый вокал, шумовые элементы; он, как отмечает музыковед А. Мур, «смешивал общепринятые техники использования инструментов, музыкальные формы и аккорды, но соединял их с импульсивностью и свирепостью» (Moore 2001).

${ }^{12}$ Hornberger 2011: 210.

13 Berliner Krankheit 1981; Die Berliner Krankheit 1981.

14 Примером того, как прошлое, напротив, использовалось для провокации, может быть панк-группа «Deutsche-Amerikanische Freundschaft» из Дюссельдорфа, которая стала известна благодаря песне «Tanz der Mussolini», призывая «танцевать Муссолини, танцевать Адольфа Гитлера, танцевать Иисуса Христа».

15 «Хиросима - как это было прекрасно».
} 
нях практически всех музыкантов этой сцены, в т.ч. «Einstürzende Neubauten». Эта тревога связана с политическими, экономическими, социальными проблемами. Во-первых, с середины 1970-х в ФРГ значительно вырос уровень инфляции и безработицы, сложнее всего работу было найти молодежи и пожилым людям ${ }^{16}$. Отсутствие экономической стабильности и уверенности в завтрашнем дне повлекло за собой образование сквоттерского движения и усиление анархистских сцен в Западном Берлине. Сквоты стали площадками для формирования и выступлений музыкальных групп, анархический протест против капитализма и государства, «унаследованный» еще от протестных движений 1968 г., часто артикулировался и в сквоттерской прессе и музыке ${ }^{17}$. Во-вторых, после событий «Немецкой осени» ${ }^{18}$ был усилен полицейский контроль, что вызывало радикальное сопротивление государству и недоверие к нему со стороны молодежи ${ }^{19}$. Также тревога населения возрастала в связи с заключенным в 1980 г. с США договором о размещении ядерных ракет на территории ФРГ (NATO-Doppelbeschluss) и очередным напряжением отношений между Западным и Восточным блоками после вступления войск СССР в Афганистан в 1979 г. ${ }^{20}$ В воспоминаниях участников сцены часто упоминается ощущение ядерной угрозы и уверенность в том, что Западный Берлин станет первой целью для удара в новой мировой войне ${ }^{21}$.

В 1982 г. главой правительства стал Гельмут Коль, политика которого была направлена на обновление страны и выход не только из экономического, но и из «духовно-политического кризиса» ${ }^{22}$ : проводились неолиберальные реформы (отменялись социальные льготы, подчеркивалась роль рынка в экономике и важность свободного предпринимательства), усиливалась поддержка церкви государством, одним из пунктов обновления страны было ее техническое обновление, выразившееся в программе по проведению кабельного телевидения в каждый дом ${ }^{23}$. Во время правления Коля общественный резонанс вызвала его политика в отношении истории: задачей бундесканцлера было нейтрализовать немецкое прошлое для построения диалога на равных с другими европейскими странами и США ${ }^{24}$. В 1984 г. во время визита в Израиль Коль употребил в речи перед кнессетом выражение «благо позднего рождения» ${ }^{25}$, имея в виду, что новое поколение политиков Германии непричастно к нацистским преступлениям. В 1985 г. противоречивым жестом, вызвавшим споры и протесты не только в ФРГ и США, был совместный визит Коля с амери-

\footnotetext{
${ }_{16}^{16}$ Doering-Manteufel, Raphael 2008: 37.

${ }^{17}$ Clarkson 2012: 77-80; Brown 2009. поколения леворадикальной группировки «Rote Armee Fraktion». См.: Weinhauer 2004.

${ }^{19}$ Ibid: 238.

${ }^{20}$ Herbert 2008: 92.

${ }^{21}$ Dax, Defcon 2005: 15; Müller 2013; Teipel 2012; Shahan 2015: 38-39.

22 Цит. по: Korte 2002: 411.

${ }^{23}$ Korte 2002: 228-31.

${ }^{24}$ Herbert 2008: 93-95.

25 «Gnade der später Geburt».
}

18 «Deutscher Herbst»- ряд террористических атак, совершенных участниками второго 
канским президентом Р. Рейганом на военное кладбище в Битбурге и поминовение памяти жертв войны: кладбище было местом захоронения не только американских солдат, но и членов Waffen-SS. В 1986 г. начался «спор историков» о том, существует ли коллективная ответственность и должно ли ее нести новое поколение немцев ${ }^{26}$.

Изменения в жизни молодых немцев и их медийный, политический и экономический контекст фиксировались в творчестве музыкальной сцены Западного Берлина. Официальная версия национальной истории, существовавшая в публичном пространстве ФРГ, не представляла возможности ассоциировать себя ни с жертвами нацистского режима, ни с преступниками, ни с политическими движениями послевоенного времени. Молодежь Западного Берлина чувствовала себя оторванной от остальной страны и вместе с тем привязанной к истории и культуре своего города. Ирония, тревога, агрессия, недоверие к государству и следующее из него сопротивление государственной исторической политике отражались в песнях, и, следовательно, становились опытом слушателей. В этот опыт также встраивалось отношение к сложному прошлому, которое для музыкантов сцены предоставляло способ говорить о проблемах настоящего.

\section{Прошлое у "Einstürzende Neubauten»}

Немецкое прошлое намеренно избрано важным сюжетом в творчестве «Einstürzende Neubauten». Переосмысление нацистского прошлого, вместе с которым переосмыслялось и понимание «немецкости» (German$n e s s)^{27}$, - основной мотив творчества этой группы, в рамках которого происходило также использование городского пространства Западного Берлина, и высказывание о немецкой музыке и немецкой культуре в целом.

Основными характеристиками раннего периода «Einstürzende Neubauten» (1979-1989) можно назвать:

1. Радикальный отказ от традиционных музыкальных эстетических форм. По сравнению с остальными музыкантами сцены, стремление «Еinstürzende Neubauten» экспериментировать с материалами и звуком приводило к гораздо более экстремальным результатам. В песнях анализируемого периода нет музыкальной структуры, текст нельзя поделить на куплеты и припевы. Баргельд чаще всего прибегал к разным видам крика, шепоту или проговариванию текста в форме речитатива, а не к пению. Группа редко использовала обычные музыкальные инструменты: звук извлекался из найденных на строительной площадке или на свалке кусков металла, водосточных труб, автомобильных пружин, строительных ин-

\footnotetext{
${ }^{26}$ Fischer, Lorenz 2015: 230-40.
}

27 «Немецкость» как калька с английского Germanness используется здесь для обозначения культурных практик, поддерживающих немецкую национальную идентичность (исследователи также упоминают практики немецкости как ответ на вопрос «что значит быть немцем?») (O’Donnell, Bridenthal, Reagin 2005: 4). В сборнике освещены разные подходы, в т.ч. с точки зрения мигрантов, которые через немецкость обозначали свою связь с покинутой родиной. Немецкость в популярной музыке как ощущение собственной национальной идентичности широко рассматривается в работах исследователя популярной музыки М. Шиллер: Schiller 2018a; 2018b; 2016; 2014a; 2014b. 
струментов и других подручных материалов. Из музыкальных инструментов группа использовала электрогитару и бас-гитару, в более поздних записях - некоторые струнные инструменты, секвенсоры ${ }^{28}$. Часто в треки вставлялись различные сэмплы ${ }^{29}$ - сделанные на кассетный магнитофон записи звуков, окружающих музыкантов в повседневной жизни.

2. Теоретическое осмысление собственной эстетики. Во многих интервью уже в 1980-х гг. музыканты (преимущественно Баргельд) не только раскрывали смысл своих песен или рассказывали о процессе их создания, но и обращались для объяснения своих работ к философским и культурологическим теориям. Так, Баргельд цитирует Вальтера Беньямина и Антонена Арто, Жиля Делеза и Феликса Гваттари, разрабатывает собственные эстетические теории, которые нашли свое проявление в творчестве группы ${ }^{30}$. Соответственно, несмотря на значение для группы импровизации и дилетантизма в раннем творчестве, «Einstürzende Neubauten» можно считать музыкальным проектом с определенной эстетической позицией, которая осознанно разрабатывалась Бликсой Баргельдом совместно с другими музыкантами группы. В эту эстетическую позицию было включено и отношение к прошлому Германии, в т.ч. к прошлому в художественной традиции: Баргельд в интервью 2000 г. связывал особенности творчества группы с тем, что «не существует немецкой традиции, к которой можно обратиться без ощущения вины. Культура, которая существовала до войны, по праву нам не дозволена из-за того, к чему она привела или, в лучшем случае, чего не предотвратила» ${ }^{31}$.

\section{Репрезентация нацистского прошлого}

Следует отметить, что репрезентация нацистского прошлого у «Einstürzende Neubauten» не носит милитаристский характер. Несмотря на шумовые композиции, использование криков, имитацию звуков выстрелов и разрыва бомб, на «вооружение» металлическими инструментами, на концертных выступлениях группа не пользовалась демонстрацией физической силы и превосходства. На записях того времени видно, что музыканты находятся на одном уровне со слушателями, вокалист падает на колени, шум инструментов хаотичный и непредсказуемый, а не плотный и подавляющий. В лирике не задействована своеобразная фонетика немецкого языка, которую немецкоязычные исполнители часто используют для обыгрывания стереотипов о немецком языке как грубом и агрессивном ${ }^{32}$.

${ }^{28}$ Секвенсор (англ. sequencer) - электронный инструмент, позволяющий записывать последовательность звуков, а затем изменять эту запись и воспроизводить еe (Davies 2001).

${ }^{29}$ Сэмпл (англ. sample) - звуковой фрагмент, который переносится непосредственно из первоначального носителя в новую запись (Fulford-Jones). Сэмплировать можно как другие музыкальные произведения (напр., сэмплы с виниловых пластинок), так и звуки окружающей среды, записанные на диктофон (как это делали «Neubauten»).

${ }^{30}$ Bargeld 1988: 98, 119-20; Bargeld 1997: 157.

${ }^{31}$ Laddish, Dippe, «Blixa Einstuerzende: Bargeld Harassed».

32 Появившиеся позже немецкоязычные группы «Rammstein» и «Laibach», также часто использующие индустриальные шумы, демонстрируют на выступлениях физическую мощь с помощью образа музыкантов и освещения снизу, «тяжелого» звучания, особого подчеркивания шипящих звуков в немецкоязычных текстах и использования альве- 
На альбоме «Zeichnungen des Patienten O.T.» ${ }^{33}$ нацистское прошлое представлено как болезнь. Название пластинки, как и заглавный трек, отсылает к истории австрийского художника Освальда Чиртнера, который участвовал в битве под Сталинградом, затем был во французском лагере для военнопленных, и после окончания войны попал в психиатрическую клинику в Вене с диагнозом «шизофрения». Его лечащий врач и искусствовед Лео Навратил предложил ему начать рисовать, и Чиртнер под псевдонимом О.Т. стал успешным художником в стиле ар-брют ${ }^{34}$. «Einstürzende Neubauten» немного сократили название книги Навратила об О.Т. и поместили фрагмент рисунка художника на обложку альбома. Образ солдата-художника создает ассоциацию между военным прошлым и психической болезнью, но, с другой стороны, комментирует творчество самих музыкантов: частое упоминание болезни в текстах и болезненный вид вокалиста тоже представлены как следствие событий прошлого.

Одним из примеров использования образов, которые связаны и с репрезентацией прошлого, и с культурными маркерами немецкости, является песня «Trinklied» ${ }^{35}$. Она выделяется в альбоме тем, что имеет конвенциональную форму. Текст «Trinklied» стилизован как народная средневековая баллада: в нем намеренно используется устаревшая лексика, он представляет собой небольшое стихотворение с фабулой, перекрестной рифмовкой и чередованием женских и мужских рифм. Тем же размером и метрикой написаны баллады Гете и Шиллера ${ }^{36}$. Баргельд намеренно произносит звук «р» раскатисто, имитируя акцент, распространенный в южнонемецких землях. Музыка, напротив, не схожа с балладами. Сюжет песни - мрачная история от первого лица: лирический герой пил в «редкостной дыре» ${ }^{37}$, и не смог оттуда выбраться, поскольку не хотел выпускать из рук кубок, и появившиеся звери обглодали его до костей.

Эта композиция скорее иронизирует над немецкими классиками: помещает их в несвойственный контекст, перемещая из категории «высокого искусства» и национального культурного наследия в застольные песни подвальных клубов Берлина. Это можно увидеть в официальном музыкальном видео, где в одном из берлинских баров песню несколько раз скандирует пьяная компания, в т.ч. участники группы. Рассматривать эту шутку как репрезентацию нацистского прошлого стоит по той причине, что Гете и Шиллер как образцы «высокого искусства» активно эксплуатировались нацистами для демонстрации превосходства немецкой литературы, и, следовательно, языка и народа, над другими ${ }^{38}$. Песня отражает

олярного («раскатистого»), а не увулярного (нормативного для немецкого языка) звука «р». О мартиальном стиле «Rammstein» в сравнении с «Neubauten» см.: Carpenter 2017.

33 «Рисунки пациента О.Т.».

${ }^{34}$ Navratil 1974.

35 «Застольная песня».

${ }^{36}$ См. к примеру «Der König in Thule», «Vor Gericht», «Der Fischer» у Гете; «Das Lied von der Glocke», «Das Siegesfest», «Die Kindsmörderin» у Шиллера.

${ }^{37}$ В оригинале «Nächtens ward ich trunken / In einem selten Loch».

${ }^{38}$ Martin 2013. 
уже упомянутую невозможность обращения к собственной культурной традиции в нейтральном ключе. Из-за нацистского прошлого музыканты вынуждены обращаться к национальным культурным сюжетам через иронию, чтобы задать им другой контекст.

Другим примером такого представления о национальном прошлом является альбом «Halber Mensch», записанный в 1985 г. Само выражение «Halber Mensch» в немецком языке обозначает обессилевшего человека, истощенного после болезни или какого-либо потрясения ${ }^{39}$. В то же время оно намекает на слова «Übermensch» и «Untermensch» («сверхчеловек» и «недочеловек»), заимствованные в нацистскую риторику из работ Фридриха Ницше. Сам Ницше упоминается в треке «Z.N.S.» («ЦНС»):

«Es tanzt die Stimulanzjen-seits / Это танцуют стимуляторы von Gut und Böse / По ту сторону добра и зла

"Was mich nicht umbringt / "Что меня не убивает, macht mich stärker" / Делает меня сильнее"

Friedrich N Punkt / Фридрих Н точка»

Репрезентация прошлого в этом случае происходит через «замалчивание» Ницше: название его известной работы («Jenseits von Gut und Böse») и популярная цитата не оставляют сомнений в том, о ком идет речь, но фамилия все равно не названа. Это можно проинтерпретировать как символическое воспроизведение «замалчивания» прошлого нацистских преступников после войны ${ }^{40}$, однако в том, как вокалист произносит эту фразу, слышна ирония, как и в каламбуре, получающемся из-за наложения друг на друга слов «Stimulanzien» и «jenseits» ${ }^{41}$. «Friedrich N Punkt» здесь играет ту же роль, что балладная структура в «Trinklied»: имя Ницше, как и творчество немецких классиков, можно отнести к немецкому культурному наследию, но у «Neubauten» отсылки к национальному наследию резко контрастируют с другими, более «низкими» контекстами, например, с употреблением наркотиков и алкоголя, описанным в текстах песен. Способом рефлексии над прошлым становится его высмеивание.

Критическое отношение к прошлому считывалось слушателями «Neubauten». В 1986 г. группа дала концерты в Золотом Зале внутри Цепеллин-трибуны в Нюрнберге. Это здание, спроектированное А. Шпеером и возведенное для спортивных мероприятий и праздников националсоциалистов в 1937 г., считалось образцом для всей государственной архитектуры при нацизме ${ }^{42}$. Украшенный мрамором и узором из золотых свастик зал предназначался для выступлений членов НСДАП. В 1980-х в нем проходили выставки и концерты, среди них - два концерта группы, организованные местным концертным агентством. Сюжет об этих концертах вышел на центральном немецком канале ZDF, где представлен как

\footnotetext{
${ }^{39}$ Schemann 2011: 538.
}

${ }^{40}$ Цитата из интервью Баргельда с американскими журналистами в 2000 г.: «Я хочу сказать, что немецкая традиция ушла. Мы ненавидим нашу культуру и наш язык. Вся наша философия и музыка была апроприирована нацистами: Дюрер, Бах, Фридрих Н точка» (Laddish, Dippe «Blixa Einstuerzende: Bargeld Harassed»).

41 «Стимуляторы» и «по ту сторону» соответственно.

${ }^{42}$ Dietzfelbinger, Liedtke 2004: 48. 
акт экзорцизма и очищения этого места от «призраков нацизма» с помощью огня, который «Neubauten» разожгли на сцене, и шума их инструментов $^{43}$. Музыканты стали восприниматься как «эксперты» по изменению значений объектов, связанных с нацистским прошлым.

\section{Репрезентация донацистского немецкого прошлого}

Однако немецкое прошлое было представлено не только как нечто, запятнанное преступлениями нацизма, что необходимо изменить до неузнаваемости. Группа использует в положительном контексте образы прошлого, связанные со значением творчества в жизни человека. Аллюзия на творчество немецких классиков есть в песне «Sehnsucht». Согласно толковому словарю «Duden», это слово обозначает «болезненную душевную потребность в ком-либо или в чем-либо недостижимом» ${ }^{44}$. Как концепт «Sehnsucht» широко освещается в немецкой философии и литератуpe, а также романтической музыке (например, «Sehnsuchtlied» Вагнера) ${ }^{45}$. В понимании «Neubauten» Sehnsucht «kommt aus Chaos / und ist die einzige Energie» ${ }^{46}$, что сходно с трактовкой этого понятия у философа XVII века Якоба Бёме, считавшего Sehnsucht основным принципом, на котором основана динамика природных механизмов после сотворения мира, поскольку природа всегда хочет вернуться в состояние хаоса, в котором она пребывала до божественного вмешательства ${ }^{47}$. «Sehnsucht» - одна из самых эмоционально напряженных песен в творчестве «Neubauten», и одна из немногих, в которых «немецкое» не связано с чем-то отрицательным. Это высказывание о цели творчества, которое является выражением желания достичь невозможного через неупорядоченность и импровизацию. Смягчение первоначальной радикальной творческой позиции позволяет перестать фокусироваться на травматичности и болезненности национального прошлого и перейти к поиску новых способов художественного выражения, в т.ч. через обращение к более ранней истории Германии.

Подобным образом прошлое присваивается на альбоме «Haus der Lüge» («Дом лжи», 1989). В его оформлении использованы элементы гравюр художника XVI в. Ханса Бальдунга Гриена. Это было сделано с целью провокации: в Британии и США обложка, на которой был изображен эякулирующий жеребец, была сочтена неприличной и выпущена распространителями пластинок с купюрой. В буклете и внутренних сторонах обложки образы, взятые с гравюр, обыгрывают название группы и ее образ как «разрушителей»: гравюра «Самсон, разрушающий храм» изображает обрушающееся строение; портреты музыкантов также стилизованы

${ }^{43}$ ZDF 1986.

${ }^{44}$ «Sehnsucht».

${ }^{45}$ Corbineau-Hoffmann 2017.

46 «происходит из хаоса / и является единственной энергией».

${ }^{47}$ Текст песни не является отсылкой на работы Беме, и Баргельд никогда не делал ссылку на них в интервью и биографических источниках. Этот пример приведен здесь, чтобы продемонстрировать связь «Sehnsucht» в творчестве «Einstürzende Neubauten» с философским, а не повседневным пониманием этого слова в значении «страсть», «желание», в котором оно часто используется в популярной немецкой культуре. 
под гравюру. Через такую рамку покупателям демонстрировалась «немецкость» альбома и самой группы еще до прослушивания пластинки.

Первая же песня «Feurio» («Пожар») ставит вопрос о виновности голландского анархиста Маринуса ван дер Люббе в поджоге Рейхстага 1933 г. Это стало поводом для введения чрезвычайного положения, ограничения гражданских свобод и репрессий против коммунистов ${ }^{48}$. Ван дер Люббе на суде полностью признал свою вину и был казнен в 1934 г. То, что его действия были представлены как леворадикальная террористическая акция, не обмануло другие страны. Считается, что ван дер Люббе был не столько преступником, сколько жертвой, орудием нацистского заговора. В 1965 г. он был реабилитирован немецким судом. Однако его имя стало поводом для дискуссии историков о том, действовал ли он в одиночку или вместе с помощниками, которые скрылись, оставив его на месте преступления. В тексте «Feurio» Маринус объявляется невиновным:

«Marinus, Marinus, hörst du mich? / Маринус, Маринус, слышишь меня?

Marinus, Marinus, du warst es nicht / Маринус, Маринус, это был не ты, es war Koenig Feurio! / Это был король Пожар!»

Образ Маринуса ван дер Люббе в песне теряет коннотации жертвы и «пешки» в нацистском заговоре, напротив, он предстает человеком, который боролся с архитектурой и государством. Так происходит присвоение прошлого, придание собственных значений историческим персонажам. Учитывая постоянную критику государства в творчестве группы и анархистские взгляды сцены, с которой они связаны, нельзя сказать, что происходит оправдание использования поджога Рейхстага в политических целях. Напротив, главный посыл песни в том, что атака на государственные структуры и поджог - это не преступление, а творческий акт.

В отличие от «Trinklied», песня «Ein Stuhl in der Hölle» («Место в аду», которая является переложением немецкой народной песни «Die Stiefmutter» ${ }^{49}$, исполнена очень серьезно и без иронии. «Музыкальным инструментом» в ней становятся люди: текст сопровождается ритмическим стуком ног по деревянному полу. После первых двух песен альбома («Prolog», «Feurio»), где слышны шумовые и электронные инструменты и крик, «Ein Stuhl in der Hölle» звучит очень тихо, требует от слушателей внимания и сохранения тишины (если речь идет о концертном исполнении). И Баргельд поет, а не проговаривает рефрен «О weh mir!» («O, горе мне!»), что придает песне несвойственную для «Neubauten» лиричность.

«Ein Stuhl in der Hölle» - это попытка придать новое звучание немецкому фольклору и продемонстрировать, что он может быть встроен в необычную стилистику «Neubauten». Песня представляет собой диалог двух человек, один из которых ребенок, которого отравила его мачеха, и поэтому он желает ей места в аду. Мрачный сюжет текста позволяет музыкантам органично интегрировать фольклор в свое экспериментальное

\footnotetext{
48 Подробнее см.: Bahar, Kugel 2013.

${ }^{49}$ Erk 1856: 5.
} 
творчество, поскольку он перекликается с образами смерти и болезни, которые постоянно упоминаются в других песнях группы.

Фольклор также «пострадал» от рук нацистов. Народные песни считались источником «расовой чистоты» немецкой культуры ${ }^{50}$, а некоторые были переделаны в нацистские гимны и марши. Вряд ли «Die Stiefmutter» когда-либо использовалась таким образом, поскольку она слишком мрачная. Тем не менее само слово «народная песня» (Volkslied) и многие народные песни вызывают у немцев ассоциации с нацистским периодом $^{51}$. Используя фольклорную песню в своем творчестве, «Einstürzende Neubauten» избавляют ее от этих ассоциаций. Немецкий фольклор становится частью «альтернативной» музыки, а национальное прошлое - источником вдохновения и новым способом творческого самовыражения.

Подводя итог, можно сказать, что «Einstürzende Neubauten» обращаются к национальному прошлому, высказывая свой протест против консервативной исторической политики государства, которая пыталась представить темное прошлое Германии как закрытую страницу истории, к которой немцы, рожденные после войны, уже не имеют прямого отношения. Напротив, в творчестве берлинской группы прошлое предстает как неотъемлемая часть настоящего. Это выражается и в регулярном использовании образов нацистского прошлого, и в творческой обработке более ранних исторических сюжетов.

«Einstürzende Neubauten» - одна из многих групп берлинской сцены того времени, представляющая собой яркий пример работы с немецким прошлым в популярной музыке. Популярная музыка 1980-х в ФРГ, в т.ч. ее «дилетантская» сцена в Западном Берлине, была средством переосмысления прошлого: в ней происходило восстановление преемственности разных периодов немецкой культуры друг к другу, принятие нацистского прошлого и его вписывание в публичный исторический нарратив. Зачастую это происходило за счет черного юмора, иронии, использования апокалиптических и нигилистических образов болезни и смерти. Слушатели, участники сцены, журналисты, представители культурных институций знакомились с таким способом говорить о проблемном прошлом и необходимостью о нем говорить. В то же время музыканты стремились преобразовать представления о том, что немцы и «немецкость» до сих пор связаны с нацизмом, войной и жестокостью, а также преодолеть подобные стереотипы у иностранных слушателей. Обращение к популярной музыке как историческому источнику позволяет понять как процессы изменения представлений о прошлом, так и влияние прошлого на национальную идентичность и ее выражение в массовой культуре.

\footnotetext{
${ }^{50}$ Probst-Effah 1994: 159-60.

51 Примером того, как неоднозначен немецкий песенный фольклор до сих пор, может быть разгоревшийся в немецких медиа скандал с исполнителем шлягера Хайно, который в 2018 г., подарил министру альбом с народными песнями XIX в. Впоследствии выяснилось, что 24 из них были включены в «Песенник СС» (Heino schenkt Ina Scharrenbach Lieder mit SS-Vergangenheit, 2018).
} 


\section{БИБЛИОГРАФИЯ / REFERENCES}

Assmann A. Das neue Unbehagen an der Erinnerungskultur. Eine Intervention. Munchen: C.H. Beck Verlag, 2013.

Bahar A., Kugel W. Der Reichstagsbrand: Geschichte einer Provokation. Köln: PapyRossa, 2013.

Bargeld B. Headcleaner: Text Fur Einsturzende Neubauten/Text for Collapsing New Buildings. Berlin: Die Gestalten Verlag, 1997.

Bargeld B. Stimme frißt Feuer. Berlin: Merve Verlag, 1988.

Bennett A., Peterson R. Introducing Music Scenes // Music Scenes: Local, Translocal, and Virtual. Nashville: Vanderbildt University Press, 2004. P. 1-17.

Berliner Krankheit // Jungen Tech. 1981. No. 3. S. 3.

Brown T.S. Music as a Weapon? "Ton Steine Scherben" and the Politics of Rock in Cold War Berlin // German Studies Review. 2009. P. 1-22.

Carpenter A. Einstürzende Neubauten to Rammstein. Mapping the Industrial Continuum in German Pop Music // German Pop Music: A Companion. Berlin: Walter de Gruyter GmbH \& Co KG, 2017. P. 151-170.

Clarkson A. Urban Tribes: Subcultures and Political Conflict in West Berlin, 1945-1991 // Social Justice. 2012. Vol. 38. No. 4 (126). P. 71-90.

Corbineau-Hoffmann A. Sehnsucht // Historisches Woerterbuch der Philosophie. / J. Ritter, K. Gruender (hrgs.). 1995. Vol. 9. S. 165-168.

Das Wort hat der Herr Bundeskanzler: Eine Analyse der Großen Regierungserklärungen von Adenauer bis Schröder / K.-R. Korte. (hrgs.) Wiesbaden: VS Verlag für Sozialwissenschaften, 2002.

Davies H. Sequencer // Oxford Music Dictionary Online. URL: https://www.oxfordmusiconline.com/ view/10.1093/gmo/9781561592630.001.0001/omo-9781561592630-e-0000047622

Dax M., Defcon R. Einstürzende Neubauten: No Beauty without Danger. Berlin: [б. и.], 2005.

Die Berliner Krankheit // Cumulus Nimbus. 1981. No. 1. S. 6.

Diederichsen D. Berlin 1981 // Sounds. 1981. Vol. 6. S. 9.

Dietzfelbinger E., Liedtke G. Nürnberg - Ort der Massen: das Reichsparteitagsgelände: Vorgeschichte und schwieriges Erbe. Berlin: Ch. Links Verlag, 2004.

Doering-Manteufel A., Raphael L. Nach dem Boom. Perspektiven auf die Zeitgeschichte seit 1970. Gottingen: Vandenhoeck und Ruprecht, 2008.

Erk L. Deutscher Liederhort: Auswahl der vorzüglichern deutschen Volkslieder aus der Vorzeit und der Gegenwart mit ihren eigenthümlichen Melodien. Berlin: T.C.F. Enslin, 1856.

Fischer T., Lorenz M.N. Lexikon der »Vergangenheitsbewältigung« in Deutschland, Debatten- und Diskursgeschichte des Nationalsozialismus nach 1945. Bielefeld: transcript Verlag, 2015. Vol. 3., überarb. und erw. Aufl.

Fulford-Jones W. Sampling // Oxford Music Dictionary Online. URL: https://www.oxfordmusiconline.com/view/10.1093/gmo/9781561592630.001.0001/omo-9781561592630-e-0000047228

Hayton J. Culture from the slums: punk rock, authenticity and alternative culture in East and West Germany: Diss. University of Illinois. 2013.

Heino schenkt Ina Scharrenbach Lieder mit SS-Vergangenheit // Spiegel Online. URL: https://www.spiegel.de/panorama/gesellschaft/heino-schenkt-ina-scharrenbach-lieder-mit-ssvergangenheit-a-1199459.html

Herbert U. Der „Historikerstreit“ — Politische, wissenschaftliche, biographische Aspekte // Zeitgeschichte, Wissenschaft und Politik: Der „Historikerstreit“ — 20 Jahre danach / V. Kronenberg (hrgs.). Wiesbaden: VS Verlag für Sozialwissenschaften, 2008. S. 92-108.

Hornberger B. Geschichte wird gemacht: die Neue Deutsche Welle: eine Epoche deutscher Popmusik. Wuerzburg: Königshausen \& Neumann, 2011.

Kruse K. Lob des Imperfekts: Kunst, Musik und Wohnen im West-Berlin der 1980er Jahre. Berlin: mikrotext, 2017.

Laddish K., Dippe M. Blixa Einstuerzende: Bargeld Harassed // Robert Buchanan Site. URL: http://robertbuchanan.info/Bargeld_Harassed.html

Lang B. Mythos Kreuzberg // Leviathan. 1994. Vol. 22. No. 4. S. 498-519.

Larkey E. Postwar German Popular Music: Americanization, the Cold War, and the Post-Nazi Heimat // Music and German National Identity. Chicago, London: University of Chicago Press, 2002. P. 234-250.

Martin B.G. 'European Literature' in the Nazi New Order: The Cultural Politics of the European Writers' Union, 1941-3 // Journal of Contemporary History. 2013. Vol. 48. No. 3. P. 486-508. 
Moore A.F. Punk rock // Oxford Music Dictionary Online. URL: https://www.oxfordmusiconline.com/view/10.1093/gmo/9781561592630.001.0001/omo-9781561592630-e-0000046257

Müller W. Subkultur Westberlin 1979 - 1989: Freizeit. Hamburg: Philo Fine Arts, 2013. 1. Aufl.

Navratil L. Über Schizophrenie und die Federzeichnungen des Patienten O.T. Munchen: Deutscher Taschenbuch Verlag, 1974.

O’Donnell K.M., Bridenthal R., Reagin N. The Heimat Abroad: The Boundaries of Germanness. Ann Arbor: University of Michigan Press, 2005.

Probst-Effah G. Der Einfluß der nationalsozialistischen Rassenideologie auf die deutsche Volksliedforschung // Musikalische Volkskultur und die politische Macht. Tagungsbericht Weimar 1992 der Kommission für Lied-, Musik-und Tanzforschung in der Deutschen Gesellschaft für Volkskunde eV. 1994. S. 156-165.

Schemann H. Deutsche Idiomatik: Wörterbuch der deutschen Redewendungen im Kontext. Berlin: Walter de Gruyter, 2011.

Schiller M. "Fun Fun Fun on the Autobahn": Kraftwerk Challenging Germanness // Popular Music and Society. 2014b. Vol. 37. No. 5. P. 618-637.

Schiller M. From soundtrack of the reunification to the celebration of Germanness: Paul van Dyk and Peter Heppner's 'Wir sind Wir' as national trance anthem // Perspectives on German Popular Music. NY: Routledge, 2017.

Schiller M. Heino, Rammstein and the double-ironic melancholia of Germanness // European Journal of Cultural Studies. 2018b. Vol. 1. No. 00 (0). S. 1--20.

Schiller M. Soundtracking Germany: Popular Music and National Identity. London: Rowman \& Littlefield International, 2018a.

Schiller M. The Sound of Uncanny Silence: German Beat Music and Collective Memory // Lied und populäre Kultur / Song and Popular Culture. 2014a. Vol. 59. P. 171-205.

Schneider F.A. Als die Welt noch unterging: Von Punk zu NDW. Mainz: Ventil Verlag, 2008.

Shahan C. Punk rock and german crisis: adaptation and resistance after 1977. London: Palgrave Macmillan, 2015.

Shahan C.M., Howes S., Hall M.M. Beyond No Future: Cultures of German Punk. NY: Bloomsbury Publishing USA, 2016.

Siebenhaar K. The Myth Of Berlin: The Imagined And The Staged City // Urban Mindscapes of Europe. Leiden: Brill Rodopi, 2006. P. 225-235.

Teipel J. Verschwende Deine Jugend: Ein Doku-Roman über den deutschen Punk und New Wave. Berlin: Suhrkamp Verlag, 2012.

Weinhauer K. Terrorismus in der Bundesrepublik der Siebzigerjahre. Aspekte einer Sozial- und Kulturgeschichte der Inneren Sicherheit. // Archiv Für Sozialgeschichte. 2004. No.44. S. 219-242.

Worley M. No Future: Punk, Politics and British Youth Culture, 1976-1984. Cambridge: U.P., 2017.

ZDF. Einstürzende Neubauten - Nürnberg 1986 - ZDF Report // YouTube. URL: https://www.youtube.com/ watch? $\mathrm{v}=$ mGAleAIbZXc

Лысенко Елизавета Николаевна, магистр культурологии, НИУ ВШЭ, ИГИТИ им. А.В. Полетаева, стажер-исследователь. lizaveta.lysenka@gmail.com

\section{Comprehension of the national past in the West Berlin music culture in the 1980s}

The article is focused on the role of popular music in the processes of comprehension and dealing with the Nazi past in West Germany in the 1980s. Popular music is examined on the example of the music scene of West Berlin, namely the band «Einstürzende Neubauten». The article considers the political, economic and social context of the West Berlin music scene, analyzes different ways of representing the national past in the music of «Einstürzende Neubauten». The conclusion is made that in the musical culture of West Berlin the continuity of different periods of German culture was restored and the troubled past was incorporated into the public historical narrative.

Keywords: West Berlin, popular music, music scene, Nazi past, cultural identity, images of the past

Lizaveta Lysenka, M. A. Higher School of Economics, Poletayev Institute, Research Assistant.lizaveta.lysenka@gmail.com 


\section{С.Г. Дюкин}

\section{РОК-Н-РОЛЛЬНЫЙ ДИСКУРС КАК ЗЕРКАЛО ПЕРЕСТРОЙКИ}

Цель статьи - выявление реформаторского потенциала рок-музыки, который проявился в ходе Перестройки. Гипотезой исследования стала мысль о том, что молодежная музыка была не столько двигателем процессов изменения советского общества, сколько отражала намерения власти и ход реальных реформ, служила для апробации реформаторского дискурса. Исследование проведено на основе анализа нарративных интервью с очевидцами событий, музыкантами и людьми, близкими к роккультуре в конце 1980-х гг., публикаций в прессе описываемого периода, неопубликованных документов. Появление и развитие описанного в статье дискурса указывает на использование рок-музыки в качестве индикатора изменений и инструмента для забрасывания камней, то есть апробации радикальных идей и решений.

Ключевые слова: рок-музыка, рок-дискурс, перестройка, идентичность, авторская индивидуальность

Существует множество потенциальных исследовательских проблем, к таковым часто ученым сообществом не относимых. Причина ложная видимость решения вопроса за счет его распространенности в публицистическом дискурсе, откуда он усваивается обыденным сознанием. Итогом становится мифологизирование проблемы - многим кажется, что ее решенность очевидна, хотя это совсем не так.

К подобным научным проблемам относится роль рок-музыки в перестройке. Если данную проблему детализировать, то необходимо выделить вопросы о субъективном или объективном характере популяризации рок-музыки в последние годы существования СССР; о степени и способах ее влияния как на ожидания разных категорий населения, так и на цели, намерения и методы самих реформаторов; о корреляции между рок-музыкой и перестроечными процессами.

О роке как музыке перестройки вышли сотни материалов в газетах «Комсомольская правда», «Московский комсомолец», «Литературная газета», «Аргументы и факты», в региональных изданиях, в журналах «Ровесник», «Комсомольская жизнь», «Студенческий меридиан», «Советская эстрада и цирк», «Аврора». Опыт СМИ был обобщен отдельными журналистами и музыкантами, издавшими книги по истории отечественного рока ${ }^{1}$. Весь данный дискурс насыщен единым пафосом, заключающимся в признании рока музыкой перестройки, обладающим ресурсами обновления и реформаторства. Правда, по мере хронологического отдаления от перестройки, авторы все больше подвергают сомнению реформаторский посыл рок-музыки. Данный факт можно объяснить как снятием социального заказа на идею соответствия рока и реформ, так и особенностями культурной памяти, накладывающей отпечаток на работы публицистов. В более поздние времена (1990-2010-е гг.) феномен рок-музыки все более глубоко проникал в научный обиход,

\footnotetext{
1 Житинский 2006; Козлов 2001; Троицкий 1991.
} 
результатом чего стал ряд работ (преимущественно диссертаций), в которых, помимо прочих вопросов, рассматривается роль и место рока в перестроечных процессах ${ }^{2}$. Согласно гипотезе нашего исследования, рок-музыка являлась индикатором социально-политических перемен, а также инструментом формирования «повестки дня», в том смысле, какой был придан данному понятию группой американских социологов, в т.ч. Б. Коэном, Д. Шоу и М. Маккомбсом, полагавшими, что массмедиа выстраивают когнитивную структуру социума на основе задаваемой ими тематики ${ }^{3}$. При этом фактором изменений рок-культура не являлась, не обладала собственным реформаторским потенциалом. Видение такого смысла в использовании и развитии рок-н-ролльного нарратива коррелирует с построениями, основной идеей которых является то, что перестроечный дискурс в полном его объеме обслуживал действия советской элиты, направленные на изменение отношений собственности. В наиболее законченной форме эти мысли выразились в трудах венгерского историка Т. Крауса ${ }^{4}$, видящего в перестроечной культуре апологию прежде всего экономического апгрейда советского общества.

Реконструкция рок-н-ролльного нарратива с целью определения места этого музыкального направления в процессе реформирования общества возможна на основе многочисленных публикаций в центральной и региональной прессе 1985-1991 гг., неопубликованных документов, регулирующих сферу молодежной культуры, а также на основе интервью с рок-музыкантами и людьми, вовлеченными в рок-культуру в период перестройки. В статье внимание сосредоточено на материале Перми: привлечены документы, регулировавшие отношения в сфере молодежной музыки, а также интервью с очевидцами событий. Это отнюдь не указывает на региональный характер исследования - региональный материал является отражением общенациональных процессов и тенденций. Пермь, в данном случае, представляет типичный крупный советский город с имеющейся рок-сценой, рок-клубом, региональными массмедиа, уделявшими внимание проблемам молодежной музыки.

Начало перестройки, как оно осмысливается сегодня, т.е. назначение на должность генсека КПСС М. Горбачева в марте 1985 г. и декларация им намерений, связанных с искоренением негативных сторон жизни советского общества, прошло практически незамеченным как для рок-сообщества, так и для потенциальной аудитории той музыки, которая к тому времени существовала в СССР на уровне полуподпольной самодеятельности, либо в сублимированном виде, будучи ассимилированной традиционной советской эстрадой, превращенной, таким образом, в стиль ВИА. Риторика 1985 г. практически не отличается от дискурса предыдущих двух лет, отмеченных усилением внимания к рокмузыке со стороны государства в аспекте контроля и ограничений. Ос-

\footnotetext{
${ }^{2}$ Алексеев 2003; Васильева 1999; Касьянова 2003; Невская 2009.

${ }^{3}$ Cohen 1963

${ }^{4}$ Kpayc 2009
} 
новные вопросы балансируют вокруг дискотек, контроля за репертуаром ансамблей и решения проблемы соотношения зарубежных и советских исполнителей в пользу последних. Упоминания о молодежной музыке в документах пермского горкома ВЛКСМ того времени связаны исключительно с надзором и контролем. В частности, в записке «О ходе аттестации ВИА и дискотек» содержится критика в адрес ансамблей изза использования «антихудожественных произведений, низкопробных сочинений самодеятельных авторов, песен, взятых из зарубежных радиопередач, записей нелицензионных пластинок» ${ }^{5}$. Ставятся такие задачи как формирование репертуара ВИА из песен представителей «отечественной песенной классики, народного творчества и прогрессивных представителей мировой музыкальной культуры» ${ }^{6}$

Типичен пафос материалов о дискотеках, опубликованных в газете «Молодая гвардия», официальном органе Пермского горкома ВЛКСМ. Именно это издание в ходе перестроечных лет стало основной печатной площадкой в Перми, где разворачивались дискуссии о рок-музыке. Ведущей проблемой дискотек авторы видят отсутствие качественного отечественного музыкального материала ${ }^{7}$. С раннеперестроечным дискурсом, основанным на концепте ускорения и связанным с идеей активизации ресурсов, коррелирует установка на развитие дискотек. Речь идет о количественных изменениях, при этом отсутствует всякая установка на апгрейд системы дискотек, на изменение отношения к зарубежной музыке, либо на обращение к новому пласту молодежной музыкальной культуры. Показателен материал о группе «Форум», главным достоинством которой обозначается вытеснение своим современным «фирменным» звучанием иностранных исполнителей. Риторической единицей текста, однозначно связывающей этот материал с текущим официальным дискурсом, становится фраза руководителя «Форума», композитора А. Морозова: «Я считаю своим гражданским долгом влиять на идейнонравственное и эстетическое воспитание молодежи» ${ }^{8}$.

Этапным моментом можно считать публикацию в октябре 1985 г. материала о «черном» рынке фирменных дисков. Во-первых, в тексте не только признается, но и оправдывается нелегальный оборот импортных пластинок, во-вторых, оправдывается популярность западной рок-музыки, т.е. соединяются интенции, связанные с экономическим и идеологическим реформированием системы. В заявлениях автора смутно просматривается декларация о легализации рыночных отношений и о принятии ценностных ориентаций западного общества. Матрицей подобных заявлений служит рок-музыка (настоящее развитие в рамках рок-

\footnotetext{
${ }^{5}$ О ходе аттестации вокально-инструментальных ансамблей и дискотек.

${ }^{6} \mathrm{O}$ мерах по упорядочению деятельности вокально-инструментальных ансамблей. Весной 1985 г. комсомольскими структурами на основе обозначенных критериев была проведена аттестация ВИА и дискотек, которую прошли 42 из 80 ансамблей и 23 из 39 танцплощадок (О ходе аттестации вокально-инструментальных ансамблей).

${ }^{7}$ Каменев 1985.

${ }^{8}$ Иванович 1985.
} 
дискурса обе темы получат несколько позже). На исходе первого этапа перестройки рок-музыка была введена в новое проблемное поле.

В сферу собственно политических дискуссий рок-среда не входила. «Телевизор точно все смотрели, но всякие политические «телеги», все эти «терки» точно никто не гонял, все просто похихикивали, ну, пели про ментов и все такое. Политических активистов среди нас точно не было» (Интервью 1). Если воспользоваться теоретической схемой А. Юрчака, то можно говорить о сохранении в рамках рок-субкультуры ситуации вненаходимости, заключающейся в полном отчуждении музыкантов и тусовщиков от официальной культуры, от провозглашаемой через СМИ социально-политической проблематики ${ }^{9}$. Сочетание активизации субкультуры с ее отчуждением от политического поля породило всплеск творческой активности, который выразился в стремительном росте количества групп, а также в ощущении приближающейся рок-н-ролльной революции, о чем вспоминают очевидцы (Интервью 2).

На рубеже 1986-1987 гг. в прессе резко возрастает объем материалов о рок-музыке. Масс-медиа всех видов открывают для советской аудитории молодежные субкультуры под именем неформалов. В конце 1986 г. по решению горкома ВЛКСМ создается Пермское городское молодежное творческое объединение при одном из ведомственных дворцов культуры, где начинает работать клуб любителей музыки, возглавляемый музыкантом местной группы «Шлагбаум». Участник событий Сергей Панин, бывший одним из лидеров музыкально-поэтической тусовки Пермского университета, описывает ситуацию следующим образом: «Были какие-то сугубо личные частные вещи, интересы, и вдруг они стали предметов всеобщего обсуждения. Ведь мы все понимали, что все это (рок-андеграунд) интересно только узкому кругу людей. Не было такого, будто нас гнобят, что не дают народу заниматься искусством. Мы ведь занимались чем-то очень специфическим и не собирались быть ни “Землянами”, ни “Машиной времени”. И вдруг все это начинает широко обсуждаться» (Интервью 2).

Определяющими концептами публицистического рок-дискурса становятся интеллектуальность и индивидуальность (авторская). Рок начинает позиционироваться как серьезное искусство, заставляющее думать. В этом духе высказываются как авторы газетных материалов, так и выступающие в роли респондентов музыканты ${ }^{10}$. В рамках этого поля впервые формируется оппозиционная дихотомия рок/эстрада (nопса). Первоначально в основу такого противопоставления кладется именно критерий интеллектуальности, которая позиционировалась присущей рок-музыке в отличие от традиционной эстрады ${ }^{11}$. В законченной форме суть данной дихотомии обозначает в интервью музыкант группы «Звуки

\footnotetext{
${ }^{9}$ Юрчак 2014.

${ }^{10}$ Иванович «Удивить своим»; «Не позволяй себе схалтурить» 1986; Князев 1986; Иванович «Рок-панорама-86»; Тихонова 1989.

${ }^{11}$ Иванович «Круиз-новая модель»; Иванович «Рок-панорама-86».
} 
МУ» А. Липницкий: «группы, работающие серьезно, обязательно стремятся донести свою концепцию до зрителя. Что же касается стремления к успеху, то этим и отличается поп, эстрада от серьезной музыки» ${ }^{12}$.

Сложное искусство, являющееся ядром молодежной культуры и имеющее массовый характер (именно так позиционируется рок-музыка советскими журналистами и самими музыкантами в период ранней перестройки) становится в рамках советского публицистического дискурса отражением общего стимулятора интеллектуализации социума. Речь идет о формирующейся установке со стороны правящей элиты на индивидуальное осознание каждым советским человеком социалистических ценностей и необходимости добросовестного ответственного труда. Также в это время новое звучание получает идея приоритета интенсивного развития советской экономики, в основе чего должен лежать переход к наукоемким отраслям производства. В этом контексте рок-музыка превращается в орудие формирования «повестки дня», в ядро медийного эксперимента, на основе которого субъект официально-публицистического дискурса отрабатывает риторику, которая, в конечном счете, призвана распространиться на все сферы общественных отношений. Субъект данного эксперимента имеет исключительно коллективный характер. Его конкретизация представляется невозможной в силу того, что субъект предложения «повестки дня» включает в себя множество государственных институтов. Это и партийные органы, и комсомол, и массмедиа. И если СМИ занимались непосредственной вербализацией новой риторики, то властные институты могут рассматриваться лишь как заказчики новой «повестки дня», не связанные с ней дискурсивно.

Второй составляющей этого проблемного поля стала ценность $u н$ дивидуализма. Отводя року особое место в системе музыкальной культуры, журналисты и музыканты настаивали на том, что одной из главных его характеристик является авторская индивидуальность, выражающаяся в исполнении только собственного репертуара, в активном неприятии повторов и клише. Как вспоминает один из рок-н-ролльных общественников Перми эпохи перестройки: «Мы спрашивали: вы свое играете? Если да, то давайте к нам, в рок-клуб» (Интервью 1). Обыденный дискурс эпохи выразился в манифесте В. Долина «Не хочу быть как все», в котором в однозначной форме заявляется, что «металлисты хотят жить так, как нравится им, они против серости и заурядности, против

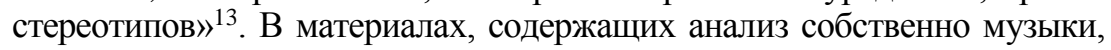
проводится та же линия неприятия эпигонства и воспроизводства стандартов $^{14}$. В законченном виде идея индивидуализации творчества доводится до крайнего субъективизма в понимании сущности рок-музыки Б. Гребенщиковым в интервью, данном им во время пермских гастролей группы «Аквариум»: «рок - это все, что меня трогает, это вся моя

\footnotetext{
12 Дашичев 1989.

13 Долин 1988.

${ }^{14}$ Сигалов 1988.
} 
жизнь» ${ }^{15}$. Связь между рок-идентичностью и авторством исполняемого материала как аксиома рок-дискурса второй половины 1980-х, подчеркивается большинством опрошенных респондентов, заставших названную эпоху. И, напротив, информанты, представляющие XXI век, в большинстве своем полагают такую взаимосвязь неуместной, впрочем, как и саму проблему феноменологических пределов рок-музыки.

С точки зрения теоретиков, исследующих феномен рок-музыки в культурологическо-эстетическом аспекте, тесная связь между авторством и исполнительством является неотъемлемым и одним из определяющих качеств этого явления ${ }^{16}$. По мнению В. Сырова, рок всегда стремится к стилевой индивидуализации творческого субъекта ${ }^{17}$. В подобных теоретических положениях налицо влияние перестроечного дискурса рок-музыки и его мощнейшего элемента, выразившегося в декларировании творческой самостоятельности как этического императива рока. Индивидуализация той эпохи связывается с эмансипацией личности, с необходимостью реализации творческого потенциала.

Следующий этап в развитии перестроечного рок-дискурса тесно связан с эволюцией идентичности советского общества и правящих кругов, начавших в конце 1986 и 1987-м г. позиционировать себя на дистанции от своих исторических предшественников. Подобно тому, как политическая элита, руководимая Горбачевым, ментально отчуждалась от эпохи Сталина и Брежнева, рок-музыка противопоставлялась традиционной советской эстраде, вокально-инструментальным ансамблям, а отчасти даже авторской песне ${ }^{18}$. Удаленность тех или иных рок-исполнителей от коммерчески ориентированной развлекательной эстрады для большинства журналистов служит в это время однозначно положительной оценкой рок-музыки. В заметке о Гребенщикове творчество группы «Аквариум» радикально отграничивается не только от поп-музыки, но и от Высоцкого, признаваемого «не своим», т.е. принадлежащим советской культуре, для поколения 25 -летних ${ }^{19}$. Если в большинстве материалов внимание авторов сосредоточено на отечественной культуре, то в ряде публикаций подчеркивается, что размежевание между роком и традиционной поп-музыкой - это универсальное явление, как это делается в статье «Битломания - от слова «Битлз» ${ }^{20}$.

Показательна в данном отношении небольшая заметка о группе «Земляне», опубликованная в январе 1987 г. Материал сосредоточен вокруг концепта реформирования, осовременивания. Мало того, в тексте звучит термин «перестройка», применяемый в данном случае по отношению к творчеству группы ${ }^{21}$. Режиссер С. Соловьев, зарекомендова-

\footnotetext{
${ }^{15}$ Иванович «Рисковать, но искать...».

${ }^{16}$ Касьянова 2003; Кнабе 2006; Набок 1993; Сыров 1997.

${ }^{17}$ Сыров 1997: 251.

${ }^{18}$ Иванович «Идет волна»; Санников 1986.

${ }^{19}$ Санников 1986.

20 Лебедев 1989.

${ }^{21}$ Юров 1987.
} 
вший себя, в том числе, двумя перестроечными рок-н-ролльными кинолентами, формулирует противопоставление поколений через негативную оценку своих ровесников и позитивную в отношении поколения рок-музыкантов: «Пока мы осторожно и умно ждали, они беззаветно сочиняли» ${ }^{22}$. Таким образом, принадлежность к рок-культуре провозглашается нравственным императивом и идеальным объектом идентификации для всего советского социума. Данная позиция вербализируется представителем творческой интеллигенции, близким к рок-культуре на определенном этапе своей деятельности, вследствие чего его оценка исследуемого феномена могла бы показаться предельно субъективной. Однако то, что позиция режиссера появилась на страницах официального советского издания, указывает на конгруэнтность подобного мнения в отношении властного дискурса того времени.

Установка на размежевание рока и дезактуализированной эстрады подтверждается и усиливается конщептом искренности, которая подчас противопоставляется профессионализму, коррелируя с любительством и дилетантизмом. На периферии данного концепта размещаются понятия прямоты и честности, которые позволяют говорить о корреляции рокдискурса в данном поле с официальной риторикой, одним из главных понятий которой на этом этапе становится гласность. Наиболее последовательный вариант отношения к рок-музыке зафиксирован в критической корреспонденции «Если нечего сказать», автор которой настаивает на том, что единственным критерием рока является дихотомия «верю-не верю», а противостоящим року качеством обозначается лицемерие ${ }^{23}$.

1988 г. занимает особое место в перестроечной истории рока. По сути, именно в это время реформаторский нарратив рок-музыки достигает кульминации, после чего происходит его заметное ослабление, а затем и полная дисфункционализация. Ведущей темой этого периода становится внедрение исполнительского коллектива в ту или иную форму хозяйствования. Исходным пунктом рассуждений на эту тему является декларация принципа творческой свободы, противником которой называется филармония с ее исключительно коммерческим интересом к исполнителям. В этом случае ставится вопрос об альтернативной форме функционирования рок-групп. Чаще всего этот вопрос не разрешается. Однако в ряде случаев журналисты (в основном, музыковеды) предлагают выстраивать хозяйственную деятельность самим коллективам, либо создавать новую форму творческих объединений ${ }^{24}$.

Практическим подтверждением интереса к организационному аспекту творческого процесса в рок-музыке стало создание в 1988 г. Перм-

22 Соловьев 1988.

${ }^{23}$ Кузнецов 1987.

${ }^{24}$ Волчек 1988; Интервью в стиле «рок» 1989; Ловковский 1988; Тихонова 1989. Иногда отрицание традиционных форм социалистического хозяйствования принимает откровенно агрессивный характер, как в случае резкой критики Киевконцерта и Укрконцерта в «Комсомольской правде». - Савинов 1988. 
ского рок-клуба на базе горкома ВЛКСМ. По признанию руководителя этой структуры Б. Бейлина, «рок-клуб был создан исключительно потому, что такие клубы были в Ленинграде, в Свердловске, и нам тоже хотелось. При этом своей тусовки-то практически не было. Потому принимали всех, кого могли найти» (Интервью 1). Работа таких объединений позиционировалась комсомольскими лидерами как приоритетная. Пермский горком ВЛКСМ подвергал критике райкомы за «недостаточную принципиальность и настойчивость в создании необходимых условий их (творческих объединений, в т.ч. рок-клуба) деятельности» 25 .

Подобный дискурс имел под собой вполне рационализированную почву. В 1988 г. вышел закон «О кооперации в СССР», позволивший творческим единицам и объединениям вести свою экономическую деятельность в статусе кооперативов, с одной стороны, выходя из составов филармоний, а с другой - лишаясь любительского статуса, который не позволял заниматься экономической деятельностью. В то же время рассуждения о перемене положения рок-групп можно связать с находившимся в зачаточном состоянии, но готовым ворваться в публичную сферу рыночным дискурсом. Уже в 1989 г. тема изменения структуры собственности обретет в советских СМИ устойчивый характер. Налицо все то же формирование повестки дня, т.е. определенная подготовка аудитории к ментальному восприятию некой темы, которая первоначально выглядит слишком радикальной для того, чтобы попасть в масс-медиа без предварительной подготовки аудитории. Если учесть, что рок-нролльная тематика входила в повестку дня через официальные (государственные) масс-медиа, безусловным фактом становится непосредственное участие государства в насыщении рок-нарратива теми или иными концептами. При этом интенции советской власти маскируются, облекаясь в одеяния альтернативной формы культуры. То, что П. Бурдье предложил называть официальной номинацией ${ }^{26}$, начинает работать на базе симулякра протестности, вызывая мощный эффект в виде соединения массового сознания с ориентирами, устанавливаемые правящей элитой.

Тема организации хозяйственной деятельности органично связана с концептом профессионализма, проникающим в описываемый дискурс в 1988-1989 гг. В отдельных заявлениях и рецензиях профессионализм подается как метод разрешения всех спорных вопросов о рок-музыке. В частности, сотрудник Минкульта СССР В. Миконин в «Комсомольской правде» именно таким образом снимает вопрос о вредном воздействии рока на молодежь. Иначе говоря, вредным может быть только музыка, исполняемая непрофессионалами, и наоборот ${ }^{27}$. Подобная позиция полностью перечеркивает тезис о том, что высокий профессионализм противоречит «выражению живой души художника» ${ }^{28}$.

\footnotetext{
${ }^{25}$ Информация о работе молодежных творческих объединений города Перми.

${ }^{26}$ Бурдье 1993.

27 Филинов 1988.

28 Ловковский 1988.
} 
В 1989 г. рок-н-ролльный нарратив в СМИ полностью видоизменяется. Он лишается реформаторской составляющей, лишаясь связи с социально-политическим и экономическим дискурсом. Публикации обретают статичный характер. Материалы в прессе о роке с этого времени посвящаются либо собственно музыке, либо исполнителям в аспекте их биографии, карьеры, либо вопросам продвижения групп и музыкантов. В «Комсомольской правде» именно в 1989 г. прекращаются дискуссии о сущности рок-музыки и ее праве на существование. Вместо этого начинают регулярно публиковаться колонки новостей о рок-исполнителях, выходе новых дисках, о концертах.

При этом преимущественно новости посвящены зарубежной музыке. В 1989 г. со страниц газетных и журнальных публикаций исчезает противопоставление отечественного и западного рока, прекращают высказываться идеи культурного протекционизма. И, напротив, наблюдается рост числа материалов о совместных музыкальных акциях, о гастролях зарубежных рок-групп и исполнителей, рецензии на новые зарубежные альбомы. Показательна заметка о проекте организации «Гринпис» и фирмы «Мелодия» в «Комсомольской правде». Автор в декларативной форме обозначает начало новой тенденции: «Цель альбома положить начало новому этапу культурного сотрудничества между Востоком и Западом» ${ }^{29}$. Чуть позже, в том же году публикуются материалы о гастролях «Pink Floyd» в Москве, о Московском музыкальном фестивале мира с участием западных групп и о других подобных акциях.

Постепенно начинает ослабевать накал противопоставления рока традиционной эстраде (поп-музыке). В немногочисленных медийных материалах, в которых сохраняется внимание к феноменологии рока, начинают звучать заявления о иррациональном интуитивном характере этой культуры, как, например, в интервью П. Мамонова, настаивающего на отсутствии целеполагания в рок-представлении ${ }^{30}$.

Таким образом, мы видим, как за 4-5-летний срок в советском официальном коммуникативном пространстве сформировался, достиг апогея и, по существу, прекратил самостоятельное существование рокн-ролльный дискурс. Его появление и функционирование во многом было инспирировано субъектами массовых коммуникаций, заинтересованных в приобретении инструмента для формирования «повестки дня», т.е. определения проблемных тем, которые нуждаются в общественном обсуждении. Помимо этого, рок-н-ролльный дискурс может расцениваться как метод политической социализации молодежи, вовлечения ее в круг социально-экономической и политической проблематики. Основными концептами дискурса стали развитие дискотек, совершенствование методов работы с молодежью, признание нелегального рынка, интеллектуализация, индивидуализачия, противостояние рока эстраде, обновление, искренность и честность, творческая свобода и професси-

${ }^{29}$ Филинов 1989.

30 Дашичев 1989. 
онализм. Окончание дискурса связано с размыванием обозначенной концептосферы, с ее ассимиляцией прочими нарративами, существующими на базе массовых коммуникаций, с обозначением курса на появление развлекательных медиа, частью которых станет и рок-музыка, отказавшись большей частью от своего протестного потенциала.

\section{ИСТОЧНИКИ}

Интервью № 1. Мужчина 1960 г.р. Записано на диктофон 16.12.2017 // Из личного архива Дюкина С.Г.

Интервью № 2. Мужчина 1969 г.р. Записано на диктофон 19.12.2017 // Из личного архива Дюкина С.Г.

Информация о работе молодежных творческих объединений города Перми // ПермГАНИ. Ф. 1753. Оп. 22. Д. 9. Л. 89-91.

О мерах по упорядочению деятельности вокально-инструментальных ансамблей, повышению идейно-художественного уровня их репертуара. План мероприятий горкома ВЛКСМ по выполнению постановления бюро городского комитета КПСС // ПермГАНИ. Ф. 1753. Оп. 19. Д. 1. Л. 74.

О ходе аттестации вокально-инструментальных ансамблей и дискотек. Записка отдела пропаганды и агитации Пермского горкома ВЛКСМ // ПермГАНИ. Ф. 1753. Оп. 19. Д. 1. Л. 73.

Волчек Г. Лидер «Наутилуса Помпилиуса» // Молодая гвардия. 1988. № 60. С. 8.

Дашичев Д. «Звуки МУ» // Комсомольская жизнь. 1989 № 21. С. 27-29.

Долин В. «Не хочу быть, как все» // Молодая гвардия. 1988. № 70. С. 5.

Иванович А. «Главное - единство усилий». Заметки о ленинградской группе «Форум» // Молодая гвардия. 1985. № 43. С. 3.

Иванович А. Идет волна // Молодая гвардия. 1986. № 128-129. С. 8.

Иванович А. «Круиз» - новая модель // Молодая гвардия. 1986. № 98. С. 3.

Иванович А. «Рисковать, но искать...» // Молодая гвардия. 1987. № 64. С. 3.

Иванович А. Рок-панорама-86 // Молодая гвардия. 1986. № 67. С. 3.

Иванович А. «Удивить своим» // Молодая гвардия. 1986. № 25. С. 3.

Интервью в стиле «рок» // Комсомольская правда. 1989. № 99. С. 4.

Каменев Д. «Тайны черного диска, или музыкальный толчок» // Молодая гвардия. 1985. № 128-129. С. 7.

Князев К. «Не отвлекаться на моду» // Молодая гвардия. 1986. № 36. С. 3.

Кузнецов Е. Если нечего сказать // Молодая гвардия. 1987. № 61. С. 3.

Ловковский Д. Панорама противоречий. Заметки о фестивале «Рок-панорама-87» // Советская эстрада и цирк. 1988. № 4. С. 4-7.

«Не позволяй себе схалтурить». Интервью с К. Брейтбургом // Молодая гвардия. 1986. № 34. C. 3.

Савинов А. Нужны ли комментарии // Комсомольская правда. 1988. № 126. С. 4.

Санников А. Спеть о главном // Молодая гвардия. 1986. № 145. С. 4.

Сигалов М. Живые и мертвые легенды // Советская эстрада и цирк. 1988. № 12. С. 8-11.

Соловьев С. «Б.Г.» // Советский экран. 1988. № 8. С. 11.

Тихонова Н. Крик // Советская эстрада и цирк. 1989. № 8. С. 29-31.

Тихонова Н. Несмотря ни на что // Советская эстрада и цирк. 1988. № 5. С. 12-13.

Филинов Ю. Бороться ли с роком // Комсомольская правда. 1988. № 77. С. 4.

Филинов Ю. «Гринпис» идет на прорыв // Комсомольская правда. 1989. № 65. С. 4.

Юров Ф. Цепочка «Землян» // Комсомольская правда. 1987. № 6. С. 4.

\section{БИБЛИОГРАФИЯ / REFERENCES}

Cohen B. The Press and Foreign Policy. Princeton: Princeton University Press, 1963. 288 p.

Алексеев И.С. Рок-культура в публичном пространстве Санкт-Петербурга 1990-х годов. Дисс... канд. социолог. наук. СПб., 2003. 24 с. [Alekseev I.S. Rok-kul'tura v publichnom prostranstve Sankt-Peterburga 1990-h godov. Diss. kand. sociolog. nauk. SPb., 2003. 24 s.].

Бурдье П. Социальное пространство и генезис классов // Бурдье П. Социология политики. Москва: Socio Logos, 1993. С. 53-97. [Burd'e P. Social'noe prostranstvo i genezis klassov // Burd'e P. Sociologiya politiki. Moscow: Socio Logos, 1993. S. 53-97.]. 
Васильева А.А. Российская рок-музыка 1970-1980-х гг. как социокультурное явление. Опыт культурологичеческого анализа. Дисс. канд. культурологии. Челябинск, 1999. 21 с. [Vasil'eva A.A. Rossijskaya rok-muzyka 1970-1980-h gg. kak sociokul'turnoe yavlenie. Opyt kul'turologichecheskogo analiza. Diss. kand. kul'turologii. CHelyabinsk, 1999. 21 c.].

Житинский А. Путешествие рок-дилетанта. Музыкальный роман. СПб.: «Амфора», «Геликон-плюс», 2006. 486 с. [ZHitinskij A. Puteshestvie rok-diletanta. Muzykal'nyj roman. St. Petersburg: «Amfora», «Gelikon-plyus», 2006. 486 s.].

Касьянова Е.В. Рок-культура в контексте современной культуры. Автореферат дисс. канд. философ. наук. СПб., 2003. 22 c. [Kas'yanova E.V. Rok-kul'tura v kontekste sovremennoj kul'tury. Avtoreferat diss. kand. filosof. nauk. St.Petersburg, 2003. 22 s.].

Кнабе Г.С. Рок-музыка и рок-среда как формы контркультуры // Кнабе Г.С. Избранные труды. Теория и история культуры. СПб.: «Летний сад», М.: РОССПЭН, 2006. С. 2050. [Knabe G.S. Rok-muzyka i rok-sreda kak formy kontrkul'tury // Knabe G.S. Izbrannye trudy. Teoriya i istoriya kul'tury. SPb.: «Letnij sad», M.: ROSSPEN, 2006. S. 20-50.].

Козлов А. Рок: истоки и развитие. Москва: Синкопа, 2001. 192 с. [Kozlov A. Rok: istoki i razvitie. Moscow: Sinkopa, 2001. 192 s.].

Краус Т. Перестройка и смена собственности. Политические концепции и историческая реальность // Смена режима глазами венгров (1989-2009). Будапешт; М., 2009. С. 21-68 [Kraus T. Perestrojka i smena sobstvennosti. Politicheskie koncepcii i istoricheskaya real'nost' // Smena rezhima glazami vengrov (1989-2009). Budapest-Moscow, 2009. S. 21-68].

Лебедев С. Битломания - от слова «Битлз» // Комсомольская жизнь. 1989. № 19. С. 22-25. [Lebedev S. Bitlomaniya - ot slova «Bitlz»// Komsomol'skaya zhizn'. 1989. №19. S. 22-25].

Набок И.Л. Рок-культура как эстетический феномен. Автореферат дисс. докт. философ. наук // http://cheloveknauka.com/rok-kultura-kak-esteticheskiy-fenomen (22.05.2017). [Nabok I.L. Rok-kul'tura kak esteticheskij fenomen. Avtoreferat diss. dokt. filosof. nauk // http://cheloveknauka.com/rok-kultura-kak-esteticheskiy-fenomen (22.05.2017).].

Невская Т.Н. Эволюция рок-музыки в России. Дисс. канд. культурологии. СПб., 2009. 22 с. [Nevskaya T.N. Evolyuciya rok-muzyki v Rossii. Diss. kand. kul'turologii. SPb., 2009. 22 s.].

Сыров В.Н. Стилевые метаморфозы рока или путь к «третьей» музыке. Нижний Новгород: Изд-во ННГУ, 1997. 209 с. [Syrov V.N. Stilevye metamorfozy roka ili put' k «tret'ej» muzyke. Nizhnij Novgorod: Izd-vo Nizhegorodskogo universiteta, 1997. 209 s.].

Троицкий А. Рок в союзе: 60-е, 70-е, 80-е...Москва: Искусство, 1991. 234 с. [Troickij А. Rok v soyuze: 60-e, 70-e, 80-e...Moscow: Iskusstvo, 1991. 234 s.].

Юрчак А. Это было навсегда, пока не кончилось. М.: НЛО, 2014. 664 с. [YUrchak A. Eto bylo navsegda, poka ne konchilos'. Moscow: Novoe literaturnoe obozrenie, 2014. 664 c.].

Дюкин Сергей Габдульсаматович, кандидат философских наук, дочент, Пермский государственный институт культуры, кафедра культурологии и философии, dudas75@mail.ru

\section{Rock-discourse as the reflection of Perestroika}

The aim of this article is detection of reform potential of rock-music during Soviet Perestroika. Hypothesis of research is idea that youth music was not so much a support for changing of the Soviet society, but it was a mirror, which reflected intentions of power and process of real reforms. Rock-music was used for the testing of reform discourse. The forming and development of this discourse indicates the use of rock-music as an indicator of changings and instrument for check of discourse field or for testing radical ideas and decisions.

Keyword: rock-music, rock-discourse, Perestroyka, identity, Authors`s individuality

Sergey G. Dyukin, PhD (Philosophy), Associate Professor, Perm State Institute of Culture, Department of Cultural Studies and Philosophy,dudas75@mail.ru 


\section{О.И. ТОГОЕВА}

\section{ВИЗУАЛЬНЫЕ ЭФФЕКТЫ СРЕДНЕВЕКОВОГО ПРАВОСУДИЯ}

В статье анализируется проблема зрительного восприятия средневекового правосудия как одного из важнейших элементов (само)репрезентации судебной власти. Обращаясь как к письменным, так и к изобразительным источникам, автор предлагает по-новому взглянуть на средневековые судебные здания, их интерьеры и убранство, на фигуры самих представителей власти и попытаться реконструировать особенности их визуального восприятия участниками заседаний и современниками в целом.

Ключевые слова: Средние века, суд, судебная архитектура, визуальный опыт, (само)репрезентация власти

В фундаментальной монографии, посвященной визуальным образам средневекового правосудия и увидевшей свет в 1994 г., Робер Жакоб с сожалением констатировал, что изучение судебной архитектуры, внешнего и внутреннего устройства зданий, их украшений и символики пребывает в зачаточном состоянии ${ }^{1}$. И хотя с тех пор прошло немало времени, историографическая ситуация не слишком сильно изменилась. Не считая отдельных, «точечных» исследований ${ }^{2}$, эта область исторических знаний остается одной из наименее разработанных. Ученые обращают мало внимания на особенности визуального оформления «пространства права» и, как следствие, вовсе не касаются вопроса о том, как именно это специфическим образом оформленное пространство воздействовало (или должно было воздействовать) на окружающих - на непосредственных участников судебных заседаний и на обычных зрителей.

Между тем, данная проблема представляется исключительно важной для общего понимания процесса отправления правосудия в любой период времени. Суд всегда оставался местом власти par exellence, а потому его зрительное восприятие самым непосредственным образом было связано с осознанием его надличностного характера. Однако сама концепция специально выстроенного для судебных нужд здания (или зала) действительно возникла лишь в эпоху Средневековья.

Идея самостоятельного, отдельного «храма Правосудия» впервые появилась в Италии ХІІ века. Образ идеального суда в трактате «Спорные вопросы судопроизводства» (Questiones de juris subtilitatibus) coздал анонимный автор, известный нам под именем псевдо-Плацентина. В своем сне (или видении) он якобы узрел великолепное здание, украшенное гигантским барельефом с выбитым на нем золотыми буквами текстом законов Юстиниана. Этим панно любовались девять женщин, представленные на барельефе. Главную из них - Правосудие (Justitia) окружали ее дочери: Разум (Ratio), Равенство (Aequitas), Религия (Religio), Добродетель (Pietas), Милосердие (Gratia), Возмездие (Vindicatio),

\footnotetext{
${ }^{1}$ Jacob 1994: 96.

${ }^{2}$ Напр.: Jacob, Marchal 1992; Bellanger 2000; Lorenz 2004: 12-24; Christian-Nils 2006.
} 
Добросовестность (Observatio) и, наконец, Истина (Veritas) ${ }^{3}$. Таким образом, уже в тексте псевдо-Плацентина подчеркивалась важность зрения - как главного способа прочувствовать, а затем и осознать все величие и значение судебной власти в жизни средневекового обывателя. Собственно, весь смысл данного пассажа заключался в описании внутреннего убранства «храма Правосудия»: зрители самым внимательным образом изучали то, чем украшено выдающееся здание, - аллегорическое панно, изображающее процесс отправления правосудия, и текст законов Юстиниана, выбитый на стенах зала. При этом никаких подробностей о самих заседаниях автор в своем трактате не приводил. Мы, к сожалению, не знаем, получили ли трактат известность за пределами Италии, однако сам обычай украшать судебные залы соответствующими изображениями и надписями в Средние века и раннее Новое время распространился по странам Западной и Центральной Европы повсеместно. Судить об этом мы можем, впрочем, опираясь в основном лишь на поздние свидетельства, сохранившиеся до наших дней.

В частности, одним из важнейших визуальных маркеров сугубо судебного пространства для эпохи позднего Средневековья являлось распятие или картина с его изображением. Одним из наиболее ранних подобных примеров считается знаменитый алтарь из Большого зала Парижского парламента, хранящийся ныне в Лувре. Первоначальная его версия была изготовлена в 1406 г. для французского короля Карла VI (1380-1422) его личным художником Коларом де Лаоном. В 1448 г. алтарь обновили, и нам он известен только в таком виде 4 . На ретабло справа от распятого Иисуса Христа были представлены Людовик IX Святой, почитавшийся в средневековой Франции как «отец правосудия» ${ }^{5}$, и Иоанн Креститель с агнцем Божьим на руках. Слева оказались изображены св. Дионисий (покровитель Франции, ее короля и короны), а также Карл Великий, еще один легендарный законотворец, которого представители династии Валуа числили в своих предках ${ }^{6}$.

Не менее красноречивым являлся и алтарь из парламента в Тулузе, датирующийся XV веком ${ }^{7}$. У подножия распятия на нем фигурировали король Карл VII (1422-1461) и его наследник, будущий Людовик XI (1461-1483). Их коленопреклоненные позы недвусмысленно намекали на то, что власть (в т.ч. судебная) дарована им Свыше - идея, получившая во Франции самое широкое распространение уже в XIII в. ${ }^{8}$

\footnotetext{
${ }^{3}$ Questiones de juris subtilitatibus 1958: 14.

${ }^{4}$ Lorentz 2004: 12.

${ }^{5}$ Цатурова 2013.

${ }^{6}$ Наибольшую популярность Карл Великий приобрел во Французском королевстве в период правления Карла V (1364-1380), происходившего от основателя династии Каролингов по линии матери, Бонны Люксембургской: Lorentz 2004: 21-22.

${ }^{7}$ Ныне хранится в музее Августинцев в Тулузе.

${ }^{8}$ Подробнее о развитии концепции Божественной инвеституры, согласно которой французский король объявлялся наместником Бога на земле и получал свои земли в управление от Всевышнего, см.: Beaune 1985: 207-229.
} 
Визуализацию еще одной важнейшей средневековой правовой максимы являла собой картина, написанная специально для зала суда в ратуше Граца (Штирия) в 1478 г. ${ }^{9}$ На ней зрители могли видеть сцену Страшного суда с Иисусом Христом во главе, под которой неизвестный художник изобразил заседание городского суда, проводя прямую аналогию между двумя этими собраниями ${ }^{10}$. Шеффены Граца, а также простые обыватели должны были легко считывать заложенный в картине смысл: автор призывал чиновников во всем уподобляться Высшему судии, быть такими же, как и он, справедливыми, но милосердными.

Та же идея присутствовала и в работе северонемецкого мастера $\mathrm{XV}$ в. «Христос на Страшном суде с предстоящими Марией и Иоанном Крестителем», хранящейся ныне в Государственном Эрмитаже, но предназначавшейся также для зала городской ратуши ${ }^{11}$. Надпись, которая обрамляла изображение, содержала призыв к судье относиться беспристрастно ко всем без исключения просителям, дабы не впасть в грех и не губить свою бессмертную душу. Справедливость и милосердие олицетворяли исходящие от лица Христа соответственно меч и лилия. Что же касается орудий Страстей Христовых, то эти атрибуты относились уже не к судьям, а к подследственным и зрителям на процессе (т.е. к возможным будущим преступникам). Здесь ясно прочитывался намек на судьбу самого Сына Божьего, безропотно претерпевшего казнь и искупившего грехи людей. Именно так, согласно доктрине св. Ансельма Кентерберийского (1033-1109), следовало вести себя каждому смертному, предстающему перед правосудием: смиренно признавать свою вину и принимать соответствующее наказание, беря пример с Христа - не только идеального судьи, но и идеального преступника ${ }^{12}$.

Причем и в более позднее время идея о суде земном как аналоге суда Высшего никуда не исчезла из светской правовой культуры. Изображения распятия или сцен Страшного суда являлись не просто традицией, а были обязательным элементом убранства судебных залов. Так, упомянутый алтарь из Парижского парламента оставался на предназначенном ему месте вплоть до французской Революции ${ }^{13}$. В 1872-1874 гг.

\footnotetext{
${ }^{9}$ Картина хранится в Муниципальном музее Граца, ее воспроизведение см.: Јacob 1994: 60. Оригинал картины, к сожалению, не сохранился; нам она известна по копии XVII в. Тем не менее, сам факт ее копирования свидетельствует об актуальности заложенных в этом изображении смыслов и в раннее Новое время. Немецкие исследователи смогли выявить около 120 подобных полотен, украшавших судебные залы на протяжении XV-XVIII вв.: Recht und Gerechtigkeit 1988: 71; Schild 1988.

${ }^{10}$ В кодексах городского права немецких земель, датируемых XIV в., нередко можно встретить уточнение: «В тот момент, когда судья начинает процесс, Господь заседает в своем небесном трибунале, располагаясь над судьей» (цит. по: Drüppel 1981: 295).

${ }^{11}$ См. о ней подробнее: Рогачевский 1996: 117-118.

${ }^{12} \mathrm{O}$ доктрине искупления св. Ансельма Кентерберийского, изложенной им в трактате «Почему Бог вочеловечился» (Cur Deus homo) и нашедшей применение в средневековом судопроизводстве, см.: Берман 1994: 173-179. О развитии в Средневековье образа Иисуса Христа как идеального преступника см.: Тогоева 2006: 278-281.

${ }^{13}$ Lorentz 2004: 12.
} 
члены парижского суда по ассизам специально заказали у художника Леона Бонна полотно «Христос на кресте» ${ }^{14}$. А распятие из парламента Нормандии в Руане по-прежнему пребывает в его главном зале.

Не менее интересным, с точки зрения визуализации судебной власти, превращения ее из умозрительного явления во вполне материальный, осязаемый артефакт, представляется традиция украшения стен судебных помещений поучительными надписями, большая часть которых также была посвящена уподоблению земного правосудия небесному. Эта идея присутствовала уже в «Спорных вопросах судопроизводства» псевдо-Плацентина, где главный герой (alter ego автора) любовался текстом законов Юстиниана, выбитым на стенах воображаемого «храма». Следы той же традиции мы находим на упомянутой выше картине немецкого мастера «Христос на Страшном суде с предстоящими Марией и Иоанном Крестителем», где изображение также совмещалось с текстовым сообщением. А в сочинении польского юриста Бартоломея Гроицкого «Порядок городских судов и дел по Магдебургскому праву» (XVI в.) в подзаголовке о содержании трактата сообщалось буквально следующее: «Изречения, из Священного писания выбранные, кои обыкновенно в местах присутствия судебного написаны бывают, дабы в них, всегда перед очами предстающими, судьи и иные особы, к суду относящиеся, мерило свое имели и согласно им по велению Божьему поступали» ${ }^{15}$. Иными словами, в ратушах городов, живущих по Магдебургскому праву ${ }^{16}$, также присутствовали на стенах поучительные надписи для всеобщего изучения.

К третьему варианту украшения судебных зданий и залов относились, безусловно, аллегорические картины. В частности, именно такие изображения мы можем и сегодня видеть в Палаццо Публико в Сиене, строительство которого пришлось на 1287-1355 гг. В залах ратуши взгляду посетителя представали фрески сугубо правового содержания. Первой из них являлась «Маэста», написанная Симоне Мартини в 13151316 гг. по заказу Совета Девяти, управлявшего Сиенской республикой с 1292 г. Она отражала идею Божьего суда, которую вершил младенец Христос, стоящий на коленях Девы Марии). Фреска сопровождалась подписью «Возлюбите справедливость вы, кто на земле судит», отсылавшей все к той же аналогии между судом небесным и судом земным,

14 Jacob 1994: 55.

15 Цит. по: Рогачевский 1996: 116.

${ }^{16}$ Магдебургское право получило большое распространение в Центральной и Восточной Германии, Чехии, Австрии, Польше, Западной России. Свое начало оно вело от епископской конституции 1188 г., признавшей самостоятельность Магдебурга, а его основная цель состояла в том, чтобы приспособить к нуждам города земское право (главным образом, «Саксонское зерцало»). К XIV веку Магдебургское право приобрело почти завершенный вид, охватив типичными судебными решениями основные области уголовного, вещного, обязательственного, торгового, наследственного и семейного права. Подробнее см.: Берман 1994: 349-356; Рогачевский 1996: 15-24. 
который должен быть столь же справедлив, как и первый ${ }^{17}$. В следующем зале ратуши располагалась фреска Амброджо Лоренцетти «Аллегория доброго правления», исполненная в 1337-1339 гг. и украсившая северную стену помещения. На ней была представлена фигура Правосудия, уравновешивающая чаши весов, которые держала над ней Мудрость. Ниже Правосудия располагалось Согласие, сжимавшее в руках шнуры, идущие от весов. На коленях этой аллегорической фигуры покоился огромный рубанок, намекавший на то, что перед законом все граждане республики абсолютно равны.

В том же зале, но уже на восточной стене А. Лоренцетти поместил еще одну фреску - «Плоды доброго правления» (1337-1339), представлявшую собой четырнадцатиметровую панораму Сиены и ее окрестностей. Здесь, над городскими воротами в воздухе парила аллегорическая фигура Безопасности, в одной руке державшая виселицу с казненным преступником, а в другой - свиток с надписью: «Каждый честный человек проходит здесь без страха. Что посеешь, то и пожнешь. И это непреложно для тех, кто эту женщину (т.е. Безопасность - O.T.) привечает у себя в стране. И она держит на высоте любую власть».

Напротив «Плодов доброго правления», для пущего контраста, Амброджо Лоренцетти представил «Аллегорию дурного правления и его последствий». В центр композиции художник поместил фигуру правителя-тирана с рогами на голове, клыками во рту и бокалом яда в левой руке - иными словами, изображение самого дьявола. Над его головой парили Жадность (с денежными мешками, зажатыми в тисках), Гордость (показывающая ярмо, от которого она освободилась) и Тщеславие (любующееся собой в зеркало). Справа от Тирана расположились Жестокость, держащая в одной руке младенца, а в другой змею, Измена, у которой на руках застыл ягненок с хвостом скорпиона, и Обман с крыльями летучей мыши. Слева же от Тирана Лоренцетти изобразил Ярость (гибрид кентавра, льва и кабана, сжимающего кинжал), Раздор в одежде с геральдическими цветами Сиены (чёрный и белый), который пилой разделял согласие, и Войну с мечом и щитом в руках. У ног же Тирана застыло поверженное Правосудие ${ }^{18}$.

Современные искусствоведы единодушно отмечают, что уникальность фресок Амброджо Лоренцетти заключалась в том, что в столь важной, как с политической, так и с правовой точек зрения, работе художник полностью обошелся без христианских религиозных сюжетов и отсылок к Библии и по большей части использовал античные образы. Однако, на мой взгляд, это не совсем так. Хорошо известно, в частности, что уже в XII столетии правитель, превратившийся в тирана, уподоблялся именно дьяволу (каким его и изобразил сиенский мастер). Эту идею

\footnotetext{
${ }^{17}$ Подробнее о фреске С. Мартини см.: Bagnoli 1999.

${ }^{18}$ Подробный анализ фресок А. Лоренцетти в Палаццо Публико см.: Christian-Nils 2006: 31-34 (и приведенную в этом исследовании более раннюю литературу); Boucheron 2018.
} 
впервые в истории политической мысли высказал и всесторонне обосновал в своем «Поликратике» Иоанн Солсберийский $(1120-1180)^{19}$. Его сочинение было хорошо известно в странах Западной Европы, в т.ч. на Аппенинском полуострове ${ }^{20}$. А потому можно предположить, что и Амброджо Лоренцетти опирался в своей работе на рассуждения прославленного секретаря Томаса Беккета.

Наконец, последним вариантом украшения судебных залов - уже в позднее Средневековье и раннее Новое время - являлись изображения легендарных судов, которые проводили выдающиеся герои прошлого (естественно, прежде всего - образцовые правители различных рангов). Таковы были, к примеру, картины на сюжет суда Камбиса, хорошо известные нам по полотнам Жерара Давида конца XV в. Первоначально эта история оказалась коротко изложена у Геродота ${ }^{21}$, затем - более подробно - в «Замечательных деяниях и речах» Валерия Максима и получила, таким образом, широкую известность: «Отец этого Отана - Сисамн был одним из царских судей. За то, что этот Сисамн, подкупленный деньгами, вынес несправедливый приговор, царь Камбис велел его казнить и содрать кожу. Кожу эту царь приказал выдубить, нарезать из нее ремней и затем обтянуть ими судейское кресло, на котором тот восседал в суде. Обтянув кресло [такими ремнями], Камбис назначил судьей вместо Сисамна, которого казнил и велел содрать с него кожу, его сына, повелев ему помнить, на каком кресле восседая, он судит» ${ }^{22}$.

История Камбиса и истории о суде Траяна (приказавшего казнить своего сына, виновного в убийстве), суде Херкамбальда (приговорившего к смерти, а затем собственными руками расправившегося с любимым племянником, виновным в изнасиловании), наконец, о суде Оттона (пославшего на костер жену, оклеветавшую и погубившую одного из его придворных), служили источником вдохновения для многих художников. Особую популярность они получили в XV в., когда картины подобного содержания начали заказывать сами судебные чиновники. Эти полотна украшали залы заседаний в Брюсселе, Лувене, Брюгге, Кельне, Монсе и в других городах преимущественно Северной Европы ${ }^{23}$.

Однако, помимо того насколько важным оказывалось для современников непосредственное содержание предстающих их взору картин, фресок или поучительных надписей, размещенных на стенах судебных помещений, следует, как представляется, задуматься еще об одной важной проблеме. Не только о том, что видели люди в залах суда, но и то, как они это делали. И здесь на первый план выходит сюжет, который,

${ }^{19}$ Ioannis Saresberiensis 1909: I, 234-267. Подробнее о концепции тирана и тираноубийства у Иоанна Солсберийского см.: Гладков 2008.

${ }^{20}$ Ullmann 1944.

${ }^{21}$ Геродот 1999: V, 25.

22 Valerius Maximus 1888: VI, 3.

${ }^{23}$ Fehr 1923: 50-51; Holk 1983; Recht und Gerechtigkeit 1988: 52-53, 156-163; Jacob 1994: 65-74. 
насколько можно понять по существующей на сегодняшний день историографии, еще ни разу не привлекал внимание исследователей, - вопрос о направлении взгляда смотрящего.

Большинство украшений судебных залов, о которых шла речь выше (распятия, алтари, аллегорические фрески и сцены легендарных судов), обычно располагались не в произвольном порядке, но помещались за спинами судей - иными словами, значительно выше человеческого роста. Об этом, в частности, свидетельствуют чудом сохранившиеся и не погибшие в пожарах Второй мировой войны фотографии 1930-х гг., на которых представлено внутреннее убранство главного зала Парламента Нормандии, не менявшееся на протяжении многих веков ${ }^{24}$. Как уже упоминалось выше, его стену - прямо за креслами судебных заседателей - украшало изображение распятия XV века, но для того, чтобы его увидеть, участники процесса или обычные посетители должны были высоко поднять голову. То же касалось и самих судей, которые располагались на возвышении, заставляя прочих присутствующих почтительно взирать на них снизу вверх. Эта традиция также брала начало в Средневековье, о чем свидетельствуют многочисленные миниатюры и рисунки, на которых фигуры судей всегда оказывались значительно крупнее, а сами они изображались восседающими на высоко стоящих креслах или скамья ${ }^{25}$. Таковы, в частности, все без исключения иллюстрации к кодексам «Саксонского зерцала» XIII в. ${ }^{26}$, а также, к примеру, иллюстрации к многочисленным средневековым копиям «Дигест» и «Институций», к «Комментариям на Декреталии» французского юриста XIV века Анри Боика, «Кутюмье Пуату» конца XV века, и т.д. ${ }^{27}$

Не менее показателен и обычай объявлять о вынесенном приговоре с высокого крыльца, как происходило, к примеру, в Нормандии. В здании ее парламента в Руане крыльцо располагалось (и по-прежнему располагается) на уровне второго этажа и, таким образом, сильно возвышалось над головами собравшихся. Данное архитектурное решение опиралось на один из важнейших христологических сюжетов и представляло собой парафраз темы Ecce hoто, получившей особую популярность в XV-XVI вв., когда выставленные на всеобщее обозрение преступники приравнивались - даже визуально - к осужденному Христу 28.

Возможно, та же идея лежала в основе устройства виселицы, эшафота и гильотины, всегда, насколько можно судить по дошедшим до нас

\footnotetext{
24 Эти фотографии можно, в частности, увидеть на странице Википедии, посвященной Дворцу правосудия в Руане: https://fr.wikipedia.org/wiki/Palais_de_justice_de_Rouen 25 Об особенностях изображения судей в средневековых кодексах см. Тогоева 2017. ${ }^{26}$ Их факсимильное воспроизведение см. в публикациях трех главных иллюминированных кодексов «Саксонского зерцала», происходивших из Дрездена, Вольфенбюттеля и Гейдельберга: Die Dresdener Bilderhandschrift des Sachsenspiegels 1902; Die Heidelberger Bilderhandschrift des Sachsenspiegels 1979; Eike von Repgow 1993.

${ }^{27}$ Их воспроизведение см. в: Morel 2007: 21, 38, 40 149, 164-165, 171, 190, 302, 307 308, 314, 323, 353; Fig. 6, 11, 16, 94, 95.

${ }^{28}$ Тогоева 2006: 279-280.
} 
изображениям и описаниям, сильно приподнятых над землей и, таким образом, открывающих лучший вид для собравшейся публики, которая взирала на приведение приговора в исполнение вновь снизу вверх ${ }^{29}$. Эта идея доступности сцены экзекуции взгляду смотрящего на нее стороннего наблюдателя ${ }^{30}$ дожила до XX в.: последняя публичная казнь с использованием гильотины была проведена во Франции в 1939 г.

Преступник, проситель или обычный зритель должен был взирать на процедуру отправления правосудия, находясь заведомо в подчиненном положении. Точно так же он смотрел на картины и надписи, расположенные на стенах судебных залов на уровне выше человеческого роста и напоминающие ему о важности суда. Значение судебной власти в целом - как идеи, как института (надличностного по своему характеру) - визуализировалось и получало буквальную интерпретацию. Физическое возвышение судебного чиновника над всеми собравшимися лучше каких бы то ни было законодательных инициатив подчеркивало его совершенно особый общественный статус.

Однако, следует, справедливости ради, упомянуть о том, что иногда средневековые источники рисуют перед нами совершенно иную картину отправления правосудия, причем правосудия идеального. Речь идет об уникальном сообщении Жана де Жуанвиля, посвященном судам Людовика IX Святого (1226-1270): «Много раз летом случалось так, что он отправлялся после мессы посидеть в Венсенском лесу. Он прислонялся к дубу, а мы рассаживались вокруг него, и все люди, у которых были [судебные] дела, свободно приходили поговорить с ним... Я видел несколько раз летом, как он приходил в парижский сад, чтобы решить дела своих людей... И он приказывал расстилать для нас ковры, мы садились вокруг него, а все пришедшие окружали его. И тогда он улаживал все их [судебные] споры так же, как... в Венсенском лесу» ${ }^{31}$.

Если довериться тексту Жана де Жуанвиля, то перед нами предстает совершенно немыслимая для Средневековья картина: французские обыватели второй половины XIII в. не просто имели свободный доступ к персоне своего правителя и, как следствие, верховного судьи, но и взирали на него при встрече сверху вниз. Для человека той поры подобное положение дел было невозможно, о чем свидетельствуют миниатюры к той же самой «Книге благочестивых речений и добрых деяний нашего святого короля Людовика» (Livre des saintes paroles et des bons faiz nostre roy saint Looys $)^{32}$. Более того, коленопреклоненная поза, в которой средневековые художники традиционно запечатлевали подданных короля (или любого иного владетельного сеньора) в сценах, иллюстрирующих ход судебного процесса, совершенно очевидным образом отсылали к ритуалу принесения клятвы верности (оммажа), когда вассал

\footnotetext{
${ }^{29}$ Их средневековые изображения см. в: Morel 2007: 230-238, 276.

30 Подробнее о рождении этой идеи см.: Spierenburg 1984; Ямпольский 1993.

31 Jean de Joinville 1874: 34-35.

${ }^{32}$ См., к примеру, миниатюры правового содержания: Morel 2007: Fig. 24, 25, 116.
} 
опускался на колени перед своим господином ${ }^{33}$. И с этой точки зрения сообщение Жана де Жуанвиля являлось по меньшей мере анахронизмом, если не сознательным искажением действительности.

Не следует забывать, что сочинение королевского биографа изначально носило сугубо апологетический характер. Оно создавалось с целью представить образ идеального правителя, который совершенно заслуженно признавался святым еще при жизни ${ }^{34}$. По меркам эпохи Средневековья Людовик IX был канонизирован исключительно быстро в 1297 г., т.е. всего через 27 лет после кончины ${ }^{35}$. Как известно, Жан де Жуанвиль писал свою «Книгу» в период с 1305 по 1309 г., и его образ правителя-судьи, сидящего под деревом, как мне представляется, был абсолютно вымышленным: его святой король являлся не просто справедливым и милосердным, как того требовала традиция, он оказывался равен и физически доступен любому своему подданному.

Не случайно средневековые миниатюристы - при всем богатстве иконографии Людовика Святого - никогда, насколько известно, не изображали сцену суда в Венсенском лесу. Художники и граверы обратились к ней лишь в XIX в., в эпоху романтизма, когда любые сообщения исторических источников воспринимались буквально - как описание событий, происходивших в реальности. Вот почему легендарная сцена суда Людовика Святого на этих изображениях полностью соответствовала рассказу Жуанвиля: на ней король обычно располагался на земле, а просители склонялись, взирая на него сверху вниз.

Как представляется, даже беглый обзор материала, который предоставляют в наше распоряжение письменные и изобразительные источники, свидетельствует о важности самой постановки проблемы чувственного восприятия судебного пространства людьми эпохи Средневековья и раннего Нового времени. И тема зрения, безусловно, выходит здесь на первый план: как с точки зрения оценки фигуры самого судьи, так и с точки зрения оценки архитектуры и внутреннего убранства судебных зданий и залов. Не менее значимым, на мой взгляд, является изучение «встречной» проблемы - вопроса о том, как сама власть смотрит на своих подданных. Применительно к правовой сфере наибольшее внимание, как мне кажется, следовало бы уделить оценке судебной системы как «всевидящего ока» (watchful eye) - выражению, которое появилось в английских юридических трактатах начала XVII в. ${ }^{36}$, а затем, по всей видимости, отчасти преобразовалось в идею Паноптикона Иеремии Бентама ${ }^{37}$. Но это - совершенно особая и чрезвычайно обширная проблема, заслуживающая отдельного и более детального исследования.

\footnotetext{
${ }^{33} \mathrm{O}$ жестах, характеризующих процедуру принесения оммажа, см.: Кулаева 2002.

34 Ле Гофф 2001: 362-379.

${ }^{35}$ Vauchez 1988: 74, 127; Ле Гофф 2001: 234-237.

${ }^{36}$ См., к примеру: Bernard 1629.

${ }^{37}$ Bentham 1787.
} 


\section{БИБЛИОГРАФИЯ / REFERENCES}

Берман Г.Дж. Западная традиция права: эпоха формирования. M., 1994 [Berman H.J. Zapadnaja tradizija prava: epoha formirovanija. M., 1994].

Геродот. История в девяти книгах. М., 1999 [Gerodot. Istoria d devjati knigah. M., 1999].

Гладков А.К. «Убийство тирана не грех, но благодеяние». Представление о неправедной власти в «Поликратике» Иоанна Солсберийского // Средние века. 2008. Вып. 69 (3). C. 81-96 [Gladkov A.K. "Ubijstvo tirana ne greh, a blagodejanije". Predstavlenie o nepravednoj vlasti v "Polikratike" Ioanna Solsberijskogo, in Srednije veka. 2008. Vip. 69 (3). P. 81-96].

Кулаева С.Б. Символические жесты зависимости в оформлении средневекового оммажа // Одиссей. Человек в истории - 2002. М., 2002. С. 151-168 [Kulaeva S.B. Simvolicheskie gesti zavisimosti v oformlenii srednevekovogo ommaga, in Odissey. Chelovek v istorii 2002. М., 2002. Р. 151-168].

Ле Гофф Ж. Людовик IX Святой. М., 2001 [Le Goff J. Ludovik IX Svjatoj. M., 2001].

Рогачевский А.Л. Меч Роланда. Правовые взгляды немецких горожан XIII-XVII вв. СПб., 1996 [Rogachevsky A.L. Mech Rolanda. Pravovie vzgljadi nemezkih gorozan XIII-XVII vv. SPb., 1996].

Тогоева О.И. «Истинная правда». Языки средневекового правосудия. М., 2006 [Togoeva O.I. "Istinnaya pravda. Yaziki srednevekovogo pravosudiya. M., 2006].

Тогоева О.И. Два тела... судьи: идеи средневекового права в исторической перспективе // Доминирование и контроль. Интерпретация культурных кодов - 2017 / Сост. и общ. ред. В.Ю. Михайлина и Е.С. Решетниковой. Саратов, 2017. С. 56-79 [Togoeva O.I. Dva tela... sud'ji: idei srednevekovogo prava $v$ istoricheskoj perspektive, in Dominirovanie I kontrol'. Interpretaziya kul'turnih kodov - 2017 / Eds. by V.Yu. Michailin, E.S. Reshetnikova. Saratov, 2017. P. 56-79].

Цатурова С.К. Людовик IX Святой - отец правосудия // Средние века. Вып. 74 (3-4). М., 2013. C. 344-362 [Tzaturova S.K. Ludovik IX Svjatoj - otez pravosudija, in Srednie veka. Vip. 74 (3-4). M., 2013. P. 344-362].

Ямпольский М. Жест палача, оратора, актера // Ad Marginem'93. М., 1994. С. 21-70 [Yampol'sky M. Gest palacha, oratora, aktera, in Ad Marginem'93. M., 1994. P. 21-70].

Bagnoli A. La Maestà di Simone Martini. Milano, 1999.

Beaune C. Naissance de la nation France. P., 1985.

Bellanger Ch. Le Christ outragé: une iconographie judiciaire? Autour des images de la Dérision du Christ en Occident à la fin du Moyen Age // Gestes et rituels judiciaires au Moyen Age occidental / Sous la dir. de Cl. Gauvard et R. Jacob. P., 2000. P. 145-171.

Bentham J. Panopticon or the inspection-house, containing the idea of a new principle of construction applicable to any sort of establishment... a series of letters, written in the year 1787, from Crecheff in White Russia, to a friend in England. L., 1787.

Bernard R. A Guide to Grand Iury Men. L., 1629.

Boucheron P. The power of images: Sienna, 1338. L., 2018.

Christian-Nils R. La justice dans ses décors (XVe-XVI ${ }^{\mathrm{e}}$ siècles). Genève, 2006.

Die Dresdener Bilderhandschrift des Sachsenspiegels / Hrsg. von K. von Amira. Leipzig, 1902. Bd. I: Facsimile der Handschrift; Leipzig, 1925-1926. Bd. II: Erläuterungen.

Drüppel H. Iudex Civitatis. Zur Stellung des Richters in der hoch- und spätmittelalterlichen Stadt deutschen Rechts. Köln, 1981.

Eike von Repgow. Sachsenspiegel: die Wolfenbütteler Bilderhandschift Cod. Guelf 3.1 Aug. 2\% Hrsg. v. R. Schmidt-Wiegand. Berlin, 1993. Bd. 1: Text. Bd. 2: Facsimile. Bd. 3: Kommentar.

Fehr H. Das Recht im Bilde. Leipzig, 1923.

Die Heidelberger Bilderhandschrift des Sachsenspiegels / Hrsg. von W. Koschorreck. Frankfurt am Main, 1979. Bd. 1: Facsimile der Handschrift. Bd. 2: Kommentar.

Holk L.E. van. Eine mittelalterliche Rechtslegende und ihre Darstellung in der Kunst des 17. Jahrhunderts // Forschungen zur Rechtsarchäologie und Rechtlichen Volkskunde. 1983. Bd. 5. S. 135-157.

Ioannis Saresberiensis episcopi Carnotensis Policratici / Recognovit C.C.I. Webb. T. 1-2. L., 1909.

Jacob R. Images de la justice. Essai sur l'iconographie judiciaire du Moyen Age à l'âge classique. P., 1994.

Jacob R., Marchal N. Jalons pour une histoire de l'architecture judiciaire // La justice en ses temples. Regards sur l'architecture judiciaire en France. P.; Poitiers, 1992. P. 23-68. 
Jean de Joinville. Histoire de Saint Louis / Ed. par N. de Wailly. P., 1874.

Lorenz P. La Crucifixion du Parlement de Paris. P., 2004.

Morel B. Une iconographie de la répression judiciaire. Le châtiment dans l'enluminure en France du XIII ${ }^{\mathrm{e}}$ au XVe siècle. P., 2007.

Questiones de juris subtilitatibus / A cura di G. Zanetti. Firenze, 1958.

Recht und Gerechtigkeit im Spiegel der europäischen Kunst / Hrsg. von W. Pleister, W. Schild. Köln, 1988.

Schild W. Bemerkungen zur Ikonologie des Jüngsten Gerichts // Forschungen zur Rechtsarchäologie und Rechtlichen Volkskunde. 1988. Bd. 10. S. 163-201.

Spierenburg P. The Spectacle of Suffering. Executions and the Evolution of Repression from a Preindastrial Metropolis to the European Expirience. Cambridge; L., 1984.

Ullmann W. The influence of John of Salisbury on Medieval Italian jurists // English Historical Review. 1944. Vol. 59 (235). P. 384-392.

Valerius Maximus. Factorum ac dictorum memorabilium libri IX / Hrsg. von C. Kempf. Lipsiae, 1888.

Vauchez A. La saintété en Occident aux derniers siècles du Moyen Age d'après les procès de canonisation et les documents hagiographiques. Rome, 1988.

Ольга Игоревна Тогоева, доктор исторических наук, ведущий научный сотрудник, Институт всеобщей истории РАН, Москва, Россия, togoeva@yandex.ru

\section{Visual effects of the medieval justice}

The article analyzes the problem of the visual perception of medieval justice as one of the most important elements of (self)representations of the judiciary. Referring to both written and pictorial sources, the author offers a new look at the medieval court buildings, their interiors and decoration, the figures of the authorities themselves, and tries to reconstruct the features of their visual perception by the direct participants of the sessions and their contemporaries.

Keywords: Middle Ages, court, judicial architecture, visual experience, (self)representation of the authorities

Olga Togoeva, Dr.Sc. (History), Leading Researcher, Institute of World History, Russian Academy of Sciences; togoeva@yandex.ru 


\section{М.С. НЕКЛЮДОВА \\ «УДАР ЖАРНАКА»: ПАМЯТЬ МЕСТА И БОРЬБА ИСТОРИЧЕСКИХ ИНТЕРПРЕТАЦИЙ ${ }^{1}$}

В статье рассматривается казус, связанный с выражением «удар Жарнака» (coup de Jarnac), которое существует во французском языке по меньшей мере три столетия. Считается, что оно отсылает к последнему судебному поединку, имевшему место во Франции в 1547 г. Во время него один из дуэлянтов, Ги Шабо де Жарнак, смог ловким выпадом ранить своего противника, что и объясняет появление идиомы. Однако с высокой степенью вероятности она связана с другим событием, которое произошло на два десятилетия позже. В 1569 г. в сражении под Жарнаком выстрелом из пистолета был убит предводитель гугенотов, принц де Конде, причем произошло это в тот момент, когда он сдался на милость победителя. Статья посвящена месту обоих этих событий в национальной и лингвистической памяти.

Ключевые слова: Жарнак, память, идиома, XVII век, Вольтер, конфликт интерпретаций

В январе 2016 г. в газете «Фигаро» появилась небольшая заметка «Жарнак: город, где упокоился блуждающий миф»². Фактически речь шла о столетии Франсуа Миттерана, уроженца Жарнака, который был похоронен в родном городе, и о паломничестве на его могилу Франсуа Олланда, бывшего тогда главой Пятой республики. Это событие стало поводом для иронического упражнения в псевдоэтимологии автора заметки Этьена де Монтети. Отталкиваясь от созвучия фамилии покойного президента со словосочетанием «блуждающий миф» (Mitterand = mythe errant), он предлагает еще один каламбур, интерпретируя топоним «Жарнак» как первое лицо единственного числа глагола «arnaque» - водить за нос, обводить вокруг пальца, и т.д. (Jarnac = j'arnaque). По мнению журналиста, именно этим был славен «блуждающий миф»³.

Толчком к этой языковой игре, скорей всего, послужила реально существующая идиома, в которой фигурирует Жарнак. C XVII в. и до наших дней французские словари фиксируют выражение «соup de Jarnac», обозначающее неожиданный и зачастую коварный удар. Оно отсылает к знаменитой дуэли, последнему судебному поединку во владениях французской короны, который состоялся 10 июля 1547 г. Ги Шабо де Монлье, позже унаследовавший титул барона де Жарнака, обвинил Франсуа де Вивонна, сеньора де Ла Шатеньере, в распускании ложных слухов, порочивших его честь. Тот, оскорбившись, послал ему публичный вызов, и король дал разрешение на поединок. Сначала преимущество было на стороне Ла Шатеньере, но Жарнак смог ловким выпадом серьезно ранить противника и выйти победителем из схватки. От-

\footnotetext{
${ }^{1}$ Статья подготовлена в рамках выполнения научно-исследовательской работы государственного задания РАНХиГС «Конструирование актуальности в интеллектуальной культуре Нового Времени» (2020).

2 Montety 2016. Это рубрика «Последнее слово», которую постоянно ведет Монтети.

3 «Блуждающий миф» - относительно часто употребляемое прозвище Миттерана.
} 
сюда, как утверждают лексикографы и историки, и пошло выражение «coup de Jarnac», которое служит напоминанием о том событии и позволяет ему сохраняться в коллективной памяти и в современной культуре.

Как легко убедиться, между этой идиомой и псевдоэтимологией Монтети есть сходство: в обоих случаях речь идет о хитрости, своего рода стратегическом обмане, позволяющем выйти победителем из трудного положения. Кроме того, их объединяет двойная языковая игра, которая служит еще одним связующим звеном между дуэлью XVI века и поведением покойного президента. Каламбур с топонимом «Жарнак» напоминает о существовании одноименной настольной игры, разновидности «Скрэббла», которая была выпущена в 1977 г. Она рассчитана на двоих игроков или на две команды; когда одна сторона заканчивает составлять слова, а другая замечает, что из невостребованных букв можно сложить еще слово, то восклицает «жарнак!» и забирает их себе. В сущности, именно это делает Монтети, который различает в названии родного города Миттерана то ли пророчество, то ли посмертное признание, выраженное глаголом первого лица.

От дуэли к настольной игре, от расхожего выражения к надгробному памятнику: амплитуда «удара Жарнака» указывает на особый статус события и порожденной им лексемы, которая способна обрастать дополнительными смыслами и получать неожиданные воплощения. Перед нами сюжетно-семантический комплекс, который во многом структурирован как «место памяти», хотя в строгом смысле слова им не является. С одной стороны, он включен в динамику взаимодействия истории и памяти, представленной Пьером Нора в качестве основного принципа существования «lieux de mémoire» ${ }^{4}$. Более того, ему свойственно тяготение к материализации, к закреплению в пространстве. С другой, в нем вроде бы отсутствует идеологическое или эмоциональное наполнение, способное запустить механизм коммеморации этого малозначительного события. За пределами одного-двух поколений, для которых дуэль между Жарнаком и Ла Шатеньере была человеческой драмой, затронувшей их личные интересы, родственные и дружеские связи и повлиявшей на расстановку сил при королевском дворе, память о ней оформляется в рассказ о примечательном происшествии, интерес которого связан с наличием перипетии - резкого поворота в судьбе обоих героев ${ }^{5}$. Тогда же, видимо, возникает выражение «удар Жарнака», сигнализирующее о его символической значимости. Однако ни то, ни другое не объясняет, почему этот лексический след события 1547 г. оказывается столь устойчивым.

Для сравнения возьмем другое выражение, тоже связанное с конкретной исторической датой: «День одураченных» (La journée des Dupes) - словосочетание, которым обозначаются события 10-11 ноября

\footnotetext{
${ }^{4}$ Nora 1997.

5 Здесь и далее под «рассказом» и «повествованием» подразумевается устойчивый нарратив, связанный с тем или иным историческим событием, который может принимать разные словесные и жанровые формы.
} 
1630 г., приведшие к политическому поражению Марии Медичи и консолидации власти Ришелье. Как и в случае «удара Жарнака», в основе рассказа об этом происшествии лежит перипетия, поскольку современники ожидали прямо противоположного исхода конфликта, т.е. опалы кардинала-министра и укрепления влияния королевы-матери. Конечно, политические последствия решения, принятого Людовиком ХІІІ в ноябpe 1630 г., кажутся несопоставимыми с итогом поединка между двумя дворянами в июле 1547 г. К тому же «День одураченных» становится частью легенды Ришелье и входит в число национальных «мест памяти», тем самым сохраняя свою уникальность, в то время как «удар Жарнака» движется по иной траектории, от обозначения единичного происшествия к имени нарицательному.

В этом историческом маршруте меня интересует момент превращения дуэли между Жарнаком и Ла Шатеньере в памятное историческое событие, которое, как представляется, совпадает с моментом возникновения выражения «соup de Jarnac». Поэтому я практически выношу за скобки воспоминания очевидцев (Вьевиль), современников (Монлюк) и младших родственников (прежде всего, Брантома, который был племянником Ла Шатеньере): нигде в этих текстах нет и намека на интересующую меня идиому. То же относится к официальной реляции о поединке, заверенной герольдами, которая служит основным источником информации о ходе боя. Ее состав, циркуляция и восприятие - тема для отдельного исследования, выходящего за рамки этой статьи. В основном я буду опираться на тексты и свидетельства, отстоящие от реального происшествия примерно на столетие, т.е. фиксирующие не индивидуальные воспоминания, а коллективные представления.

\section{Французская поговорка}

Начну с очевидного: в XVII и XVIII вв. письменно-печатная историографическая традиция продолжает соседствовать с коллективной памятью, передающейся устно или посредством личных, семейных записок, не предназначенных для публичного оглашения. В этой коллективной памяти дуэль Жарнака и Ла Шатеньере сохраняется в качестве своего рода вехи. К примеру, когда в середине XVIII в. Сен-Симон пишет о кончине презираемого им герцога де Ларошфуко (сына автора «Максим»), то указывает, что по материнской линии тот приходился двоюродным праправнуком тому самому Франсуа де Вивонну, «фавориту Генриха II, который был убит в его присутствии во время публичного боя один на один с Ги де Шабо, сыном сеньора де Жарнака» ${ }^{6}$. Хотя дуэль произошла почти за столетие до рождения Ларошфуко, он оказывается ей сопричастен по праву крови, поскольку, с точки зрения мемуариста, переплетение родовых связей является главной и объективной исторической реальностью.

Сен-Симон не упоминает об «ударе Жарнака», хотя это выражение начинает появляться в печатных текстах во второй половине XVII в.

\footnotetext{
${ }^{6}$ Saint-Simon 1840: 133.
} 
Едва ли не первую его письменную фиксацию мы находим у историка, знатока генеалогии Жана Ле Лабурера, который в 1659 г. выпустил комментированное издание мемуаров современника Жарнака и Ла Шатеньере, дипломата Мишеля де Кастельно. В обширных примечаниях к тексту, к которым мы еще вернемся, аббат Ле Лабурер утверждал, что эта «французская поговорка», возникшая после известного поединка, означает «непоправимый удар» (une atteinte sans remede) ${ }^{7}$. Ему возражал лексикограф Жиль Менаж в своем (уже посмертно опубликованном) «Этимологическом словаре» (1694). Процитировав слова ученого собрата, он заметил, что аббат ошибся, и на самом деле «удар Жарнака - это неожиданный удар» (un coup imprévu) ${ }^{8}$. Так же интерпретирует его и Жан Менюдье, который преподавал французский язык в Байройте и опубликовал несколько билингвальных пособий в помощь немецкоязычной публике. В очередном издании «Гения французского языка» (1681), он объяснял это выражение исключительно в плане неожиданности («Das hebt die Sach auff einmahl») $)^{9}$. Любопытно, что в более раннем варианте этой же книги, напечатанном в 1674 г., «удар Жарнака» отсутствует: по-видимому, его популярность постепенно нарастает к 1680-м гг. В пользу такого предположения свидетельствует и включение идиомы в словарь Ришле 1680 г., в основном ориентированный на придворный и литературный узус. Можно было бы предположить, что именно на него опирался Менюдье, когда позаимствовал колоритное выражение для своего «Гения французского языка». Однако Ришле толкует «соup de Jarnac» по-другому, как «удар, который поражает и приканчивает того, кого хотят уничтожить или кому хотят навредить» ${ }^{10}$.

Итак, в XVII в. «удар Жарнака» колеблется между двумя значениями, оба из которых вроде бы восходят к дуэли: ловкий выпад Ги Шабо, якобы подсказанный ему итальянским учителем фехтования, действительно был неожиданным. Можно сказать, что он также был неотвратимым, поскольку Ла Шатеньере не сумел его парировать. Но в каком смысле его можно считать непоправимым и, тем более, приканчивающим? Согласно засвидетельствованной герольдами реляции, полученная Ла Шатеньере рана не была смертельной, и если бы не его упрямство (сперва он не желал признать поражение, а затем не давал себя перевязать), то у него был бы шанс выжить. Более того, его отказ признать поражение вынуждал Жарнака добить противника, но он вместо этого воззвал к королю, умоляя позволить завершить поединок и избежать смертоубийства ${ }^{11}$. Эти документально зафиксированные детали неоднократно воспроизводились в текстах XVII в. Уже в 1602 г. Сипион Дюплеикс

\footnotetext{
7 «Ce Seigneur de Iarnac $\langle\ldots\rangle$ se signala par ce fameux combat $<\ldots$ \& et par ce coup mortel $<\ldots>$ qui a fait le Prouerbe François du coup de Iarnac, pour signifier vne atteinte sans remede» (Castelnau 1659. T.II: 600).

${ }^{8}$ Ménage 1694: 226.

${ }^{9}$ Menudier 1681: 258-259.

${ }^{10}$ Richelet 1680: 189.

${ }^{11}$ Franklin 1909: 99-103.
} 
опубликовал полный текст реляции в своих «Военных законах касательно дуэлей», попутно указав, что манускрипт ему передал адвокат и историк права Габриэль де Ла Рошмайе ${ }^{12}$. В 1648 г, реляция была напечатана в двухтомнике «Истинный театр чести и рыцарства, или Героическое зерцало благородства», выпущенном крупным специалистом по геральдике, Марком де Вюльсоном, сьером де Ла Коломбьером, который в свою очередь ссылался на документы из кабинета братьев Дюпюи ${ }^{13}$.

Однако параллельно с письменной документальной традицией существовала устная, в которой рассказ о дуэли имел несколько иное преломление. Ее отголоски сохраняются в книге Жана де Ла Тайя «Примечательная речь о дуэлях», которая вышла в 1607 г. ${ }^{14}$ Сам Ла Тай не был свидетелем поединка (хотя в принципе мог бы, поскольку он родился где-то между 1533 и 1540 гг.), но у него была возможность слышать рассказы очевидцев. В своем повествовании он ссылается на сеньора де Буаси, который был секундантом Жарнака ${ }^{15}$. При этом его версия событий не слишком комплиментарна по отношению к победителю: когда Ла Шатеньере был повержен, то Жарнак обратился к Генриху с вопросом: «Государь, удовлетворена ли моя честь?». Не получив немедленного ответа, он повернулся к противнику, чтобы его добить, и тогда король бросил жезл на землю, тем самым остановив поединок ${ }^{16}$. Этот рассказ затем перекочует в «Истинные и древние обычаи поединков» (1617) Виталя д’Одигье ${ }^{17}$, которого, наряду с подлинной реляцией и другими документами, процитирует Вюльсон. Тем самым устный рассказ-воспоминание оказывается и альтернативой официального коммюнике, и частью историографической традиции.

Хотя версия Ла Тайя / Буаси демонстрирует готовность Жарнака добить Ла Шатеньере, когда тот, уже будучи раненым, отказывается признать поражение и пытается подняться, важно, что такое развитие событий остается нереализованным. Откуда же у Ришле взялась идея, что «coup de Jarnac» означает «прикончить того, кого хотят уничтожить»? Перед тем как ответить на этот вопрос, процитирую еще одного лексикографа, на этот раз начала XVIII в. В 1718 г. Филибер-Жозеф Ле Ру опубликовал «Комический, сатирический, критический, бурлескный, вольный и провербиальный словарь», в котором «удару Жарнака» посвящена небольшая статья. В ней приводятся несколько значений этого выражения, слегка меняющего свой смысл в зависимости от контекста или, точнее, сферы применения. Их лексикограф выделяет четыре: азартные игры, война, светская жизнь и любовь. В первом случае идио-

\footnotetext{
${ }^{12}$ Dupleix 1611: 459-460.

13 Vulson de La Colombière 1648: 437.

${ }^{14}$ La Taille 1607: 26-36.

15 La Taille 1607: 34. Имеется в виду Клод Гуфье, маркиз де Буаси (1501-1570), великий конюший Франции, позднее герцог де Роанне.

${ }^{16}$ La Taille 1607: 32.

${ }^{17}$ Audiguier 1617: 386-394.
} 
ма означает «сделать неудачный ход и проиграть партию»; во втором «проиграть сражение, быть побежденным, полностью разбитым»; третий и четвертый предполагают личную неудачу, финансовую потерю, утрату расположения возлюбленной. При этом Ле Ру не упоминает исторической дуэли, его «жарнак» - «род небольшого кинжала или короткой обоюдоострой шпаги», а в переносном смысле словосочетание «удар жарнака» означает «гибельный, роковой, смертельный удар, которого нельзя избежать, от которого невозможно оправиться и излечиться» ${ }^{18}$.

Существует гипотеза, что в основе словаря Ле Ру лежал набросок бурлескного словаря, над которым незадолго до своей кончины работал Пьер Ришле ${ }^{19}$. По легенде рукопись была украдена, что на деле могло указывать на распространенную практику более или менее законного наследования больших лексикографических проектов ${ }^{20}$. Если принять предположение о прямой связи двух словарей, то описанные Ле Ру области применения идиомы и оттенки ее значения могли относиться к хронологически более ранней эпохе - скажем, к последней трети XVII в., учитывая, что Ришле умер в 1698 г. Если же словарь Ле Ру не имеет отношения к Ришле, то мы имеем дело с постепенным уточнением значения идиомы, которая от 1680 к 1718 г. не меняет основного смысла, но становится как бы более специализированной. Однако все это не объясняет, откуда берется идея, что «удар Жарнака» может быть не только неожиданным, но и гибельным, роковым, смертельным.

\section{Жарнакские луга}

Как мы видели, Ле Ру связывает одно из значений «удара жарнака» с военными действиями, а именно, с проигранным сражением. Эта ассоциация вряд ли случайна, поскольку в эпоху религиозных войн под Жарнаком разыгралась одна из трагедий, долго сохранявшаяся в национальной памяти. В 1569 г. там произошла битва королевских сил под командованием герцога Анжуйского (будущего Генриха III) и протестантской армии, во главе которой стояли принц де Конде и адмирал де Колиньи. Перевес оказался на стороне короны; тяжело раненый Луи де Бурбон, принц де Конде, попал в руки победителям и был застрелен в затылок капитаном гвардейцев герцога Анжуйского, Франсуа де Монтескиу. Эта гибель расценивалась современниками как убийство, поскольку Конде, по одним свидетельствам, уже сдался, а по другим - был беспомощен и не сопротивлялся. Так, Пьер Л'Этуаль в своем дневнике (впрочем, начатом ок. 1574 г.) сообщает, что Монтескиу убил принца «хладнокровно и, как говорят, по приказу своего господина», т.е. герцога Анжуйского. Он же фиксирует легенду, что перед смертью Конде, как Цезарь, прикрыл лицо плащом ${ }^{21}$. Конечно, об этой гибели много писали протестантские авторы. Если брать только ближайшие по време-

\footnotetext{
${ }^{18}$ Le Roux $171: 275$

${ }^{19}$ Bray 1986: 244-245. Cp.: Barsi 2003: 63-79.

${ }^{20}$ Многочисленные примеры см.: Considine 2008.

${ }^{21}$ L'Estoile 1826: 55-56.
} 
ни публикации, то в «Подлинной и полной истории беспорядков» (1572) Ла Попелиньер упоминает, что принц успел сдаться, но «несчастье шло за ним по пятам и, как только он был узнан, так тут же был убит (как все говорят) Монтескиу, пробившим ему голову смертельным залпом из пистолета (une pistolade mortelle)»22. Анри Этьенн был склонен возложить вину за произошедшее на Екатерину Медичи:

Был послан некий Монтескиу, капитан гвардейцев герцога Анжуйского, который наперекор военным законам, наперекор данному слову, хладнокровно, без почтения к тому, откуда принц происходил, сзади выстрелил ему в голову из пистолета (un coup de pistole dans la teste), ибо эта женщина заранее приняла меры, чтобы несчастный принц не смог избежать смерти ${ }^{23}$.

Наконец, в очередном дополненном издании «Состояния Церкви» Жана де Эно, вышедшем в 1581 г., тоже говорится о том, что, «наперекор всем божеским и человеческим законам», Конде был «убит выстрелом из пистолета в затылок (d'un coup de pistole au derriere de la teste) неким человеком по имени Монтескиу» ${ }^{24}$.

Этот список может быть продолжен, поскольку о гибели Конде писал и Агриппа д’Обинье во «Всеобщей истории», и де Ту в «Истории своего времени», и многие другие авторы. Однако приведенных цитат достаточно, чтобы увидеть, как постепенно вырабатывается стандартное повествование об этом трагическом происшествии. У Л’Этуаля нет упоминания способа, каким Монтескиу разделался с Конде; а у Ла Попелиньера речь идет о залпе. Но уже к середине 1570-х гг. появляется словосочетание «выстрел из пистолета», в котором используется то же существительное «соир» как и в «ударе Жарнака». Сам по себе оборот «соup de pistole[t]» ничем не примечателен и вполне нормативен; с точки зрения нашего сюжета показательно лишь то, что сперва о смерти Конде рассказывается без его помощи, а затем он становится неотъемлемой частью нарратива. И, в отличие от выпада Жарнака, этот выстрел под Жарнаком можно с полным основанием назвать подлым, роковым, смертельным и призванным добить противника.

Таким образом, «coup de Jarnac» мог отсылать не к дуэли между Жарнаком и Ла Шатеньере в 1547 г., а к сражению под Жарнаком, во время которого Франсуа де Монтескиу пристрелил принца де Конде. Эта альтернативная генеалогия идиомы была достаточно распространена, чему есть прямые свидетельства, в основном относящиеся ко второй половине XVIII века. Так, в марте 1791 г. в Национальной Ассамблее обсуждался вопрос о принадлежности остатков клермонского графства (Клермон-ан-Бовези), которое еще в XVI в. было присоединено к королевскому домену; затем в XVII в. эти земли были дарованы Великому Конде и оказались в собственности его рода; наконец Луи-Жозеф де Бурбон, принц де Конде, заключил сделку с Людовиком XVI, согласно

\footnotetext{
${ }^{22}$ La Popelinière 1572: $190^{\mathrm{r}}$.

${ }^{23}$ Estienne 1576: XL.

${ }^{24}$ Hainault 1581: 545.
} 
которой они возвращались в королевский домен, но ему выплачивался обременительный для казны пенсион ${ }^{25}$. Учитывая, что к тому времени принц уже был в эмиграции, да и с правовой точки зрения эта финансовая операция была сомнительной, Ассамблея, после некоторых дебатов, признала все соглашения, совершавшиеся с XVI в., недействительными и вернула земли короне. Председателем на этом сеансе был аббат де Монтескиу-Фензансак, что побудило остроумцев окрестить всю процедуру «ударом жарнака». Как комментировал один из журналистов:

С ужасом было замечено, что разорение принца де Конде было решено при президентстве одного из Монтескиу; это обстоятельство обновило ту преступную связь, которая на протяжении двух веков существует между этими именами, и лишение клермонских земель снова именуется ударом жарнака ${ }^{26}$.

С точки зрения нашего сюжета важно, что идиома вспоминается тогда, когда рядом оказываются два родовых имени, Конде и Монтескиу, т.е. референцией тут служит не дуэль, а сражение при Жарнаке. Еще одно, не менее любопытное свидетельство устойчивости этой ассоциации, восходит к предреволюционной эпохе. В 1786 г. бордосский юрист Пьер-Иасинт Дювиньо (в будущем - активный деятель революции, окончивший свои дни на эшафоте) опубликовал «Историческую похвалу маршалу де Бирону», где опять-таки связал «удар Жарнака» с гибелью Конде от выстрела Монтескиу:

Без сомнения, именно этот отвратительный поступок породил поговорку «наносить или получать удар Жарнака». Как унизительно для нации создание подобных выражений! Эта поговорка - чудовищный, но вечный памятник, невольно воздвигнутый виновными их собственными руками, дабы внушать омерзение самым далеким потомкам ${ }^{27}$.

Слова о «памятнике» тут нужно понимать буквально, поскольку он существовал не только на словах, но и в материальной реальности. Но прежде сделаем небольшое отступление, касающееся судьбы Ги Шабо де Монлье, который в 1547 г. вышел победителем из поединка с Ла Шатеньере. Его дальнейшая карьера складывалась вполне благополучно: в 1559 г. он унаследовал отцовский титул и стал бароном де Жарнаком, занимал ряд важных должностей, в частности был губернатором Ла Рошели и «постоянным мэром» Бордо. Его родовые земли - собственно, Жарнак и проч. - находились между Ангулемом и Коньяком, практически на одинаковом расстоянии между Ла Рошелью и Бордо. Во время религиозных войн Жарнак, несмотря на то, что сам примкнул к реформированной (протестантской) церкви, сохранял верность королю и пытался - не слишком успешно - поддерживать его авторитет в Ла Рошели. Сражение 1569 г. происходило на его землях, и тело принца де Конде было привезено в его замок, и лишь потом отдано родственникам. В 1770 г. Шарль-Розали де Роган-Шабо, граф де Жарнак, представитель другой ветви этого большого рода, унаследовавший замок и земли, ре-

\footnotetext{
${ }^{25}$ Archives Parlementaires 1886: 22-29, 54-56, 109-128

${ }^{26}$ Magasin historique 1791: 182.

${ }^{27}$ Duvigneau 1786: 133.
} 
шил воздвигнуть на месте предполагаемого убийства принца монумент, призванный напоминать об этом преступлении. По-видимому, помимо чувства фамильной ответственности, к этому его могла подтолкнуть локальная традиция, сохранившая «память» о том, где именно пролилась кровь Конде. На это указывает отчасти романическое свидетельство Летиции Хокинс, которая была знакома с графом и, скорее всего, передавала его собственный рассказ:

Для увековечивания этого события, произошедшего в 1569 году, граф Жарнак возвел на том самом месте, по-прежнему отмеченном вросшим в землю пнем, прекрасно замысленный саркофаг и обелиск, сделанные по его собственному наброску. Обелиск венчала урна, на одной из ее сторон был овал с именем, датой и словами «Obiit gloriose». На боку саркофага он написал строчку из «Генриады»: «O plaines de Jarnac! ô coup trop inhumain!». Из уважения к семейству Монтескиу он не стал добавлять туда завершающую строку из этой строфы: «Barbare Montesquiou, moins guerrier qu'assassin» ${ }^{28}$.

Памятник этот простоял менее двух десятков лет и был снесен во время Революции. В 1818 г. его восстановили, но без урны и цитат из Вольтера: таким его можно видеть и по сей день.

Наличие памятника, воздвигнутого графом де Жарнаком на его родовых землях, где принц Конде был убит позорным выстрелом в затылок - все это, видимо, способствовало закреплению альтернативной версии происхождения идиомы и, соответственно, усилило ее негативный смысл. Обелиск как бы фиксировал то самое место в Жарнаке, где был нанесен удар. Хотя и до его появления были предпосылки к тому, чтобы это пространство воспринималось как памятное. Если верить Бенжамену Приоло, в 1651 г. Великий Конде на пути в Бордо захотел увидеть «поле боя, пропитанное кровью Конде» ${ }^{29}$. Конечно, в контексте Фронды это был отчетливый политический жест, что не отменяет его мемориального характера. Такого рода паломничества подкрепляли память места. Тем не менее решающая роль тут, как всегда, принадлежит Вольтеру.

Как мы видели, на оригинальном памятнике в Жарнаке была воспроизведена одна строчка из «Генриады», написанной в 1723 г. Это часть тирады, произносимой самим Генрихом IV, оплакивающим гибель своего родича и сподвижника:

O plaines de Jarnac ! o coup trop inhumain! Barbare Montesquiou, moins guerrier qu'assassin, Condé déjà mourant, tomba sous ta furie: J'ai vu porter le coup, j'ai vu trancher sa vie...

Жарнакские луга, о мне удар несносный! О варвар Монтескю! Убийца поносный; Конде сражен упал от зверства твоего; Я злой зрел твой удар, зрел тяжку смерть его... ${ }^{30}$

Выбор выражений заставляет подозревать, что Вольтер намеренно играл словами, ставя рядом «plaines de Jarnac» и «соup trop inhumain», и тем самым вызывая в памяти идиому «соup de Jarnac». Трудно сказать, в какой степени он сам связывал ее с событиями 1569 г., но нет сомне-

\footnotetext{
${ }^{28}$ Hawkins 1824: 173.

${ }^{29}$ Prioli 1665: 63-64.

${ }^{30}$ Вольтер 1803: 28.
} 
ния, что его строки добавили веса альтернативной версии происхождения «удара Жарнака». Этот патетический пассаж был на слуху и много цитировался. О его популярности, в частности, говорит тот факт, что он попадает в выборку лучших мест из «Генриады», предлагавшихся английскому читателю в начале XIX в. Не исключено, что под его влиянием в «Разговорном словаре для дам и юношества» под редакцией Уильяма-Александра Дакетта (1841), утверждалось, что «этот столь драматический факт породил поговорку “удар жарнака”, используемую в переносном смысле для обозначения предательского удара или действия» ${ }^{31}$.

Итак, можно констатировать, что параллельно с дуэльной версией происхождения «удара Жарнака», которая существует с середины XVII столетия, когда ее фиксирует Жан Ле Лабурер, имела хождение другая, альтернативная генеалогия, связанная с битвой при Жарнаке. С большой долей вероятности именно она стоит за тем истолкованием идиомы, которое ей дает Ришле в 1680 г., а затем Ле Ру в 1718 г. Но с полной уверенностью мы можем говорить о ее бытовании только во второй половине XVIII века, когда появляются прямые отсылки к «соup de Jarnac» как к своего рода мемориалу трагической гибели принца де Конде. Важную роль тут сыграла «Генриада», хотя, судя по Дювиньо, не меньшее значение могла иметь локальная традиция: местная память о кровавых событиях прошлого - пресловутый пень, который в XVIII в. продолжает служить естественным мемориалом того, что произошло в XVI в. - затем закрепляется в виде каменного обелиска. При этом непохоже, чтобы такая версия происхождения идиомы воспринималась людьми XVII и XVIII вв. как конфессионально окрашенная. Конечно, убитый под Жарнаком принц де Конде был предводителем гугенотов, но он принадлежал к младшей ветви королевского рода, и для значительной части современников и потомков это было более важным обстоятельством. К примеру, Мишель де Кастельно, чьи мемуары комментировал Ле Лабурер, был непосредственным участником битвы при Жарнаке на стороне короля. Его рассказ о гибели Конде в целом повторяет тот, который мы видели в «Подлинной и полной истории беспорядков» (1572) Ла Попелиньера, за исключением эмоционально-оценочной части: принц успел сдаться, но «как только он был узнан, он был застрелен (il receut un coup de pistolet) Монтескиу и вскоре скончался, оставив по себе память одного из самых великодушных принцев своего времени» ${ }^{32}$. Кастельно писал свои мемуары во второй половине 1570-х гг. и, судя по всему, не был непосредственным очевидцем этой сцены, а повторял уже сложившийся рассказ о ней, отсюда сходство выражений у него и Ла Попелиньера, который сражался на противоположной стороне. Искренняя приверженность Кастельно трону и католической церкви не мешала ему явно сожалеть о произошедшем.

\footnotetext{
${ }^{31}$ Duckett 1841: 143.

${ }^{32}$ Castelnau 1659. T.I: 236.
} 
Записки Кастельно возвращают нас к проблеме происхождения выражения «coup de Jarnac». Мемуарист его не употребляет, как не упоминает о дуэли между Жарнаком и Ла Шатеньере, выходящей за пределы его воспоминаний. Сам Ги Шабо, барон де Жарнак, появляется в них лишь мельком; в основном его имя фигурирует в документах эпохи, которые публикует Ле Лабурер, а затем в обширной биографической статье, которую комментатор включает в свое издание. Иначе говоря, Ле Лабурер рассказывает о знаменитой дуэли в приложении к мемуарам, в которых речь идет о сражении при Жарнаке. Сама по себе процедура вполне типична для исторического комментария образца XVII столетия, вбиравшего в себя всю возможную релевантную и иррелевантную информацию. Однако не исключено, что она объясняет некоторое замешательство антиквария при определении идиомы. Его «непоправимый удар» (une atteinte sans remede) как бы учитывает и «дуэльную» генеалогию, и ее альтернативу.

Все сказанное не дает ответа, когда точно возникла идиома и какова изначальная иерархией ее значений, поскольку у нас отсутствуют свидетельства ее употребления между 1547 и 1569 гг., или непосредственно после 1569 г. Поэтому в заключение выскажу несколько чисто гипотетических предположений. Нет сомнений, что дуэль между Жарнаком и Ла Шатеньере произвела сильнейшее впечатление на современников. Хотя выпад, позволивший Жарнаку одержать верх над противником, не был его изобретением, за ним закрепляется техническое наименование «удар Жарнака», которое распространяется на оружие, при помощи которого он совершается. Позднее, через профессиональный лексикон искусства фехтования, этот термин проникает в другие типы состязаний и игр. Однако после сражения при Жарнаке к техническому и позитивному значению выражения «соup de Jarnac» добавляется более общее и негативное (подлый, предательский удар). Судя по всему, в XVII в. эти два смысловых оттенка существуют порознь и в разных стратах, отсюда споры о правильном употреблении идиомы.

Как справедливо заметил Ричард Сколар по поводу «le je-ne-saisquoi», в XVII в. общие места (loci communis) нередко оказываются спорными территориями, за которые идет глухая борьба между фракциями, представляющими разные направления мысли ${ }^{33}$. В силу этого отдельные фигуры речи и идиомы, являющиеся ключевыми для своего времени, могут быть избыточно семантизированы, что приводит к бесконтрольному расширению их реферативного поля. В случае «удара Жарнака» мы имеем дело с конфликтом интерпретаций, который примечателен тем, что выбор той или иной генеалогии и, соответственно, семантики, происходит спонтанно, почти без вмешательства законодателей вкуса и хороших манер (исключение составляет Менаж). Но, парадоксальным образом, по мере распространения негативного узуса, легенды

\footnotetext{
${ }^{33}$ См., в частности: Scholar 2005: 59-60.
} 
о происхождении как бы меняются местами, и дуэльный нарратив оказывается соединен с изначально не свойственной ему идеей подлого удара исподтишка. По-видимому, за этим стоит постепенное формирование концепции национального прошлого: уже к середине XVII в. выражение «coup de Jarnac» воспринимается как своего рода историческое свидетельство. Когда Ле Лабурер пишет о нем как о «французской поговорке», то безусловно подчеркивает его национальный (в противоположность общечеловеческому) характер ${ }^{34}$. Накануне и во время революции 1789 г. это прошлое либо отвергается как «чудовищное», либо выступает в качестве «ужасного» предвестия настоящего, что выводит на первый план память о битве при Жарнаке. Напротив, в XIX в. эпоха религиозных войн начинает романтизироваться, что сказывается в предпочтении красочного «дуэльного» нарратива, меж тем, как воспоминание о гибели Конде окаменевает и превращается в памятник.

\section{БИБЛИОГРАФИЯ / REFERENCES}

Вольтер. Генриада. Епическая поэма г. Волтера. Вновь переведенная Иваном Сирьяковым. СПб.: Имп. Акад. Наук, 1803 [Genriada. Epicheskaia poema g.Voltera. Vnov' perevedennaia Ivanom Sir'iakovym. SPb: Imp. Akad. Nauk, 1803].

Archives Parlementaires de 1787 à 1860 - Première série (1787-1799). Tome XXIV - Du 10 mars 1791 au 12 avril 1791. Paris : Librairie Administrative P. Dupont, 1886.

Audiguier V. de. Le vray et ancien usage des duels. Paris : P.Billaine, 1617.

Barsi M. Le «Dictionnaire burlesque » de Richelet et sa continuation per Philibert Joseph Le Roux // Lingua, cultura e testo: miscellanea di studi francesi in onore di Sergio Cigada. Milan: Vita e Pensiero, 2003. P. 63-79.

Bray L. César-Pierre Richelet (1626-1698) Biographie et œuvre lexicographique. Tübingen, Max Niemeyer Verlag, 1986.

Castelnau M. de. Les Memoires, Illustrez et Augmentez de Plusieurs Commenaires \& Manuscrits, tant Lettres, Instructions, Traittez, qu'autres Pieces Secrettes \& Originalles servants à donner la verité de l'Histoire des Regnes de François II. Charles IX. \& Henry III. \& de la Regence par J. Le Laboureur. En 2 vols. Paris: P. Lamy, 1659.

Considine J. Dictionaries in Early Modern Europe Lexicography and the Making of Heritage. Cambridge: Cambridge University, 2008.

Duckett W. Dictionnaire de conversation à l'usage des dames et des jeunes personnes, ou Complément nécessaire de toute bonne éducation. T.VII. Paris : Langlois et Leclercq, 1841.

Dupleix S. Les loix militaires touchant le duel. Paris: François Gueffier, 1611.

Duvigneau P.-H. Éloge historique d'Armand de Gontaud, baron de Biron, maréchal de France sous Henri IV: suivi de notes historiques sur les actes de valeur \& de patriotisme de la noblesse de Guienne, \& particulièrement de celle de Gascogne, sous les règnes de François I, Henri II, François II, Charles IX, Henri III \& Henri IV, depuis 1522 jusqu'en 1592. T.I. Geneve, 1786.

Estienne H. Discours merveilleux de la vie, actions et deportemens de Catherine de Medicis roine mere. Declarant les moyens qu'elle a tenus pour usurper le gouvernement du royaume de France, et ruiner l'estat d'iceluy. Seconde Ed. S.1., 1576.

Fabre D. Proverbes, contes, chansons // Nora P. (dir.). Les lieux de mémoire. Paris, Gallimard, 1997. T.III. P. 3555-3580.

Franklin A. Le duel de Jarnac et de La Chataigneraye, d'après une relation contemporaine et officielle. Paris : Émile-Paul, 1909.

Hainault J. de. L'estat de l'Eglise, avec le discours des temps depuis les Apostres iusques au present. Augmente \& reueu tellement en ceste edition, que ce qui concerne le siege Romain, \& autres Royaumes depuis l'Eglise primitiue iusques à ceux qui regnent auiourdhuy, y est en brieues Annales proposè. Item vn traité de la religion \& republiques des Iuifs, depuis le retour de l'exil de Babylone, iusques au dernier saccagement de Ierusalem. S.l. : Eustace Vignon, 1581.

\footnotetext{
34 Об отношении к поговоркам как к историческому свидетельству, появляющемуся уже в XVI веке, см.: Fabre 1997.
} 
Hawkins L.-M. Memoirs, Anecdotes, Facts, and Opinions. T.II. London, 1824.

La Popelinière H. L.-V. de. La vraye et entière histoire des troubles et choses mémorables avenues, tant en France qu'en Flandres, \& pays circonvoisins, depuis l'an 1562. Avec les considerations sur les guerres civiles des François. Basle: Pierre Davantes, 1572.

La Taille J. de. Discours Notable des Duels, de leur origine, en France et du malheur qui en arrive tous les iours au grand interest du public. Paris: Rigaud, 1607.

Le Roux Ph.-J. Dictionaire Comique, Satyrique, Critique, Burlesque, Libre \& Proverbial Avec une Explication très - fidèle de toutes les manières de parler Burlesques, Comiques, Libres, Satyriques, Critiques et Proverbiales, qui peuvent se rencontrer dans les meilleurs Auteurs, tant Anciens que Modernes. Amsterdam : LeCene, 1718.

L'Estoile P. de. Journal de Henri III, de Henri IV et de Louis XIII. T.I. Paris: Foucault, 1826.

Magasin historique ou Journal général, contenant tout ce qui est décidé à l'Assemblée nationale, à l'Hôtel-de-Ville de Paris, dans les districts, et les nouvelles authentiques de la Province, etc. S.1., 1791.

Ménage G. Dictionaire étymologique ou Origines de la langue françoise. Paris : Anisson, 1694.

Menudier J. Le genie de la langue francoise, c'est a dire ses proprietes, ses elegances. Bielke, 1681.

Nora P. Entre mémoire et histoire // Nora P. (dir.). Les lieux de mémoire. P., Gallimard, 1997. T. I. P. 23-43.

Prioli B. Ab excessu Ludovici XIII de rebus gallicis historiarum libri XII. Carolopoli: G. Ponceleti, 1665.

Richelet P. Dictionnaire françois: contenant les mots et les choses, plusieurs nouvelles. J.-H. Widerhold, 1680.

Scholar R. The Je-Ne-Sais-Quoi in Early Modern Europe: Encounters with a Certain Something. Oxford: O.U.P., 2005.

Vulson de La Colombière M. Le vrai Théâtre d'honneur et de chevalerie, ou le miroir héroïque de la noblesse. Paris : A. Courbé, 1648.

Неклюдова Мария Серzеевна, Ph.D., заведующая, лаборатория историкокультурных исследований, ШАГИ РАНХиГС; neklyudova-ms@ ranepa.ru

\section{"Jarnac's Blow" \\ Local memory and the conflict of historical interpretations}

This article examines the expression "Jarnac's blow" (coup de Jarnac), which existed in the French at least for three centuries. Supposedly it refers to the last judicial duel that took place in France in 1547. During the fight one of the duelists, Guy Chabot de Jarnac, was able to wound his opponent with a dexterous thrust, which explains the appearance of the idiom. However, it is highly probable that it was associated with another event that occurred two decades later. In 1569, at the battle of Jarnac, the leader of the Huguenots, Prince de Condé, was treacherously shot at the moment when he surrendered to the mercy of the winner. The article is devoted to the interpretation of these events in national and linguistic memory.

Keywords: Jarnac, memory, idiom, 17th century, Voltaire, conflict of interpretations

Maria Neklyudova, Ph.D., head of laboratory of historical and cultural research, School of Advanced Studies in the Humanities, Russian Presidential Academy of National Economy and Public Administration (RANEPA); neklyudova-ms@ ranepa.ru 


\section{МЕРТВОЕ ТЕЛО КАК ОБЬЕКТ ЧУВСТВЕННОГО ВОСПРИЯТИЯ В ПРОСТРАНСТВЕ АНДСКОЙ ЦИВИЛИЗАЦИИ}

Статья посвящена проблеме отношения к мертвому телу, которое бытовало среди носителей Андской цивилизации преимущественно в XV-XVII вв. Автор анализирует погребальные обычаи и сопутствующие представления, зафиксированные в письменных (в т.ч. архивных) и материальных источниках. Делается вывод, что в Андской цивилизации существовало представление о необходимости регулярного физического контакта с телами умерших, что наложило отпечаток на представления о мертвом теле. Но после того, как этот контакт стал затруднен или невозможен, соответствующие представления подверглись трансформации. В итоге на современном этапе андское отношение к мертвому телу приблизилось к христианскому.

Ключевые слова: Андская цивилизация, погребальный обряд, мумификачия, жертвоприношения, сакральность

Смерть и все с ней связанное неизбежно сопровождает человеческое общество. Несмотря на универсальность самой категории смерти, в разных культурах сложился ряд моделей отношения к ней и ее составляющим. Не является исключением и человеческое тело после смерти: отношение к нему варьируется от признания его в высшей степени нечистым (например, в зороастризме ${ }^{1}$ или иудаизме ${ }^{2}$ ) до придания ему сакрального статуса, что наблюдалось по отношению к телам христианских святых ${ }^{3}$. Конечно, все культурное разнообразие смерти не ограничивается этими двумя крайностями; между ними существовало и существует великое множество промежуточных вариантов.

Предмет исследования - отношение к мертвому телу в культурном пространстве Андской цивилизации. Хронологические рамки охватывают не весь период ее существования, а преимущественно XV-XVII вв. эпоху расцвета инкского государства Тавантинсуйу и ранний колониальный период, но при необходимости будут совершаться экскурсы за его пределы; и отдельно будет рассмотрен вопрос о современном состоянии андского отношения к мертвому телу. Объект исследования - разнообразные ритуалы и представления, связанные с мертвым телом. На наш взгляд, распространенный в литературе термин «погребальные обряды/ритуалы» в контексте Анд искусственно сужает рамки анализа, поскольку в этом регионе обряды, связанные с мертвыми, проводились не только в контексте похорон. Источники по данной теме многочисленны, но крайне неоднородны и разбросаны. Из письменных следует отметить хроники и сообщения, посвященные в основном государству инков ${ }^{4}$, а

\footnotetext{
${ }^{1}$ Мейтарчиян 2001: 145-146.

${ }^{2}$ Ганцфрид 2012: 538, 546-547.

${ }^{3}$ Angenendt 1994: 149-155; Браун 2004: 83-100.

${ }^{4}$ Cieza 2005; Betanzos 2004; Cobo 1892, 1893; Anello 1895; Pizarro 2013; Segovia 2019; Molina 2010; Murúa 2001; Пома де Айяла 2011.
} 
также памятники, отражающие борьбу церкви и колониальных властей с индейскими верованиями (произведения теоретиков и практиков «искоренения идолопоклонства» ${ }^{5}$ и документы процессов против индейцев, обвиняемых в идолопоклонстве ${ }^{6}$ ). К этой группе можно отнести и заметки путешественников преимущественно XIX - начала XX в ${ }^{7}$. Эти источники носят в основном вспомогательный характер, однако их ценность заключается в том, что в них зафиксированы данные о ряде погребальных сооружений, к настоящему времени полностью или частично разрушенных. К наиболее значимым материальным источникам относятся данные погребений и иконография. Немалую ценность представляют этнографические материалы, полученные в основном в XX в., но именно они позволяют наглядно оценить эволюцию андских представлений о смерти. Одна из главных сложностей работы с имеющимися источниками заключается в том, что они отражают совершенно разные аспекты одной проблемы. В хрониках говорится преимущественно об обрядах самих инков, т.е. высшей знати государства, а материалы процессов против идолопоклонства отражают пласт низовой, «народной» религии, уже подвергнувшейся трансформации, но и те, и другие показывают индейские верования и ритуалы глазами испанцев, что неизбежно ведет к цепочке искажений. Археология и иконография дают аутентичный материал, но их данные без сопутствующих письменных источников не всегда поддаются однозначной расшифровке, к тому же соответствующий андский материал в значительной своей массе относится к доинкским эпохам. Все это требует большой осторожности при проведении сравнительного анализа данных по разным культурам и периодам.

Тема погребальных традиций Андской цивилизации не относится к малоисследованным. Археологическое изучение региона началось с изучения погребений, хотя изначально было направлено почти исключительно на погребения знати. Одна из первых попыток осмысления и истолкования погребальных обычаев американских индейцев (включая Перу), была серия статей британского исследователя Ричарда Летчема «Погребальные обычаи индейцев Чили и других частей Америки» ${ }^{8}$. Важным этапом для развития историографии проблемы стало также введение в научный оборот процессов против идолопоклонства индейцев, начиная с исследований Пьера Дювьоля9.

В современных исследованиях погребальных обычаев Анд обычно делается акцент на социально-политических аспектах проблемы ${ }^{10}$, в то время как духовно-чувственные отодвигаются на второй план. Еще одна

\footnotetext{
${ }^{5}$ Arriaga 1621; Álvarez 1998; Perez 1631; Ondegardo 1916.

${ }^{6}$ Самая обширная коллекция соответствующих документов хранится в Архиепископском архиве Лимы.

${ }^{7}$ Tschudi 1847; Squier 1877; Hrdlička 1914.

${ }^{8}$ Latcham 1915: 443-493; Latcham 1916: 85-144, 273-326.

${ }^{9}$ Duviols 1986. К сожалению, при работе над настоящей статьей у автора не было возможности обратиться к данной публикации.

${ }^{10}$ Alosno Sagaseta 1989: 109-135; Isbell 1997; Gil García 2002: 59-83.
} 
характерная черта современной историографии - фрагментированность. За последние несколько десятилетий вышло большое количество исследований, которые прямо или косвенно касаются погребальных обрядов и основываются на новейших данных археологии ${ }^{11}$ и этнологии ${ }^{12}$. Однако большинство исследований посвящены локальным культурам и отдельным областям, что в перспективе требует работы по обобщению и анализу всего обширного корпуса этих материалов.

В мировоззрении носителей Андской цивилизации не проводилось резкой границы между жизнью и смертью ${ }^{13}$; вернее, смерть рассматривалась как неотъемлемая часть жизни: почившие члены общества продолжали оставаться его неотъемлемой частью. Причем смерть как один из важнейших этапов в жизни индивида сопровождалась многочисленными ритуалами и была окружена множеством верований и представлений, которые можно поделить на две большие группы: 1) собственно погребальные, т.е. относящиеся к физической смерти индивида и погребению его тела; 2) постпогребальные, практиковавшиеся по завершении похоронного цикла с целью обеспечить благосостояние общины. В погребальных практиках можно также выделить такую подгруппу, как заупокойные обряды, направленные на успокоение умершего и его успешное отправление в загробный мир. Такие ритуалы проводились и спустя значительное время после физической смерти человека.

Одна из наиболее характерных андских погребальных традиций стремление сохранить тело покойного в максимально нетленном состоянии. Археологические данные показывают, что именно древнее Перу может считаться колыбелью мумификации ${ }^{14}$. Особенно тщательно сохранялись тела знатных персон, что подтверждают источники, описывающие мумии инкских правителей. Хронист Бернабе Кобо так писал об андских традициях мумификации «Они бальзамировали мертвое тело с большим искусством [...] они делали это столь деликатно и с таким мастерством, что через двести лет некоторые из тех мертвых, что были найдены в Куско, сохранились настолько хорошо... что, казалось, не прошло и месяца, как они умерли» ${ }^{15}$. Имеются многочисленные подтверждения того, что эта практика существовала как до, так и после инков. Археологические свидетельства демонстрируют примеры сохранения тела как в горных, так и в прибрежных доинкских культурах ${ }^{16}$. Даже

${ }^{11}$ Andrushko, Torres Pino, Bellifemine 2006; Alva 2001; Arriola 2015; Becker and Alconini 2018; Fernández Juárez 2001; Isla and Reindel 2006; Lau 2011; Prieto Burmester 2008; Verano 2008.

12 Abercrombie 1998; Bascopé Caero 2001; Bugallo y Valca 2016; Cáceres 2001; Harris 1983; Irarrazaval 1999; Onofre Mamani 2001; Sendón y Manríquez 2016; Spedding 2008.

${ }^{13}$ Pizarro 2013: 91.

${ }^{14}$ Guillén 2005: 142. Мумификация в Андах не всегда делалась намеренно; нередко хорошее состояние тел объясняется природными условиями, причем искусственную мумификацию не всегда легко отличить от естественной (Guillén 2005: 143).

${ }^{15}$ Cobo 1893: 238.

${ }^{16}$ Wieckowsky 2014: 211-220; Guillén 2005: 142-149. 
в случаях, если тела сохранились плохо, особенности конструкции погребальных сооружений указывают на стремление эти тела сохранить ${ }^{17}$.

Неудивительно, что для пришедших в Новый Свет европейцев подобные практики были одними из самых одиозных; большее отторжение и неприятие вызывали, пожалуй, только человеческие жертвоприношения. Последние, впрочем, сравнительно быстро сошли с исторической сцены, в то время как стремление индейцев сохранять тела умерших и совершать над ними обряды доставило христианизаторам множество неприятных минут. Это нашло отражение в ряде источников. Так, например, в справочнике для священников, посвященном особенностям работы с индейцами, есть обширный раздел вопросов, которые следовало задавать прихожанам на исповеди. Немало места там отведено вопросам, связанным с отношением к мертвым телам: «Ты кормил мертвое тело? Ты почитал мертвые тела? Ты хоронил их за пределами церкви? Когда ты его хоронил, похоронил ли ты вместе с ним много вещей, одежды и остального, чем он владел?» ${ }^{18}$. Список таких вопросов можно продолжить. Он наглядно показывает, что в 1631 г., когда были изданы эти инструкции, церковь уже сформировала перечень наиболее «богопротивных» индейских обычаев, с которыми боролась в первую очередь. Конечно, этот перечень не лишен определенного схематизма, однако другие источники показывают, что в целом он вполне отражал реалии мировоззрения индейцев соответствующей эпохи.

Среди обычаев колониального времени, связанных с мертвым телом, особого внимания заслуживает практика кражи трупов с церковных кладбищ и их хранение в укромных местах ${ }^{19}$ с целью последующего отправления языческих ритуалов. При этом показательно, что данная практика фиксируется как в центральном нагорье ${ }^{20}$, территория которого в наибольшей степени охвачена источниками колониального периода, так и в менее изученном боливийском альтиплано ${ }^{21}$. Ее широкий географический охват показывает важность почитания мертвого тела не только в областях, примыкающих к центру бывшего инкского государства, но и в более отдаленных районах.

Велико значение этой практики и с точки зрения политики христианизации, что подтверждается ее упоминанием как в перечне вопросов для исповеди, так и в документах, связанных с искоренением идолопоклонства. Самому этому явлению посвящена обширная литература ${ }^{22}$, и

\footnotetext{
${ }^{17}$ Isbell 1997: 148.

${ }^{18}$ Perez 1631: 130.

19 Для обозначения этих укромных мест используется кечуанское слово machay, которое встречается как в колониальных, так и в современных словарях и переводится как «пещера» (Santo Tomás 1560: 147). В некоторых областях центральной сьерры подобный обычай зафиксирован археологически (Hrdlička 1914: 6).

${ }^{20}$ AAL. Serie Hechicerías e idolatrías. Leg. 3:8. 1656: 1,3,5; AAL. Serie Hechicerías e idolatrías. Leg. I:14. 1604: 1-2; Arriaga 1621: 35; Calancha 1638: 376.

21 Álvarez 1998: 14.

${ }^{22}$ Duviols 1986; Gruzinski 1992; Gareis 2005 115-142; Acosta 2014; Escalante 2016; etc.
} 
мы не будем подробно на нем останавливаться. Отметим лишь, что целью этого института, созданного во многом по образу Инквизиции, было искоренение языческих верований индейцев. В то или иное индейское поселение направлялся ревизор (visitador), а его инспекция называлась «визитом» (visita). В ходе процесса велась документация, в которой наибольший интерес представляют протоколы допросов индейцев. Именно там описываются обычаи, ритуалы и верования, которые стремилась искоренить церковь. Одним из завершающих элементов процесса было уничтожение всех физических свидетельств языческих культов индейцев: разного рода талисманов, трав, идолов, а также мумий ${ }^{23}$.

Возвращаясь к вопросу о краже тел, отмечу, что именно страх их уничтожения во многом толкал индейцев на совершение этого преступления, а также представление о том, что погребение в земле не отвечает нуждам самих умерших. В нескольких источниках зафиксировано представление о том, что погребение в земле «давит» на тело, не давая ему хорошо отдохнуть. В качестве примера можно привести выдержку из показаний индейца на одном из допросов по поводу идолопоклонства: «...усопшие, которые умирают в церкви, вынимаются из нее и относятся в мачаи, потому что земля угнетает их, а мачаи нет» ${ }^{24}$. Практически идентичные представления зафиксированы в трактате Пабло Хосе де Арриага тридцатью годами ранее ${ }^{25}$. Это позволяет заключить, что в Андах существовало представление о прямой зависимости между состоянием тела и благополучием души, связанной с этим телом. Такое представление не является уникальным для Анд, но именно здесь должное состояние тела поддерживалось тесным и регулярным контактом с ним, что не могло не отразиться на образе смерти в целом.

Помимо практики сохранения тела как такового к важным погребальным обрядам следует отнести многочисленные манипуляции, связанные с ним: обмывание, одевание, подношение еды, текстиля, керамики, напитков, жертвоприношения животных (обычно лам и морских свинок) или людей в случае, если хоронили персону высокого ранга ${ }^{26}$. Есть также сведения, что иногда при этом осуществлялась своего рода гендерная стратификация, когда в погребения клали специфически женские украшения и предметы ${ }^{27}$. В рамках нашего хронологического периода телам, как правило, придавали сидячую позу ${ }^{28}$ - как из практиче-

\footnotetext{
${ }^{23}$ Сам термин «мумия», несмотря на его распространенность в литературе, в дискурсе того времени встречается редко; чаще всего употреблялись либо термин сиегро («тело»), либо кечуанское слово mallqui. В хрониках, посвященных истории государства инков, часто можно встретить слово bulto (дословно «тюк», «тюфяк») для обозначения мумифицированного тела; подробнее см.: Alonso Sagaseta 1989: 110-111.

${ }^{24}$ AAL. Serie Hechicerías e idolatrías. Leg. 3:8. 1656: 5.

${ }^{25}$ Arriaga 1621: 35.

${ }^{26}$ Cobo 1893: 237-238; Pizarro 2013: 64; Segovia 2019: 162; Murúa 2001: 126; Cieza 2005: 177.

27 Álvarez 1998: 115.

${ }^{28}$ Andrushko, Torres Pino y Bellifemine 2006: 68-69.
} 
ских (тела для сохранности укутывали тканью, порой в несколько слоев), так и мировоззренческих соображений (чтобы еще больше усилить визуальное сходство с живыми).

Особенности погребальных обычаев весьма подробно зафиксированы как нарративно, так и археологически ${ }^{29}$. Во втором случае речь идет о трех основных компонентах: 1) структура погребения (гробница, земляная могила, похоронная башня и т.п.); 2) тело покойного; 3) погребальные подношения ${ }^{30}$. Наиболее подробные данные письменных источников посвящены в основном государству инков ${ }^{31}$, хотя есть описания погребальных обычаев и побережья, в частности государства Чимор $^{32}$. Были уверены в необходимости таких подношений также индейцы колониальной эпохи, жившие во времена борьбы с идолопоклонством $^{33}$. Очевидно, что существует непосредственная генетическая связь между погребальными обычаями инков и некоторых доинкских государств (особенно сьерры) с традициями колониального времени. Конечно, о полной идентичности говорить не приходится: можно привести много примеров, показывающих различие между ними. Но принципиальных отличия, на наш взгляд, два. Во-первых, это масштаб: похороны правителей и в целом знати проводились с куда большим размахом, чем рядовых членов социума. Во-вторых, способ отправления соответствующих ритуалов: если до прихода испанцев эти ритуалы отправлялись открыто, то после Конкисты индейцы были вынуждены совершать их тайно. Как следствие мы можем говорить о существовании ряда общеандских представлений, объектом которых было мертвое тело. Впрочем, мы вправе с уверенностью говорить лишь о некоторой совокупности родственных ритуалов и воззрений, а не о цельной системе.

Главной целью постпогребальных обычаев и традиций было поддержание благополучия общины. Предки, пребывавшие в пространстве сакрального, могли помочь своим живым потомкам в их повседневных делах. Осуществлялось это посредством тесного взаимодействия с телами предков, которое реализовывалось с помощью регулярных подношений еды, питья, одежды и прочих необходимых вещей. Данные ритуальные манипуляции были очень схожи с теми, которые осуществлялись в рамках погребального этапа. Кроме того, были распространены представления, согласно которым тела предков наделялись свойствами оракулов: им задавали вопросы, а они на них отвечали ${ }^{34}$. При мумиях

\footnotetext{
${ }^{29}$ Обзор основных находок в этой области до 1997 г. см. Kaulicke 1997: 7-54.

${ }^{30}$ Kaulicke 1997: 25.

${ }^{31}$ Обзор ключевых описаний похоронных обрядов у хронистов см. Negro 1996: 125127. Хотя императорские мумии инков не сохранились, археологические исследования погребений знати этого периода (Andrushko, Torres Pino y Bellifemine 2006: 63-92) в целом подтверждают данные хронистов.

${ }^{32}$ Calancha 1638: 555.

33 Anello 1895: 134; Arriaga 1621: 14,34; AAL. Serie Hechicerías e idolatrías. Leg. 3:8. 1656: 2; AAL. Serie Hechicerías e idolatrías. Leg. I:14. 1604: 2.

${ }^{34}$ Cieza 2005: 63.
} 
инков состояли специальные служащие, главной обязанностью которых было толкование слов мумифицированных предков ${ }^{35}$.

Реализация постоянных контактов с телами умерших требует соответствующих погребальных сооружений. Во многих андских культурах они строились таким образом, чтобы обеспечить беспрепятственный доступ к телам предков, а в некоторых случаях и возможность последующих захоронений ${ }^{36}$. Типы погребальных сооружений Анд крайне разнообразны и неоднородны даже в рамках отдельных культур, но эта особенность - обеспечение доступа к телам предков - объединяет погребения разных андских культур и эпох. В этом отношении очень показателен один из мавзолеев культуры Рекуай. Он спроектирован таким образом, что человек, входивший в него, был вынужден совершать все необходимые манипуляции в полусогнутом состоянии. Это заведомо ставило посетителя в подчиненное по отношению к усопшим положение, подчеркивало почтительное к ним отношение. Размеры гробницы не позволяли находиться там сразу нескольким людям, что лишний раз придавало акту общения с мертвыми сокровенность и даже интимность $^{37}$. Такая организация пространства гробниц не была повсеместно распространенной, хотя и встречается нередко в разных вариациях: например, когда входная дверь была настолько низкой, что попасть внутрь можно было только ползком ${ }^{38}$. Тем не менее, этот пример весьма характерен с точки зрения взаимодействия живых и мертвых. Андские погребения с открытым доступом нередко были коллективными; есть сведения, что количество тел в таких погребениях могло превышать сотню $^{39}$. Впрочем, не исключено, что такие цифры вызваны несовершенством расчетов или тем, что в период борьбы с идолопоклонством индейцы прятали тела представителей разных родов в одной пещере. Однако доказано, что в некоторых особо крупных мавзолеях могло покоиться одновременно несколько десятков человек ${ }^{40}$.

Вопрос регулярных ритуалов с мумиями в более позднее время известен преимущественно на инкском и колониальном материале и уже довольно хорошо изучен ${ }^{41}$, поэтому здесь имеет смысл подробнее остановиться лишь на наиболее существенных и характерных моментах.

\footnotetext{
35 Alonso 1989: 113.

${ }^{36}$ Наиболее подробно этот вопрос исследован на материале культур горных областей Перу (Isbell 1997). Однако данный обычай не был повсеместным: представители прибрежных культур (самая известная из них - культура Моче) погребали своих умерших преимущественно в земляных могилах, а также в гробницах, куда не осуществлялся доступ после захоронения (Alva 2001; Arriola 2015: 186-209; Isla and Reindel 2006: 380-381).

${ }^{37}$ Lau 2011: 114.

${ }^{38}$ Hrdlička 1914: 6; Squier 1877: 353.

${ }^{39}$ Hrdlička 1914: 38.

40 В частности, в недавно найденном неразграбленном захоронении культуры Уари обнаружены останки 71 человека. - Wieckowsky 2014: 216.

${ }^{41}$ Alonso Sagazeta 1989: 109-135; MacCormack 1991: 94-96; Isbell 1997: 39-68.
} 
Важным элементом многих инкских календарных праздников был вынос мумий и отправление традиционных ритуалов «кормления» и переодевания ${ }^{42}$. Это был четко установленный канон, его нарушение грозило неприятностями и неудачами социуму и государству, но есть данные, что аналогичные ритуалы совершались не только в четко установленное, но и во «внеурочное» время. В частности, больному предписывалось дополнительно покормить и напоить умерших предков ${ }^{43}$, дабы они поспособствовали выздоровлению своего потомка. Сообщение Кристобаля де Молина не очень конкретно относительно подробностей такого ритуала. Однако нет причин сомневаться, что это кормление было аналогично обрядам, которые проводились и по другим поводам.

В Андах традиционно сильно представление о связи мертвых с водой. В инкское время эти представления стали объектом эксплуатации со стороны государства. Например, шестой инкский правитель Инка Рока прославился в том числе тем, что обеспечил долину Куско необходимым количеством воды для сельского хозяйства (вероятно, посредством строительства каналов). В результате его мумия стала использоваться в ритуалах для привлечения дождя: «Когда была нужда в воде для посевов, его имели обыкновение носить в процессии, богато одетого и с закрытым лицом [...] верили, что он способствует дождям» ${ }^{44}$. Схожие представления фиксируются и на материале культуры Моче: в двух захоронениях из одного городища обнаружены следы вскрытия подношений во время проливных дождей ${ }^{45}$.

Оставляя в стороне политические и социальные коннотации этого обычая, отметим, что он демонстрирует важность непосредственного контакта для достижения требуемого эффекта; веру в сакральное и физическое присутствие предка, благодаря чему он имеет возможность оказывать воздействие на окружающую действительность. Вероятно, при этом важен и статус предка при жизни: чем он выше, тем более значительны возможности этого предка влиять на жизнь потомков. Таким образом, почитаемыми в течение длительного времени мумиями становились тела лишь тех, кто мог передать определенные полномочия, связанные со статусом и контролем над ресурсами ${ }^{46}$, чем объясняется активное использование мумий правителей с целью повлиять на стихии. Это соображение подкрепляется данными о том, что в период борьбы с идолопоклонством индейцы стремились перезахоронить именно тела курак ${ }^{47}$, т.е. наиболее знатных и влиятельных членов общины.

В колониальную эпоху, когда во многих случаях непосредственный контакт с телами умерших был невозможен, индейцы порой ис-

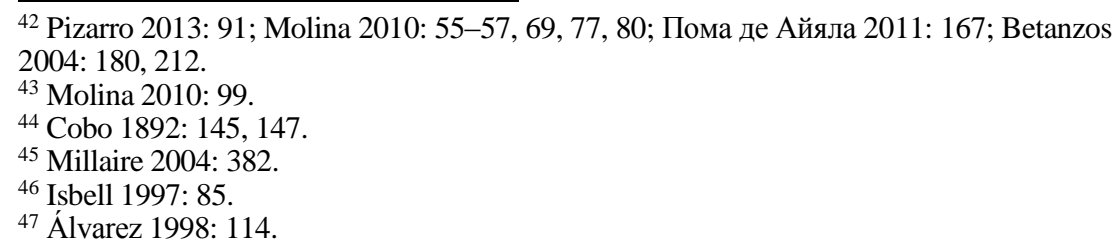


пользовали определенные их части: «...они отрезают ногти на ногах и руках и несколько волос; и это, завернутое в коку и связанное тканью, они относят, чтобы похоронить в месте, где им следует почитать его» ${ }^{48}$. Схожим образом можно интерпретировать и сведения о том, что после сожжения испанцами мумии восьмого инкского правителя Виракочи индейцы сохранили пепел, который впоследствии был обнаружен с мумиями других инков ${ }^{49}$. Определенные части тела умерших использовались в ритуалах и в доиспанский период; наиболее известные примеры трофейные головы, получившие широкое распространение в некоторых доинкских культурах ${ }^{50}$, а также характерные для культуры Моче ритуальные перезахоронения отдельных частей тела ${ }^{51}$. Имеются сообщения о том, что инки использовали прах, внутренности, а также ногти и волосы для создания «двойников» царских мумий ${ }^{52}$. Но обычай, упомянутый в сообщении Бартоломе Альвареса, все же иного порядка. Эта ритуальная метонимия была вынужденной и в какой-то мере суррогатной, поскольку в Андах ногти и волосы как таковые все же не рассматривались как особо значимые части тела, хотя и есть свидетельства их использования в колдовских целях ${ }^{53}$. При этом нельзя исключать, что под «различными чародействами» (diversas hechicerías) подразумевается то же самое, т.е. использование волос и ногтей как заменителей целого тела.

Несмотря на свидетельства того, что в ряде случаев почитание предков и их мумий продолжалось и после физического уничтожения последних $^{54}$, в долгосрочной перспективе эта традиция оказалась весьма уязвимой и в итоге прекратила свое существование. Одна из главных причин, на мой взгляд, заключается в том, что с уничтожением мумий делался невозможным физический контакт с ними. И наоборот - там, где это непосредственное взаимодействие было и остается возможным (в случае с землей, камнями, горами и т.п.), почитание соответствующих субстанций и связанные с этим ритуалы и представления по-прежнему являются живым компонентом мировоззрения ${ }^{55}$. Налицо тот факт, что именно физический контакт был/является в рамках Адской цивилизации одним из важнейших компонентов взаимодействия со сферой сакрального, в том числе взаимодействия живых и мертвых.

Какие выводы об отношении к мертвому телу в Андах рассматриваемого периода можно сделать на основе приведенных данных? Выше уже подчеркивалось, что источники подтверждают факт необходимости

\footnotetext{
48 Álvarez 1998: 116.

${ }^{49}$ Isbell 1997: 55. 2018: 235-252; Proulx 2001: 119-136. Burmeister 2008: 314.

52 Betanzos 2004: 212; Isbell 1997: 56-57.

53 Ondegardo 1916: 194.

${ }^{54}$ MacCormac. 1991: 410.

${ }^{55}$ Mannheim 2019: 269; Marzal 1983: 212; Janusek 2015: 335-365.
}

${ }^{50}$ Verano 2008: 1047-1060; Blom and Couture 2018: 205-221; Becker and Alconini

${ }^{51}$ Millaire 2004: 371-288; Alva 2001: 235, 240; Belkus Guitiéres 2008: 245-259; Prieto 
физического контакта между живыми и мертвыми. В рамках погребальных обычаев это касается всех покойных вне зависимости от их социального статуса. На уровне постпогребальном продолжительное взаимодействие с мертвым телом осуществлялось, скорее всего, в тех случаях, когда покойный принадлежал к верхушке общества или заслужил от общины особую благодарность за свои заслуги.

Какие возможные мировоззренческие последствия имел этот постоянный физический контакт? Очевидно, в Андской цивилизации (по крайней мере, в заданном временном отрезке) сформировалось особое отношение к мертвому телу, в рамках которого отсутствовало его восприятие как нечистой субстанции. Известно, что во многих религиях труп воспринимается как ритуально нечистый объект; относительно же Анд, на наш взгляд, нет оснований предполагать существование подобных представлений. Те ритуалы и обычаи, которые могут быть интерпретированы как свидетельства бытования таких представлений (в частности, зафиксированный в раннеколониальное время обычай стирать одежду умершего $\left.{ }^{56}\right)$, скорее иллюстрируют переход человека из одного состояния в другое, чем нечистоту его тела в процессе этого перехода.

Для того чтобы лучше показать динамику этих представлений, приведем некоторый материал по современному состоянию андского видения мертвого тела.

Налицо кардинальное переосмысление некогда фундаментальной для андской культуры мировоззренческой концепции. Тем не менее, определенная преемственность с доиспанским и раннеколониальным периодом все же имеет место. Несмотря на то, что в современной андской ритуальной практике физический контакт с телами умерших сильно урезан по сравнению с доиспанским периодом, некоторые традиции еще носят в себе следы того, что в прошлом картина была иной. Один из наиболее ярких примеров - зафиксированный среди индейцев Куско следующий обычай. Гости, заходя в дом, где есть покойник, первым делом обнимают его, прося таким образом прощения. Если этого не сделать, то умерший может начать мстить живым ${ }^{57}$. Еще одним примером такого порядка можно считать традицию, распространенную среди индейцев аймара в районе озера Титикака. На день всех святых там принято устанавливать алтари с подношениями мертвым и с фигурками из хлеба в виде человеческих фигур ${ }^{58}$. Еще один обычай некоторых аймара - делать символическое изображение умершего, для чего использовалась его одежда ${ }^{59}$. Все эти предметы символизируют не только души умерших, но и их тела. Конечно, это лишь отголоски былых представлений, ныне практически забытых. Некоторые исследователи отмечают обычай по сохранению древних мумий или костей предков современ-

\footnotetext{
56 Arriaga 1621: 34.

57 Cáceres Chalco 2001: 190-192.

${ }^{58}$ Fernández 2001: 211-212.

${ }^{59}$ Onofre 2001: 242.
} 
ными индейцами ${ }^{60}$, но такие сообщения крайне редки и существенно не меняют общей картины.

В то же время фиксируются обряды и обычаи, показывающие отношение к мертвому телу как к чему-то нечистому, например, обычай выливать воду, в которой стиралась одежда умершего, на перекрестке дорог ${ }^{61}$, а также взгляд на тело как на нечто вредоносное, чего стоит пугаться. В связи с этим упомянем запрет на участие в похоронах детей и женщин, зафиксированный во многих областях Анд ${ }^{62}$, из страха, что мертвец может им навредить. При этом в некоторых общинах бытует страх, что душа умершего опасна для всех живых все зависимости от возраста и пола ${ }^{63}$. В некоторых областях родственники из аналогичных опасений не участвуют в выносе тела ${ }^{64}$. Сюда же относится и зафиксированное в отдельных регионах Боливии представление о том, что мумии, которых находят при раскопках, могут вызывать эпидемии ${ }^{65}$.

К особой категории можно отнести обычаи с общей семантикой как в христианстве, так и в андском мировоззрении. Речь идет прежде всего о семантике цвета, связанном с мертвыми: в обоих случаях таковым выступает черный. Черный в качестве траурного цвета и символа смерти зафиксирован как в источниках колониальной эпохи ${ }^{66}$, так и в современных этнографических материалах ${ }^{67}$. На наш взгляд, здесь идет речь об универсальной категории, поэтому не приходится говорить о каком-то влиянии одной мировоззренческой концепции на другую.

Данные этнографии показывают, что отношение современных индейцев к мертвому телу скорее ближе к христианству, чем к «традиционным», доиспанским и раннеколониальным верованиям. Можно сделать вывод, что как таковые постпогребальные обряды отошли в прошлое; как их реликт могут рассматриваться ритуалы во время праздника всех святых, которые заключаются в подношении кушаний к могилам и обустройства в домах специальных алтарей ${ }^{68}$. Семантически эти современные обычаи имеют мало общего с более ранними, поскольку в них отсутствует такой объединяющий элемент, как почитание общего предка обширными группами людей.

Относительно причин такой трансформации отношения к мертвому телу трудно прийти к однозначному выводу. С одной стороны, невозможно отрицать влияние христианства и в целом порядков, установленных в Перу после прихода испанцев, тем более что они находились

${ }^{60}$ Bugallo y Mario Vilca 2016: 33-35, 85 .

${ }^{61}$ Fernández 2001: 204.

${ }^{62}$ Fernández 2001: 203; Onofre 2001: 240; Ortega 2001: 253.

${ }^{63}$ Harris 1983: 138, 140.

${ }^{64}$ Bascopé Caero 2001: 274.

${ }^{65}$ Spedding 2008: 74; Bugallo y Mario Vilca 2016: 355.

${ }^{66}$ Cobo 1893: 237; AAL. Serie Hechicerías e idolatrías. Leg. I:14. 1604: 2.

${ }^{67}$ Например, Abercrombie 1998: 337. При этом есть сведения 40-х гг. ХIX в. о том, что траурным цветом перуанских индейцев был темно-синий (Tschudi 1847: 480).

${ }^{68}$ Irarrazaval 1999: 51, Sendón y Manríquez 2016: 415-431. 
в прямой конфронтации с соответствующими элементами индейских воззрений. С другой - нельзя сбрасывать со счетов и такой фактор, как развитие и внутренние трансформации самого андского мировоззрения.

На протяжении веков в Андах такие консервативные элементы мировоззрения, как погребальные обряды и отношение к мертвому телу, не оставались неизменными. Мы полагаем, что более тщательные исследования как до, так и после заданного нами хронологического промежутка могут показать еще большую вариативность и адаптивность этого мировоззренческого компонента.

\section{БИБЛИОГРАФИЯ / REFERENCES}

Браун П. Культ святых. Его становление и роль в латинском христианстве. М.: РОССПЭН, 2004. 207 c. [Braun P. Kult svyatih. Ego Stanovleniye i rol v latinskom hristianstve. / Per. s angl. M.: ROSSPEN, 2004. 207 s.]

Ганцфрид С. Кицур Шульман Арух. М.: Издатель Л. Городецкий, 2012. 590 с. [Gantsfrid S. Kitsur Shulman Aruh. M.: Isdatel L. Gorodetskiy, 2012. 590 s.]

Мейтарчиян М.Б. Погребальные обряды зороастрийцев. М.; СПб.: Институт востоковедения РАН; Летний сад, 2001. 248 с. [Meytarchiyan M.B. Pogrebalniye obryadi zoroanstriytsev. M., SPb: Institut Vostokovedeniya RAN, Letniy sad, 2001. 248 s.]

Пома де Айяла Ф. де. Первая новая хроника и доброе правление. М.: Памятники исторической мысли. 2011. 291 с. [Poma de Ayala F. de. Pervaya novaya hronika i dobroye pravleniye. M.: Pamyatniki istoricheskoy misli, 2011. $291 \mathrm{s.]}$

AAL. Serie Hechicerías e idolatrías. Leg. I:14. 1604.

AAL. Serie Hechicerías e idolatrías. Leg. 3:8. 1656.

Abercrombie T.A. Pathways of memory and power. Ethnography and history among an Andean people. Madison: University of Wisconsin Press, 1998. 603 p.

Acosta A. Prácticas coloniales de la iglesia en el Perú. Siglos XVI y XVII. Sevilla: Aconcagua Libros, 2014. 424 p.

Álvarez B. De las costumbres y conversión de los indios del Perú. Madrid: Ediciones Polifemo, 1998. $462 \mathrm{p}$.

Alonso Sagazeta A. Las momias de los incas: su función y realidad social // Revista española de Antropología Americana. 1989. №19. P. 109-135.

Alva W. The royal tombs of Sipán: art and power in Moche society // Studies in the history of art. 2001. Vol. 63. P. 222-245.

Andrushko V.A., Torres Pino E.C., Bellifemine V. The burials at Sacsauaman and Chokepukio: a bioarchaeological case study of imperialism from the capital of the Inca empire // Nawpa Pacha: Journal of Andean Archaeology. 2006. №28. P. 63-92.

Anello O. Historia del reino y provincias del Perú, de sus incas reyes, descubrimiento y concernientes la historia. Lima: Imprenta y librería de S. Pedro, 1895. 217 p.

Angenendt A. Heilige und Reliquien. Die Geschichte ihres Kultes vom frühen Christentum bis zur Gegenwart. München: Verlag C. H. Beck, 1994. 470 S.

Arriaga P. J. de. Extirpación de la idolatría del Perú. Lima: Geronimo de Contreras, 1621. 157 p.

Arriola L.D.The Preparation of Corpses and Mummy Bundles in Ychsma Funerary Practices at Armatambo // Funerary practices and models in the ancient Andes. The return of the living dead. Cambridge: Cambridge University Press, 2015. P. 186-209.

Bascopé Caero V. Eñ sentido de la muerte en la cosmovisión andina: el caso de los valles andinos de Cochabamba // Chungara: Revista de Antropología Chilena. 2001. Vol. 33. № 2. P. 271-277.

Becker S.K., Alconini S. Violence, Power, and Head Extraction in the Kallawaya Region, Bolivia // Social Skins of the Head. Body Beliefs and Ritual in Ancient Mesoamerica and the Andes. Albuquerque: University of New Mexico Press. 2018. P. 235-252.

Belkus Guitiéres L. Plataforma Uhle: enterrando y desenterrando muertos // Arqueología mochica: nuevos enfoques. Lima: PUCP, 2008. P. 245-259.

Betanzos J. de. Suma y narración de los incas. Madrid: Ediciones Polifemo, 2004. 355 p. 
Blom D.E., Couture N.C. From Wawa to "Trophy Head". Meaning, Representation, and Bioarchaeology of Human Heads from Ancient Tiwanaku // Social Skins of the Head. Body Beliefs and Ritual in Ancient Mesoamerica and the Andes. Albuquerque: University of New Mexico Press. 2018. P. 205-221.

Bugallo L., Valca M. Wa`kas, diablos y muertos: alteridades significantes en el mundo andino. Jujuy: Universidad Nacional de Jujuy, 2016.

Cáceres Chalco E. La muerte como sanción y compensación: visión de equilibrio y reciprocidad en Cusco // Chungara: Revista de Antropología Chilena. 2001. Vol. 33. №2. P. 187-200.

Calancha A. de la. Coronica moralizada. Barcelona: Pedro Lacavalleria, 1638. 922 p.

Cieza de León P. de. Crónica del Perú. El señorío de los incas.Caracas: Biblioteca Ayacucho, 2005. 497 p.

Cobo B. Historia del Nuevo Mundo. T.III. Sevilla: Imprenta de E. Rasco, 1892. 350 p.

Cobo B. Historia del Nuevo Mundo. T.IV. T.IV. Sevilla: Imprenta de E. Rasco, 1893. 245 p.

Duviols P. Cultura andina y represión: Procesos y visitas de idolatrías y hechicerías Cajatambo, s. XVII. Cuzco: Centro de Estudios Rurales Andinos Bartolomé de las Casas, 1986. 570 p.

Escalante M.E. La raiz del mal: la extirpación de la idolatría en el Perú colonial. Lima: Pakarina, 2016. $148 \mathrm{p}$.

Fernández Juárez G. Almas y difuntos ritos mortuorios entre los aymara lacustres del Titicaca // Chungara: Revista de Antropología Chilena. 2001. Vol. 33. №2. P. 201-219.

Gareis I. Las religiones andinas en la documentación de la extirpación de las idolatrías // Religiones andinas. Madrid: Enciclopedia Iberoamericana de Religiones, 2005. P. 115-142.

Gil García F.M. Donde los muertos no mueren. Culto a los antepasados y reproducción social en el mundo andino. Una discusión orientada a los manejos del tiempo y espacio // Anales del Museo de América. 2002. №10. P. 59-83.

Gruzinski S. De la idolatría. Una arqueología de la ciencias religiosas. México: Fondo de Cultura Econónica, 1992. $226 \mathrm{p}$.

Guillén S.E. Mummies, cults and ancestors. The Chichoro mummies of the South Central Andes // Interacting with the dead: perspectives on mortuary archaeology for the new millennium. Gainesville: University Press of Florida, 2005. P. 142-149.

Harris O. Los muertos y los diablos entre los laymi de Bolivia // Revista Chungara. 1983. №11. P. 135-152.

Hrdlička A. Anthropological work in Peru in 1913, with notes on the pathology of the ancient Peruvians. City of Washington: Smithsonian Institution, 1914. 69 p.

Irarrazaval D. Un cristianismo andino. Quito: Abya-Yala, 1999. 238 p.

Isbell W. Mummies and mortuary monuments: a postprocessual prehistory on central Andean social organization. Austin: University of Texas press, 1997. $371 \mathrm{p}$.

Isla Y., Reindel M. Burial patterns and sociopolitical organization in Nasca 5 society // Andean Archaeology III: North and South. New York, 2006. P. 374-400.

Janusek J.W. Of monoliths and men. Human - lithic encounters and the production of an animistic ecology at Whonko Wankane // The archaeology of wak'as: exploration of the sacred in the pre-Columbian Andes. Colorado: University of Colorado Press, 2015. P. 335-365.

Kaulicke P. La muerte en el antiguo Perú. Contextos y conceptos funerarios: una introducción // Boletín de Arqueología PUCP. 1997. Vol.1. P. 7-54.

Latcham R.E. Costumbres mortuorias de los indios de Chile y otras partes de América // Anales de la Universidad de Chile. 1915. №73. P. 443-493.

Latcham R.E. Costumbres mortuorias de los indios de Chile y otras partes de América. Continuación // Anales de la Universidad de Chile. 1916. №74. P. 85-114.

Latcham R.E. Costumbres mortuorias de los indios de Chile y otras partes de América. Continuación // Anales de la Universidad de Chile. 1916. №74. P. 273-326.

Lau G.F. Andean expresions. Art and archaeology of the Recuay culture. Iowa City: University of Iowa Press, 2011. 338 p.

MacCormack S. Religion in the Andes. Vision and imagination in early colonial Peru. Princeton: Princeton University Press, 1991. 488 p.

Makowsky K. La religión de las altas culturas de la costa del Perú prehispánico // Religiones andinas. Madrid: Enciclopedia Iberoamericana de Religiones, 2005. P. 39-88.

Mannheim B. Lengua, cultura e historia entrelazadas // El estudio del mundo andino. Lima: PUCP, 2019. P. 267-273.

Marzal M. La transformación religiosa peruana. Lima: PUCP, 1983. 458 p. 
Millaire J.-F. The manipulation of human bones on the Peruvian north coast // Latin American Antiquity. 2004. Vol. 15. №4. P. 371-388.

Molina C. de. Relación de las fábulas y ritos de los incas. Madrid, Frankfurt am Main: Iberoamericana, Vervuert, 2010. 328 p.

Murúa M. de. Historia general del Perú. Madrid: Dastin, 2001. 571 p.

Negro S. La persistencia de la visión andina de la muerte en el virreinato del Perú // Antropologica. 1996. Vol. 14. P. 121-141.

Ondegardo P. de. Informaciones acerca de la religión y gobierno de los incas. Lima: Imprenta y librería Sanmarti y ca., 1916. 206 p.

Onofre Mamani L.D. Alma Imaña: rituales mortuorios andinos en las zonas rurales aymara de Puno circumlacustre (Perú) // Chungara: Revista de Antropología Chilena. 2001. Vol. 33. №2. P. 235-244.

Ortega Perrier M. Escatología andina: metáforas del alma // Chungara: Revista de Antropología Chilena. 2001. Vol. 33. №2. 3. 253-258.

Perez Bocanegra I. Formulario e institución de curas, para administrar a los naturales de este reino. Lima: Impreso por Geronimo de Contreras, $1631.720 \mathrm{p}$.

Pizarro P. Relación del descubrimiento y conquista de los reinos del Perú. Lima: Fondo de Cultura Económica, 2013. 236 p.

Prieto Burmester G. Rituales de enterramiento arquitectónico en el núcleo urbano moche: una aproximación desde una residencia de elite en el valle de Moche // Arqueología mochica: nuevos enfoques. Lima: PUCP, 2008. P. 307-323.

Proulx D.A. Ritual Uses of Trophy Heads in Ancient Nasca Society // Ritual sacrifice in ancient Peru. Austin: University of Austin Press, 2001. P. 119-136.

Santo Tomás D. de. Lexicon, o Vocabulario de la lengua general del Perú. Valladolid: Francisco Fernández de Córdova, 1560.

Segovia B. de. Conquista y población del Pirú, fundación de algunos pueblos.Lima: PUCP, 2019. $238 \mathrm{p}$.

Sendón P., Manríquez V. Altares para los muertos en los Andes // Anthropos. 2016. Bd. 111. P. 415-431.

Speding A.S. Religión en los Andes: extirpación de idolatrías y modernidad de la fe andina. La Paz: Instituto Superior Ecuménico Andino, 2008. 200 p.

Squier G. Peru: incidents of travel and exploration in the land of the Incas. New York Harper and Brothers, $1877.599 \mathrm{p}$.

Tschudi J. J. von. Travels in Peru. London: David Bogue, 1847. 506 p.

Verano J.W. Trophy head-taking and human sacrifice in Andean South America // Handbook of South American Archaeology. New York: Springer, 2008. P. 1047-1060.

Wieckowsky W. Los rituales funerarios y la identidad de los difuntos en el mausoleo de Castillo de Huarmey // Castillo de Huarmey. El mausoleo imperial Wari. Lima: MALI, 2014. P. 211-221.

Новосёлова Елена Владимировна, кандидат исторических наук, стариий преподаватель, МИРЭА - Российский технологический университет; e-mail: HelenaNovoselova@yandex.ru

\section{Dead body as an object of sensory perception in the space of the Andean civilization}

The article is dedicated to the attitude to the dead body, which existed among the representatives of the Andean civilization mainly in the $15^{\text {th }}-17^{\text {th }}$ centuries. The author analyzes funeral customs and representations recorded in written (including archival) and material sources. It is concluded that in the Andean civilization of the period under review, there was an idea of the need for regular physical contact between livings and dead bodies, which left an imprint on the idea of a dead body. But when this contact became very difficult or impossible, these representations underwent a transformation. Presently the Andean attitude to the dead body is closer to the Christian one.

Keywords: Andean civilization, funeral rites, mummification, sacrifice, sacrality

Elena Novoselova, PhD (History), Senior Lecturer, MIREA - Russian Technological University; e-mail: Helena-Novoselova@yandex.ru 


\section{O.B. ОКУНЕВA}

\section{МАЛЕНЬКИЙ ОСТРОВ БОЛЬШИХ ЛИШЕНИЙ \\ ВЗГЛЯД НА «АНТАРКТИЧЕСКУЮ ФРАНЦИЮ» В БРАЗИЛИИ КАК НА ПРОСТРАНСТВО СЕНСОРНОЙ ДЕПРИВАЦИИ}

В статье на примере истории первой французской колонии в Бразилии (1555-1560) рассматривается проблематика использования пространства сенсорной депривации в качестве инструмента властных отношений. Сохранившиеся свидетельства о тяготах и лишениях колонистов повествуют об ограниченности пространства, недостаточности запасов продовольствия одновременно с отсутствием привычных продуктов питания, а также жесткой и временами жестокой регламентацией главы колонии. Наряду с выявлением уникальной и верифицируемой информации источников статья затрагивает проблематику конструирования авторами XVI века определённых образов с помощью литературных приёмов.

Ключевые слова: «Антарктическая Франция», Бразилия, раннее новое время, сенсорная депривация, дискурсивные стратегии

Начавшаяся весной 2020 г. пандемия коронавирусной инфекции и введение по всему миру различных ограничений и карантинных мер не только значительно изменили привычный уклад жизни людей, но и привлекли внимание исследователей к проблемам переживания изоляции и лишений в разные исторические эпохи. Отсутствие привычных сигналов от органов чувств, нахождение в замкнутом пространстве, ограничение свободы и невозможность действовать по собственному усмотрению - подобные ситуации неоднократно возникали во времена войн и осад, в длительных морских плаваниях и изнурительных пеших переходах, в ходе тюремного заключения или нахождения в плену. Изоляция от внешнего мира с его изобилием раздражителей и однообразная среда практически всегда рассматривались в качестве наказания (хотя индивид мог и добровольно выбрать для себя путь воздержания, аскезы, затворничества и т.п.). Насильственное удержание человека в этом состоянии - один из механизмов осуществления власти индивида/группы лиц над окружающими, выстраивания и поддержания различных иерархий.

Проблема использования пространства сенсорной депривации в качестве инструмента властных отношений будет рассмотрена на примере истории первой французской колонии на атлантическом побережье Бразилии. Поселение под названием «Антарктическая Франция» (1555$1560)$ было основано не только в новой и во многом чуждой европейцам среде, лишённой знакомых ориентиров и привычных сигналов от органов чувств, но и - из военно-стратегических соображений - располагалось на маленьком острове, что создавало специфический эффект изоляции и лишений в пространстве, которое, напротив, изобиловало экзотической сенсорной информацией. Хотя «Антарктическая Франция» просуществовала всего несколько лет, сохранились свидетельства о тяготах существования там рядовых колонистов, что было связано с ограничен- 
ностью пространства, недостатком припасов и отсутствием привычных продуктов питания, жёсткой и временами жестокой регламентацией со стороны руководителя колонии (и даже его самодурством).

Впрочем, необходимо сразу же оговорить, что массив свидетельств о бразильской колонии складывался в условиях идеологического противостояния католиков и протестантов накануне и во время Религиозных войн во Франции и, кроме того, во многом создавался постфактум, что нельзя не учитывать при анализе ${ }^{1}$. Так, сведения об ужасных лишениях обычных колонистов и о непомерной тирании главы колонии, Николя Дюрана де Вильганьона, исходят в основном от противников последнего. В тот момент, когда Вильганьон возглавил экспедицию в Бразилию, он испытывал симпатии к протестантизму и благодаря этому получил поддержку адмирала Гаспара де Колиньи. Основав колонию, Вильганьон даже обратился к Жану Кальвину в Женеву с просьбой прислать для него проповедников, что и было сделано. В дальнейшем он рассорился с посланцами Кальвина, изгнал их из колонии, сам же вернулся в католичество. И протестанты, и Вильганьон разными путями вернулись из Бразилии во Францию, а поселение вскоре было захвачено португальцами.

Уже во Франции Вильганьон проявил себя ревностным католиком, а протестанты развернули против него настоящую памфлетную войну, стремясь как можно сильнее его очернить и порой в этом преуспевая ${ }^{2}$. Причем многие мотивы обвинений относятся к проблематике властных отношений на фоне сенсорной депривации или негативного чувственного опыта. Часть из них находит отражение и в других источниках, менее заинтересованных в очернении Вильганьона.

Первым таким перекрёстно подтверждённым фактом являются размеры колонии на острове: один лье или около того в окружности по одним сообщениям ${ }^{3}$, половина французского лье в окружности при соотношении длины к ширине как 6 к 1 по другим ${ }^{4}, 600$ шагов в длину и около сотни в ширину по третьим ${ }^{5}$. Диапазон характеристик простирался от «весьма приятного благодаря большому количеству пальм, кедров... и ароматических кустарников, зеленеющих круглый год» ${ }^{6}$ до «пустынного и кишащего опасными тварями и змеями» ${ }^{7}$. С практической точки зрения у острова был один важный недостаток - отсутствие соб-

\footnotetext{
${ }^{1}$ Подробнее см.: Окунева 2013:179-200.
}

2 Показательным примером такой риторики является следующее произведение: Ode contenant vne briefue description de Villegaignon au Bresil, \& des cruautez qu'il y a exercees // La Response aux lettres, s.d.: 6v-10. Об образе Вильганьона-предателя см. также: Окунева 2012: 139-166.

${ }^{3}$ Thevet 1557: 118; Thevet 1575: 11.

${ }^{4}$ Léry 1578: 199-200.

5 Barré 1557: 384.

6 Thevet 1557: 118. Интересно, что когда в следующем своём сочинении о Бразилии 1575 г. Теве почти дословно воспроизвёл это же описание, единственным значимым различием стало всего одно слово: из «весьма приятного» (fort plaisante) в 1557 г. остров стал «довольно приятным» (assez plaisante). - Thevet 1575: 16.

${ }^{7}$ Richer 1562: 15. 
ственных источников пресной воды. Даже сторонники Вильганьона не замалчивали этого факта: так, автор первого сочинения об «Антарктической Франции» Андре Теве в 1557 г. сообщал: «верно и то, что [здесь] нет пресной воды, которая не сыскалась бы довольно далеко отсюда» ${ }^{8}$, a в 1575 г. писал уже более определённо, что «значительным неудобством этого острова является отсутствие пресной воды: на нём самом не найти ни единой капельки, а искать её надо на материке на расстоянии половины лье отсюда» ${ }^{9}$. Ещё в момент обустройства колонии деятельный по натуре лейтенант экспедиции Николя Барре оптимистично утверждал, что проблему решит цистерна с запасом пресной влаги на полгода ${ }^{10}$. Отведавший же из неё воды Жан де Лери оценил её так: «она была столь же зелена, скверна и грязна, как вода из заброшенной канавы, кишащей лягушками» ${ }^{11}$. Другой протестантский автор развил идею Лери: «напитком [колонистов] была порченая и вонючая вода из грязной цистерны, что было скорее ядом для человеческого тела, нежели пропитанием» ${ }^{12}$.

В результате воду, как и продовольствие, доставляли с материка на кораблях и шлюпках колонистов, а также на индейских челноках; выход из строя плавсредств, принадлежащих французам, ставил под удар всю жизнедеятельность колонии, поскольку и вода, и съестные припасы, и дерево доставлялись исключительно кораблями ${ }^{13}$.

Схожая ситуация сложилась с продовольствием. Старых запасов из Франции не хватало, а местной пищи вроде бы было в изобилии, но она, с одной стороны, была непривычной, а с другой стороны, её поставки требовали постоянных контактов с индейцами с материка. Подавляющее большинство французских путешественников в Бразилию XVI начала XVII в. сходилось во мнении, что у индейских союзников всегда можно выменять достаточное количество и дичи, и рыбы, и маниока, а расплатиться за припасы можно парой безделушек вроде гребня, бус, рыболовных крючков. На это же, судя по всему, рассчитывал и Вильганьон, но дело не заладилось. Постоянным мотивом свидетельств о жизни колонистов стали жалобы на скудость рациона при непомерном физическом труде. Идея лишений, претерпеваемых в далёком краю, с готовностью подхватывалась полемистами из обоих лагерей. Протестанты говорили о лишениях то как о следствии дурного управления Вильганьона, то как о жертве, которую они с радостью приносили Богу ради распространения Его слова за пределами Старого Света. В свою очередь, сторонники Вильганьона и он сам возлагали ответственность за неурядицы в колонии на смутьянов-проповедников и именно их представляли виновными в том, что тяжёлый труд по обустройству колонии и все связанные с этим тяготы и лишения в результате оказались напрасными.

\footnotetext{
${ }^{8}$ Thevet 1557: 118.

${ }^{9}$ Thevet 1575: 16.

${ }^{10}$ Barré 1557: 385.

${ }^{11}$ Léry 1578: 146.

${ }^{12}$ Histoire des choses mémorables 1561: 26.

${ }^{13}$ Barré 1557: 385.
} 
У лейтенанта экспедиции Н. Барре мы находим любопытное, хотя и сделанное мимоходом замечание о предполагаемой организации питания в колонии: весь пассаж посвящён сложности перехода с одного вида пищи на другой из-за необходимости экономить оставшиеся от плавания припасы, поэтому интересующая информация остаётся в тени. Однако она находит неожиданное подтверждение в полемическом протестантском сочинении, после чего можно говорить уже не о уникальном, а о перекрёстно зафиксированном свидетельстве. Речь идёт о следующем утверждении Барре: «Из тех припасов, что мы привезли из Франции, чтобь использовать здесь (выделено мной $-O . O$ ), с первого дня пришлось оставить сидр, а пить взамен сырую воду, вместо же сухарей... приноровиться к некоей местной муке» ${ }^{14}$. Сравнение с другим источником позволяет отчасти подтвердить, а отчасти нюансировать утверждение Барре: речь идёт не столько о намерениях Вильганьона, сколько о том, чего от него ожидали будущие колонисты:

Отправляясь из Гавра, пассажиры совершенно не озаботились выяснением, загрузил ли Вильганьон на корабли припасы для тех, кому предстояло жить [в колонии], что было бы разумным. Поэтому, прибыв на место и узнав, что припасов для их пропитания нет, они сочли весьма странной и возмутительной необходимость питаться исключительно местной пищей - фруктами и кореньями вместо хлеба и водой вместо вина, да ещё в таких малых количествах, что один человек с лёгкостью съел бы порцию, предназначавшуюся четверым...

Верно и то, что моряки, недавно возвратившиеся из тех краёв, давали понять, что в той местности достаточно припасов для пропитания отправившихся туда людей, оттого не было необходимости загружать [продовольствием] корабли из Франции. Таковы были ответ и оправдание вышеупомянутого Вильганьона, чтобы очистить себя от этого обвинения ${ }^{15}$.

Желающие обвинить Вильганьона в дурном управлении колонией использовали ту же идею (питание корабельным провиантом уже после высадки в Бразилии) уже в ином ключе - не как изначальное намерение, а как вынужденную необходимость - и изображали честолюбца Вильганьона рассылающим письма о своих небывалых успехах, в то время как в реальности у него не было ни денег, ни зерна, ни рабочих с ремесленниками, а питаться приходилось запасами с кораблей ${ }^{16}$.

Определение «припасы» («vivres») без дальнейших уточнений не позволяет обоснованно рассуждать о соотношении белковой (дичь, рыба) и углеводной (маниок) составляющей в рационе колонистов. Тем не менее у индейцев выменивался отнюдь не только маниок ${ }^{17}$, а сами французы занимались рыболовством и даже попытались посеять пшеницу и посадить виноградную лозу, хотя из этих попыток ничего не вышло.

\footnotetext{
${ }_{14}$ Barré 1557: 383.

${ }^{15}$ Histoire des choses mémorables 1561: 9v-10.

${ }^{16}$ Richer 1562: 19v.

17 «В том, что касается припасов, дикари приносят [Вильганьону] то, что водится в их краю: рыбу, крупную и мелкую дичь (поскольку они не держат у себя домашних животных), муку из тех кореньев, о которых мы уже говорили, но не хлеб и вино, и всё это за несколько дешёвых вещиц вроде маленьких ножиков разных видов и рыболовных крючков». - Thevet 1557: 118.
} 
Впрочем, представление о том, что рядовые колонисты питались горсточкой маниока в день, оказалось устойчивым. Когда же упоминание маниока казалось рассказчику недостаточным доказательством лишений, в ход шла тяжёлая артиллерия: изображение принципиально несъедобного для французов (например, змей) в качестве пропитания. Так, в изложении протестанта Рише, лютого противника Вильганьона, вторая партия колонистов по прибытии на остров занялась «рыболовством, натягиванием сетей, поиском кореньев и их очисткой, а также охотой на змей с целью их съесть» ${ }^{18}$.

Очевидно, что обеспечение продовольственной безопасности колонии на материке, при наличии доступа к пресной воде и самостоятельной, без оглядки на индейцев, охоте и рыболовстве происходило бы с меньшими трудозатратами. Из-за чего же обитателям «Антарктической Франции» приходилось терпеть столько неудобств и лишений? Теве утверждает, что причинами этого были военно-политические соображения ${ }^{19}$. Обосноваться на острове, а не на берегу действительно было сознательным решением Вильганьона. Остров был естественным образом защищён, и его стратегические преимущества признавали как друзья, так и недруги главы колонии ${ }^{20}$. В свою очередь, тот факт, что колония настолько зависела от индейцев, диктовал Вильганьону значительную сдержанность в отношениях с местными союзниками ${ }^{21}$.

Тем не менее, существовали области, где он не мог не проявить принципиальности. Так, значительную проблему представляло то, что индейцы обоих полов ходили обнажёнными, а местные обычаи гостеприимства предписывали предложить гостю на ночь женскую компанию. Очевидно, что это не могло не произвести эффекта на колонистов. Контраст подобной «свободы нравов» со строгими предписаниями христианской морали, а также вынужденным многомесячным воздержанием во время плавания через океан не мог не вызвать недовольства у рядовых членов колонии, многие из которых и без того отличались буйным нравом: их частично набрали по тюрьмам из числа осуждённых на галеры или на смертную казнь, поскольку достаточного количества добровольцев для отправки в Новый Свет не нашлось 22 .

${ }^{18}$ Richer 1562: 25v.

19 Thevet 1575: 16.

${ }^{20} \mathrm{Cp}$ : «[остров] наилучшим образом укреплён от природы» ([l'^̂le est] merveilleusement et naturellement forte); «это место прекрасно от природы и его легко удерживать» (lieu est naturellement beau et facile à garder). - Léry 1578: 119; Barré 1557: 379.

${ }^{21}$ Показательна здесь фраза из своеобразного «франко-индейского разговорника», в котором моделируются основные сценарии взаимоотношений французов с местными племенами: герой (француз) осведомляется у индейцев, не ненавидят ли они «нашего предводителя» (т.е. главу колонии). - Colloque de l'entrée ou arrivée en la terre du Brésil, entre les gens du pays nommez Tououpinambaoults, et Toupinenkins en langage sauvage et François // Léry 1578: 488.

22 Живописные детали подобного набора по тюрьмам Парижа и Руана приводит в своих мемуарах современник и земляк Вильганьона, католический священник Клод Атон: Mémoires de Claude Haton 1582:38. Факт рекрутирования личностей, «достой- 
Вильганьон, командовавший таким контингентом, разумеется, ввёл строжайшую дисциплину. Свободным индейским женщинам доступ на остров был запрещён ${ }^{23}$, походы в индейские деревни строго регламентрованы, любые контакты с индеанками разрешались только после женитьбы, а та была возможна исключительно при условии предварительного крещения местных жительниц. Кроме того, Вильганьон попытался запретить сожительство с индейскими женщинами не только у своих подчинённых, но и у тех французов, которые обосновались в Бразилии задолго до него и осуществляли роль торговых посредников и переводчиков. В случае с ними Вильганьон добился лишь частичного успеха, при этом вызвав их сильнейшее раздражение, вплоть до того, что они возглавили против него заговор (подробнее об этом ниже). Ж. де Лери, который в остальных случаях постоянно критикует Вильганьона, именно в вопросе морали и чистоты нравов хвалит главу колонии ${ }^{24}$. Впрочем, из лагеря недоброжелателей Вильганьона доносились и другие голоса: в Бразилии, мол, он потворствовал разврату подчинённых с индеанками и не препятствовал содомии в своём ближнем кругу ${ }^{25}$. Таким образом, даже единоверцы Лери и Рише, побывавшие в колонии в одно и то же время и наблюдавшие одни и те же действия Вильганьона, сделали из них два противоположных вывода.

Чем же предлагалось заниматься жителям «Антарктической Франции», запертым на небольшом островке без права его покидать? Выбор занятий был небольшим и сводился к труду по обеспечению физической безопасности колонии (возведение форта, укреплений, оборонительных сооружений) и безопасности продовольственной. Сетования на тяжёлый /непосильный /изнурительный труд содержатся во многих свидетельствах; противники Вильганьона охотно развивали этот мотив, сподвижники главы колонии упоминали о нём как об общем необходимом усилии, однако сам по себе этот факт никто не опровергал. В 1575 г., т.е. более двух десятилетий после событий, Теве счёл нужным вставить в рассказ об обустройстве поселения пассаж о том, что не одни лишь рядовые рабочие трудились над скорейшим возведением крепости, но и руководители не гнушались подать пример усердия ${ }^{26}$. Весьма вероятно, что эта вставка была ответом на многочисленные выпады протестантов против Вильганьона, требовавшего от рабочих непосильного труда - не

\footnotetext{
ных порки кнутом и исполненных дурного нрава» упоминается и в полемическом «анти-Вильганьоновском» сочинении протестанта П. Рише: Richer 1562: 15.

${ }^{23}$ Существует, однако, свидетельство Жана де Лери об индейских рабынях, которые содержались на острове, а по ночам, не в силах терпеть навязанную им под страхом телесных наказаний европейскую одежду, сбрасывали её и отправлялись разгуливать нагишом. - Léry 1578: 231-232. Подобное утверждение является единичным и не встречается в других источниках.

${ }^{24}$ Léry 1578: 180-181. Отметим также подтверждение этого запрета на сожительство христианина с язычницей у католика Теве: Thevet 1575: 19.

${ }^{25}$ Richer 1562: 28.

26 Thevet 1575: 11-12.
} 
только тяжёлого, но и усердного и спорого 27. Отозвавшийся на книгу Теве своим собственным сочинением о пребывании в Бразилии Жан де Лери сообщил о личном опыте работы на строительстве укреплений:

Уже на следующий день после приезда [речь идёт о второй партии колонистов], как и в дальнейшие дни, невзирая на нашу слабость и утомление после морского путешествия, вкупе с обычной в этих краях жарой и скудным пайком... Вильганьон заставил нас таскать землю и камни в свой форт с таким усердием..., что это отнюдь не походило на обращение любящего отца, каковым он обещал нам быть... Тем не менее мы были исполнены столь горячего желания завершить устройство этого поселения... что не было ни одного из нас, кто, превосходя предел своих сил, не включился бы с радостью в эту работу, хотя никто из нас не был привычен к такому ремеслу ${ }^{28}$.

Впрочем, в случае с Лери и его спутниками-протестантами подобный ударный и добровольный труд продолжался всего месяц, после чего вновь прибывшие сочли свои обязательства выполненными. Поскольку одновременно между ними и главой колонии нарастали противоречия по богословским вопросам, градус взаимного недовольства быстро повышался. Сочетание тяжёлого труда под жарким солнцем и скудного пропитания ещё до приезда протестантов стало почвой для заговора рядовых колонистов против Вильганьона. О нём сообщает Н. Барре: в начале 1556 г., т.е. два или три месяца спустя после прибытия в Бразилию, тридцать раздражённых своим бытом ремесленников и рабочих, при подстрекательстве переводчиков-старожилов, возмущённых новой дисциплиной, постановили от него избавиться, чтобы захватить богатства колонии, сбежать к индейцам и зажить на свободе. Барре отмечает «низкие» и «корыстные» мотивы заговорщиков, но не скрывает и объективных причин их недовольства многочисленными лишениями:

[Подстрекатель] обратился к тем ремесленникам и рабочим, которые, как он знал, жили в сожалениях, тяжком труде и скудной пище... Внезапная смена рациона [c сухарей на маниок и с сидра на воду] была сочтена странной даже ремесленниками, которые приехали лишь ради собственной наживы. Вдобавок к этому сложный переезд по морю, суровые и пустынные места обитания и невероятный труд, который им задавали из-за необходимости обосноваться там, где мы находились, [позволили подстрекателю] с лёгкостью их прельстить ${ }^{29}$.

Интересно, что участников первого заговора не только Барре, но и другой протестантский автор изображают, пусть и с некоторой долей сочувствия, но также презрительно - как «недалёких людей, мало или вовсе не сообразных с помыслами чести», «уверивших себя в том, что наложенное на них ярмо всё тяжелеет» и что их заговор оправдан борь-

\footnotetext{
27 «С рассвета и до заката одним нужно было дробить камни, другим - перетаскивать землю и рубить лес, учитывая, что место, время и обстоятельства требовали величайшего усердия и быстроты [diligence] ввиду опасности как от местных жителей, так и от португальцев, смертельных врагов французов в этих краях» - Histoire des choses mémorables 1561: 10v. Ср. у Лери: «[Вильганьон] заставил нас носить землю и камни в свой форт с таким усердием [diligence], что невзирая на испытываемые нами неудобства и слабость мы вынуждены были трудиться с утра до ночи»-Léry 1578: 165. ${ }^{28}$ Léry 1578: 165-166.

${ }^{29}$ Barré 1557: 383.
} 
бой с «жестоким игом рабства, которое на них хотели навесить против всех законов» ${ }^{30}$. Вильганьон избежал смерти и сурово наказал бунтовщиков, хотя зачинщики из числа переводчиков-старожилов оказались вне досягаемости; четверых колонистов заковали в кандалы, из них один прямо в кандалах бросился в море и утонул, другого удавили, а ещё двое были низведены до положения рабов ${ }^{31}$. «Оставшиеся служат без малейшего ропота», - не без удовлетворения отмечал Н. Барре ${ }^{32}$.

Тот же арсенал наказаний (кандалы, принудительные работы, сбрасывание со скалы и повешение /удавление) будет фигурировать во втором эпизоде расправы Вильганьона с мнимыми или реальными заговорщиками, на сей раз из числа протестантов. Именно этот второй эпизод и составил Вильганьону славу «Каина Америки», а казнённых им жертв протестанты возвели в ранг «первых мучеников Америки»; основной массив гневных и пристрастных обличений Вильганьона относится именно к нему, но, к счастью для исследователей, сохранились и ответы самого Вильганьона на выдвинутые обвинения, позволяющие представить его логику. Перекрёстное сравнение полемически окрашенных свидетельств интересно тем, что аргументы и эмоциональные высказывания сторон относятся к ситуации использования пространства сенсорной депривации в качестве инструмента властных отношений.

Канва событий, очищенная от проклятий в адрес Вильганьона, выглядит следующим образом. Кардинально разойдясь с Вильганьоном в вопросах толкования таинства евхаристии, протестанты сочли невозможным и далее подчиняться главе колонии. Они покинули остров Колиньи и обосновались на материке по соседству в ожидании попутного торгового корабля, с которым можно было бы вернуться в Европу. Когда через два месяца такой корабль зашёл в залив Гуанабара, протестанты с большим трудом уговорили капитана пустить их на борт. Но корабль оказался ветхим и ненадёжным: ещё не успев выйти в открытое море, он уже набрал в трюм воды. Пятеро протестантов устрашились плавания на таком судне и в последний момент предпочли вернуться на остров к Вильганьону. Тот же решил, что за ним собрались шпионить, а вся история с отъездом протестантов была разыграна для усыпления его бдительности. Через некоторое время, окончательно убедив себя в этом, он казнил троих вернувшихся, сохранив жизнь двоим.

В протестантской версии событий мотивы Вильганьона были объявлены плодом его больного воображения, чудовищной подозрительности и нечистой совести. Однако любопытным образом перечисление мотивов совпадает и у протестантов, и у самого Вильганьона ${ }^{33}$. Отметим также и то, насколько страхи главы колонии соотносились с реальным
${ }^{30}$ Histoire des choses mémorables 1561: 10v.
${ }^{31}$ Barré 1557: 384. По другим сведениям, двоим была устроена показательная казнь, а ещё двое были посажены в тюрьму в оковах и приговорены к принудительным об- щественным работам, пусть и не навсегда. - Histoire des choses mémorables 1561: 11v. 32 Barré 1557: 384.
${ }^{33}$ Histoire des choses mémorables 1561: 33v.; Les Propositions contentieuses, 1561: 5v-7. 
болезненным опытом первого заговора: и там, и там фигурировали изгнанные нежелательные элементы, боязнь восстания среди окрестных индейцев и угроза предательства со стороны собственного окружения. Даже исход двух эпизодов оказался почти идентичным: после первого заговора были в назидание остальным казнены двое, а двое других оставлены в живых; после эпизода с возвращением пятерых протестантов демонстративно казнили троих, двоим сохранили жизнь. Интересно и то, насколько совпадают выводы о пользе показательного применения силы, сделанные после первого эпизода лейтенантом Барре, а после второго - самим Вильганьоном: «оставшиеся живут без малейшего ропота и работают гораздо более усердно, чем раньше» (Барре), «сделав это, я легко удержал своих людей в страхе и в послушании» (Вильганьон).

Разумеется, изложение у протестантов расцвечено примерами жестокости и самодурства Вильганьона: после трогательного прощания пятерых со своими товарищами на ветхом корабле и даже соревнования в самопожертвовании (так, Лери утверждает, что одним из пятерых вернувшихся чуть было не стал он сам) ${ }^{34}$ Вильганьон сначала лживо принимает вернувшихся, затем играет с ними, как кошка с мышкой, бросает их в темницу, заставляет в письменном виде дать отчёт о том, в чём состоит их вера, а те безропотно идут на заклание, не поддаются уговорам окружающих французов сбежать и тем самым сохранить себе жизнь, демонстрируют чудеса выдержки в присутствии грозного обвинителя и палача ${ }^{35}$. Рассказ о мученичестве троих протестантов воспроизводит обычный для мартиролога нарратив с определённой схемой поведения мучителя и обвиняемых. Тот факт, что дело происходит в Новом Свете, пока ещё не отражён. Рассказчики порой не замечают комического несоответствия собственных клише реалиям «Антарктической Франции»: так, в одной из версий Вильганьон требует от обвиняемых протестантов на острове Колиньи письменного акта веры (“articles de foi”), заверенного нотариусом ${ }^{36}$, причём на следующих страницах рассказчик с удовольствием воспроизводит этот образцовый акт, из чего должно следовать, что требование Вильганьона было исполнено. При этом другой протестантский автор может раздражённо бросить: «Вильганьон рассказывает повсюду, что он потребовал ... нотариально заверенных актов веры - но кто из нас, побывавших в Америке, видел там хотя бы одного-единственного нотариуса? На острове Колиньи ничего не продаётся и не покупается, там не сеют и не жнут, там нет никакого товаропотока, никто ничего не сдаёт и не берёт в аренду, нет ни дающего в долг, ни берущего заём; в этом месте нет даже пера и чернил, чтобы описать происходящее - так есть ли что-то более непристойное, чем такая ложь [Вильганьона о нотариусе]?» ${ }^{37}$.

\footnotetext{
${ }^{34}$ Léry 1578: 510-511.

${ }^{35}$ Histoire des choses mémorables 1561: 26-42v.

${ }^{36}$ Histoire des choses mémorables 1561: 26.

${ }^{37}$ Richer 1562: 31-31v.
} 
Схожим стереотипом мышления (или фигурой речи) выглядит обращение пятерых вернувшихся к Вильганьону с просьбой позволить жить вместе с его людьми, «пользуясь теми же вольностями и свободами» (franchises et libertés): данная формулировка повторена дважды ${ }^{38}$, хотя рассказчик только и делает, что перечисляет лишения, тяготы и страдания людей Вильганьона, так что в их беспросветном существовании трудно заподозрить наличие каких-либо свобод и вольностей.

В целом судить о том, насколько оправданы были подозрения Вильганьона относительно мятежа протестантов, на основании имеющихся источников сложно. Впрочем, Жан де Лери не без бравады заявляет, что, если бы не пиетет перед инициатором всей эпопеи с бразильской колонией адмиралом Колиньи и нежелание его огорчать, протестанты из «Антарктической Франции» с лёгкостью одолели бы Вильганьона и сбросили бы его в море, настолько он отвратил от себя своей жестокостью и самодурством ${ }^{39}$. Идёт ли здесь речь о бахвальстве или же какое-то основание для такого заявления имелось? Соответственно и слова того же Лери о десяти тысячах протестантских поселенцев, процветавших бы на берегах залива Гуанабара, если бы не отступничество Вильганьона ${ }^{40}$, возможно истолковать и как риторическое сожаление об упущенных возможностях, и как косвенное подтверждение витавшей в воздухе идеи возвращения Дюпона из Франции с многочисленным контингентом ${ }^{41}$. В любом случае одно остаётся бесспорным: тот, кто наушничал Вильганьону (сам он неоднократно повторял, что «его известили», «ему доложили», «ему стало известно») безошибочно нащупал болевые точки руководителя колонии и расставил акценты так, как втайне желал бы сам Вильганьон.

Когда в конце XVII - начале XVIII в. протестантские историки вновь вернутся к колониальному эпизоду в Бразилии, тот же самый эпизод с утоплением трёх человек уже рассматривается иначе. Так, в 1702 г. Пьер Бейль во втором издании своего «Исторического и критического словаря» (статья «Вильганьон») указывал, что глава «Антарктической Франции» казнил не всех вернувшихся протестантов, а лишь некоторых: «Поскольку Вильганьон спас жизнь двум остальным, похоже, что трое [погибших] были казнены не исключительно по причине своей рели-

${ }^{38}$ Histoire des choses mémorables 1561: 29v, 33.

${ }^{39}$ Léry 1578: 193-194.

${ }^{40}$ Léry 1578: 245, 506.

41 Заметим также, что ожидание некоей «армады» из Франции, снаряжённой на средства частного лица, фиксируется также и в португальских источниках; в этом случае речь идёт об одном из распространённых страхов, которым португальцы предумышленно или же искренне их разделяя - пугали собственную метрополию, побуждая её обращать больше внимания на нужды Бразилии. - Carta do Pe Leonardo do Vale escripta de S.Vicente a 23 de Junho de 1565 // Azpilcueta Navarro, 1988: 474475; Carta do Ir. José de Anchieta ao Provincial de Portugal; Baía, 9 de julho de 1565 // Leite, 1960: 254; Carta do P. Quiricio Caxa ao provincial de Portugal; Baía, 13 de julho de 1565 // Leite, 1960: 259; Soares F. Coisas notaveis do Brasil (De Algumas coisas mais notaveis do Brasil e de Alguns costumes dos Indios), 1590 // Albuquerque 1989: 140-141. 
гии». Жестокость же Вильганьона, подчёркнутая протестантами XVI в., также рассматривается Бейлем вне непосредственной связи с его религиозными взглядами: «Если он был груб и жесток, то это относилось либо к дикарям, либо к его слугам или тем, кто нарушал его запреты; религия здесь была не при чём» ${ }^{42}$.

Пока же, во второй половине XVI в., преобладающей характеристикой Вильганьона усилиями протестантов остаётся «самодур», «тиран» и жестокий деспот. Мучимый нечистой совестью и будто бы сам истязаемый внутри невидимым палачом ${ }^{43}$, он избивает подчинённых до полусмерти, изрыгая при этом своё любимое ругательство, а затем приказывает перевернуть жертву на другой бок, чтобы продолжить пытку (объект избиения у разных авторов меняется: то это пленный индеец, и тогда даже окрестные дикари остаются в удивлении при виде такой жестокости ${ }^{44}$, а то французский колонист, столяр Ла Рош ${ }^{45}$ ); капает раскалённым жиром на обнажённую плоть жертвы ${ }^{46}$; заставляет сидящих на цепи за прежние проступки работать больше, чем на галерах ${ }^{47}$, третирует своего верного мажордома ${ }^{48}$, приговаривает одного из офицеров к несправедливому и непереносимому для его чести наказанию, так что тот сбегает с острова ${ }^{49}$, топчет ногами поделки из местного дерева, которые один из ремесленников рассчитывает сбыть по возвращении во Францию и немного заработать (рассказчик квалифицирует это как «жестокое и варварское деяние») $)^{50}$. Множатся упоминания «дурного обращения», «угнетения», «бесчеловечности», ударов палкой или кулаком, цепей, оков и ножных кандалов, а также тюрьмы, в которой будущие протестантские мученики за веру проводят последние часы перед казнью.

Часть этих примеров можно было бы счесть риторическими клише, однако некоторые из них подтверждаются при сопоставлении источников, как, например, то, что провинившихся колонистов и попавших на остров в качестве рабов индейцев сажали на цепь или иным образом заключали в оковы и даже особые ножные кандалы ${ }^{51}$. Весьма неожиданным и любопытным свидетельством того, насколько они были распространены во французской колонии, стало замечание католика Теве о том, что окрестные индейцы стали включать в свои ритуалы практику заковывания жертвы в кандалы вместо прежнего опутывания верёвкой, и источником этого нового знания послужили именно французы ${ }^{52}$.

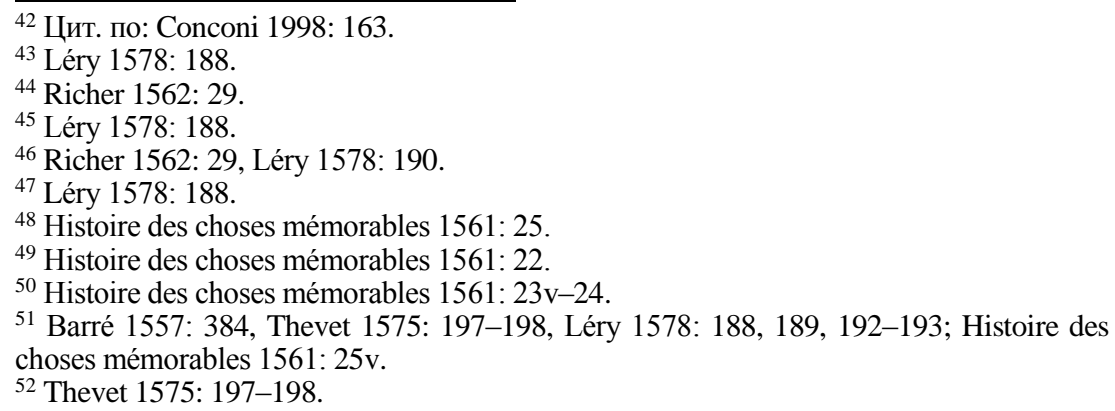


Среди примеров использования пространства сенсорной депривации в качестве инструмента властных отношений есть и неожиданные случаи, относящиеся не к области лишений и телесных наказаний, а... вестиментарных практик. Кажущееся единичным и уникальным свидетельство при дальнейшем рассмотрении становится проявлением более глубинной системы взглядов и оценок; использование авторами XVI в. примеров и метафор из области вестиментарного весьма интересно для изучения пересечения проблематики культурных пространств и чувственных восприятий в контексте режимов власти. Итак, вот неожиданный пример самодурства и тирании Вильганьона, приводимый Лери:

Имея у себя большой запас шерстяных и шелковых тканей, которые он предпочитал сгноить в сундуках, нежели отдать своим людям (а ведь некоторые из них были практически полностью раздеты), и располагая также камлотовыми тканями самых разных цветов, [Вильганьон] соорудил себе шесть наборов одежды, чтобы менять во все дни недели. У него были камзолы и шоссы красные, желтые, коричневые, белые, синие и зелёные. Можете вообразить, насколько прилично всё это было его возрасту, профессии и рангу, который он хотел занимать. Мы же научились довольно точно определять по цвету его наряда его текущее настроение: когда мы видели зелёное и жёлтое, то могли сказать, что на горизонте собираются тучи. Но когда он наряжался в длинную мантию из жёлтого камлота, отороченную чёрным бархатом, самые жизнерадостные весельчаки из его окружения говорили, что он похож на комедийного актёра или карнавального персонажа ${ }^{53}$.

Эпизод с цветными камзолами является уникальным свидетельством, подтверждения этой информации в других источниках нет; кроме того, он не комментировался и в историографии. Однако нельзя не заметить, насколько описание Лери точно укладывается в модель, предложенную современным французским историком М. Пастуро в его известной работе о семантике цвета в Средние века и раннее Новое время:

Жёлто-зелёный, а вернее говоря, сочетание или сопоставление жёлтого и зелёного - двух цветов, которые никогда не сближались в средневековых цветовых классификациях - в средневековом восприятии, видимо, представляло собой нечто агрессивное, сумбурное, тревожное. В сочетании друг с другом эти иявета ассоииируются с нарушением порядка, сумасшествием, расстройством чувств u рассудка (выделено мной - O.O.). Они появляются в костюмах придворных шутов и буффонов, в одежде безумца из книги Псалмов и прежде всего в одежде Иуды, жёлтый плащ которого в XIV-XVI вв. часто сочетается с другим предметом одежды зелёного цвета ${ }^{54}$.

Зелёно-жёлтое у Лери в описании самодурства и бесчинств Вильганьона несёт два смысла - и прямой, и фигуральный: такой вывод можно сделать, сравнив данный пример с ещё одним случаем упоминания такого же сочетания цветов, на сей раз в описании внешности индейцев.

В соответствующей главе Лери, среди прочего, выстраивает своеобразные картины, сравнимые с театральными явлениями, располагая их от наиболее величественной до самой комичной. Такой смешной (на самом деле издевательский) внешний вид индейца заключается в том, чтобы изобразить его наполовину в его собственном «дикарском» обла-

${ }^{53}$ Léry 1578: 190-191.
${ }^{54}$ Пастуро 2012: 220. 
чении, а наполовину - в европейской одежде из цветных тканей, причём один рукав должен быть жёлтым, а другой зелёным: «для довершения картины ему будет не хватать только шутовского жезла ${ }^{55}$. Буквальный смысл такой «картины» связан с тем, что цветные европейские ткани действительно были предметом меновой торговли с индейцами, и эта информация перекрёстно подтверждается различными источниками. Фигуральный же смысл того, что из всех возможных сочетаний цветов Лери авторской волей наряжает индейца именно в желтое и зелёное это штрих к образу дикаря как шута или обезьяны белого человека.

Другой пример использования вестиментарных метафор мы находим у ещё одного яростного обличителя Вильганьона - протестанта Рише. Начинает он их использовать сперва в буквальном смысле ${ }^{56}$, но затем они становятся всё более отвлечёнными: в «Антарктической Франции» Вильганьон «так никогда и не сбросил одеяние атеиста, в которое он [ранее] облачился» ${ }^{57}$; Вильганьон подобен королю, надевшему соответствующий наряд, чтобы играть в трагедии, но без скипетра, королевского убора и раздутого чванства являющемуся не более чем жалким человеком ${ }^{58}$. Наконец, ещё один образ, на сей раз основывающийся не на одеянии, а на его отсутствии: голый Вильганьон в своём пустом театре кистью рисует города, дворцы, замки и морские порты ${ }^{59}$, в то время как в реальности все постройки острова Колиньи - не более чем свиные стойла из грязи (ещё одна излюбленная метафора Рише, повторенная не менее четырёх раз). Важно, что такие сравнения относятся к культурному пространству Старого Света. Другой же протестантский автор, не менее яростно нападая на Вильганьона, попытался в схожей вестиментарной метафоре отразить колорит Света Нового: «Ты [Вильганьон] предстаёшь лишённым всякого разумения, прикрываясь одним лишь подобием наряда из детского лепета и софизмов; тот наряд похож на одеяния из перьев у дикарей, с которыми ты так долго прожил» ${ }^{60}$. От метафоры словесной недолог путь к метафоре изобразительной, и вот уже в многофигурной протестантской карикатуре «Опрокидывание большого котла» («Renversement d'une grande marmite») Вильганьона рисуют в виде индейского предводителя в головном уборе из перьев и с характерной для бразильских индейцев деревянной палицей в руках, выступающей здесь в качестве пародии на скипетр монарха ${ }^{61}$.

Как бы то ни было, в пресловутом королевском одеянии или без него Вильганьон со всеми своими обыкновениями (подозрительностью, гневливостью и склонностью мучить подчинённых) под пером протестантских авторов предстаёт воплощением ярости и неистовства. Инте-

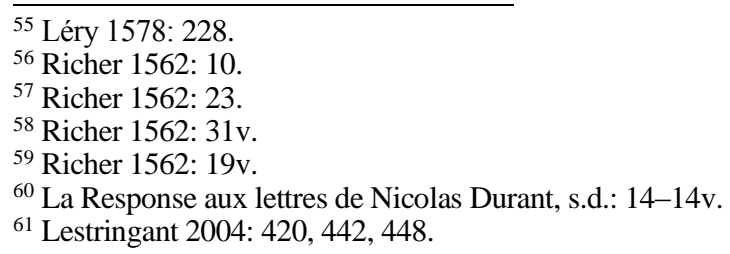


ресно, что когда при публикации «Истории одного путешествия в Бразилию» Жана де Лери в 1578 г., а затем и при последующих переизданиях, книге в качестве предисловия или напутствия были предпосланы своеобразные стихотворные рецензии, то автор одной из них описывал, какие именно препятствия пришлось преодолеть Лери на пути к выходу в свет своего сочинения. Эти препоны были с одной стороны нематериальными («Ложь», «Неистовая Ярость», «Война»), а с другой стороны персонифицированными. Первой же такой парой препятствий были Неистовая Ярость (Fureur), и её олицетворение - Вильганьон ${ }^{62}$.

На противоположном полюсе - страдающие колонисты, чьи тяготы связаны с голодом из-за скудности и непривычности пищи и с необходимостью тяжело работать в неудобных условиях. Даже протестантские проповедники от Кальвина, прибывшие в Бразилию позже и знавшие, на что именно они идут, считали нужным подчёркивать, что сознательно выбрали путь лишений, хотя могли бы наслаждаться жизнью на родине ${ }^{63}$. Даже желчные упрёки, которыми уже после падения колонии обменивались протестанты и Вильганьон, во многом сводились к обоюдному возмущению тем фактом, что устроенное ценой таких трудов и невзгод поселение оказалось потерянным и все усилия пошли прахом ${ }^{64}$. Утешить и одних, и других могли бы идеологи второй французской колонии в Бразилии («Равноденственной Франции» в Мараньяне, на севеpe Бразилии, в начале XVII в.), которые взывали к терпению:

[Tе, кто спрашивают о Бразилии, обычно считают, что уроженец Франции] никогда не сможет обосноваться в суровом и диком краю, покрытом лесами, населённом варварскими народами, в жарком климате. На это [ответим], что любое начало всегда сложно, но мало-помалу трудность становится лёгкой. Нет ни города, ни деревни во всём мире, которые не были бы неудобными для жизни в самом своём начале... Вот португалец: разве он не из Европы, как и мы? разве он не подвержен болезням, трудам и тяготам, как француз? Да! Но он имеет перед нами то преимущество, что он более терпелив и знает, что сначала нужно посеять, а потом уже собирать урожай; и вот он уже так хорошо обосновался в Бразилии... Я уверяю, что эта земля была бы столь же удобна французам, что и Франция, если бы только она была возделана и снабжена необходимыми французскому темпераменту припасами... ${ }^{65}$

Отметим, насколько именно такие лишения и тяготы французов в Бразилии оставались характерными как для первой, так и для второй

${ }^{62} «$ Fureur, mensonge et la guerre dispose / Villegagnon, Thevet et le François / A retarder de ta plume la voix / Et les discours tant beaux qu'elle propose». - Anonyme. A Jean de Lery sur son Histoire d'Amerique // Le Moine 1972: 232.

${ }^{63}$ Histoire des choses mémorables 1561: 15v, 16-16v.

${ }^{64} \mathrm{Cp}$. у протестантов: из-за того, что Вильганьон дурно распорядился защитой «Антарктической Франции», «неприятель получил в своё распоряжение крепость, построенную... потом и трудом многих достойных людей», и у Вильганьона, обличающего «ущерб и урон, который я потерпел из-за проповедников [протестантской] доктрины, помешавших моему столь успешно начатому предприятию в Бразилии, ... стоившему мне и моим людям больших расходов и трудов». - Histoire des choses mémorables 1561: 5; Les Propositions contentieuses 1561: 13.

${ }^{65}$ Evreux 1614: 189. 
колонии. К сожалению, проявлять то терпение, к которому красноречиво призывал автор приведённого пассажа, французам оказалось некогда и негде: второе поселение просуществовало ещё меньше, чем первое.

Таким образом, анализ комплекса свидетельств о французской колонии в Бразилии показывает, в какой мере информация о лишениях и использовании сенсорной депривации в качестве инструмента властных отношений в замкнутом пространстве оказывается зависимой от формы, в которую авторы облекают эти сведения. Каждый из изученных авторов XVI в., без сомнения, горячо согласился бы с определением своего собственного свидетельства о жизни в колонии как «безыскусной правды» в противоположность «красноречиво изложенной лжи» оппонентов ${ }^{66}$, однако эта «безыскусная правда» зачастую представлена с весьма искусным применением риторических приёмов, подобно тому, как ощущение «свежести и наивности взгляда» на бразильские реалии, которое, к примеру, столь ценил у Лери выдающийся французский антрополог и философ Клод Леви-Стросс, создано литературными средствами ${ }^{67}$.

Выявленные дискурсивные стратегии при описании тягот существования в колонии не отменяют самого факта неудобств, лишений или страданий. Собранные воедино элементы сведений из разных источников подтверждают друг друга, и даже у мрачных эпизодов заговоров и казней в «Антарктической Франции» находятся причины, которые заклятые идейные противники неожиданно объясняют схожим образом.

В любом случае, история «маленького острова больших лишений» не прошла бесследно: в дальнейшем свои усилия по колонизации разных регионов Нового Света французы будут соотносить с полученным на нём опытом.

\section{БИБЛИОГРАФИЯ / REFERENCES}

Окунева О.В. Предатели и предательство во французской Бразилии XVI - начала XVII в. // Одиссей. Человек в истории. 2012. М.: Наука, 2012. С. 139-166 [Okuneva O.V. Predateli i predatel`stvo vo franczuzskoj Brazilii XVI-nachala XVII vv. // Odissej. Chelovek v istorii. 2012. M.: Nauka, 2012. S. 139-166].

Окунева О.В. Католические и протестантские авторы XVI в. о первой французской колонии в Бразилии // Ретроспективная информация источников: образы и реальность / Под ред. И.Н. Данилевского и О.И. Тогоевой. М.: ИВИ РАН, 2013. С. 179-200 [Okuneva O.V. Katolicheskie i protestantskie avtory' XVI v. o pervoj franczuzskoj kolonii v Brazilii // Retrospektivnaya informaciya istochnikov: obrazy` i real'nost' / Pod red. I.N. Danilevskogo i O.I. Togoevoj. M.: IVI RAN, 2013. S. 179-200].

Пастуро М. Символическая история европейского средневековья. Пер. с фр. Е. Решетниковой. СПб., Александрия, 2012 [Pasturo M. Simvolicheskaya istoriya evropejskogo srednevekov`ya. Per. s fr. E. Reshetnikovoj. SPb, Aleksandriya, 2012].

Albuquerque L. de (ed.) O reconhecimento do Brasil. Lisboa, Editora Alfa, 1989.

Azpilcueta Navarro M. Cartas Avulsas. Belo Horizonte, Editora Itatiaia, 1988.

Conconi B. Les fortunes de la France Antarctique de Villegagnon au temps de la crise de la conscience européenne: les métamorphoses d'une controverse // La France - Amérique $\left(\mathrm{XVI}^{\mathrm{e}}-\mathrm{XVIII}{ }^{\mathrm{e}}\right.$ siècles). Actes du XXXV colloque international d'études humanistes. Paris, Droz, 1998.P. 143-165.

${ }^{66}$ Имеется в виду программное утверждение Лери в его обращении к читателю: Léry 1578: 98-99.

${ }^{67}$ Lestingant 2010: 161-162. 
Evreux Y. d'. Suite de l'Histoire des choses plus mémorables advenues en l'île de Maragnan es années 1613 et 1614 // Evreux Y. d', Clastres H. (éd.). Voyage au nord du Brésil fait en 1613 et 1614. Paris, 1985.

Histoire des choses memorables advenues en la terre du Bresil, partie de l'Amerique australe, sous le gouvernement de N. de Villeg. depuis l'an 1555 jusques a l'an 1558. S. 1.,1561.

La Response aux lettres de Nicolas Durant, dict le Cheualier de Vilegaignon, addressées à la Royne Mere du Roy, ensemble la Confutation d'vne heresie mise en auant par ledict Villegaignon, contre la souueraine puissance \& authorité des Rois. S. 1., s.d.

Le Brésil d'André Thevet. Les Singularités de la France Antarctique (1557) / Ed. par F. Lestringant. Paris, Editions Chandeigne,1997.

Leite S. Monumenta Brasiliae, vol. IV. Roma, Monumenta historica Societatis Iesu, 1960.

Le Moine R. Amérique et les poètes français de la Renaissance. Ottawa, Éditions de l'Université d'Ottawa, 1972.

Les Propositions contentieuses entre le chevallier de Villegaignon, \& maîstre Iehan Caluin, concernant la verité de l'Eucharistie. A la Royne, mere du Roy, 1561.

Lestringant F. Interview // Topoi. Revista de História. Universidade Federal do Rio de Janeiro, vol. 11, № 20 (janeiro-junho 2010). P. 161-162.

Lestringant F. Le Huguenot et le Sauvage. L'Amérique et la controverse coloniale en France au temps des guerres de Religion (1555-1589). Genève, 2004

Mémoires de Claude Haton, contenant le récit des événements accomplis de 1553 à 1582, principalement dans la Champagne et la Brie, publiés par Félix Bourquelot. Paris, 1857, v. 1.

Richer P. La refutation des folles resveries, execrables blasphemes, erreurs \& mensonges de Nicolas Durand, qui se nomme Villegaignon : divisée en deux livres. S.1., 1562.

Thevet A. La Cosmographie universelle d'André Thevet cosmographe du Roi, illustrée de diverses figures des choses les plus remarquables vues par l'auteur et inconnues de nos Anciens et Modernes (1575) // Les Français en Amérique pendant la seconde moitié du XVI siècle. Paris, PUF, 1953.

Окунева Ольга Владимировна, кандидат исторических наук, доктор, университет Париж-Сорбонна, стариий научный сотрудник, Институт всеобщей истории PAH; olga.okouneva@gmail.com

\section{Little Island, Great Desolation: “Antarctic France" in Brazil as a Space of Sensory Deprivation}

The article examines the instrumental use of sensory deprivation to establish and maintain domination within a limited area, such as the first French colony in Brazil, the so-called "Antarctic France". Testimonies of this colonial enterprise show the colonists' hard life: limited space, insufficient food supplies and the lack of familiar alimentation, as well as authoritarian (and sometimes brutal) governance.

The article identifies unique and cross-confirmed information from such testimonies, and examines the ways $16^{\text {th }}$ century authors used rhetoric and literary techniques to produce desired effect.

Keywords: Antarctic France, Brazil, early modern history, sensory deprivation, literary techniques

Olga Okuneva, PhD in Modern History (Moscow State University, University of ParisSorbonne), Senior Research Fellow, Institute of World History, Russian Academy of Sciences; olga.okouneva@gmail.com 


\title{
A.В. СТОГОВА
}

\section{ВЗГЛЯД НА ВЛАСТЬ И ГОРОД С ОЧКАМИ И БЕЗ: ОПИСАНИЯ ПАРИЖА И ЛОНДОНА В 1698 ГОДУ}

\begin{abstract}
Статья посвящена рассмотрению двух связанных между собой текстов - «Путешествия в Париж в 1698 году», составленного английским медиком и ученым, членом Лондонского королевского общества Мартином Листером на основе личных наблюдений в ходе поездки, и пародии на это сочинение, «Путешествия в Лондон в 1698 году» юриста, поэта и сатирика Уильяма Кинга. Анализ этих произведений показывает, как приложение к изучению города идеи ученого, на чьи наблюдения не должны влиять существующие авторитетные мнения, и который не должен обращать внимание лишь на то, что бросается в глаза, становится для Листера инструментом критики авторитарной власти Людовика XIV. C другой стороны, сатира Кинга демонстрирует, что наблюдения, не соотнесенные с авторитетными мнениями, не позволяют отделить значимое от незначительного, что лишает создаваемый образ города его важнейшей характеристики - статуса столицы государства и центра власти. Он использует этот тезис как инструмент критики новой модели знания и науки, продвигаемой Лондонским королевским обществом. В обоих случаях независимость взгляда ученого-наблюдателя и стремление отказаться от признания авторитетов неизбежно коррелирует с непризнанием авторитета существующей политической власти.
\end{abstract}

Ключевые слова: город, власть, наука, наблюдатель, путешествие, Париж, Лондон, зрение, Лондонское королевское общество

В раннее Новое время культура путешествий претерпевала существенные трансформации, в самом общем виде они обычно описываются как переход от паломничеств к познавательному путешествию. Безусловно, это описание слишком обще, чтобы адекватно отразить все происходившие изменения, поскольку практики, связанные с путешествиями, не только менялись, но и становились более разнообразными. Однако в одном аспекте оно, несомненно, справедливо: начиная с эпохи Возрождения, все рассуждения о том, каким должно быть путешествие, связывали его с получением знаний. Юстин Штагль в своем исследовании отмечал, что в течение XVI в. сложилась настоящая методология путешествования - ars apodemica, которая в идеале требовала от путешественников принимать во внимание столь много всяческих аспектов, что это должно было способствовать получению поистине энциклопедических знаний. Дабы сделать эту программу сколько-нибудь выполнимой, «авторы советовали путешественникам уделять внимание только действительно важным вещам», и в целом это соответствовало риторике эмпиризма раннего Нового времени ${ }^{1}$. В этом плане опыт путешествия, особенно если оно имело отношение к уже известным пространствам Европы, как это и предполагало ars apodemica, был заранее структурирован уже имеющимися знаниями и особенностями пространства. Многие города в конце XVII в. были уже настолько хорошо известны, что что-то существенно новое (из того, что представлялось важным) о них

\footnotetext{
${ }^{1}$ Stagl 2004: 81.
} 
сказать было сложно. Вместе с тем сам Штагль, вслед за другими исследователями связывал любопытство, которое лежало в основе культуры путешествий раннего Нового времени, с изучением неизвестных ситуаций ${ }^{2}$. Рано или поздно стремление рассказать «важное» и при этом «новое» должны были вступить в противоречие, в значительной мере именно с этим связано то, что традиция ars apodemica постепенно теряла свое значение. В наибольшей степени это было актуально для такого жанра, как описания отдельных городов или регионов, ибо набор того «важного», что можно было в них обнаружить, был существенно ограничен. Изменение модели описания неизбежно должно было повлечь за собой и метаморфозы образа города. Один из вариантов этих изменений и станет объектом рассмотрения в данной статье.

В конце XVII в. с разницей в несколько месяцев в Лондоне были опубликованы два текста с почти одинаковым названием - «Путешествие в Париж в 1698 году» ${ }^{3}$ и «Путешествие в Лондон в 1698 году», ${ }^{4}-$ которые, удивительным образом, до сих пор остаются практически неизученными. Автором первого был натуралист и известный врач, член Лондонского королевского общества Мартин Листер. В первой половине 1698 г. Листер по поручению Вильгельма III сопровождал в Париж английского посла лорда Портленда ${ }^{5}$. На основе путевых заметок, сделанных в ходе этой поездки, он составил текст, который был опубликован уже через несколько месяцев. Другое сочинение, по всей видимости, было написано очень быстро, «по горячим следам», ибо его успели опубликовать все в том же году. Оно было создано английским юристом и писателем-сатириком, другом Джонатана Свифта, Уильямом Кингом.

Его путешествие, в отличие от описанного Листером, было вымышленным, а текст представлял собой очевидную сатиру. Полное название, обозначенное на титульном листе, звучало следующим образом: «Путешествие в Лондон в 1698 году, [описанное] согласно хитроумному методу, использованному д-ром Мартином Листером в том же году. Изначально написано по-французски господином Сорбьером и недавно переведено на английский». Это название отсылает не только к «Путешествию в Париж», но и к еще одному тексту, память о котором была еще жива. Речь идет об «Описании путешествия в Англию, в котором затрагиваются вопросы состояния наук и религии, а также другие любопытные предметы» Самюэля Сорбьера 1664 г.) $)^{6}$. Это сочинение, издан-

\footnotetext{
${ }^{2}$ Stagl 2004: 2.

${ }^{3}$ Lister 1699. Все цитаты приведены согласно второму изданию книги, сделанному в 1699 г., пагинация совпадает с первым изданием.

${ }^{4}$ [King] 1698.

${ }^{5}$ Ханс Уильям Бентинк, первый граф Портленд был одним из фаворитов короля Вильгельма III и видным дипломатом. В 1698 г. он был отправлен в Париж на переговоры с французским королем, завершившиеся подписанием полгода спустя Гаагского договора о разделе испанских владений (который в свою очередь стал поводом для начала Войны за испанское наследство).

${ }^{6}$ Sorbière 1664.
} 
ное во Франции и на французском языке, было, тем не менее, очень хорошо известно английским читателям, поскольку его публикация сопровождалась дипломатическим скандалом. Английский король Карл II потребовал наказания для автора, оскорбившего английскую нацию и лично премьер-министра лорда Кларендона ${ }^{7}$. Оскорбленными себя почувствовали и члены Лондонского королевского общества, принимавшие Сорбьера во время его визита. Историограф Лондонского королевского общества и капеллан герцога Бэкингема Томас Спрат в 1665 г. опубликовал язвительный разбор сочинения француза - «Замечания касательно путешествия в Англию господина де Сорбьера» ${ }^{8}$. Об этой истории Кинг и напоминает читателю, выдавая свое сочинение за очередной опус французского путешественника ${ }^{9}$. Подобная реакция делает оба «Путешествия» 1698 г. интересным источником для изучения не только изменений образа города и манеры его описания, но и того, в каких контекстах эти изменения оценивались.

«Хитроумный метод» Мартина Листера, к которому апеллировал Кинг, заключался в стремлении представить читателю Париж, опираясь только на личные наблюдения. К концу XVII в. личный опыт, безусловно, доминировал в жанре травелогов, благодаря чему их уже довольно легко отличить от иных сочинений о чужих землях. В особенности это характерно для описаний хорошо известных территорий, к коим, безусловно, относился Париж. Англичане, желавшие узнать о нем, не отправляясь при этом в поездку, располагали значительным корпусом текстов, сообщавших, более или менее подробно обо всем примечательном, что можно было лицезреть во французской столице ${ }^{10}$. Сформировались достаточно устойчивые представления о том, что именно является достойным повествования, как правило путешественники считали своим долгом заимствовать у других характеристику какого-нибудь значимого объекта, если им не довелось видеть его лично, чтобы не упустить ничего важного. Были выработаны и стереотипные модели рассказа, формирующие представления о том, на что именно следует обращать внимание при посещении города и отдельных его достопримечательностей.

Эта детерминированность взгляда нашла свое полное выражение в первом путеводителе современного типа - «Новом описании всего наиболее интересного и примечательного в городе Париже» Жермена

\footnotetext{
${ }^{7}$ Ему вменялись в вину и другие прегрешения, испортившие отношения не только с Англией, но и с Голландией. Обвинения, предъявленные Сорбьеру, можно найти в постановлении об аресте издания: Arrest du Conseil d'Estat 1664. Согласно королевскому указу, Сорбьера отправили в ссылку в Нант, а книга подлежала уничтожению. ${ }^{8}$ Sprat 1665.

${ }^{9}$ В обращении к читателю, написанному от имени Сорбьера, автор сообщает о желании представить более справедливое описание Лондона, нежели то, что вызвало столько неудовольствия 30 лет назад. Однако текст не имеет отношения к французскому автору, скончавшемуся почти за тридцать лет до этой публикации, в 1670 г.

${ }^{10}$ Уже к середине столетия интересующиеся читатели располагали внушительным списком описаний Парижа. См. о них: Лазарев 2010: 162-190.
} 
Бриса, изданного в 1684 и переведенного на английский язык в 1687 г. Особенно показательно название текста в английском переводе, в котором перечисляются все достойные внимания путешественника объекты $^{11}$. В оригинале это двухтомное издание, снабженное указателем всех достопримечательностей (а в более поздних изданиях - впервые в истории - также картой и иллюстрациями), давало самую полную информацию о прекраснейшем, богатейшем, «бесподобном» городе ${ }^{12}$. Рассказ о французской столице начинался с описания Лувра и затрагивал все значимые современные строения, коллекции и даже жителей. В конечном счете Брис создал впечатляющий образ блистательного города, наглядно отражавший величие и процветание французского государства.

По сути дела, «Описание» Бриса было настолько подробным, что делало совершенно невозможными и бессмысленными любые попытки повторить эту информацию в записках путешественников. Неудивительно, что Листер отказывается следовать привычным схемам. Составляя свое, гораздо более краткое описание Парижа, он обращает внимание на два важных факта. Во-первых, само название его записок - «Путешествие в Париж в 1698 году» - говорило читателю о том, что речь идет о самой актуальной характеристике (текст был издан в том же году, в котором состоялась поездка), учитывающей все новейшие достопримечательности. Это было немаловажно в связи с тем, что французские короли, начиная с Генриха IV, берутся активно перестраивать и модернизировать город, превращая его в зримый образ величия французской монархии $^{13}$. Даже Людовик XIV, не любивший Париж и в нем практически не живший, приложил немало усилий в этом направлении. В его правление перестраивается Лувр, появляется множество новых величественных строений, среди которых Дом инвалидов, здание нынешнего Института Франции, церковь Сен-Сюльпис, такие площади как Вандомская или площадь Побед, не говоря уже о памятниках, прославляющих монарха. Париж постоянно менялся и приукрашивался, в силу чего именно новое свидетельство, более актуальное, чем наблюдения Бриса, и могло заинтересовать читателя. Во-вторых, Листер намеренно отказывается следовать привычным шаблонам и составлять свой рассказ из описания тех парижских достопримечательностей, которые считаются наиболее этого достойными. Речь идет не только о том, что он включил в свое повествование лишь увиденное собственными глазами, но и о том, что он увидел не совсем то, что могли ожидать читатели.

В отличие от современных туристов, чей выбор определяется в первую очередь вкусами и интересами и ограничен лишь временем и

\footnotetext{
11 «Новое описание Парижа, в котором особое внимание уделяется всем церквям, дворцам, монастырям, колледжам, больницам, библиотекам, кабинетам редкостей, ученым академиям, картинам, медалям, статуям и другим скульптурам, монументам и публичным надписям. С упоминанием обо всех иных примечательных вещах в этом великом и прославленном городе». Brice 1687.

12 [Brice] 1684: N.P.

${ }^{13}$ См. об этом: Дежан 2015: 7-32.
} 
количеством денег, опыт путешественника XVII в. очень сильно зависел от его социального статуса и репутации. Помимо улиц и площадей, прогулки по которым только стали входить в моду, общедоступными, в т.ч. для приезжих, пространствами были лишь парки, театры, ярмарки и первые кофейни ${ }^{14}$. Ко всему остальному - королевским резиденциям и частным домам, коллекциям книг, произведений искусства и всевозможных редкостей, монастырям - доступ можно было получить, только обладая необходимыми связями и занимая определенное положение в обществе. К концу XVII в. сложились три основных типа европейских путешествий - дипломатическое, ученое и образовательное, и они были связаны не только с целями, но и с возможностями проникнуть в те или иные социальные круги и соответствующие пространства. С этими же возможностями коррелировали и интересы читателей, которых в первую очередь волновали не описания архитектуры (если только речь не шла о каком-то новом строении или памятнике), а эти внутренние, закрытые для постороннего взгляда пространства.

Листер отправился в Париж в качестве медика в составе посольства лорда Портленда, а посему вполне логично было бы ожидать от него рассказа о королевских резиденциях и домах высокопоставленных чиновников. Понимая эти ожидания, Листер первым делом оговаривает, что ничего из этого читатель в его тексте не обнаружит:

«Но, чтобы доставить вам, мой читатель, удовлетворение, я обещаю не беспокоить вас церемониями, как государственными, так и религиозными или политическими, ибо по собственному желанию я не хотел бы иметь отношения ни к одной из них, разве что к ним приведет моя прогулка или мои размышления. По моим наблюдениям вы с легкостью обнаружите, что я интересуюсь главным образом природой больше, а не властью, и что я был куда больше рад видеть господина Бремана, в своем белом жилете копающегося в Королевском саду лекарственных растений, нежели господина Сенто, провожающего посла. И я обнаружил, что мне легче запомнить имена и внешний вид сотни растений, чем 5-6 принцев» ${ }^{15}$.

Однако же новизна текста Листера заключается вовсе не том, что он игнорирует все то примечательное, что мог увидеть в качестве члена посольства, отдавая предпочтение объектам, которые интересны ему как ученому. И то, и другое в его тексте оказывается вторичным по отношению к чувственному опыту прогулки и интеллектуальному опыту размышлений. Выдвигая на первый план идею «прогулки и размышлений», Листер (как истинный последователь беконианской традиции, вдохновлявшей членов Лондонского королевского общества) ставит чувственный и интеллектуальный опыт выше традиций и авторитетов. Он готов обращать внимание на все, что может дать город для его зрения, слуха, обоняния и осязания, не подчиняя свой взгляд существующим представлениям о важном и интересном, и предлагает читателю те размышления, которые в действительности были вызваны этим опытом, а не те, которые должны были бы появиться. Как отмечала одна из современ-

\footnotetext{
${ }^{14}$ Первое кафе под названием «Прокоп» открылось в Париже в 1686 г.

${ }^{15}$ [King] 1698: 2-3.
} 
ных исследовательниц работ Листера Анна-Мари Рос, ключевое отличие его «Путешествия» от уже существовавших на тот момент текстов заключается в подчеркивании автором собственного опыта и стремлении отстраниться от всего, что может исказить его наблюдения очевидца $^{16}$. Впрочем, этот пафос изрядно смягчался иронией. Незначительность объектов, на которых порой останавливается взгляд Листера, дублируется несерьезностью, которая то и дело заметна в его повествовании, когда вполне основательные размышления перетекают в шутливые, a «возвышенные» объекты вызывают в памяти забавные анекдоты.

В итоге город в получившемся тексте представлен через размышления об увиденном в ходе прогулок. И хотя пространство города оказывается первичным, мы видим его описанным не в его собственной логике, а переупорядоченным в соответствии с логикой мысли. Объекты, не расположенные рядом и нередко очень разные по своему типу, соседствуют в тексте, обретая новые связи и значения. Но эти связи и значения определяются не столько изначальным интересом, прилагаемым к возможностям города, сколько возможностями города, увиденными через призму неизбежного личного интереса.

Именно это попрание иерархий и авторитетов, связанных с определением того, что важно и достойно наблюдения и публичного обсуждения, и отметил Уильям Кинг. Вопрос о том, что новая наука стремится сделать объектом изучения то, что недостойно пристального внимания, обсуждался как минимум с того момента, когда изобретение телескопа дало возможность увидеть все, что находится бесконечно далеко, а появление микроскопа позволило разглядывать всякие незначительные мелочи. Как писал Филипп Болл, согласно устоявшимся еще в средневековой культуре взглядам, «маленькие и далекие объекты были маленькими и далекими именно потому, что нам не следует о них задумываться» ${ }^{17}$. Эти идеи, развивавшиеся в религиозной традиции и опиравшиеся на образ сотворенного Богом мира, по мнению исследователя, были унаследованы светской критикой бэконианской науки.

В «Путешествии» Кинга Ф. Болл совершенно справедливо видит проявление представлений о «культурной структурированности способа ранжирования значимого в природе» ${ }^{18}$. В подтверждение этому исследователь приводит следующие слова, не упоминая, правда, что они пародируют приведенное выше высказывание Листера: «Я обнаружил в себе большую склонность и способность запомнить внешний вид сотни сорняков, нежели пяти-шести принцев» ${ }^{19}$. За сатирой Кинга скрывается не только критика культуры любопытства, связанной в первую очередь с новой наукой, продвигаемой Лондонским королевским обществом, которую высмеивали многие современники, включая Свифта. Как отме-

\footnotetext{
${ }^{16}$ Roos 2011: 376-377.

${ }^{17}$ Ball 2012: 382.

${ }^{18}$ Ball 2012: 382.

${ }^{19}$ [King] 1698: 2.
} 
чал тот же Болл, в этой сатире ощущается недовольство распространением культуры экспертов и специалистов, которые сами назначили себя таковыми ${ }^{20}$. Кинг не случайно напоминает читателям о тексте Сорбьера и, косвенно, его критика Томаса Спрата. Сорбьер, как и Листер, понимал, что его текст не вполне соответствует нормам жанра, и общая тональность его пояснений близка к тому, о чем писал Листер: «Я едва коснулся многих предметов, которые требуют длительных рассуждений для того, чтобы ясно их представить, но пускался в объяснение других, о которых ты, вероятно и не хотел бы знать» ${ }^{21}$. Сорбьер объяснял это тем, что заметки были составлены для развлечения знатного покровителя, хорошо знакомого с его образом мыслей, и не предназначались для публикации. Посему он призывал читателя снисходительно отнестись и к легкомысленно-ироничному стилю, и к возможным неточностям, но обращал внимание на то, что увиденное было важно для него как повод для размышлений: «По тем мыслям, которые приходили мне на ум в течение этих трех коротких месяцев, я предоставляю тебе судить о размышлениях, которые могли занимать меня в течение тридцати лет» ${ }^{22}$.

Текст Сорбьера все же был опубликован, причем также менее чем через год после возвращения во Францию ${ }^{23}$, что вызывало неизбежные сомнения касательно представленной отговорки. И, хотя стиль сочинения соответствовал популярной в то время во Франции литературе, чуравшейся педантства и призванной развлечь читателя, ученый статус автора как королевского историографа, и то, что текст вышел он с посвящением вовсе не другу-покровителю ${ }^{24}$, а королю, заставляли искать в нем серьезный подтекст. Неудивительно, что современники заподозрили, что простодушие Сорбьера является напускным и скрывает под собой язвительную сатиру ${ }^{25}$. Спрат разразился язвительным и многословным сочинением, призванным дискредитировать эту «дерзкую клевету на нашу нацию» ${ }^{26}$. Одним из основных его тезисов было обвинение в поверхностности суждений. Она объяснялась преимущественно через фигуру автора - Сорбьер не был настоящим, серьезным ученым, не знал английского языка и пробыл в Англии очень недолго. Но, кроме того, он не опирался в своих суждениях на авторитетные мнения, за исключением нескольких «педантских цитат», несмотря на то что все любимые

\footnotetext{
${ }^{20}$ Ball 2012: 382.

${ }^{21}$ Sorbière 1664: N.P. (Av lectevr).

${ }^{22}$ Sorbière 1664: N.P. (Av lectevr).

${ }^{23}$ Сорбьер отправился в Англию в начале лета 1663 г., а первое издание его «Описания путешествия в Англию» было выпущено 16 мая 1664 г.

${ }^{24}$ Им был один из членов семьи Ботрю, с которыми был связан Сорбьер - Николя Ботрю маркиз де Вобран.

${ }^{25}$ В постановлении об аресте книги говорилось: «Автор под тем предлогом, что он с полной наивностью рассказывает о том, что видел, позволяет себе выступать против истины с различными вещами, порочащими английскую нацию». Arrest du Conseil d'Estat 1664: 3.

${ }^{26}$ Sprat 1665: 2.
} 
Сорбьером античные авторы единодушно утверждают, что оратор должен использовать все доступные ему знания ${ }^{27}$. Все это не позволяло ему, с точки зрения Спрата, вынести сколько-нибудь серьезное и ценное суждение. Проявлялась же эта достойная осуждения поверхностность, вопервых, в развлекательности (Спрат уподоблял текст Сорбьера прециозным романам, чтение которых предполагало только получение удовольствия ${ }^{28}$ ), а во-вторых, в том, что француз очень часто опускает то, что достойно внимания, сосредотачивая его на ничего не значащих, нередко случайных вещах, кажущихся чужестранцу необычными. «Где тогда его философское любопытство? Где его тяга к познанию хороших вещей? Где его любовь к великим и удивительным искусствам?» ${ }^{29}$ - восклицал Спрат, порицая неспособность и нежелание Сорбьера выбрать достойный объект для изучения.

Кинг не только уподобляет текст Мартина Листера произведению Сорбьера, обращавшего внимание на недостойные объекты. Он дискредитирует и критику со стороны Лондонского королевского общества, выставляя на посмешище ученых, отстаивающих ценность своих наблюдений, хотя сами занимаются такой же жалкой и вредной для общества ерундой, как и те, кого они пытаются критиковать. В «Путешествии в Лондон» Кинг избирает очень интересный способ для своей сатиры. Использование «хитроумного метода Листера», обозначенного в заглавии, подразумевает то, что Кинг нарочито дословно воспроизводит пассажи из его текста, выделяя их курсивом и даже отсылая к конкретным страницам, где эти цитаты можно обнаружить, и применяя их к описанию Лондона, добавляя при этом собственные размышления и оценочные суждения. Иногда, впрочем, как это можно видеть из приведенной выше цитаты, Кинг немного жульничал для усиления эффекта. Ему показалось недостаточным противопоставить принцев растениям (plants), и он заменил последние сорняками (weeds). Прибегая к такому способу, Кинг, безусловно, следует давней традиции полемических текстов, но, поскольку в названии своего сочинения он отсылает и к Сорбьеру, то в первую очередь подобная манера (вплоть до визуального восприятия текста) должна была напомнить читателям о «Замечаниях» Спрата. Тот не только цитировал Сорбьера для построения на основе этих цитат собственных рассуждений, но и соединял вместе разные отрывки, вырывая их из контекста и придавая новое значение. Так же поступает и Кинг: он в основном следует за повествованием Листера от страницы к странице, но нередко вкрапляет цитаты из других частей его рассуждений. Порой

\footnotetext{
${ }^{27}$ Sprat 1665: 202.

${ }^{28}$ Sprat 1665: 43.

${ }^{29}$ Sprat 1665: 44-45.
} 
эти вкрапления состоят всего из одного-двух слов и, по всей видимости, не имеют другой цели, кроме указания на манеру критики Спрата ${ }^{30}$.

В результате складывается очень интересная картина, поскольку тексты Листера о Париже и Кинга о Лондоне оказываются одновременно очень похожими и радикально отличными. И Кинг, играя на этом сочетании, пародирует суждения, основанные на индивидуальном чувственном опыте, выведенном за рамки культурно значимой иерархии ценностей. И поскольку речь в обоих текстах идет о столичных городах - пространствах, ассоциировавшихся с присутствием власти, сама манера построения текста У. Кинга утрирует трансформации образа властного пространства, которые происходят под влиянием частного опыта наблюдателя, который Листер стремится представить в тексте.

Как Листер и обещал в обращении к читателю, он не уделяет никакого внимания французскому двору - центру политической и социальной жизни, хотя в его тексте есть описания Лувра, Версаля и других королевских резиденций. Более того, за исключением нескольких королевских дворцов, «прогулка» никогда не приводит его к тем местам, которые могли бы ассоциироваться с властью. В его описании нет городских резиденций герцогов, министров или других влиятельных лиц, также отсутствуют описания ратуши, Арсенала, Бастилии и прочих пространств демонстрации и осуществления власти. Это отсутствие, более чем заметное для современников, подчеркивалось тем, что в некоторых случаях эти пространства упоминались, но лишь в связи с другими, более интересными автору объектами. Наиболее показательным, конечно же, является пример с описанием Версаля, почти полностью посвященном садам и паркам, но не знаменитому дворцу - основной резиденции Людовика XIV и центра придворной жизни.

Вместо привычного способа изображения Парижа и окрестностей как места государственной власти и наглядного свидетельства ее величия, Листер, опираясь на свои наблюдения прохожего ${ }^{31}$, рисует совершенно другой образ. Множество новых строений, памятников, площадей, фонтанов, выставленное напоказ богатство - все то, что было принято расценивать как проявление величия и могущества, становится в его

\footnotetext{
${ }^{30}$ Например, следующие слова Листера, имеющие отношение к одной из описываемых коллекций («Я обратил внимание на три вида сов, одна из которых была рогатой, все они крайне отличаются от наших европейских»), Кинг переделывает таким образом: «Я обратил особое внимание на двух сов [Р. 73], невероятных размеров [P. 2], но поскольку у них не было рогов, я посчитал, что они ничем не отличаются oт европейских [P. 73]». Lister 1699: 73; [King] 1698: 18. (здесь и далее в квадратных скобках приведены маргиналии в тексте Кинга 1698 г., курсив также воспроизводится по этому изданию - А.С.) Кинг, несомненно, обесценивает наблюдение Листера, но при этом добавление слов «невероятных размеров» не играет в этом существенной роли. Но, поскольку в оригинальном тексте они относились к величию Парижа, то это соединение высмеивает принципы, на которых строилась критика Спрата.

${ }^{31}$ В этом отношении он очень похож на фланера. От этого культурного типажа, получившего распространение в XVIII-XIX веках, его отличает отсутствие интереса к «жизни» города и нежелание следовать его топографии.
} 
глазах свидетельством деспотизма: «В конечном счете, необходимо сказать, что великолепие и количество этих дворцов и садов является наилучшим, заслуживающим наибольшего одобрения следствием своевольного правления» ${ }^{32}$. Он пишет ${ }^{33}$ : «по всему Парижу» можно увидеть свидетельства прославления монарха: «Загляните в “Описание Парижа"34, где они собраны в большом количестве. У римлян в правление Августа (первого абсолютного хозяина над этим народом, так же как нынешний король является таковым для французов) народ высказал по этому поводу гораздо более тонкую мысль и пожелание - De nostris annis tibi Jupiter augeat annos ${ }^{35}$ ». Для него в значительной мере именно умение абстрагироваться от того, что кажется великим, и обратить внимание на незначительное или, по меньшей мере, менее значительное, предоставляет возможность для непредвзятого критического взгляда. Мелочи и детали, которые замечает прохожий, чей взгляд не зависит от существующих культурных иерархий, оказываются в его построениях куда более ценными источниками информации: «Приятно наблюдать, как король дисциплинирует этот великий город, требуя повиновения в мелочах. Он повелел разом снять все вывески и не устанавливать их далее одного или двух футов от стены, а также не превышать этих небольших размеров, что и было охотно выполнено. Так что теперь, вывески вовсе не заслоняют улицу и, будучи очень малы и повешены так высоко, они оказываются столь незначительными, что их могло бы и не быть вовсе» ${ }^{36}$.

Вполне в духе бэконианской науки, этот перенос взгляда с того, что признано «значительным» и «великим», на «неприметные мелочи» напрямую связан с отказом от следования авторитетам и значимостью непосредственного наблюдения. Листер специально оговаривает свою позицию, предвосхищая возможные возражения читателей:

«Но мы уже знаем все, что вы можете нам сказать, или можем прочитать об этом в “Современном состоянии Франции" 37 и “Описании Парижа" - двух книгах, которые легко найти в каждой книжной лавке Лондона. Все это верно, вы можете поступить именно так, и я советую вам не пренебрегать ими, если вы имеете намерение вынести суждение о величии французского двора и колоссальной грандиозности города Парижа. Я и сам пробовал смотреть через эти очки, но обнаружил, что они не подходят для моего зрения, а посему намереваюсь обойтись без них. В отношении таких явлений нашей Природы как

${ }^{32}$ Lister 1699: 216.

${ }^{33}$ Lister 1699: 220-221.

${ }^{34}$ Имеется в виду текст Ж. Бриса, о котором шла речь выше.

35 «Да умножит тебе Юпитер лета из наших лет». См. у Тертуллиана: «Да, если бы природа покрыла сердца человеческие какою-либо прозрачною материею для пропускания света, то чьи сердца не оказались бы испещренными образами нового и нового императора, заботящегося о раздаче подарков? Это можно было бы видеть тогда даже в то время, когда кричат: “да умножит тебе Юпитер лета из наших лет”. Христианин не умеет как произносить эти слова, так и желать нового императора. Но ты говоришь: такова чернь. Хотя чернь, однако, римская, и никто столько не мучит христиан, как чернь». Тертуллиан 2004: 272.

36 Lister 1699: 16.

${ }^{37}$ [Evelyn] 1652. 
большие города и монументальные дворцы я вполне могу обойтись и без микроскопов или увеличительных стёкол» ${ }^{38}$.

Тексты, подобные «Описанию Парижа» Бриса, оказываются в интерпретации Листера своеобразными увеличительными стеклами, необоснованно преувеличивающими значимость «дворцов».

Помимо путеводителя Бриса Листер упоминает в числе книг, от которых он намеревается дистанцироваться, «Состояние Франции» анонимно изданный в 1652 г. трактат, в котором анализируется устройство власти и общества в современной Франции. Это очень любопытно, во-первых, потому что текст был написан Джоном Ивлином, ставшим впоследствии одним из основателей Лондонского королевского общества. А во-вторых, в силу того, что трактат (в котором Парижу уделено не так уж много внимания) представлен автором как результат осмысления личных наблюдений в ходе путешествия. По мнению Ивлина, эти наблюдения должны иметь достойную цель, особенно, когда речь идет о молодом человеке: «Он должен путешествовать разумно и, подобно философу, старательно (на протяжении всего своего паломничества) обращать внимание на те вещи, которые могут наилучшим образом послужить к пользе и достатку его собственной страны по его возвращении» ${ }^{39}$.

Это целеполагание, влияющее на то, как и что именно рассматривает путешественник, заставляющее его фокусироваться на том величественном и прекрасном, что есть в Париже, и делает наблюдателя столь уязвимым, поскольку монарх, со своей стороны, прилагает все усилия, чтобы создать нужное впечатление. Листер, как было отмечено в посвящении канцлеру лорду Соммерсу, помещает в свой текст «только факты и несколько коротких заметок непредвзятого наблюдателя» ${ }^{40}$. Эта непредвзятость понимается им как нежелание попадать под влияние не только существующей традиции, но и «великого короля, который доставил Европе немало беспокойства, а Англии стоил особенно много крови и денег» ${ }^{41}$, который сделал из французской столицы и ее окрестностей пространство репрезентации власти, наполнив Париж объектами, которые притягивают взгляд и затмевают все остальное.

Подобно Анри Лефевру, который уже в XX в. обращал внимание на «другие Парижи», скрытые за фасадами, границами гетто и в подземных коммуникациях и выпадающие из поля зрения туристов и «наивных парижан», Листер представляет в своем тексте Париж, который остается незамеченным. Однако «другие Парижи» Лефевра преимущественно скрыты от взгляда по тем или иным причинам, главным образом потому, что в разросшемся мегаполисе «каждый имеет некий свой путь... и не слишком хорошо знаком с остальным» ${ }^{42}$. Большинство удовлетворя-

\footnotetext{
${ }^{38}$ Lister 1699: 2.

${ }^{39}$ Cit. ex: [Evelyn] 1652: N.P.

${ }^{40}$ Lister 1699: N.P.

${ }^{41}$ Lister 1699: N.P.

42 Лефевр 2008: 141.
} 
ется созерцанием банального Парижа, легко доступного взгляду, который цепляется за привычные, хорошо известные, ставшие символическими точки в пространстве города и упускает все остальное. «Другой Париж» Листера не связан с этой категорией, ибо в любом случае все самое ценное скрыто внутри дворцов и кабинетов и дозволяется лицезреть лишь избранным. Было совершенно естественным, что каждый путешественник увидит свой Париж, в зависимости от того, какие двери откроет его положение, связи и репутация. Для него не столь важно, куда именно приведет прогулка, сколько то, на что обращает внимание путешественник и насколько он способен увидеть в окружающем пространстве не то, что от него ожидают. Речь идет о городе, ускользающем от взгляда тех, кто разглядывает дворцы в увеличительное стекло. В каком-то смысле он говорит о проникновении за фасад - фасад города, дворца, человека, за набор привычных значений, что позволяет увидеть в Париже много интересного, прекрасного, приносящего удовольствие, но также и поучительного, недостойного и неприглядного.

Уильям Кинг очень чутко уловил, что в основе «хитроумного метода» Мартина Листера лежит вопрос о статусе традиции по отношению к индивидуальному опыту и о познавательной ценности «мелочей», разглядыванием которых занималась экспериментальная наука. Листер обращал в свою пользу тезис о том, что «чувства легко обмануть, особенно если они усилены микроскопом», используемый критиками экспериментальной науки ${ }^{43}$. Он демонстрировал, что чувства оказываются обмануты тогда, когда авторы даже не осознают, что они рассматривают то, что привыкли считать важным, через микроскоп, очки или увеличительные стекла, а посему не только их представления оказываются искажены, но они к тому же не способны увидеть ничего другого.

Кинг же подчеркивает, что, отказываясь принимать во внимание авторитетные суждения и полагаясь только на собственные ощущения, Листер оказывается не в состоянии оценить значимость того, что видит. Его слова, приведенные выше, он переделывает следующим образом:

«Я не намеревался смотреть через очки [Р. 2] "Современного состояния Англии”, написанного Др. Чемберленом, или других подобных исследований, ибо, доверяя своему зрению, я собирался обойтись без них. Но, к удовлетворению читателя, [Р. 2], я обещаюо не обременять его иеремониями, как государственныли, так и религиозныли или политическими. Хоть я и встретил английского джентльмена, который предложил показать мне принцев крови, первого министра государства, Лорда-мэра или другие чины, имеющие отношение к городу столь невероятно великому как Лондон, но отклонил эту любезность и сказал ему, что я получу больше удовольствия, если увижу достойного Джсона Шарпа из Хакни в его белом сюртуке [Р. 3], выкрикивающего «Хей, турнепс! Четыре пучка за пенни», нежели сэра Чарльза Коттерела, провожающего посла. И я обнаружил в себе большую склонность и способность запомнить внешний вид сотни сорняков, нежели пяти-щести принщев» ${ }^{44}$.

43 Лисович 2015: 142.

${ }^{44}$ [King] 1698: 2. 
Не случайно Кинг упоминает о трактате Эдварда Чемберлена «Аnglia Notitia, или Современное состояние Англии» (1669), вдохновленный «Современным состоянием Франции» Ивлина, через «очки» которого отказывался смотреть Листер. Чемберлен, как и Ивлин, сделал обзор системы управления государством и представил основных влиятельных лиц, управление церковью и армией, судопроизводство и т.п. и завершил все описанием Лондона. Иными словами, он говорил о «важных» для понимания Англии вещах, и этот контекст делал очевидным, что ключевой чертой Лондона является его статус столицы и центра власти.

Пародируя отказ Листера от «большого» в пользу «малого», от того, что признано важным, ради второстепенного и незначительного, Кинг показывает, как такое описание лишает город его отличительной черты - статуса столицы государства, а посему само оно оказывается лишенным всякой ценности. То, что у Листера было инструментом критики авторитарного правления Людовика XIV, Кинг превращает в сатиру на буржуазную критику королевской власти. Он намеренно рисует город, в котором власть не просто не замечена наблюдателем, но и как бы действительно отсутствует, в силу чего он лишен всего значимого, прекрасного, ценного, равно как и разумного порядка. Историю с регламентацией городских вывесок Кинг переиначивает таким образом, что мы видим, что с попустительства магистрата, лондонцы могут вешать вывески «такого размера, какого им только вздумается, даже чудовищной величины». Некоторые из них достигают таких размеров, что заслоняют солнце и могут сравняться по длине с трехмачтовым судном ${ }^{45}$.

Как видно даже из приведенной цитаты, отказ от рассмотрения всего политического, неразрывно связанного с монархической властью, оставляет в поле зрения (что не удивительно после событий середины столетия) только буржуазное - вместо мастера королевских церемоний сэра Чарльза Коттерелла появляется зеленщик Джон Шарп. Оппозицию между важным и незначительным Кинг переводит в социальную плоскость. Без короля, двора, королевской администрации, и страна, и Лондон оказываются пространством третьего сословия. Кинг намеренно опускает те пассажи, где Листер описывает достопримечательности Парижа, делающие этот город «величественным и прекрасным»: дворцы, церкви, обсерватории и другие сооружения. Единственными достопримечательностями Лондона, помимо Гайд-парка и Сент-Джеймского парка, оказываются Ньюгейтская тюрьма и разнообразные таверны, постоялые дворы и питейные заведения.

Иными словами, без присутствия власти и всего того, что она делает для города, он перестает быть столицей и выглядеть таковой, оказывается неотличим от любого другого крупного населенного пункта.

Сам прием, используемый Кингом, - заимствование прямых цитат из описания Парижа для характеристики Лондона, демонстрирует, что наблюдения Листера могут быть применены к совершенно любому го${ }^{45}[$ King] 1698: 8. 
роду. Социальная ничтожность буржуазного города коррелирует с ничтожностью интересов его жителей (не случайно в нем так много питейных заведений!). И в такой образ города у Кинга оказываются встроены ученые и коллекционеры, которым он, вслед за Листером, уделяет много внимания. С одной стороны, они неспособны увидеть величественное и прекрасное в том, что рассматривают: «У него есть очень хорошие картины, хотя я снова должен признаться, что не получаю удовольствия от живописи. Он показал мне некоторые картинь Рубенса, где второстепенные аллегорические персонажи изображены на полотне очень беззаботныли и причудливо одетыли. Он также показал мне одного ван Дейка, однако написанного дезабилье [Р. 39] во франтоватом халате и со старомодной прической» ${ }^{46}$. С другой стороны, их интересы совершенно бессмысленны и не приносят никакой пользы, вроде «ученых бесед» о том, как долго кошка может выжить, попав в воздушный насос ${ }^{47}$.

В первую очередь получающийся образ города и его жителей - это то, что способен увидеть «своими глазами» virtuoso ${ }^{48}$, от лица которого написан текст. Отказ слепо следовать существующей иерархии ценностей преподносится как неспособность не просто различать то, что имеет значение и достойно рассмотрения и то, что таковым не является, но, как в случае с упомянутыми выше картинами, - вообще увидеть великое и величественное. Интересы повествователя мелочны, и взгляд останавливается только на ничтожных вещах. Кинг не просто убирает все, что на его взгляд достойно внимания, из описания Лондона, чтобы почеркнуть это обстоятельство, но нередко наглядно демонстрирует, как взгляд такого наблюдателя упускает важное и задерживается на незначащем. Опираясь на заметку Листера, что отелями в Париже именуются и гостиницы, и особняки аристократов, он использует такую же игру значениями слова inn, которым обозначают как постоялые дворы, так и судебные корпорации. Его наблюдатель, хотя и знает о существовании последних, не уделяет им ни малейшего внимания и не придает никакого значения: «В Лондоне имеется огромное количество «иннов» [P.16] постоялых дворов, где можно снять себе жилье, как, например «Былк» на Бииопгейт-стрит, «Голова сараџина» на Фрайдей-стрит, «Белая лошадь» на Флит-стрит и другие. Но кроме этого, так именуют и многие другие заведения, например «Клиффордс-инн», "Клементс-инн», «Лайонс-инн», где обитают некоторые джентльмены, занимающиеся правосудием. По всей видилости, это означает, что раньше юристы могли жить на постояльх дворах, как и приезжие ${ }^{49}$. То, что созданный им наблюдатель не способен понять ценность увиденного, лишает, с точки зрения Кинга, всякой ценности и его наблюдения. С другой стороны, то, что «ученая культура» не выпадает из поля зрения такого наблюда-

\footnotetext{
${ }^{46}$ [King] 1698: 15.

47 [King] 1698: 16-17.

48 Так в Англии именовали ученых.

${ }^{49}$ [King] 1698: 8.
} 
теля, но видится им одной из достопримечательностей Лондона, наряду с пабами, утками в пруду и бродячими торговцами, должно дать понять читателю, что на самом деле она не имеет отношения к истинно ценным и достойным явлениям культуры.

Упоминание о книге Чемберлена важно и тем, что в ней (опять же вслед за Ивлиным) дается пояснение того, как правильно «смотреть» на страну и город. И представленный подход расходится с тем, что предлагает Листер, и выступает своего рода оппозицией. Чемберлен уподоблял себя строителю, проделывающему огромную и разнообразную работу, чтобы выстроить книгу, для чего ему необходимо полагаться не только на свои знания и наблюдения: «Другие строители пользуются только своими мозгами, или умом уже умерших (то есть книгами), доступ к которым могут получить в любое время, но в этой работе, мы намеревались советоваться с живыми, причем с избранными...» ${ }^{50}$. Упоминая именно об этой книге, Кинг, по всей видимости, хочет обратить внимание на то, сколь разным оказывается результат, если автор опирается только на свои наблюдения, и если он соотносит их с наблюдениями других людей. Именно отсутствие таких «очков», т.е. знаний, полученных от других, не позволяет его наблюдателю и, следовательно, Листеру, правильно оценивать то, что он видит, когда опирается только на собственный опыт. Таким образом, инструмент, который Листер использовал для критики власти, Кинг превращает в оружие сатиры на экспериментальную науку, продвигавшуюся Лондонским королевским обществом, членом которого Листер и являлся.

В этой связи важным и, возможно, наиболее интересным обстоятельством является то, что и Чемберлен, и Ивлин также являлись одними из первых членов Общества. Ненавязчиво сделанными упоминаниями Кинг выстраивает две линии сопоставления: Чемберлен/Ивлин - Листер и Спрат - Сорбьер, лишний раз подчеркивая, что наблюдения Листера мало чем отличаются от тех, что были сделаны французским путешественником и вызвали такое возмущение среди ученых. Учитывая, что собственный текст Кинг выдает за новое сочинение Сорбьера, можно предположить, что он, помимо прочего, намекает на то, к каким «достижениям» пришла экспериментальная наука по сравнению с 1660-ми годами, к которым относились тексты Спрата и Чемберлена. Но также имеет значение и намек на то, что Листер отказывается следовать даже тем смехотворным идеям, которые продвигало Лондонское королевское общество. Кинг был знаком с инструкциями для путешественников, которые публиковались в журнале «Философские транзакции» ${ }^{51}$ и, вместе с составленными на их основе описаниями чужих земель, высмеивались за стремление рассказывать удивительные сказки, приукрашивать дей-

${ }^{50}$ Chamberlayne 1669: N.P.

${ }^{51}$ В 1700 г. он опубликовал сатиру на этот журнал и его редактора Ганса Слоана: King 1988. О журнале «Философские транзакции» и о критике, в частности со стороны Джонатана Свифта, см.: Михайлов 2014: 9-23. 
ствительность ради удивления читателя ${ }^{52}$. Листер, следуя этим заповедям и желая удивить читателя, обнаружив необычное в том, что прекрасно известно, скатывается, с его точки зрения, до рассказа о том, что вообще не должно привлекать никакого внимания.

Анализ текстов Листера и Кинга показывает, сколь сильные политические коннотации имело знание в культуре раннего Нового времени. Невооруженный взгляд Листера на пространство столичного города расценивается и им самим, и критикующим его Кингом, в первую очередь в политическом контексте. Эти тексты прекрасно иллюстрируют тезис Стюарта Кларка о том, насколько Реформация и Научная революция способствовали тому, что зрение оказывается «каким угодно, только не объективным или безопасным в его предполагаемой связи с “внешним фактом"» ${ }^{53}$. В конечном счете, и пафос Листера, касающийся освобождения индивидуального взгляда от чужого влияния (как от преломляющих его чужих мнений, так и от воздействия со стороны разглядываемой реальности), и критика такого бесцельного разглядывания со стороны Кинга, в приложении к пространству столичного города имеют очевидную политическую значимость. Несмотря на кажущуюся легкомысленность обоих текстов, в них поднимается вопрос о значимости позиции независимого субъекта. Независимость взгляда ученого-наблюдателя и стремление отказаться от признания авторитетных суждений неизбежно коррелируют с непризнанием авторитета существующей политической власти.

\section{БИБЛИОГРАФИЯ / REFERENCES}

Дежан Д. Как Париж стал Парижем. История создания самого притягательного города в мире. М.: Центрполиграф, 2015 [Dezhan D. Kak Parizh stal Parizhem. Istorija sozdanija samogo pritjagatel'nogo goroda v mire. M.: Centrpoligraf, 2015].

Лазарев А.В. Париж иностранцев эпохи ars apodemica (1570-1640 гг.) // Homo viator. Путешествие как историко-культурный феномен / Под ред. А.В. Толстикова и И.Г. Галковой. М.: ИВИ РАН, 2010. С. 162-190 [Lazarev A.V. Parizh inostrancev jepohi ars apodemica (1570-1640 gg.) // Homo viator. Puteshestvie kak istoriko-kul'turnyj fenomen / Pod red. A.V. Tolstikova i I.G. Galkovoj. M.: IVI RAN, 2010. S. 162-190].

Лефевр А. Другие Парижи // Логос. 2008. № 3 (66). С. 141-147 [Lefevr A. Drugie Parizhi // Logos. 2008. № 3 (66). S. 141-147].

Лисович И.И. Скальпель разума и крылья воображения: Научные дискурсы в английской культуре раннего Нового времени. М: Изд. Дом Высшей школы экономики, 2015 [Lisovich I.I. Skal'pel' razuma i kryl'ja voobrazhenija: Nauchnye diskursy v anglijskoj kul'ture rannego Novogo vremeni. M: Izd. Dom Vysshej shkoly jekonomiki, 2015].

Тертуллиан. Апология. М., СПб.: АСТ, Северо-Запад, 2004 [Tertullian. Apologija. M., SPb.: AST, Severo-Zapad, 2004].

Михайлов И.А. Английское Просвещение и журнал Philosophical Transactions of the Royal Society. Новая эпоха развития европейской науки // Философские науки. 2014. №5. С. 923 [Mihajlov I.A. Anglijskoe Prosveshhenie i zhurnal Philosophical Transactions of the Royal Society. Novaja jepoha razvitija evropejskoj nauki // Filosofskie nauki. 2014. №5. S. 9-23].

Arrest du Conseil d'Estat rendu contre un livre intitulé "Relation d'un voyage en Angleterre" composé par le sieur de Sorbière, au désavantage de la nation anglaise et du roy de Danemark. Paris: Impr . et Libr . ord . du roi, 1664.

Ball Ph. Curiosity: How Science Became Interested in Everything. L.: The Bodley Head, 2012.

\footnotetext{
${ }^{52}$ См. об этом: Pearl 2012.

${ }^{53}$ Clark 2007: 1.
} 
[Brice G.] Description nouvelle de ce qu'il y a de plus remarquable dans la ville de Paris, par M. B***. Paris: Vve Audinet, 1684.

Brice G. A New Description of Paris: Containing a Particular Account of All the Churches, Palaces, Monasteries, Colledges, Hospitals, Libraries, Cabinets of Rarities, Academies of the Virtuosi, Paintings, Medals, Statues and Other Sculptures, Monuments and Publick Inscriptions. With All Other Remarkable Matters in that Great and Famous City. London: for Henry Bonwicke, 1687.

Chamberlayne E. Angliae Notitia, Or The Present State of England: the First [-second] Part. Together with Divers Reflections Upon the Antient State Thereof. [London]In the Savoy, printed by T.N. for J. Martyn, printer to the Royal Society, and are to be sold at the Sign of the Bell in S. Pauls-Church-Yard, 1669.

Clark S. Vanities of the eye. Vision in Early Modern Culture. Oxford: University Press, 2007.

[Evelyn J.] The State of France, as it stood in the IX ${ }^{\text {th }}$ yeer of this present Monarch, Lewis XIIII. Written to a Friend by J. E. London: M. M. G. Bedell \& T. Collins, 1652.

[King W.] A Journey to London in 1698. After the ingenious method of that made by Dr. M. Lyster to Paris in the same year, etc. Written originally in French by Monsieur Sorbière, and newly translated into English. L., 1698.

King W. The Transactioneer (1700). Los Angeles, 1988.

Lister M. A Journey to Paris in the Year 1698. London: for Jacob Tonson, 1699.

Pearl J.H. Geography and Authority in the Royal Society's Instructions for Travelers // Travel Narratives, the New Science, and Literary Discourses 1569-1750 / ed. by Judy A. Hayden. Burlington: Ashgate, 2012. Pp. 71-83.

Roos A.M. Web of Nature: Martin Lister (1639-1712), the First Arachnologist. Leiden, Boston: BRILL, 2011.

Sorbière S. Relation d'un voyage en Angleterre: où sont touchées plusieurs choses, qui regardent l'estat des sciences, \& de la religion, \& autres matières curieuses. Paris: chez Lovis Billaine, 1664.

Sprat Th. Observations on Monsieur de Sorbier's Voyage into England written to Dr. Wren, professor of astronomy in Oxford. L., 1665.

Stagl J. A History of Curiosity: The Theory of Travel 1550-1800. L., N.Y.: Routledge, 2004.

Анна Вячеславовна Стогова, кандидат исторических наук, стариий научный сотрудник, Институт всеобщей истории РАН,; дочент, кафедра истории и теории культуры, факультет культурологии РГГУ; genderhistory@ gmail.com.

\section{A look at power and the city with and without spectacles Descriptions of Paris and London in 1698}

This article examines two related texts - Journey to Paris in 1698 by Martin Lister, an English physician and scholar and member of the Royal Society of London, based on personal observations during his travels, and a satire on this work, Journey to London in 1698 by the lawyer, poet and satirist William King. An analysis of these writings shows how the application of the idea of the scholar, whose observations should not be influenced by existing authoritative opinions and who should not succumb to paying attention only to what catches his eye, towards the study of the city becomes for Lister an instrument for the criticism of the authoritarian power of the French king Louis XIV. King's satire, on the other hand, shows that observation without reference to authoritative opinion fails to distinguish the significant from the inconsequential, which deprives the city's image of its most important characteristic: its status as the capital and centre of power. He uses this thesis as an instrument to criticize the new model of knowledge and science promoted by the Royal Society of London. In both cases, the independence of the scholarobserver's view and the tendency to refuse recognition of authoritative judgments inevitably correlate with a failure to recognise the authority of existing political power.

Keywords: city, power, science, observer, journey, Paris, London, vision, Royal Society of London

Anna V. Stogova (PhD, IGH RAS, Senior Researcher, Department of Historical and Theoretical Studies; Russian State University of Humanities, Associate Professor, Department of History and Theory of Culture, Faculty of Cultural Studies; genderhistory@ gmail.com 


\section{С.A. ВАСИЛЬЕВА}

\section{РЕЛИГИОЗНЫЕ ИСТОЧНИКИ ИДЕАЛЬНОЙ МОДЕЛИ \\ ТЮРЕМНОГО ЗАКЛЮЧЕНИЯ \\ В СОЦИАЛЬНО-ПРАВОВОМ ДИСКУРСЕ КОНЦА ХУІІ - НАЧАЛА ХІХ В.}

Статья посвящена изучению религиозных истоков системы одиночного тюремного содержания нового типа, возникшей в Великобритании и США в конце XVIII начале XIX в. Эпоха Просвещения привела к радикальным изменениям в системе уголовного правосудия. Этот период принято считать началом «эры карательной сдержанности»: постепенное законодательное ограничение санкций в виде смертной казни привело к качественным изменениям всей системы уголовных наказаний. Английские протестанты впервые предложили рассматривать наказание как средство перевоспитания осужденного в условиях одиночного заключения. Идеальной моделью реформатория стал образ «кита Ионы» как места и обстоятельства, когда грешник, преступивший закон, сможет установить невероятное соединение с Господом, покаяться и получить искупление. Исход такой теологии - надежда на то, что Бог позволит «вырваться из тюрьмы измененной личностью».

Ключевые слова: пенитенциарные реформы, одиночное тюремное заключение, пенсильванская система тюремного содержания

Классическая криминология рассматривает период конца XVIII начала XIX в. как отправную точку становления национальных пенитенциарных систем - государственных институтов, ведающих исполнением уголовных наказаний, наложенных на граждан в соответствии с законом. В основу этих систем были положены принципы исправления осужденных в условиях обеспечения изолящии от общества в специализированных учреждениях - тюрьмах или пенитенциариях. Эта схема с тремя необходимыми условиями до сих пор составляет базис политики исполнения уголовных наказаний.

Проблема осмысления генезиса современной пенитенциарной системы интересовала исследователей начиная с середины XIX в. Одновременно можно констатировать появление классической школы криминологии и уголовного права, представители которой связывают трансформацию отношений общества и государства к исполнению уголовного правосудия с идеями Просвещения и утверждением гуманизма в качестве базового принципа человеческого общежития. Результатом поиска эффективного средства сдерживания и противодействия преступности стала стартовавшая в конце XVIII столетия и растянувшаяся на весь последующий век, кардинальная реформа уголовного правосудия. Она привела к рождению обновленной модели тюрьмы, которую, чтобы не путать с карательными тюрьмами - наследием Средневековья, назвали пенитенциарием или реформаторием.

В свете криминологической теории К. Маркса и его последователей, призывавших «сорвать с институтов наказания их идеологический покров... и описывать их в реальных производственных отношениях» ${ }^{1}$,

\footnotetext{
${ }^{1}$ Rusche, Kirchheimer 1939: 20.
} 
возникновение такого рода тюрьмы связывают с закономерностями развития капитализма в странах Европы и переходом к системе принудительного труда как источника трудовых ресурсов.

Сторонники неклассического взгляда на рассматриваемую проблему в западноевропейской историографии объединены в условную исследовательскую группу приверженцев ревизионизма. Ревизионисты рассматривают процесс перехода к пенитенциарным учреждениям как результат изменения социальной природы наказания. Популярной вариацией ревизионизма стала распространенная в европейской и американской историографии теория «социального контроля», которая рассматривает тюрьму как один из элементов всеобъемлющей социальной программы по контролю над девиациями в обществе, наряду с психиатрическими больницами, школами, приютами и богадельнями ${ }^{2}$.

Современная модель интеллектуально-культурной истории в первую очередь отдает предпочтение изучению «взаимодействия между движением идей и их исторической “средой обитания” - теми социальными, политическими, религиозными, культурными контекстами, в которых идеи рождаются, распространяются, развиваются» ${ }^{3}$. Этот метод позволяет пересмотреть предметное поле исследования генезиса социального института тюрьмы в контексте национальной уникальности социальных и культурных практик. Первое и, пожалуй, главное принципиальное отличие английской практики реформирования правоохранительной системы от аналогичных континентальных процессов подметил еще Дж. Тревельян, рассуждая о «знаменитых атаках» философов Европы и Англии на существующую систему закона и наказания. Историк связывал эти «атаки» на континенте с Вольтером и «философами», а в Англии - с «философией» и религией (курсив мой. - C.B.). В продолжение темы историк призывал воздержаться от популярного, но в корне ошибочного рассмотрения XVIII века для Англии как «века нерелигиозного», убедительно доказывая, что религия, во всем многообразии ее форм, свойственных островной империи, на протяжении сменявшихся поколений оставалась «мощной силой в английской жизни» ${ }^{4}$.

Общественное мнение было пронизано религиозностью: практически половина всех печатных материалов были религиозного характера, одни только проповеди методистов под открытым небом собирали тысячи англичан. Поэтому рассматривать важнейшую реформу уголовного правосудия и генезис современной тюрьмы вне учета религиозного мировоззрения англичан XVIII в. значит искажать их социальную природу. Мы постараемся раскрыть идейное влияние христианской теологии, привнесенной английскими протестантами в сферу социального реформизма, на формирование фундамента пенитенциарных систем Нового времени. С этой целью проследим, как обозначенные выше принципы

\footnotetext{
${ }^{2}$ См., напр.: Rothman 1971.

${ }^{3}$ Репина 2004: 271.

${ }^{4}$ Тревельян 2002: 378-380.
} 
исполнения уголовных наказаний - исправление, изоляция и специально организованное пространство - актуализировались в религиозном дискурсе пенитенциарных преобразований конца XVIII - начала XIX в.

Бросив даже самый поверхностный взгляд на внутреннее устройство христианского монастыря и тюремного учреждения, невозможно не заметить явного сходства между этими двумя социальными институтами. Причем кроме подобия внешних деталей (келейно-камерная система, строгий режим изоляции, постоянный труд, ряд важных ограничений), поражает глубинное подобие основополагающих целей - достичь покаяния/исправления потенциального грешника/преступника. На это сходство обращали внимание первые исследователи тюремных моделей XIX - начала XX в. Один из «пионеров» научной криминологии Йохан Зеллинг заметил: «... источник всей нашей пенитенциарной системы... надо искать в церкви, в особенности те ее черты, которые касаются тишины, изоляции, душевных и физических испытаний, как верной дороги к спасению»5.

В поисках идеальной модели заточения с целью покаяния достаточно было обратиться к главному авторитету для англичан - Библии. Современный историк Т. Лабутина, анализируя влияние событий английской революции XVII в. на интеллектуальный мир англичан, ссылается на концепцию британского историка Кристофера Хилла, подтверждающую значительное влияние Библии на все сферы жизни общества, в т.ч. использование Писания в качестве «модели» для парламентариев ${ }^{6}$. Эта особенность сохранилась и в XVIII в., разве что изменились акценты, и «с начала и до конца столетия приверженцы нового пуританизма... старались применять милосердие Нового Завета, вместо грубых наставлений Ветхого» ${ }^{7}$. Тюремная реформа последней четверти века хоть и стала, по мнению Р. Макгоуэна, порождением «активной филантропии и неведомого раньше милосердия» ${ }^{8}$, в качестве идейного источника обратилась именно к Ветхому Завету.

Одной из наиболее устойчивых аллюзий к Писанию, используемых как реформаторами, так и тюремными проповедниками, стал образ ветхозаветного пророка Ионы, который жил в VIII в. до Рождества Христова. Библейская история Ионы начинается с момента ослушания Бога и противоречия Его воле, а затем бегства в попытке уйти от гнева Всевышнего. Корабль, на котором плыл Иона, застигла великая буря, и Иона, глубоко осознав свою вину перед Богом, попросил моряков бросить его в море, где был поглощен огромной рыбой, в чреве которой и провел три дня. Из чрева кита пророк вознес Богу горячую покаянную молитву, каялся в своем непослушании, и через три дня по Божественному повелению кит изверг Иону на берег. В молитве Иона говорил о

\footnotetext{
${ }^{5}$ Цит. по: James 1990: 31.

6 Лабутина 2015: 22-23.

7 Тревельян 2002: 375.

${ }^{8}$ McGowen 1986: 316.
} 
беде и опасности, в которой оказался из-за непослушания, об охватившем его отчаянии, которому он почти покорился, о покаянии и Божьей милости: «В скорби я к Богу взывал и Он услышал меня. Из могильных глубин, Господи, молил я Тебя, и Ты услышал мой плач... Душа моя надежду потеряла, но вспомнил Господа я. Господь, Тебе молился я, и Ты молитву услышал мою в Храме Твоём святом» 9 .

Итак, оказавшись в заточении, Иона осознал свое преступление, испытал очищающее страдание. Английский комментатор Библии, пресвитерианский священник Мэтью Генри (1662-1714) толкует историю Ионы, используя образ тюрьмы: «Его тюрьмой стало чрево кита - уединенная, мрачная темница; но и в этом месте он имел доступ к Богу и мог свободно общаться с Ним. Люди могут лишиться возможности общаться друг с другом, но не лишиться общения с Богом. В то время Иона оказался на дне моря, но и из бездны он взывает к Богу; так Павел и Сила молились Богу в тюрьме, заключенные в колоды». Итак, кит «стал темницей, пребывать в которой был осужден Иона за свое непослушание... и оттуда он воззвал к Богу, и сделал это не напрасно. Бог услышал его, услышал глас его страдания, голос его прошения». Подробно разбирая молитву Ионы, М. Генри последовательно выделяет смену эмоциональных состояний грешника: Иона отмечает, как низко он пал, в каком ужасном положении оказался; собственная совесть говорила ему, что он поступил нечестиво. Тем не менее, пророк не дает себе погрузиться в отчаяние, и поддерживает себя утешительными перспективами избавления: «он останется жив; он вновь будет смотреть на небеса, видеть свет солнца, хотя сейчас похоже, ввергнут в кромешную тьму» ${ }^{10}$. Наконец, одно из трех возможных толкований чудесного избавления Ионы ${ }^{11}-$ пример Божьей милости к бедным раскаявшимся грешникам: Иона согрешил и поступил безрассудно, его собственное отступничество не исправило его... Тем не менее благодаря его молитве и смирению перед Богом совершается чудо в природе для его спасения» ${ }^{12}$.

В библейской истории мы встречаем все элементы будущего механизма пенитенциарной системы:

- грех/преступление, выразившееся в ослушании, в отступлении от установленных норм и правил.

- вынужденное заточение, как наказание за преступление установленных границ;

- страдание, вызванное заточением, которое рассматривается как путь к искуплению/как наказание и путь к свободе;

\footnotetext{
${ }^{9}$ Ион. 2:2, $2: 7$.

${ }^{10}$ Там же.

${ }^{11}$ Самое распространенное толкование библейского примера Ионы - прообраз воскресения Христа. Он умер и был погребен и лежал в могиле, как Иона, три дня и три ночи - осужденный за наши грехи; а на третий день Он вышел, как Иона, чтобы через Своих посланников проповедовать о покаянии и прощении грехов даже язычникам. Сам Иисус указывает на это событие как на прообраз своего трехдневного погребения и воскресения (см.: Мф 12:40).

${ }^{12}$ Иона 2 гл. - Библия - Комментарии Мэтью Генри: https://bible.by/matthew-henry/32/2/
} 
- покаяние/раскаяние, как акт, охватывающий разум, чувства и волю. Библейское покаяние подразумевает: разумом человек осознает свои грехи, под чувствами принято понимать печаль и скорбь ${ }^{13}$, вызванные уязвлением совести и «живым ощущением разлучения с Богом». Воля как часть покаяния подразумевает твердое желание преображения и очищения, радикальный пересмотр взглядов и ценностей, решимость жить по заповедям Божьим. От раскаявшегося преступника ожидают понимания сущности своего преступления и вреда, нанесенного обществу, и воспитания устойчивого желания вернуться в общество честным гражданином; - искупление и освобождение/исправление и возвращение в общество.

Одной из важнейших составляющих идейного содержания пенитенциарной реформы стало конструирование специального пространства, в условиях которого все ожидаемые процессы (осознание своего греха/преступления и жажда искупления, достижение покаяния/исправления, возвращение к праведности/свободе) были бы возможны. Существующие условия исполнения уголовных наказаний не только не соответствовали поставленным целям, но приводили к противоположному результату. Английские тюрьмы «оставались до конца столетия национальным позором» ${ }^{14}$. Было очевидно, что реформаторские инициативы по борьбе с преступностью обречены на провал, пока не будет создано той среды, в условиях которой удивительная «алхимическая» составляющая - покаяние - чудодейственным образом реформирует преступника/грешника в честного человека. Поэтому важнейшим этапом идейного комплекса пенитенциарной реформы стало проектирование специального пространства как условия для воплощения гуманистических стремлений, милосердных ожиданий и утилитарных амбиций - пенитенциария, или реформатория, который впоследствии просветитель Дж. Бентам назвал «мельницей для перемалывания негодяев в честных людей».

Знаменитый реформатор, филантроп и врач Джон Говард в обзоре европейских тюрем высоко отзывался о системе одиночного заключения, наблюдаемой им в тюрьме Ватикана, которую он называл Silentium. Идея одиночного заключения по образу «чрева кита Ионы» быстро набирала сторонников в обществе, где еще были сильны традиции строгого пуританизма, под которыми прошел XVII век. Логика такого содержания казалась простой и понятной: под воздействием молчания и «шокового» одиночества человек сможет постичь глубину своего морального падения. Этот опыт он никогда не забудет в последующем и вряд ли впадет в те же соблазны, рискуя оказаться в подобном заключении вновь.

В 1775 г. английский просветитель Джонас Хэнвей выступил с трудом, который так и назывался «Одиночное тюремное заключение». Трактат фундирован религиозным мировоззрением автора: причины преступности Хэнвей сводит к падению авторитета религии в обществе, а средство противодействия таковой - в духовном обращении преступника/грешника. Пропагандируя преимущества одиночного тюремного заключения, как альтернативного смертной казни вида наказания, Хэн-

132 Кор. 7:10. Печаль ради Бога производит неизменное покаяние ко спасению.

14 Тревельян 2002: 374. 
вей от первого лица размышляет: «Если бы я был приговорен к повешению, а потом приговор изменили бы на тюремное заключение, если бы у меня были книги, перо, чернила и бумага, я бы и не пожелал компании; и хотя "человек был создан не для того чтобы пребывать в одиночестве", я предпочел бы одиночество плохой компании. Дьявол во мне будет менее силен, чем когда он в окружении других демонов» ${ }^{15}$.

Так в идейном комплексе будущей реформы появился важнейший концепт - режсим одиночного заключения. Французский философ Мишель Фуко, анализируя рождение тюрьмы, описывал идею Хэнвея, используя религиозную терминологию:

«...изоляция вызывает “страшный шок”, который, защищая заключенного от дурных влияний, помогает ему углубиться в себя и вновь услышать в недрах своего сознания голос добра; работа в одиночестве должна быть не только ученичеством, но и обращением; она должна перестраивать не только игру интересов, присущих homo oeconomicus, но и императивы морального субъекта. Одиночная камера, техника христианского монашества, сохранившаяся лишь в католических странах, становится в этом протестантском обществе инструментом, с помощью которого можно перестроить одновременно и homo oeconomicus, и религиозное сознание. Тюрьма должна образовывать “пространство между двумя мирами”, между преступлением и возвратом к праву и добродетели; место преобразования индивида, которое вернет государству утраченного гражданина. Аппарат для преобразования индивидов, который Хенуэй называет "реформаторием"»"

Итак, пространство между мирами и «аппарат для преобразования индивидов» - тюремная камера, которую Хэнвей и другие авторы сравнивали с чревом кита Ионы, стала воплощением надежд христианских реформаторов, связанных с процессом ожидаемого позитивного изменения личности осужденного преступника. Именно в тюремной камере заключенный предположительно должен был испытать смену эмоциональных состояний, пережитых Ионой в чреве кита - осознать суть преступления; очиститься страданием и скорбью, вызванными муками совести, и через искреннее покаяние обрести путь к свободе. Автор издания «Проповеди для заключенных. С включением молитв, рекомендованных для узников одиночного содержания», викарий графства Дарем Джон Брюстер в одной из проповедей обращался к осужденным:

«Я рекомендую вам пересмотреть моменты прошлой жизни и спутников ваших вожделений. Я бы хотел, чтобы вас постоянно кружило в смятении ума и упреках совести. Я хотел бы попросить вас проследить каждый момент вашего пути с какими усилиями и трудностями сопряжено было обладание награбленным, подозрения и зависть со стороны подельников, постоянный трепещущий страх попасть в руки правосудия. Стоило ли приносить в жертву сиюминутному удовольствию греха вашу Свободу? Стоило ли ради этого поступиться Честностью, Истиной, Религией? Ради этого вы отреклись от ощущения внутреннего покоя и домашнего счастья, отреклись от жены, которая могла бы успокоить ваши печали, от детей - утешения в старости, от любви к Богу и других благодатей, похоронив себя в одиночестве тюрьмы?» ${ }^{17}$.

\footnotetext{
${ }^{15}$ Hanway 1776: 104-105.

${ }^{16}$ Фуко 1999: 180.

${ }^{17}$ Brewster 1790: 27-28.
} 
Непременным итогом самосозерцания в одиночестве, по замыслу апологетов одиночного заключения, должно было стать «сокрушительное покаяние», сродни тому, которое испытал Иона. В этот ключевой момент совесть преступника/грешника выступает в виде самостоятельного инструмента наказания: «Каждый заключенный сам превратится в инструмент собственного наказания: его совесть станет тем самым инструментом возмездия. Заключенный в полном одиночестве, отдаленный от порочного окружения, без возможности соприкосновения с побочными соблазнами... арестант будет вынужден задуматься о своем грехе, услышать голос совести, пробужденный силой религии» ${ }^{18}$. Таким образом, страдание - непременный спутник покаяния. Тюремные проповедники нередко выбирали для проповеди ветхозаветное изречение: ««Вот, Я расплавил тебя, но не как серебро; испытал тебя в горниле страдания» ${ }^{19}$. Если заключение приносит преступнику/грешнику физические и моральные испытания, то какими бы унизительными и ужасными не были эти мучения, они необходимы как часть очищения: «Если же они окованы цепями и содержатся в узах бедствия, то Он указывает им на дела их и на беззакония их, потому что умножились, и открывает их ухо для вразумления и говорит им, чтоб они отстали от нечестия. Если послушают и будут служить Ему, то проведут дни свои в благополучии и лета свои в радости; если же не послушают, то погибнут от стрелы и умрут в неразумии» ${ }^{20}$. Божественное присутствие, таким образом, не исключается из сущности страданий уголовного наказания, наложенного авторитетом государства, скорее, Бог использует государственную власть как способ добраться до нарушителя Завета 21.

Пока европейская общественная мысль оттачивала теоретические аспекты гуманизации и реформирования уголовного наказания, в молодой американской республике возникли благоприятные условия для претворения этих идей в жизнь. В штате Пенсильвания адепты «Религиозного общества друзей» (квакеры) образовали Общество облегчения страданий арестантов. Своими проектами пенитенциарных преобразований они сумели заинтересовать власти штат, и добились государственных субсидий на возведение прогрессивных тюрем, основанных на принципе одиночного содержания. Первую тюрьму, возведенную по такому принципу в столице Пенсильвании Филадельфии, квакеры назвали «Домом покаяния», что впоследствии превратилось в нарицательное «пенитенциарий». Одиночные камеры-кельи площадью двадцать девять квадратных футов были полностью оборудованы всем необходимым для организации изолированного существования - окошком для передачи еды и книг, выходом в индивидуальный дворик для «прогулок» на свежем воздухе, краном с питьевой водой, и даже системой ка-

\footnotetext{
${ }^{18}$ Vaux 1827: 9.

${ }^{19}$ Ис. 48:10.

${ }^{20}$ Иов. 36:6-13.

${ }^{21}$ См., напр.: Sommers 1835.
} 
нализации. Чтобы не нарушать самосозерцание арестанта, тюремщики носили мягкую войлочную или резиновую обувь, разговоры велись исключительно шепотом, а колеса тюремного экипажа обивали кожей для бесшумного передвижения. Сидя в такой камере, легко было ощутить себя поглощенным и помещенным в утробу библейского Левиафана.

Режим одиночного содержания, названный пенсильванским по имени штата, в котором впервые был апробирован, изначально базировался на теологических аргументах, и вынужденная изоляция виделась как необходимое условие и лучшее средство исправления преступников. Впоследствии, когда тюремное реформирование стало сугубо государственной прерогативой, пенсильванская пенитенциарная модель подверглась детальному анализу с позиций рентабельности, преступных рецидивов, влияния на физическое и психическое здоровье заключенных. Альтернативные тюремные модели, основанные на совместном содержании арестантов и широком применении принудительного труда, показали бо́льшую эффективность и рентабельность. Теологические дискуссии о природе исправления преступника/грешника постепенно перешли в русло поиска психолого-педагогических и правовых средств и методов, обеспечивающих раскаяние, как осознание человеком своей вины в совершенном преступлении.

Приговор теологии и идеологии одиночного заключения можно было вынести крылатой фразой, порожденной английским Просвещением или протестантским богословием: «благими намерениями вымощена дорога в ад» ${ }^{22}$. Идея христианского покаяния и искупления была постепенно выхолощена из контента пенитенциарных реформ, осталась только оболочка - тюремная камера одиночного содержания. Вслед за К. Марксом, осудившим пенсильванскую систему как «...изолирование человека от внешнего мира и насильственное погружение его в глубокое душевное одиночество, соединение юридического наказания с теологическим мучительством...» ${ }^{23}$, многие общественные деятели, правоведы, врачи и представители педагогического сообщества подчеркивали сугубо карательный характер квакерского эксперимента.

Современные исследования настаивают на такой пенитенциарной политике, при которой «одиночное заключение должно применяться только в исключительных случаях или тогда, когда это абсолютно необходимо в целях проведения уголовного расследования». В целом же полагают, что такое содержание «оказывает подтвержденное многими документами и данными негативное воздействие на психическое здоровье и благополучие заключенных и может быть приравнено к жестокому, бесчеловечному или унижающему достоинство обращению и наказанию, особенно когда применяется в течение длительных сроков» ${ }^{24}$. От-

\footnotetext{
${ }^{22}$ Авторство крылатого выражения часто приписывают писателю XVIII в. Самюэлю Джонсону. По другой версии, автор изречения - английский богослов.

${ }^{23}$ Маркс, Энгельс 1955: 203.

${ }^{24}$ Одиночное заключение 2008.
} 
метим, что острие критики режима одиночного содержания нацелено, главным образом, на последствия такого заключения, его влияние на человека. Столетие спустя мало кто помнит о благих намерениях, которыми «мостили» реформу христианские реформаторы XVIII века. Тем не менее, нам удалось обнаружить одно малоизвестное исследование Ричарда Атертона, в прошлом тюремного капеллана, где автор представил любопытный разбор тюремной модели одиночного содержания с точки зрения изначального искажения оснований, заложенных в идею.

В монографическом исследовании «Призыв служить: христианское воззвание к тюремному служению» Атертон сравнил последовательности процессов покаяния - наказания - искупления в «механизме» функционирования социальных моделей монастыря и тюрьмы. Анализируя монашеский путь к искуплению, Атертон пишет: «когда преследование первых христиан осталось в прошлом, ... кровавая борьба мученика сменилась самоистязанием аскетов» ${ }^{25}$. Осознание своей грешной природы и непоколебимая уверенность в том, что каждый грех подлежит наказанию, вынуждали христианина на постоянный поиск очищения от всех форм греха в глазах Бога. А поскольку такие грехи как, например, гордость или лень, не предусматривали наказание со стороны государства, санкционированное церковью, «ретивые» христиане изобрели «строго личное наказание» - монастырь, куда добровольно заключали себя те, кто осознавал свою греховную природу и стремился избавиться от нее. Самодисциплина монахов - целибат, рутинная изнуряющая повседневная работа, пост, ограничения сна - оформилась в определенный режим. Цель этой добровольной ежедневной жертвы заключалась в том, чтобы преодолеть слабость плоти и очистить дух, приготовляя душу к жизни вечной. Таким образом, в механизме монастыря христианское покаяние (как единство стремлений разума, чувств и воли) акт свободной воли, наказание следовало за покаянием как епитимья нравственно-исправительная мера, за которой следовало искупление грехов $^{26}$. Наказание, таким образом, было, тем самым, признаком очищения и подтверждением решимости больше не грешить.

Механизм тюремного заключения, убежден Атертон, насильственно меняет местами последовательность процессов: жизнь заключенного (ограничение свободы, вынужденное безбрачие, повседневная рутинная работа) - это составляющие наказания, наложенного на него государством для очищения от своего «преступления» в отношении общества и от греха перед лицом Господа. И в процессе этого очищения его должно 25 Atherton 1987: 95.

${ }^{26}$ Современное богословие, особенно православное, воздерживается от трактовки епитимьи как наказания, или способа искупить преступление. Однако, рассматривая в исторической ретроспективе средневековое католичество, современные богословы подтверждают понимание епитимьи как «исключительно церковного наказания, предназначенного для искупления грехов в земной жизни» и не исключают такое отношение к епитимье и в настоящее время // Епитимья / Православная энциклопедия «Азбука веры». URL: https://azbyka.ru/epitimiya 
посетить покаяние, дабы он смог вернуться в общество, которому нанес вред, раскаявшимся и искупившим свой грех. Концептуальное отличие тюрьмы от монастыря заключается в последовательности действий и степени свободы воли. В «механизме» монастыря покаяние предшествует наказанию, а не является его следствием, как предполагает пенитенциарный механизм. Тогда монашеское «строго личное» наказание не рассматривается как способ достижения покаяния, а как его следствие, «как знак решимости больше не грешить». Пенитенциарное наказание также рассматривается как «имеющее потенциальную функцию искупления посредством покаяния, но наказание здесь не как акт собственного разума и воли, а как насильственные действия со стороны государства. Поэтому, - завершает анализ Атертон, - несмотря на кажущееся сходство тюрьмы и монастыря, целевое назначение их различно». Развивая мысль, он задается глубоким вопросом: «Может быть, одной из самых случайных ошибок в истории было решение возвести институты монастырского типа, заточить в них десятки тысяч людей, у которых нет ни призвания, ни склонности, ни в большинстве случаев физических или духовных ресурсов, чтобы извлечь какую-либо реальную пользу от монашеского образа жизни?» ${ }^{27}$.

В современных пенитенциарных моделях, построенных на идеях европейского Просвещения, практически не используется религиозный тезаурус. На смену покаянию пришло пенитенциарное исправление, искуплению - ресоциализация и воспитание правопослушного поведения. Одиночное заключение признано «жестоким, бесчеловечным или унижающим достоинство обращением», и практически повсеместно применяется как временная дисциплинарная мера.

Используя современный сленг, можно заключить, что идея тюрьмы-реформатория (то самое чрево кита Ионы) с течением времени была изрядно «прокачана», обросла многочисленными приложениями и в своем первозданном виде уже не встречалась. В содержании пенитенциарных реформ XIX века, детально изученных в рамках нормативистского подхода (когда юридические нормы рассматриваются в искусственной изоляции от социальных практик, как формально-юридические установления государства) исходный замысел христианских реформаторов стал практически неуловимым. Тем не менее, благодаря современному инструментарию новой культурно-интеллектуальной истории аналитическому взору исследователя открывается еще один источник пенитенциарных реформ конца XVIII - начала XIX века. Дискуссия же о средствах и источниках исправления арестантов кажется нескончаемой, а преступный рецидив, как мерило эффективности пенитенциарной модели, оставаясь стабильным, вынуждает современных пенологов продолжать поиски более эффективных способов защиты общества.

${ }^{27}$ Atherton 1987: 36, 38. 


\section{БИБЛИОГРАФИЯ / REFERENCES}

Лабутина Т.Л. Английская революция середины XVII века и интеллектуальный мир англичан // Диалог со временем. 2015. № 53. C. 16-29. [Labutina T.L. Anglijskaya revolyuciya serediny XVII veka i intellektualnyj mir anglichan // Dialog so vremenem. 2015, № 53. S. 16-29].

Маркс К., Энгельс Ф. Сочинения. 2-е изд. Т. 2. М., 1955. 652 с. [Marks K., Engels F. Sochineniya. 2-e izd. T. 2. M., 1955. 652 s.].

Одиночное заключение: сб. материалов и документов / сост. Шарон Шалев. Лондон: Центр криминологии им. Мангейма, 2008. URL: http://www.solitaryconfinement.org/ [Odinochnoe zaklyuchenie: sbornik materialov i dokumentov. /sost. Sharon Shalev. London: Centr kriminologii im. Mangejma, 2008].

Репина Л.П. История исторического знания. Пособие для вузов / Л.П. Репина, В.В. Зверева, М.Ю. Парамонова. М.: Дрофа, 2004. 288 с. [Repina L.P. Istoriya istoricheskogo znaniya. Posobie dlya vuzov / L.P. Repina, V.V. Zvereva, M.Yu. Paramonova. M.: Drofa, 2004. 288 s.]

Тревельян Дж. М. Социальная история Англии от Чосера до королевы Виктории. Смоленск, 2002. 614 c. [Trevel yan Dzh. M. Socialnaya istoriya Anglii ot Chosera do korolevy Viktorii. Smolensk, 2002. 614 s.].

Фуко М. Надзирать и наказывать. Рождение тюрьмы. М., 1999. 480 с. [Fuko M. Nadzirat i nakazyvat. Rozhdenie tyurmy. M., 1999. 480 s.].

Atherton R. Summons to serve: the Christian call to prison ministry. L., 1987. 150 p.

Brewster J. Sermons for prisons. To which are added prayers for the use of prisoners in solitary confinement. Stockton, 1790. 212 p.

Hanway, J. Solitude in imprisonment. With Proper Profitable Labour and a Spare Diet, the Most Humane and Effectual Means of Bringing Malefactors, who Have Forfeited Their Lives, Or are Subject to Transportation, to a Right Sense of Their Condition; with Proposals for Salutary Prevention. L., 1776. 144 p.

James T.C. A Living Tradition: Penitentiary Chaplaincy. Ottawa, 1990. 217 p.

McGowen R. A Powerful Sympathy: Terror, the Prison, and Humanitarian Reform in Early Nineteenth Century Britain // Journal of British Studies. 1986. Vol. 25. № 3. P. 312-334.

Rothman D.J. The Discovery of the Asylum: Social Order and Disorder in the New Republic. Boston, 1971. $380 \mathrm{p}$.

Rusche G., Kirchheimer O. Punishment and Social Structure. New York, 1939. 268 p.

Sommers C.G. Memoir of the Rev. John Stanford, D.D., Late Chaplain to the Humane and Criminal Institutions in the City of New York. New York, 1835. $447 \mathrm{p}$.

Vaux R. Letter on the Penitentiary System of Pennsylvania, adressed to William Roscoe, Esquire, of Toxteth Park, near Liverpool. Philadelphia, 1827. 15 p.

Васильева Светлана Анатольевна, кандидат исторических наук, доцент, заместитель начальника кафедры, кафедра философии и истории Академии ФСИН Poccuu,vasi-svetlana@yandex.ru.

\section{Religious sources of the ideal model of imprisonment in social and legal discourse of the late xviii-early xix century}

This article is devoted to the study of the religious origins of the modern prison system of solitary confinement, that was developed in the UK and the USA in the late XVIII - early XIX century. The period of the Enlightenment led to radical changes in the system of criminal justice. This period is considered to be "the era of punitive restraint": gradual legislative restrictions put on such sanctions as death penalty led to qualitative changes in the entire system of criminal penalties as a whole. Religious principles of the Protestants expressed in the model of solitary confinement. The ideal model of the reformatory was the image of the "Jonah's Whale" as a place and circumstance when the sinner (prisoner) was able to establish an incredible connection with God, to repent and atone for his crimes. The outcome of this theology was the hope that God would break out of prison "the reborn identity".

Keywords: prison reform, solitary confinement, Pennsylvanian prison system

Svetlana Vasilieva, PhD (History), associate professor, deputy head, Chair of Philosophy and History, Academy of Penal Service of Russia, vasi-svetlana@yandex.ru 


\section{C.Е. СИДОРОВА}

\section{МУСКУЛЬНАЯ СИЛА И ВОДА: СЛУГИ И ТЕХНОЛОГИИ ОХЛАЖДЕНИЯ В КОЛОНИАЛЬНОЙ ИНДИИ}

Во времена Британской Индии, попадая в колонию, британцы оказывались в трудно переносимых климатических условиях. В стремлении уберечься от зловредного воздействия окружающей среды, они воспроизводили элементы привычной им обстановки, одним из атрибутов которой была прохлада. В знойные и дождливые месяцы британцы тратили немало усилий на охлаждение воздуха вокруг них, для чего использовали приспособления разной степени сложности, а также приводивших их в действие специальных слуг. Сопротивляясь естественным природным условиям, европейцы организовывали локусы своей колониальной культуры, существовавшей по принципу разбросанных по субконтиненту оазисов, где искусственно создаваемый холод обеспечивал не только комфорт для работы и жизни, но и условия для поддержания достойного имиджа властителей.

Ключевые слова: Британская Индия, колониальная культура, местные слуги, жара, холод, технологии терморегулирования

Дневниковые записи леди Марии Нюджент (1771-1834), жены английского главнокомандующего на службе в Индии, в период с марта по сентябрь 1812, 1813, 1814 гг. пестрят прилагательными - сильная (great), невыносимая (intolerable), ужасная-преужасная (dreadful, very dreadful), чрезмерная (excessive), влажная и удушливая (damp and vapour), угнетающая (oppressive), неописуемая (indescribable), которые она использует вместе с одним и тем же словом - жара (heat) ${ }^{1}$. Жалобы на жару с указанием конкретных температурных значений, группирующихся, как правило, вокруг показателя в $100^{\circ} \mathrm{F}$ (ок. $\left.38^{\circ} \mathrm{C}\right)-$ привычный элемент колониальных нарративов - дневников, мемуаров, путевых записок, которые являются источниками для данного исследования.

Начальный опыт столкновения приезжавших в южнозиатскую колонию англичан с незнакомым миром был едва ли не в первую очередь телесным и сводился к улавливанию обрушивавшихся на них новых зрительных образов, запахов, вкусов, звуков, осязательных ощущений. Жара, выраженная в предельных значениях ртутного столбика и распознаваемая с помощью терморецепторов кожи, была для привыкших к холодному климату англичан одним из наиболее заметных и назойливых элементов окружающей действительности. В самые знойные месяцы с марта по июнь, а порой и до сентября, заполоняя все пространство колониальной повседневности, она была источником постоянного и изнуряющего дискомфорта, который обременял неприятными физиологическими состояниями, утомительными дополнительными процедурами и действиями в течение дня. Маргарет Макмиллан в книге о буднях колониальных жен, матерей и дочерей в Британской Индии дает довольно подробную подборку английских страданий из-за знойно-

\footnotetext{
${ }^{1}$ Nugent 1839. Vol. I: 68-315; Vol. II: 201-388.
} 
го климата, в которой упоминаются постоянно потные тела и необходимость менять одежду по много раз в день, обездвиженность, утомляемость и леность, ведшие к скуке и обретению тучности, особый режим дня, когда вся активная деятельность смещалась на ранние утренние и вечерние часы, переносы кроватей в сад по ночам и обратно в дом днем, ни на минуту не смолкавшая и оглушавшая какофония от стрекота цикад, немелодичных криков птиц и т.д. ${ }^{2}$. Внешние раздражители, воспринимаемые органами чувств, воздействовали на настроение и ум, пробуждая негативные эмоции, мысли и суждения.

Однако наиболее тесный и интимный телесный опыт соприкосновения с новой реальностью был связан непосредственно с нарушением целостности физической оболочки английских тел, зловредным воздействием на органы и организмы. Жара делала их нестойкими и проницаемыми для болезней и смерти. Как пишет Дэвид Арнолд в книге «Колонизованное тело...», колониальные врачи полагали, что среди всех недугов лихорадка (малярия), холера и дизентерия были самыми распространенными в Индии и служили главной причиной смертности европейцев. Эта «царствующая троица» (reigning trinity) была следствием жары и повышенной влажности ${ }^{3}$. Именно эти три напасти приключаются с героем сатирического стихотворения Р. Киплинга, членом парламента Пэджетом, подвергнутым испытанию индийским зноем, который он до этого легкомысленно называл «Азиатским солнечным мифом» ${ }^{4}$. Другие болезни - проказа, оспа, авитаминоз, столбняк, туберкулез и т.д., которые, как считалось, не имели своим источником климатические особенности, гораздо реже служили объектом пристального внимания колониальной медицины, по крайней мере, до второй половины XIX в. ${ }^{5}$ В другой книге, посвященной колониальному ландшафту, Арнолд приводит статистику, свидетельствующую об огромной, порой троекратной разнице, в уровне смертности среди солдат, офицеров, гражданских чиновников и их жен, дочерей, сестер в Англии и Индии в пользу последней. «B начале XIX в. европейцы в Индии полагали, что их преследует смерть и, хотя они не думали, что находятся на грани расового исчезновения, но видели себя жертвой неослабного смертоносного урагана» ${ }^{6}$.

Вместе с физическим ущербом жара наносила травмы и морального характера, все так же используя тела в качестве коммуникаторов. Риторика колониальных нарративов часто имела негативные коннотации, основанные на евроцентричных дискриминационных представлениях об

2 MacMillan 2018: 105-108. Подборку выдержек из колониальных писем и дневников, объединенных в главу «Жара и пыль» см. в: Ghose 2008: 220-241. Эту подборку можно расширять бесконечно, так как редкий текст времен Британский Индии не содержит упоминания невыносимого климата.

${ }^{3}$ Arnold 1993: 30.

${ }^{4}$ Kipling. Pagett, M.P.

${ }^{5}$ Arnold 1993: 28-32.

${ }^{6}$ Arnold 2006: 43. 
иерархии культур, их моральной зрелости и отсталости, цивилизационном разрыве между ними. Высокие температуры к неудовольствию британцев увеличивали пористость границ между их собственной и иноземной культурами и, в частности, вели к интенсификации нежелательного обмена физиологическими жидкостями между их индивидуальными представителями. Жаркий климат способствовал утрате силы воли, размягчению нравов, потаканию слабостям, эмоциональной несдержанности. Оказываясь под его воздействием, британские мужчины (а именно они составляли основной контингент колонистов до начала XIX в.) начинали вести туземный образ жизни и почти поголовно вступали в браки и сексуальные связи с местными женщинами, от которых на свет появлялись многочисленные дети-полукровки с неясным социальным статусом, по представлениям того времени, усвоившие вместе с материнской кровью низменные черты туземного характера. К концу XVIII в. кровосмесительная практика с тревогой воспринималась в английском обществе как признак падения нравов среди соотечественников и деградации британского характера в колонии ${ }^{7}$. Но и в XIX в., когда на смену восточным женщинам в свободных одеждах в Индию хлынул поток чопорных, затянутых в корсеты англичанок, принявшихся за восстановление подмоченной репутации мужчин, опасность подобралась к их семьям вместе с молоком индийских кормилиц, которым вскармливали уже чистокровное английское потомство. Среди главных отличий в условиях протекания беременности, родов и материнства европейских женщин в Англии и Индии медицинские трактаты в первую очередь называли климат, неблагоприятный для нежной и чужеземной конституции матерей и детей ${ }^{8}$. В условиях тропиков женщинам после родов полагалось не вставать с постели в течение нескольких недель, а с учетом того, что им также не рекомендовалось кормить грудью, отказаться от услуг няни-кормилицы было почти невозможно. Считалось, что как с кровью туземных матерей или с молоком местных кормилиц детям передадутся дурные качества, свойственные примитивным народам.

В качестве специфического элемента другого мира жара была не только физическим явлением с непривычными температурными параметрами, но и превращалась в культурный феномен, обраставший негативными характеристиками. Д. Арнолд показал, как в процессе изучения Индии ее природа, климат и ландшафт под оком европейских путешественников, натуралистов, топографов, медиков подвергались социальному конструированию путем вылепливания концепции тропиков в качестве «объекта колониального страха и желания... территории смерти и болезней, одиночества и ущербности» ${ }^{9}$. Он назвал этот культурно-интеллектуальный процесс «тропикализацией» Индии. В «Колонизованном

\footnotetext{
${ }^{7}$ Подробнее см. Dirks 2006, Chakraborty 2019.

${ }^{8}$ A Domestic Guide to Mothers 1836. P. V. См. также: Goodive 1856: XIV; Hunt, Kenny 1883: 379-381; Birch 1879: 14-23.

${ }^{9}$ Arnold 2006: 3 .
} 
теле» он пишет, что «колониальная медицина посредством топографических обследований и дискурсивной риторики по поводу физиологических и патологических следствий “жаркого климата” определяла Индию как экзотическое пространство, опасную и незнакомую среду» ${ }^{10}$. В результате индийская жара, которая делала чуждый мир некомфортным, агрессивным и опасным, превращалась во врага, а заполненное ею пространство в поле битвы, на котором нужно было одержать не только физическую, но и моральную победу ${ }^{11}$.

Данная статья посвящена «солдатам», сражавшимся на этом поле боя и их «оружию», т.е. индийским слугам, служившим в англо-индийских колониальных домах, и различным приспособлениям для поддержания относительно комфортного температурного режима. В центре внимания - конкретные терморегулирующие практики и вещи, бытование которых было обусловлено одним из универсальных свойств материальных предметов/тел - температурой, физической величиной, характеризующей их степень нагретости и способность людей воспринимать тепло или холод. Статья посвящена технологиям охлаждения тел снаружи, а именно способам понижения температуры воздуха ${ }^{12}$.

В Индии британцы охотно применяли местные технологии охлаждения воздуха. Проще всего можно было обеспечить ощущение прохлады с помощью вееров, опахал или чаури ${ }^{13}$. Чаще всего такая услуга была востребована во время трапез, поэтому их держали стоявшие за спинами едоков кхидматгары (лакеи). Томас Уильямсон, проведший на военной службе в Индии 20 лет (1778-1798), в книге-наставлении об образе жизни в колонии описывал типичный званый ужин в Калькутте: «...кхидматгар стоит за стулом своего хозяина и... создает ему прохладу с помощью ручного опахала из пальмового листа или отгоняет насекомых метелкой чаури, сделанной из бычьего хвоста, перьев павлина или травы $\kappa x a c-\kappa x a c^{14} \gg$. Такой способ требовал постоянного присутствия слуги, а то и нескольких непосредственно вблизи господина, а производимый опахалами эффект был невелик. Тот же Уильямсон замечал: «нетрудно представить, что, когда за каждым гостем стоят два и более человека, жизненное пространство наполняется испарениями от них самих, их

\footnotetext{
${ }^{10}$ Arnold 1993: 28, 32.

${ }^{11}$ См. о схожем восприятии холода: Hansson, Norberg 2009.

12 За рамками настоящей статьи оставлены колониальные практики охлаждения тел изнутри, а также способы сопротивления жаре с использованием свойств проводимости, абсорбции и отражения материалов и веществ, применяемые для строительства зданий, производства одежды и т.д.

13 Чаури - густой хвост тибетского яка, укрепленный на рукояти, часто богато декорированной (мог быть из серебра или слоновой кости). В древности знак царской власти. Использовались также кисточки коровьих хвостов. - Yule, Burnell 1996: 214.

${ }^{14}$ Растение семейства злаковых родом из Индии. Другое название - ветивер.
} 
хозяев, еды, и все это уничтожает любой комфорт и прохладу, создаваемую с помощью искусственных приспособлений» ${ }^{15}$.

Поэтому наряду с индивидуальными средствами существовала более крупная конструкция - панкха, о которой европейцы неизменно отзывались в комплиментарных выражениях. Панкха вызывала у только что прибывших в колонию англичан, получивших прозвище гриффины, удивление. Фанни Паркс (1794-1875), жена колониального чиновника, прожившая в Индии почти четверть века, подробное описание этого приспособления в дневниковой записи от 20 марта 1823 г. начала так: «Для гриффина панкха, которую он видит в первый раз, в диковинку. Это гигантское опахало представляет собой обтянутую тканью деревянную раму длиной в десять, двадцать, тридцать, а то и более футов, подвешенную под потолком и приводимую в движение вперед-назад человеком снаружи с помощью блоков и веревки, протянутой через отверстие в стене. Это местное изобретение является предметом величайшей роскоши. Они очень красивы, иногда украшены росписью и позолотой. Веревки обернуты шелком и протянуты таким образом, что во время движения не задевают канделябры, расположенные на той же линии, что и панкха» ${ }^{16}$. В 1873 г. автор, скрывшаяся за инициалами А.Ю., писала о панкхе: «...иногда это всего лишь карниз с тяжелой оборчатой тканью, а иногда рама с натянутым на нее полотном, подобранным в цвет комнаты, с притороченной широкой оборкой. Она подвешивается на красных веревках к высокому потолку и раскачивается с помощью шнура, выпущенного в наружные помещения или на веранду через дверной проем или отверстие, в которые встроен блок или ролик» ${ }^{17}$. Джон Флетчер Херст (1834-1903), американский епископ Методистской епископальной церкви, путешествовавший по Индии и Цейлону в 1890 г., описывал панкху как короткую портьеру из плотного небеленого льна шириной в фут и длиной во много ярдов в зависимости от пространства, которое требуется обдувать («...рама на пароходе соответствовала длине стола»). Когда он впервые увидел панкху в церкви, она поразила его как самое забавное из доселе виденных устройств. «Вскоре я привык даже к церковным панкхам. В одной из англиканских церквей в Мадрасе была панкха не только для паствы, но и для церковнослужителя и чтеца, и еще одна прямо над кафедрой для священника во время службы. То есть там было несколько индивидуальных опахал» ${ }^{18}$.

Все колониальные нарративы, затрагивавшие вопросы быта, упоминали или содержали подробные описания этого устройства. Им были оснащены практически все помещения в частных и казенных домах. На

15 Williamson 1810: 214-215, 213. О традиционном для английских застолий столпотворении слуг, создававшем удушливую обстановку, упоминала А.Ю. (имя автора неизвестно): A.U. 1873: 73-74. Подробнее см.: Сидорова 2019.

${ }^{16}$ Parks 1850: 25.

${ }_{17}^{17}$ A.U. $1873:$ 79-80.

${ }^{18}$ Hurst 1891: 230. 
живописных, графических и фотографических изображениях сцен колониального быта панкха является обязательным элементом интерьера. Херст писал о буднях в Мадрасе: «Панкху можно увидеть везде. Нет ни одного дома, в котором бы ее не было. Не успеете вы войти в помещение, еще до того, как вы сняли шлем и промокнули испарину, вас уже обдувают. Эта штуковина раскачивалась все время, что я гостил у друзей. Все конторы оснащены ими. Нет ни одного банка или пароходного офиса, где бы она не двигалась вперед-назад» ${ }^{19}$.

Панкхи приводились в движение специальными слугами, которых в ранних текстах называют bearer, в более поздних - панкхавала, кули, панкха-кули. Они выполняли свою работу, как правило, сидя на корточках или лежа на спине, мерно размахивая рукой или ногой с привязанной к ней веревкой. Число этих слуг увеличивалось в штате домашней челяди в жаркое время года, так как панкха должна была работать постоянно. Массовое появление дополнительных работников в домохозяйствах знаменовало начало знойного сезона, что зафиксировано и в уже упомянутом стихотворении Киплинга: «В апреле пришла потница вместе с кули и панкхой» (April began with punkah, coolies, and prickly-heat). Эти слуги неизменно фигурируют в колониальных нарративах до начала $\mathrm{XX}$ в. в качестве постоянных работников (как, например, в более жаркой Мадрасской провинции, о чем упоминают авторы книги по домоводству в Индии А.Ф. Стил и Г. Гардинер) или сезонных (в Бенгалии панкха устанавливалась с 15 марта по 1 ноября, в Бомбее с мая по июнь ${ }^{20}$.

Панкхавалль все время находились в непосредственной близости от хозяев. Как правило, привязанные к панкхам веревки, протянутые сквозь двери или отверстия в стене, позволяли господам оставлять слуг в прихожих, вестибюлях, на верандах, но нередко они работали внутри хозяйских помещений. Капитан Годфри Манди в 1829 г., описывая обычаи светских вечеров в Калькутте, отмечал: «курение трубок-хукка в гостиных в присутствии дам представлялось гриффину менее обескураживающим, нежели полуобнажённая фигура слуги, раскачива-вшего панкху» ${ }^{21}$. А.Ю. делилась болезненным опытом: «Иногда панкха по необходимости расположена так, что носильщик находится в той же комнате, и вы вынуждены в течение восьми-девяти месяцев жить в постоянном присутствии дикого, полуодетого человека, который целыми днями сидит на корточках на полу и лениво тянет веревку, поддерживая безостановочное движение туда-обратно огромного опахала» 22.

Труд был настолько механическим и нудным, что требовалось немало усилий для поддержания постоянного ритма работы. Европейцы традиционно ругали кули за леность, нерасторопность, сонливость. Погруженные в сон панкхаваллы были частыми героями словесных и изоб-

${ }^{19}$ Hurst 1891: 230.

${ }^{20}$ Steel, Gardiner 1893: 31, 32-33, 46.

${ }^{21}$ Mundy 1832: 299.

${ }^{22}$ A.U. $1873: 80$. 
разительных зарисовок. 19 марта 1812 г. Нюджент записала в дневнике: «Мне жаль несчастных носильщиков, потому что работа должна быть очень нудной, и они, как правило, пребывают в полусонном состоянии» ${ }^{23}$. Спустя почти 80 лет Херст ей вторил: «Бедные создания, кули часто засыпают, но даже тогда продолжают раскачивать панкхи. Я видел одного спящего в бомбейском банке, но и в таком состоянии его рука продолжала работать. Иногда, когда они полностью истощены, они привязывают веревку к ноге и двигают ей, пока руки отдыхают» ${ }^{24}$. А.Ю. писала:

«Конечно, необходимо нанять отдельную смену носильщиков для работы по ночам, но даже в этом случае кто-нибудь из них непременно заснет, так что, если есть возможность, лучше обойтись вовсе без них. Немногие вещи являются бо́льшим испытанием для самообладания, чем пробуждение в удушливой жаре и обнаружение неподвижной панкхи над головой. Тщетно вы будете кричать: "Bearer, bearer, pankah tanno!"25, ибо он мирно спит по другую сторону стены или двери; а ваши телодвижения и раздражение лишь усугубят ощущение жары. Джентльмен обычно выходит из положения, встав и запустив какой-нибудь предмет в голову носильщика; леди хватает панкху за оборку и резко дергает, что, как правило, достаточно для пробуждения спящего, так как он никогда не выпускает веревку из руки; на какое-то время он пробуждается, но это достигается ценой физического жара и морального стресса и сопровождается риском впустить через занавески бдительного москита, который точно лишит вас сна» ${ }^{26}$.

Карикатура конца XIX в. как раз показывала пробуждение хозяина посреди ночи и заснувшего рядом на высоком табурете слугу с веревкой в руке. Выбравшийся из-под москитной сетки хозяин приглашает домашнюю челядь посмотреть на нерадивость их сослуживца. Последняя сцена изображает избиение несчастного другими слугами ${ }^{27}$. Побои были распространенной мерой наказания для панкхавал. У Киплинга одуревший от зноя член парламента Пэджет, «позабыв, что он либерал», лупил «своих арийских братьев, которые обмахивали его».

Другим источником раздражения для европейцев были конфессиональные предубеждения слуг. Судя по некоторым косвенным замечаниям, панкхаваль были индусами и, чтобы сохранять ритуальную чистоту, подобно другим слугам отказывались выполнять работу, не предусмотренную нормами их кастовой группы. Фанни Паркс в отрывке о лености и праздности слуг писала: «Носильщики помимо раскачивания панкхи только едят и спят» ${ }^{28}$. Кроме того, даже в таком бесконтактном общении с белыми господами-париями они находили основания для проявления предрассудков. Нюджент рассказывала о хитростях обращения со слугами, которыми с ней делились уже привыкшие к колониальной жизни англичане: «За обедом я услышала о многих странных обычаях индусов от господина Эддисона, приятного, умного человека, который долго

\footnotetext{
${ }^{23}$ Nugent 1839. Vol. I: 122.

${ }^{24}$ Hurst 1891: 230.

25 Носильщик, носильщик, тяни панкху.

${ }^{26}$ A.U. 1873: 80.

27 The Graphic. February 21, 1891.

${ }^{28}$ Parks 1850: 25-26.
} 
прожил в Индии. Он говорит, что человек, отказывающийся из-за кастовых предубеждений раскачивать панкху, чтобы создать прохладу для вас, станет это делать, если вы поставите перед собой стакан воды. Тогда он будет охлаждать именно ее, и это примирит его с его совестью» ${ }^{29}$.

Некоторая передышка в этих изнурительных отношениях появлялась с наступлением холодного сезона. А.Ю. сообщала, что в Калькутте он приходил в ноябре, когда «панкхи праздно повисали в частных помещениях и убирались в церквах, где они были препятствием для видимости и звука. Временные bearers, нанятые на восемь месяцев для поддержания этих устройств в безостановочном движении, увольнялись из всех семей, и комнаты, наконец, освобождались от их постоянного и раздражающего присутствия» ${ }^{30}$. Викрам Доктор в статье о прошлом и настоящем панкхи ссылается на газету "The Times of India", которая в ноябре 1902 г. сообщала об отъезде 10-15 тысяч человек, нанятых на сезон панкхавалами в тогдашней имперской столице - Калькутте: «Они принадлежали к разным кастам и приезжали из всех частей страны». Там же упоминалась организованная система тиккадаров ${ }^{31}$, когда предприимчивые люди «нанимали в деревнях панкха-кули на лето, привозили их в Калькутту, определяли в дома на работу и получали определенный процент от их заработка». В. Доктор продолжает: «Эти ежегодные людские притоки и оттоки были столь предсказуемы, что по окончании сезона дакойты ${ }^{32}$ поджидали бедных кули, возвращавшихся в деревни, что заставляло последних сбиваться для безопасности в большие группы $>^{33}$.

Зависимость от мускульной силы и физиологии людей заставляла британцев непрерывно усовершенствовать способы охлаждения воздуха. В. Доктор цитирует автора еще одной статьи из "Тimes of India" за 1894 г.: «"мы регулярно ожидаем ежегодный урожай изобретений, связанных с панкхой и приведением ее в движение”. Предложений бесчисленное множество, но неизменно все заканчивается возвратом к апатичному труду панкха-кули» ${ }^{34}$. О том же сокрушалась А.Ю.:

«Много механических приспособлений было предложено, некоторые из них даже запатентованы, с целью освобождения панкхавал от их невыносимого положения. Но, похоже, ни одно из них не имеет перспектив войти в широкое употребление. Требуется гораздо больше энергии, чем может обеспечить любая из машин среднего размера и умеренной стоимости; человеческий же труд в Индии столь дешев, а конкретно эта бессмысленная тяжелая работа столь соответствует способностям людей, что, кажется, вряд ли им когда-нибудь найдется замена» ${ }^{35}$.

Однако если внутри помещения было жарко, то панкха приводила в движение лишь горячий воздух. Нехитрая техника, которая должна

${ }^{29}$ Nugent 1839. Vol. I: 106.

${ }^{30}$ A.U. 1873: 90.

${ }^{31}$ Тиккадар - временный работник.

32 Дакойт - бандит, разбойник.

${ }^{33}$ Doctor 2019.

${ }^{34}$ Doctor 2019

${ }^{35}$ A.U. $1873: 81$ 
была обеспечивать приток холодных воздушных масс, заключалась в занавешивании окон и дверей циновками, смоченными водой. Они назывались татти. Циновки делали из кхас-кхаса - «волокна коричневого цвета, длиной от 10 до 20 дюймов (стоимостью 32 фунта за маунд ${ }^{36}$ ), которое в плетеном виде заключалось в раму из расщепленного бамбука». Т. Уильямсон сообщал: «сделать татти не слишком тонкой и не слишком толстой было большим искусством» ${ }^{37}$. «Загонять» охлажденный воздух внутрь должен был ветер с улицы. И.Г.Т. Робердо, гражданский чиновник на службе Ост-Индской компании в 1799-1807 гг., писал:

«В большинстве западных дистриктов [Бенгалии] в определенное время года свирепствует горячий ветер, он, точно невидимый огонь, сдирает кожу с лица за пять минут, окажись вы на его пути. В наших низинах он слабее... мы противостоим ему с помощью татти. Они прикрепляются на окна и двери с той стороны дома, где обычно дует ветер, который наполняет помещение запахом травы кхаскхас. Циновки постоянно смачиваются... и воздух, просачивающийся сквозь них, делает место комфортным. В дополнение к этому от травы исходит очень приятный аромат, а звуки капающей воды усиливают ощущение прохлады. Татти разворачивают вскоре после восхода солнца и оставляют иногда до полуночи» ${ }^{38}$.

Смачиванием татти занимался специальный слуга - бхишти, т.е. разносчик воды, неизменным атрибутом которого был массак - бурдюк из козы крупного размера, в котором он переносил воду. Для заполнения массак погружали в реку или пруд, или же заливали водой, зачерпнутой из колодцев кожаными корзинами (dole $)^{39}$. Уильямсон сообщал:

«В холодное время года и в дождливый сезон его [бхишти] обязанности очень легкие. Он должен всего лишь обеспечить водой лошадей, заполнить несколько емкостей водой, нужной для приготовления еды, купания, питья и т.д., на что уходит не более получаса. Однако в летние месяцы его работа трудна. Помимо вышеперечисленных обязанностей, которые сами по себе возрастают в десять раз, он должен смачивать татти... К середине дня бхишти должен заполнить несколько огромных глиняных емкостей (nauds), расположенных рядом с домом, потом принести татти, разложить их на земле и тщательно смочить, затем закрепить в соответствующих проемах и в течение всего дня, как правило до полуночи сбрызгивать их целиком, а также пополнять запасы воды в бочках по мере ее расходования. Хотя это случается не часто, но в особо засушливые периоды бхишти продолжают свою работу на протяжении всей ночи» ${ }^{40}$.

Именно одновременное использование татти и панкхи давало наилучший результат, о чем писали многие, в частности Р.Г. Уоллес: «Татти создают воздух, а панкхи заставляют его циркулировать». И эту житейскую мудрость он даже облек в рифмованные строчки: «...Застоявшийся воздух панкха разгоняет, / В это время циновки-татти бхишти остужает...» ${ }^{41}$. Писательница Мэри Шервуд, которая в качестве жены чиновника Ост-Индской компании, провела в Индии 11 лет (с 1805 по

\footnotetext{
${ }^{36}$ Маунд - около 37 кг.

${ }^{37}$ Williamson 1810: 234.

${ }^{38}$ Roberdeau 1925: 137.

${ }^{39}$ Williamson 1810: 231. О бхишти и воде из колодцев см. Сидорова 2020.

${ }^{40}$ Williamson 1810: 231-232.

${ }^{41}$ Wallace 1823: 125, 138.
} 
1816 г.), воссоздавала фон жизни в жаркий сезон в Канпуре в 1807 г.: «По утрам мы не слышим ничего кроме монотонного звука "клик-клак", создаваемого панкхой, а если его нет, то меланхоличного стона жгучего ветра и всплесков капающей воды, которую льют на татти» ${ }^{42}$.

Однако даже сочетание панкхи и татти давало сбой в обеспечении помещений прохладой. С одной стороны, имел место все тот же человеческий фактор: засыпающие или попросту прозевавшие момент высыхания циновок бхишти. С другой стороны, подобно парусным кораблям функциональность татти зависела от ветра. В безветренные дни проку от мокрых циновок было немного. Эти «изъяны» упомянуты в мемуарах Реджинальда Хебера, епископа Калькуттского с 1823 г по 1826 г. Он описывал свой уклад жизни в жарком месяце апреле:

«Мы с женой встаём в 4 утра и наслаждаемся приятной конной прогулкой ежедневно, хотя вскоре после шести горячее солнце гонит нас обратно. Мы пытались сохранять прохладу в наших комнатах с помощью татти... Во время сильного ветра они очень полезны, но в этом году четыре дня из пяти были безветренными вовсе. Кроме того, с татти есть ещё одна незадача: если бхишти пренебрегает своей работой хотя бы несколько минут (если кто-нибудь ещё не следит за ним, он постоянно впадает в сон), в дом врывается поток раскаленного возду$\mathrm{xa}$, что делает пребывание в комнате и доме невыносимым. Тогда по совету других мы стали закрывать все окна в доме около восьми утра, позволяя панкхе гонять только тот воздух, что был внутри дома, и по возможности избегали притока внешних воздушных масс. В результате температура в доме была значительно ниже, чем снаружи, на уровне 80-85 F вместо 100. Конечно, мы были заперты словно в могиле, однако, если мы приближались к открытой двери или окну, то это было все равно, что находиться около устья домны.... ${ }^{43}$.

Неудачный опыт использования татти зафиксирован и у Марии Нюджент в записи от 16 марта 1812 г.: «Впервые использовала тати... Тяжко думать, что эти несчастные создания [бхишти] вынуждены трудиться так долго, мы же в результате извлекаем единственную пользу, которая заключается в том, что вместо сухого бодрящего воздуха имеем влажный и горячий как в паровой бане» ${ }^{44}$.

Задача обеспечения постоянного воздушного потока, направленного на татти была решена с помощью термантидота - механизма, по свидетельству авторов словаря англо-индийской лексики «ХобсонДжобсон» в 1830-1832 гг., предположительно придуманного доктором Спилсбери ${ }^{45}$. Другую версию предлагает Джулиус Джеффрис (18001877), британский хирург, писатель, изобретатель, состоявший на медицинской службе в Индии с 1822 по 1835 г. В книге «Британская армия в Индии» (1858) он описывает воздуходувную машину, придуманную еще во второй половине XVIII в. д-ром Дессагийером для вентиляции Палаты общин, и ее дальнейшую адаптацию д-ром Рэнкиным, состояв-

\footnotetext{
42 Kelly 1857: 334.

${ }^{43}$ Heber 1828: 102.

${ }^{44}$ Nugent 1839. Vol. I: 120.

${ }^{45}$ Yule, Burnell 1996: 915.
} 
шим на Бенгальской медицинской службе, для использования в Индии ${ }^{46}$. Рэнкину же принадлежало и изобретение названия механизма.

Как бы то ни было, но уже в 1830 г. Фанни Паркс фиксировала ее использование в быту. В дневниковой записи от 29 марта, сделанной в Канпуре, она сообщала, что впервые видела термантидот, который «она зарисовала, чтобы сконструировать для себя такой же» ${ }^{47}$. Второй раз Паркс упомянула его 1 февраля 1831 г. уже в качестве своей собственности, которая была погружена на лодку во время переезда из Лакхнау в Аллахабад. 1 марта она писала о подготовке к знойному сезону:

«Становится очень жарко... Мы надеемся обеспечить прохладу с помощью термантидота, для чего выстроили террасу и веранду. Термантидот - это конструкция, на которую страшно смотреть, однако он принесет нам пользу и подобно пароходу будет работать без ветра и вместе с обыкновенными татти создаст то, без чего невозможна свежесть. Термантидот - это огромная машина для подачи холодного воздуха в дом. Она делается из мангового дерева или из сала ${ }^{48}$, колеса и ось - из железа. Его высота составляет примерно 7 футов, ширина 5 или 6, а длина от 9 до 12 футов... Термантидот, полый внутри, круглый по форме, имеет выступающую воронку, которая вставляется в окно и фиксируется, сама машина стоит снаружи на веранде. Четыре огромные лопасти внутри него прикреплены к железной оси, которая пропущена через центр машины и вращается двумя людьми, стоящими снаружи. Когда лопасти приходят в движение, они выталкивают воздух из термантидота через воронку в дом. Чтобы сделать воздух, поступающий внутрь помещения, холодным, в досках, которые образуют две плоские стороны термантидота, вырезаются круглые отверстия диаметром примерно в 4 фута. Снаружи этих отверстий прикрепляются татти из кхас-кхаса. Вакуум, образующийся за счет выталкивания воздуха из машины, заполняется новой порцией, проникающей сквозь татти. С каждой стороны термантидота вверху устанавливается длинная воронка, низ которой закрыт пластиной с мелкими отверстиями. Вода постоянно льется в воронки и попадает через отверстия на татти, расположенные под ними, сохраняя их все время влажными. Эта вода стекает вниз в две такие же воронки и пройдя через маленькое горлышко сбоку, собирается в лоханки или большие глиняные бадьи... Таким образом, весь воздух, попадающий в машину через кхас-кхас прохладный, и именно он благодаря крутящимся лопастям попадает в дом. Термантидот стоит на четырех маленьких колесах, которые позволяют передвигать такую громоздкую и тяжеловесную машину. Кхас-кхас был прикреплен только сегодня. Вы не представляете, насколько ароматен, изыскан и бодрящ запах свежего кхас-кхаса....»99.

Слуг, которые были приставлены к термантидоту, называли кули. Фанни Паркс так описывала их труд: «Одни кули постоянно заняты подачей воды в глиняных горшках другим, сидящим наверху термантидота, чья задача следить за тем, чтобы татти были все время мокрыми» ${ }^{50}$. Очевидно, что в процессе были задействованы и бхишти, доставлявшие воду в хозяйство. Кроме того, еще два человека приводили в движение барабан термантидота, раскручивая его за ручки. Фанни Паркс сообщала, что «во время горячих ветров требуется от 12 до 14 дополнитель-

\footnotetext{
46 Jeffreys 1858: 142-143.

${ }^{47}$ Parks 1850: 134.

48 Шорея исполинская (лат. Shorea robusta).

${ }^{49}$ Parks 1850: 199-200.

${ }^{50}$ Parks 1850: 200.
} 
ных кули, если у вас более одного термантидота, или, если он работает круглосуточно; но эти люди, а также дополнительные бхишти увольняются с наступлением сезона дождей» ${ }^{51}$. Джулиус Джеффри, отмечая недостатки термантидота, указывал на необходимость непомерно больших физических затрат со стороны кули для эффективной работы конструкции: «Воздух в барабане вместо того, чтобы выходить наружу при каждом повороте, остается внутри и вращается там подобно молоку в маслобойке... Можно считать виноватым в этом приставленного к вентилятору кули, однако дефект заложен в самом устройстве Дессагийера, так как оно работает с полной отдачей только на большой скорости» ${ }^{52}$. Эффект, производимый правильно работающим термантидотом, был весьма заметным. В юмористической манере его описал Джордж Франклин Аткинсон в книге об индийском быте:

«Эта душа [полковник] неустанно заботится о приспособлениях для лучшего обустройства дома, например, предназначенных для понижения температуры... Его последняя затея - запатентованный “термантидот”, то, что английский фермер назвал бы гигантской веялкой. Вашему вниманию будет явлен оригинальный метод охлаждения воздуха в комнате с помощью особого вентилятора, который вращается, если мне не изменяет память, со скоростью сто пятьдесят миль в час или около того! Там, на веранде, вы видите слугу, крутящего ручку колеса, которое не останавливается ни днем, ни ночью. Если вы войдете в комнату, то на себе ощугите достигаемый эффект, обнаружив, что ваша шляпа слетела в соседний угол, а ваши волосы беспорядочно развеваются, залепив вам все лицо и глаза! И если на противоположной веранде также находится термантидот, создающий вихревые порывы ветра, а над вашей головой изо всех сил раскачивается свисающая с потолка панкха, то вам недостает только струи воздуха снизу, чтобы почувствовать себя в центре урагана - идеального циклона. Вместе с татти - смоченных волокнистых экранов, закрывающих все остальные проемы в доме - “наш полковник" бесспорно имеет самый прохладный дом в Kabob»53.

В то время как в холодном климате поддержание комфортного температурного режима обеспечивалось экзотермическими реакциями за счет использования топлива, в жарком - он поддерживался с помощью приспособлений и механизмов, бесперебойное функционирование которых требовало постоянного приложения большой мускульной силы, а расходным материалом, нуждавшемся в постоянном пополнении, была вода. Паркс прямо писала, что «жаркий климат в сочетании с предубеждениями местных жителей вынуждали хозяев держать большое число слуг $\aleph^{54}$, что было порой весьма накладно для семейного бюджета.

Жара влияла на экономику и цикличность колониальной жизни: «Холодный сезон заканчивался, и вновь дни становились все жарче и жарче, огонь больше не разводили, длина брюк изменялась, люди все раньше и раньше возвращались домой по утрам, и все позже и позже выходили оттуда по вечерам, окна и двери закрывались, панкха начинала работать днем, затем раскачивалась

\footnotetext{
${ }^{51}$ Parks 1850: 210.

52 Jeffreys 1858: 144.

53 Atkinson n. d., n. p. Фанни Паркс выражалась точнее: «В комнатах на 10 градусов холоднее, чем тогда, когда у нас были просто татти». - Parks 1850: 204.

${ }^{54}$ Parks 1850: 210.
} 
уже и по ночам, потом появлялись татти, а вслед за ними термантидоты, пока вновь не наступал май и обнаруживал несчастный англо-индийский мир опять окруженным необходимой, но неудобной броней против жаркой погоды» ${ }^{55}$.

Описанная выше битва за холод или, другими словами, насильственное навязывание тропическому пространству несвойственных ему температурных значений имело отношение к процессам установления иерархий и проблемам власти в контексте столкновения двух культур пришлой, колониальной и местной, локальной.

Домашней территорией британской культуры был регион с относительно прохладным климатом, поэтому обеспечение комфортного температурного режима в Индии было для англичан, прежде всего, способом создания привычной обстановки и попыткой организации в тропиках места европейской повседневности. Однако, будучи доминирующей политической силой на субконтиненте, колониальная культура волейневолей превращала свойственные ей черты, в т.ч. холод, в индикаторы власти. С этой точки зрения, изначально диктуемое физиологической потребностью наполнение пространства прохладой означало наделение его атрибутом власти. Этот атрибут был особого свойства - тактильным, распознаваемым терморецепторами кожи, но имел то же предназначение, что и более традиционные, визуальные - маркирование той или иной территории как зоны непосредственного присутствия властителей.

Кроме того, один из устойчивых стереотипов, сложившийся в европейской культурной традиции в период географических открытий и имперского строительства, наделял холодные регионы земного шара и людей, там проживавших, чертами маскулинности, а значит потенциалом активного действия и властного превосходства. Как пишут авторы исследования о холоде: «С точки зрения внешнего наблюдателя Арктика и Антарктика часто кодировались как зоны маскулинности, куда мужчины могли отправиться, чтобы показать свою отвагу и способность победить страшный и зловещий ландшафт» ${ }^{56}$. В холоде они демонстрировали выносливость, стойкость и мужественность. Отношения между холодом и маскулинностью опосредовались через категории эмоций. Пониженные температурные значения увязывались с понижением «температуры накала» страстей, обузданием чувственности, замораживанием эмоциональности, затвердеванием воли и характера, т.е. того, что высвобождалось или размягчалось, подавлялось в жарком плавильном котле тропиков, под пагубное воздействие которых попадали британские колонизаторы. Неслучайно для описания связей между имперским и колониальным народами нередко использовалась «гендерная» парадигма, когда западной цивилизации стали приписываться черты, свойственные мужскому началу, а восточной, «тропической» - женскому. Например, философ и политический деятель Эдмунд Берк в одной из речей на судебном процессе по делу Уоррена Хейстингса, генерал-губернатора Бен-

55 Arnold 1854: 253-254.

${ }^{56}$ Hansson, Norberg 2009: 7. 
галии, говорил о «чаше», наполненной такими пороками, как «прелюбодеяние, грабеж, насилие», протягиваемой добропорядочному гражданину Британии манерной восточной падшей женщиной. В образе падшей женщины был представлен не кто иной, как наваб Аркота ${ }^{57}$. Соответст-венно, искусственно создаваемый холод обеспечивал условия не только для физиологического комфорта и здоровья, но и для восстановления репутации, укрепления силы воли для отторжения «чаши» с соблазнами, поддержания достойного имиджа властителей, которым не следовало выглядеть больными, вялыми, разморенными, потными, а значит нестойкими, уязвимыми и подверженными вредному влиянию тропиков.

Здесь интересна роль британских женщин, приезжавших в колонию и призванных представлять интересы маскулинной, эмоционально холодной культуры. Ханссон и Норберг, размышляя о человеческих отношениях, «измеренных с помощью шкалы термометра», пишут: «Когда речь заходит о женщинах, холодность часто презентуется в жизнеотрицающих образах ${ }^{58}$, а описания, фокусирующиеся на холодных чертах характера, как правило, относятся к женщинам, имеющим доступ к власти. Существует множество клишированных образов, таких как "ледяная дева" (ice maiden, ice virgin), “снежная королева" (ice queen), которые свидетельствуют, что влиятельная женщина воспринимается как бесстрастная и бесплодная» ${ }^{59}$. В колонии, где женщины, напротив, должны были производить потомство, следующие поколения имперских правителей, одним из символов сдержанности, благочестия, добронравия и выносливости стал корсет. Как пишет Маргарет Макмиллан:

«Женщины, жившие в Индии в период расцвета Раджа, могли бы легче переносить жаркую погоду, если бы от них не ожидали, что они станут одеваться так же, как Дома. Вплоть до Первой мировой войны даже в самое пекло они носили чулки и платья, которые спадали тяжелыми складками до самой земли; они никогда не выходили из дома с обнаженными руками, до тех пор, пока во время Второй мировой войны стандарты не были смягчены. Вниз они надевали нижние юбки, рубашки и на протяжении большего периода Раджа неизменные корсеты - железный каркас для мэмсахибов, такой же, каким была для Индии Индийская гражданская служба» ${ }^{60}$.

Диссонанс между измученным телом и необходимостью поддерживать сконструированный образ непоколебимого правителя Фанни Паркс, страдавшая в одиночестве от индийской лихорадки и жары, подавленности, упадка сил и отвращения к жизни, передала такими словами: «...только вообразите, я - англичанка, а готова повеситься на панкхе!» ${ }^{61}$.

Наконец, в отличие от политических триумфов англичан в Индии, сопровождавшихся масштабными территориальными завоеваниями, победа над климатом не могла иметь такой же географический охват. Со-

\footnotetext{
${ }^{57}$ Цит. по: Dirks 2006: 159.

${ }^{58}$ В качестве примера они приводят Снежную королеву и мертвую Белоснежку.

${ }^{59}$ Hansson, Norberg 2009: 8.

${ }^{60}$ MacMillan 2018: 109.

${ }^{61}$ Parks 1850: 302.
} 
противляясь природным условиям, англичане организовывали локусы своей колониальной культуры по принципу разбросанных по субконтиненту оазисов, на границах которых происходила смена температурных режимов. Удержание отвоеванных у жары пространств под своим термоконтролем требовало непрерывного привлечения немалых ресурсов, что свидетельствовало о состоятельности их обладателей. Холод, таким образом, становился маркером элитарности, ценностью, доступной избранным, в данном случае представителям властного меньшинства, огораживавшим свое пространство границами холодного фронта. Однако с учетом уровня развития технологий и эндотермического характера запускаемых ими процессов, требовавших не топлива, а мускульной силы, прилагаемой к несложным приспособлениям, климатическое одомашнивание тропического пространства происходило за счет допущения элементов чужой культуры в виде постоянного и близкого присутствия полуобнаженных слуг и диковинных предметов. Они в свою очередь наполняли его специфическими запахами и звуками, определенной ритмикой движений. Все это делало по-европейски прохладное место экзотическим на вид, слух и запах. Латая границы между культурами в одном месте, британцы оголяли их в другом, создавая бреши, через которые восточный мир вливался и обустраивал пространство европейской власти в тропиках, делая его гибридным и неоднородным.

\section{БИБЛИОГРАФИЯ / REFERENCES}

Сидорова С.Е. Баварчи, кхансаман и кхидматгар: слуги на кухне и в столовой колониального бунгало в Индии // Вестник Института востоковедения РАН. Т. 3 (9), 2019. С. 142-152. [Sidorova S.E. Bavarchi, kkhansaman i kkhidmatgar: slugi na kuhne i v stolovoj kolo-nial'nogo bungalo v Indii // Vestnik Instituta vostokovedeniya RAN. T. 3 (9), 2019. S. 142-152].

Сидорова С.Е. Чесотка дхоби: домашние слуги и гигиена в колониальной Индии // Социальные и гуманитарные науки. Сер. 9: Востоковедение и африканистика. № 4, 2020. С. 116-133. [Sidorova S.E. CHesotka dhobi: domashnie slugi i gigiena v kolonial'noj Indii // Social'nye i gumanitarnye nauki. Ser. 9: Vostokovedenie i afrikanistika. № 4, 2020. S. 116-133].

A Domestic Guide to Mothers in India, Containing Particular Instructions on the Management of Themselves and Their Children. By a Medical Practitioner of Several Years Experience in India. Bombay: American Mission Press, 1836.

A.U. Overland, Inland, and Upland. A Lady's Notes of Personal Observation and Adventure. L.: Seely, Jackson, \& Halliday, 1873.

Arnold D. Colonizing the Body: State Medicine and Epidemic Disease in Nineteenth-Century India. Berkeley, Los Angeles: University of California Press, 1993.

Arnold D. The Tropics and the Traveling Gaze: India, Landscape, and Science, 1800-1856. Seattle, L.: University of Washington Press, 2006.

Arnold W.D. Oakfield; or, Fellowship in the East. 2 vols. Vol. I. L.: Longman, Brown, Green, and Longmans, 1854.

Atkinson G.F. Curry and Rice on Forty Plates or, The Ingredients of Social Life at "Our Station" in India. $3^{\text {rd }}$ ed. London, no date.

Birch E.A. Goodive's hints for the Management and Medical Treatment of Children in India. Calcutta: Thaker, Spink \& Co., 1879.

Chakraborty S. From Bibis to Ayahs: sexual labour, domestic labour, and the moral politics of empire // Sinha N., Varma N. (eds.) Servants' past. Late eighteenth to twentieth-century South Asia. Vol. II. New Delhi: Orient black swan, 2019. P. 41-72.

Dirks B.N. The Scandal of Empire: India and Creation of Imperial Britain. Cambridge (Mass.): The Belknap Press of Harvard University, 2006. 
Doctor V. View: The Past and Possible Future of „Punkahs“// The Economic Times. April 06, 2019 // https://economictimes.indiatimes.com/industry/miscellaneous/view-the-past-andpossible-future-of-punkahs/articleshow/68748849.cms?from=mdr

Ghose I. (ed.) Memsahibs Abroad. Writings by Women Travellers in Nineteenth Century India. Oxford: Oxford University Press, 2008.

Goodive H.H. Hints for the General Management of Children in India, in the Absence of Professional Advice. L.: W. Thaker and Co., 1856.

Hansson H., Norberg K. Cold Matters. Cultural Perceptions of Snow, Ice and Cold. Umea: Umea University and Royal Skyttean Society, 2009.

Heber R. Narrative of a Journey through the Upper Provinces of India: From Calcutta to Bombay, 1824-1825, (with Notes upon Ceylon,) an Account of a Journey to Madras and the Southern Provinces, 1826, and Letters Written in India. In 3 vols. V. I. L.: J. Murray, 1828.

Hull E.C.P. The European in India, or, Anglo-Indian's Vade-Mecum: a Handbook of Useful and Practical Information for Those Proceeding to or Residing in the East Indies, Relating to Outfits, Routes, Time for Departure, Indian Climate and Seasons, Housekeeping, Servants, etc.: also an Account of Anglo-Indian Social Customs and Native Character. L.: Henry S. King \& Co., 1871.

Hunt S.L., Kenny A.A. Tropical Trials. A Handbook for Women in the Tropics. L.: W.H. Allen \& Co., 1883.

Hurst J.F. Indika: The Country and the People of India and Ceylon. N.Y.: Harper \& Brothers, 1891.

Jeffreys J. British Army in India. L.: Longman, Brown, Green, Longmans \& Roberts, 1858.

Kelly S. (ed.). The life of Mrs. Sherwood (chiefly autobiographical) with extracts from Mr. Sherwoods journal during his imprisonment in France \& residence in India. L.: Darton \& Co., 1857.

Kipling R. Pagett, M.P. // http://www.kiplingsociety.co.uk/poems_pagett.htm

MacMillan M. Women of the Raj. The Mothers, Wives and Daughters of the British Empire in India. L.: Thames \& Hudson, 2018.

Moore W. J. A Manual of the Family Medicine for India. L.: J.\&A. Churchill, 1877.

Mundy G.C. Pen and pencil sketches, being the journal of a tour in India. In 2 vols. Vol. II. L.: John Murray, 1832.

Nugent, Maria. A Journal from the Year 1811 till the Year 1815, Including a Voyage to and Residence in India, with a Tour to the North-Western Parts of the British Possessions in that Country, under the Bengal Government. 2 vols. L.: Printed by T. and W. Boone, 1839.

Parks F. Wanderings of a Pilgrim, in Search of the Picturesque, During Four-and-Twenty Years in the East; with Revelations of Life in Zenana. 2 vols. Vol. I. London, 1850.

Roberdeau I.G.T. A Young Civilian in Bengal in 1805. Life in Calcutta and at Mymensingh // Bengal Past and Present. 1925 (January-June), Vol. XXIX, Serial Nos 57-58. P. 110-147.

Steel F.A., Gardiner G. The Complete Indian Housekeeper and Cook. Giving the Duties of Mistress and Servants, the General Management of the House, and Practical Recipies for Cooking in All Its Branches. Edinburgh: Edinburgh Press; Bombay: Educational Society Press, 1893.

The Graphic. February 21, 1891 // https://www.amazon.co.uk/Original-Victorian-Punkah-WallahCreighton-Peterborough/dp/B00SWW1T5I.

Wallace R.G. Fifteen Years in India; Or, Sketches of a Soldier's Life: Being an Attempt to Describe Persons and Things in Various Parts of Hindostan. From the Journal of an Officer in His Majesty's Service. London: Longman, Hurst, Rees, Orme, and Brown, 1823.

Williamson T. Vade-Mecum or, Complete Guide to Gentlemen Intended for the Civil, Military, or Naval Service of the Hon. East India Company. Vol. I. L.: Black, Perry, and Kingsbury, 1810.

Yule H., Burnell A.C. Hobson-Jobson // The Anglo-Indian Dictionary. Great Britain: Mackeys of Chatham, 1996.

Сидорова Светлана Евгеньевна, кандидат исторических наук, старший научный сотрудник, Центр индийских исследований, Институт востоковедения РАН, veta.sidorova@mail.ru

\section{Muscular energy and water Servants and cooling technologies in Colonial India}

In the days of British India, getting into a colony, the British found themselves in difficult climatic conditions. In an effort to protect themselves from the harmful effects of the heat, they reproduced elements of their familiar environment, one of the attributes of which was 
coolness. In the hot and rainy months, the British spent a lot of effort to cool the air in their homes, for which they used devices of varying degrees of complexity and special servants who powered them. Resisting natural conditions, the Europeans organized the loci of their colonial culture, which existed on the principle of oases scattered over the subcontinent, where the artificially created cold provided not only comfort for work and life, but also the conditions for maintaining a decent image of colonial rulers.

Key words: British India, colonial culture, native servants, heat, cold, technologies of temperature control

Sidorova Svetlana, Institute of Oriental Studies, Russian Academy of Sciences; Center for Indian Studies, senior research fellow; PhD, veta.sidorova@mail.ru 


\section{К.Д. СКРИПНИК \\ СИГНИФИКА ЛЕДИ ВИКТОРИИ УЭЛБИ ПОРТРЕТ В ИНТЕРЬЕРЕ ВРЕМЕНИ ${ }^{1}$}

В статье рассматриваются идеи сигнифики - науки о значении, сама концепция которой возникает на рубеже XIX-XX вв. благодаря леди Виктории Уэлби (18371912), имя которой на протяжении длительного времени было незаслуженно забыто. Описываются основные факты ее жизни, показана связь характеристик личности Уэлби и идей сигнифики в контексте интеллектуальной атмосферы ее времени. Личность и работы леди Уэлби оказали влияние на развитие философских и семиотических исследований, а также на установление связей между мыслителями различных стран. Заслуга Уэлби - в создании целостной динамической теории знака и значения, теории, интегрирующей различные аспекты изучения значения - от логико-лингвистических до аксиологических и практических.

Ключевые слова: Виктория Уэлби, сигнифика, знак, смысл, значение, значимость

На рубеже XIX-XX вв. в западной литературе фиксируется всплеск интереса к проблеме значения в широком контексте развития различных дисциплин - философии, логики, лингвистики, психологии, в рамках которых формируется определенный спектр подходов к ее исследованию. За всего лишь тридцать лет появляются работы Ч. Пирса по семейотике (семиотике), М. Бреаля по семантике, Ф. де Соссюра по семиологии, Ч. Огдена и Ричардса по значению значения, оставшиеся в памяти и обсуждаемые до нашего времени. В это же время формируется «концепция теории знаков как универсально обоснованной, фундаментальной ветви науки» ${ }^{2}$, получившей от своего создателя - леди Виктории Уэлби название сигнифики. Если первые из названных авторов и их научные исследования не нуждаются в особом прояснении, то и личность Виктории Уэлби, и специфика разработанной ею сигнифики не вполне известны не только отечественному, но и зарубежному читателю. Жизнь и работы леди Виктории Уэлби, как-то странно забытые, почти затерянные во времени, вновь оказались в фокусе внимания западных исследователей более чем через пятьдесят лет после ее ухода из жизни.

Цель статьи - рассмотреть предложенную Викторией Уэлби науку - сигнифику, ввести читателя в круг ее идей и научного творчества, в ее роль в развитии связей между учеными, принадлежащими к разным областям науки. «Портрет», о котором идет речь в названии, будет, скорее, диптихом - рассмотрим и личность леди Уэлби, и базовые характеристики сигнифики как науки о значении. Мазки портрета не будут всегда ровными, композиция вряд ли станет совершенной - где-то отдельные

\footnotetext{
${ }^{1}$ Исследование выполнено при финансовой поддержке РФФИ в рамках научного проекта № 20-011-00261.

${ }^{2}$ Eschbach 1983: xxviii.
} 
детали будут выписаны более тщательно, где-то - менее, с использованием широких и несколько небрежных движений кисти.

Рожденная в аристократической среде Виктория Александрия Мария Луиза Стюарт-Уортли, будущая леди Уэлби, в период расцвета своего творчества называвшая себя (и именно так сохранившаяся в комментаторской литературе) Виктория, леди Уэлби, с детства была отмечена своеобразным взаимоотношением с окружающим миром. Одной из ее восприемниц была женщина, уже через пять дней после крещения Виктории ставшая королевой - речь идет о королеве Виктории, не раз впоследствии оказавшей влияние на свою крестницу не только тем, что в течение двух лет Виктория Стюарт-Уортли была фрейлиной королевы, но и созданием той самой эпохи, которая вошла в историю под названием «викторианской». Прямым и самым важным влиянием, которое испытала Виктория Уэлби, было, конечно же, влияние ее матери, леди Эммелины, оставшейся вдовой, когда Виктории было всего семь. Леди Эммелина, несомненно, была незаурядной женщиной, автором книг стихов, драматических произведений и путевых заметок, жанр которых был первым «опытом письма» Виктории, сопровождавшей свою мать в ее длительных путешествиях на протяжении семи лет.

Достаточно небольшого перечня мест, чтобы понять, как много впечатлений могла получить маленькая Виктория: Северная и Южная Америка (от Вашингтона до Гаваны, Панамы и Перу), Иберийский полуостров и Марокко, Европа и Средний (Ближний) Восток. Но это не были просто поездки «мимо»: они сопровождались встречами с массой известных людей (скажем, в США это был президент Тэйлор и знаменитый Даниэль Уэбстер) и фиксацией своих впечатлений в записках. Уже в 1852 г. Виктория публикует книжку о впечатлениях о поездке по Америке 12-летней девочки. Несомненно, эти путешествия и встречи оказали влияние на всю оставшуюся жизнь (говорю «несомненно», основываясь и на личном опыте - примерно в таком же возрасте посчастливилось побывать в самых разнообразных местах от Западной Сибири до Германии, от центра страны до Закавказья). К этому добавляется и перенимаемый от матери «опыт письма», умения и навыки не только устного, но и письменного общения. Отсутствие систематического образования (факт, который также оказал влияние на последующее развитие и, судя по результатам, влияние положительное) вкупе с получением огромного личного опыта, встречами с выдающимися людьми своего времени создали ту базу, которая позволила сформироваться самобытному мыслителю, самостоятельному, пытливому, общительному и открытому. Встречи с яркими людьми продолжились и после окончания путешествий (связанного со смертью леди Эммелины во время путешествия по Востоку в 1855 г.): с 1861 г. леди Виктория Уэлби становится фрейлиной своей крестной - королевы Виктории и два последующих 
года проводит при дворе, что дает ей возможность общаться с такими известными политиками как Дерби, Гладстон, Пальмерстон.

В определенной степени личность Виктории Уэлби и ее отношение к делу может быть характеризовано следующим. После того, как ее сын женился, титул леди Уэлби перешел к ее невестке; чтобы можно было отличить ее от невестки, она стала называться «Виктория, леди Уэлби», иногда просто «В. Уэлби». Объяснив эту ситуацию в письме ${ }^{3}$ к Ч. Пирсу от 22.12.1903, она специально оговаривает, что «не в титулах» дело, что считала бы честью, если бы те, кто трудится (на ниве исследований, понятно из контекста), воспринимали ее как серьезного труженика.

Несомненно, воспринимать Викторию Уэлби иначе трудно, если познакомиться хотя бы с некоторыми результатами ее деятельности. Первая ее книга «Нити и петли» ${ }^{4}(1891)$, была посвящена религиозной тематике, в частности, неясностям и двусмысленностям религиозного дискурса, если использовать современную терминологию. Намеченные трудности исследования связывались ею с трудностями интерпретации, особенно интерпретации метафор. Речь, правда шла не о том, чтобы избегать метафор в серьезном исследовании, а о том, чтобы использовать метафоры с ясным каркасом интерпретации, позволяющим прояснять идеи, лежащие в основе метафорических выражений. Этот каркас интерпретации связан в первую очередь с ответом на вопрос, являются ли религиозные тексты людским порождением без какого-либо «божественного промысла» или все-таки имеется некая «высшая истина», задающая весь настрой интерпретационного каркаса. Книга предназначалась для достаточно широкого круга публики и могла бы казаться не очень существенной с научной точки зрения, если бы следом не были опубликованы две статьи в журналах с весьма серьезной (вплоть до сегодняшнего дня) научной репутацией: «Значение и метафора» ${ }^{5}$ в «The Monist» и «Смысл, значение и интерпретация» ${ }^{6}$ - в «Mind». В 1897 г. выходит вторая книга ${ }^{7}$, посвященная двусмысленностям и заблуждениям, связанным с неаккуратным обращением с языком, предлагающая пример проведения и лингвистической реформы, и реформы преподавания и обучения языку. Книга заслуживает по меньшей мере двух замечаний: здесь впервые появляется особый термин для предлагаемой, скажем так, концепции - «сенсифика» (sensifics), который позднее был признан не вполне удачным и заменен на «сигнифику»; второе - образовательная реформа была одной из тем, на базе которых были установлены отношения между леди Уэлби и будущим автором «Значения значения» Ч. Огденом.

В это же десятилетие выходят материалы и сборники, демонстрирующие результаты работы по сбору и систематизации примеров неак-

\footnotetext{
${ }^{3}$ Hardwick 1977: 13.

${ }^{4}$ Welby 1890.

${ }^{5}$ Welby 1893.

${ }^{6}$ Welby 1896.

${ }^{7}$ Welby 1897.
} 
куратного и небрежного употребления языка в научных, философских и психологических текстах ${ }^{8}$. Они не только доказывали не-спекулятивный характер предложений Виктории Уэлби, не только подкрепляли ее теоретические тезисы добротным эмпирическим материалом, но и подтверждали, что она настоящий «труженик», о чем она писала в упомянутом выше письме. Не перечисляя многих других работ (полный перечень можно найти у С. Петрилли ${ }^{9}$ ), написанных в этот период и позже, необходимо назвать две последние книги ${ }^{10}$ Виктории Уэлби, выразившие ее основные идеи новой науки о значении.

Что касается организационных способностей и заслуг Виктории Уэлби, то достаточно сказать, что в 1872 г., обнаружив, что постепенно исчезают умения рукоделия, которые, среди прочего, позволяли викторианским женщинам иметь собственную нишу для общения и развития, она на собственные деньги организует общество вышивальщиц. Благодаря леди Уэлби патронессой общества выступает королева Виктория, оно становится Королевским обществом вышивальщиц (существует и поныне). Интеллектуальные заслуги леди Уэлби привели к тому, что она стала членом Аристотелевского общества Лондона, в 1890 г. избирается членом Антропологического института Великобритании и Ирландии (получил статус «Королевский» в 1907 г.). Леди Уэлби оказала огромную помощь в организации и была в числе основателей Социологического общества Великобритании в 1903 г. - на этот факт в опубликованном некрологе обращает особое внимание Д. Макдональд ${ }^{11}$, на протяжении нескольких лет работавший ее секретарем.

В течение многих лет Виктория Уэлби вела значительную переписку со многими известными людьми своего времени. Эпистолярный жанр был для нее привычным способом общения, изложения своих идей, получения помощи и критических замечаний, оказания (иногда весьма скрытого) влияния на своих корреспондентов. Так, Ч. Пирс, переписка с которым продолжалась на несколько лет и закончилась только с уходом из жизни леди Уэлби, в одном из писем замечает: «Не думаю, что я составил свои трихотомии в том виде, который они имеют, под влиянием Вашей книги и вполне убежден, что никакое подобное влияние вообще не имело места. Хотя, конечно, это могло получиться бессознательно. При чтении Вашей книги мой ум мог глубоко впитать Ваши идеи таким образом, что я этого теперь совершенно не помню» ${ }^{12}$. Хотя Пирс говорит здесь о книге Виктории Уэлби, это с полной ответственностью может быть отнесено и к ее письмам. В наиболее близкой к нам по времени работе, в которой приводится и широко используется большой объем писем леди Уэлби, ее автор, С. Петрилли, пишет: «Для Уэлби диалоги-

\footnotetext{
${ }^{8}$ Welby 1892; Welby 1893a; 1898.

${ }^{9}$ Petrilli 2009.

${ }^{10}$ Welby $1903 ; 1911$.

${ }^{11}$ Macdonald 1912.

${ }^{12}$ Пирс 2000: 318.
} 
ческий обмен, критика, столкновение и отзывчивое понимание были необходимыми реквизитами приобретения знания. Она подчеркивала важность постановки вопросов, которые считала указателями для возможного исследования - даже без требований обязательных ответов на данные вопросы, разве что в форме новых вопросов. Благодаря ее щедрому посредничеству, ее корреспонденты обменивались мнениями друг с другом - непосредственно или через нее» ${ }^{13}$. Помимо просто переписки с учеными и философами леди Уэлби пользовалась еще и правом (которое, например, в явном виде дал ей Пирс) пересылки полученных ею писем от одного автора другим своим корреспондентам, знакомя тем самым их с идеями друг друга, давая возможность установить новые творческие и личные связи и отношения. Иногда подобные попытки были весьма удачными, как в случае введения идей и работ Пирса в интеллектуальное пространство британских философов, иногда попытки оканчивались провалом как в случае с Пирсом и Расселом.

Здесь, не вдаваясь в подробности ее эпистолярного наследия - тем более, что первый шаг был нами сделан в другом месте ${ }^{14}-$ следует обязательно упомянуть, что важность переписки леди Уэлби была осознана только после ее смерти - сначала ее дочерью, издавшей два тома ее переписки $^{15}$, затем другими исследователями - И. Лиебом ${ }^{16}$, Ч. Хардвиком $^{17}$ и частично В. Шмитцом ${ }^{18}$. Огромное количество писем леди Уэлби и ее корреспондентов было использовано С. Петрилли ${ }^{19}$. Что касается знакомства отечественного читателя с письмами леди Уэлби, то, помимо авторской статьи, вряд ли возможно обнаружить иные издания - да, кажется, и сама фигура леди Уэлби стала привлекать внимание лишь после опубликования некоторых писем Ч. Пирса, адресованных ей.

Что касается развития леди Уэлби идей сигнифики в последнее десятилетие XIX - первые годы XX в., то они стали результатом предшествующей работы по исследованию метафоры, неясностей и двусмысленностей, связанных с использованием языка, с одной стороны, а, с другой, представляли собой вполне естественную эволюцию их автора. Эта эволюция характеризовалась переходом от сбора материала, свидетельствующего об имеющихся нелепостях, коммуникативных затруднениях и ошибках, связанных с пониманием и интерпретацией значений в обычном и научном словоупотреблении, к первичной концептуализации, попытке теоретизирования, построению системного и обоснованного анализа, к исследованию и выработке практических путей выхода. Так, соглашаясь с некоторыми комментаторами ${ }^{20}$ ее творчества, можно

\footnotetext{
${ }^{13}$ Petrilli 2009: 15.

${ }^{14}$ Скрипник 2019.

${ }^{15}$ Cust 1929; 1931.

${ }^{16}$ Lieb 1953.

${ }^{17}$ Hardwick 1977.

${ }^{18}$ Schmitz 1990.

${ }^{19}$ Petrilli 2009.

${ }^{20}$ Myers 1995.
} 
говорить, что исходным пунктом развития исследовательской деятельности леди Уэлби был «принцип метафоры», для которого характерно различение уровня буквального языка и уровня «смысла»; последний представляет собой подлинное значение выражений языка.

Возвращение к подлинным значениям возможно, конечно, реализовать через использование исключительно денотативных функций языковых выражений, но это был бы неверный ход - очевидно, денотативные значения, предполагающие использование только буквального языка, привели бы к значительному его обеднению и к исключению возможностей использования языка для репрезентации иной, порой скрытой реальности. По сути дела, Виктория Уэлби говорит о том, что теперь стало просто трюизмом - использование языка не исключительно в буквальном смысле позволяет с помощью достаточно ограниченного множества средств порождать практически бесконечное число их сочетаний и вариантов их использования и употребления. Но в этом случае уровень смысла, отличающийся от буквального уровня, требует установления процедур интерпретации, поскольку языковых выражений с фиксированным значением не так уж много. Именно этот круг идей отстаивался в ее статье, помещенной в журнале «Mind»: «...то, что она [Виктория Уэлби] стремится обосновать в работе "Смысл, значение и интерпретация”, это знакомый тезис о том, что ученые и философы уделяют слишком мало внимания нуждам интерпретации, игнорируя условия значения, и что самая большая нужда заключается в систематическом изучении значения... и и его внедрении в образование» ${ }^{21}$.

Систематическое изучение значения и есть цель сигнифики. Попытка однозначного определения сигнифики непроста: хотя, по некоторым сведениям, Виктория Уэлби «приценивалась» к нему еще в 1894 г., в первый раз оно официально появляется в 1896 г. в указанной выше статье 22 наряду с термином «сенсифика». Обрисуем сигнифику, опираясь и на собственные определения ее, данные Викторией Уэлби в разных работах, и, одновременно, используя в качестве руководства комментарии ван Данцига ${ }^{23}$, Д. Вуйсье ${ }^{24}$, А. Эшбаха ${ }^{25}$ и С. Петрилли ${ }^{26}$.

В последней своей книге леди Уэлби дает следующее определение: «Сигнифика коротко и предварительно может быть определена как изучение природы значимости (Significance) во всех еe формах и отношениях и, таким образом, ее "работы" в каждой возможной сфере человеческой целесообразной деятельности. Но тот факт, что это изучение полностью отрицалось даже в образовании, затрудняет формулировку полностью удовлетворительного определения ${ }^{27}$. Проясняя это определение,

\footnotetext{
${ }^{21}$ Myers 1995: 13.

${ }^{22}$ Welby 1896.

${ }^{23}$ Dantzig 1948.

${ }^{24}$ Vuysje 1953.

${ }^{25}$ Eschbach 1983.

${ }^{26}$ Petrilli 2009.

${ }^{27}$ Welby 1985: vii.
} 
Виктория Уэлби пишет: «то, что естественным образом предшествует и является самым (главным) условием человеческих взаимоотношений как подлинного занятия человека в этом мире» есть интерпретативная функция, о которой здесь говорили ранее.

В этом же, 1911 г., появляется ${ }^{28}$ определение сигнифики, согласно которому сигнифика - «...наука и метод образования, основанные на значении понимания точной значимости терминов и понятий и их влияния на мышление и жизнь». В этом же году статья «Сигнифика», появляется в Британской энциклопедии; в ее начале сигнифика определяется как «наука о значении или изучение значимости при том условии, что достаточное значение придается ее практическому аспекту как методу мышления (mind), который включен во все виды умственной (mental) активности, включая логику» ${ }^{29}$. После этого определения повторяется текст более ранней, кажется, одной из первых, статей, в которой дается характеристика сигнифики. Имеется в виду статья 1902 г. ${ }^{30}$, написанная совместно Викторией Уэлби, Джорджем Стаутом и Джеймсом Болдуином; приведем лишь наиболее важные фрагменты. «Сигнифика имплицирует аккуратное различие между (a) смыслом, или сигнификацией, (b) значением, или интенцией, и (c) значимостью, или идеальной значимостью (ценностью, worth)»; «предлагаемый метод умственного обучения, нацеленный на концентрацию интеллектуальных активностей (деятельностей) на том, что по имплицитному допущению конституирует начальную и конечную цель любого обучения - то, что сейчас безразлично называют его значением или смыслом, его импортом или значимостью»; «сигнифика предоставляет также средства для привлечения внимания к отставанию языка в сравнении с другими видами человеческой коммуникации и к неотложной необходимости стимулирования мышления посредством создания широкого интереса к логической, практической, равно как и эстетической, ценности всех видов выражения».

Несмотря на естественную эволюцию понимания сигнифики, Виктория Уэлби сохраняла понимание значения как определенной трехсоставной или трехуровневой структуры, включающей смысл, значение и значимость. «Классифицированное использование терминов, выражающих ценность, утверждает три главных уровня или класса этой ценности - уровни смысла, значения и значимости: (а) первый из них на начальном этапе естественно ассоциируется со смыслом в его наиболее примитивной референции; то есть, с органическим ответом на окружающую среду и с существенно выразительным (экспрессивным) элементом во всем опыте. Мы подвергаем остракизму бессмысленность в речи, а также спрашиваем “в каком смысле?” используется слово или может быть оправдано утверждение; (b) но “смысл” сам по себе не является целенаправленным; последнее является главной характеристикой слова “зна-

\footnotetext{
${ }^{28}$ Welby 1933.

${ }^{29}$ Hardwick 1977: 167.

${ }^{30}$ Welby, Stout, Baldwin 1902: 529.
} 
чение", которое, собственно, и предназначено для специального смысла, выражающегося в намерении передать; (c) термин “значимость” полезно использовать как включающий смысл и значение, но превосходящий их по рангу и покрывающий далеко идущие следствия, импликации, конечный результат или исход некоторого события или опыта» ${ }^{31}$. Хотя вряд это можно считать точными определениями, но становится ясной главная черта сигнифики, определяемая стремлением учесть динамический характер языка и знака (не только языкового), пластичность различных уровней выражения и коммуникативный характер значения в широком смысле слова, объединяющем смысл, значение и значимость.

В некоторых более ранних работах последний элемент назывался иногда «интерпретацией», иногда «переводом» (в более широком смысле слова, смысле, сопряженным с «трансляцией», может быть, смысле, аналогичном тому, о котором говорит Р. Якобсон ${ }^{32}$, называя его «трансмутацией»). Но введение понятия значимости является гораздо более подходящим, потому что именно он в наиболее яркой степени отражает то новое, что появляется в предложенной Викторией Уэлби трактовке знака: значение его может быть адекватно воспроизведено в более широком, чем просто лингвистический или логический, аспекте - значение есть специфическая человеческая, социальная характеристика, а иногда даже характеристика более крупного масштаба, вплоть до «космического». В первую же очередь речь идет о включении в адекватную реконструкцию значений и чувственных, и волевых, и ценностных их характеристик: «Мы уже затронули некоторые формы этой триады, - пишет Виктория Уэлби в книге «Что такое значение?», - которые могут также быть представлены как сигнификация, интенция и идеальная ценность. С этой точки зрения, референция смысла главным образом инстинктивная, значения - волевая, значимости - моральная... Сигнифика анализирует отношение знака в широком смысле каждой из референций, признавая восходящую степень практической важности» ${ }^{33}$.

Для того, что точнее выразить смысл этих «трех уровней», трех «классов выражения», трех элементов значения, Уэлби вводит и иные тройственные единства, «триады». Так, например, со «смыслом» коррелируются «тенденция», «сигнификация», «органический ответ на окружающую среду», со «значением»- «интенция», «специфический смысл, который передается намеренно», со «значимостью» - «идеальная ценность» (иногда - «worth», иногда - «value»), «существенный интерес» и другие. Обращая внимание на то, что Виктория Уэлби, хотя довольно часто использовала триадические построения, относилась к «триадизму» достаточно критично, Шмитц ${ }^{34}$ сводит коррелирующие между собой различные «триады» в таблицу из одиннадцати групп триад.

\footnotetext{
${ }^{31}$ Welby 1911: 79.

32 Якобсон 1985: 362.

${ }^{33}$ Welby 1983: 46-47.

${ }^{34}$ Schmitz 1985: xcvi.
} 
Обратим внимание на сам термин «сигнифика» и основания для его выбора, тем более, как видели, был и иной вариант названия новой науки, иными словами, выбор названия сопровождался рассмотрением ряда вариантов. Среди вариантов были «семантика» и «симболика» (symbolics), те, с кем названием обсуждалось, предлагали к рассмотрению и «семиотику», и «семасиологию», и «сематологию». Однако, некоторые не устраивали, потому что уже были «обременены» определенной денотацией, некоторые несли излишние коннотации. Нужен был новый термин, поскольку речь шла о новом подходе к значению, подходе, который выходит за рамки лингвистического, логического, философского, психологического и иных взглядов. Речь шла о некоем интегрирующем исследовании значения, включающем достижения и различия всех упомянутых подходов, но обогащенным аксиологическими и даже прагматико-практическими аспектами функционирования знаков и значений. Это можно понять, потому что потенциал знака, его «сигнифицирующая», означающая «сила» с самого начала несли в себе больше, чем просто использование знака: «означивать» - это не только указывать посредством знака, но и придавать значимость, ценность такому указанию. Ценность же зависит от гораздо большего числа факторов, нежели просто лингвистические, логические и иные «измерения». Если первым уровнем значения выступает «смысл», то и он является весьма динамичной характеристикой. Так, если речь идет о смысле слова, то Виктория Уэлби замечает, что «строго говоря, нет такой вещи как смысл слова - есть только смысл, в котором оно используется: обстоятельства, состояние ума, референция, «универсум рассуждения» ${ }^{35}$.

Выбор названия и обсуждение сделанного выбора представляет собой пример, отлично иллюстрирующий то, что имеется в виду под «интерьером времени». В данном случае это пример заинтересованного обсуждения, доброжелательного отношения со стороны маститых исследователей, представляющих разные сферы науки и гуманитаристики, к новому явлению, представленному человеком из иной сферы, человеком, не принадлежащем науке, не получившем систематического образования (следует, наверно, прибавить и то, что это женщина). На новое предложение, новый термин отозвались такие британские исследователи как Г. Сиджвик и Д. Стаут, французские - А. Бергсон, М. Бреаль и А. Лаланд, голландцы ван Иден (Ееден) и де Хаан, американец Ч. Пирс и другие. Это не единственный пример единства ученых, они были, вероятно, и раньше - вспомним деятельность М. Мерсенна, будут и позже - достаточно назвать знаменитый Венский кружок. Важно, что их объединяла не только, а, быть может, и не столько, профессиональная деятельность, сколько внимание к новым возможностям, поощрение стремления к новому знанию со стороны других, принадлежащих и не принадлежащих к исследовательскому сообществу.

\footnotetext{
${ }^{35}$ Welby 1983: 5.
} 
В письме к А. Лаланду от 7.02.1911 леди Уэлби отмечает: «...пользуясь возможностью, скажу, что моя статья "Сигнифика" имеется в новой Encyclopedia Britannica, а также в новом оксфордском словаре и в “Философском словаре” Болдуина. Можете ли вы включить определение данного термина и в Ваш Словарь? Это название формально признали профессор Бергсон и другие мои французские корреспонденты...» ${ }^{36}$. Леди Уэлби поддерживала переписку с А. Лаландом давно - и, в частности, относительно термина «сигнифика», когда леди Уэлби обсуждала с ним такие варианты перевода данного названия на французский как «signifique» по аналогии с «statistique», «economique» или «sémantique», Лаланд в ответном своем письме ${ }^{37}$ (от 20.08.1903) возражал подобному транскрибированию, предлагая термин «signifik».

В Нидерландах первым, кто ввел термин «significa» как соответствие английскому «significs», был де Хаан, оценивший в одной из своих статей сигнифику леди Уэлби гораздо более объемно и, кажется, вполне справедливо, как «философию языка»:

«30 марта 1912 года в своем поместье Харроу близ Лондона в возрасте 75 лет скончалась леди Виктория Уэлби, основатель новой философии языка, которую она назвала сигнификой и название это было принято английскими и американскими философами. Сама создательница характеризовала сигнифику как философию значимости, то есть философию человеческой способности к выражению (expression). Язык не является единственным средством человеческого выражения, и сигнифика, следовательно, охватывает больше, чем философию языка - философию выражения. Для овладевающего сигнификой предметом интереса являются и другие средства выражения: музыка, живопись, скульптура, химические и математические формулы, геометрические фигуры и жесты. И все же вербальный язык представляет собой, конечно, наиболее привычное и хорошо знакомое средство выражения и (практически то же самое) отношения. Ввиду этого сигнификант (significian) (неологизм, введенный Викторией Уэлби, специалист по сигнифике - K.C.) начинает прежде всего с феномена языка» ${ }^{38}$.

Добавляя к портрету отдельные штрихи, следует обратить внимание и на «самооценку» его героев. Виктория Уэлби рассматривала сигнифику как некий универсальный инструмент, который может быть использован гораздо шире по сравнению с тем, что предлагалось иными научными подходами. Теория знаков и значения в ее концепции представлялась наиболее фундаментальной и наиболее глубокой ветвью науки, выступающей даже не в качестве средства разрешения назревших проблем, а, скорее, как новая стартовая точка. Сигнифика, по справедливому замечанию А. Эшбаха ${ }^{39}$, есть практическая процедура, новый взгляд, объединяющий логическую, практическую и эстетическую ценность всех форм выражения.

Несомненно, предложенный портрет не может считаться завершенным. Требуется тщательнее выписать не только взаимоотношение

\footnotetext{
${ }^{36}$ Petrilli 2009: 310.

${ }^{37}$ Petrilli 2009: 257.

${ }^{38}$ Schmitz 1990: 220.

${ }^{39}$ Eschbach 1983: xxviii.
} 
сигнифики с иными концепциями знака и значения, предложенными семиотикой Чарльза Пирса ${ }^{40}$, семантикой Мишеля Бреаля и призывающей к росту общения между людьми концепцией Андре Лаланда, подходом к проблеме значения, предложенным Бертраном Расселом и ранней аналитической философией ${ }^{41}$, но и обратить внимание читателя на то влияние, которое - явно или неявно, признанно или нет - оказала личность Виктории Уэлби и предложенная ею сигнифика на новые интеллектуальные движения, среди которых в первую очередь следует назвать движение сигнифики в Нидерландах ${ }^{42}$ или идею единства науки, связанную с Венским кружком. Продолжение работы позволит сделать портрет более емким, ярким и глубоким, чтобы он не затерялся в очередной раз в архивах и запасниках истории мысли, а занял то место, которое принадлежит ему по праву.

\section{БИБЛИОГРАФИЯ / REFERENCES}

Пирс Ч. Начала прагматизма. СПб.: Алетейя, 2000. 352 с. [Pirs Ch. Nachala pragmatizma. SPb.: Aletejja, 2000. $352 \mathrm{~s}]$.

Скрипник К.Д. Философское эпистолярное наследство: феномен леди Виктории Уэлби // Философский журнал / Philosophy Journal. 2019. T. 12. № 2. C. 131-143. [Skripnik K.D. Filosofskoe jepistoljarnoe nasledstvo: fenomen ledi Vik-torii Ujelbi // Filosofskij zhurnal / Philosophy Journal. 2019. T. 12. № 2. S. 131-143.].

Якобсон Р.О. О лингвистических аспектах перевода // Якобсон Р.О. Избранные работы. M.: Прогресc, 1985. C. 361-368. [Jakobson R.O. O lingvisticheskih aspektah perevoda // Jakobson R.O. Izbrannye raboty. M.: Progress, 1985. S. 361-368.].

Cust N. (ed.) Echoes of Larger Life: A Selection from the Early Correspondence of Victoria Lady Welby. London: Jonathan Cape. 1929.

Cust N. (ed.) Other Dimensions: A Selection from the Later Correspondence of Victoria Lady Welby. London: Jonathan Cape. 1931.

Dantzig, David van. Significs, and Its Relation to Semiotics // Melanges philosophiques, Vol. 2. (Library of the Xth International Congress of Philosophy. Amsterdam, 11-18 August 1948). Amsterdam: L. J Veen Ltd. 1948. P. 176-189.

Eschbach A. Significs as Fundamental Science // Welby V. What is Meaning? Studies in the Development of Significance. Reprint of the edition: London, 1903. Amsterdam. John Benjamins Publ.Co., 1983. Pp. ix-xxxii.

Hardwick Ch.S. (ed.) Semiotic and Significs. The Correspondence between Charles S. Peirce and Victoria Lady Welby. Bloomington \& London. Indiana University Press. 1977. 201 p.

Lieb, Irwin C. (ed.) Charles S. Peirce's Letters to Lady Welby. New Haven: Whitlocks, Inc., $1953.55 \mathrm{p}$.

Macdonald, D. Lady Welby // The Sociological Review, vol. V, 1912. Reprint 1964: 152-156.

Mannoury, G. A Concise History of Significs // Welby V. What is Meaning? Amsterdam: John Benjamin Publ.Co., 1983. P. xxxiii - xlii.

Myers W.A. Victoria, Lady Welby // Waithe, M.E. (ed.) A History of Women Philosophers. Vol. 4. Kluwer Academic Publishers, 1995. Pp.1-24.

Pietarinen A.-V. Welby, Peirce and Russell: The Role of Language in Early Analytic Philosophy. Riga, 2008. 39 p.

Petrilli S. Sign, Meaning, and Understanding in Victoria Welby and Charles S. Peirce // Signs and Society. 2015, vol.3, No. 1. P. 71-102.

Petrilli S. Signifying and Understanding. Berlin, De Gruyter Morton, 2009. 1048 p.

Schmitz W.H. (ed.) Essays on Significs. Papers presented on the Occasion of the $150^{\text {th }}$ Anniversary of the Birth of Victoria Lady Welby. Amsterdam. John Benjamins. 1990. 313 p.

\footnotetext{
40 Petrilli 2015.

${ }^{41}$ Pietarinen 2008.

${ }^{42}$ Mannoury 1983.
} 
Vuysje D. 1953 Significs. Its Tendency, Methodology, and Applications // Proceedings of the American Academy of Arts and Sciences. 1953.Vol. 80. No.3. Pp. 223-270.

Welby V. Meaning and Metaphor // The Monist. 1893, vol.3. No.4. P. 510-525.

Welby V. Links and Clues. London: Macmillan \& Co., 1881. 438 pp.

Welby V. Sense, Meaning and Interpretation // Mind. 1896. V. V. N 17. P. 24-37; N 18, P. 186-202. Welby V. Significs // Encyclopedia Britannica, $11^{\text {th }}$ ed., vol. XXV. New York, 1911. P. 78-81.

Welby V. Significs // Murray, A.H. et al. (eds.) A New English Dictionary on Historical Principles. Vol. X. Oxford: Clarendon Press. 1911. New edition, Vol. IX. Oxford, 1933.

Welby V. Significs and Language / Repr. of the ed. London, 1911. Amsterdam: John Benjamin Publ. Co., 1985. 435 p.

Welby V. Witnesses to Ambiguity: A Collection. Grantham: W. Clarke, 1898.

Welby V. What is Meaning? Amsterdam: John Benjamin Publ.Co., 1983. 321 p.

Welby V. Grains of Sense. London: J.M. Dent \& Co. 1897.

Welby V. A Selection of Passages from 'Mind' (January 1876 to July 1892), 'Nature' (1870, and 1888 to 1892), 'Natural Science' (1892), bearing on changes and defects in the significance of terms and in the theory and practice of logic. (For private circulation only). August 1893. Grantham: W. Clarke (Late L. Ridge) (1893a).

Welby V. The Use of 'Inner' and 'Outer' in Psychology: Does the Metaphor Help or Hinder? A small collection of extracts bearing upon this question respectfully submitted to the International Congress of Experimental Psychology, August 1892. For private circulation. Grantham: W. Clarke (Late L. Ridge). (An Outsider).

Welby V., Stout G., Baldwin J. Significs // Baldwin J. (ed.) Dictionary of Philosophy and Psychology in Three Volumes. Vol. 2. New York; London. Macmillan. 1902. P. 529.

Скрипник Константин Дмитриевич, доктор философских наук, профессор, кафедра истории зарубежной и отечественной философии, Южный федеральныий университет; skd53@mail.ru

\section{Significs of Lady Victoria Welby: Portrait in the interior of time}

The publication considers the ideas of significs-the science of meaning, the ideas and the concept of which arise at the turn of the nineteenth and twentieth centuries thanks to their author-Victoria Lady Welby (1837-1912), whose name for a long time was undeservedly forgotten. It describes the main facts of her life, shows the relationship between the characteristics of Welby's personality and the ideas of significs in the context of the intellectual atmosphere of her time. The personality and work of Lady Welby influenced the development of philosophical and semiotic research, as well as the establishment of connections between scholars from different countries. Welby's contribution is to create an integral dynamic theory of sign and meaning, a theory that integrates various aspects of the study of meaning - from logical-linguistic to axiological and practical.

Keywords: Victoria Lady Welby, significs, sign, sense, meaning, significance

Konstantin D. Skripnik, Dr.Sc. (Philosophy), Professor, Institute of Philosophy and Sociopolitical Sciences, Southern Federal University (Rostov-on-Don, Russia); skd@mail.ru 


\section{Е.Н. КРЫЛОВА \\ СУДЬБА ЧИНОВНИКА \\ ИЗДАТЕЛЬСКАЯ ДЕЯТЕЛЬНОСТЬ А.И. МИРЕЦКОГО}

В статье рассматривается судьба чиновника министерства финансов А.И. Мирецкого. На страницах организованного им в Киеве в 1911 г. журнала А.И. Мирецкий отражал настроения многочисленной группы малообеспеченных чиновников, недовольных условиями своего существования. Его деятельность способствовала знакомству чиновников с условиями труда и быта в других государственных учреждениях и частях Российской империи, осознанию ими собственных интересов и формированию стратегии по улучшению своего положения.

Ключевые слова: «Спутник чиновника», журнал «Кружок», А. И. Мирецкий, издательская деятельность, чиновничество в начале XX в.

Первая русская революция внесла изменения в систему распространения массовой информации. По Новым Временным правилам о печати, принятым 24 ноября 1905 г., любой желающий подданный старше 25 лет, обладающий общей гражданской правоспособностью, мог издавать периодическое издание на территории Российской империи. Для этого необходимо было подать местной власти заявление по определенной форме и договориться с типографией о печати номеров издания. Законодательные изменения внесли коррективы и в характер периодических изданий. Все профессиональные издания начала XX в. были представлены двумя типами: первый - газеты и журналы, возникшие на волне революционной борьбы с целью организовать рабочих в профессиональные союзы, и второй - газеты и журналы, имевшие целью повышение авторитета профессии, развитие отрасли, обмен профессиональным опытом и профессиональной информацией ${ }^{1}$.

В начале XX в. появляются первые журналы для чиновников и их число постепенно растет. Местом издания становятся крупные города Российской империи, прежде всего Киев и Санкт-Петербург. Среди изданий, ориентированных на государственных служащих - «Газета чиновника» ${ }^{2}$, журналы «Спутник чиновника» и «Вестник чиновника». Чиновники проявляли интерес к издательской деятельности. Формально на нее ограничений не было, но начальство не приветствовало увлечения подчиненных, отвлекающие от основной работы

В 1911 г. в Киеве А.И. Мирецкий начинает издание ежемесячного иллюстрированного литературно-научного журнала «Кружок» ${ }^{4}$. В офи${ }^{1}$ Сляднева 2016: 166, 178.

${ }^{2}$ Крылова 2019: 25-47.

${ }^{3} \mathrm{~B}$ своде законов Российской империи «О службе гражданской» в главе «Ограничения для лиц, состоящих на службе» отмечено, что «служащим чиновникам запрещается издавать в свет сочинения, заключающие в себе что либо, касающееся до внешних и внутренних отношений Российского государства, без дозволения своих начальств». - Свод законов Российской империи 1897: 171.

${ }^{4}$ РГИА. Ф. 776. Оп. 17. Д. 123. 
циальных документах Главного управления по делам печати он значится как «ежемесячный семейный литературный и научный журнал» 5 .

Алексей Михайлович Мирецкий - чиновник министерства финансов, редактор-издатель двух журналов ${ }^{6}$, почетный член Екатерининского попечительства сельских детских приютов Тульской губернии. Известно, что он происходил «из мещан г. Сквиры, окончил курс Сквирского двухклассного городского училища», затем поступил на государственную службу в Киевскую Казенную палату, занимал должность помощника бухгалтера, а с 1 июля 1905 г. был помощником делопроизводителя канцелярии Губернского Распорядительного комитета. Мирецкий был «довольно усерден и исправен по службе, занявшись же журналистикой, он стал относиться к служебному делу с меньшим вниманием и усердием и поэтому успешность его службы значительно понизилась». Среди личных качеств сослуживцы отмечали «большое самомнение и отсутствие всякого понимания служебного и житейского такта» ${ }^{7}$.

По неизвестной причине издание журнала «Кружок» прекратилось на втором номере. «Вследствие кратковременного существования журнала, общий его характер и направление не определились с полной ясностью». Но «по некоторым статьям беллетристического и публицистического характера, помещенным в двух вышедших номерах журнала можно заключить, что под «классовыми и групповыми интересами» редакция разумела преимущественно интересы чиновничества в широком значении этого слова. Ничего резко тенденциозного или предосудительного в каком-либо отношении журнал не представлял» ${ }^{8}$.

Документы об открытии журнала были поданы Киевскому губернатору 8 февраля 1911 г. Первоначально печать журнала предполагалась в Киевской губернской типографии, но в марте Мирецкий изменил свое решение и договорился с типографией Л.В. Хмелиовского ${ }^{9}$ (газеты «Последние новости»). Программа проектируемого журнала включала: 1 . Оригинальные и переводные повести и рассказы, 2. Стихи, 3. Юмористический отдел, 4. Беседа, 5. Научные статьи, 6. В области искусства, 7. В области благотворительности, 8. Жизнь обществ и клубов в Киеве и 9. Справочный отдел ${ }^{10}$. Во вступительной статье «От редакции» Мирецкий указывал на появление целого ряда периодических изданий, «ставящих себе целью духовное и умственное развитие лиц, связанных общностью труда и тождеством условий существования». Цель журнала принять участие в формировании новых форм общественной жизни через слово, «установление «тесной», духовной связи между «Кружком» и читателями, освещение культурных и общественных вопросов» ${ }^{11}$ в форме дру-

\footnotetext{
${ }^{5}$ РГИА. Ф. 776. Оп. 17. Д. 123. Л. 1.

${ }^{6}$ Кружок. Киев. 1911, Спутник чиновника. Киев; СПб. 1911-1914.

${ }^{7}$ РГИА. Ф. 776. Оп. 17. Д. 273. Л. $8-8$ об.

${ }^{8}$ РГИА. Ф. 776. Оп. 17. Д. 273. Л. $10-10$ об.

${ }^{9}$ РГИА. Ф. 776. Оп. 17. Д. 123. Л. 3.

${ }^{10}$ РГИА. Ф. 776. Оп. 17. Д. 123. Л. 1 об.

${ }^{11}$ Кружок 1911. № 1. Апрель.
} 
жеской беседы. Из 12 статей в первом апрельском номере журнала две статьи написаны редактором А.И. Мирецким: «Сиротки» и «Беседа». В журнале помещено объявление о продаже книги А.И. Мирецкого «Неравномерность обложения и способы устранения ее» ${ }^{12}$.

Номер был отпечатан в типографии газеты «Последние новости». По имеющимся в Главном управлении по делам печати сведениям о этой газете ${ }^{13}$ редактор неоднократно подвергался штрафам и арестам, что свидетельствует о связях А.И. Мирецкого с «неблагонадежными элементами» Киевского общества. Между тем «Кружок» продавался во всех книжных магазинах и киосках Киева. По заявлению редакции в нем принимали участие «видные местные и столичные литературные силы, а также профессора университета» ${ }^{14}$. Два номера журнала (апрель и май) стали «пробой пера» Мирецкого, убедив его в том, что он нашел свободную нишу в новой сфере: освещение интересов чиновников.

Журнал «Спутник чиновника» стал выходить с июня 1911 г. «Профессиональный характер журнала виден из его названия и пояснения, стоящего на обложке каждого номера: «журнал для чиновников всех ведомств». Задачи журнала, по определению редакции: 1. объединение чиновничества, 2. защита их интересов, 3. улучшение условий жизни и деятельности. В характеристике издания указано, что «рисуя яркими красками тяжелое материальное положение чиновничества и его бесправное, беззащитное и приниженное состояние, благодаря произволу начальников и высших властей, журнал призывает чиновников всех ведомств сплотиться и общими силами добиться с одной стороны улучшения условий своей жизни и деятельности, а с другой - поднятия своего правового положения в обществе и государстве» ${ }^{15}$. В журнале дано следующее описание чиновника, отодвинутого «на задворки общественной жизни»: «Из мрака канцелярских стен день за днем постепенно стал вырисовываться облик чиновника, среди безмолвия... стали слышаться голоса, сливающиеся в цельный, скорбный вопль, полный жалоб - на тяжкую, беспросветную жизнь, на невозможные, каторжные условия труда... В редакцию полились безыскусственные, неприкрашенные стоны, просто, до жути просто рассказывающие о жизни впроголодь, о 20-ти часовой работе, о “власти сильных", о постепенном, незаметном увядании над перепиской и составлением годами бумаг, о жестоком формализме, съедающем проблески всякой живой мысли, карающем всякий порыв личности, о всем том, что стерло с лица чиновника черты человека, иссушило, измельчило его душу» ${ }^{16}$.

В журнале печатались статьи о жизни служащих в Западной Европе, о движении среди чиновников во Франции и Германии в защиту

\footnotetext{
12 Мирецкий 1908. В книге рассмотрены приемы обложения налогами земли и лесов в Киевской, Полтавской, Черниговской и других губерниях.

${ }^{13}$ РГИА. Ф. 776. Оп. 16. Д. 421. Л. 23,44,67,93; Д 422. Л. 2, 8, 12, 19,22, $24,43$.

${ }^{14}$ Кружок 1911. № 1. Апрель.

15 РГИА. Ф. 776. Оп. 17. Д. 273. Л. 10 об.

${ }^{16}$ Спутник чиновника. 1911. № 12. 1 декабря.
} 
своих прав. Поскольку чиновники по действующему закону не могли подавать коллективные заявления или просьбы начальству, редакция журнала приняла роль посредника и обратилась к своим читателям, а через них и к другим чиновникам, с просьбой указать, какие именно реформы необходимо провести в жизнь, чтобы добиться желаемых целей. Были выявлены следующие пожелания: изменение порядка назначения на должности и увольнения, полная отмена «третьего пункта», по которому начальство могло уволить чиновника без объяснения причины $^{17}$. Мирецкий также обратился к чиновникам через журнал с призывом принять участие в предстоящих выборах в Государственную Думу, причем рекомендовал избирателям не считаться с мнением начальства, а поступать согласно своим политическим убеждениям ${ }^{18}$. Как отмечает И.А. Голосенко «собранные и систематизированные редакцией материалы о положении рядового чиновничества не остались анкетной ненужностью... По запросу Государственной Думы они были переданы ей для принятия соответствующих законов» ${ }^{19}$.

Первый номер «Спутника чиновника» вышел 16 июня 1911 г. в Киеве. Издание продолжалось в Киеве до апреля 1914 г. (№ 6), затем было перенесено в Санкт-Петербург, где вышел № 7 журнала 10 мая 1914 г. Выход последнего № 13 состоялся 13 июля 1914 г. Всего вышло 86 номеров журнала.

«Спутник чиновника» включал сведения о законах и распоряжениях правительства, научные и экономические статьи, статьи по вопросам, касающимся различных отраслей деятельности чиновников и учреждений, повести, рассказы, фельетоны и стихи, внутреннее и внешнее двухнедельное обозрение, хронику событий в жизни чиновников, письма и ответы. Журнал стремился широко охватить жизнь чиновников всех ведомств России и их деятельность. По заявлению редакции, сотрудники журнала - лица, близко знакомые с бытом и службой чиновников. Редакция имела сотрудников и корреспондентов в разных городах России и, кроме того, «обратилась к служащим правительственных учреждений западных государств с просьбой прислать в редакцию для помещения в журнале статьи и сведения, касающиеся условий службы, экономической и культурной жизни чиновников Западной Европы» ${ }^{20}$. Контент-анализ номеров журнала «Спутник чиновника» показывает постепенное увеличение статей при сохранении объема издания. Видна тенденция и к росту доходов за счет увеличения площади, отводимой под рекламу. Заголовки статей определяют общий тон номера: например, «К аресту А.И. Мирецкого», «Запрещают», «В чем спасение», «Телефонное извращение», «Конфискация» и др. ${ }^{21}$

${ }^{17}$ Свод законов Российской империи 1897: 185; РГИА. Ф.776. Оп.17. Д. 273. Л. 11-11 об.

18 РГИА. Ф. 776. Оп. 17. Д. 273. Л. 11 об.

${ }^{19}$ Голосенко 2000: 129-141: 131.

${ }^{20}$ Спутник чиновника 1911. № 1. 16 июня.

${ }^{21}$ Спутник чиновника 1914. № 1.22 января. 
У Мирецкого сложились сложные отношения с властью. За три года, с декабря 1911 г. по декабрь 1913 г., журнал был оштрафован 4 раза на суммы от 100 до 500 руб., и редактор подвергался аресту три раза за публикацию статей, нарушающих обязательное постановление ${ }^{22}$. Арест и наложение штрафа осуществлялись на основе обязательного постановления Киевского, Подольского и Волынского Генерал-губернатора от 5 ноября 1910 г., по которому запрещалось «оглашение или публичное распространение каких-либо статей или иных сообщений, возбуждающих враждебное отношение к правительству», а также «ложных о деятельности правительственного установления или должностного лица, войска, или воинской части сведений, возбуждающих в населении враждебное к ним отношение» ${ }^{23}$. Всего в документах Главного управления по делам печати фигурируют 12 статей журнала. Так, за статью в № 12 от 1 декабря 1911 г. «Наследство г. Ласточкина» Киевский губернатор постановил: «редактора означенного журнала губернского секретаря Алексея Ивановича Мирецкого подвергнуть в административном порядке штрафу в размере ста рублей ${ }^{24}$, с заменою, при неуплате, арестом на два месяца» ${ }^{25}$. На запрос начальника Главного управления по делам печати по поводу редактора-издателя Киевский губернатор ответил, что «в журнале «Спутник чиновника» Мирецкий неоднократно задевал своих сослуживцев и начальство» ${ }^{26}$. В статье «Наследство г. Ласточкина» были «допущены инсинуации по адресу бывшего управляющего палатою действительного статского советника А.В. Ласточкина и ложные сведения о его деятельности» ${ }^{27}$. Напомним, что согласно своду законов Российской империи «О службе гражданской» «начальства обязаны строго наблюдать, чтобы занятие частной должности лицами, состоящими на государственной службе или занимающими в правительственных установлениях штатные должности по найму, не наносило ущерба служебным интересам и не препятствовало исполнению этими лицами обязанностей их по государственной службе» ${ }^{28}$. В статье «Наследство г. Ласточкина» управляющий Казенной палатой обвинялся в растрате средств на содержание Палаты. Управляющий Казенной палатой «эти выходки Мирецкого внес в конце 1911 года на обсуждение Общего присутствия Казенной палаты, которое признало их возмутительными и свидетельствующими о невысоком нравственном уровне Мирецкого» ${ }^{29}$. Мирецкому предложили ускорить свой переход в другое учреждение. Однако место в Городской управе, на которое он рассчитывал, и добровольный уход из Казенной палаты не состоялся. Увольнение

\footnotetext{
${ }^{22}$ РГИА. Ф. 776. Оп. 17. Д. 273. Л. 24, Л. 53, 56.

${ }^{23}$ РГИА. Ф. 1405. Оп. 543. Д. 734. Л. 54.

24 Здесь и далее подчеркнуто в источнике.

25 РГИА. Ф. 776. Оп. 17. Д. 273. Л. 4.

${ }^{26}$ РГИА. Ф. 776. Оп. 17. Д. 273. Л. 9 об.

27 РГИА. Ф. 776. Оп. 17. Д. 273. Л. 10.

${ }^{28}$ Свод законов Российской империи 1897: 174.

${ }^{29}$ РГИА. Ф. 776. Оп. 17. Д. 273. Л. 10.
} 
произошло лишь 22 августа 1912 г., т.е. почти через девять месяцев, когда за свою издательскую деятельность Мирецкий был помещен в тюрьму и не мог уже выполнять свои непосредственные должностные обязанности. Несмотря на то, что по Уставу о службе гражданской Мирецкого можно было уволить по «третьему пункту» ${ }^{30}$ без объяснения причины, начальство этим правом не воспользовалось.

Отметим, что в декабре 1911 г. подписка на журнал «Спутник чиновника» принималась уже в 38 городах Российской империи: СанктПетербурге, Москве, Одессе, Уфе, Омске, Ярославле, Гдове, Баку, Ростове на Дону, Риге, Ташкенте и др. С января 1912 г. «Спутник чиновника» стал выходить один раз в 10 дней (ранее - один раз в две недели).

26 апреля 1912 г. начальник Главного управления по делам печати С.С. Татищев направил Киевскому губернатору А.Ф. Гирсу письмо, в котором просил губернатора навести справки о личности издателя «и о том, на какие именно средства ведется им издание упомянутого выше журнала и кто состоит его сотрудниками» ${ }^{31}$. По результатам проведенного расследования оказалось, что редактор журнала - помощник делопроизводителя канцелярии Киевского Губернского Распорядительного комитета в чине губернского секретаря Алексей Иванович Мирецкий, 27 лет, орденов и знаков отличия не имеет, женат, состоит на государственной службе в министерстве финансов. Профессиональные качества Мирецкого были охарактеризованы его непосредственным начальством как соответствующие занимаемой должности, однако, нравственные вопросы, связанные со службой, вызывали сомнения. В частности, в 1906 г. в Киевский Губернский Распорядительный комитет поступило заявление, в котором А.И. Мирецкий был обвинен во взяточничестве, но дело дальнейшего хода не получило. Мирецким было подано «прошение об увольнении его от службы в Казенной палате, но почему это прошение не получило движения следов не сохранилось» ${ }^{32}$. Отвечая на вопрос о средствах, на которые ведется журнал, Киевский губернатор пояснил, что «для ведения означенного журнала больших средств не требуется: печатается журнал в типографии Яковлева в количестве 2000 экземпляров, за общую цену -85 руб. ...Редакцию и контору журнала представляет небольшая квартира Мирецкого, который сам ведет все дела и, между прочим, сам лично рассчитывается с типографией Яковлева, внося деньги, преимущественно частями, спустя некоторое время после выпуска в свет №№ журнала. Что касается состава сотрудников, то выяснить таковой негласными путями не представляется возможным, прибегнуть же к гласным расспросам в редакции журнала, в виду конфиденциальности Вашего письма признаю неудобным» ${ }^{33}$.

${ }^{30}$ Свод законов Российской империи 1897: 185.

${ }^{31}$ РГИА. Ф. 776. Оп. 17. Д. 273. Л. 7 - 7 об.

32 РГИА. Ф. 776. Оп. 17. Д. 273. Л. 9 об.

${ }^{33}$ РГИА. Ф. 776. Оп. 17. Д. 273. Л. 11 об. 
В характеристиках петербургских периодических изданий направление журнала отмечено как оппозиционное ${ }^{34}$. Это отмечает и КерчьЕникальский градоначальник: «содержание журнала, явно преследует цель возбуждения неудовольствия в среде чиновников и подстрекательство к проявлению такового» ${ }^{35}$. Статьи в № 17 от 21 июня 1912 г. были рассмотрены на заседании Киевского Временного комитета по делам печати, и признаков преступлений, караемых уголовными законами, в них не было обнаружено. Однако 15 августа 1912 г. за статьи в № 22 «К товарищам», «Могу казнить и миловать» и «По Дарвину» редакториздатель журнала Мирецкий был подвергнут в административном порядке аресту на три месяца и помещен в Киевскую губернскую тюрьму.

Указанные статьи подпадали под действие обязательного постановления. В статье «К товарищам» был опубликован призыв выбирать тех депутатов в Государственную Думу, которые будут способствовать «освобождению русского чиновничества от тяжелого материального положения и бесправия». Статья «По Дарвину» написана в форме сказки о почтово-телеграфном ведомстве, в котором по циркуляру разрешено вступать в брак только с сослуживцами. Сказка заканчивалась нравоучением: «Дети, учитесь и не пишите циркуляров по Дарвину» ${ }^{36}$.

30 сентября супруга Мирецкого отправила на имя министра внутренних дел телеграмму: «Мой муж редактор журнала «Спутник чиновника» с 16 августа арестован на три месяца за помещение трех статей, две из которых печатались раньше в Киеве без всякого взыскания. Третья основана на статьях иногородних газет. Такое наказание, вызванное, по-видимому, предвыборными соображениями является жестоким и несправедливым. Семья осталась без всяких средств к существованию. Покорнейше прошу об освобождении». Однако Главное управление по делам печати признало ходатайство «не подлежащим удовлетворению». Одновременно 10 сентября в квартире Мирецкого был произведен обыск, в результате которого были обнаружены: «1. 1677 экземпляров воззваний, озаглавленных «К чиновникам» и «Краткие сведения о желаниях русского чиновничества»; 2. 370 экземпляров листков по поводу избрания членов в IV Государственную Думу; 3. Компрометирующая Алексея Мирецкого переписка его с известным своей неблагонадежностью бывшим почтово-телеграфным чиновником Владимиром Николаевым Дьяковым-Тарасовым, про-живающим в Париже, и отчетность и переписка по изданию журнала «Спутник чиновника»» ${ }^{37}$.

24 января 1913 г. Мирецкий снова был подвергнут в административном порядке штрафу в размере ста рублей, с заменой, при неуплате арестом на один месяц ${ }^{38}$ за статьи в № 2 и 4 от 11 и 21 января журнала

\footnotetext{
${ }^{34}$ РГИА. Ф.776. Оп. 8. Д. 2199. Л. 91.

35 РГИА. Ф. 776. Оп. 17. Д. 273. Л. 15.

${ }^{36}$ Спутник чиновника 1912. № 22. 11 августа.

${ }^{37}$ РГИА. Ф. 776. Оп. 17. Д. 273. Л. 30, 31-31 об.

38 РГИА. Ф. 776. Оп. 17. Д. 273. Л. 34.
} 
«Сцилла и Харибда», «Патриции и Плебеи», подходящие под действие обязательного постановления Киевского, Подольского и Волынского Генерал-губернатора от 5 ноября 1910 г. Статья «Сцилла и Харибда» была посвящена правовому положению чиновников, в ней говорилось об отсутствии у чиновников гарантий, об их ответственности за исполнение незаконных распоряжений начальства. «Мы имеем право требовать для себя точных, обстоятельных законоположений, определяющих права и обязанности начальствующих и подчиненных». В статье «Патриции и Плебеи» отмечалась некомпетентность многих начальствующих чинов. «Раньше печать не имела права выносить неурядицы на свет. Только в последнее время грехи чиновничества выплыли на свет Божий и широкой волной захлестнули общественное внимание» ${ }^{39}$.

В феврале 1913 г. Мирецкий обратился с ходатайством о понижении платы за пересылку по почте журнала в Главное управление почт и телеграфов. Ходатайство было признано не заслуживающим удовлетворения ${ }^{40}$. Несмотря на наличие репрессивных мер по отношению к редактору-издателю журнала со стороны власти, Мирецкий просил Главное управление почт и телеграфов о содействии в распространении издаваемого им журнала. Неоднократно обличая тяжелую жизнь чиновников тружеников почтово-телеграфного ведомства и произвол начальства, Мирецкий рассчитывал на удовлетворение своего ходатайства.

С апреля 1913 г. Мирецкий дополняет журнал иллюстрированными приложениями с рассказами, стихами, шаржами и карикатурами, и проектами уставов общества взаимопомощи, ссудо-сберегательных и похоронных касс. 3 июля начальник Главного управления по делам печати С.С. Татищев получил письмо от директора департамента полиции, в котором отмечено, что журнал «несмотря на принятые против его редактора Алексея Иванова Мирецкого со стороны Киевского губернатора репрессивные меры, продолжает издаваться с тем же вредным направлением... министр внутренних дел... приказал вновь обратить особое внимание Вашего Сиятельства» ${ }^{41}$. Однако Татищев признал: «журнал этот ведется настолько умело, что до настоящего времени не представилось возможности привлечь редактора его к ответственности в судебном порядке. Что касается мер административного воздействия, то таковые применяются к означенному редактору Киевским губернатором неукоснительно». Закрыть же журнал «не предоставляется возможным, в виду того, что по действующим законам о печати, приостановка как и совершенное прекращение повременных изданий может последовать лишь по постановлению суда, а в содержании... нет признаков преступлений, караемых уголовными законами, - следовательно, нет оснований для привлечения редактора к судебной ответственности. В виду изложенного и за невозможностью вести борьбу с вредным направлением журнала

\footnotetext{
${ }^{39}$ Спутник чиновника 1913. № 2. 11 января.

${ }^{40}$ РГИА. Ф. 776. Оп. 17. Д. 273. Л. 37.

${ }^{41}$ РГИА. Ф. 776. Оп. 17. Д. 273. Л. 38, 39.
} 
«Спутник чиновника» при помощи мер, предоставленных законом инспекции по делам печати, я... находил бы в данном случае целесообразным соответствующее воздействие департамента полиции на круг лиц, входящих в состав редакции названного журнала» ${ }^{42}$. Меры были приняты, и уже 25 сентября 1913 г. редактор журнала был подвергнут штрафу в 500 р. за напечатание в №o 23 и 24 статей под заглавием «Внимание», «Как увольняют», «Пособие», «Мертвые души», «В тисках произвола».

В статье «Внимание» редакция призывала «собирать и обрабатывать материалы для членов Государственной Думы при изменении внесенных на рассмотрение палаты ведомственных законопроектов». В статье «Как увольняют» была описана неограниченная власть начальников мелких учреждений, которая сделалась истинным бичом для служащих. Показан пример увольнения чиновника ради места для «своего человечка». Статья «Пособия» посвящена больной для служащих теме: отказам в пособии мелким чиновникам. В статье «Мертвые души» говорилось о почтово-телеграфном ведомстве: перлюстрация, махинации с биржевыми телеграммами в Киевском почтово-телеграфном округе, подлоги с пособиями на несуществующих чиновников. За два года по серой схеме было получено 9 тыс. руб. Пособия получают «свои люди». В статье «В тисках произвола» увольнение чиновников рассматривалось как одна из причин самоубийств. 29 сентября 1913 года, за статью «Герои», в № 27 от 20 сентября Мирецкий был подвергнут штрафу в 500 руб. с заменой при неуплате арестом на три месяца за неоднократное нарушение обязательного постановления ${ }^{43}$. «Герой» статьи - учитель с маленькой зарплатой, автор говорит: «бегство народных учителей - тяжелая болезнь нашей школы» ${ }^{44}$, присутствует критика разъяснений Сената по поводу земских учителей. Все статьи, за которые редакториздатель А.И. Мирецкий был подвергнут административным взысканиям, содержали в себе критику вышестоящего начальства.

В сентябре сразу за три номера (№№ 23,24,27) Мирецкий был оштрафован, а за невозможностью оплатить штраф в 1000 руб. он был арестован и вся корреспонденция на его имя, как частная, так и относящаяся к его деятельности в журнале, пересылалась Киевской почтовой конторой в жандармское управление. Его жена Антонина Мирецкая обратилась к министру внутренних дел с жалобой на то, что Киевская почтовая контора не доставляет в редакцию корреспонденцию и денежные переводы, несмотря на имеющуюся у нее официально заверенную доверенность мужа. Находя, что таким образом создаются условия, не позволяющие продолжение выпуска в свет журнала, Мирецкая просила о выдаче ей всей разрешенной корреспонденции и о беспрепятственном доставлении ее в будущем, о чем было сделало соответствующее распоряжение. На время ареста мужа Мирецкая стала редактором журнала, а

\footnotetext{
42 РГИА. Ф. 776. Оп. 17. Д. 273. Л. 44 об. -45.

${ }^{43}$ РГИА. Ф. 776. Оп. 17. Д. 273. Л. 56.

${ }^{44}$ Спутник чиновника 1914. № 27. 20 сентября.
} 
20 марта 1914 г. он был вновь включен в число редакторов. В апреле 1914 г. подписка на «Спутник чиновника» принималась во всех почтово-телеграфных учреждениях. При этом редакция неоднократно обращалась к «товарищам-читателям» с просьбой «оказать содействие к широкому распространению нашего товарищеского журнала» ${ }^{45}$.

В мае 1914 г. редакция и контора переехала в Петербург. В первом петербургском номере редакция еще раз обозначила задачу журнала: обслуживать интересы «среды рядовых, обделенных материальными благами и правовыми гарантиями государственных служащих» ${ }^{46} .28$ мая в газете «Русское знамя» вышла заметка о публичной лекции соредактора «Спутника чиновника» А.М. Любовича ${ }^{47}$, в которой он призвал чиновничество «К объединению на платформе профессиональных союзов и к взаимодействию с обществом под откровенным девизом: «в борьбе обретешь ты право свое». Заметка заканчивалась открытым вопросом: куда «смотрит администрация и известно ли об этом министру внутренних дел? Известно ли также начальнику Главного управления по делам печати, что «Спутник чиновника» ведет весьма заметным образом революционную пропаганду среди последнего?» ${ }^{48}$.

30 мая состоялось заседание Санкт-Петербургского комитета по делам печати и в Главное управление было доложено: рассмотрев вышедшие в Петербурге два номера журнала и не «найдя в их содержании признаков преступления или проступка и указаний на нарушение Обязательного Постановления С.-Петербургского Градоначальника от 4 сентября 1913 года, комитет постановил уголовного преследования не возбуждать и С.-Петербургскому Градоначальнику не сообщать». В личном докладе министру внутренних дел отмечалось: «по двум вышедшим номерам журнала «Спутник чиновника» трудно окончательно определить настоящее его направление, так как нет возможности применить к ним какой-либо уголовный закон, или же одно из обязательных постановлений градоначальника» ${ }^{49}$. Это свидетельствует о слабой коммуникации между Санкт-Петербургским и Киевским комитетами по делам печати, поскольку наблюдение за журналом в Киеве осуществлялось.

12 июня в газете «День» появилась заметка «Своеобразная конфискация», в которой была приведена жалоба, поданная Мирецким начальнику Главного управления по делам печати о том, что номер журнала, сданный на Почтамт 31 мая в 6 часов вечера был разослан подписчикам лишь 6 июня. Было проведено разбирательство, в итоге почтдиректором, которому было поручено «подвергнуть виновных в указанной выше небрежности чинов строгим личным взысканиям, приняты надлежащие меры к предупреждению подобных случаев» ${ }^{50}$. Этот и ряд дру-

\footnotetext{
${ }^{45}$ Спутник чиновника 1914. № 6.17 апреля.

${ }^{46}$ Спутник чиновника 1914. № 7. 10 мая.

${ }^{47}$ Подробнее см.: Голосенко 2000: 129-141: 132-133.

${ }^{48}$ РГИА. Ф. 776. Оп. 10. Д. 1459. Л. 5.

${ }^{49}$ РГИА. Ф. 776. Оп. 10. Д. 1459. Л. 4, 6 об.

${ }^{50}$ РГИА. Ф. 776. Оп. 10. Д. 1459. Л. 29; 30.
} 
гих эпизодов показывают, что для решения текущих проблем Мирецкий использовал средства массовой информации и общественное мнение как механизмы давления на власть, а власть действовала на основании законов, не находя в статьях Мирецкого «признаков преступления или проступка», что может свидетельствовать о непонимании той роли, которую начинают играть в новых условиях средства массовой информации.

Алексей Иванович Мирецкий три года выпускал «Спутник чиновника». Журнал отражал настроения многочисленной группы малообеспеченных чиновников и существовал на пожертвования читателей на «укрепление журнала». Болышую часть содержания журнала занимали статьи, посвященные служащим в почтово-телеграфном ведомстве и министерстве финансов, что можно объяснить личными связями редактора. Личные связи и контент журнала способствовали распространению издания, а перенос редакции в Санкт-Петербург позволил редактору принимать участие в подготовке проектов для Государственной Думы по улучшению материального положения чиновников.

На примере издательской деятельности А.И. Мирецкого можно проследить судьбу российского чиновника начала XX века: являясь государственным служащим и общественным деятелем, он первое время успешно совмещал государственную службу и издательскую деятельность, но в дальнейшем издательская деятельность потребовала от него пристального внимания, что отразилось на службе и в конечном итоге привело к его увольнению. При этом еще до увольнения со службы новый журнал «Спутник чиновника» Мирецкий использовал в личных целях «сводя счеты» с сослуживцами. Личные разногласия были перенесены на страницы издания и нашли отклик среди читателей - чиновников, которым конфликт подчиненного и руководителя оказался близок и понятен. Семена упали на благодатную почву, поскольку читательская аудитория была недовольна своим положением.

Обнажая пороки существующего трудового уклада и публикуя в основном сообщения негативного толка, редактор вступал в конфликт с режимом, что оборачивалось для него арестами и штрафами. Административные меры, однако, не имели эффекта, и А.И. Мирецкий после оплаты очередного штрафа снова публиковал статьи, критикующие действия местной администрации. Подобные меры (аресты и штрафы) создавали Мирецкому образ борца за интересы «обездоленных» чиновников, а объявления в журнале об очередном штрафе способствовали притоку денежных средств от сочувствовавших читателей.

В начале XX в. создаются частные средства массовой информации, которые освещают проблемы существующего строя, появляется и тиражируется (в том числе за счет перепечаток из других изданий) большой объем негативно окрашенной информации. За счет отсутствия в информационном поле такого же числа проправительственных изданий, которые могли бы минимизировать отрицательный эффект, создавая свой контент позитивного характера, образ власти постепенно дискредитиру- 
ется, и начало этому процессу можно увидеть на примере критики начальства на страницах журнала «Спутник чиновника» А.И. Мирецкого.

\section{Архивные документы}

Российский государственный исторический архив (РГИА). РГИА. Ф. 776. Оп.8. Д.2100, Д. 2199; Оп. 10. Д. 1459; Оп. 16. Д. 421, Д. 422; Оп. 17. Д. 123, Д. 273.

РГИА. Ф. 1405. Оп. 543. Д. 734.

\section{БИБЛИОГРАФИЯ / REFERENCES}

Мирецкий А.И. Неравномерность обложения и способы устранения. Обложение земель и лесов. Вып. 1. 1908. [Mireckij A.I. Neravnomernost' oblozheniya i sposoby ustraneniya. Oblozhenie zemel' i lesov. Vyp. 1. 1908].

Мирецкий А.И. Руководство по поставке дров на варку пищи и хлебопечение нижним чинам и на лагерные офицерские кухни в Киевском военном округе. Киев, 1908. [Mireckij A.I. Rukovodstvo po postavke drov na varku pishchi i hlebopechenie nizhnim chinam i na lagernye oficerskie kuhni v Kievskom voennom okruge. Kiev: izd. avt., 1908].

Свод законов Российской империи, повелением государя императора Николая Первого составленный. Т. 3: Уставы о службе гражданской. СПб. 1897. 768 с. [Svod zakonov Rossijskoj imperii, poveleniem gosudarya imperatora Nikolaya Pervogo sostavlennyj. T. 3: Ustavy o sluzhbe grazhdanskoj. SPb. 1897. 768 s.].

Голосенко И.А. Социальная идентификация рядового чиновничества России начала XX века: историко-социологический очерк // Журнал социологии и социальной антропологии. 2000. Т. 3. № 3. С. 129-141. [Golosenko I.A. Social'naya identifikaciya ryadovogo chinovnichestva Rossii nachala HKH veka: istoriko-sociologicheskij ocherk // ZHurnal sociologii i so-cial'noj antropologii. 2000. T. 3. № 3. S. 129-141].

Крылова Е.Н. Газета «Чиновник» - парадокс или корпоративное средство массовой информации начала XX в.? // История повседневности. 2019. № 3 (11). С. 25-47. [Krylova E.N. Gazeta «CHinovnik» - paradoks ili korporativnoe sredstvo masso-voj informacii nachala HKH v.? // Istoriya povsednevnosti. 2019. № 3 (11). S. 25-47].

Крылова Е.Н. Образ российского чиновника начала XX века на страницах журнала «Спутник чиновника» // Реформы в повседневной жизни населения России: история и современность. 2020. T.1. С. 112-118. [Krylova E.N. Obraz rossijskogo chinovnika nachala HKH veka na stranicah zhurna-la «Sputnik chinovnika»// Reformy v povsednevnoj zhizni naseleniya Rossii: istoriya i sovremennost'. 2020. T.1. S. 112-118].

Сляднева О.В. Профессиональные издания 1906-1914 гг. // Петербург газетный, 17111917. Вып. 2. 2016. C. 166-185. [Slyadneva O.V. Professional'nye izdaniya 1906-1914 gg. // Peterburg gazetnyj, 1711-1917. Vyp. 2. 2016. S. 166-185].

Крылова Елена Николаевна, кандидат исторических наук, доцент, кафедра рекламы и общественных коммуникаций, Ленинградский государственный университет им. A.С. Пушкина:hellennak@yandex.ru

\section{The fate of an official: publishing activities of A. I. Miretsky}

The article is devoted to the fate of an official of the Ministry of Finance, A.I. Miretsky, who established a magazine in Kiev in 1911. On the pages of his publication, Miretsky reflected the moods of a large group of low-income officials who were dissatisfied with the conditions of their existence. The publishing activity of Miretsky contributed to familiarizing officials with working and living conditions in other state institutions and parts of the Russian Empire, forming a strategy to improve their situation.

Keywords: A.I. Miretsky, publishing activity, officialdom in the beginning of the $20^{\text {th }} \mathrm{c}$.

Elena Krylova, Candidate of Historical Sciences, Associate Professor, Associate Professor, Department of advertising and public communications, Leningrad State University named after A. S. Pushkin: hellennak@yandex.ru 


\author{
А.В. ВолодькО \\ ВКЛАД ИМПЕРАТРИЦЫ МАРИИ АЛЕКСАНДРОВНЫ \\ В РАЗВИТИЕ ЖЕНСКОГО ОБРАЗОВАНИЯ В РОССИИ \\ ОТКРЫТЫЕ ВСЕСОСЛОВНЫЕ ГИМНАЗИИ
}

Статья посвящена активному участию императрицы Марии Александровны в ре-
форме женского образования в России и создании открытых всесословных гимназий.
Масштаб проведенных под ее руководством преобразований соответствовал эпохе
Великих реформ. Она умела выделять из поступающих проектов и предложений
наиболее целесообразные и отвечающие духу времени, привлекая для их реализации
лучшие педагогические силы. Ее активная поддержка экспериментальных образова-
тельных «пилотных проектов» способствовала постепенному распространению их
положительных результатов на всю систему женского образования.

Ключевые слова: императрица Мария Александровна, Россия, женское образование, открытые всесословные гимназии

Начало системе женского образования в России было положено при Екатерине II. В 1764 г. по инициативе просветителя и педагога Ивана Ивановича Бецкого императрица издала указ о создании в Петербурге первого учебного заведения для девочек-дворянок - Воспитательного общества благородных девиц (Смольный институт). Цель Общества формулировалась следующим образом: «дать государству образованных женщин, хороших матерей, полезных членов семьи и общества». ${ }^{1}$ Годом позже при Смольном было учреждено Мещанское отделение, куда принимали учениц недворянского происхождения (кроме выходцев из крепостных крестьян). Для того времени это было весьма прогрессивное начинание - Институт стал одним из первых в Европе государственных учебных заведений для женщин. После воцарения Павла I руководство женским образованием и благотворительностью перешло к его жене императрице Марии Федоровне. При ней число женских учебных заведений по образцу Смольного достигло десяти, причем открывались они не только в столице и Москве, но и в некоторых губернских городах ${ }^{2}$. Обучение приобрело более практический характер: с 1803 г. в институтах создавались педагогические классы, где готовили домашних воспитательниц для замены гувернанток-иностранок ${ }^{3}$.

В 1828 г., после смерти вдовствующей императрицы, Николай I реорганизовал механизм управления учреждениями, которым она покровительствовала: их передали в ведение IV Отделения Собственного

\footnotetext{
${ }^{1} \mathrm{O}$ воспитании благородных девиц в Санкт-Петербурге при Воскресенском монастыре; с приложением Устава и штата сего Воспитательного Общества. Указ от 5 мая 1764 г. // Полн. собр. законов Российской империи, с 1649 года. Собр. 1-е.: в 45 т. СПб., 1830. Т. 16: 742-755.

2 Пономарева 201: 93.

${ }^{3}$ Там же: 93-94.
} 
его Императорского величества канцелярии (с 1844 г. переименовано в Ведомство учреждений императрицы Марии или Мариинское ведомство). В 1845 г. при нем был создан Главный совет женских учебных заведений, который возглавил выдающийся общественный деятель и меценат принц Петр Георгиевич Ольденбургский. Система женских институтов продолжала расширяться - к середине XIX в. их насчитывалось уже 29. Однако к тому времени правила и традиции этих учебных заведений во многом устарели и уже не отвечали велениям времени. В первую очередь это было связано с их закрытостью (оторванностью учениц от семьи) и элитарностью (сословностью). Поэтому в эпоху великих преобразований Александра II важное место в процессе общественных дискуссий занимала реформа женского образования. Широкий общественный резонанс вызвала статья знаменитого врача и ученого Николая Ивановича Пирогова «Вопросы жизни» в «Морском сборнике» (1856), где он подверг критике существующую систему сословного и утилитарного воспитания, противопоставив ей открытое «общечеловеческое образование», и призывал уделить особое внимание воспитанию и образованию женщины, которое делало бы из нее не «куклу», а «главного зодчего общества», которому поручено подрастающее поколение ${ }^{4}$.

Статья дала импульс общественной дискуссии по вопросам педагогики, которая выявила настоятельную необходимость реформирования и демократизации системы женского образования в стране, и власть начала предпринимать практические шаги по ее подготовке. В том же 1856 г. министр народного просвещения А.С. Норов подал соответствующий доклад императору, который повелел «приступить к устройству на первый раз в губернских городах женских школ, приближенных по курсу к гимназиям $\rangle^{5}$. Однако переход от проектов к практике произошел в другой структуре - Мариинском ведомстве, ставшем своего рода «альтернативным министерством женского образования». И произошло это во многом благодаря усилиям еще одной «женщины на троне» супруги императора - Марии Александровны. На личности этой незаурядной женщины со сложной судьбой следует остановиться особо.

Принцесса Максимилиана Вильгельмина Августа София Мария родилась в 1824 г. в семье великого герцога Людвига II Гессенского. В 1839 г. принцесса познакомилась с наследником российского престола великим князем Александром Николаевичем, а в 1841 г. они обвенчались. Принцесса приняла православие и новое имя - Мария Александровна. Это был один из нечастых для монарших семей случаев брака по любви, и долгое время семейная жизнь цесаревны была счастливой. Удачно складывались и отношения Марии Александровны с новыми родственниками - императорской семьей: они полюбили цесаревну за ум, такт и доброту. Светскими обязанностями она тяготилась, и главное место в ее жизни занимала семья - несмотря на слабое здоровье, она

${ }^{4}$ Пирогов 1985: 29-51, 468.

5 Чистикова 2014. Том I (Гуманитарные науки): 39-40. 
родила мужу восьмерых детей и уделяла пристальное внимание их образованию и воспитанию. В то же время и по статусу, и по склонности характера Мария Александровна активно занималась благотворительностью. Так, в 1846 г. под ее попечительство было передано Царскосельское училище для девиц духовного звания, и, по словам ее первого биографа адмирала Дмитрия Сергеевича Арсеньева, именно по результатам руководства этим учебным заведением цесаревна выработала свою концепцию «идеалов женского воспитания» в России 6 .

В 1855 г. в ее жизни начался новый этап: Александр Николаевич после кончины отца стал всероссийским самодержцем Александром II, a Мария Александровна - императрицей. В этом статусе она поддерживала прогрессивные реформы мужа, а ее просветительская и благотворительная деятельность приобрела новый масштаб: в частности, императрица стала официальным покровителем Мариинского ведомства. Последние десятилетия жизни Марии Александровны складывались трагически: она пережила смерть любимого сына и наследника престола Николая Александровича, вынуждена была мириться с многочисленными изменами мужа (его романы она иронически называла «умилениями») и даже с тем, что у императора появилась вторая семья - он долгие годы находился в близкой связи с княжной Е.М. Долгоруковой и имел от нее четырех детей. Здоровье Марии Александровны продолжало ухудшаться, что усугублялось переживаниями из-за многочисленных покушений на мужа, императора Александра II. В 1880 г. императрица в возрасте 55 лет скончалась от легочного заболевания.

Нельзя сказать, что личность Марии Александровны обошли вниманием мемуаристы и исследователи, однако в большинстве случаев их интересуют в основном трагические обстоятельства ее семейной жизни, а общественная деятельность императрицы освещалась гораздо слабее. Между тем ее достижения на этом поприще впечатляют. Достаточно сказать, что императрица стояла у истоков организации Российского Общества Красного Креста, активно участвовала в реформе женского образования, создала Мариинский театр и балетную школу в Петербурге. Но никаких упоминаний об этом не найти даже в воспоминаниях и дневниках фрейлины императрицы А.Ф. Тютчевой, хотя эта энергичная и прогрессивная дама, много лет входившая в «ближний круг» Марии Александровны, живо интересовалась не нарядами и балами, как многие другие фрейлины, а политическими и социальными вопросами.

Расходятся современники и в оценках личных качеств императрицы. Буквально все мемуаристы признают за ней недюжинный ум, отмечают ее набожность, скромность и доброжелательность к людям, некоторые говорят о силе воли. Однако уже упомянутая Тютчева считала, что она «не была призвана по своей натуре, совершенно лишенной темперамента, к тому положению, которое ей предназначила судьба», упрекала «за отсутствие инициативы, интереса и активности во всех обла${ }^{6}$ Арсеньев 2018: 271-275. 
стях, куда она могла бы внести жизнь и движение», осторожность «нерешительность, которая делала в конце концов отношения с ней утомительными и тягостными». ${ }^{7}$ В то же время такой недруг самодержавия как П.А. Кропоткин, в молодости служивший при дворе, относился к Марии Александровне с большим уважением: называл ее «наиболее симпатичной» из всех членов царской фамилии, говорил о ее «искренности» и, в отличие от многих современников, подчеркивал заслуги императрицы перед обществом. Так, он писал: «Теперь известно, что Мария Александровна принимала далеко не последнее участие в освобождении крестьян. Но тогда про это мало знали. Больше знали о том деятельном участии, которое принимала Мария Александровна в учреждении женских гимназий» ${ }^{8}$. Такой разнобой в оценках, вероятно, связан с особенностями характера Марии Александровны: природной скромностью, нелюбовью к публичности, сдержанностью, неумением и нежеланием выпячивать себя - одним словом, как выражались мемуаристы, стремлением «не слыть, а быть». Кроме того, ей приходилось учитывать позицию императора Александра II, который весьма болезненно воспринимал любые слухи о влиянии жены на его решения. Известный мемуарист П.В. Долгоруков рассказывает, что в первые месяцы после воцарения император советовался с ней, и она даже присутствовала на докладах министров. Но затем из-за слухов «будто Мария Александровна им управляет», он перестал говорить с ней о делах 9 . Возможно, Долгоруков, критиковавший всех и вся, несколько утрирует, но у императрицы, несомненно, были причины проявлять осторожность. Поэтому свои добрые дела она творила в тишине, без лишнего шума и огласки. Этим, по-видимому, можно объяснить неосведомленность о ее общественной деятельности даже лиц из окружения императрицы.

Центральное место в просветительской деятельности Марии Александровны занимали вопросы женского образования. Она живо интересовалась постановкой этого дела в Германии, посещала немецкие школы для девочек, убедилась, что им вполне по силам получать образование «мужского» образца, из чего сделала следующий вывод: «а не ввести ли эту систему и у нас, столько девочек прозябают во тьме, не имея ни возможности, ни желания часто познать этот мир». Кроме того, Мария Александровна (в т.ч. в связи с воспитанием собственных детей) серьезно изучала педагогику и пришла к мысли, что «познание науки управлять людьми, учить их, нужно тоже ввести в программу» ${ }^{10}$.

Таким образом, в середине XIX в. эти проблемы были предметом широкого общественного обсуждения, и власть тоже осознавала необходимость реформы женского образования. Однако из-за неповоротливости бюрократической машины Министерства народного просвещения

\footnotetext{
${ }^{7}$ Тютчева 1990.

${ }^{8}$ Кропоткин 1988.

9 Долгоруков 2019: 13-14.

${ }^{10}$ Гомаюнов 2009: 50-51.
} 
главным центром преобразований стало Мариинское ведомство во главе с Марией Александровной. В 1856 г., практически одновременно с докладом А.С. Норова Александру II, помощник инспектора Николаевского сиротского института Александр Александрович Чумиков представил императрице развернутую записку с критикой обучения в закрытых институтах и обоснованием преимуществ открытых женских учебных заведений для выходцев из разных сословий. На ее основе Министерство народного просвещения поручило Чумикову составить проект организации таких училищ ${ }^{11}$. Педагог предложил устраивать их по образцу немецких женских школ, с 6-летним сроком обучения на уровне мужского уездного училища с дополнительным изучением химии, технологии домашнего и сельского хозяйства. Однако рассмотрение проекта, как и предложений Норова, затянулось, и в конечном итоге, как выразился сам Чумиков, он «опочил вечным сном» в недрах Министерства ${ }^{12}$.

Чтобы сдвинуть дело с мертвой точки, императрица и Мариинское ведомство инициировали более скромный «пилотный» проект, основанный на идее выдающегося российского педагога Николая Алексеевича Вышнеградского, занимавшего в то время должность инспектора классов Павловского института. В 1857 г. Вышнеградский предложил открыть при Институте классы для «приходящих девиц»: «желая сделать институт более полезным для образования русских девочек, ходатайствует о разрешении открыть при нем классы для экстерн, т.е. для детей, которые бы только приходили на уроки, проводя все остальное время дома у своих родителей» ${ }^{13}$. Главный совет женских учебных заведений Мариинского ведомства в целом одобрил проект, но несколько видоизменил его, постановив создать в Петербурге под личным покровительством императрицы женское училище для приходящих девиц с семилетним сроком обучения. В училище допускались ученицы из всех свободных сословий, которым по окончании курса предоставлялись те же права, что и выпускницам закрытых институтов, т.е возможность работы домашними учителями. Предметы в программе подразделялись на обязательные (Закон божий, русский язык и словесность, всеобщая и отечественная история, география, естествоведение, арифметика, женское рукоделие, пение, чистописание и рисование) и необязательные, за дополнительную плату (немецкий и французский языки, музыка и танцы). Финансирование предусматривалось смешанное: плата за обучение (25 руб. в год) и государственные субсидии от Мариинского ведомства. Данная система вводилась в виде эксперимента сроком на три года, а затем по итогам работы училища предполагалось выработать общий устав учебных заведений для приходящих девиц. ${ }^{14}$

${ }^{11}$ См. Деревнина 2013: 39-40.

${ }^{12}$ Гомаюнов 2009: 52.

${ }^{13}$ РГИА. Ф. 761 Главный совет женских учебных заведений при Четвертом отделении собственной Его Императорского Величества канцелярии. Оп. 1. Д. 797. Л. 2.

${ }^{14}$ Там же. Д. 1379. Л. 113 об. 
15 марта 1858 г. проект был утвержден императором и уже 22 марта подписан Указ Главному совету об устройстве Мариинского женского училища для образования приходящих девиц в Санкт-Петербурге, попечителем училища назначался председатель Совета принц П.Г. Ольденбургский ${ }^{15}$. 19 апреля первое всесословное открытое училище распахнуло свои двери. Благодаря энергии, энтузиазму и организаторским способностям Вышнеградского, который был назначен начальником училища, новое учебное заведение немедленно приобрело огромную популярность: уже к июню 1858 г. число учениц выросло со 140 до 200, а к августу поступило еще 100 заявлений на прием, которые не могли быть удовлетворены из-за недостатка помещений ${ }^{16}$. Так почти сразу же встал вопрос о создании новых училищ по образцу первого. В августе по распоряжению императрицы и с санкции императора в Петербурге были учреждены еще три Мариинских училища - Коломенское, Васильевское и Петербургское. Начальником всех этих заведений стал Вышнеградский ${ }^{17}$. П.А. Кропоткин констатировал, что «они были поставлены очень хорошо, с широкой программой и в демократическом духе» ${ }^{18}$.

С 1859 г. аналогичные женские училища стали активно создаваться в Москве и провинции, и к 1864 г. их было уже 17. А в 1860 г. была реализована и вторая идея императрицы - относительно педагогического образования: при Мариинском училище начали действовать педагогические классы (позднее педагогические курсы) $)^{19}$, в которых выпускницы получали дополнительную подготовку в качестве учителей начальных классов. В 1862 г. училища были переименованы в женские гимназии.

Успешный эксперимент способствовал активизации работы по созданию женских училищ. В мае 1858 г., наконец, было принято «Положение о женских училищах ведомства министерства народного просвещения». Финансировать содержание училищ предполагалось с помощью общественных и благотворительных организаций, а также частных пожертвований. Ходатайствовать перед Министерством о субсидиях можно было только в крайних случаях. Женские училища делились на I и II разряды - шести- и трехгодичные. Учебные программы учениц І разряда включали закон Божий, русский язык, арифметику, основы геометрии, географии, общие сведения по естественной истории и физике, а также всемирную и русскую историю. Кроме того, по желанию учащихся за особую плату им могли давать уроки иностранного языка (французского или немецкого), рисования, чистописания и рукоделия. Учебная программа училищ II разряда была сокращенной. Кроме закона Божьего и русской грамматики там преподавали сокращенную русскую историю, географию, начала арифметики, чистописание и рукоделие.

\footnotetext{
15 Там же. Л. 122, 242.

16 Деревнина 2013: 45.

17 РГИА. Ф. 761 Главный совет женских учебных заведений при Четвертом отделении собственной Его Императорского Величества канцелярии. Оп. 1. Д. 1379. Л. 243.

${ }^{18}$ Кропоткин. Там же.

${ }^{19}$ См. Семенов 1892: № 3: 24-39; № 4: 9-22.
} 
С точки зрения учебного процесса эти школы во многом строились по прогрессивной модели училищ Мариинского ведомства. Однако изза избранного способа финансирования создание сети учебных заведений шло трудно: провинциальное дворянство, от которого должны были поступать основные пожертвования, относилось к новым школам без энтузиазма. Поэтому, «чтобы самые училища возвысить в общественном мнении», Министерство народного просвещения ходатайствовало, чтобы все подведомственные ему учебные заведения также были переданы под покровительство императрицы ${ }^{20}$. Постепенно процесс создания гимназий ускорился и в 1880 г., к концу жизни Марии Александровны, их сеть уже была весьма разветвленной: 262 гимназии и прогимназии, из которых 30 действовали под эгидой Мариинского ведомства ${ }^{21}$.

Другим направлением деятельности императрицы в сфере женского образования стало реформирование институтской системы. К решению этой задачи она привлекла другого выдающегося педагога - Константина Дмитриевича Ушинского. Здесь императрица также избрала «пошаговый» подход, начав с преобразования Смольного института, куда К.Д. Ушинский в 1859 г. был назначен инспектором классов. В мае того же года он представил в совет Смольного «Проект некоторых преобразований в распределении классов». Несмотря на довольно «скромный» заголовок, речь шла о всеобъемлющей программе на основе важнейшего для Ушинского принципа демократизации образования и народности воспитания. Одобренный Марией Александровной проект предусматривал ликвидацию разделения состава учащихся на «благородных» и «неблагородных» (т.е. уравнивание «дворянской» и «мещанской» частей Института), преподавание учебных предметов на русском языке и открытие, как и в гимназиях, педагогического класса для специализированной подготовки учениц. Кроме того, Ушинский ввел в практику педагогической работы совещания и конференции педагогов, и отчасти изменил «закрытый» характер учреждения: воспитанницы получили право проводить каникулы и праздники у родителей. Однако деятельность Ушинского в Смольном продолжалась недолго: уже в 1862 г. конфликт с консервативно настроенной начальницей Института обернулся для него весьма серьезными по тому времени обвинениями, в том числе в атеизме. Ему пришлось покинуть институт, но императрица сумела защитить его от репрессий, сохранив Ушинского в штате Мариинского ведомства и отправив в длительную зарубежную командировку ${ }^{22}$, пока не улягутся страсти. Что же касается реформы, которую ему не удалось завершить, то она, как отмечал видный педагог Дмитрий Дмитриевич Семенов, «...не умерла. Она продолжалась с некоторыми лишь несущественными изменениями... Мало того, реформа Ушинского постепенно введена и во все остальные институты империи. И теперь ин-

\footnotetext{
${ }^{20}$ Стоюнин 1991: 218.

${ }^{21}$ См. Семенов. Там же.

${ }^{22}$ См. Семенов 1895: № 1: 28 -47; № 2: 9-24.
} 
ститутка не является уже каким-то анахронизмом на общем фоне современного русского общества. Она наравне с гимназисткой успешно работает на поприще семейной и общественной деятельности». ${ }^{23}$

Императрица Мария Александровна внесла большой вклад в развитие женского образования в России. Преобразования, проведенные под ее руководством, вполне соответствовали по масштабу эпохе великих александровских реформ. Возможно, она, в отличие от необычайно активной предшественницы - Марии Федоровны, не руководила патронируемыми учебными заведениями в «ручном режиме», не составляла лично их уставы и правила распорядка. Да в этом и не было необходимости: ведь в ее распоряжении был такой, как бы сейчас сказали, эффективный «менеджер» и преданный делу сподвижник, как принц Ольденбургский. Важнее другое: она умела выделять из поступающих проектов и предложений наиболее целесообразные и отвечающие духу времени, и привлекать для их реализации лучшие педагогические силы, а также искусно обходить бюрократические барьеры, сломать которые порой бывает не по силам даже императрице, за счет экспериментальных «пилотных проектов» и постепенного распространения их положительных результатов на всю систему женского образования.

\section{БИБЛИОГРАФИЯ / REFERENCES}

Арсеньев Д.С. Жизнеописание императрицы Марии Александровны, 1838-1854. М.: Кучково поле, 2018. 560 c. [Arsen`ev D.S. Zhizneopisanie imperatricy Marii Aleksandrovny`, 1838-1854. M.: Kuchkovo pole, 2018. 560 s.]

Вахромеева О.Б., Уколова Е.В. Женские учебные заведения Мариинского ведомства в Петербурге в дореволюционной России // Актуальные проблемы гуманитарных и естественных наук, 2014. № 11. С. 84-86. [Vaxromeeva O.B., Ukolova E.V. Zhenskie uchebny`e zavedeniya Mariinskogo vedomstva v Peterburge v dorevolyucionnoi Rossii // Aktual’ny`e problemy` gumanitarny`x i estestvenny`x nauk, 2014. № 11. S. 84-86].

Гомаюнов С.А. История школы и школа истории. Вятская Мариинская женская гимназия 1859-1917. Вятка: Буквица, 2009. 226 c. [Gomayunov S.A. Istoriya shkoly`i shkola istorii. Vyatskaya Mariinskaya zhenskaya gimnaziya 1859-1917. Vyatka: Bukvicza, 2009. 226 s.]

Двадцатипятилетие Санкт-Петербургских женских гимназий Ведомства учреждений императрицы Марии. СПб.: тип. Ф. Елконского, 1883. 89 с. [Dvadczatipyatiletie SanktPeterburgskix zhenskix gimnazii Vedomstva uchrezhdenij imperatricy Marii. SPb.: tipografiya F. Elkonskogo, 1883. 89 s.]

Деревнина Е.А. Коломенская женская гимназия Мариинского ведомства. К истории создания учебного заведения // Известия Российского Государственного педагогического университета им. А.И. Герцена. 2013, № 162. С. 38-48. [Derevnina E.A. Коlomenskaya zhenskaya gimnaziya Mariinskogo vedomstva. K istorii sozdaniya uchebnogo zavedeniya // Izvestiya Rossijskogo Gosudarstvennogo pedagogicheskogo universiteta im. A.I. Gercena. 2013, № 162. S. 38-48].

Днепров Э.Д., Усачева Р.Ф. Женское образование в России. М.: Дрофа, 2009. 286 с. [Dneprov E.D., Usacheva R.F. Zhenskoe obrazovanie v Rossii. M.: Drofa, 2009. 286 s.]

Добролюбов Н.А. Мысли об учреждении открытых женских школ // Русский вестник, 1858. T. 14. C. 218-231. [Dobrolyubov N.A. My'sli ob uchrezhdenii otkry ty'x zhenskix shkol // Russkij vestnik, 1858. T. 14. S. 218-231].

Долгоруков П.В. Петербургские очерки. Памфлеты эмигранта, 1860-1867. М.: Юрайт, 2019. 383 c. [Dolgorukov P.V. Peterburgskie ocherki. Pamflety` e`migranta, 1860-1867. M.: Yurajt, 2019. 383 s.]

${ }^{23}$ См. Семенов. Там же. 
Козлова Н.И. Из истории женского образования в С.-Петербурге. СПб.: Петрополис, 1996. 104 c. [Kozlova N.I. Iz istorii zhenskogo obrazovaniya v S.-Peterburge. SPb.: Petropolis, 1996. $104 \mathrm{~s}$.

Кропоткин П.А. Записки революционера. М.: Московский рабочий, 1988. 544 с. [Kropotkin P.A. Zapiski revolyucionera. M.: Moskovskij rabochij, 1988. 544 s.] URL: https://www.litres.ru/petr-kropotkin/zapiski-revolucionera/chitat-onlayn/page-11/

Лапчинская В.П. Возникновение женских гимназий в России и история первых лет их деятельности (Петербург, 1858-1868): Автореферат дисс. канд. педагог. наук. М., 1951. 14 c. [Lapchinskaya V.P. Vozniknovenie zhenskix gimnazii v Rossii i istoriya pervy`x let ix deyatel nosti (Peterburg, 1858-1868): Avtoreferat diss. kand. pedagog. nauk. M., 1951. 14 s.]

Лапчинская В.П. Николай Алексеевич Вышнеградский и его роль в развитии женского образования в России // Советская педагогика, 1962. № 6. С. 112-124. [Lapchinskaya V.P. Nikolaj Alekseevich Vyshnegradskij i ego rol v razvitii zhenskogo obrazovaniya $\mathrm{v}$ Rossii // Sovetskaya pedagogika, 1962. № 6. S. 112-124].

Лихачева Е.О. Материалы для истории женского образования в России. 1856-1880. СПб.: тип. М.М. Стасюлевича, 1901. 648 c. [Lihacheva E.O. Materialy` dlya istorii zhenskogo obrazovaniya v Rossii. 1856-1880. SPb.: tipografiya M.M. Stasyulevicha, 1901. 648 s.]

Лихачева Е.О. Николай Алексеевич Вышнеградский в женских гимназиях. СПб.: тип. И.Н. Скороходова, 1898. 40 с. ГLixacheva E.O. Nikolaj Alekseevich Vyshnegradskij v zhenskix gimnaziyax. SPb.: tipografiya I.N. Skoroxodova, 1898. 40 s.]

О воспитании благородных девиц в Санкт-Петербурге при Воскресенском монастыре; с приложением Устава и штата сего Воспитательного Общества. Указ от 5 мая 1764 г. // Полн. собр. законов Российской империи, с 1649 года. Собр. 1-е.: в 45 т. СПб., 1830. T. 16. C. 742-755. ГO vospitanii blagorodnyx devicz v Sankt-Peterburge pri Voskresenskom monastyre; s prilozheniem Ustava i shtata sego Vospitatel`nogo Obshhestva. Ukaz ot 5 maya 1764 g. // Poln. sobr. zakonov Rossijskoj imperii, s 1649 goda. Sobr. 1-e.: v 45 t. SPb., 1830. T. 16. S. 742-755].

Пирогов Н.И. Избранные педагогические сочинения. М.: Педагогика, 1985. 496 с. [Pirogov N.I. Izbranny`e pedagogicheskie sochineniya. M.: Pedagogika, 1985. 496 s.]

Пономарева В.В. Женские институты в социокультурной политике Российской Империи в 1764-1855 гг. // Вестник Московского университета. Серия 21. Управление (государство и общество), 2017. № 1. C. 87-103. [Ponomareva V.V. Zhenskie instituty` v sociokul turnoi politike Rossijskoi Imperii v 1764-1855 gg. // Vestnik Moskovskogo universiteta. Seriya 21. Upravlenie (gosudarstvo i obshhestvo), 2017. № 1. S. 87-103].

Правила внутреннего порядка Мариинского женского училища. СПб., 1859. 10 с. [Pravila vnutrennego poryadka Mariinskogo zhenskogo uchilishha. SPb., 1859. 10 s.]

Правила для поступления в число учениц Санкт-Петербургских и Царскосельской женских гимназий и программы гимназического курса. СПб.: тип. В. Демакова, 1878. 26 с. [Pravila dlya postupleniya v chislo uchenicz Sankt-Peterburgskix i Czarskosel`skoj zhenskix gimnazij i programmy` gimnazicheskogo kursa. SPb.: tipografiya V. Demakova, 1878. $26 \mathrm{s.]}$

Положение о женских гимназиях и прогимназиях Министерства народного просвещения. Утвержд. 24 мая 1870 года // в кн.: Сб. постановл. по Мин. нар. просв. СПб., 1871. Т. IV. C. 1620-1629. [Polozhenie o zhenskix gimnaziyax i progimnaziyax Ministerstva narodnogo prosveshheniya. Utverzhd. 24 maya 1870 goda // v kn.: Sb.. postanovl. po Min. nar. prosv. SPb., 1871. T. IV. S. 1620-1629].

Правила для поступления в число учениц Санкт-Петербургских и Царскосельской женских гимназий и программы гимназического курса. СПб.: тип. В. Демакова, 1884. 26 с. [Pravila dlya postupleniya v chislo uchenicz Sankt-Peterburgskix i Czarskosel`skoj zhenskix gimnazij i programmy` gimnazicheskogo kursa. SPb.: tipografiya V. Demakova, 1884. $26 \mathrm{~s}$.]

Правила для поступления в число учениц Санкт-Петербургских и Царскосельской женских гимназий и программы гимназического курса. СПб.: тип. В. Демакова, 1905. 90 с. [Pravila dlya postupleniya v chislo uchenicz Sankt-Peterburgskix i Czarskosel`skoj zhenskix gimnazij i programmy` gimnazicheskogo kursa. SPb.: tipografiya V. Demakova, 1905. 90 s.]

Семенов Д.Д. Из пережитого. В Мариинской женской гимназии // Русская школа, 1892. № 3. C. 24-39; № 4. C. 9-22. 「Semenov D.D. Iz perezhitogo. V Mariinskoj zhenskoj gimnazii // Russkaya shkola, 1892. № 3. S. 24-39; № 4. S. 9-22].

Семенов Д.Д. Из пережитого. Мое первое знакомство с К.Д. Ушинским // Русская школа, 1895. № 1. C. 28-47; № 2. C. 9-24. [Semenov D.D. Iz perezhitogo. Moe pervoe znakomstvo s K.D. Ushinskim // Russkaya shkola, 1895. № 1. S. 28-47; № 2. S. 9-24]. 
Скворцов И.В. Прошлое и настоящее С.-Петербургских женских гимназий Ведомства учреждений императрицы Марии. 1858-1908. СПб., 1908. [Skvorczov I.V. Proshloe i nastoyashhee s.-peterburgskix zhenskix gimnazij Vedomstva uchrezhdenij imperatricy Marii. 1858-1908. SPb., 1908.

Стоюнин В.Я. Избранные педагогические сочинения. М.: Педагогика, 1991. 368 с. [Stoyunin V.Ya. Izbranny`e pedagogicheskie sochineniya. M.: Pedagogika, 1991. 368 s.]

Страннолюбский А. Три встречи с Н. А. Вышнеградским // Образование, 1893. № 11. C. 253-260. [Strannolyubskij A. Tri vstrechi s N. A. Vy`shnegradskim // Obrazovanie, 1893. № 11. S. 253-260].

Тютчева, Анна. При дворе двух императоров (воспоминания и фрагменты дневников фрейлины двора Николая I и Александра II). М.: Мысль, 1990. 64 с. [Tyutcheva, Anna. Pri dvore dvux imperatorov (vospominaniya i fragmenty dnevnikov frejliny dvora Nikolaya I i Aleksandra II). M.: Mysl', 1990. 64 s.] URL: https://royallib.com/read/ tyutcheva_anna/pri_dvore_dvuh_imperatorov_vospominaniya_i_fragmenti_dnevnikov_freylin i_dvora_nikolaya_i_i_aleksandra_ii.html\#0

Устав училищ для приходящих девиц Ведомства учреждений императрицы Марии // Полное собрание законов Российской империи. Собрание 2. Т. 37. Отд. 1. СПб.: тип. II Отделения Собственной Е.И.В. канцелярии, 1865. № 37849. [Ustav uchilishh dlya prixodyashhix devicz Vedomstva uchrezhdenij imperatricy Marii // Polnoe sobranie zakonov Rossijskoj imperii. Sobranie 2. T. 37. Otd. 1. SPb.: tip. II Otdeleniya Sobstvennoj E.I.V. kancelyarii, 1865. № 37849].

Учебные заведения Ведомства учреждений императрицы Марии. СПб.: тип. В.Д. Смирнова, 1906. 479 с. [Uchebny`e zavedeniya Vedomstva uchrezhdenij imperatricy Marii. SPb.: tipografiya V.D. Smirnova, 1906. 479 s.]

Чистикова Е.А. Создание женских средних училищ при министре народного просвещения А.С. Норове // Ярославский педагогический вестник, 2014. № 2. Том I (Гуманитарные науки). С. 39-40. [Chistikova E.A. Sozdanie zhenskix srednix uchilishh pri ministre narodnogo prosveshheniya A.S. Norove // Yaroslavskij pedagogicheskij vestnik, 2014. № 2. Tom I (Gumanitarnye nauki). S. 39-40].

Чумиков А.А. К вопросу об основании женских гимназий в России // Русская старина. 1888. T. 58. C. 277-280. [Chumikov A.A. K voprosu ob osnovanii zhenskix gimnazij v Rossii // Russkaya starina. 1888. T. 58. S. 277-280].

Чумиков А.А. Мысли об устройстве женских училищ в губернских городах // Журнал для воспитания. 1857. № 3. С. 321-342; № 4. C. 431-448. [Chumikov A.A. Mysli ob ustrojstve zhenskix uchilishh v gubernskix gorodax // Zhurnal dlya vospitaniya. 1857. № 3. S. 321-342; № 4. S. 431-448].

Володько Анна Вячеславовна, научный сотрудник Института всеобщей истории PAH: avolodko@inbox.ru

\section{Empress Maria Alexandrovna's contribution to the development of fe- male education in Russia: women's all-estate open gymnasiums}

The article is devoted to the life of Empress Maria Alexandrovna and, specifically, her active role in the Russian female education reform and the establishment of all-estate open gymnasiums. The scale of transformations put into effect under her guidance was quite worthy of the era of her husband Tsar Alexander's great reforms. She was able to assess critically the submitted projects and proposals, selecting the most expedient and relevant ones, and to engage the best specialists in pedagogical science and practice in their implementation. Maria Alexandrovna actively supported various experimental "pilot projects" in the educational sphere, facilitating the entrenchment of their positive results within the whole female education system.

Keywords: Empress Maria Alexandrovna, Russia, female education, all-estate open gymnasiums

Anna Volodko, researcher, Institute of World History, Russian Academy of Sciences: avolodko@inbox.ru 


\author{
A.B. ГРОМОВА
}

\title{
ВЕЛИКАЯ КНЯГИНЯ ЕЛИЗАВЕТА ФЕДОРОВНА ПОКРОВИТЕЛЬСТВО МУЗЫКАЛЬНОМУ ОБРАЗОВАНИЮ
}

Статья посвящена покровительству Великой княгини Елизаветы Федоровны музыкальному образованию на примере двух основных московских училищ музыкального направления. Рассматриваются различные аспекты попечительства в целях качественного обеспечения учебного процесса, помощи «недостаточным учащимся», поощрения наиболее талантливых учеников, создания условий для широкого практического применения учащимися полученных знаний в лучших творческих коллективах России. Также уделено внимание содействию Великой княгини возникновению в России новых музыкальных и театральных направлений при участии преподавателей и выпускников Музыкально-драматического и Синодального училищ.

Ключевые слова: Великая княгиня Елизавета Федоровна, Синодальное училище иерковного пения, Музыкально-драматическое училище, Московское филармоническое общество, образование, попечительство, благотворительность

Великая княгиня Елизавета Федоровна (1864-1918), урожденная принцесса Гессенская и Рейнская, супруга Великого князя Сергея Александровича (1857-1905) ${ }^{1}$, внесла значительный вклад в развитие благотворительного движения. После замужества, в 1884 г., Елизавета Федоровна начала свою деятельность в области благотворительности, продолжая традиции попечительства, принятые в учреждениях под покровительством Императорского дома Романовых, брала под свою опеку существующие организации и основывала новые, тщательно выбирая наиболее необходимые и востребованные направления. До 1917 г. Елизавета Федоровна взяла под свое покровительство в России более 150 -ти благотворительных и просветительских организаций и учреждений ${ }^{2}$. Отдельное место среди них занимали учебно-воспитательные заведения. Елизавета Федоровна вникала в административно-хозяйственные вопросы, выделяла личные средства для финансирования, поддерживала введение новшеств в учебные программы.

Великая княгиня, опираясь на традиции Романовской благотворительности в области образования, следовала принципам всестороннего развития личности, заложенным в детстве ее матерью великой герцогиней Алисой Гессенской и Рейнской, выдающейся благотворительницей и общественным деятелем; бабушками - королевой Викторией и принцессой Елизаветой Прусской. Великогерцогские резиденции в Земле Гессен и родном Дармштадте, королевские замки и дворцы в Англии были центром притяжения самых талантливых людей своего времени ученых и философов, музыкантов и художников. Музыка и пение были непременной составляющей образования детей.

\footnotetext{
${ }^{1}$ Пятый сын императора Александра II, командующий Лейб-гвардии Преображенского полка (1887-1891), Московский генерал-губернатор (1891-1904), командующий Московским военным округом (1896-1905).

${ }^{2}$ РГИА. Ф. 1409. Оп. 16. Д. 914. Л. 2-21
} 
После замужества Елизавета Федоровна нашла в своем супруге Великом князе Сергее Александровиче, знатоке живописи, любителе музыки и театра, единомышленника и соратника на ниве покровительства науке и искусству. Елизавета Федоровна, обладая обширными знаниями в области художественной и музыкальной культуры, планомерно и последовательно включала элементы музыкального и церковно-певческого образования в учебные программы опекаемых ею учебных заведений на разных уровнях - от обучения музыкальной грамоте младших школьников в заведениях Елизаветинского благотворительного общества $(1891)^{3}$ до профессионального музыкального обучения в Елизаветинской гимназии ${ }^{4}$. Появление Московского Синодального училища церковного пения в XIX в. явилось некоторым итогом насыщенной истории певческого искусства, а также важнейшей вехой, определившей будущее православного духовного пения. Важно, что в самый ответственный период деятельности училища оно было под особым покровительством Великой княгини. Елизавета Федоровна ценила Синодальный хор, поддерживала его, заботилась о сохранении и развитии им певческих традиций, также помогала Синодальному училищу, способствовала продвижению качественного развития образования профессиональных регентов - руководителей церковно-певческими хорами, а также учителей церковного пения. Еще в 1830 г. для малолетних певчих Синодального хора впервые было открыто училище. Затем официально был утвержден штат (1857), по которому это училище являлось низшим учебным заведением, где дети получали 4-классное образование. Число взрослых певчих в Синодальном хоре в то время составляло в среднем 30 человек. В училище получали образование 65 человек, большая часть которых пользовалась казенным содержанием в певческих и регентских классах.

8 июня 1886 г. Александром III был подписан заранее разработанный обер-прокурором Синода К.П. Победоносцевым указ «О преобразовании управления Московским Синодальным певческим хором, училищем при нем и синодальным недвижимым имуществом в Москве и ее окрестностях ${ }^{5}$. Училище отчасти отделили от Синодального хора. Из него сделали 8-классное среднее учебное заведение, установив 3 отделения. Первое - низшее, для обучения малолетних певчих (1-4 классы), другое - среднее (5-6 классы), для подготовки регентских помощников, а третье - высшее (7-8 классы), для выпуска полноценных регентов и учителей церковного пения 6 . Учреждение находилось в главном веде-

\footnotetext{
${ }^{3}$ Елизавета Федоровна создала Елизаветинское благотворительное общество в Москве и Московской губернии (1892-1917) и стала его пожизненной попечительницей. За 25 лет через Елизаветинские приюты и ясли прошло около 9 тыс. детей, а число матерей, получивших разного рода детскую помощь, доходило до 16 тыс.

${ }^{4}$ C 1894 г. под покровительством Елизаветы Федоровны состояла основанная в 1878 г. в Москве Елизаветинская женская гимназия при Доме воспитания сирот убитых воинов русско-турецкой войны.

${ }^{5}$ См.: Металлов 1911: 122.

${ }^{6}$ Синодальное училище церковного пения ... 1900: 36
} 
нии Священного Синода и, как и Синодальный хор, подчинялось прокурору Московской Священного Синода конторы ${ }^{7}$. Творческой жизнью хора и училища руководил Наблюдательный совет. В его состав входили известные всей стране музыканты. Среди них были (в разное время): П.И. Чайковский, Д.В. Разумовский, Н.А. Губерт, С. И. Танеев, В.И. Сафонов, А.С. Аренский, С.Н. Василенко и др. Постепенно Наблюдательный совет вырос и превратился в организацию, объединившую многих передовых людей своего времени вокруг идеи совершенствования церковно-певческого дела и науки, композиторского творчества и педагогического образования. Члены Совета осуществляли в начале XX в. экспертизу духовно-музыкальных произведений и текстов научных трудов. Под контролем Совета существовали частные церковно-певческие хоры Москвы. Древлехранилище училища - уникальное собрание манускриптов - формировалось под его эгидой. Совет координировал проекты по изучению музыкальной медиевистики, подготавливал издания первого в России церковно-певческого научного журнала ${ }^{8}$.

Великокняжеская чета посещала Синодальное училище. С.В. Смоленский вспоминал (1895): «Посещение училища Сергеем Александровичем и Елизаветой Федоровной... Пели великолепно, как очень редко. Великий князь сказал мне на прощание: "Ваш хор - сущее наслаждение. Я буду у вас еще раз на Пасхе". Дамы по обыкновению плакали» ${ }^{9}$. Особое впечатление оставляли службы с участием певчих училища в Успенском соборе Кремля. Тезоименитства императорской семьи, церемонии при встречах восточных иерархов Церкви, коронационные торжества в присутствии представителей иностранных государств, - все это вдохновляло учащихся и певчих Синодального хора. Известны частые концерты Синодального хора и учащихся Синодального училища в генерал-губернаторском доме. Исполнялись произведения А. Кастальского, М. Балакирева, П. Чайковского, Д. Бортнянского. В начале Первой мировой войны в присутствии Великой княгини не раз совершались молебны о русской армии. Например, хор в ее присутствии пел на освящении лазарета для раненых и приюта для увечных воинов. Певчие Синодального хора и училища служили панихиды у гробницы Великого князя Сергея Александровича в Чудовом монастыре ${ }^{10}$.

Новые программы обучения и списки музыкальных предметов были утверждены в 1910 г. Наряду с предметами обычной средней школы, изучали латынь, греческий, догматическое богословие, психологию, основы философии, крюковую семиографию, историю музыки; проходили полный курс теории, начиная с сольфеджио, гармонии до контрапункта, фуги и форм включительно; фортепиано и скрипка были обязательными предметами. Преподавателями училища в разное время были

\footnotetext{
${ }^{7}$ Цыплакова 2018: 120.

${ }^{8}$ Собрание узаконений и распоряжений правительства, 1892 г. . . . 1893: 248

${ }^{9}$ Матвеенко 2010: 49.

${ }^{10}$ Московский листок. 1909: 2.
} 
М. Ипполитов-Иванов, В. Калинников, С. Кругликов, А. Кастальский, Н. Кочетов, Д. Крейн и др. Учебная программа уже больше соответствовала курсу не начального или среднего, а высшего образования. Училище состояло из более чем 100 учеников в 1890-е гг. и 130-ти - в 19001910-е гг. Выпускники несли хоровую культуру по всей России, направлялись на работу в разные города учителями пения в средние учебные заведения, реже - регентами церковных хоров. В стенах училища получили музыкальное образование выдающиеся композиторы и дирижеры. Среди них - Н.С. Голованов, Н.М. Данилин, П.А. Ипполитов, М.Г. Климов, А.В. Никольский, П.Г. Чесноков, К.Н. Шведов. Приведем свидетельство выпускника Московского Синодального училища церковного пения, выдающегося дирижера, народного артиста СССР Николая Семеновича Голованова: «Синодальное училище дало мне все: моральные принципы, жизненные устои, привило мне священную любовь к труду, железную дисциплину, умение работать много и систематически. В 1909 году весной я окончил училище со званием регента 1-го разряда и учителя пения, и был оставлен в Москве в качестве помощника регента Н.M. Данилина в Синодальном хоре и преподавателя училища. В этом же году осенью я впервые выступил публично, как дирижер в Большом зале консерватории в концерте Синодального хора (исполнялась «Литургия» Рахманинова) и считаю эту знаменательную для меня дату началом моей сорокалетней музыкальной деятельности». ${ }^{11}$

Особое значение для развития отечественной музыкальной культуры имело решение Елизаветы Федоровны взять под свое покровительство Московское филармоническое общество (МФО) и состоящее при нем Музыкально-драматическое училище (МДУ) 1213 февраля 1892 г. Почетным членом Московского филармонического общества состоял Великий князь Сергей Александрович с 1892 г. вплоть до своей гибели.

Музыкально-драматическое училище ведет свою историю с 22 октября 1878 г., когда известным дирижером и пианистом П.А. Шостаковским была открыта частная музыкально-театральная школа под патронажем Общества любителей музыкального и драматического искусства. В 1883 г., по инициативе Шостаковского, Общество любителей музыкального и драматического искусства было переименовано в Московское филармоническое общество, а Школа преобразована в Музыкально-драматическое училище при Московском филармоническом обществе. Шостаковский остался директором. Был утвержден новый Устав ${ }^{13}$.

\footnotetext{
${ }^{11}$ Николай Голованов... 2017: 17

12 В 1918 г. Училище было реорганизовано в Музыкально-драматический институт, с 1919 г. - Государственный институт музыкальной драмы, с 1922 г. - Государственный институт театрального искусства, в 1925 г/ переведен на положение техникума и получил наименование - Центральный техникум театрального искусства, с 1931 г. - Театральный комбинат, с 1935 г. - Государственный институт театрального искусства, в 1991 г. был присвоен статус академии, и Институт был переименован в Российскую академию театрального искусства - ГИТИС.

${ }^{13}$ Отчет двадцатипятилетней деятельности (1878-1903)... 1904: 3.
} 
В 1886 г. Музыкально-драматическое училище Московского филармонического общества было приравнено к консерваториям Императорского Русского музыкального общества. В училище преподавались художественные предметы по учебному плану, составленному Художественным советом и утвержденному Великой княгиней Елизаветой Федоровной: игра на инструментах, входящих в состав оркестра; пение solo, пение хоровое; теория музыки, история музыки вообще и русской духовной музыки в частности; история драмы, культуры, литературы; сценическая игра, декламация; мимика, танцы и фехтование. Кроме того, преподавались Закон Божий, русский, французский, немецкий, итальянский (для изучающих пение) языки, математика, физика, естествознание, история, география, рисование, черчение и чистописание.

МДУ содержалось как на средства Московского филармонического общества, так и на суммы, вносимые за обучение самими учащимися или же лицами и ведомствами, содержащими на свой счет стипендиатов. Для пополнения средств МДУ имело право давать в свою пользу концерты и спектакли. В 1893-94 уч. г. Попечительный совет постановил учредить Фонд для выдачи пособия «недостаточным» учащимся. По докладу секретаря Ее Императорского Высочества камергера Н.А. Жедринского Елизавета Федоровна пожертвовала в Фонд 500 руб. В 189495 уч. г. Правление МФО в память об императоре Александре III пожертвовало капитал для учреждения 2-х стипендий его имени. Елизавета Федоровна пожертвовала на нужды МДУ 12648 руб. 84 коп. из сумм, собранных на благотворительном базаре ${ }^{14}$. С 1 января 1898 г. «по милостивому ходатайству Ее Императорского Высочества Великой княгини Елизаветы Федоровны» Музыкально-драматическому училищу была назначена ежегодная правительственная субсидия в размере 5000 руб. ${ }^{15}$

Среди преподавателей драматического отделения училища были актеры Малого театра А.И. Южин, О.А. Правдин. В 1891-1901 гг. в состав преподавателей входил Вл.И. Немирович-Данченко. Для Немировича-Данченко это назначение стало, по его словам, «выездом на новую, важную дорогу к главной цели». Немирович-Данченко вспоминал:

«Филармоническое общество и училище находилось под покровительством Великой княгини Елизаветы Федоровны... Елизавета Федоровна любила театр, привязалась к моим школьным спектаклям, ...старалась бывать даже на моих простых классах. Отношение к ней в московском обществе было хорошее... я занимался ежедневно без всякого счета, утром и вечером и до поздней ночи - и то не хватало времени. Мне удалось завести большой порядок... тем крепче зрела мысль, что школа без театра - явление бесполезное и не стоит ею заниматься, что воспитанники должны расти при театре, в нем должны получать первую сценическую практику в толпе, на выходах и в маленьких ролях; а потому, если мне не удастся создать в этом же году свой театр, я школу брошу...» ${ }^{16}$.

Усилия Вл.И. Немировича-Данченко по созданию общедоступного театра нашли встречное движение со стороны ревнителей театрального

\footnotetext{
14 Устав Музыкально-драматического училища...: 21, 23.

15 Отчет двадцатипятилетней деятельности $(1878$ - 1903). . .: 29.

${ }^{16}$ Немирович-Данченко: 251, 252, 304.
} 
просвещения К.С. Станиславского, А.Ф. Федотова и Ф.П. Комиссаржевского. В 1888 г. ими было основано Московское общество искусства и литературы. Общество было призвано «способствовать распространению познаний среди своих членов в области искусства и литературы, содействовать развитию изящных вкусов, а также давать возможность проявления и способствовать развитию сценических, музыкальных, литературных и художественных талантов» ${ }^{17}$. В 1891 г., находясь перед угрозой закрытия из-за финансовых трудностей, Общество искусства и литературы получило поддержку со стороны Елизаветы Федоровны, имя которой привлекало и средства для продолжения его деятельности. Созданное при поддержке Елизаветы Федоровны Правление в составе К.С. Алексеева (Станиславского), И.А. Прокофьева, Т.В. Митюшина, И.Н. Грекова, Н.А. Лукутина, П.В. Голубкова, А.М. Левитского обеспечивало материальное положение Общества в течение более 10 лет $^{18}$.

В своих воспоминаниях «Моя жизнь в искусстве» Станиславский писал об Обществе: «При новом упадке заинтересовалась делом модная в то время в Москве великая княгиня Елизавета Федоровна. Ее имя дало популярность падающему делу и средства для его продолжения» ${ }^{19}$.

Знакомство Великокняжеской четы со спектаклями Общества состоялось еще 10 февраля 1897 г., когда в Охотничьем клубе давался спектакль «Уриэль Акоста» в пользу учащихся Елизаветинской женской гимназии. В Отчете Попечительства о недостаточных ученицах гимназии говорилось: «Этот спектакль был осчастливлен посещением Их Императорских Высочеств Великого князя Сергея Александровича и Великой княгини Елизаветы Федоровны. ...Живой интерес к трагедии «Уриэль Акоста» в исполнении высокоталантливых членов артистического общества, собрал в залы Охотничьего клуба весьма многочисленную публику, а продажа художественно-разрисованных программ значительно увеличила сбор со спектакля» ${ }^{20}$.

В это же время произошло важное для организации будущего театра событие: Станиславский и Немирович-Данченко были приглашены в генерал-губернаторский дом, чтобы поставить спектакль для великосветской публики. Конечно, это решение не было спонтанным. Елизавета Федоровна и Сергей Александрович уже имели возможность познакомиться со спектаклями Станиславского, а Великая княгиня могла оценить преподавательский дар Немировича-Данченко в МДУ. Премьера состоялась 11 февраля 1898 г. Немирович-Данченко вспоминал: «Спектакль вышел очень удачным и оказался первой зарницей нашего будущего театра» ${ }^{21}$. Спектакль состоял из четырех частей: сцена из поэмы А.С. Пушкина «Евгений Онегин»; одноактная комедия А. Доде «Лилия»;

\footnotetext{
17 Устав Московского общества искусства и литературы...: 1.

${ }^{18}$ Савельева: $168-169$.

${ }^{19}$ Станиславский: 330.

${ }^{20}$ Отчет состоящего под Августейшим Ея Императорского Высочества.. . 1898: 5-6.

${ }^{21}$ Немирович-Данченко: 304.
} 
сцена из оперы «Песнь торжествующей любви» (музыка А.Ю. Симона, либретто Н. Вильде по одноименной повести И.С. Тургенева); 1 акт «Романтиков» Э. Ростана. В народных сценах были заняты ученики МДУ и любители из Общества литературы и искусства 22 . Альбом с фотографиями участников спектакля сохранил Немирович-Данченко, и можно предположить, что альбом был подарен ему Великой княгиней на память о спектакле ${ }^{23} .12$ сентября 1898 г. Немирович-Данченко писал А.С. Суворину: «...ведь и то доверие, которым мы пользуемся у Их Высочеств, пришло случайно, благодаря тому, что Елизавета Федоровна оценила мои труды в покровительствуемом ею Училище; а оба они - по спектаклю, поставленному мною с К.С. Алексеевым во дворце. Без того и другого мы долго проводили бы время в кабинетных мечтаниях» ${ }^{24}$.

В отчете театра за первый год его существования сообщалось: «1 декабря 1898 года Художественно-Общедоступный театр был удостоен посещением Их Императорских Высочеств г. Московского Генерал-Губернатора Великого князя Сергея Александровича и Великой княгини Елизаветы Федоровны, присутствовавших на 24-м представлении трагедии графа А.К. Толстого «Царь Федор Иоаннович» ${ }^{25}$. А 2 декабря Сергей Александрович писал своему брату Павлу Александровичу: «...вечером ездили смотреть «Феодора Иоанновича» с труппой Алексеева; ну, я тебе скажу роль царя была бесподобно разыграна! Ты знаешь, что на подмостках меня трудно расшевелить, а тут прямо я был форменно растроган игрой этого молодого актера по имени Москвин» ${ }^{26}$.

22 декабря 1898 г. Великая княгиня присутствовала на спектакле в пользу нуждающихся учеников МДУ. В том же сезоне 10-е представление трагедии Софокла «Антигона» (в переводе Д.С. Мережковского), было дано в пользу Общества вспомоществования ученицам Елизаветинской гимназии ${ }^{27}$. Директор Императорских театров В.А. Теляковский отмечал особое покровительство театру Великого князя Сергея Александровича и Великой княгини Елизаветы Федоровны, которое проявлялось в разных формах: создание убежища для театральных деятелей, организация ежегодных благотворительных спектаклей, материальная помощь в оснащении театров, поддержка театральных съездов. Московский генерал-губернатор состоял покровителем Общества призрения престарелых и лишенных способностей к труду артистов и их се-мей, а в 1896 г. председательствовал на открытии I Всероссийского съез-да актеров, что придало авторитет этому мероприятию. 11 марта 1899 г. в Большом театре состоялся концерт в пользу нуждающихся учеников МДУ и убежища для престарелых артистов (отрывки из «Парсифаля»

\footnotetext{
${ }^{22}$ Савельева: 161.

${ }^{23}$ Москва - Святая Земля Великого Князя Сергея Александровича...: 196-197.

${ }^{24}$ Немирович-Данченко: 240.

${ }^{25}$ Музей МХАТ. Ф.1. Опись документов 1-го сезона 1898-1899. Л. 46.

${ }^{26}$ Великий Князь Сергей Александрович...: 507.

${ }^{27}$ Музей МХАТ. Там же. Л. 69, Л. 70.
} 
при участии усиленного хора учащихся МДУ). Сергей Александрович прибыл в Большой театр с супругой и по окончании концерта выразил «много лестного» администрации Филармонического общества ${ }^{28}$.

1897-1898 уч. г. ознаменовался переменами. Вследствие тяжелой болезни П.А. Шостаковский вынужден был отказаться от должности директора. На его место был назначен профессор училища С.Н. Кругликов. В период смены руководства Елизавета Федоровна неоднократно посещала Училище. В отчете МДУ записано: «...Оставив всякую официальность, Ее Высочество изволила предпринять ряд посещений Музыкально-Драматического Училища, не уведомляя о своем приезде. Такая чисто материнская заботливость со стороны Великой Княгини по отношению к училищу, его деятелям и питомцам, усугубила силы и рвение тех и других - и дело не пошатнулось» ${ }^{29}$.

13 февраля 1902 г. исполнилось десятилетие попечительства над Московским филармоническим обществом Великой княгини Елизаветы Федоровны. Годичный акт Училища состоялся в зале Благородного собрания. После отчета Общества за истекший год Елизавета Федоровна вручила аттестаты выпускникам, затем присутствовала при исполнении учащимися музыкальных и драматических произведений. Директора Правления пожертвовали капитал в 5000 руб., на который образовали две стипендии при МДУ: одну - имени Великой княгини Елизаветы Федоровны и другую - имени Великого князя Сергея Александровича. Попечительский совет также собрал 2500 руб. на учреждение ежемесячных стипендий имени Елизаветы Федоровны, которые в течение года выдавались 16-ти беднейшим ученикам Училища ${ }^{30}$.

В соответствии с Уставом, утвержденным 16 сентября 1903 г., Музыкально-драматическое училище стало высшим специальным музыкальным учебным заведением в ведении Министерства внутренних дел, которое должно было выпускать «оркестровых исполнителей, виртуозов на инструментах, концертных певцов, драматических и оперных артистов, капельмейстеров, композиторов и учителей музыки». Художественному совету предоставлялось право избрания артистов в звание почетных членов МДУ. Эти лица утверждались в данном звании Елизаветой Федоровной, присваиваемый им особый знак, носимый как жетон, состоял из золотого лаврового венца с лирой посередине и изображением печати МДУ, представляющей собой герб Великой княгини с надписью кругом: «Печать Музыкально-Драматического училища Московского Филармонического общества». По окончании выпускных экзаменов в день, выбранный Елизаветой Федоровной, назначался публичный го-

\footnotetext{
28 Труды Первого Всероссийского съезда сценических деятелей...: 11, 24.

29 Отчет Музыкально-драматического училища... 1898: 24.

${ }^{30}$ Отчет двадцатипятилетней деятельности (1878-1903): 42. Великая княгиня постоянно поддерживала фонд Попечительного совета, передавая средства благотворительных спектаклей и базаров. В начале 1903 г. по ходатайству Великой княгини ежегодная правительственная субсидия была увеличена до 10000 руб.
} 
дичный акт МДУ, на котором раздавались дипломы, аттестаты и медали и читался отчет о деятельности Училища за минувший год ${ }^{31}$.

19 ноября 1903 г. на Общем собрании МФО в Почетные члены Общества были единогласно избраны Великий князь Константин Константинович, министр внутренних дел В.К. Плеве и управляющий министерством финансов Э.Д. Плеске. 29 ноября в честь 25-летия МФО и МДУ состоялся годичный акт, который посетили Великий князь Сергей Александрович, Великая княгиня Елизавета Федоровна и Великий князь Константин Константинович. Инспектор научных классов Г.Д. Волконский прочитал краткий очерк о 25-летней истории Училища и Общества, после чего состоялся прием делегаций с поздравлениями от Консерватории, Императорского Русского музыкального общества, Малого театра, Московского Художественного театра, Оркестра императорских театров, Русского хорового общества и др. Затем состоялось чествование основателя общества и училища П.А. Шостаковского. В заключение, Их Императорским Высочествам, как Почетным членам Училища, были переданы особые знаки - жетоны ${ }^{32}$. С 1883 г., т.е. с утверждения первого Устава Московского филармонического общества и его Музыкально-драматического училища, за 20 лет прошло обучение 6828 человек, из которых пользовались стипендиями 1472 или 21,55\% учащихся.

23 февраля 1906 г. Московское филармоническое общество, как сообщалось в очередном отчете, «лишилось Августейшего покровительства Ее Императорского Высочества Великой княгини Елисаветы Феодоровны» и только 16 февраля 1912 г. было получено Высочайшее соизволение на принятие Общества и его Училища под Августейшее Покровительство Великой княгини Марии Георгиевны ${ }^{33}$.

Деятельность Синодального училища церковного пения и Музыкально-драматического училища Московского филармонического общества под покровительством Великой княгини Елизаветы Федоровны позволяет выявить определенные закономерности их состояния и развития. В случае попечения о каждом учебном заведении Великая княгиня считала первоочередной задачей не только духовное воспитание учащихся, но и материальное обеспечение учебного процесса, являющееся необходимым условием качества образования. Усилия Елизаветы Федоровны, которая вкладывала свои личные финансовые средства в развитие учреждений и широко привлекала благотворителей, обеспечивали строительство новых учебных зданий, общежитий, мест для отдыха учащихся. Неотьемлемой частью ее покровительства становилась забота о «недостаточных учащихся», учреждение именных стипендий, устройство зарубежных образовательных поездок для самых талантливых.

Обязательным условием попечительства Великой княгини Елизаветы Федоровны было создание возможности для практических заня-

\footnotetext{
${ }^{31}$ Устав Музыкально-драматического училища....: 3, 24, 39.

32 Отчет Московского филармонического общества... 1904: 27.

${ }^{33}$ Отчет Московского филармонического общества... 1913: 6.
} 
тий: для учащихся МДУ - на сцене Художественного театра или в импровизированном театре генерал-губернаторского дома, для певчих Синодального училища - выступления на благотворительных концертах, участие в торжествах и встречах Николая II в Кремлевских соборах, в архиерейских церковных службах, военных и церковных парадах.

Великая княгиня вела большую работу по сбору средств, привлекая частных благотворителей, обращаясь с ходатайствами о субсидиях из казны. Финансирование подопечных учебных заведений было постоянной строкой при распределении средств от проведения ею благотворительных базаров, цветочных праздников, спектаклей, выставок и.т.п. В свою очередь руководство и учащиеся опекаемых ею учреждений становились участниками ее благотворительных начинаний - в пользу Особого Комитета Ее Императорского Высочества для объединения в Москве благотворительной деятельности, вызванной войной на Дальнем Востоке; 85 губернских Комитетов Верховного совета по призрению семей лиц, призванных на войну; учреждений РОКК; Елизаветинской гимназии; детских приютов и яслей Елизаветинского благотворительного общества Ведомства учреждений Императрицы Марии и др.

Главной задачей учебных заведений под покровительством Великой княгини Елизаветы Федоровны было подготовить высокопрофессиональных специалистов - от учителей пения и регентов епархиальных хоров, окончивших курс Синодального училища, до таких столпов отечественной музыкальной культуры как Н. Голованов, знаменитых певцов, актеров и режиссеров как Л. Собинов, О. Книппер, В. Мейерхольд. Непременным условием организации учебного процесса Елизавета Федоровна считала обеспечение преемственности знаний, приобщение учащихся к достижениям мировой и отечественной культуры. Этой цели служило знаменитое древлехранилище Синодального училища. Творческие достижения выпускников подопечных Великой княгини Елизаветы Федоровны Московского Синодального училища церковного пения и Музыкально-драматического училища Московского филармонического общества создавали плодотворную среду для появления новых театральных школ и исполнительских форм на рубеже XIX-XX вв.

\section{БИБЛИОГРАФИЯ / REFERENCES}

Музей МХАТ. Ф.1. Опись документов 1-го сезона 1898-1899. Л. 69.

РГИА. Ф. 1409. Оп. 16. Д. 914. Л. 2-21.

Великий князь С.А. Романов. Биографические материалы. М.: Новоспасский монастырь. 2018. Кн. 5. 752 c. [Velikij knyaz S.A. Romanov. Biograficheskie materialy’. M.: Novospasskij monastyr`. 2018. Kniga 5. 752 s.].

Гессенские принцессы в российской истории. Каталог международной выставки, М.: ИД Тончу, 2018. 330 c. [Gessenskie princessy` v rossijskoj istorii. Katalog mezhdunarodnoj vy`stavki, M.: Izdatel`skij dom Tonchu, 2018. 330 s.].

Матвеенко Д.Я. Великая княгиня Елизавета Федоровна и студенчество: становление личностной культуры молодого человека. СПб.: Левша, 2010. 119 с. [Matveenko D.Ya. Velikaya knyaginya Elizaveta Fedorovna i studenchestvo: stanovlenie lichnostnoj kul tury` molodogo cheloveka. SPb.: Levsha, 2010. 119 s.]. 
Матвеенко Д.Я. Духовно-воспитательная деятельность Великой княгини Елизаветы Фёдоровны на примере Синодального училища // Церковь и Русский мир: история, традиции, современность / Сост. А.С. Мельков, М.К. Парамонова. М.; Ярославль: Рендер, 2010. 232 c. [Matveenko D.Ya. Duxovno-vospitatelnaya deyatel'nost Velikoj knyagini Elizavety Fyodorovny na primere Sinodal'nogo uchilishha // Cerkov` i Russkij mir: istoriya, tradicii, sovremennost / Sost. A.S. Mel’kov, M.K. Paramonova. M; Yaroslavl: Render, 2010. 232 s.].

Металлов В. Синодальное училище церковного пения в его прошлом и настоящем // Русская духовная музыка в документах и материалах. М.: Тип. т/д. Н.Бердоносов, Ф. Пригорин и Ко., 1911. 149 с. ГMetallov V. Sinodal'noe uchilishhe cerkovnogo pe-niya v ego proshlom i nastoyashhem // Russkaya duxovnaya muzy`ka v dokumentax i materialax. M.: Tipografiya t/d. N. Berdonosov, F. Prigorin i Ko., 1911. 149 s.].

Москва - Святая Земля Великого Князя Сергея Александровича и Великой Княгини Елизаветы Федоровны. Каталог выставки. М.: Союз Дизайн, 2016. 335 c. ГMoskva - Svyataya Zemlya Velikogo Knyazya Sergeya Aleksandrovicha i Velikoj Knyagini Elizavety` Fedorovny`. Katalog vy`stavki. M.: Soyuz Dizain, 2016. 335 s.].

Московский листок. 1900. № 346. 12 дек. [Moskovskij listok. 1900. № 346.12 dek.].

Московский листок. 1901. № 72. 13 мар. [Moskovskij listok. 1901. № 72.13 mar.].

Московский листок. 1909. № 98. 30 апреля. [Moskovskij listok. 1909. № 98.30 aprelya.].

Немирович-Данченко Вл. И. Творческое наследие. Из прошлого. В 4 т. М.: Моск. Худож. театр, 2003. 734 c. [Nemirovich-Danchenko Vl. I. Tvorcheskoe nasledie. Iz proshlogo. V 4 t. M.: Mosk. Xudozh. teatr (GUP IPK Ul`yan. Dom pechati), 2003. 734 s.].

Николай Голованов и его время. Челябинск: Авто Граф, 2017. 536 с. [Nikolaj Golovanov i ego vremya. Chelyabinsk: Avto Graf, 2017. 536 s.].

Отчет состоящего под Августейшим Ея Императорского Высочества Великой Княгини Елисаветы Феодоровны покровительством Попечительства о недостаточных ученицах Елисаветинской женской гимназии с 14 ноября 1896 года по 1 января 1898 г. М., 1898. [Otchet sostoyashhego pod Avgustejshim Eya Imperatorskogo Vy`sochestva Velikoj Knyagini Elisavety` Feodorovny` pokrovitel`stvom Popechitel`stva o nedostatochny`x ucheniczax Elisavetinskoj zhenskoj gimnazii s 14 noyabrya 1896 goda po 1 yanvarya 1898 g. M., 1898].

Отчет Музыкально-драматического училища Московского филармонического общества, состоящего под Августейшим Ея Императорского Высочества Великой Княгини Елисаветы Феодоровны покровительством. За 1897-98 учебный год. М., 1898 [Otchet Muzy`kal'no-dramaticheskogo uchilishha Moskovskogo filarmonicheskogo obshhestva, sostoyashhego pod Avgustejshim Eya Imperatorskogo Vy`sochestva Velikoj Knyagini Elisavety` Feodorovny` pokrovitel`stvom. Za 1897-98 uchebny`i god. M., 1898].

Отчет двадцатипятилетней деятельности (1878-1903) Московского Филармонического общества и его Музыкально-драматического училища, состоящих под Августейшим Ея Императорского Высочества Великой Княгини Елисаветы Феодоровны покровительством // Отчет Московского филармонического общества и Музыкально-драматического училища... За 1902-1903 уч. г. М., 1903. 「Otchet dvadczatipyatiletnei deyatel ’nosti (1878-1903) Moskovskogo Filarmonicheskogo obshhestva i ego Muzy`kal no-dramaticheskogo uchilishha, sostoyashhix pod Avgustejshim Eya Imperatorskogo Vy`sochestva Velikoj Knyagini Elisavety Feodorovny pokrovitel'stvom // Otchet Moskovskogo filarmonicheskogo obshhestva i Muzykal`no-dramaticheskogo uchilishha... Za 1902-1903 uch. god. M., 1903].

Отчет Московского филармонического общества и Музыкально-драматического училища... За 1903-1904 уч. г. М., 1904. [Otchet Moskovskogo filarmonicheskogo obshhestva i Muzykal `no-dramaticheskogo uchilishha... Za 1903-1904 uchebny`j god. M., 1904].

Отчет Московского филармонического общества и Музыкально-драматического училища... За 1912-1913 уч. г. М., 1913. [Otchet Moskovskogo filarmonicheskogo obshhestva $\mathrm{i}$ Muzy `kal no-dramaticheskogo uchilishha... Za 1912-1913 uchebny` ${ }^{\prime}$ god. M., 1913].

Русская духовная музыка в документах и материалах. Сборник. T. I: Синодальный хор и Училище церковного пения: Воспоминания. Дневники. Письма / Сост., вступ. ст. и коммент.: С.Г. Зверева и др. М.: Языки рус. культуры, 1998. 682 с. [Russkaya duxovnaya muzyka v dokumentax i materialax. Sbornik. T. I: Sinodal'ny j xor i Uchilishhe cerkovnogo peniya: Vospominaniya. Dnevniki. Pis`ma / Sost., vstup. st. i komment.: S.G. Zvereva i dr. M.: Yazy`ki rus. kul'tury’, 1998. 682 s.].

Савельева Л.И. Из фондов Музея Московского Художественного Академического театра // Памятники культуры. Новые открытия: Письменность. Искусство. Археология: еже- 
годник. М.: Наука, 1999. С. 157-177. [Savel`eva L.I. Iz fondov Muzeya Moskovskogo Xudozhestvennogo Akademicheskogo teatra//Pamyatniki kul'tury`. Novy`e otkry`tiya: Pis`mennost`. Iskusstvo. Arxeologiya: ezhegodnik. M.: Nauka, 1999. S. 157-177.].

Синодальное училище церковного пения и Синодальный хор в Москве // Энциклопед. словарь Брокгауза и Ефрона. Т. XXX. СПб., 1900 [Sinodal noe uchilishhe cerkovnogo peniya i Sinodal`ny`j xor v Moskve // Encikloped. slovar` Brokgauza i Efrona. T. XXX. SPb., 1900].

Собрание узаконений и распоряжений правительства, изд. при правительствующем Сенате. 1892 г. № 245. СПб., 1893. С. 248. [Sobranie uzakonenij i rasporyazhenij pravitel`stva, izd. pri pravitel`stvuyushhem Senate. 1892 g. № 245. SPb., 1893. S. 248.].

Станиславский К.С. Собрание сочинений: в 9 т. Т. 5. Кн.1. М.: Искусство, 1993. 628 с. [Stanislavskij K.S. Sobranie sochinenij: v 9 t. T. 5. Kn.1. M.: Iskusstvo, 1993. 628 s.].

Труды Первого Всероссийского съезда сценических деятелей. Ч.1. СПб., 1898. [Trudy' Pervogo Vserossijskogo s“ezda scenicheskix deyatelej. Ch.1. SPb., 1898.].

Устав Московскаго общества искусства и литературы [утвержден 7 августа 1888 года] М.: скоропеч. А.А. Левенсон, 1897. 16 c. [Ustav Moskovskago obshhestva iskusstva i literatury [utverzhden 7 avgusta 1888 goda] M.: skoropech. A.A. Levenson, 1897. 16 s.].

Устав Музыкально-драматического училища Московского филармонического общества, состоящего под Августейшим Ея Императорского Высочества Великой Княгини Елисаветы Феодоровны покровительством. М.: скоропеч. А.А. Левенсон, 1903. 41 с. [Ustav Muzy'kal’no-dramaticheskogo uchilishha Moskovskogo filarmonicheskogo obshhestva, sostoyashhego pod Avgustejshim Eya Imperatorskogo Vy`sochestva Velikoj Knyagini Elisavety Feodorovny pokrovitel`stvom. M.: skoropech. A.A. Levenson, 1903. 41 s.].

Цыплакова С.М. Музыкальное образование в Синодальном училище конца XIX-XX веков // Педагогический вестник. Вып. 5. Новосибирск: АНС "СибАК"; Ялта: Гуманитарнопедагог. академия, 2018. С. 120-121. [Cyplakova S.M. Muzy'kal’noe obrazovanie v Sinodal 'nom uchilishhe koncza XIX-XX vekov // Pedagogicheskij vestnik. Vyp. 5. Novosibirsk: ANS "SibAK"; Yalta: Gumanitarno-pedagog. akademiya, 2018. S. 120-121].

Alice Grossherzogin von Hessen und bei Rhein Prinzessin von Grossbritannien und Irland / Mittheilungen aus Ihren Leben und aus Ihren Briefen. Zweite Auflag. Darmstadt, 1883. $431 \mathrm{~s}$.

Громова Анна Витальевна, кандидат исторических наук, стариий научный сотрудник, Институт всеобщей истории РАН, председатель Наблюдательного совета, Фонд содействия возрождению традиций милосердия и благотворительности «Елисаветинско-Сергиевское просветительское общество»; a.v.g.15@ таil.ru

\section{Grand Duchess Elizaveta Feodorovna as a patron of music education}

The article is devoted to Grand Duchess Elizaveta Feodorovna's activities as a patron of music education in Russia, focusing on the two main Moscow schools specializing in music as a case study. The author analyzes various aspects of her patronage aimed at providing high-quality teaching, assisting poor pupils, and encouraging the most talented ones, creating a wide basis for practical application of knowledge acquired by graduates in the best on-stage performance groups of Russia. Attention is also paid to the Grand Duchess's effort to encourage new trends in Russian musical and performance arts through the contribution of the two Schools' teachers and graduates.

Keywords: Grand Duchess Elizaveta Feodorovna, Synodal School of Church Music, Music and Drama School, Moscow Philharmonic Society, education, patronage, charity

Anna Gromova, PhD, Senior research fellow, Institute of World History, Russian Academy of Sciences, Chairman of the Supervisory Committee of the "Elizabeth and Sergiy Educational Society" Foundation for Support of Mercy and Charity Traditions; a.v.g.15@mail.ru 


\title{
Д.М. НЕЧИПОРУК
«МЫ БЫЛИ ЧУЖЕЗЕМЦАМИ, НО НЕ ПОСТОРОННИМИ» СТРАТЕГИИ ПОЛИТИЧЕСКОЙ АДАПТАЦИИ МЕНЫШЕВИКОВ В ГЕРМАНИИ В 1920-е гг. ${ }^{1}$

\begin{abstract}
Автор исследует стратегии политической адаптации меньшевиков в Германии и их вовлеченность во внутриполитические процессы Веймарской республики. В зависимости от участия в международном социалистическом движении, места внутри Социал-демократической партии Германии, положения в Заграничной Делегации берлинских меньшевиков можно поделить на интернационалистов, «изоляционистов» и «интеграционистов». Политику Заграничной Делегации в 1920-е гг. определяли интернационалисты Ю.О. Мартов, Ф.И. Дан и Р.А. Абрамович. Полноценная адаптация политэмигрантов в Германии была бы невозможна без содействия меньшевиков«интеграционистов», имевших хорошие связи в немецкой социал-демократии. Один из старых лидеров меньшевиков А.Н. Потресов находился в берлинской эмиграции в изоляции. Он контактировал с «интеграционистами», но из-за политических разногласий не взаимодействовал с Заграничной Делегацией.
\end{abstract}

Ключевье слова: адаптация, Германия, Интернационал, меньшевики, эмиграция

Одна из главных проблем изучения политической эмиграции и депортации, касается адаптации иностранцев к новым условиям в стране проживания. На протяжении длительного времени вынужденная или насильственная разлука с родиной означала для эмигранта прекращение полноценного участия в политической жизни страны. Лишь развитие транспортных коммуникаций в XX в., а также новых средств передачи и распространения информации серьезно изменили облик эмиграции. Новые коммуникационные возможности позволяют мигрантам вдалеке от родины сохранять свою идентичность, язык, культурные традиции ${ }^{2}$. Но в любом случае изгнание или вынужденный отъезд означает депривацию возможностей и необходимость приспосабливаться к чужой стра$\mathrm{He}^{3}$. В случае политической эмиграции происходит процесс отчуждения политэмигрантов от родной страны, где в их отсутствие формируются новые порядки и новая социальная реальность. Надежда на скорое возвращение дополняется нежеланием верить, что всё изменилось окончательно. В противном случае политэмигранты, находясь в изгнании, вынуждены переосмысливать как своё новое положение, так и изменения на родине 4 . В свою очередь, возможность реэмиграции после долгих лет отсутствия, как правило, означает для политэмигранта возвращение в новую реальность или надежду на примирение с тем политическим строем, который поначалу не был принят ${ }^{5}$.

\footnotetext{
${ }^{1}$ Исследование выполнено по результатам стажировки в архиве Международного института социальной истории (Амстердам) в 2011 г.

${ }^{2}$ Appadurai 1996.

${ }^{3}$ Саид 2003.

${ }^{4}$ Kettler 2011.

5 Земсков 1991; Лавринец 2010.
} 
В данной статье речь пойдет о стратегиях адаптации меньшевиков в эмиграции в 1920-1930-е гг. и их международных контактах. Вопрос до сих пор не исследован всесторонне в отечественной историографии ${ }^{6}$. За последние четверть века историки проделали большую работу по изучению политической активности меньшевиков как в дооктябрьский, так и в послеоктябрьский период. Хорошо изучена политическая эволюция меньшевизма и анализ меньшевиками революционных событий 1917 г. ${ }^{7}$ Появились монографии о видных меньшевиках Ю.О. Мартове, Г.В. Плеханове, П.Б. Аксельроде, Б.И. Николаевском ${ }^{8}$. Одно из главных достижений постсоветской историографии - публикация документов по истории меньшевизма и выход многотомного издания по истории меньшевизма ${ }^{9}$. После выхода в свет подробного исследования А. Либиха о меньшевиках в эмиграции российские исследователи также начали исследовать историю меньшевизма в изгнании ${ }^{10}$.

Вынужденная эмиграция по политическим обстоятельствам является давним феноменом ${ }^{11}$ В XX в. политическая эмиграция приобрела глобальные масштабы. На каждом континенте можно найти страны, откуда уезжали люди, несогласные с политикой страны или произошедшими изменениями ${ }^{12}$. Российская революция 1917 г. и Гражданская война привели к отъезду значительного числа бывших подданных Российской империи. Точное число уехавших в это время до сих пор неизвестно. Оценки варьируются от 700 тыс. до 3 млн чел. ${ }^{13}$ Особенностью массового исхода россиян в 1917-1923 гг. было то, что это произошло одномоментно, в очень сжатый промежуток времени. Американский историк Марк Раев считал, что массовая эмиграция привела к возникновению «России за рубежом» со своими центрами в Европе, Азии (Маньчжурии), Америке ${ }^{14}$. Хотя обычно об эмиграции 1920-х судят по большому числу уехавших видных политиков, артистов, учёных, предпринимателей, большинство уехавших из страны были обычными неизвестными людьми, которым предстояло найти свое место под солнцем в новых непростых послевоенных условиях.

\footnotetext{
${ }^{6}$ Макарчук 2006; Антошин 2007; Смагина 2014.

${ }^{7}$ Кара-Мурза 2006; Мировая социал-демократия 2006; Ненароков 2012; Малыхин 2017; Протасова 2017; Урилов 2017.

${ }^{8}$ Тютюкин 1997; Урилов 1997; Ненароков 2001; Фельштинский, Чернявский 2012. Однако нет до сих пор монографий по таким видным меньшевикам, как А.Н. Потресов, В.С. Войтинский, Р.А. Абрамович.

${ }^{9}$ Меньшевики в 1917 году...; Меньшевики в большевистской России...; Меньшевики в эмиграции...

${ }^{10}$ Liebich 1997; Малыхин 2006.

${ }^{11}$ Burke 2017.

${ }^{12}$ Israel 1999; McConnell 2013; Wright, Zuniga 2017.

${ }^{13}$ Robinson 2002: 16; Johnson 2007. Австралийская газета «The Beverly Times» co ссылкой на Лигу наций сообщала о 400 тыс. русских во Франции, 100 тыс. в Китае, 90 тыс. в Польше, 50 тыс. в Германии, 50 тыс. в Чехословакии, 30 тыс. в Болгарии. Cм.: Russian Immigrants // The Beverley Times. 1934. 2 February: 4.

${ }^{14}$ Раев 1994.
} 
Приспособление проходило трудно. Неслучайно, наиболее распространёнными образами российских иммигрантов были таксист, дворянин и артист, которые вели свободную, но материально непростую жизнь за рубежом ${ }^{15}$. Из общего числа российских иммигрантов выделялись политэмигранты, уезжавшие из большевистской России по мере того, как становилось понятно, что их борьба с новой советской властью проиграна. Этот процесс не закончился вместе с окончанием Гражданской войны. Так, часть социалистов покинула Советский Союз в середине 1920-х гг. Несмотря на трудную жизнь на чужбине, политэмигранты располагали возможностями для адаптации и сохранения привычного образа жизни, по-прежнему занимаясь политической или публицистической деятельностью. Многие социалисты из России продолжали участвовать в деятельности международных интернационалов. Чехословацкое правительство по сути институционализировало у себя присутствие обширной колонии политэмигрантов, поддержав её материально и дав возможность наладить в Праге собственную культурную жизнь ${ }^{16}$. Часть политэмигрантов прочно обосновалась в бывших частях Российской империи, прежде всего, в новых балтийских странах и Финляндии.

Состав политической эмиграции был разнороден. На правом фланге находились монархисты, часть которых продолжала лелеять надежду на восстановление самодержавия в России. Центр был занят кадетами, многие из которых активно переосмысляли свое видение произошедшего в России, сильно правея в своих взглядах или, наоборот, левея. На левом фланге расположились эсеры и меньшевики. Первые в силу своей относительной многочисленности расселились в разных европейских городах, создав наиболее видные представительства в Праге и Париже ${ }^{17}$. Лидеры эсеров были представлены в Социалистическом рабочем Интернационале, поддерживая связь с европейскими социалистами. Однако в целом эсеры пытались найти опору, в первую очередь, в эмигрантской русской среде. Эсеры были сильно разочарованы своим поражением и до начала 1930-х гг. в их среде были сильны иллюзии о скором и неизбежном падении большевистской власти ${ }^{18}$.

Отношение менышевиков к советской власти было сложнее, поскольку до окончательного размежевания они находились с большевиками в одной партии - Российской социал-демократической рабочей партии (РСДРП). В разгар Гражданской войны отношение меньшевиков к советской власти формулировал их лидер Ю.О. Мартов (1873-1923). В программной статье «Линия социал-демократии» Мартов, негативно относясь к «перевороту 25 октября», тем не менее, не поддерживал и антибольшевистские выступления в Сибири, Поволжье и на Урале. Он выступал против любых попыток насильственного свержения коммуни-

\footnotetext{
${ }^{15}$ Robinson 2002: 17.

${ }^{16}$ См.: Серапионова 1995.

${ }^{17}$ Иммонен 2015: 316-318.

18 Бюллетень Американской Федерации... 1930. № 1.
} 
стов, тем более с помощью иностранной военной интервенции. Для Мартова свержение советской власти означало победу контрреволюционных сил и отказ от главных завоеваний новой власти, которые разделяли и меньшевики: передачу земли крестьянам и государственное регулирование производства. Поэтому несмотря на отношение к коммунистам как к враждебной власти, лидер меньшевиков считал необходимым наладить прямое сотрудничество с большевиками для защиты социальных завоеваний. По мысли Мартова, после окончательной победы над контрреволюцией, партия сможет начать борьбу с большевиками «за выпрямление линии революции» ${ }^{19}$. Такое восприятие политики советской власти как утопической, непоследовательно марксистской в попытке осуществить быстрый «скачок» к коммунистическому хозяйству, но, тем не менее, содержащей реальные «не утопические» меры, легли в основу «линии Мартова», которая определяла отношение меньшевиков к Советскому Союзу до конца 1930-х гг.

В отличие от эсеров, меньшевики были гораздо более социально и политически гомогенной группой. Оказавшись в эмиграции в период с 1918 по 1927 г., подавляющее большинство меньшевиков перебралось в Берлин, который был близок им по двум причинам ${ }^{20}$. Во-первых, как представители РСДРП меньшевики имели наиболее тесные связи именно с немецкими социал-демократами. Во-вторых, для части меньшевиков еврейского происхождения Берлин был комфортен как город, где проживало большое количество немецких и восточноевропейских евре$\mathrm{eB}^{21}$. Например, видный меньшевик Р.А. Абрамович вскоре после переезда стал берлинским корреспондентом крупнейшего печатного издания на идиш - нью-йоркской газеты «Форвертс» ${ }^{22}$.

Проиграв политическую борьбу большевикам к 1920 г., меньшевики не стремились эмигрировать, большинство сделало это вынужденно. Процесс эмиграции в Европу фактически растянулся на десятилетие. Первые меньшевики уехали из России в 1918-1920 гг. в силу разных обстоятельств и, как тогда казалось, не навсегда. В январе 1922 г. под давлением советских властей покинули Россию Г.Я. Аронсон, Б.И. Николаевский, Ф.И. Дан, С.М. Шварц. Часть перебралась в Берлин или оставила советскую службу за рубежом в 1923-1927 гг. Меньшевики выбирали различные стратегии адаптации в стране, в которой стремительно происходили политические изменения на фоне непростого экономического положения и болезненного восприятия поражения Германии в Первой мировой войне. В зависимости от своего участия в международном социалистическом движении и внутренней политики Германии и положения внутри собственного политического круга всех берлинских меньшевиков можно поделить на интернационалистов, «изоля-

\footnotetext{
${ }^{19}$ Мартов. Линия социал-демократии // Меньшевики в большевистской России 275-279.

${ }^{20}$ Очень мало меньшевиков проживало в Праге и Париже. См.: White 2010: 23.

${ }^{21}$ Будницкий, Полян 2013: 127-128.

${ }^{22}$ IISG. R. Abramovič Papers. Boxes 35-36.
} 
ционистов» и «интеграционистов». Интернационалистами считались Ю.О. Мартов, Р.А. Абрамович, Ф.И. Дан. Все трое, не одобряя октябрьский захват власти большевиками, несмотря на репрессии продолжили бороться внутри страны за социал-демократический характер пролетарской революции. Однако к 1919 г. легальные возможности меньшевиков в борьбе за политический курс были исчерпаны: им не давали устраивать собрания, печатать агитационные материалы, члены партии, включая лидеров, постоянно арестовывались. Мартов в статье «Новый курс в Советской России» констатировал, что за пределами Москвы партия не может вести целенаправленную политическую деятельность: «В Витебске Абрамовичу разрешили прочесть лекцию, а в Смоленске признали опасным и не разрешили. Только в Туле во время кампании перевыборов в Совет нашей партии предоставили свободу агитации (однако, газеты все еще не разрешили). В ряде губернских и уездных городов партия продолжает жить под режимом исключительного закона.» ${ }^{23}$.

В то же время европейская известность и международный авторитет лидеров меньшевиков в социал-демократических кругах были последними ресурсами, которые могли помочь исправить безнадежное положение ослабленной партии в советской России. Заступничество немецких и австрийских социал-демократов с просьбами «амнистировать» менышевиков, с одной стороны, и международная социалистическая солидарность в борьбе за пролетарскую революцию - с другой, демонстрировали важность зарубежного представительства партии в Европе. Первым представителем РСДРП за рубежом после установления власти большевиков был идеолог меньшевизма П.Б. Аксельрод. Но однозначно отрицательное отношение к советской власти и разногласия с Мартовым относительно перспектив возрождения II Интернационала побудили Аксельрода сложить полномочия в самом начале 1920 г. Чтобы определиться с новым зарубежным представителем, ЦК РСДРП поручил Мартову и Абрамовичу отправиться в Европу. Руководство большевиков не стало препятствовать выезду, но Мартов опасался, что его отъезд усугубит положение меньшевиков, подвергавшихся преследованиям, о чем он поведал Аксельроду: «жутко уезжать в теперешней обстановке: повсюду наших товарищей преследуют, и все друзья и даже посторонние уверены, что мое присутствие одно только несколько сдерживает большевиков; мой отъезд, а особенно известия о моей деятельности за границей могут их разнуздать окончательно» ${ }^{24}$. В итоге Мартов смог выехать в сентябре 1920 г., а в ноябре вместе с семьей в Германию уехал Абрамович. Изначально Мартов планировал пробыть в Европе не более двух месяцев, но в итоге и Мартов, и Абрамович остались в Германии, не теряя первое время надежд на возвращение в Россию.

Оказавшись в Берлине, Мартов принял активное участие в дискуссии Независимой социал-демократической партии Германии (НСДПГ)

\footnotetext{
${ }^{23}$ Меньшевики в большевистской России. 1918-1924. Меньшевики в 1919-1920: 100.

${ }^{24}$ Там же: 610.
} 
по вопросу о её вступлении в Коммунистический Интернационал. Это был главный вопрос для лидера меньшевиков на тот момент, поскольку Мартов воспринимал НСДПГ как союзников. Он не соглашался с её левым крылом, желавшим провести на ближайшем Галльском съезде решение о вхождении в Коминтерн. Для участия в октябрьском съезде НСДПГ в качестве лидера российских социал-демократов Мартов организовал Заграничную Делегацию РСДРП (ЗД). Из Советской России на съезд был приглашён председатель Коминтерна Г.Е. Зиновьев, который должен был убедить делегатов присоединиться к международному коммунистическому движению. Мартов изначально планировал оппонировать Зиновьеву, но из-за проблем со здоровьем его речь на съезде прочитал А. Штейн. По итогам голосования съезд так и не пришел к единому мнению. Произошёл раскол, и часть партии решила присоединиться к Коммунистической партии Германии. Речь Мартова на съезде НСДПГ была продолжением его борьбы с большевиками за определение курса пролетарской революции, но с другой стороны - демонстрацией его интернационализма как антибольшевизма. Он был убежден, что воссоздание Интернационала должно проводиться не российскими коммунистами, но «марксистскими элементами рабочих партий западных стран» 25 .

Вскоре после съезда по инициативе Мартова был учрежден печатный орган ЗД - «Социалистический вестник» («СВ»), первый номер которого вышел в свет в феврале 1921 г. $^{26}$ Появление своего журнала за рубежом означало для меньшевиков превращение в группу политэмигрантов, хотя сами они тогда ещё отказывались считать себя таковыми. Задачей «СВ» было информирование европейских социалистов о текущих событиях в России. Никто тогда не мог предположить, что издание «СВ» растянется на десятилетия. Вплоть до своей кончины в апреле 1923 г. Мартов оставался лидером меньшевиков в эмиграции и олицетворением интернационализма. Затем руководство ЗД перешло к его ближайшим соратникам Дану и Абрамовичу.

Фёдор Дан был выслан в Германию в начале 1922 г. По прибытии он немедленно был включен в состав ЗД, позднее став её руководителем. Он активно включился в работу международного социалистического движения, участвуя в качестве делегата РСДРП на конференции трёх Интернационалов, состоявшейся в Берлине в апреле 1922 г. ${ }^{27}$ Являясь главой ЗД, он представлял меньшевиков на самых важных международных встречах европейских социал-демократов. Дан имел прочные позиции в Социалистическом рабочем Интернационале, который был создан в результате объединения Венского и Бернского интернационалов в мае 1923 г. К числу его близких товарищей по Социалистическому рабочему Интернационалу относились австрийские социал-демократы Ф. Адлер и

\footnotetext{
25 Там же: 709.

${ }^{26}$ См.: Елфимов 1995.

27 В конференции участвовали представители Бернского, Венского и Коммунистического Интернационалов. См.: Nishikawa 2010: 163-174.
} 
О. Бауэр, французский социалист Л. Блюм. Все основные резолюции, касающиеся Советского Союза, принимались с учётом мнения Дана. $\mathrm{B}$ берлинский период эмиграции Дан тесно сотрудничал с австрийскими и французскими социал-демократами, а с британскими и немецкими социалистами отношения складывались непросто из-за жёсткой антисоветской позиции последних ${ }^{28}$. Контакты ЗД РСДРП с Французской секцией Рабочего интернационала и с Социал-демократической партией Австрии были затруднены. В 1930-е гг. отношение Дана к внутренней политике большевиков стало менее критичным. Откликаясь на статьи Бауэра в австрийской прессе, в которых утверждалось, что сталинская модернизация приведёт страну к заметному социально-экономическому прогрессу ценой больших жертв, Дан с некоторыми оговорками и замечаниями соглашался с таким видением индустриализации. Однако далеко не все члены ЗД готовы были увидеть в советской индустриализации способ построения современного социалистического общества ${ }^{29}$. Разное видение советского будущего привело к возникновению серьезных разногласий внутри ЗД, в то время как отношения с австрийскими коллегами по Интернационалу, поддержавшими сталинскую индустриализацию, оставались дружественными на протяжении 1930-х гг. ${ }^{30}$

Рафаил Абрамович был вторым человеком в ЗД. С юности он участвовал в деятельности РСДРП, являясь членом еврейской социалистической партии «Бунд» и ведя работу в черте оседлости. В годы революции и Гражданской войны пытался противостоять политике Ленина и Троцкого, не отрицая того, что большевизм отражает чаяния рабочих масс, но попытка стать легальным оппонентом большевиков провалилась. Его навыки собирать пожертвования, знание языков, трудолюбие и неутомимость очень сильно помогли меньшевикам в берлинской эмиграции. Помимо важной роли в Социалистическом рабочем Интернационале Абрамович имел тесные связи с еврейскими рабочими организациями в Америке ${ }^{31}$. Свободное знание идиша и огромный опыт работы в еврейской среде в Российской империи помогли ему в поддержании контактов с еврейским социалистическим движением в США. Дважды Абрамович ездил в США для сбора средств, которые были необходимы для выхода в свет «СВ» и для полноценной деятельности ЗД. За годы своей европейской эмиграции Абрамович стал одним из самых уважаемых ветеранов в среде меньшевиков. В 1930-е гг. взаимодействие Дана и Абрамовича было уже не таким бесконфликтным, как в 1920-е гг. Изза разногласий по вопросу о перспективах строительства демократического социализма в СССР на фоне усиления репрессий, их отношения испортились. Абрамович был не согласен со статьей О. Бауэра, Ф. Дана, А. Дюнуа и Ж. Жиромского «Интернационал и война, где, по его мне-

\footnotetext{
${ }^{28}$ Liebich 1997: 170, 192-193.

${ }^{29}$ Малыхин 2017: 22.

${ }^{30}$ См.: Peter 1999.

${ }^{31}$ Michels 2017.
} 
нию, утверждалось, что «большевистская диктатура строит и может при благоприятных условиях - построить социализм в России» ${ }^{32}$. С Абрамовичем в целом были согласны члены ЗД Г. Аронсон, М. Кефали, Б. Николаевский. Различное отношение к политическим процессам в СССР во второй половине 1930-х гг. привели к расколу внутри меньшевиков, и в 1940 г. Дан и его сторонники вышли из ЗД33.

Важную роль в установлении контактов ЗД с германскими социалдемократами играли те меньшевики, которые сумели успешно интегрироваться в политические и экспертные структуры СДПГ в 1920-е гг. или даже в довоенное время. Член РСДРП Александр Штейн эмигрировал в Германию ещё в 1906 г., став активным деятелем СДПГ. Он принимал участие в издании специального бюллетеня о России, а также был членом комитета помощи политическим заключенным в России. В годы первой мировой войны он вступил в НСДПГ и стал издателем партийной газеты «Freiheit» («Свобода»). В годы Гражданской войны и красного террора Штейн переписывался с Мартовым, выступая посредником между меньшевиками и руководством НСДПГ. После раскола в НСДПГ он вернулся в СДПГ. Штейн помог меньшевикам адаптироваться в Берлине, выступая в качестве формального издателя «СВ» и помогая наладить связи в социал-демократических кругах. Другими словами, Штейн был главным покровителем ЗД в Берлине ${ }^{34}$.

Видный меньшевик Владимир Войтинский, сыгравший заметную роль в революции 1917 г., в 1920-е гг. также проживал и работал в Берлине. В 1918-1919 гг. он участвовал в политической борьбе в Грузии, находясь на одной стороне с грузинскими меньшевиками. Войтинский был представителем Грузии в Италии и Франции в 1919-1921 гг. и только после падения Грузинской демократической республики перебрался в Германию. В Берлине он быстро завоевал репутацию первоклассного статистика, став главой статистического отдела Всеобщей конфедерации профсоюзов Германии. Вместе с супругой, Эммой Савельевной, Войтинский находился в центре внутриполитических процессов Веймарской республики, участвуя в разработке антикризисных мер в начале 1930-х гг. «Мы были чужеземцами, но не посторонними» - так охарактеризовал Войтинский свой период в Германии ${ }^{35}$. Он держался в стороне от ЗД, поддерживая хорошие отношения с Абрамовичем и Штейном $^{36}$. Близкий друг Войтинского по берлинской эмиграции меньшевик Пётр Гарви также не входил в ЗД. Благодаря протекции Штейна, Гарви получил позицию специалиста по России в секретариате СДПГ ${ }^{37}$. Меньшевик Юрий Денике на первых порах сотрудничал с большевиками,

\footnotetext{
${ }^{32}$ Меньшевики в эмиграции. Ч. 1: 740.

${ }_{33}$ Р. Абрамович - В.С. Войтинскому, 4 марта 1940 г. // IISG. Vladimir Voitinskij Papers. Box 1.

${ }^{34}$ IISG. Alexander Stein Papers. Box 3 (Nekrologe); Liebich 1997: 172, 220.

${ }^{35}$ Woytinsky 1960: 382.

${ }^{36}$ IISG. Vladimir Voitinskij Papers. Boxes 1, 7.

${ }^{37}$ Ненароков 2009.
} 
став в 1920 г. профессором Московского университета. В 1922 г. Денике получил работу в советском постпредстве в Берлине. Обзаведясь контактами в социал-демократической среде, Денике покинул постпредство в 1926 г., чтобы сделать карьеру в СДПГ. Он был плодотворным публицистом, тесно сотрудничал с видным теоретиком СДПГ Рудольфом Гильфердингом. Сближение Денике с ЗД произойдет уже после того, как её деятельность будет перенесена в США ${ }^{38}$. Соратником Гильфердинга был еще один российский меньшевик, Александр Шифрин, известный в немецкой социал-демократической печати под псевдонимом Макс Вернер ${ }^{39}$. Участие этих меньшевиков в деятельности немецкой социал-демократии, с одной стороны, позволило избежать изоляционистского существования в эмигрантской среде, а с другой, - обособиться от ЗД, поддерживая при этом личные контакты с её членами.

Особняком в изоляции от ЗД держались два видных члена РСДРП: Павел Борисович Аксельрод и Александр Николаевич Потресов. Оба стояли у истоков РСДРП, участвовали вместе с Лениным в революционной деятельности, но в итоге стали непримиримыми оппонентами, как лидера большевиков, так и самого большевизма как политического направления. И Аксельрод, и Потресов негативно отнеслись к захвату власти большевиками, считали необходимым объединение всех антисоветских сил для противодействия коммунистам. В 1920-е гг. с такой позицией сотрудничество с ЗД было невозможным. Аксельрод, тем не менее, пользовался всеобщим уважением как партийный патриарх. В свою очередь, Потресов, приехавший из СССР в Германию в 1925 г., не смог найти общий язык с членами ЗД. Потресов переписывался с Войтинским и Гарви, которые помогали социал-демократу помещать его статьи в немецкой социал-демократической печати, но оба отклонили предложение Потресова участвовать в деятельности эмигрантского журнала «Записки социал-демократа», который выходил в 1930-е гг. Войтинский откровенно писал Потресову, что новый «бюллетень» будет восприниматься как прямой вызов «СВ» ${ }^{40}$. К тому же Войтинский в начале 1930-х практически не публиковался на русском языке, печатаясь в немецких изданиях. Потресов, в свою очередь, в это время сотрудничал с журналом А.Ф. Керенского «День». Его ближайшим сподвижником в этом начинании был Семён Иванович (Португейс), также стоявший на антибольшевистских позициях и до 1942 г. не входивший в состав $3 Д^{41}$.

Большой трагедией для меньшевиков стал приход к власти национал-социалистов. Для многих из них Германия стала вторым домом. Как показано выше, часть меньшевиков сумела найти себя в Веймарской республике, но после окончательного утверждения Гитлера во власти им пришлось покинуть Германию. Для многих это была не последняя

\footnotetext{
${ }^{38}$ Haimson 1974: XVII-XXI.

${ }^{39}$ Люкс 2019: 106.

${ }^{40}$ IISG. Vladimir Voitinskij Papers. Box 6 (Potresov's letters).

${ }^{41}$ Кара-Мурза 2006.
} 
эмиграция, начало второй мировой войны заставило меньшевиков эмигрировать снова, на этот раз в США. За океаном новым главой ЗД стал Абрамович. Будучи, в отличие от Дана, более гибким лидером, Абрамович включил в состав ЗД старых меньшевиков (Португейс, Гарви, Денике), не участвовавших в её работе в берлинский период. Опыт американской эмиграции оказался для меньшевиков отличным от европейского, к тому же после окончания Второй мировой войны международная обстановка кардинально изменилась. Во внешней политике на первый план выходило противостояние двух держав-победителей - США и $\mathrm{CCCP}$, и симпатии меньшевиков, входивших в ЗД, были на стороне Америки. Кроме того, в США прибыла новая волна эмигрантов, в т.ч. уже незнакомых с реалиями дореволюционного времени ${ }^{42}$. Всё это требовало переосмысления прежних взглядов. В среде меньшевиков произошло размежевание на настроенных просоветски и антисоветски. Не было единого мнения и насчёт новых эмигрантов, в особенности власовцев, настроенных как антисоветски, так и антимарксистки. В 1949 г. была учреждена «Лига борьбы за народную свободу», куда вошли представители разных сил, включая меньшевиков. Наконец, во второй половине 1940-х началось сближение меньшевиков и эсеров, понимавших, что прежние разногласия принадлежат истории. В итоге в 1951 г. ЗД прекратила существование, хотя издание «СВ» продолжалось до 1965 г.

\section{БИБЛИОГРАФИЯ / REFERENCES}

\section{Источники}

IISG. R. Abramovič Papers. Boxes 35-36.

IISG. Alexander Stein Papers. Box 3.

IISG. Vladimir Voitinskij Papers. Box 1, 6, 7.

Бюллетень Американской Федерации. Партия Социалистов-Революционеров. 1930.

Меньшевики в 1917 году. Т. 1-3. М., 1994-1997.

Меньшевики в эмиграции. Протоколы Заграничной Делегации РСДРП. 1922-1951 гг. Ч. 1-2. М., 2010.

Меньшевики в большевистской России. 1918-1924. Т. 1-4. М., 1999-2004.

Антошин А.В. Меньшевики в эмиграции после Второй мировой войны // Отечественная история. 2007. № 1. С. 102-115. [Antoshin A.V. Men'sheviki v jemigracii posle Vtoroj mirovoi voiny // Otechestvennaja istorija. 2007. № 1. P. 102-115].

Будницкий О.В., Полян А.Л. Русско-еврейский Берлин (1920-1941). М., 2013. 490 с. [Budnickii O.V., Polian A.L. Russko-evrejskij Berlin (1920-1941). M., 2013. 490 p.].

Елфимов Е.А. Меньшевистский журнал «Социалистический вестник» в первые годы эмигрантского существования // Культура Российского Зарубежья / отв. ред. А.В. Квакин, Э.А. Шулепова. М., 1995. С. 189-196. [Elfimov E. А. Men'shevistskij zhurnal «Socialisticheskii vestnik» v pervye gody jemigrantskogo sushhestvovanija // Kul'tura Rossijskogo Zarubezh'ja / otv. red. A.V. Kvakin, Je.A. Shulepova. M., 1995. P. 189-196].

Земсков В.Н. Рождение «второй эмиграции» 1944-1952 // Социологические исследования. 1991. № 4. C. 3-24 [Zemskov V.N. Rozhdenie «vtoroj jemigracii» 1944-1952 // Sociologicheskie issledovanija. 1991. № 4. P. 3-24].

Лавринец П. Эмигрантский текст в переписке «возвращенцев» (А.П. Дехтерев, А.П. Ладинский, Н.Я. Рощин) // Toronto Slavic Quarterly. Academic Electronic Journal in Slavic Studies. 2010. № 34. ГLavrinec P. Jemigrantskij tekst v perepiske «vozvrashhencev» (A.P. Dehterev, A.P. Ladinskii, N.Ja. Roshhin) // Toronto Slavic Quarterly. 2010. № 34. URL: http://sites.utoronto.ca/tsq/34/tsq34_lavrinets.pdf].

${ }^{42}$ См.: Антошин 2007. 
Иммонен Х. Мечты о новой России. Виктор Чернов (1873-1952). СПб., 2015. 486 с. [Immonen H. Mechty o novoj Rossii. Viktor Chernov (1873-1952). SPb., 2015. 486 p.].

Кара-Мурза А.А. Первый советолог русской эмиграции: Семен Осипович Португейс // Полис. Политические исследования. 2006. № 1. С. 122-140 [Kara-Murza А. А. Pervyi sovetolog russkoj jemigracii: Semen Osipovich Portugejs // Polis. Politicheskie issledovanija. 2006. № 1. P. 122-140].

Люкс Л.М. Эмигрантский мыслитель Александр Шифрин и его анализ фашизма 19291933 гг. // Вопросы философии. 2019. № 1. С. 105-115. [Ljuks L.M. Emigrantskij myslitel' Aleksandr Shifrin i ego analiz fashizma 1929-1933 gg. // Voprosy filosofii. 2019. № 1. P. 105-115].

Макарчук С.В. Социал-демократия Сибири и Дальнего Востока: зарубежные связи в межреволюционный период 1907-1917 гг. // Мировая социал-демократия: теория, история и современность: материалы научной международной конференции / ред. совет A.О. Чубарьян и др. М., 2006. C. 306-312. [Makarchuk S.V. Social-demokratija Sibiri I Dal'nego Vostoka: zarubezhnye sviazi v mezhrevoljucionnyi period 1907-1917 gg. // Mirovaja social-demokratija: teorija, istorija I sovremennost': materialy nauchnoj mezhdunarodnoj konferencii / red. sovet A.O. Chubar'jan i dr. M., 2006. P. 306-312.].

Малыхин К.Г. Оценка «правыми» меньшевиками социально-экономических преобразований большевиков (20-30-е гг.) // Известия вузов. Северо-Кавказский регион. Сер.: Общественные науки. 2006. № 1. C. 39-42 「Malyhin K.G. Ocenka «pravymi» men'shevikami social'no-iekonomicheskikh preobrazovanij bol'shevikov (20-30-e gg.) // Izvestija vuzov. Severo-Kavkazskij region. Serija: Obshhestvennye nauki. 2006. № 1. P. 39-42].

Малыхин К.Г. Русское зарубежье 20-30-х годов XX века: оценка большевистского реформирования России. Ростов-н/Дону; Таганрог, 2018. 214 с. 「Malyhin K.G. Russkoe zarubezh'e 20-30-kh godov XX veka: ocenka bol'shevistskogo reformirovanija Rossii. Rostov-naDonu; Taganrog, 2018. 214 p.]

Мировая социал-демократия: теория, история и современность. М., 2006. 584 с. [Mirovaja social-demokratija: teorija, istorija I sovremennost'. M., 2006. 584 p.].

Ненароков А.П. Войтинский - Гарви и гарвятам: письма 1933-1939 // Ненароков А.П. В поисках жанра: Записки архивиста с документами, комментариями, фотографиями и посвящениями. Кн. 2. М., 2009. С. 198-277. ГNenarokov A.P. Voitinskij-Garviigarviatam: pis'ma 1933-1939 // Nenarokov A.P. V poiskakh zhanra: Zapiski arhivista s dokumentami, kommentarijami, fotografijami I posvjashhenijami. Kn. 2. M., 2009. P. 198-277l.

Ненароков А.П. Последняя эмиграция Павла Аксельрода. М., 2001. 166 с. [Nenarokov A.P. Poslednjaja jemigracija Pavla Aksel'roda. M., 2001. 166 p.].

Ненароков А.П. Правый меньшевизм. Прозрения российской социал-демократии. М., 2012. 600 c. [Nenarokov A.P. Pravyj men'shevizm. Prozrenija rossijskoj social-demokratii. M., 2012. 600 p.].

Протасова О.Л. «Вольный художник» марксизма: жизнь и идейные взгляды Н.В. Вольского // Диалог со временем. 2017. № 58. C. 71-87. 「Protasova O.L. «Vol'nyi khudozhnik» marksizma: zhizn' i idejnye vzgljady N.V. Vol'skogo // Dialog so vremenem. 2017. № 58. P. 71-87].

Раев М. Россия за рубежом. История культуры русской эмиграции. 1919-1939. М., 1994. 296 c. [Raeff M. Rossija za rubezhom. Istorija kul'tury russkoj jemigracii. 1919-1939. M., 1994. 296 p.].

Саид Э.Б. Мысли об изгнании // Иностранная литература. 2003. № 1. С. 112-119. [Said Е. Mysli ob izgnanii // Inostrannaja literatura. 2003. № 1. P. 112-119].

Серапионова Е.П. Российская эмиграция в Чехословацкой Республике, 20-30-е годы. М., 1995. 196 c. [Serapionova E.P. Rossijskaja jemigracija v Chehoslovackoj Respublike, 2030-e gody. M., 1995. 196 p.].

Смагина С.М. Заграничная Делегация РСДРП и ее роль в европейском социал-демократическом движении в 30-е годы XX века // Историческая и социально-образовательная мысль. 2014. Т. 6. № 6. Ч. 1. С. 95-100. 「Smagina S. M. Zagranichnaja Delegacija RSDRP i ee rol' v evropejskom social-demokraticheskom dvizhenii v 30-e gody XX veka // Istoricheskaja i social'no-obrazovatel'naja mysl'. 2014. Vol. 6. № 6. Pt. 1. P. 95-1001.

Тютюкин С.В. Г. В. Плеханов. Судьба русского марксиста. М., 1997. 376 с. [Tjutjukin S.V. G. V. Plekhanov. Sud'ba russkogo marksista. M., 1997. 376 p.].

Урилов И.Х. История российской социал-демократии (меньшевизма). Ч. 7. М., 2017. 384 с. [Urilov I.H. Istorija rossijskoj social-demokratii (men'shevizma). Part 7. M., 2017. 384 p.]. 
Урилов И.Х. Ю.О. Мартов: политик и историк. М., 1997. 469 с. [Urilov I.H. Ju.О. Martov: politik i istorik. M., 1997. 469 p.].

Фельштинский Ю.Г., Чернявский Г.И. Через века и страны. Б.И. Николаевский: судьба меньшевика, историка, советолога, главного свидетеля эпохальных изменений в жизни России первой половины XX века. M., 2012. 542c. [Fel'shtinskij Ju.G., Chernjavskij G.I. Cherezvekaistrany. B.I. Nikolaevskij: sud'ba men'shevika, istorika, sovetologa, glavnogo svidetelja jepohal'nykh izmenenij v zhizni Rossii pervoj poloviny XX veka. M., 2012. 542 p.].

Appadurai A. Modernity at Large: Cultural Dimensions of Globalization. University of Minnesota Press. 1996. 229 p.

Burke P. Exiles and Expatriates in the History of Knowledge, 1500-2000. Brandeis University Press. 2017. 312 p.

Haimson L.H. (ed.) The Mensheviks. The University of Chicago Press. 1974. 476 p.

Israel M. South African Political Exile in the United Kingdom. MacMillan Press and St. Martin Press. 1999. 281 p.

Johnson S. «Communism in Russia Only Exists on Paper»: Czechoslovakia and the Russian Refugee Crisis, 1919-1924 // Contemporary European History. 2007. № 3. P. 371-394. URL: https://doi.org/10.1017/S0960777307003980

Kettler D. The Liquidation of Exile: Studies in the Intellectual Emigration of the 1930s. Anthem Press. 2011. 220 p.

Liebich A. From the Other Shore: Russian Social Democracy after 1921. Harvard University Press. 1997. 476 p.

McConnell F. Citizens and Refugees: Constructing and Negotiating Tibetan Identities in Exile // Annals of the Association of American Geographers. 2013. № 4. P. 967-983.

Michels T. The Abramovitch Campaign and What It Tells Us about American Communism // American Communist History. 2016. № 3. P. 283-291.

Nishikawa M. Socialists and International Actions for Peace 1914-1923. Frank \&Timme. 2010. $342 \mathrm{p}$.

Peter H.R. Fedor I. Dan und Otto Bauer: Briefwechsel (1934-1938). Campus Verlag. 1999. 188 p.

Robinson P. The White Russian Army in Exile 1920-1941. Clarendon Press, 2002. 257 p.

White E. The Socialist Alternative to Bolshevik Russia: The Socialist Revolutionary Party, 1921-39. Routledge. 2011. 180 p.

Woytinsky E.S. Two Lives in One. Praeger. 1965. 324 p.

Woytinsky W.S. Stormy Passage. The Vanguard Press. 1960. 535 p.

Wright T.C., Zuniga R.O. Chilean Political Exile // Latin American Perspectives. 2007. № 4. P. 31-49. URL: https://www.jstor.org/stable/27648032

Дмитрий Михайлович Нечипорук, кандидат исторических наук, доцент, старший научный сотрудник, сетевой исследовательский Центр "Человек, природа, технологии", Тюменский государственный университет, d.m.nechiporuk@utmn.ru

\section{"We were aliens, but no longer outsiders": the strategies of political ad- aptation of the Mensheviks in Germany in 1920s}

The article is devoted to a history of Menshevism in German exile in the 1920s. The author studies three strategies of political adaptation in Weimar Republic: Internationalism, Integration, and Isolation. A chosen strategy depended on the participation in the international socialist movement, a position either within the Social Democratic Party of Germany, or the position adopted in the Foreign Delegation, a governing body of Mensheviks' party abroad. The Foreign Delegation Policy in the 1920s was led by the internationalists Martov, Dan, and Abramovich. The adaptation of Mensheviks-internationalists in Germany would not have been possible without the assistance of "integrationists" who worked as the specialists and experts in German Social Democracy Party. One of the leaders of the Mensheviks A.N. Potresov found himself in isolation in German exile. He maintained contacts with some "integrationists", but because of acute political differences with Dan, Potresov stayed away from the Foreign Delegation. This division came to an end after the collapse of the Weimar Republic in 1933, when Mensheviks moved to the other states.

Key words: adaptation, Germany, International, Mensheviks, political exiles, emigration.

Dmitrii Nechiporuk, PhD in History, senior research fellow, Research Center «Human, Environment \&Technology», Tyumen State University 


\section{ИСИДОР СЕВИЛЬСКИЙ. ЭТИМОЛОГИИ, ИЛИ НАЧАЛА КНИГА V. О ЗАКОНАХ И ВРЕМЕНАХ ${ }^{1}$}

Вторая часть книги $\mathrm{V}$ «Этимологий» Исидора Севильского посвящена времени. Она включает 12 глав (XXVIII-XXXIX) и по объему сопоставима c первой частью, посвященной законам. Открывает ее глава, в которой дается определение слова «хроника» (XXVIII), потребовавшаяся автору для создания подобия единства этой части - она позволяет завершить ее главой, в которой дается краткое хроникальное изложение человеческой истории от Адама до современных автору событий (XXXIX). Десять глав, находящиеся между ними, посвящены различным временным промежуткам: мгновениям и часам (XXIX), дням (XXX), ночам (XXXI), неделям (XXXII), месяцам (XXXIII), солнцестояниям и равноденствиям (XXXIV), временам года $(\mathrm{XXXV})$, годам (XXXVI), олимпиадам, люстрам и юбилеям (XXXVII), векам и возрастам (XXXVIII). Как и в других частях работы, Исидор рассматривает указанные временные промежутки через анализ этимологии слов, связанных с ними. Так в главе «О днях» он толкует происхождение слова «день» (dies), говорит о двояком понимании его сущности (как дня, и как суток), приводит различия у разных народов начала отсчета времени дня, указывает на отличия в наименовании дней недели у евреев и римлян, на фазы дня: утро (mane), полдень (meridies), вечер (suprema); завершается глава рассмотрением таких терминов как «вчера» (hesternum), «сегодня» (hodie), «завтра» (cras) и «послезавтра» (perendie). Эти главы представляют собой переработанный вариант текста, написанного Исидором несколько ранее сочинения «О природе вещей». Последняя глава текстуально идет в разрез с предыдущими, представляя из себя историческую хронику. В основе ее - сокращенный текст ранее написанной Исидором «Великой хроники», составленной на основе хроники Евсевия Кесарийского (ок. 260/265339/340), переведенной на латинский язык Иеронимом Стридонским (342419/420). Исидор, вслед за Августином (de civ. Dei. 22, 30), делит здесь всю мировую историю на шесть эпох-возрастов, в соответствии с днями творения: от Адама до Ноя (до 2242 г.), от Ноя до Авраама (до 3184 г.), от Авраама до Самуила и Саула (до 4121 г.), от Давида до Седекии (4609), от пленения евреев до Юлия Цезаря (5154), и от Октавиана до Ираклия (до 5824 г.).

Исидор опирается на римские и христианские источники, редко сообщая нам о своих заимствованиях. Среди римских авторов упоминается лишь Вергилий (XXXI. 3; 5; 14; XXXV. 3; XXXVI. 1); из христианских авторов - Евсевий Кесарийский и Иероним (XXVIII. 1); один раз приводится цитата из книги «Бытия» (XXX. 3). На самом деле, мы можем выявить значительное число текстов римских и христианских авторов, которые использовались Исидором для написания этой части работы. Определяющее значение, в силу грамматического характера сочинения Исидора, имеют тексты римских антикваров и грамматиков: пассажи из них зачастую используются Исидором слово в слово, либо близко к тексту оригинала. Это прежде всего «О латинском языке» Варрона и «Комментарии» Сервия, заимствования из

\footnotetext{
${ }^{1}$ Продолжение. Начало см.: Диалог со временем. Альманах интеллектуальной истории. М.: ИВИ РАН, 2020. Вып. 76. С. 391-407.
} 
них встречаются наиболее часто в главах XXIX-XXXVIII, а также «О значении слов» Секста Помпея Феста и «Сатурналии» Макробия; встречаются и заимствования из сочинений Лукреция, Квинтилиана, Авла Геллия. Автор использует также сочинения христианских авторов, прежде всего Августина, Иеронима, Амвросия. Для главы XXXIX, помимо «Хроники» ЕвсевияИеронима и «О граде Божьем» Августина, Исидор, очевидно, пользовался бревиариями Постумия Руфа Феста и Евтропия, «Священной историей» Кассиодора. Для шестого периода, сведений о котором не было в «Хронике» Иеронима, он использовал «Хронику» Проспера Аквитанского (V в.), Виктора Туннунского, а также Иоанна Бикларийского (VI в.).

$$
\text { *** }
$$

\section{Глава XXVIII. О слове «хроники»}

(1) По-гречески хроникой (chronica) зовется то, что по-латински именуется последовательностью времен; у греков издал такую хронику Евсевий, епископ Кесареи, а

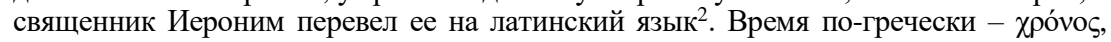
по-латински же-tempus.

\section{Глава XXIX. О мгновениях и часах}

(1) Время членится на мгновения, часы, дни, месяцы, годы, люстры, столетия, возрасты. Мгновение (momentum) - наименьший и самый краткий промежуток времени; назван так от движения (motus) звезд. (2) Оно представляет из себя самую малую по краткости долю часа, когда одно мгновение проходит, другое воспоследует. Чac (hora) - греческое слово, но и по-латински оно звучит так же [ळ̋ра]. Hora (час) суть граница времени, подобно тому как ora суть побережье моря, берег реки или край одежды.

\section{Глава ХХХ. О днях}

(1) День (dies) есть [время] присутствия солнца, или когда солнце над землей; ночь же - когда солнце под землей. Ведь от того, день или ночь, зависит то, солнце над землей, либо под землей ${ }^{3}$ В надлежащем смысле день (dies legitimus) состоит из дня и ночи и длится двадцать четыре часа, пока солнце не завершит свой бег по небу, сделав оборот от одного восхождения на востоке до другого. В вольном же понимании день есть промежуток времени от восхода до заката. (2) У дня две части: дневная и ночная; весь день - двадцать четыре часа, одна часть - двенадцать часов ${ }^{4}$. (3) День (dies) назван так от лучшей его части. Откуда и закрепилось в словоупотреблении, что мы говорим о числе дней без упоминания ночи, как написано в божественном законе (Genes. 1, 5): «И был вечер, и было утро: день один». (4) Согласно египтянам, день начинается с захода солнца; согласно персам, - с восхода солнца; согласно афинянам, - с шестого часа дня; согласно римлянам, - в полночь ${ }^{5}$. Откуда и сегодня рассвет зовется gallicinum, ведь крик петуха (gallus), тогда, когда веет полночный бриз, предвещает приход дня. (5) Дни (dies) названы от богов (deus), чьими именами римляне назвали некоторые небесные светила. Так, первый день они назвали от Солнца, оно главное среди светил, и день этот также находится во главе всех дней. (6) Второй - от Луны, которая и блеском своим, и величиной более всего напоминает Солнце, да и свет свой заимствует у него. Третий - от планеты Марс, именуют ее «вечерней звездою» (Vesper). Четвертый - от планеты Меркурий, которую некоторые называют «белым кругом». (7) Пятый - от планеты Юпитер, которую зовут Фаэтоном. Шестой - от планеты Венера, именуют ее Люцифером, поскольку меж прочих небесных тел отличается более ярким свечением. Седьмой - от планеты Сатурн,

\footnotetext{
2 Текст «Хроники» Евсевия, где тот суммировал сведения античной хронологии и составил синхронистические таблицы библейских сведений от Авраама до 325 г. н.э., сохранился в латинском переложении, сделанном Иеронимом Стридонским.

${ }^{3}$ Cм.: Varr. LL. V. 68; VI. 4.

${ }^{4}$ Cp.: Isid. De rer. nat. I. 1.

${ }^{5}$ Cм.: Macr. Sat. I. 3. 2-6. Cp.: Cp.: Isid. De rer. nat. I. 2.
} 
которая, как говорят, находясь на шестом небе, имеет тридцатилетний цикл своего небесного обращения ${ }^{6}$. (8) Дали же язычники дням наименования этих семи небесных тел, поскольку считали, что они оказывают влияние на каждого, полагая, что получили они от Солнца - дух, от Луны - тело, от Меркурия - ум и язык, от Венеры - удовольствие, от Марса - кровь, от Юпитера - воздержность, от Сатурна - влагу. Вот какова была глупость язычников, которые выдумывали для себя столь смешные толкования ${ }^{7}$. (9) У евреев же первый день недели именуется «первым после субботы» (una sabbati), у нас - воскресеньем, днем Господа нашего (dies dominicus), язычники назвали его днем Солнца ${ }^{8}$. Второй - «вторым после субботы» (secunda sabbati), язычники называют его днем Луны. Третий - «третьим после субботы» (tertia sabbati), язычники называют его днем Марса. Четвертый - «четвертым после субботы», язычниками он зовется днем Меркурия. (10) Пятый - «пятым после субботы» (quinta sabbati), т.е. пятый с воскресения, язычники называют его днем Юпитера. Шестой - «шестым после субботы» (sexta sabbati), у тех же язычников зовется он днем Венеры. Суббота - седьмой день от воскресения, язычники посвятили его Сатурну и назвали днем Сатурна. Суббота (sabbatum) с еврейского на латинский переводится как «день отдыха», потому что Бог в этот день отдыхал от всех своих трудов. (11) Названия дней лучше, однако, звучат из уст христианина, если употребляются в согласии с церковной практикой. Если, однако, привычка случайно побудит его к тому, и с уст его слетит то, что он осуждает сердцем, то пусть знает, что все те, по именам кого эти дни названы, были людьми и за какие-то заслуги смертные, поскольку были они могущественны весьма и славны в свое время, предоставлены были им почитателями божественные почести в поименовании их именами дней и светил; но сначала светила были названы по именам людей, а от светил названы уже и дни ${ }^{9}$. (12) Дни отдыха (feriae) названы так от [глагола] «говорить» (fari), потому что в такие дни появляется время для разговоров, т.е. для того, чтобы обсуждать божеский промысел или дела человеческие. Но среди таковых есть праздничные дни, установленные в интересах людей, и дни, установленные для исполнения божеских ритуалов. (13) Есть три части дня: утро (mane), полдень (meridies) и вечер (suprema). (14) Утром свет ярок и полон силы, уже не сумерки. А названо утро так от [прилагательного] «хороший» (manus), ведь древние использовали manus в значении «хороший» (bonus) ${ }^{10}$. Действительно, что может быть лучше, чем свет? Другие считают, что утро именуется так от манов (manes) ${ }^{11}$, которые обитают между луной и землей. Третьи полагают, что от воздуха, поскольку он manus, т.е. разрежен, а также прозрачен. (15) «Полдень» (meridies) назван так, как если бы говорили medidies, т.e. «cepeдина дня» ${ }^{12}$; или потому, что тогда день «наиболее чист»; ведь merus означает «чистый» $^{13}$. Действительно, в течение всего дня нет времени более светлого, чем полдень, когда солнце блистает золотом посреди неба и освещает равным светом весь земной мир. (16) Suprema - последняя фаза дня, когда путь солнца клонится к закату; названа так оттого, что «доживает» (superest) до скончания дня ${ }^{14}$. (17) «Вечер» (serum) назван так от «засовов» (serae), что закрыты, когда приходит ночь, чтобы каждый мог чувствовать себя в безопасности во время сна. (18) «Сегодня» (hodie) есть как бы «в этот день» (hoc die) ${ }^{15}$; а «ежедневно» (quotidie) происходит не от соtidie, поскольку quotidie есть quot diebus ${ }^{16}$. (19) «Завтра» (cras), т.е. «в будущем». (20) «Вчера» (hesternum) - днем прежде; произошло оттого, что день этот нам уже чужой

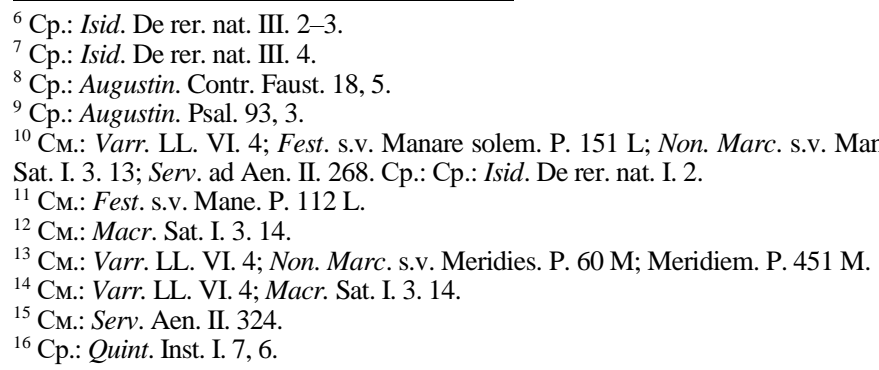


(extraneus), поскольку прошел. (21) «Канун» (pridie) есть как бы «в предыдущий день» (priori die) ${ }^{17}$. (22) «Послезавтра»-perendie, т.е. per ante diem, или in antecessum, т.е. «наперед».

\section{Глава XXXI. О ночи}

(1) Ночь названа nox от [глагола] «вредить» (nocere $)^{18}$, поскольку вредит глазам. Освещается она светом Луны и небесных светил, дабы не быть беспросветной, и чтобы утешить всех тех, что работают ночью, и чтобы все души живые, которые не могут переносить солнечного света, хотя бы таким обладали в достатке. (2) Чередование ночи и дня создано ради чередования сна и бодрствования с тем, чтобы умерять бремя дневного труда ночным отдыхом. (3) Ночь проистекает либо из того, что солнце утомляется от долгого небесного пути и, когда достигает края неба, становится слабым и, растекшись, испускает свое [последнее] сияние; либо из того, что под землей оно действует с той же силой, с какой несет свет над землей, но тень от земли порождает ночь ${ }^{19}$. Отсюда и Вергилий (Aen. 2, 250): «Ruit Oceano nox, involvens umbra magna terramque polumque» (и ночь опустилась, / Мраком окутав густым небосвод, и землю, и море; - пер. С.А. Ошерова). (4) Есть семь частей ночи: вечер (vesper), сумерки (crepusculum), полночье (conticinium), глубокая ночь (intempestum), предрассветная пора (gallicinum), раннее утро (matutinum), рассвет (diluculum) ${ }^{20}$. (5) Вечер (vesper) получил наименование от западной звезды, что появляется на закате солнца и предшествует надвигающейся темноте. О ней Вергилий (Aen. 1, 374): «Ante diem clauso conponit vesper Olympo» (Прежде чем Веспер взойдет и ворота Олимпа запрутся) ${ }^{21}$. (6) Сумерки названы tenebras оттого, что «удерживают тени» (tenere umbras $)^{22}$. (7) «Сумерки» (crepusculum) - полумрак, ведь creperum мы называем нечто сомнительное, т.е. то, что между светом и тьмой ${ }^{23}$. (8) «Полночье» (conticinium) время, когда все умолкает, ведь conticescere означает «молчать» ${ }^{24}$. (9) «Глубокая ночь» (intempestum) - срединное и бездеятельное время ночи, когда ничего нельзя делать и все упокоено глубоким сном. Ведь время не осознается само по себе, только через посредство человеческих действий ${ }^{25}$. (10) А середина ночи лишена действия. Поэтому intempesta [означает] «бездеятельная», как бы «без времени» (sine tempore), т.е. «без действия», через которое воспринимается время; откуда выражение: «Intempestive venisti» (Вы пришли не вовремя). Так что «глубокая ночь» (intempesta) говорится оттого, что исчезает время, т.е. действие ${ }^{26}$. (11) «Предрассветная пора» названа gallicinium из-за петухов (galli) - предвестников света 27. (12) «Раннее утро» (matutinum) - время между уходом сумерек и приходом зари; названо оно matutinum оттого, что это время зачинающегося утра (mane). (13) «Рассвет» (diluculum) есть как бы зачинающийся «маленький свет дня» (diei lux $)^{28}$. Эту пору, что предшествует солнцу, [именуют] также зарей (aurora). (14) Заря (aurora) - прелюдия становящегося светлым

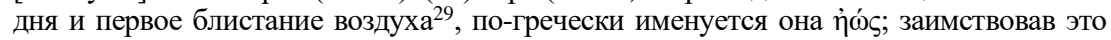
слово, мы именуем ее aurora, как бы eorora. Откуда эта строка (Virg. Aen. 2, 417): «et laetus Eoos / Eurus equis» (и Эвр, что радостно гонит / коней Зари) и (Virg. Aen. 1, 489): «Eoasque acies» (и рати Зари).

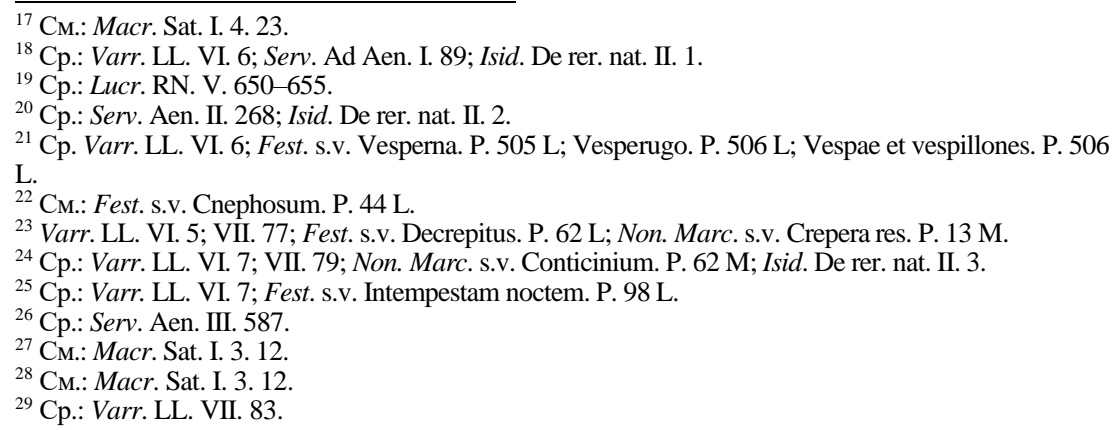




\section{Глава ХХХІІ. О неделе}

(1) Неделя названа hebdomada от семи [входящих в нее] дней, повторением их составляются и месяцы, и годы, и века; действительно, у греков [числительное] семь зовется غ̇лт́. Мы называем неделю septimana, как бы «семь рассветов», ведь mane означает «свет». Восьмой же день есть тот же, что и первый, к нему возвращается и от него начинается вновь дней недели порядок ${ }^{30}$.

\section{Глава XXXIII. О месяцах}

(1) Слово «месяц» (mensis) - греческое, произошло оно от слова луна. Луна погречески зовется $\mu$ ү́ $\eta$; откуда у евреев «законные» месяцы отсчитываются не из обращения солнца, а из движения луны, то есть от новолуния до новолуния ${ }^{31}$. (2) Египтяне, однако, первыми стали определять день месяца, из-за большей скорости обращения луны, дабы не возникла какая ошибка при вычислениях из-за ее скорости, по движению солнца, поскольку более медленное вращение солнца дает возможность легче его высчитать. (3) Месяц январь (Ianuarius) назван так от Януса (Ianus), которому он был посвящен язычниками; или потому, что является как бы порогом и дверьми (ianua) года. Отсюда и сам Янус изображается двуликим, чтобы демонстрировать ликом своим начало и конец года. (4) Февраль (Februarius) именуется так от Februus, то есть от Плутона, которому в этом месяце делали жертвоприношения. Действительно, римляне посвятили январь богам вышним, а февраль - богам Манам. Так что февраль назван так от Februus, т.е. от Плутона, а не от febris (лихорадка), т.е. болезни. (5) Март (Martius) назван так из-за Марса (Mars), вождя римлян, или оттого, что в это время все живое стремится к мужественности (mas) и удовольствию соития. (6) Этот месяц именуют и месяцем новшеств, поскольку месяц Март - года начало. Он же зовется и «новой весной», разумеется, от появления побегов, поскольку в этом месяце зеленеющие новины позволяют дельцам оценить виды на урожай. (7) Апрель (Aprilis) зовется так от Венеры, как если бы [говорилось] Aphrodis; ведь по-гречески Венера зовется Афродитой (Афробі́тп); или оттого, что в этом месяце все расцветает (aperiuntur in flore), как бы Aperilis. (8) Май (Maius) назван от Майи (Маia), матери Меркурия; либо от «благородных» (maiores) по рождению, которые стояли во главе государства. Действительно, этот месяц римляне посвятили старшим, а следующий младшим (minores). (9) Отсюда тот и зовется Июнем (Iunius), ведь прежде народ был разделен на центурии старших и младших ${ }^{32}$. (10) Июль (Iulius) же и Август (Augustus) названы в честь известных мужей, Цезарей Юлия и Августа ${ }^{33}$. Действительно, первоначально они именовались Квинтилием (Quintilis) и Секстилием (Sextilis); Квинтилий - оттого, что был этот месяц пятым (quintus) от Марта, который у римлян считался первым месяцем года; Секстилий, аналогичным образом, - оттого, что шестой (sextus). (11) Сентябрь (September) зовется так от [порядкового его] числа и [слова] «дождь», поскольку он седьмой (septimus) от марта и приносит [с собой] дождь (imber). Подобным образом Октябрь (October), Ноябрь (November), а также Декабрь (December) получили наименования от [соответствующего] числительного и [существительного] «дожди» (imbres). Декабрь (December) венчает круговорот чисел, поскольку десятью завершается [исчисление] предшествующих чисел [десятка] ${ }^{34}$. (12) Кален-ды (Kalendae), Ноны (Nonae) и Иды (Idus) римляне учредили либо ради праздничных дней, либо из-за обязанностей магистратов. Ведь в эти дни в городах сходятся на собрания. (13) Некоторые полагают, что Календы зовутся так от [глагола] «поклоняться» (colere) $)^{35}$, ведь у древних в начале каждого месяца производились жертвоприношения; также и у евреев. Большинство из латинских авторов полагают, что Иды названы от [глагола] «есть» (edere), так как эти дни у древних были днями

\footnotetext{
${ }^{30}$ Cp.: Isid. De rer. nat. III. 1.

${ }^{31}$ Cp.: Varr. LL. VI. 10; Isid. De rer. nat. IV. 1.

${ }^{32}$ Cp.: Varr. LL. VI. 33; Serv. Georg. I. 43. Cм.: Fest. s.v. Iunium. P. 92 L.

${ }^{33}$ CM.: Fest. s.v. Iulium. P. 92 L; Augustin. Contr. Faust. 18, 5.

${ }^{34}$ Cм.: Varr. LL. VI. 34; Isid. De rer. nat. IV. 3-4.

${ }^{35}$ CM.: Varr. LL. VI. 27-29; Fest. s.v. Procalare. P. 251 L; Gell. V. 17; Non. Marc. s.v. Calendarum. P. $23 \mathrm{M}$.
} 
пиршеств. (14) Ноны названы от нундин (nundinae). Нундины же - это дни публичных собраний, либо рыночные дни ${ }^{36}$.

\section{Глава XXXIV. O солнцестояниях и равноденствиях}

(1) «Солнцестояние» (solstitium) названо так, как если бы [говорили] «стояние солнца» (solis statio), потому что когда солнце «стоит», начинают расти либо дни, либо ночи ${ }^{37}$. «Равноденствие» (aequinoctium) названо так оттого, что тогда день и ночь состоят из равного числа часов ${ }^{38}$. (2) Есть два солнцестояния: одно - летнее, за восемь дней до Календ июля, с этого времени солнце начинает возвращаться к нижним пределам; другое - зимнее, за восемь дней до январских Календ, в это время солнце начинает стремиться к вышним пределам. Отсюда следует, что день зимнего солнцестояния самый короткий, тогда как летнего - самый длинный ${ }^{39}$. (3) Точно так же есть и два

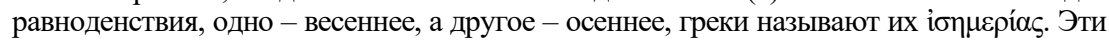
равноденствия приходятся на восьмой день до апрельских Календ и на восьмой день до Календ октября, поскольку некогда год делился только на две части, т.е. на летнее и зимнее солнцестояние, и на два полушария.

\section{Глава XXXV. O временах года}

(1) Есть четыре времени года: весна (ver), лето (aestas), осень (autumnus) и зима (hiems $)^{40}$. Названы же они сезонами (tempora) от баланса (temperamentum) присущих им качеств, поскольку, соответственно порядку, отличаются (temperare) они своей влажностью, сухостью, жарой и холодом. Их называют и периодами (curricula), поскольку не стоят [на месте], а проходят (currere). (2) Известно, что после сотворения мира сезоны были разделены по три месяца каждый, исходя из природы движения солнца. Древние так разделяют эти сезоны: в первый месяц весна именуется «новой» (novum), во второй - «зрелой» (adultum), в третий - «клонящейся к завершению» (praeceps); (3) так и лето в течение трех месяцев - «новое», «зрелое» и «клонящееся к завершению»; и осень так же - «новая», «зрелая», «клонящаяся к завершению»; точно также и зима - «новая», «зрелая» и «клонящаяся к завершению», либо «уходящая» (extrema). Откуда и эта строка (Virg. Georg. 1, 340): «Extremae sub casu hiemis» (Тотчас, едва лишь зима отойдет; - пер. С.В. Шервинского). Весна названа ver оттого, что она делает все зеленым (virere). Ведь тогда земля после зимы покрывается травами и все расцветает. (4) Лето зовется aestas от aestus, т.е. от зноя ${ }^{41}$; aestas (лето) также и как бы usta, т.е. «сожженное» и «высушенное», ведь зной все иссушает. (5) Oceнь (autumnus) названа от времени, когда опадают листья деревьев и все созрева$\mathrm{eT}^{42}$. (6) Характер астрономической полусферы (hemispherium) дал наименование зиме (hiems), поскольку тогда солнце обращается по краткому пути ${ }^{43}$. Откуда и само

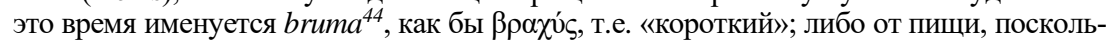
ку тогда увеличивается аппетит. Действительно, по-гречески прожорливость зовется

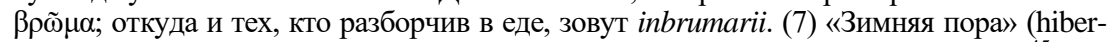
nus) - та, что между зимой (hiems) и весенней порой (vernum), как бы hievernus ${ }^{45}$; это слово обычно означает «зима» - часть дала значение всему слову. Эти сезоны увязываются также с отдельными частями небесного свода. (8) Весна, разумеется, связана с востоком (oriens), поскольку тогда все появляется (oriri) из земли; лето с югом, оттого что часть его особо пышет зноем; зима - с севером, оттого что студит холодами и постоянной стужей; осень - с западом, из-за того, что несет тяжелые хвори, отчего

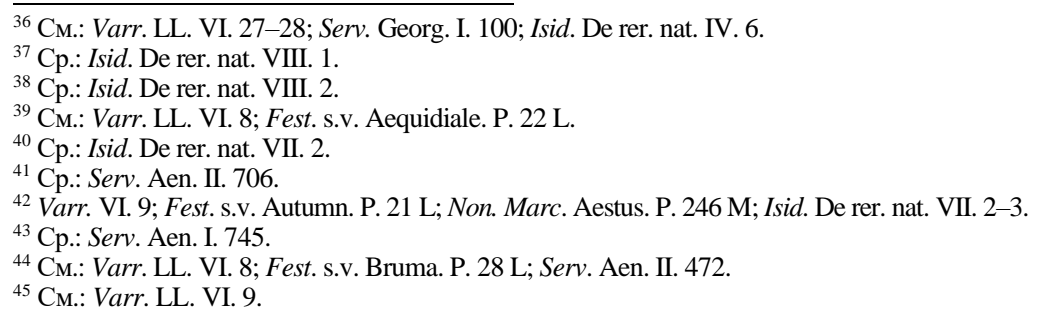


тогда опадают с деревьев все листья. Перемежает она холод и тепло, сталкивает меж собой противоположные воздушные массы, отчего и изобилует осень болезнями.

\section{Глава XXXVI. О годах}

(1) Год - оборот солнца ${ }^{46}$, когда, совершив круг в триста шестьдесят пять дней, возвращается оно в то же место звездного неба. Год (annus) назван так оттого, что крутится он бесконечно, благодаря постоянно возвращающимся вновь месяцам. Оттуда [происходит] и «кольцо» (anulus), как бы annuus, т.е. круг, который замыкается на себе ${ }^{47}$; [так] у Вергилия (Georg. 2, 402): «Atque in se sua per vestigia volvitur annus» (вращается год по своим же следам прошлогодним; - пер. С.В. Шервинского). (2) Так и у египтян изображался он до изобретения букв символом дракона, кусающего собственный хвост, поскольку всегда повторяется вновь. Другие производят год ג̇ло̀ $\tau$ о๊̃ $\alpha v \alpha v \varepsilon o v ̃ \sigma \theta \alpha 1$, т.е. от возобновления; ведь он всегда возвращается вновь. (3) Года бывают трех видов. Год либо лунный (lunaris) - в триста дней; либо солнечный (solstitialis), который включает двенадцать месяцев; либо великий (magnus), когда все планеты собираются в одном месте, он случается по прошествии многих солнечных лет $^{48}$. (4) Цезарем Августом были установлены эры (aera) из отдельных лет, когда он впервые охватил весь римский мир, произведя перепись ${ }^{49}$. Эра (aera) названа так оттого, что каждая область обещала вносить средства (aes) в казну государства.

\section{Глава XXXVII. Об олимпиадах, люстрах и юбилеях}

(1) Олимпийские игры у греков были учреждены в окрестностях греческого города Элида, где граждане Элиды проводили состязания раз в пять лет, а четыре года меж ними были свободны от соревнований. По этой причине временной цикл состязаний жителей Элиды назвали олимпиадой, одна олимпиада насчитывает четыре года ${ }^{50}$. (2)

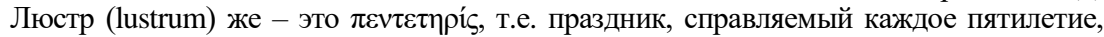
поскольку, как говорят, римляне проводят его по примеру олимпиад на пятый год; ведь в то время ни консулов, ни эр еще не было. Это и период в пять лет. Назван он так оттого, что город Рим каждые пять лет, после того как в государстве проводилась перепись, очищался (lustrare) ${ }^{51}$. (3) «Юбилей» (iubileus) означает «год освобождения». Это и слово, и число у евреев, оно заключает в себе взятые семь раз семь лет, т.е. сорок девять лет. В этот год трубили в трубы, ко всем возвращалась прежняя собственность, прощались долги и подтверждался свободный статус лиц. (4) Это число и теперь сами мы почитаем в день Пятидесятницы после Воскресения Господня ${ }^{52}$, когда, прощая грехи и уничтожая все долговые расписки, от всякого обязательства освобожденные, даем возможность снизойти на нас милости Духа Святого.

\section{Глава XXXVIII. O веках и возрастах}

(1) Века (saecula) состоят из поколений; и оттого названы они saecula, что следуют (sequi) друг за другом: ведь как только одни проходят, за ними следуют другие ${ }^{53}$. Некоторые называют так период в пятьдесят лет, который евреи именуют юбилеем.

(2) По этой причине тот еврей, который из-за жены и детей, и любви к своему хозяину оставался в рабстве, после того как [хозяин] протыкал ему ухо, должен был служить тому вечно (in saeculum), т.е. до исхода пятидесятилетнего срока ${ }^{54}$. (3) [Слово]

\footnotetext{
${ }^{46}$ Isid. De rer. nat. VI. 1.

${ }^{47}$ CM.: Varr. LL. VI. 8; Fest. s.v. Annus. P. 6 L; Serv. Aen. I. 269; Isid. De rer. nat. VI. 2.

${ }^{48}$ Cp.: Serv. Aen. I. 269.

${ }^{49}$ Август проводил переписи в 28 и 8 гг. до н.э., и в 14 г. н.э. Cp.: Isid. De rer. nat. VI. 7.

${ }^{50}$ Cм.: Isid. De rer. nat. VI. 5.

${ }^{51}$ Cp.: Varr. LL. VI. 11; Fest. s.v. Lues. P. 107 L; Lustra. P. 107 L; Serv. Aen. I. 283; Non. Marc. s.v. Lustrare. P. 335 M; Isid. De rer. nat. VI. 6.

52 Пятидесятница, т.е. Троица, справляется на пятидесятый день после пасхи, знаменуя сошествие Духа Святого на апостолов на пятидесятый день после Воскресения Христа. Ср.: Hieronym. Ep. XXXVI. 9; LXXVIII. 12.

${ }^{53}$ CM.: Varr. LL. VI. 11.

${ }^{54}$ Exod. 21: 5-6: «но если раб скажет: люблю господина моего, жену мою и детей моих, не пойду на волю, то пусть господин его приведет его пред богов и поставит его к двери, или к косяку, и проколет ему господин его ухо шилом, и он останется рабом его вечно».
} 
«эпоха» (aetas) употребляется обычно и в отношении одного года, как в анналах, и семи, как в отношении возрастов человека, и ста, и любого иного числа лет ${ }^{55}$. Отсюда эпоха - это и промежуток времени, который состоит из многих веков. Говорили aetas, как если бы aevitas, т.е. по аналогии со словом вечность (aevum). (4) Действительно, вечность - это бесконечная эпоха, у которой не известны ни начало, ни конец. Греки называют ее $\alpha i \tilde{v}$; слово ставится у них иногда вместо слова «век», иногда вместо «вечность». Оттуда и заимствовано оно римскими авторами. (5) В собственном значении aetas используется двояко: либо в отношении возраста человека, как то: младенчество (infantia), молодость (iuventus), старость (senectus); либо мира, первым возрастом которого является период от Адама до Ноя, вторым - от Ноя до Авраама, третьим - от Авраама до Давида, четвертым - от Давида до переселения евреев в Вавилон; пятым - от [Вавилонского пленения] до прихода Спасителя во плоти; шестым - тот, который протекает теперь, им завершится сам мир ${ }^{56}$. (6) Таким образом, последовательная смена этих периодов осознается через смену поколений и царств.

\section{Глава XXXIX. O перечне времен}

(1) На начало первого возраста приходится сотворение мира, ведь в первый день, имя которому «свет», Бог создал ангелов; во второй, именуемый «твердь», - небеса; в третий, под названием «разделение» - воды и землю; в четвертый - небесные светила; в пятый - тварей морских; в шестой - тварей земных и человека, которого нарек Адамом.

\section{Первый возраст}

230 (2) Адам, двухсот тридцати лет отроду, породил Сифа, от которого [произошли] дети Бога.

435 Сиф, двухсот пяти лет отроду, породил Еноса, который начал призывать имя Господне.

625 Енос, ста сорока лет отроду, породил Каинана.

795 Каинан, ста семидесяти лет отроду, породил Малелеила. Малелеил, ста

960 шестидесяти пяти лет отроду, породил Иареда. 1122 вознесен на небеса.

Енох, ста шестидесяти пяти лет отроду, породил Мафусала. (4) Мафусал,

1287 ста шестидесяти семи лет отроду, породил Ламеха.

1454 Ламех, ста восьмидесяти восьми лет отроду, породил Ноя. Строится ковчег. Когда Ною было 600 лет, произошел потоп. [Когда же Ною было 500 лет,

1642 он породил трех сыновей - Сима, Хама и Иафета ${ }^{57}$. На шестисотом году его жизни случился потоп. Таким образом, от Адама до этого катаклизма про-

2242 шло 2252 года.]

\section{Второй возраст}

2244 (5) Через два года после потопа Сим, когда ему было сто лет, породил Арфаксада, от которого произошли Халдеи. Арфаксад, ста тридцати пяти лет

2379 отроду, породил Салу, от которого произошли Самаритяне и Индусы.

2509 Сала, ста тридцати лет отроду, породил Евера, от которого произошли 2509 евреи.

(6) Евер, ста тридцати четырех лет отроду, породил Фалека. Строится баш-

2643 ня [и в это время при строительстве башни произошло разделение языков и расселение людей по всей земле].

Фалек, ста тридцати лет отроду, породил Рагава. Богам впервые служат молебствие.

2773 Рагав, ста тридцати двух лет отроду, породил Серуха. Появляется царство Скифов.

2905 Серух, ста тридцати лет отроду, породил Нахора. (7) Появляется царство египтян.

\footnotetext{
${ }^{55}$ Cp.: Serv. Georg. III. 190.

${ }^{56}$ Cp.: Augustin. De civ. D. XXII. 30.

${ }^{57}$ Cp.: Gen. 5:3-32; Isid. Chon. Maior. 3-18.
} 
3035 Нахор, семидесяти девяти лет отроду, породил Фарру. Возникают Ассирийское и Сицинийское царства.

3114 Фарра, семидесяти лет отроду, породил Авраама ${ }^{58}$. Зороастр изобрел магию.

3184

3284 (8) Авраам, ста лет отроду, породил Исаака и Измаила ${ }^{59}$, от него - Исмаилиты.

3344 Исаак, шестидесяти лет отроду, породил Иакова. Он зачинает царство аргивян.

3434 Иаков, когда было ему девяносто лет отроду, породил Иосифа ${ }^{60}$. Фороней дал Греции законы ${ }^{61}$.

3544 Иосиф, 110 лет. (9) В Греции начинают растить хлеб.

3688 Рабство евреев [в Египте продолжалось] 144 года. Атлас изобрел астрономию.

3728 Моисей, 40 лет. Евреи начали пользоваться письмом.

3755 (10) Иисус, 27 лет. Эрихтоний в Трое [первым] запряг квадригу. Гофониил, 40 лет. Кадм дал грекам алфавит.

3795 Аод, 80 лет. Изобретены басни.

3875 Девора, 40 лет. Аполлон [открыл искусство врачевания и] изобрел кифару.

3915 (11) Гедеон, 40 лет. Меркурий создал лиру. Авимелех, 3 года. В Греции изобретен хор.

3955 Фола, 23 года. Приам правил в Трое.

3958 Иаир, 22 года. Кармента изобрела латинский алфавит. Иеффай, 6 лет. Гер3981 кулес бросился в огонь.

4003 Есевон, 7 лет. Александр похитил Елену.

4009 (12) Авдон, 8 лет. Троя захвачена.

4016 Самсон, 20 лет. Асканий основал Альбу.

4024 Илий [первосвященник], 40 лет. Захватывается ковчег завета.

4044 Самуил и Саул, 40 лет. Полагают, в это время жил Гомер ${ }^{62}$.

4084

4124

4164 (13) Давид, 40 лет. Карфаген основывается Дидоной. [Гад, Нафан, Асаф пророчествовали.]

4204 Соломон, 40 лет. Возводится Иерусалимский храм.

4221 (14) Ровоам, 17 лет. Разделяются царства Израиль и Иудея.

4224 Авиуд, 3 года. При нем Авимелех был верховным священником.

Асаф, 41 год. Ахия, Амос, Иегу, Иоиль [и Азария] пророчествовали.

4265 (15) Иосафат, 25 лет. Пророчествовали Илия, Авдий и Михей. Иорам, 8 лет. Пророчествовали Илия и Елисей.

4290 Охозия, 1 год. Илия восходит на небеса.

Афалия, 7 лет. Прославился священник Ионадав.

4298 (16) Иоас, 40 лет. Умирает Елисей.

4299 Амасия, 29 лет. Основан Карфаген.

4306 Озия, 52 года. Греками учреждаются Олимпийские игры.

4346 Иоафан, 16 лет. Рождается Ромул.

4375 (17) Ахаз, 16 лет. Основывается Рим.

4426 Езекия, 29 лет. В Риме появляется сенат.

4443 Манассий, 55 лет. Прославилась пророчица Самия.

4459 Амон, 21 год. Впервые производится ценз.

4488 (18) Иосия, 32 года. Становится известным философ Фалес.

4543 Иоаким, 11 лет. Навуходоносор захватывает Иудею.

\footnotetext{
${ }^{58}$ Cp.: Gen. 11:10-26; Isid. Chron. Maior. 19-29.

${ }^{59}$ Cм.: Gen. 17:19-21.

${ }^{60}$ Cм.: Gen. 30:23-24.

${ }^{61}$ Cм.: Isid. Etym. V. 1. 1.

${ }^{62}$ Cp.: Isid. Chron. Maior. 31-106.
} 
4555 Седекия, 11 лет. Сожжен Иерусалимский храм ${ }^{63}$.

4587

4598

4609

4679 (19) Пленение евреев, 70 лет. Пишется история Юдифи.

4713 Дарий, 34 года. Пленение евреев завершается.

4733 Ксеркс, 20 лет. Возвеличиваются трагики Софокл и Еврипид, [они считаются самыми известными и почитаемыми].

(20) Артаксеркс, 40 лет. Ездра восстановил сожженный Закон.

4773 Дарий, [именуемый также Нотом ${ }^{64}$ ], 19 лет. В это время жил Платон.

Артаксеркс, 40 лет. Составляется книга Есфири.

4792 (21) Артаксеркс, [именуемый также и Охом], 26 лет. Заявляют о себе Демосфен и Аристотель.

4832 Ксеркс [сын Оха], 4 года. Появляется знаменитый Ксенократ.

4858 Дарий [сын Арсама], 6 лет. Александр взял Иерусалим.

(22) Александр [Македонский], 5 лет. [Александр] завоевал Азию.

4863 Птолемей, 40 лет. Зачинается первая книга Маккавеев.

Филадельф, 38 лет. Становятся известными переводчики Септуагинты.

4868 Евергет, 26 лет. Иисус составляет книгу Премудрости.

4873 (23) Филопатер, 17 лет. Повествование второй книги Маккавеев.

Епифан, 24 года. Римляне завоевали греков.

4913 Филометер, 35 лет. Сципион завоевал Африку.

4951 Евергет, 29 лет. Брут подчинил Испанию.

Сотер, 17 лет. Фракийцы покоряются римлянам.

4977 Александр, 10 лет. Сирия покорена римлянами.

4994 (25) Птолемей, 8 лет. В Риме зарождается искусство риторики.

Дионисий, 30 лет. Помпей захватывает Иудею.

5018 Клеопатра, 2 года. Египет покоряется римлянам.

5053 Юлий [Цезарь], 5 лет. Он первым возложил на себя монархическую

5082 власть ${ }^{65}$.

5099

5109

5117

5147

5149

5154

5210

5233

5237

5251

5265

5275

5277

5293

5294

5313

5334

5356

5375

5388

5389

\section{Шестой возраст}

(26) Октавиан, 56 лет. Рождается Христос.

Тиберий, 23года. Христос распинается на кресте.

Гай Калигула, 4 года. Матфей написал Евангелие.

Клавдий, 14 лет. Марк издал Евангелие.

(27) Нерон, 14 лет. Убивают Петра и Павла.

Веспасиан, 10 лет. Иерусалим разрушается Титом.

(28) Тит, 2 года. Был он красноречивым и набожным.

Домициан, 16 лет. Иоанн высылается на Патмос.

Нерва, 1 год. Иоанн возвращается в Эфес.

Траян, 19 лет. Умирает апостол Иоанн.

(29) Адриан, 21 год. Появляется толкователь Аквила.

Антонин [Пий], 22 года. Становятся известны Валентин и Маркион.

Антонин [Вер], 19 лет. Возникает ересь Катафригов.

(30) Коммод, 13 лет. Появляется толкователь Феодотион.

Гельвий Пертинакс, 1 год. Не имеется ничего важного для истории.

Север, 13 лет. Появляется толкователь Симмах.

(31) Антонин, 7 лет. Начинается пятое возведение Иерусалима.

\footnotetext{
${ }^{63}$ Cp.: Isid. Chron. Maior. 107-163.

${ }^{64}$ Т.е. «Незаконнорожденный».

${ }^{65}$ Cp.: Isid. Chron. Maior. 167-226.
} 
5407 Макрин, 1 год. В течение его краткой жизни никаких деяний не совершается.

5414 Аврелий, 3 года. Появляется Савеллий.

(32) Александр, 13 лет. Появляется знаменитый Ориген.

5415 Максим, 3 года. Он одолел германцев.

Гордиан, 7 лет. Он отпраздновал триумф над парфянами и персами.

5418 (33) Филипп, 7 лет. Он был первым христианским императором.

5431 Деций, 1 год. Стал известен монах Антоний.

5434 Галл, 2 года. Новат породил ересь.

5441 Валериан, 15 лет. Киприан коронован на мученичество. (34) Клавдий, 2 года. Он изгнал готов из Иллирии.

5448 Аврелиан, 5 лет. Он преследует христиан.

Тацит, 1 год. [Он не совершил ничего памятного].

5449 (35) Проб, 6 лет. Зародилась манихейская ересь.

5451 Кар, 2 года. Он отпраздновал триумф над персами.

5466 Диоклетиан, 20 лет. Он по сожжении священных книг учиняет гонения на

5468 христиан.

5473 Галерий, 2 года. [Не произвел ничего достойного для истории].

5474 (36) Константин, 30 лет. Собирается Никейский Синод.

5480 Константций, 24 года. Появляется ересь человекоподобия.

5482 Юлиан, 2 года. Он из христианина сделался язычником.

5502 (37) Иовиан, 1 год. Он вновь стал христианином. Валентиниан, 14 лет. Готы переходят в ересь.

5504 Грациан, 6 лет. Становится известным Присциан. Валентиниан, 9 лет. Иероним объявляется в Вимфлееме.

5534 Феодосий, 3 года. Становится известным Иоанн Анахорет.

5558 (38) Аркадий, 13 лет. Здравствует Иоанн Богослов.

5560 Гонорий, 15 лет. Становится известен епископ Августин.

5561 Феодосий, 27 лет. Появился ересиарх Нестор.

5575 (39) Марциан, 6 лет. Собирается Халкедонский Синод.

5581 Лев Великий, 16 лет. Египет оскаливается ересью Диоскора.

5590 Зенон, 17 лет. Возникла ересь ацефалов.

5593 (40) Анастасий, 27 лет. Упоминается епископ Фульгенций.

5606 Юстин, 8 лет. Отвергается ересь ацефалов.

5621 Юстиниан, 39 лет. Вандалы побеждаются в Африке.

5648 Юстин, 11 лет. Армяне принимают веру Христову.

5654 (41) Тиберий, 7 лет. Лангобарды захватывают Италию.

5670 Мауриций, 21 год. Готы становятся католиками. Фока, 7 лет. Римляне вырезаются персами.

5687 (42) Ираклий правит 17 лет. [В течение четвертого и пятого года его прав-

5714

5722

5761

5772

5779

5800

5807

5824 ления при очень религиозном правителе Сисебуте] в Испании евреи принимают христианскую веру. [Такими событиями наполнено все время от зарождения мира до настоящего момента - десятого года короля Рецесвинта, каковой является 696 годом [новой] эры, 5857 годом [от основания миpa]]. Остающееся время шестого возраста одному Богу известно.

Перевод с латинского А.А. Павлова

Павлов Андрей Альбертович, кандидат исторических наук, дочент, Сыктывкарский государственный университет им. Питирима Сорокина; aаpavlov@ rambler.ru

Andrey Pavlov, PhD (History), Associate Professor, Department of Russian and Foreign History, Syktyvkar State University; aapavlov@ rambler.ru 


\title{
A.А. ЯКОВЛЕВ \\ ФРАГМЕНТЫ МОРАЛЬНОЙ ТЕОЛОГИИ В ЗАПИСНЫХ КНИЖКАХ ДЖОНА ЛОККА
}

\begin{abstract}
Согласно Локку, «закон морали» столь же важен для спасения, как «закон дел» и «закон веры», и предполагает неукоснительное исполнение всех моральных предписаний, возвещенных в Евангелии. Локк также считал неприемлемой «слепую веру» и противопоставлял ей веру ясную и понятную, рациональную и просвещенную, открыто и свободно исповедуемую любым человеком. В ответе на вопрос, как и в каком интеллектуальном контексте происходило становление моральной теологии Локка, свою роль могут сыграть не только основные теологические тексты философа, но и его записные книжки (1692-1698).
\end{abstract}

Ключевые слова: моральная теология, закон морали, арминианство, слепая вера, сотериология, первородный грех, испытательный закон, У. Молинё, Ж. Леклерк

В 1692 г. Уильям Молинё (1656-1698), отметив сделанные Локком в «Опыте о человеческом понимании» (1690) «намеки» на возможность доказательства морали «математическим методом», предложил ему написать трактат на эту тему ${ }^{1}$. В ответном письме от 20 сентября того же года Локк выразил готовность обдумать этот вопрос при первой же возможности ${ }^{2}$. И, подобно «намекам», содержащимся в «Опыте», в его записных книжках появились записи, отражающие поиск исходного принципа, из которого можно было бы вывести весь кодекс морали. В наиболее полном виде эти идеи получили выражение в трактате « $\mathrm{Pa}$ зумность христианства, каким оно возвещено в Писании» (1695).

Размышления о возможности доказательства морали «математическим методом», хотя и не дали искомой системы этики, привели Локка к переосмыслению и более общей формулировке исходной задачи, а также к появлению в его дискурсе понятия «закон морали». На вопрос о том, как и в каком историческом контексте произошла эта трансформация, ответ должен дать историк идей - исследователь мышления Локка, и свою роль здесь могут и должны сыграть не только главные теологические тексты философа, но и содержание его записных книжек. Ниже публикуются некоторые из его записей того времени.

Первая запись - «Scriptura Sacra» (Священное Писание) датирована 1692 г. В ней обсуждается вопрос о неоднородности различных частей Писания с точки зрения их «вдохновенности». Принимая во внимание дальнейший ход мысли Локка, можно заключить, что это не что иное, как размышление о критериях выбора исходного материала и поиск отправной точки, которую философ - в ходе создания «Разумности христианства» - находит в суждении «Иисус был Мессией». По форме данная запись представляет собой реферат первых глав книги Уильяма Лаута (1660-1732), направленных против Жана Леклерка (1657-1736) и его

\footnotetext{
${ }^{1}$ Locke 1975: 516, 549, 643.

${ }^{2}$ Correspondence: 508, 524.
} 
книги «Пять писем о вдохновенности Священных Писаний», содержавших полемику с Ришаром Симоном (1638-1712). Критерием «вдохновенности» текстов Локк, как и Леклерк, считал, прежде всего, их ясность и простоту. Все вопросы, помеченные латинским Q, принадлежат Локку. Все, что таким образом не помечено, выписано из книги Лаута.

Вторая запись - «Реccatum originale» (Первородный грех) также датируется 1692 г. По выражению Локка, которое мы встречаем в записи «Заблуждение», это - «исследование», живое размышление о наследовании/ ненаследовании греха теми, кто его не совершал, а не выражение еретической позиции. Но сам вопрос все же ставится, как и в «Рaзумности христианства» три года спустя, и ожидаемо вызывает со стороны критиков обвинения в социнианстве. В конце записи упомянут оппонент Локка ${ }^{3}$ Джонас Прост, помощник бывшего архиепископа Кентерберийского Уильяма Санкрофта. Прост апеллировал к изначальной порочности человеческой природы как оправданию применения «непрямого», мягкого насилия со стороны светской власти для упрочения государственной религии; а Локк, отвергавший любое насилие в религиозных вопросах, искал аргументы в пользу толерантности ${ }^{4}$.

Третья запись - «Ноmo ante et post Lapsum» (Человек до и после грехопадения) датируется 1693 г. В «Разумности христианства» тезис о «заражении» грехом обсуждается чуть более подробно, подвергается сомнению и отвергается. Подготовительные записи к «Разумности христианства» свидетельствуют: Локк искал подтверждение своей позиции у апостола Павла ${ }^{5}$, что в дальнейшем вылилось в создание его второго теологического труда «Парафраза и примечания к Посланиям св. Павла» (1705-1707). Внимание привлекает понятие «испытательного закона»: Локк предполагает, что Адам был сотворен смертным, а бессмертным мог стать в том случае, если бы исполнил предложенный Богом закон 6 . История человечества трактуется как постепенное отпадение от Бога и заражение пороком. И в этом «умалении любви к Богу», а не в самом первородном грехе - причина поразившего человечество «порока».

Четвертая запись - «Закон» (Law) датируется 1693 г. Это набросок важного «звена» в цепи аргументации Локка. Моральные понятия, полагает он, не имеют смысла вне идеи закона, а последний не существует без Того, Кто назначает наказания за нарушение закона.

Пятая запись - «Sacerdos» (Жрец) датируется 1698 г. Локк говорит о религии и морали как «неразрывных частях поклонения Богу» и о том, что служители истинной религии вправе возложить на себя функции и языческих жрецов, и философов. Необходимо также отметить, что понятие «закона морали», упомянутое в «Разумности христианство» при обсуждении «закона веры» и «закона дел», стало для Локка важным

\footnotetext{
${ }^{3}$ Proast 1999: 41-116.

${ }^{4}$ Locke 2002: lii.

${ }^{5}$ Locke 1999: 198-201.

${ }^{6}$ Locke 2002: liv.
} 
элементом его сотериологических рассуждений. Главным условием спасения Локк считал «святую жизнь», т.е. полное подчинение человека христианским заповедям и их неукоснительное соблюдение.

Шестая запись - «Заблуждение» (Error) датирована 1698 г. и посвящена критике спекулятивных «систем», подменяющих веру в Бога верой в произвольный и не рассчитанный на понимание со стороны паствы набор догматов. Локк защищает «исследование» и «проверку», видя в них долг человека перед Богом и противопоставляя их «слепой вере». По словам М. Голди, Локк «утверждает приоритет искренности в вере и приоритет морали в поведении» ${ }^{7}$. Термин «искренность» в приложении к вере действительно часто используется Локком, но гораздо чаще он употребляет выражение «explicit faith»: в этом случае речь идет не только об искренней, но также осмысленной, одновременно простой и понятной, просвещенной, и даже разумной, рациональной, продуманной вере, открыто, явно и недвусмысленно выражаемой человеком.

При переводе были учтены сохраненные современными публикаторами (В. Нуово и М. Голди) зачеркивания и подчеркивания и не вполне логичная нумерация вопросов, которая, по всей видимости, объясняется тем, что записи предназначались для личного пользования и не редактировались автором.

\section{SCRIPTURA SACRA ${ }^{8}$}

(Scriptura Sacra) A vindication of the Divine Authoritie \& inspiration of the writeings of the old \& new Testamt by. Wm Lowth $8^{\circ}$ [Lon] Ox. 92 p. 288

Не все книги обладают равным вдохновением. - $1 \mathrm{Q}$ что такое равное вдохновение? Если вдохновением обладает Новый, то им обладает и Ветхий благодаря подтверждению, данному Новым Ветхому. 2 Вдохновенны, потому что предназначены Богом для вечного пользования и наставления Церкви и как закон христианской веры на все времена. $3 \mathrm{Q}$ Должны ли они по той же причине не быть очень ясными, а их смысл непогрешимо очевидным для тех, кому они должны служить законом?

Вдохновенно то, что написано благодаря побуждению, руководству и содействию Бога и предназначено Им для вечного пользования Церковью. 3 Q Что имеется в виду под Побуждением, Руководством и Содействием в этом случае? 5 Q Должно ли не быть вдохновенным то, что не предназначено для вечного пользования Церковью?

Бог определил средства сохранения учения Христа до конца мира. 6 Q Следует ли из этого, что все написанное св. Лукой было вдохновенным?

Записи - наилучшее обычное средство передачи учения будущим векам. Ибо Бог никогда не совершает чудес больше, чем необходимо. 7 Q Все ли в Новом Завете было предназначено Богом к тому, чтобы это было записано?

Устное предание притязают только Энтузиасты. 9 Q Отвечает ли название Энтузиасты их аргументам в пользу частного откровения?

Благодаря писаниям, сохраненным обычными методами провидения, люди могут знать вашпу волю Божью так же, как знают историю прежних веков и мнения философов и т.д. 9 Q Воля тоже служит определенной цели? Ибо это весьма неясно.

\footnotetext{
${ }^{7}$ Locke 1999: 345.

${ }^{8}$ Перевод по: Locke 2002: 42-43.
} 
Бог использовал писания для наставления иудейской церкви. В. Моисей под Божьим руководством записал Его закон в книге. 10 Q Будете ли вы доказывать, что, если Ветхий Завет был вдохновенным, то таким же является и Новый?

Естественно предположить, что апостолы должны были позаботиться о том, чтобы оставить христианской церкви точное наставление, подобное иудейскому. 11 Q Писал ли автор, не считая это человеческой выдумкой?

Св. Матфей писал специально для иудеев, которым он проповедовал. 12 Q Полагал ли он, что это должно быть универсальным законом?

\section{PECCATUM ORIGINALE ${ }^{9}$}

Вопросы о вменении Адамова греха его потомкам

1 Верно ли, что Бог вменяет первородный грех Адама его потомкам?

Если вы ответите [да], то я спрашиваю,

2 в каком смысле это верно? Вменяет ли вам Бог этот грех заслуженно и правильно или это как бы вследствие греха? Или, проще говоря, полагает ли Бог, что они совершили этот грех в Адаме, или же из-за этого греха, совершенного им одним, подвергает их тем же бедам, которые навлек Адам, совершив его?

1 Если Вы говорите, что Бог полагает, что они совершили этот грех в Адаме, то я спрашиваю,

3 основано ли это полагание Богом, что они совершили этот грех в Адаме, на их реальном участии с Адамом в этом грехе или лишь на свободном волеизъявлении Божием?

$1^{\circ}$ Если Вы говорите, что оно основано на их реальном участии с Адамом в этом грехе, то я спрашиваю две вещи:

4 первое: можно ли говорить об их реальном участии в этом грехе с Адамом, если они не давали согласия ни в одном своем действии и даже не существовали, когда грех был совершен?

5 второе: участвовали ли они реально с Адамом во всех его грехах, совершенных после его грехопадения, и со своими родителями, и со всеми их предками, жившими после Адама, во всех их грехах так же, как с ним в том грехе?

Если вы говорите, что да, участвовали, то я спрашиваю,

6 участвовали ли они реально с Адамом во всех его актах веры и раскаяния после его грехопадения и также во всех подобных актах всех других благочестивых предков, которые действительно были актами Адама и предков (хотя и совершенными не без содействия благодати) или любыми их грехами?

$\mathrm{Q}$ Если вы говорите, что полагание Богом, что потомки Адама совершили этот грех в нем, основано только на свободном изъявлении божественной воли, то я задаю еще два вопроса, а именно:

7 первый: согласуется ли с Божьей истиной и правдой полагание Им, что потомки Адама совершили этот грех в нем, если они не давали своего согласия на это ни в одном своем действии и даже не существовали, когда он был совершен?

8 второй: мог ли Бог, сохранив Свои атрибуты, сотворить человека изначально подверженным всем бедам, следующим из полагания, что потомки Адама совершили грех в нем, а также подвергнуть их этим бедам, произвольно решив, что они совершили этот грех в Адаме?

Q Если же вы говорите, что Бог не полагает, что потомки Адама совершили этот грех в нем, но только подвергает их из-за греха, совершенного одним лишь Адамом, тем же бедам, которые тот навлек его совершением, то я задаю три вопроса, а именно:

9 во-первых: какие именно беды навлек Адам, совершив свой грех?

10 во-вторых: подвергает ли Бог, учитывая совершение греха одним лишь Адамом, его потомков всем бедам, которые он навлек, совершив его, или лишь некоторым?

11 в-третьих: являются ли беды, которым Бог подвергает потомков Адама, учитывая совершение им грехов, такими, что людям лучше было бы не быть, чем быть?

${ }^{9}$ Перевод по: Locke 2002: 229-230. 
1 Если вы говорите, что эти беды таковы, что им лучше не быть, чем быть, тогда я спрашиваю,

12 разве не мог Бог также сотворить человека изначально подверженным тем же бедам, каким подверг потомков Адама из-за греха, которого Он им не вменяет как совершенного ими в Адаме?

2 Если вы говорите, что эти беды не таковы, что людям лучше не быть, чем быть, то у меня больше нет вопросов.

\section{HOMO ANTE ET POST LAPSUM ${ }^{10}$}

Прост

Человек был сотворен смертным и владел всем миром, в котором, владычествуя над тварями, он был движим инстинктом и разумом и не мог иметь никаких порочных желаний, а владея всем на свете и не зная алчности и тщеславия, не мог и грешить. Поэтому Бог дал ему испытательный закон, запрещавший всего один плод, сам по себе полезный, целебный и вожделенный. Наказанием за нарушение этого закона была смерть. Ибо, хотя человек был сотворен смертным, древо жизни должно было, когда испытательный закон в достаточной мере засвидетельствовал бы его послушание, облечь его в бессмертие и избавить от умирания. Но он согрешил, и смертный приговор был немедленно исполнен, ибо он был изгнан и отлучен от древа жизни, Быт III 22, и, лишенный того, что могло исцелить любой недуг, проистекавший из слишком вольного владения тварями, и продлить его век, он начал с этого времени умирать, будучи разделен с источником жизни. Так что теперь он и в нем все его потомки по необходимости умирали, и так грех вошел в мир, и с грехом смерть.

Но Бог заключает с человеком новый договор, ковенант милости, и обещает состояние вечной жизни, хотя и оставляет смерть. Несмотря на то, что Адам и Ева были наказаны за первородный грех смертью и тем, что за нею следовало, смерть не могла служить наказанием за грех для всех их потомков, ибо нельзя называть наказанием то, что они, не имея никакой надежды на бессмертие и не ожидая его, были, как изначально все люди, рождены смертными. Согрешив, Адам и Ева познали добро и зло, т.е. различие между добром и злом, ибо без греха люди не знали бы и зла. Совершив грех, они убоялись Бога и составили ужасные идеи и представления о Нем, что умалило их любовь к Нему и обратило умы к известной твари. Этот корень всего зла оставил в них отпечаток и таким способом заразил их детей, а когда частная собственность и труд, ставшие необходимыми после того, как земля была проклята, постепенно породили различия в положении людей, появилось место для алчности, гордыни и тщеславия, которые, войдя в обыкновение и став примером для подражания, распространили порок, до такой степени поразивший человеческий род. JL

$3 \mathrm{AKOH}^{11}$

Источником и основанием всякого закона является зависимость. Зависимое разумное существо находится под властью, руководством и господством того, от кого оно зависит, и существует для целей, поставленных ему этим высшим существом. Если бы человек был независим, то не мог бы иметь иного закона, кроме собственной воли, и иной цели, кроме самого себя. Он был бы Богом для самого себя, и единственным мерилом, и единственной целью всех его действий было бы исполнение его воли.

\section{SACERDOS $^{12}$}

Древние знали учителей двух родов: одни из них обещали научить умилостивлению и искуплению и были первоначально их жрецами, которые, как правило, объявляли себя посредниками между богами и людьми и были в этом главными, во всяком случае без них ничего не происходило. Миряне довольствовались второстепенными ролями, если только сами не платили за церемонию, и тогда она принадлежала им

\footnotetext{
${ }^{10}$ Перевод по: Locke 2002: 231.

11 Перевод по: Locke 1997: 328-329.

12 Перевод по: Locke 2002: 17-18.
} 
самим. Но главной, по крайней мере существенной и сакральной, частью церемонии всегда был жрец, и без него никто ничего не предпринимал. У древних были и другие учителя - философы, которые делились на школы и обещали тем, кто к ним обращался, что научат их знанию вещей и правилам добродетели. Философы держались в стороне от публичных богослужений и церемоний, оставляя это на откуп жрецам, а жрецы не мешали философам обучать людей знанию природы и морали. Деление на две части или области знания, находившиеся под управлением двух совершенно разных групп людей, основывалось на допущении двух разных источников знания, а именно Откровения и Разума. Ибо жрецы, совершая обряды и поклоняясь богам, никогда не ссылались на разум, но всегда настаивали на воле богов, древности обычая и традиции, что в конечном счете сводило все их обряды к откровению. Философы же притязали только на разум и из него выводили все свои учения. О том, сколь мало их жизнь отвечала их собственным правилам и насколько она была полна не добродетели, но хвастовства и тщеславия, рассказывает Цицерон, Tuscalanarum Quaestionum, bk. II, ch. 4.

Иисус Христос, принеся человечеству благодаря откровению с небес истинную религию, воссоединил религию и мораль как неразрывные части поклонения Богу, которые никогда не должны существовать отдельно друг от друга. Теперь главное, что должен был делать человек, чтобы угодить Божеству и заслужить Его прощение, состояло в святой жизни, а от внешней церемонии зависело мало или совсем ничего, и поэтому она была почти полностью изъята из истинной религии, и вместо нее были введены два очень ясных и простых обычая. Всякая пышность тоже была отменена, а из внешних церемоний осталось лишь то, что диктовали приличия и порядок, необходимые в общественных собраниях. В силу такого характера истинной религии, исходящей непосредственно от Бога, служители ее, которые нередко тоже называют себя жрецами, возлагают на себя роли и языческих жрецов, и философов, и заявляют не только о праве публично совершать все внешние действия христианской религии и регулировать порядок церемоний, но также о праве учить людей моральным обязанностям в отношении друг друга и самих себя и предписывать им, как вести себя в жизни.

\section{ЗАБЛУЖДЕНИЕ ${ }^{13}$}

Великий раскол среди христиан вызван расхождением во мнениях. Каждая секта имеет свой набор мнений, называемый ортодоксией. Того, кто заявляет о согласии с ними, даже если его вера слепа и непроверена, считают ортодоксом, находящимся на пути к спасению. Но если он начнет исследовать и оспаривать какое-то из этих мнений, его тут же заподозрят в ереси, а если он выступит против них или выскажет противоположное мнение, то осудят как человека заблудшего и обреченного на вечные муки.

Можно сказать в отношении этого, что нет и не может быть ничего более ошибочного. Ибо свой долг исполняет именно тот, кто исследует, даже если после тщательной проверки он примет заблуждение за истину, а не тот, кто принимает исповедание (ибо до самих истин он не доходит), не проверив, истинно оно или нет. Разумеется, тот, кто исполняет свой долг, прилагая к этому все силы, ближе к небесам, чем тот, кто ничего не делает. Ибо если наш долг состоит в поиске истины, то, несомненно, тот, кто искал, хотя в каких-то пунктах не нашел, более послушен воле своего Создателя, чем тот, кто ничего не искал, но заявляет, что нашел истину, хотя не искал и не находил ее. Ибо тот, кто принимает все мнения какой-либо церкви, не проверив их, на самом деле не искал истину и не находил ее, но нашел лишь тех, кто, как он считает, ее нашел. И поэтому, слепо принимая их слова на веру, он присягает им, а не Богу - тому единственному, кого невозможно обмануть и кто не введет в заблуждение.

На этом пути некоторые церкви (в которых өртөдөкеня прппшнаетея моралғ, как можно заметить, мнения ставятся выше жизни и забота проявляется об ортодоксии, а не о морали) излагают условия спасения не так, как это делал Творец нашего спасе-

${ }^{13}$ Перевод по: Locke 2002: 81-83. 
ния. Условием спасения они считают веру в набор суждений, называемых основными догматами, и почитают их, потому что составителям угодно было включить их в вероисповедание. Но на самом деле это не вера, а всего лишь исповедание, ибо достаточно кому-нибудь примкнуть к тем, кто исповедует то же самое, как о незнании им каких-то догматов или неверии в них тут же забывают, а его самого считают теперь вполне ортодоксальным и не вызывающим подозрений человеком. Но как только обнаруживается, что он отказывается от слепой веры, которой от него ждут, хотя она и не признается церковью, его ортодоксальность сразу ставится под вопрос, а его самого записывают в еретики. Не стану отрицать, что человек может спастись и на пути слепой веры, веруя в Бога Отца Всемогущего и в то, что Иисус Христос - единственный Его Сын наш Господь, поскольку многие догматы сект таковы, что человек может быть спасен без веры в них. Но мне, признаться, трудно понять, почему церкви, делающие условиями спасения ни больше, ни меньше, как знание собственных исповеданий и веру в них, довольствуются слепой верой своих членов. Истина состоит в том, что невозможно спастись без подлинной веры в то, что Бог в Евангелии сделал абсолютно необходимым для спасения, и без искреннего послушания тому, что Он в нем заповедал. Для человека, верующего в Иисуса Христа, в то, что он послан от Бога, чтобы стать Спасителем мира, первым шагом к ортодоксии является искреннее послушание Его закону.

Возражение. Но способен ли невежественный и с трудом читающий поденщик изучить Евангелие и стать ортодоксом? Ответ. Крестьянин, не умеющий читать, не такой уж невежда: он уверен в себе и знает, в тех случаях, когда это касается его поступков, что́ правильно и что́ неправильно. Если он искренне подчинится свету природы, этой копии морального закона в Евангелии, то, несмотря на все заблуждения, придет ко всем истинам Евангелия, которые ему необходимо знать. Ибо тому, кто по-настоящему верует, что Иисус Христос послан от Бога, чтобы стать его Господом и Владыкою, и приступает искренне и непритворно к праведной жизни, зная о своем долге, а когда у него возникают сомнения в том, что его заботит, не колеблясь просит тех, кто лучше осведомлен в Христовом законе, сказать ему, что на этот счет заповедал его Господь и Учитель, и прочитать ему закон, касающийся того долга, который его заботит, и предписывающий, как ему поступить, - тому нет нужды знать, что́ в поступках других людей правильно или неправильно, но важно самому жить праведно и исполнять собственный долг. Ему достаточно такого знания и такой ортодоксии, и это приведет его к спасению. Такая ортодоксия понятна любому, кто решит вести праведную жизнь. Поэтому можно сформулировать как принцип христианства, что правильным и единственным путем к спасительной ортодоксии является искреннее и твердое стремление к праведной жизни.

Все мы многого не знаем в Священном Писании и нередко заблуждаемся в отношении возвещенных в нем учений. Поэтому заблуждения не подлежат осуждению, ведь речь идет о нашем спасении. А если они опасны, то невежды и неграмотные люди явно защищены лучше других, ибо у них меньше заблуждений, и они не терзают себя спекуляциями, понять которые они неспособны и до которых им нет никакого дела. Праведная жизнь в послушании закону Христа их Господа - вот что им необходимо, и если они получают ответы в той мере, в какой это касается их частных обязанностей, то достаточно ортодоксальны и не будут осуждены за незнание спекуляций, знать которые им не позволяют способности, обстоятельства и отсутствие свободного времени.

Мы видим здесь отличие ортодоксии, требуемой Евашгежем христианством, от ортодоксии сект, или, как их еще называют, церквей. Первая требует искренно веровать в то, что абсолютно необходимо для спасения, а также знать другие учения о вере, возвещенные в Слове Божием, и веровать в них - в соответствии со своими возможностями, способностями и помощью, которая оказывается, и получать знания о правилах и мерах своего долга в отношении своих поступков, и проявлять искреннее послушание им. Другая ортодоксия, а именно ортодоксия сект, требует веровать в пакеты догматов церковных систем, в которых отсутствует знание о правилах част- 
ных обязанностей человека и не требуется искреннее и строгое послушание им. Ибо исповедания веры, на которых настаивают в некоторых общинах, являются всего лишь спекулятивными мнениями: их требуют признавать и под ними подписываться, но на предписания и правила морали и следование им, насколько мне известно, никто не обращает внимания, и никого особенно не беспокоит вопрос об их полноте и соблюдении в церковном общении.

Впрочем, следует заметить, что этот способ привлечения и сохранения паствы гораздо эффективнее первого и гораздо лучше отвечает этой цели, поскольку человеку легче исповедовать веру в некую совокупность мнений, о которых он, возможно, даже не читал, а каких-то из них, возможно, не понимает, даже если читал и изучал (ибо от него требуется лишь исповедание, выраженное в согласии, не предполагающем сомнений и опровержений), чем соблюдать обязанности праведной жизни в искреннем послушании предписаниям Евангелия, касающимся его поступков. Предписаниям, понять которые не составляет труда для тех, кто желает и готов им подчиниться. JL

Перевел А.А. Яковлев

\section{БИБЛИОГРАФИЯ / REFERENCES}

Correspondence of John Locke. In Eight Volumes / Ed. by E.S. de Beer. Oxford: Clarendon Press, 1976. Vol. IV. 707 p.

Le Clerc J. Five Letters Concerning the Inspiration of the Holy Scriptures. Translated out of French. London: [n.p.], 1690. 239 p.

Locke J. An Essay Concerning Human Understanding / Ed. by P.H. Nidditch. Oxford: Clarendon Press, $1975.748 \mathrm{p}$.

Locke J. Political Essays / Ed. by M. Goldie. Cambridge: C.U.P., 1997. 409 p.

Locke J. The reasonableness of Christianity / Ed. by J. C. Higgins-Biddle. Oxford: Clarendon Press, 1999. $261 \mathrm{p}$.

Locke J. Writings on Religion / Ed. by V. Nuovo. Oxford: Clarendon Press, 2002. 290 p.

Lowth W. A Vindication of the Divine Authority and Inspiration of the Writings of the Old and New Testament. An Answer to a Treatise lately Translated out of French, Entituled Five Letters concerning the Inspiration of the Holy Scriptures. Oxford: Theater, 1692. 288 p.

Proast J. A Third Letter concerning Toleration: in Defence of the Argument of The Letter concerning Toleration, briefly Consider'd and Answer'd. Oxford: L. Lichfield, 1691. 79 p.

Яковлев Анатолий Александрович, кандидат философских наук, независимый исследователь,yakovlev1632@gmail.com

\section{Fragments of Moral Theology in John Locke's Notebooks}

According to Locke the Law of Morality is crucial for Salvation, in the same way as the Law of Works and the Law of Faith, requiring full observance of all moral precepts delivered in the Gospel. Locke also deemed unacceptable the so called "implicit" or blind faith, and contrasted it with the Faith plain and explicit, rational and enlightened, openly and freely professed by any believing person. The content of his notebooks (1692-1698), as well as Philosopher's main theological works, may be of help in tracing how and in what intellectual context occurred the making-up of his Moral Theology.

Keywords: Moral Theology, Law of Morality, Arminianism, Implicit Faith, Explicit Faith, Soteriology, Original Sin, Probationary Law, William Molyneaux, Jean Le Clerc

Anatoly A. Yakovlev, Cse in Philosophy, independent scholar, yakovlev1632@gmail.com 
Ю.С. ШИПИцЫНА

\section{ИМПЕРИЯ И ВЛАСТЬ ЗНАНИЯ: СОВРЕМЕННЫЕ ПОДХОДЫ К ИЗУЧЕНИЮ БОТАНИКИ В ХVIII В. ${ }^{1}$}

В статье представлен обзор современной историографии вопроса о взаимосвязи развития ботанического знания и имперских властных институтов в XVIII в. На основе различных теоретических подходов раскрывается содержание понятия «имперская ботаника». Особое внимание уделено теоретическому наследию французского социолога Бруно Латура.

Ключевые слова: Бруно Латур, естественная история, имперская ботаника, история науки

В последние несколько десятилетий изучение взаимодействия науки и власти является одним из ведущих историографических трендов $^{2}$. Бурное развитие ботаники в условиях расширения могущества империй XVIII века и многообразие локусов изучения данной темы побудило ученых к объединению усилий в недавнем коллективном труде «Имперская ботаника в долгом XVIII веке». Здесь термин «Botany of Empire» нашел свое устойчивое обоснование и четкие хронологические рамки: конец XVII - начало XIX века ${ }^{3}$. В современном историографическом дискурсе имперская ботаника предстает как феномен, возникающий не «благодаря» империи и тем более не «вопреки» ей, а - внутри границ имперского дискурса. Внимание сосредотачивается на функционировании ботаники как науки, пользующейся поддержкой политических институтов и участвующей в экономической экспансии на благо суверенитета национальных государств.

Опираясь на идею «мыслительных центров» Б. Латура ${ }^{4}$, Д. Миллер и П. Рейл в своей работе «Образы империи: путешествия, ботаника и способы репрезентации природы» показывают, как многие события XVIII столетия были подчинены интенсивному процессу освоения природных ресурсов с целью их дальнейшего использования. В качестве примера представлена длительная академическая карьера Дж. Бэнкса (1723-1820), президента Лондонского королевского общества, и блестящего координатора «охотников за растениями», разосланных с экспедициями по всему земному шару ${ }^{5}$.

Л. Шибингер и К. Свон в монографии «Колониальная ботаника: наука, торговля и политика в мире в раннее Новое время» подчеркива-

\footnotetext{
${ }^{1}$ Исследование выполнено при поддержке гранта Российского научного фонда (проект № 19-18-00186 «“Культура духа” vs “Культура разума”: интеллектуалы и власть в Британии и России в эпоху Перемен (XVII-XVIII вв.)»).

${ }^{2}$ Писарев, Гавриленко 2020: 2.

${ }^{3}$ The Botany of Empire 2027.

${ }^{4}$ Latour 1987.

${ }^{5}$ Miller, Reill 1996.
} 
ют роль ботаники внутри политического и научного контекстов естественной истории, доказывая, что "развитие ботаники и европейской торговой и территориальной экспансии были двумя взаимозависимыми процессами» ${ }^{6}$. С позиции истории искусств в книге Терезы $\mathrm{O}^{\prime}$ Мэлли и Эми Мэйерс «Искусство естественной истории: иллюстрированные трактаты и ботанические рисунки, 1400-1850» исследуется пересечение эстетических и научных ценностей в визуализации знания ${ }^{7}$.

Труд Д. Блэйхмар «Видимая империя: ботанические экспедиции и визуальная культура в испанском просвещении» акцентирует внимание на роли ботанической иллюстрации в легитимации и распространении сложно переплетенных научных и империалистических интересов испанских экспедиций XVIII века ${ }^{8}$.

В этих сочинениях ботаническая наука предстает безусловно причастной к колониальным захватам XVIII в. сродни тому, как академическая география и картография рассматриваются в качестве инструментов имперской экспансии XIX столетия9 ника предстает как глобальное явление, тесно связанное с противоборством колониальных держав на морях. Отдаленные территории оказывались подчинены экономике метрополии, выступая в роли поставщика сырьевых ресурсов и высокодоходных агрокультур. Внутри этой системы имперской конкуренции научные, экономические и политические инициативы были тесно переплетены. В значительной степени все возрастающий оборот поставок растений и его коммерческая составляющая были обусловлены расширением сети административных структур и улучшением технологий транспортировки.

Открытие новых растений было тесно связано с трансформацией ценностей. Торговля опиумом и сахаром, предметами китайской экзотики стала символом такой экономической деятельности, которая обещала не только высокий доход, но и высокий социальный статус. Идеология прогресса, поощряла конкуренцию и побуждала к активной деятельности на политическом поприще ${ }^{10}$. Так в один ряд с политикой и коммерцией как сферами реализации карьерных амбиций становится наука. Публикации в научных журналах, членство в научных обществах, возможность культивации экзотического растения в новом климате в рамках государственного или частного ботанического сада - все это, помимо прочего, также формирует престижную профессиональную и социальную идентичность.

Бурный рост многообразия ботанических образцов актуализировал задачу классификации эмпирического материала. Благодаря биноминальной системе классификации Карла Линнея сложился единый

\footnotetext{
${ }^{6}$ Schiebinger, Swan 2007: 3.

${ }^{7}$ O'Malley, Meyers 2008.

${ }^{8}$ Bleichmar 2012.

${ }^{9}$ Иванов 2020: 27.

${ }^{10}$ Batsaky, Cahalan, Chikin 2017: 9.
} 
научный дискурс, а новый lingua franca в сфере науки, в свою очередь, лишь усилил интерес к растениям: ажиотаж вокруг ботаники к концу XVIII столетия охватил почти весь земной шар. Ботаника формировала совершенно особенный тип личности натуралиста, руководствующегося в своих поступках строгой рациональностью, но в то же время решительностью, энтузиазмом, готовностью к авантюрам, утонченностью и изысканностью, созвучным окружающей его природе $\mathrm{e}^{11}$.

Еще одной потенциально продуктивной идеей для понимания феномена имперской ботаники является концепция Латура «действия на расстоянии». Взаимоотношения между центром и периферией становятся возможным на практике благодаря формированию структур, которые отвечают за сбор и транспортировку «свидетельств» от периферии к центру в процессе все возрастающего «цикла накопления». Под свидетельствами понимаются любые значимые данные как в текстовой, так и в визуальной форме. «Цикл накопления» продолжается до тех пор, пока свидетельства успешно осваиваются центром, тем самым порождая знание/распознавание, доступное даже для тех путешественников, кто впервые отправился на окраины империи. Чем обширнее становится «цикл накопления», тем крупнее масштаб тех структур, которые могут быть мобилизованы и использованы для будущих имперских амбиций центра, и тем сильнее обнаруживается властный дисбаланс между центром и периферией ${ }^{12}$.

Рассуждения М. Ямпольского о естественной истории земли (natural history) позволяют увидеть специфику кодирования исторической информации в ботанических «артефактах»: «Особенность естественной истории (и ее отличие от описаний памятников) заключалась в том, что она обращена на объекты, по сути, не имеющие истории, как бы существующие вне времени. Объекты эти никак не укоренены в “дискурсивных практиках" и являются, так сказать, объектами чистой видимости, совокупностью поверхностей, форм и цвета. Соответственно, естественная история изначально мыслит не столько в темпоральных категориях, сколько в категориях больших картин, коллекций, в которых объекты разных эпох и разных стран помещены вместе, в некоем кристалле одновременности, отражающем принцип непрерывности природы» ${ }^{13}$.

Как справедливо замечает С.Э. Принс: «“Естественная история” любопытный термин... это одновременно и концепция, и практика: концепция, которая до недавнего времени строилась на убеждении, что природа может быть разъединена и систематически уложена в большие стандартные схемы, и практика, которая включала в себя все: от чучел птиц и гербариев - до исследования костных останков и создания иллюстраций. Но важнее всего понимать, что естественная история всегда основывается на вере в возможность постижения и покорения челове-

\footnotetext{
${ }^{11}$ Fuse Aublet 1775.

${ }^{12}$ Latour 1987: 215-257.

13 Ямпольский 2003.
} 
ком природы» ${ }^{14}$. В этом состоит главный результат изысканий исследователей о взаимосвязи имперского и ботанического дискурсов - одна из актуальных проблем современности заключается в том, чтобы человек осознал себя частью природы и проявлял бережное к ней отношение.

\section{БИБЛИОГРАФИЯ / REFERENCES}

Иванов К. Астрономы и топографы в борьбе за Центральную Азию. Заметки к эпистемологии колонизации // Логос. 2020. Т. 30. № 2. С. 15-40. Ivanov K. Astronomy i topografy v bor'be za Central'nuyu Aziyu. Zametki k epistemologii kolonizacii // Logos. 2020. T. 30. № 2. S. 15-40.

Писарев А., Гавриленко С. В поисках ускользающего объекта: наука и ее история // Логос. 2020. T. 30. № 1. C. 1-28. [Pisarev A., Gavrilenko S. V poiskah uskol'zayushchego ob"ekta: nauka i ee istoriya // Logos. 2020. T. 30. № 1. S. 1-28].

Ямпольский М.Б. История культуры как история духа и естественная история // Новое литературное обозрение. 2003. № 1. [YAmpol'skij M.B. Istoriya kul'tury kak istoriya duha i estestvennaya istoriya // Novoe literaturnoe obozrenie. 2003. № 1] URL: https://magazines.gorky.media/nlo/2003/1/istoriya-kultury-kak-istoriya-duha-iestestvennaya-istoriya.html

Batsaki Y., Cahalan S. B., Tchikine A. Introduction // The Botany of Empire in the Long Eighteenth Century. Cambridge, 2017. P. 1-11.

Bleichmar D. Visible Empire: Botanical Expeditions and Visual Culture in the Hispanic Enlightenment. Chicago, 2012.

Fuse Aublet J. B. Histoire des plantes de la Guiane Française. London, Paris, 1775.

Latour B. Science in Action: How to Follow Scientists and Engineers through Society. Cambridge, 1987.

Miller D. Ph., Reill P. H. Visions of Empire: Voyages, Botany, and Representations of Nature. Cambridge, 1996.

Moved Natural Objects. Spaces in Between // Journal of History of Science and Technology. Vol. 5. 2012.

O'Malley T., Meyers A. R. W. The Art of Natural History: Illustrated Treatises and Botanical Paintings, 1400-1850. Washington, 2008.

Prince S. A. Stuffing Birds, Pressing Plants, Shaping Knowledge Natural History in North America, 1730-1860 // Transactions of the American Philosophical Society, New Series. Vol. 93. No. 4. 2003, pp. I-XVIII, p. 1-113.

Schiebinger L., Swan C. Colonial Botany: Science, Commerce, and Politics in the Early Modern World. Philadelphia, 2007.

The Botany of Empire in the Long Eighteenth Century. Cambridge, 2017.

Шипицына Юлия Сергеевна, лаборант-исследователь, Лаборатория эдиционной археографии, Уральский федеральный университет, shipitsyna.phd@gmail.com

\section{Empire and the power of knowledge: Modern approaches to studying botany in the 18th century}

The article presents a review of contemporary studies of the topic of the links between a botany and empire in the $18^{\text {th }}$ century. The term of "the botany of empire" is defined in the context of various theoretical approaches. The special attention has been given to theoretical heritage of French sociologist Bruno Latour.

Keywords: The botany of empire, Bruno Latour, history of science natural history.

Yulia Shipitsyna, laboratory researcher, Laboratory of Edition Archaeography, the Ural Federal University; shipitsyna.phd@gmail.com

\footnotetext{
${ }^{14}$ Prince 2003: 1.
} 


\section{ОТ ИСТОРИИ ДЕТСТВА К ГЕНДЕРНОЙ ИСТОРИИ: НОВЫЙ ВЗГЛЯД НА ЖИЗНЬ СЕМЬИ ПОСЛЕДНЕГО РУССКОГО ИМПЕРАТОРА}

В статье представлена рецензия на монографию Хелен Раппапорт «Дневники княжон Романовых. Загубленные жизни». Реконструкция биографий дочерей Николая II Ольги, Татьяны, Марии и Анастасии осуществлена через призму «истории детства» и «гендерной истории». Отмечается как методологическая новизна подхода автора книги, так и противоречивость некоторых суждений и выводов.

Ключевые слова: чарская семья, история детства, гендерная история, биография

В последние десятилетия издано много работ, посвященных семье Николая II, в основном просветительского и агиографического характера, но обилие литературы не создало «перенасыщения» темой. Яркий пример - уже ставшая бестселлером книга британского историка Хелен Раппапорт о дочерях Николая II $^{1}$. Изданная в России в 2015 г., через год после выхода англоязычного варианта, она уже успела выдержать несколько переизданий $(2016,2017,2018,2019)$, но не вызвала никакого отклика со стороны профессионального исторического сообщества.

Рецензируемое издание, построенное как серия очерков, посвящённых основным вехам жизни - Ольги, Татьяны, Марии и Анастасии, написано на стыке двух междисциплинарных подходов: истории детства и гендерной истории. Перед читателем возникают образы великих княжон в развитии - от детских лет к пубертатному периоду. Повествование о детях предваряется рассказом о жизни их матери, принцессы Гессен-Дармштадтской, будущей императрицы Александры Фёдоровны. Такой «пролог» позволяет увидеть викторианские «корни» воспитательных практик в царской семье. Интересно, что рождение четырех дочерей в отсутствие наследника престола вызывало в России и на Западе разное отношение (62). Если русское патриархальное сознание воспринимало отсутствие наследника как «наказание Божие», то на Западе маленьких княжон рассматривали как тех, кто в будущем послужит залогом союзнических и дружеских отношений между странами. А в России рождение подряд Татьяны (1897), Марии (1899) и Анастасии (1901) вызвало разочарование, в т.ч. в великокняжеской среде (77). В сложившейся династической ситуации император не исключал, что наследницей престола могла бы стать Ольга, которой тогда не было и пяти лет (95). Радостная весть о появлении в царской семье сына в 1904 г. всколыхнула русское общество. Однако западная пресса отнеслась к этому событию весьма сдержанно, выразив неудовольствие тем, что в честь рождения Алексея был дан 301 пушечный залп с Петропавловской крепости,

\footnotetext{
${ }^{1}$ Раппапорт 2015. Авторское название более адекватно содержанию книги - 'Тhe Romanov Sisters: The Lost Lives of the Daughters of Nicholas and Alexandra' («Сестры Романовы: Потерянные жизни дочерей Николая и Александры»). Упоминание о дневниках в русском издании носит отчётливо выраженный рекламный характер.
} 
в то время как каждая из дочерей удостаивалась лишь 101 залпа - в этом увидели «дискриминацию по гендерному признаку»; к тому же последовало недвусмысленное замечание, что четыре княжны также вполне могли бы «обеспечить преемственность династии» (122-123).

Болезнь Алексея привела к тому, что семья стала жить как в затвоpe, что, по мнению автора, негативно сказалось на сестрах. Она отмечает, что «замкнутость и самодостаточность» и «трогательная детская неосведомленность о мире вокруг» были «результатом той странной тепличной обстановки, в которой они воспитывались» (157-158). Но в годы русско-японской войны царские дети участвовали в организации помощи раненым: «вязали шерстяные шапки и шарфы для солдат», помогали в организации отправок солдатских писем домой (115-116). Утверждение об «оранжерейных условиях» (160) жизни сестёр является преувеличением. Они принимали участие в общественно полезных делах, например, в акции помощи туберкулёзным больным и других благотворительных мероприятиях (241-242). При этом, действительно, Александра Фёдоровна наперекор общественному мнению ограничивала участие детей в придворных мероприятиях, смотрах, балах, полагая, что это может принести им больше вреда, нежели пользы $(201,232)$.

С появлением Алексея, жизнь царских дочерей, прежде размеренная и безмятежная, была омрачена постоянными страданиями как матери, так и брата, которому теперь уделялось основное внимание родителей. Поэтому девочки «все больше и больше ощущали, что им не хватает материнского внимания из-за ее постоянного нездоровья» (178-179). «Алексей был явно центром вселенной для матери, в результате чего девочки семьи Романовых, казалось, обречены были... всегда быть в тени своего дарованного Богом брата» (202). Все это преподносится как проявления «гендерной дискриминации», хотя очевидно, что особое внимание к больному ребенку - явление, свойственное любой семье.

Особое место в книге занимает повествование о первых увлечениях и влюблённостях дочерей Романовых в 1910-е гг. И, хотя автор отмечает их «невинный» характер (228), в детских играх Ольги и её сестёр с офицерами царского конвоя исследовательница видит «очень странный и весьма извращенный вид общения», упрекая царицу в том, что она не видела в этом ничего «страшного» (276). Автор стремится подавать все детские увлечения и влюблённости ОТМА исключительно во «фрейдистском» ключе, хотя никаких свидетельств не приводится. Между строк читается, что стремление к «раскрепощению» у дочерей было порождено именно их затворническим образом жизни $(282)^{2}$.

Болезнь матери и брата еще больше сплотила ОТМА, хотя «психологически негативно отражалась на девочках: в важнейшие годы своего

\footnotetext{
${ }^{2}$ К сожалению, Раппапорт не использовала ценную информацию из дневников духовника царской семьи протоиерея Афанасия Беляева (1917), в которых он отмечал у девушек «чистоту помышлений» и «полное незнание земной грязи - страстной и греховной». - Дневник протоиерея А.И. Беляева... 2006: 355.
} 
становления четыре сестры еще больше, чем когда-либо, нуждались в материнском внимании», а «в их повседневной жизни царила болезнь и страдание» (264). Автор обвиняет императрицу в симуляции болезней, в том, что она «терпела лишь тех врачей, которые подтверждали ее собственный диагноз», подыгрывали «ее представлениям о себе как хроническом инвалиде» (193). В итоге, «сестры оказались запертыми в отупляющем, искусственном мирке, который не давал им взрослеть» (284).

Авторское отношение к возрасту её героинь противоречиво: с одной стороны, их мир потерял детскую беззаботность с рождением Алексея и началом «гендерной дискриминации» в семье. Тем не менее, даже когда Ольге уже 18 лет, а ее сёстры вступили в раннеподростковый возраст, они всё ещё по своему мировосприятию остаются «детьми». Однако рассказ о влюблённости Ольги в офицера Павла Воронова показывает обратное: узнав о его готовящейся свадьбе, она переступает через свои чувства и, желая ему добра («Господи, пошли ему счастья, моему любимому»), старается немедленно забыть о нём (290-291). Перед нами предстаёт образ глубокого, взрослого, думающего человека, готового пожертвовать своими привязанностями ради блага другого, здесь как раз и проявляется настоящая, взрослая любовь к Воронову, а не слепая влюблённость, характерная для «детского» отношения к жизни.

Родители отнюдь не считали ОТМА «детьми», не имеющими права на собственное мнение, наоборот, с полным уважением относились к их самостоятельному выбору. Когда в 1914 г. всерьёз рассматривалась возможность брака Ольги с румынским принцем Каролем, венценосцы настаивали на том, что этот брак может состояться только при условии «добровольного согласия их дочери» (299-300). Начавшаяся вскоре мировая война «похоронила» активно обсуждаемые на Западе варианты будущих браков царских дочерей. С первых же дней войны ОТМА приняли участие в оказании помощи раненым солдатам: Александра Фёдоровна и старшие дочери - Ольга и Татьяна - обучились на медсестёр (321), а Мария и Анастасия посещали больницы с целью моральной поддержки раненых (334). Они также занимались организацией помощи пострадавшим от войны (Особый Петроградский комитет великой княжны Ольги Николаевны, «Татьянинский комитет») (328-329).

Раппапорт удивляет, почему Александра Фёдоровна разрешила детям активное участие в общественной жизни только в 1914-1917 гг. и «не предоставила своим дочерям возможность играть более значительную роль в обществе раньше» (342). Однако если следовать авторской логике, по которой сёстры Романовы до этого жили исключительно в «отупляющем, искусственном мирке», то могли ли они быть способными заниматься ответственной общественной работой?

События после Февральской революции и свержения монархии, даны в книге, при этом особое внимание уделяется повседневной жизни царской семьи в заключении сначала в Царском Селе (425-429), затем в Тобольске (440-478) и Екатеринбурге (497-504). Примечательно, что 
сёстры Романовы смогли найти общий язык с охранявшими их солдатами (468), а также много занимались физической работой по дому и вне него (с. 478). Автор по личным мотивам приняла решение опустить подробный рассказ о гибели семьи в июле 1918 г. (17) и завершила повествование кратким обзором судеб тех, кто участвовал в воспитании царских дочерей, входил в узкий круг их общения (505-511).

Книга Х. Раппапорт действительно представляет собой новую страницу в изучении жизни семьи Николая II. Использование ряда неопубликованных источников (из западных архивов и частных коллекций), проработка массива источников личного происхождения, иностранной и русской периодики - всё это, безусловно, вызывает уважение к проделанной работе. Однако можно ли признать успешным авторский эксперимент в построении исследования на стыке детской и гендерной истории? Однозначно ответить на этот вопрос невозможно. «Камнем преткновения» для автора стал вопрос о возрасте (не биологическом, а социальном) её героинь. С одной стороны, ещё в малолетних детях она пытается увидеть «взрослое» стремление к свободе, осознанному познанию мира, в детских забавах и играх - гендерный подтекст, но при этом невысоко оценивает «взрослый» мир княжон, сводя подчас их мировосприятие к поверхностному, «детскому» уровню.

Противоречивость отнюдь не является слабой стороной книги, наоборот, написанное в полемичном ключе, исследование вызывает читателя на диалог или даже спор с автором. Хочется надеяться, что к этому «диалогу» с книгой присоединятся и другие исследователи жизни последней царской семьи.

\section{БИБЛИОГРАФИЯ / REFERENCES}

Дневник протоиерея А.И. Беляева, настоятеля Федоровского собора в Царском Селе // Августейшие сестры милосердия / сост. Н.К. Зверева. М. Вече, 2006. С. 349-376. [Dnevnik protoiereya A. I. Belyaeva, nastoyatelya Fedorovskogo sobora v Carskom Sele // Avgustejshie sestry miloserdiya / sost. N. K. Zvereva. M. Veche, 2006. S. 349-376].

Раппапорт Х. Дневники княжон Романовых. Загубленные жизни / пер. с англ. А. Мовчан. М.: Изд-во «Э», 2015. 608 с. [Rappaport H. Dnevniki knyazhon Romanovyh. Zagublennye zhizni / per. s angl. A. Movchan. M.: Izd-vo «E», 2015. 608 s.

Князев Марк Андреевич, аспирант, Институт международных отношений и мировой истории, ННГУ им. Н. И. Лобачевского; kn.mark.nn@ mail.ru

\section{From 'childhood history' to 'gender history'} a new look at the life of the family of the last Russian emperor

The article presents a review of the monograph by Helen Rappaport 'The Diaries of the Romanov Princesses. Ruined lives' ['The Romanov Sisters: The Lost Lives of the Daughters of Nicholas and Alexandra']. The reconstruction of the biographies of the four daughters of Nicholas II was carried out through the prism of 'childhood history' and 'gender history'. Both the methodological novelty of Rappaport's approach and the inconsistency of some of the author's judgments and conclusions are noted.

Keywords: royal family, childhood history, gender history, family history, biography Mark A. Knyazev, postgraduate student, Institute of International Relations and World History, Lobachevsky Nizhny Novgorod State University; kn.mark.nn@mail.ru 


\section{CONTENTS}

\section{History and theory}

Nikolay Gubanov, Nikolay Gubanov

The history of scientific ideas through the prism of the history of philosophical ideas

Oksana Golovashina

Social framework of historical responsibility

in search of rational grounds for historical estimates....

\section{Intellectual history today}

Sergey A. Vorontsov

Coins and Flowers: Some Images of the Textual Authority

in the Works of Isidore of Seville...

Maya Petrova

Dungal and Macrobius: on the Perception of Ancient Texts by Medieval Authors

Lilia Iliasova

The novels about "new people" at the turn of the 1860s-70s

and their reception by the Russian society

Irina Vorontsova

«Reform, reformation and replenishment of the Church».

Historical and analytical review of A.V. Kartashev's treatise.

Sergey Krikh

The Russian Marxists and the Ancient Near East.

Nikolai Nikolaev

"The disappointed pacifist". Problems of war and peace in P.N. Milyukov's journalism at the beginning of the XX century....

Vladimir Sapon

Disappointment in the "Russian American"

the US press of 1917-1918 on political activities of P.N. Milukoff

Aleksei Suslov

In memory of Vladimir Petrovich Sapon (1969-2020) - historian and teacher.

\section{Controversy over terms}

\section{Vasily Orlov, Eduard Rung}

The term "Aristocracy" and its Use for Nobility in the Achaemenid Empire....

Denis Sukhino-Khomenko

The "Anglo-Saxon schism": a terminological discussion in the Anglophone mass media and current challenges to the medieval academic community

\section{History and memory}

Liudmila Novoseltseva

Comprehension of the national experience of interaction

with Hungarian political elites in Serbian liberal journalism $(1861-1872) \ldots \ldots \ldots \ldots \ldots \ldots \ldots \ldots$

Matvey Lomonosov

On the Roads from Intra-Ethnic Polyphony to Ethno-National "Symphony".

The Kosovo Myth and Serbian Historians ....

Cultural practices, images, representations

\section{Taisiia Demicheva}

The language of the empire and the image of the "noble savage"

in French travel essays of the second half of the 18th century.

Vasily Dudarev

Germany in the life of Russian writers and poets of the first half of the 19th century

Ruslan Kondrashuk

The image of the Roman Empire in American newspapers at the end of $19^{\text {th }}$ century.

Andrey Avdashkin, Igor Sibiryakov

"Together Forever": friendship of the USSR and PRC

in the optics of the Soviet provincial newspapers 
Lizaveta Lysenka

Comprehension of the national past in the West Berlin music culture in the 1980s.

Sergey Dyukin

Rock-discourse as the reflection of Perestroika

\section{Spaces of power and power of space}

Olga Togoeva

Visual effects of the medieval justice.

Maria Neklyudova

"Jarnac's Blow". Local memory and the conflict of historical interpretations

Elena Novoselova

Dead body as an object of sensory perception in the space of Andean civilization.

300

Olga Okuneva

Little Island, Great Desolation: "Antarctic France" in Brazil as a Space of Sensory Deprivation...

Anna Stogova

A look at power and the city with and without spectacles

Descriptions of Paris and London in 1698.

Svetlana Vasilieva

Religious sources of the ideal model of imprisonment

in social and legal discourse of the late $18^{\text {th }}-$ early $19^{\text {th }}$ century

Svetlana Sidorova

Muscular energy and water Servants and cooling technologies in Colonial India

Konstantin Skripnik

\section{History through personality}

Significs of Lady Victoria Welby: Portrait in the interior of time

Elena Krylova

The fate of an official: publishing activities of A.I. Miretsky.

\section{Historical essays}

\section{Anna Volodko}

Empress Maria Alexandrovna's contribution

to the development of female education in Russia: women's all-estate open gymnasiums.

Anna Gromova

Grand Duchess Elizaveta Feodorovna as a patron of music education

Dmitrii Nechiporuk

"We were aliens, but no longer outsiders"

the strategies of political adaptation of the Mensheviks in Germany in 1920s

\section{Translations and publications}

Isidore of Seville. Etymology, or beginnings.

Book V. On Laws and Times (translated by A. Pavlov).

Anatoly Yakovlev

Fragments of Moral Theology in John Locke's Notebooks

\section{Reading books...}

Yulia Shipitsyna

Empire and the power of knowledge

Modern approaches to studying botany in the 18th century

Mark Knyazev

From 'childhood history' to 'gender history'

a new look at the life of the family of the last Russian emperor.

CONTENTS. 


\section{СОДЕРЖАНИЕ}

\section{История и теория}

Н.Н. Губанов, Н.И. Губанов

История научных идей сквозь призму истории идей философских.

О.В. Головашина

Социальные рамки исторической ответственности

в поисках рациональных оснований исторических оценок

\section{Интеллектуальная история сегодн}

\section{С.А. Воронцов}

Цветы и монеты: некоторые образы авторитета текста

в произведениях Исидора Севильского.

М.С. Петрова

Дунгал и Макробий: к вопросу о восприятии античных текстов средневековыми авторами.. Л.Р. Ильясова

Романы о «новых людях» рубежа 1860-1870-х гг. в восприятии русского общества.......

И.В. Ворониова

Трактат А.В. Карташева «Реформа, реформация и исполнение Церкви»....

С.Б. Крих

Русские марксисты о ближневосточной древности

Н.Ю. Николаев

«Разочарованный пацифист»: проблематика войны и мира

в публицистике П.Н. Милюкова в начале XX века

B.П. Canor

Разочарование в «русском американце»: пресса США 1917-1918 гг.

о политической деятельности П.Н. Милюкова

А.Ю. Суслов

Памяти Владимира Петровича Сапона (1969-2020)

\section{Споры о терминах}

\section{В.П. Орлов, Э.В. Рунг}

Термин «аристократия» и его применение для обозначения знати

в Ахеменидской империи. ...

Д.В. Сухино-Хоменко

«Англо-саксонская схизма»: терминологическая дискуссия

в англоязычном медиа-пространстве и вызовы сообщества медиевистов

\section{История и память}

\section{Л.К. Новосельиева}

Осмысление национального опыта взаимодействия с венгерскими

политическими элитами в сербской либеральной публицистике (1861-1872)

М.Ю. Ломоносов

На путях от внутриэтнической полифонии к этно-национальной «симфонии»

Косовский миф и сербские историки 1980-1990-х гг.

\section{Культурные практики, образы, репрезентации}

\section{Т.М. Демичева}

Язык империи и образ «благородного дикаря» во французских очерках

о кругосветных путешествиях второй половины XVIII века

В.С. Дударев

Германия в жизни российских писателей и поэтов первой половины XIX века

Р.А. Кондрашук

Образ Римской империи в американской прессе конца XIX века.

А.А. Авдашкин, И.В. Сибиряков

«Навеки вместе»: дружба СССР и КНР в оптике советской провинциальной печати..... 


\section{Е.Н. Лысенко}

Осмысление национального прошлого

в музыкальной культуре Западного Берлина 1980-х гг.

С.Г. Дюкин

Рок-н-ролльный дискурс как зеркало Перестройки

\section{Пространства власти и власть пространства}

О.И. Тогоева

Визуальные эффекты средневекового правосудия

276

М.С. Неклюдова

«Удар Жарнака»: память места и борьба исторических интерпретаций ...

287

Е.В. Новоселова

Мертвое тело как объект чувственного восприятия в пространстве Андской цивилизации..

О.В. Окунева

Маленький остров больших лишений: взгляд на «Антарктическую Францию»

в Бразилии как на пространство сенсорной депривации.

A.В. Стогова

Взгляд на власть и город с очками и без: описания Парижа и Лондона в 1698 году......

С.А. Васильева

Религиозные источники идеальной модели тюремного заключения

в социально-правовом дискурсе конца XVIII - начала XIX века

C.Е. Сидорова

Мускульная сила и вода: слуги и технологии охлаждения в колониальной Индии

\section{К.Д. Скрипник}

\section{История через личность}

Сигнифика леди Виктории Уэлби: портрет в интерьере времени

Е.Н. Крылова

Судьба чиновника: издательская деятельность А.И. Мирецкого

\section{Исторические очерки}

\section{А.В. Володько}

Вклад императрицы Марии Александровны в развитие женского образования

в России: открытые всесословные гимназии.

А.В. Громова

Великая княгиня Елизавета Федоровна: покровительство музыкальному образованию.... Д.М. Нечипорук

«Мы были чужеземцами, но не посторонними»

стратегии политической адаптации меньшевиков в Германии в 1920-е гг.

\section{Переводы и публикации}

Исидор Севильский. Этимологии, или начала.

Книга V. О законах и временах (перевод А.А. Павлова).

А.А. Яковлев

Фрагменты моральной теологии в записных книжках Джона Локка

\section{Читая книги...}

\section{Ю.С. Шипицьына}

Империя и власть знания: современные подходы

К изучению ботаники в XVIII в.

М.А. Князев

От истории детства к гендерной истории: новый взгляд

на жизнь семьи последнего русского императора. 


\section{ДИАЛОГ СО ВРЕМЕНЕМ 76 / 2021}

\section{Поиск DOI: http://search.rads-doi.org/index.php/ ; http://www.doi.org/}

https://doi.org/10.21267/AQUILO.2021.76.76.026

Н.Н. Губанов, Н.И. Губанов

https://doi.org/10.21267/AQUILO.2021.76.76.027

О.В. Головашина

https://doi.org/10.21267/AQUILO.2021.76.76.028

С.A. Воронцов

https://doi.org/10.21267/AQUILO.2021.76.76.029

М.С. Петрова

https://doi.org/10.21267/AQUILO.2021.76.76.030

Л.Р. Ильясова

https://doi.org/10.21267/AQUILO.2021.76.76.031

И.В. Ворониова

https://doi.org/10.21267/AQUILO.2021.76.76.032 С.Б. Крux

https://doi.org/10.21267/AQUILO.2021.76.76.033

Н.Ю. Николаев

https://doi.org/10.21267/AQUILO.2021.76.76.034

В.П. Сапон

https://doi.org/10.21267/AQUILO.2021.76.76.035

А.Ю. Суслов

https://doi.org/10.21267/AQUILO.2021.76.76.036

В.П. Орлов, Э.В. Рунг

https://doi.org/10.21267/AQUILO.2021.76.76.037

Д.В. Сухино-Хоменко

https://doi.org/10.21267/AQUILO.2021.76.76.015

Л.К. Новосельиева

https://doi.org/10.21267/AQUILO.2021.76.76.003

М.Ю. Ломоносов

https://doi.org/10.21267/AQUILO.2021.76.76.001

T.M. Демичева

https://doi.org/10.21267/AQUILO.2021.76.76.002

В.С. Дударев

https://doi.org/10.21267/AQUILO.2021.76.76.004

P.А. Кондрашук

https://doi.org/10.21267/AQUILO.2021.76.76.005

А.А. Авдашкин, И.В. Сибиряков
https://doi.org/10.21267/AQUILO.2021.76.76.006

Е.Н. Лысенко

https://doi.org/10.21267/AQUILO.2021.76.76.007

С.Г. Дюкин

https://doi.org/10.21267/AQUILO.2021.76.76.008

О.И. Тогоева

https://doi.org/10.21267/AQUILO.2021.76.76.009

М.С. Неклюдова

https://doi.org/10.21267/AQUILO.2021.76.76.010

Е.В. Новоселова

https://doi.org/10.21267/AQUILO.2021.76.76.011

О.В. Окунева

https://doi.org/10.21267/AQUILO.2021.76.76.012

A.B. Стогова

https://doi.org/10.21267/AQUILO.2021.76.76.013

С.А. Васильева

https://doi.org/10.21267/AQUILO.2021.76.76.014

C.E. Сидорова

https://doi.org/10.21267/AQUILO.2021.76.76.016

К.Д. Скрипник

https://doi.org/10.21267/AQUILO.2021.76.76.017

Е.Н. Крылова

https://doi.org/10.21267/AQUILO.2021.76.76.018

А.В. Володько

https://doi.org/10.21267/AQUILO.2021.76.76.019 А.В. Громова

https://doi.org/10.21267/AQUILO.2021.76.76.020

Д.М. Нечипорук

https://doi.org/10.21267/AQUILO.2021.76.76.021

A.А. Павлов (Пер.: Исидор Севильский [фрг.])

https://doi.org/10.21267/AQUILO.2021.76.76.022

А.А. Яковлев

https://doi.org/10.21267/AQUILO.2021.76.76.023

Ю.С. Шипицына

https://doi.org/10.21267/AQUILO.2021.76.76.024

М.А. Князев

Адрес редакции: 119334, Москва, Ленинский проспект, д. 32-А, к. 1423

Тел. (495) 938-53-91 Web-стр.: http://roii.ru/about Эл. почта: dialogue.time@yandex.ru

Формат 60x90 / 16. Бумага офсетная № 1. Гарнитура Таймс. Печать офсетная. Усл. печ. л. 30.

Тираж 600. Отпечатано в типографии Onebook.ru OOО «Сам Полиграфист».

Москва, Волгоградский пр., д. 42, стр. 5. info@onebook.ru ; www.onebook.ru Тел.: +7 (495) 545-37-10

ISSN 2073-7564

Журнал индексируется в Российском индексе научного Цитирования (РИНЦ);

включен в диссертационный перечень ВАК по специальности история;

в базы данных SCOPUS (с 2016 г.); WoS Core Collection (Emerging Sources Citation Index [ESCI]) (с декабря 2017 г.). Подписной индекс: 36030

Полные электронные версии статей представлены на сайте: http://roii.ru/publications/dialogue Журнал зарегистрирован в Федеральной службе по надзору за соблюдением законодательства в сфере массовых коммуникаций и охране культурного наследия (Свидетельство ПИ № ФС 77-24798 от 29 июня 2006 г.). Электронная версия — Эл. № ФС 77-53624 